Syria's Monuments: Their Survival and Destruction 


\title{
Heritage and Identity
}

ISSUES IN CULTURAL HERITAGE PROTECTION

\author{
Edited by \\ Joris D. Kila \\ James A. Zeidler \\ Editorial Board \\ Charles Garraway (UK) \\ Patrick Boylan (UK) \\ Karl von Habsburg (Austria) \\ Laurie W. Rush (USA) \\ Thomas Schuler (Germany)
}

VOLUME 5

The titles published in this series are listed at brill.com/ichp 


\title{
Syria's Monuments: \\ Their Survival and Destruction
}

\author{
By \\ Michael Greenhalgh
}

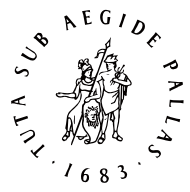

B R I L L

LEIDEN | BOSTON 
This is an open access title distributed under the terms of the CC BY-NC-ND 4.0 license, which permits any non-commercial use, distribution, and reproduction in any medium, provided no alterations are made and the original author(s) and source are credited. Further information and the complete license text can be found at https://creativecommons.org/licenses/by-nc-nd/4.0/

The terms of the cc license apply only to the original material. The use of material from other sources (indicated by a reference) such as diagrams, illustrations, photos and text samples may require further permission from the respective copyright holder.

An electronic version of this book is freely available, thanks to the support of libraries working with Knowledge Unlatched. More information about the initiative can be found at www. knowledgeunlatched.org.

Cover illustration: Serjilla, seen here in 2003, is in the Jebel Riha, some 8okm southwest of Aleppo, and is one of the many "Dead Cities" travellers described in north and south Syria. Thriving in Late Antiquity, growing grapes and olives, it had houses, villas and public baths. Some structures were decorated with mosaics and frescoes; all were built from the limestone on which the town stood. Like other sites, Serjilla declined and was then largely abandoned; the possible reasons are discussed in the text.

The complete endnotes are available on the site of the Koninklijke Brill NV, Leiden (http://dx.doi.org/ 10.6084/mg.figshare.349139o)

The Library of Congress Cataloging-in-Publication Data is available online at http://catalog.loc.gov LC record available at http://lccn.loc.gov/2016037424

Typeface for the Latin, Greek, and Cyrillic scripts: "Brill". See and download: brill.com/brill-typeface.

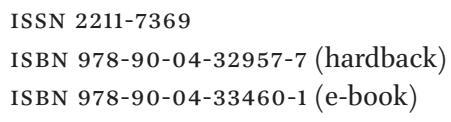

Copyright 2017 by Michael Greenhalgh. Published by Koninklijke Brill NV, Leiden, The Netherlands. Koninklijke Brill NV incorporates the imprints Brill, Brill Hes \& De Graaf, Brill Nijhoff, Brill Rodopi, Brill Sense, Hotei Publishing, mentis Verlag, Verlag Ferdinand Schöningh and Wilhelm Fink Verlag. Koninklijke Brill NV reserves the right to protect this publication against unauthorized use.

This book is printed on acid-free paper and produced in a sustainable manner. 


\section{Contents}

Introduction 1

The Extent of Syria 6

Mapping Syria 8

The Syria of Yesterday 11

1 The State of Syria in Recent Centuries 13

Governance 17

Earthquakes and Disease $\quad 21$

Trade 24

Circassians and Other Settlers amongst the Monuments 27

Nomadic Arabs 33

Agriculture and Desertification 35

Conclusion: Impact of Ottoman Decline on Antiquities 40

2 Travel throughout Syria 45

Where to Go and How to Get There 46

Languages, Dress and Descriptions 50

Scholars in the East 54

The Bible as a Guidebook 55

Changing Horizons Meet the Unchanging East 62

Biblical Monuments "Identified" 68

Other Guidebooks: Baedeker, Cook \& Murray 74

Confected Guidebooks: An Example 78

Travel then Tourism: The Agony and the Ecstasy 80

Taxes and Robbery 82

Profiteering Sheikhs 90

Haram/Forbidden: Access to Muslim Sites 93

Architectural Quality: Is Syria Worth Visiting? 98

One-upmanship and Verbal Wars in Travel Narratives 102

Modernisation Changes Travelling in the Unchanging East 108

Conclusion 110

3 The Life and Death of Monuments $\quad 116$

Superstitions and Monuments $\quad 116$

Treasure-hunting and Locals' Knowledge of the Past 120

Vandalism 125

Roads Milestones Bridges 127 


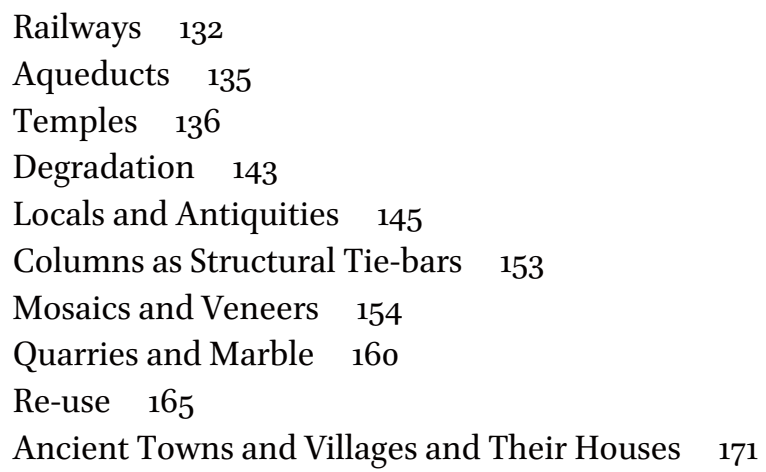

4 The Seabord: Harbours and Ports North to South 184

Iskenderun 185, Seleucia Pieria 188, Lattakia 19o, Banias 194,

Tortosa/Tartus \& Ruad 195, Tripoli 195, Byblos 197, Beirut 199,

Sidon 202, Sarepta 207, Tyre 207, Acre 215, Haifa 218, Caesarea 219, Jaffa 223, Ascalon 225, Gaza 229

5 Aleppo and the North 238

Aleppo 238, Antioch 240, Cyrrhus \& Menbij 243, Dead Cities 245, Apamea \& Qalaat Mudiq 249, Deir Semaan \& Saint Simeon 251, Hama \& Homs 253, Qasr Ibn Wardan 258, Hosn Suleiman 259

6 Damascus and the Centre 262

Damascus 262, Baalbek 267, Palmyra 276, Anjar, Medjel Anjar \& the Nearby Temple 282

7 Bosra and the South 287

Bosra 287, Hauran 290, Shahba 296, Slim, Hit, Atil 298, Suweida 300, Qanawat 301, Salkhad 303, Deraa 304, Ledja 306, Ezraa 308, Burak \& Mismiye 309, Bashan 310, Jaulan / Golan Heights 311, Counting the Settlements 314

8 West of the River Jordan 319

Samaria, Janin, Capernaum 319, Jerusalem 322, Herodium 326, Jericho \& Hebron 327, Tiberias 327, Beisan / Beth Shean / Scythopolis 328

9 East of the River Jordan 331

Irbid 331, Pella 332, Yajuz 333, Umm al-Jimal 333, Gadara 335,

Difficult Sites - Jerash, Amman, \& Petra 337, Jerash 340, Amman 343, Um Rasas 346, Iraq Al-Amir 347, Madaba 349, Petra 351 
10 Fortresses Roman, Muslim and Crusader 356

Building and Rebuilding "Crusader" Fortresses 358, Saphet 36o, Shaizar 36o, Baalbek 361, Beirut 361, Athlit 363, Kerak 365, Krak des Chevaliers 366, Desert Castles 366, Qasr El-Hallabat 368, Mschatta and Nearby Antiquities 368, Qasr al-Heir West 370, Qasr al-Heir East 371, Roman Fortresses 373, Qasr el-Abyad 375, Qasr el-Bai'j 376, Masada and Its Siege Camps 376

11 Mayhem: Archaeology, Museums and Mandates 379

Archaeology 380

Digging in Palestine 388

Filling Western Museums 390

The First World War and the French \& British Mandates 395

Conclusion 404

Epilogue: The Monuments of Syria in $2016 \quad 409$

Syria: Timelines 410

History of Archaeology and Travel in Syria 411

Recent Political/Military Developments in the Region, and

Their Sources 412

Websites Detailing Syria's Monuments 414

Damaged Sites, Monuments and Museums 415

Photographic Evidence of Destruction in Syria $\quad 416$

Guides/Surveys of Monuments and Regions $\quad 416$

Computer Reconstructions $\quad 418$

Conclusion: Warning about "Restoration"

Appendix: Brief Biographies of Traveller-Scholars 423

Bibliography $\quad 426$

Sources 426

Modern Scholars 455

Index 480

Illustrations 
Michael Greenhalgh - 978-90-04-33460-1 Downloaded from Brill.com12/05/2021 10:56:24PM via Australian National University 


\section{Introduction}

For what was Syria so remarkable? The lustre of its early glories, the vicissitudes of its fortunes, and the blood that has drenched its soil. It was also noted for its admirable fertility, the variety of its climate, and the advantageous position which it occupied in the very heart of the ancient world, which rendered it the chosen abode of early commerce and civilization. $^{[1]}[1846]$

The answers given above appear in a primer for students, Geography and sacred history of Syria, including Phoenicia, Palestine, or the Holy Land, with Idumea, made interesting, which is a mine of information and prejudgments, such as on the Arabs who live in Syria and Palestine: "little firmness and stability of character... covetousness, ingratitude, jealousy, faithlessness, and indolence."[2] Or Casola's 1494 (post-) judgment on the Muslims in Jerusalem: "I declare that they may be as great and as learned as you like, but in their ways they are like dogs." [3]

Such texts provided ready-made opinions for armchair readers back home, but the majority of travellers who visited Syria (and there were hundreds of them) as well-educated pilgrims, traders, diplomats, scientists, soldiers, sailors and eventually archaeologists offered richer and more subtle assessments of the locals they met and the monuments they admired. This book is based on their accounts, because these offer the only possible entrée for Westerners into what was for centuries a strange and alien world. Literate and knowledgeable visitors write at length to explain many aspects of Syria, from the people (Arabs, Bedouin, Turks, Druze, Christians, Jews) and the physical environment (agriculture, drought, marshes) to the pressures on the built environment (earthquakes, dilapidation, taxation, communications). All these elements are essential to framing the context in which the ancient architecture of Syria survived, tottered or disappeared completely. Some mediaeval sources in Arabic (translated into Western languages in the 19th century) write a little about local architecture, but none do so in detail, and our travellers' accounts offer us the only comprehensive (and sometimes encyclopaedic) picture of what they saw. Some of this is long gone; some is in danger (see the Epilogue for this century's civil war), but plenty survives for us to echo their amazement at the huge quantities of ancient churches and housing that survived into the 19th century. Today the "Dead Cities" near Aleppo survive to entrance us, each like a deserted Pompeii yet these are but a small fraction of the ancient 
towns and villages our travellers saw, most now gone thanks to the march of modernisation.

European travellers in earlier centuries naturally had an ethno-centric approach to the Middle East, offering assessments of the locals while describing cities and monuments that would disappear or change over the course of the centuries. This book presents a broad synthesis of how Greater Syria "developed" from Late Antiquity onward, concentrating on the state of the area in recent centuries, and providing travellers' detailed information on many of her sites, as they travelled through these lands before the collapse of the Ottoman Empire.

As we shall see, our travellers were remarkably diverse in origins, interests and opinions. If, to those aficionados of that 2oth-century post-colonial lament, many accounts seem "orientalist," this is far from being the case. Most judgments do indeed end up canted in favour of the West, which without any debate at all had better agriculture, building practices, trade and governance. But such conclusions are far from pre-judged, because most travellers did not arrive with such a facile check-list of prejudices. Instead, they spent time on the ground, and some observers were equipped with the necessary languages to discuss matters with the locals. "Orientalism" implies a standard list of attitudes, which visitors could check off one by one in the countries they visited. What follows will demonstrate that our travellers had far too many diverse views to be strapped into such a 2oth-century straightjacket. A very few had attitudes that were indeed imperialist; a very few thought (like Napoleon) the area ripe for invasion and yet fewer still for colonising; some were fixated on gaining trading advantage (often in antiquities) over their European rivals; some concentrated on agriculture; but many focussed on antiquities in the study of which they could use their classical education to advantage.

Religion was and remained for some a problem, as well as a focus. Syria was a Christian land long before the Islam arrived, and much of the Western animus against that newer religion was because Christians (and Jews) in the Ottoman Empire were officially treated as inferior and, for centuries, rigorously prohibited from visiting some Muslim religious buildings. This book concentrates on ancient architecture in part because of such restrictions, and in part because few travellers were equipped (as they indeed were for structures Greek and Roman) to deal with Islamic architecture from well-grounded knowledge. Thus although they admired Aleppo for its orderly life and clean streets, they have very little to say about its markets and mosques, nor much about the conspicuous citadel, usually barred to them because it was a military installation. 
This Introduction sketches for the reader the features of the country as seen by travellers, introducing the reasons for considering a "Syria" larger than her present-day borders, and outlining why accurate mapping of parts of the country (and hence knowledge of its monuments) took so long to achieve. The book then falls into three sections plus an epilogue. Chapters 1-3 discuss the state of the country and her ancient monuments, and the trials and tribulations travellers encountered there, concentrating on the 19th century, and demonstrating how foreigners learned about the area via pilgrimage, war, diplomacy, trade and the benefits of a classical education. Because travellers did not take much account of them, and because so many had over the centuries been converted into mosques, apart from their mosaic floors little appears below about churches.

Chapters 4-10 offer a gazetteer of towns and other sites, divided geographically into Aleppo and the North, Damascus and the Centre (including Palmyra), Bosra and the South, and Palestine and present-day Jordan. Our travellers did not visit or at least comment at length on ancient sites on or near the Euphrates (such as Raqqa, Resafa, Deir al-Zor), so these are omitted. A chronological division into Roman, Byzantine and Muslim would have been confusing, since most Byzantine settlements were originally Roman, and there are few exclusively Muslim settlements (Anjar is an exception). In any case our travellers, although usually able to distinguish Byzantine from earlier Roman, generally lacked any knowledge of the historical development of settlements after Rome, and usually gave much less attention to Muslim buildings than to earlier ones, because spectacular mosques were generally inaccessible to non-Muslims.

Before the general Conclusion, the third section (just Chapter 11) might be called the European Carve-Up, because this terminology is richly deserved. Syria, in a key location with Mediterranean access, and with plenty of fertile soil which would support a much larger population, had long been eyed by Europeans for a takeover, via trade and even settlement. It first mentions the attempted occupation of Egypt via Syria under Napoleon, because this brought the two countries to European attention together with a host of documentation for Egypt. It also deals with the plunder of the country for Western museums. But it concentrates on the true carve-up by the Western powers of the defeated Ottoman Empire, examining the effect of the ensuing Mandate (French and British) on archaeology, museums and monuments.

The Epilogue provides an outline sketch of the present state of Syria's monuments, together with ample Internet references, so that the reader may pursue in detail individual sites and, in some cases, monuments. Needless to say, 
the monuments have often suffered as an echo of the sufferings of Syria and her people.

Syria boasted many very old monuments, known through ancient authors, and still contained many towns with Roman layouts. ${ }^{1}$ Indeed, "when Greece was in her infancy, and long before Rome had even been founded, the coast of Syria was covered with magnificent and wealthy cities," but these had disappeared ${ }^{[4]}$ Artefacts from the earliest centuries have survived. ${ }^{2}$ This book might have included extended discussions of international strategy, because Western visitors were generally alert to Syria's location at an important point between Asia and Africa, as Beaujour noted in $1829 .{ }^{[5]}$ This was an element which came into prominence during the First World War and its aftermath ${ }^{[6]}$ These factors are touched on in Chapters Eleven and Twelve, but to try and locate them in the context of European diplomacy would have made a very different book, as would any attention to the religious divisions and attitudes throughout the Empire. ${ }^{3}$

Nearly 240 years earlier than our primer Sandys, travelling in 1610, had passed judgment over the whole of what he calls the Turkish Empire:

Those rich lands at this present remain waste and overgrown with bushes, receptacles of wild beasts, of thieves and murderers, large Territories dispeopled, or thinly inhabited, good Cities made desolate, sumptuous buildings become ruines, glorious Temples either subverted, or prostituted to impiety; true Religion discountenanced and oppressed, all Nobility extinguished, no light of learning permitted, nor virtue cherished; violence and rapine insulting over all., $[7]$

Gibbon found that "Palestine is a territory scarcely superior to Wales either in fertility or extent," and Newman in 1864 noted as particular problems "frequent changes of government, the rapacity of officials, the insecurity of property, the religious animosity of rival sects, the barbarian ignorance of the peasantry as

1 Segal 1988 for town planning: deals with Philadelphia, Gerasa, Bostra and Philippopolis. With 176 illustrations. Some good photos from earlier decades, on ground and aerial, e.g. from 1930s. Valuable for bringing together many earlier town plans and reconstructions. Neglia 2009 47-75: Il paesaggio urbano della Siria ellenistico-romana, including roads, colonnaded streets.

2 Ebla to Damascus 1985 for an overview; 365-440: Hellenistic and Roman periods; 442-474: Byzantium; 476-532: Islam.

3 Maclean \& Matar 2011, 79-123 Chapter Three: British factors, Governors, and Diplomats; ibid, 156-197, Chapter Five: The Peoples of the Islamic Empires. For Sunni, Shi'a, Christians, etc. 
to the enlightened principles of agriculture."[8] This was, after all, the so-called Unchanging East (which we shall encounter again), with an ancient church, prehistoric monuments which "still illustrate the rural superstitions of the dim ages," and mountains which "still shelter in their fastnesses the rites and descendants of ancient paganism." ${ }^{\text {[9] }}$ Such opinions are not universal but, as this book will demonstrate, Western travellers from the 17th century found many aspects of the Ottoman Empire (with its multiple interactions with the outside world ${ }^{4}$ ) inferior to conditions at home, especially agriculture, population, public safety and manufactures, many like Sandys emphasising how strange it was that such rich lands should be under-exploited, and opportunities for improvement (not to mention Western commerce) missed. As we have already seen, Westerners could also relay standardised prejudices about Syrian peoples: the Druze were warlike, the Maronites industrious but superstitious, the Muslims fanatical, and so on. ${ }^{[10]}$ As for exactly what happened in Palestine since the Ottoman conquest of 1516, "historians are mining Ottoman archives for insights into the political, economic, and social changes." ${ }^{5}$

The cause of Syria's degradation was unanimously attributed to the unreformed attitudes of central government, and to the lax and sometimes nonexistant control of the further reaches of the Empire, such as Syria. In 1796 the lugubrious Volney (of olympic-class pessimism) wished to investigate the reasons for decline and fall, ${ }^{[11]}$ and he saw in Syria a terrible warning, a presage of what might happen when Europe declined:

No where perceiving aught but robbery and devastation, tyranny and wretchedness, my heart was oppressed with sorrow and indignation. / Every day I found in my route fields abandoned by the plough, villages deserted, and cities in ruins. Frequently I met with antique monuments; wrecks of temples, palaces, and fortifications; pillars, aqueducts, sepulchres. ${ }^{[12]}$

He compared what he saw with what he read in Josephus and Strabo, and abandoned settlements and traces of agriculture confirmed for him that their estimate of a population of $12 \mathrm{~m}$ in their own day must have been correct:

4 Atassi 1986 for the 18thC; Faroqhi 2004 for an excellent briefing and large bibliography.

5 Baram \& Carroll 2002, 140: "Avoided, ignored, or misrepresented, the Ottoman period for Palestine (1516-1917) is thus a contested era. In the vast sweep of prehistoric to Biblical to the Classic Eras, archaeologists present the dynamics of change and transformation. But for the centuries of Ottoman rule are seen as an exception, either as desolate or passively engulfed by Western triumph." 
Every where one might have seen cultivated fields, frequented roads, and crowded habitations. Ah! what are become of those ages of abundance and of life? What are become of so many productions of the hand of man? ${ }^{[13]}$

Similar reactions were evoked a century earlier by the ruins of Egypt. ${ }^{[14]}$ Archaeologists today have also turned to the "afterlife" of towns, investigating reasons for decline and abandonment. ${ }^{6}$

\section{The Extent of Syria}

The Syria of today joins the Mediterranea Sea from south of Antioch (south of the Turkish border) and down to south of Tartous, where Lebanon begins, and then Israel. On a high plain, to the east of the Lebanon mountains, the country extends in a narrow fertile strip from north of Aleppo through Hama, Homs and Damascus to Deraa in the south (beyond which is Jordan, with Jerash and Amman). Palmyra, some $235 \mathrm{~km}$ NE of Damascus, is well into the desert, and to Deir al-Zor, on the Euphrates, which forms the boundary with Iraq, is another $205 \mathrm{~km}$. Isidore of Seville, the Spanish encyclopaedist (c.56o-636), knew a lot about Syria; it included Palmyra and Tyre, Apamea and Edessa, Antioch and Gaza, and Galilee and Jaffa as part of Palestine. ${ }^{[15]}$ For the Crusaders, Syria stretched as far east as the Tigris and Euphrates, and "there are three Palestines, which are parts of Greater Syria."[16] For Affagart, travelling in 1533-34, La Grande Syrie consisted of five parts, from the River Tigris in the east, to Palestine on the coast. ${ }^{[17]}$ In 1907, "used in a broad sense the term Syria means the narrow strip of land at the east end of the Mediterranean, about 400 miles long and ranging in breadth from 70 to 100 miles." ${ }^{[18]}$ That was one opinion; another in 1883 , demonstrating the flexibility of the nominations, was that

on désigne souvent sous le nom de Palestine toutes les régions comprises depuis l'Egypte jusqu'aux confins de l'Asie-Mineure et de la Mésopotamie, avec la Phénicie, la Coelé-Syrie, l'Idumée, l'Arabie Pétrée et une partie de l'Arabie Déserte. ${ }^{[19]}$

Lebanon and its creation provide yet another view of boundaries. ${ }^{7}$

6 Christie \& Augenti 2012 for eleven case studies from the classical world, although none from Syria.

7 Salibi 1988, 57-71: Talking Geography. 
The Roman Province of Syria (later a moveable feast, ${ }^{8}$ just as was "Arabia" 9 ) abutted Cilicia to the north, Mesopotamia to the north east and east, and Palestine and then Egypt to the south. There had been Hellenistic settlements as well. ${ }^{10}$ Beauvau in 1608 extends this by including Cilicia ${ }^{[20]}$ while Sanson, the Royal Geographer in 1683 , narrows it somewhat:

La Sourie, autresfois Syrie la grande: Les Anciens l'ont divisé en trois parties principales: Syrie, particulière, \& qui comme la plus grande, \& la meilleure retenoit le nom du tout; Phoenice, ou Phoenicie: Judée, ou Palestine: celle-cy est la plus avancée vers le Midy, la Sourie vers le Septentrion, la Phoenicie reste au milieu; \& toutes sont le long de la Mer Méditerranée, dépuis l'Anatolie jusques à l'Egypte. La Sourie particulière \& seule touche à l'Eufrate, le reste à l'Arabie. ${ }^{[21]}$

Besson in 1862 repeated the Roman divisions, ${ }^{[22]}$ and Saint-Aignan remarked in 1864 that the Holy Land also had different boundaries at different periods, with "á l'époque de sa plus grande prospérité" some $6.5 \mathrm{~m}$ inhabitants, reduced in his day to perhaps $300,000 .{ }^{[23]}$ Modern definitions also vary. ${ }^{11}$

As we have seen in outline above, the geographical extent of Syria is a variable feast for travellers, not to mention the Ottomans. This book deals with Greater Syria, because that is how most travellers conceived of the region, and because it would therefore be illogical to confine our study to the frontiers of today's Syria as acknowledged (at least by Westerners) after the First World War. (T.E. Lawrence might for many good reasons have been named Lawrence of Greater Syria, but admittedly that title lacks the éclat of Lawrence of Arabia.)

Syria was of course the target of pilgrimage from the early centuries of Christianity, and their exact itineraries are sometimes known ${ }^{12}$ into this, part of a transforming Roman Empire. ${ }^{13}$ Charlemagne sought to get a handle on religious establishments in the Holy Land, and sent commissioners to investigate.

8 Salibi 1988, 61-62: "Under the Romans, there was actually a province of Syria, with its capital at Antioch, which carried the name of' the territory. Otherwise, down the centuries, Syria, like Arabia and Mesopotamia. was no more than a geographic expression."

9 Bowersock 1988: Ptolemy and changing perceptions of geographical divsions and regions. Piccirillo 2002, 28-55, Roman province of Arabia (Syria, Lebanon, Jordan, Palestine): La fondation de la province de l'Arabie.

10 Cohen 2006 for the ancient sources.

11 Nour 1982, XI: "Syria is what the Arabs call Bilad al-Sam, which includes modern states of Syria, Lebanon, Palestine and Jordan."

12 Bowmann 2011: the 4th-century Bordeaux Pilgrim.

13 Ball 2000. 
Most unusually, they returned with actual building measurements, and their reports enabled Michael McCormick to draw up an overview of religious establishments there. ${ }^{14}$ Again, although we shall not deal in any detail with pilgrimage, a major impulse was to see the sites of the Bible and the classical ruins en route; hence to omit Palestine would be as confusing as to omit Jordan (another product of the Great War, and with many travellers ${ }^{15}$ ) and some erstwhile monument-rich sites in present-day Israel and the Occupied West Bank. To the north, we also deal with sites now in Turkey, such as Iskenderun and Antakya, which in earlier centuries were seen as a southern extension of Cilicia. The book does cover Jordan, often discussed by pilgrims on their way to Jerusalem.

\section{Mapping Syria}

Before travelling, Westerners could learn about Syria from maps, but these often reflected the prevailing lack of knowledge, and there were none to be used in on-the-ground detail. A similar situation pertained for Asia Minor. ${ }^{16}$ A famous map was produced by D'Anville in several editions. The 1764 version has a legend that reads Orbis Romani Pars Orientalis. This includes Jerash, Amman and Petra, so the notion (cf. Wikipedia: Jerash) that Seetzen "discovered" Jerash in 1806 can be discounted. He did, however, visit the site on the ground, whereas many of D'Anville's locations are vague or mis-placed. Thus his map shows only part of the (very faint) Jordan feeding into Eilat; he has Jerash just SW of Petra, when it is in fact well north of his misshapen Dead Sea, although he has Amman in about the correct location. Burckhardt, ${ }^{17}$ travelling in the early 19th century, necessarily took D'Anville's map with him, and is quick to detail D'Anville's mistakes of location on various occasions where what he finds differs from the location "laid down" by the cartographer; but curiously, he is silent about any error in D'Anville's location of Petra. D'Anville relied on descriptions by ancients and moderns alike, and these could be confusing

14 McCormick 2011, 95-116 for Charlemagne and the architectural dimensions of Holy Land monuments. Ibid, chapters $2 \& 3$ for Holy Land churches, and Travel and comparative sociology of early mediaeval religious houses, both for the Carolingian period; chapter 4 for Carolingian establishments in the Holy Land.

15 Caubet 1997 discusses the 1761-6 Danish Expedition, published by Niebuhr Copenhagen 1774-8; then gives brief biographies of Burckhardt, Laborde, De Saulcy, August Salzmann, De Vogüé, Rey, Luynes, Clermont-Ganneau.

16 El-Mudarris 2013: European geographical knowledge of Asia Minor.

17 Masse 1996 for a short biography. 
because their parameters were so different. ${ }^{[24]}$ An admirer was astounded by his map of Egypt because "par la seule force de sa critique, il a assigné, avec une justesse qui nous confondoit de surprise, la position des villes anciennes, celles des villages et le cours des canaux d'un pays qu'il n'avoit jamais visité."[25]

D'Anville's map collection was so extensive that the details in other maps were invaluable in producing his own, by simple incorporation. The King acquired the collection in $1779 .{ }^{[26]}$ What is more, D'Anville's maps changed in different editions, as he took account of suggestions and corrections. ${ }^{[27]}$ So did those of his predecessors and successors, indicating what was little known by generalities or a blank. Thus Guillaume Delisle's Map of 1701 gives few details east of Damascus, but "locating" with a dot Ruines de Thadmor ou Palmyre, and in the great blank below, Dans ces Deserts on voit les Ruines de plusieurs Villes anciennes. To the south east of this inscription we read Grand Palais deserté. The same map locates Baalbek, Crac [Kerak, not Krak des Chevaliers] and Ascalon ruinée. The legend states that the map was Dressée sur les Mémoires les plus recens rectifiéz par les Observations de Mrs de l'Academie Rle des Sciences. Deserts, indeed, formed a large proportion of Syrias land mass; for our travellers, Palmyra was deep in the dangerous desert (235 km from Damascus); but there was another $205 \mathrm{~km}$ across yet more desert before reaching Deir al-Zor and the Euphrates - indication enough why so few ventured east beyond Palmyra. Closer to safety, the plain of Baalbek yielded unmapped villages, boasted Callier in 1835 . $^{[28]}$

By the mid-19th century the most inhabited central parts of Syria as well as the actual coast (by which most travellers entered the country) were well known and mapped. But even slightly inland, Newbold could complain in 1850 that "The mountainous country lying between the coasts of Tyre and Sidon and the valley of the Jordan presents almost a complete blank, even in our latest maps of Palestine," ${ }^{29]}$ and went on to describe inaccuracies in the location of various monuments on the map he used:

M. Kiepert, who constructed the map, appears fully sensible of the difficulties he had to encounter in laying down this part of Palestine from these travellers' observations, as will appear from his memoir on the map. ${ }^{[30]}$

Maps did not improve quickly. In 1861, indeed, Joanne \& Isambert were still relying on surveys taken some thirty years earlier, noted as "excellente pour le tracé des côtes," which was hardly the most difficult territory to deal with. ${ }^{[31]}$ However, north of Aleppo, east of Palmyra and south of Damascus had been 
less visited and the scanty mapping reflected this. These were desert or deserted areas, and travellers were wary: "Cet abandon s'explique par la situation même du pays; le courant des voyageurs européens n'était pas attiré vers des régions réputées dangereuses ou inaccessibles et qui sont comme abandonnées par leurs propres habitants."[32]

In other words, rather than early cartographers necessarily supplying maps for travellers, it could equally be travellers supplying information and corrections to the cartographer, but leaving areas such as the Hauran and points south to the few hardy individuals daring to go there. In such dangerous areas, it was unsurprising that many sites were mis-identified, and therefore misled later travellers. ${ }^{18}$ This disparity between maps and the land they supposedly represent has huge implications for travellers, which are not solved anywhere in the East or in North Africa until the coming of surveyors for the railways in the later 19th century. Travellers, for example, in those many regions of Syria which did not yield visible inscriptions, had to guess where they were from earlier descriptions, and crude reasoning, Seetzen even claiming in 1809 that he travelled to Syria to fill lacunae in earlier accounts. ${ }^{[33]}$ Burckhardt thought he had found Petra (as indeed he had), but identified the site by a process of elimination: "I am persuaded, from all the information I procured, that there is no other ruin between the extremities of the Dead sea and Red sea, of sufficient importance to answer to that city." ${ }^{[34]}$ For Jerash, again he located the site, but no thanks to D'Anville, "who places it to the north-east of the lake of Tiberias, forty miles to the north-westward of this place."[35]

Inevitably, then, cartography or its lack dictated where the cautious or the brave travelled. The Djebel Hauran is due south of Damascus, a region with Ezraa to its north, Bosra in the centre, and Umm al-Jimal to the south; its architecture is in contact with that of the buildings around Aleppo, in the "Dead Cities." ${ }^{[36]}$ Continuing south-south-west, one arrived at Jerash then Amman, and due west at Beisan. This could be a dangerous area to visit, as indicated by some European maps; and Salverte claimed in 1861 that even caravans feared to venture there. ${ }^{[37]}$ Pococke's 1745 map covers this area with a Legend of conventional signs. Frederick Hasselquist's map, drawn from travels 1749-52, simply leaves the area blank. John Pinkerton's 1813 map of Turkey in Asia includes the Hauran, but the area only a few kilometres to the east is marked Desert of Syria. Colton's magnificent 1855 map of Turkey in Asia indicates Ezraa, but not Bosra, and the area only a few kilometres east of Suweida (i.e. the desert) is used for the map's title. By 1895 , William Wright provides a sketch-map of

18 Miller 2000: Burckhardt \& Robinson on the Kerak plateau, and their influence on later travellers via sites and routes they mis-located. 
Bashan, but only as far south as Bosra (his book is focussed on Palmyra). The maps in Baedeker's 1876 volume put them all to shame, with a detailed map of the Hauran, its settlements, roads and geography.

\section{The Syria of Yesterday}

Except for those travellers arriving through Iraq (usually British, from India ${ }^{19}$ ), most would arrive from somewhere in Turkey, usually hopping from Istanbul via Smyrna, via the Greek Islands and Cyprus (the jumping-off point for many military attacks $\left.{ }^{[38]}\right)$, landing somewhere on the coast, and then making their way inland; or from the south, having visited Egypt, and interested in seeing Palestine, the Holy Land. ${ }^{20}$ The intrepid crossed Sinai to get to Palestine, and a few even braved deserts and Bedouin to visit Petra; but most took a boat from Alexandria. For the majority, the Euphrates was too distant to contemplate, and marauding Bedouin meant that it was only the rich and the very confident (with well-armed protection) who got as far east as Palmyra. It therefore makes sense for this book, focussed mainly on the 19th century, to treat "Syria" as the modern country plus Lebanon, Israel and Jordan, to take account of how travellers arrived, and the sites they visited, passing back and forth across today's boundaries, all of which (except for those of Israel and the Occupied Territories) came into being as a result of the First World War (see chap.11). The Encyclopaedia Britannica (11th edition), includes present-day Iraq:

Syria, the name given generally to the land lying between the easternmost shore of the Levantine Gulf and a natural inland boundary formed in part by the Middle Euphrates and in part by the western edge of the Hamad or desert steppe. ${ }^{[39]}$

The following chapters will demonstrate the truth of the opening quote to this Introduction. Syria, both the country of today's national boundaries, and the Greater Syria as understood by travellers in earlier centuries, is indeed remarkable for the survival through many vicissitudes of unparalleled monuments and sites.

There are two bibliographies, one for source-texts (generally up to the First World War), and the second for modern scholars. The source-texts are

19 Hachicho $1964,54-76$ for The Desert Route to India (via Aleppo-Basra), followed $76-91$ for The Overland Route to India (via Egypt and the Red Sea). Jenour 1791.

20 Aiken 2010, 1-17 Inscribing Terra Sancta. This chapter deals with pre-19th century authors. 
referenced in the endnotes which, in the e-book version, offer over 300,000 words of additional supporting material. In the print version, the endnote references are given in the abbreviated author_date_page format. Some of the source-texts quotations include my comments, which are intended (because not all works are equally valuable) to help the reader navigate between the excellent, the useful, the regurgitative and the plagiaristic.

Names (both personal and place) are a problem, because travellers use different transliterations for the current (and variable) Arabic names. In the endnotes quoting directly from travel accounts, except for omitting accents I have left them exactly as travellers have written them, but have myself relied on the name and spelling (omitting the accents) found in Karl Baedeker, Palestine and Syria. Handbook for travellers (Leipzig \& London 1876), as well as on modern conventions, especially those in Ross Burns' Monuments of Syria, where some sites have four or more appelations.

I have left the languages of previous centuries as written, with their often cavalier attitude to accents, capitalisation, and syntax. Square brackets within quotations indicate my additions to the cited text, usually for short explanations or dates. English travel books were frequently translated into French, and vice versa, so the versions I have cited often reflect this mixture.
[1] Gaskin_1846_34
[2] Gaskin_1846_35
[3] Casola_1907_257
[4] Farley_1862_203
[5] Beaujour_1829_371
[6] Roederer_1917_XXVII- XXVIII
[7] Sandys_1673_Preface
[8] Newman_1864_16
[9] Farren_1838_243
[10] Thomson_1886_V
[11] Volney_1796_24
[12] Volney_1796_1-2
[13] Volney_1796_7-9
[14] Hachicho_1964_163

\author{
[15] Isidore_1911_Book_XV_ \\ 14-15 \\ [16] Vitri_1896_XCVI \\ [17] Affagart_1902_149-150 \\ [18] Bliss_1907_X \\ [19] Haussmann_de_ \\ Wandelburg_1883_6 \\ [20] Beauvau_1608_120 \\ [21] Sanson_1683_11-12 \\ [22] Besson_1862_4 \\ [23] Saint-Aignan_1864_25 \\ [24] Dacier_1802_23-24 \\ [25] Dacier_1802_13 \\ [26] Dacier_1802_38 \\ [27] Dacier_1802_41-42
}

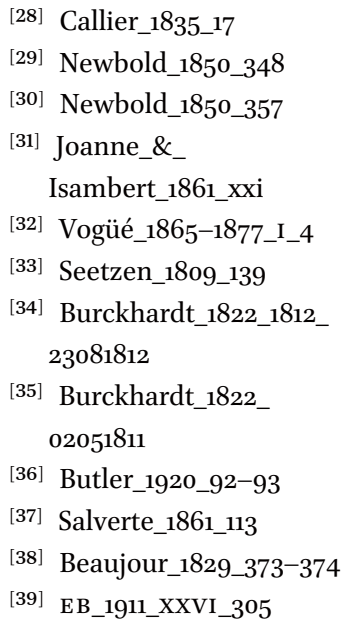




\section{The State of Syria in Recent Centuries}

The countless ruins of Palestine, of whatever date they may be, tell us at a glance that we must not judge the resources of the ancient land by its present depressed and desolate state. ${ }^{[1]}[1856]$

This chapter will demonstrate that it was the physical state of the country which first helped preserve many antiquities, and then the increasing modernisation under western influence which helped destroy so many sites in the face of growing prosperity and population.

Agriculture and desertification (a problem for other countries as well ${ }^{1}$ ), population levels and movement, public safety and governance, and transport by land and sea, all affected survival then destruction. Where lands were not cultivated, villages and even towns were abandoned and arable land could become desert, the domain of fierce Bedouin who acknowledged only tribal links and terrorised locals and travellers alike, as Brünnow \& Domaszewski tabulate for Provincia Arabia. ${ }^{[2]}$ (Brünnow \& Domaszewski's accounts of many sites were excellent, and met with praise for their extent and documentation, ${ }^{[3]}$ with an impressive amount of photography. ${ }^{2}$ ) They had done so for centuries, surely before the time of the Romans. Attacks on pilgrims were one of the reasons given for the launching of the First Crusade. Ottoman central government in Constantinople, a long way from Syria, could not regularly maintain public safety, and local and regional chieftains could be as importunate and expensive and difficult for travellers as the Bedouin.

Roads were inadequate, and ports few, so that population increase from the later 19th century and the modernisation and improved transport they brought saw a thirst for building materials for houses, roads, railways and ports, most conveniently and cheaply filled by dismantling ancient monuments and sometimes whole towns. The social mix changed, and the economy fluctuated over the centuries. ${ }^{3}$ This chapter surveys all these interrelated elements, which

1 Brandt \& Thornes 1996.

2 MacAdam 1986, 277-306 for catalogue of the 961 images taken by the Brünnow \& Domaszewski 1897-8 expedition, not all of which appear in the three volumes of Provincia Arabia.

3 Issawi 1988, 39-92 General and social developments: Syria; Fortin 1999, 131ff: Organisation de l'économie. 
were crucial for monuments, because stasis ensured their survival, whereas development and prosperity damaged and destroyed them.

In the Middle Ages, Christianity declined with the Muslim invasions, ${ }^{4}$ and with population expansions has lost many of her structures in the past two centuries. ${ }^{5}$ Syria was probably prosperous throughout all her territory, because (according to one theory) "the expansion of Islam into Syria-Palestine in the 630 s was accompanied by only minimal disruption to socio-economic life in both towns and the countryside." ${ }^{6}$ For another scholar, "Il est significatif de constater que des terres abandonnées à l'époque omeyyade ne seront de nouveau cultivés qu'au XXe siècle!"7

In the 18th and especially the 19th centuries, while the region was "a terrain upon which nineteenth and early twentieth-century British travellers and imperialist administrators constructed at times overlapping and more frequently divergent discourses about the Middle East," ${ }^{1}$ well-educated travellers from the West frequently reached a consensus, amidst their often patent desires to master the region. ${ }^{9}$ They observed that the potential of the country

4 Piccirillo 2002, Roman province of Arabia (Syria, Lebanon, Jordan, Palestine): 80-113 for Sanctuaires et présence monastique en Arabie; 219-253: La fin d'une province et d'un communauté. Kennedy 1992 for their effect on rural settlement. Kuhnen 1990 for Graeco-Roman Palestine.

5 Hirschfeld 2002: A dozen monasteries in western Samaria, parts dismantled last century, because 155 in the British mandate photos (1917-1948) "one can trace the various structural elements of the monastery that were still standing then." Most of the church has gone, but 172 Conder and Kitchener (1882) saw rich decoration that recalled 6thC Syria and Mount Gerizim.

6 Walmsley 200748 for quote; 34-46: Condition of towns in the later sixth century; 71-112 Sites and settlement processes. This deals with existing and new towns, and surveys recent archaeological work. For the older theory, cf. Fortin 1999, 141: Long decline from 6thC, with Persians, pillage, earthquakes and epidemics - then a long decline in agriculture with the introduction of Islam. Piccirillo 2002, 252-253 for various theories of abandonment of the Roman province of Arabia, including Arab invasion, climate, epidemics, bedouinisation. Magness 2012, 349: Palestine continued to flourish under early Islamic rule. See Bartl \& Moaz 2008 for up-to-date research and theories from late antiquity to early Islam in Syria; Sivan 2008 for a well-referenced and broad survey; Canivet 1992 for conference proceedings on Byzantium to Islam.

7 Fortin 1999, 141: Islam goes for cotton and linen for export; ibid., 163-5 La période islamique et le commerce de longue distance.

8 Nash 2005, 201.

9 Karsh \& Karsh 1999. 
was not being realised because of failures of administration and development. ${ }^{10}$ In those centuries the Muslim invasions were also believed to have curtailed prosperity, the Duc de Luynes writing that

Ce ne put être que l'invasion formidable et inattendue de l'islamisme, désorganisateur et destructeur fanatique, qui culbuta ainsi, là comme dans le Hauran, un état de choses où l'ordre et la sécurité obtenaient des garanties. Tout en faisant la part aux immenses et irrémédiables catastrophes des tremblements de terre dont la trace est partout sur le sol comme dans l'histoire, celle qui renversa l'œuvre d'une si antique civilisation fut bien plus destructive encore. ${ }^{[4]}$

It must be remembered that western countries were then developing an interrelated infrastructure combining trade, industry and agriculture predicated on improved transport and other communications, and supported by more-orless stable governments adequately policing a population who, rich or poor, lived sedentary lives in one fixed place in town or countryside, and without too much religious intolerance. In Syria they found a country very different from back home: a population sharply divided between sedentary and nomadic, infrastructure and agriculture often neglected, a distant and often ineffectual central government exacerbated by various local tyrants, and inadequate communications plagued by robbers and tribal warfare. The majority who "read" Syria against their knowledge of the Bible considered that it "contrasts painfully with the glory that invested it in the days of David and Solomon... the moral degradation of the people, sunk in the darkest errors of the Greek and Romish heresies, which contrasts yet more sorrowfully with that divine light once enjoyed by its favored inhabitants."[5]

This state of affairs often meant that marshes remained undrained, harbours blocked, roads undeveloped - all features which graced many ancient sites, and thereby tended to preserve their antiquities, even as admiring travellers suffered from diseases such as malaria. Trade was one of the reasons for Europeans to be in Syria, backed up by consuls who knew where antiquities were to be found, and could not only arrange early versions of package tours, but send details home of interesting sites and actual finds. Consuls could also be involved in trade, as was Harborne in Constantinople from 1583, on whose

10 Quataert 2005, 111-141: The Ottoman economy: population, transportation, trade, agriculture, and manufacturing. 
initiative the Levant Company operated in Syria. ${ }^{11}$ During the 19th century the population of some areas increased at the expense of others, and deserted areas such as the Hauran (until re-population efforts in the late 19th century) preserved many ancient monuments intact, including thousands of houses.

There were several aspects of the country with which Westerners would have been unfamiliar. One was the sharp population divide between the sedentary and the nomadic, continuing well into the 2oth century. Nomadic bedouin made some towns and villages uninhabitable, roads dangerous, and turned good agricultural land into desert - all problems which we shall find travellers describing in detail in the following chapters. Campbell in 1758 noted that "they never inure themselves to any labour; their constant employment is riding, feeding their flocks, and robbing on the highway. ${ }^{p[6]}$ Nor was there just a division between settled and nomadic, for "all [the tribes and sects of Syria] seem to vie in perpetuating the respective virulence and antipathies of their ancestral schisms, and each class lives in distinct and recognized habits of separation from all others." ${ }^{\text {[7] }}$ Travelling could end in death, which discouraged others. ${ }^{[8]}$

Prejudice against Islam informs some judgments helped by the contribution of Christian art. ${ }^{12}$ Reid believed it was the Christians who kept the country going, building bridges etc "while the Turks sat and smoked their pipes." ${ }^{[9]}$ Wortabet had a vision of "when the Cross will be elevated above images and superstitions... when ports are whitened with the sails of commerce, and plunder, confiscation fills the land with plenty; when justice substitutes despotic will, and order arises from a heap of confusion., ${ }^{[10]}$ From the mid-19th century, what is more, Christian monasteries and missions proliferated in Syria, naturally spreading western ideas, one of which was the Holy Land where "the Jews shall again possess the land of their fathers," but with the problem of clearing out the present inhabitants by purchase, emigration or force. ${ }^{[11]}$ The difficulties did not stop Oliphant, author of The Land of Gilead (1881), for attempting to help the Jews in the 188 os. ${ }^{[12]}$

11 Hachicho 1964, 22: "Richard Forster was appointed as the first English consul in Syria on the 3 oth of June, 1583, with Tripoli as his residence. The jurisdiction of the first consul extended to Aleppo, Damascus, Tripoli, Jerusalem, Amman and all other parts of Syria and Palestine."

12 De Francovich 1984, 1-6o L'arte siriaca e il suo influsso sulla pittura medioevale nell'Oriente e nell'Occidente; ibid. 190-201 La problematica dell'arte siriaca - because of its complicated sources, where often we have a result (Vienna Genesis) but no source. Fansa \& Bollmann 2008 for 4 th -7 thC Christian art in Syria. 


\section{Governance}

The universal desire expressed by all classes of people in this country, that a European Christian power should be induced to come and take possession of it. Four thousand British troops ... with the indubitable assistance of the native inhabitants," would easily take possession of all Syria... Acre and El Arish secured, Palestine could oppose little resistance. ${ }^{[13]}[1830]$

If the above quotation was unduly optimistic after Napoleon's failure both in Egypt and before the walls of Acre, yet in the same year it was written the French landed in Algeria and colonised it, an early stage in the development of their empire. ${ }^{13}$ Well before 1900 , as we shall see, travellers observed in Syria a country which they considered to be in difficulties, and certainly not fulfilling its potential. If they tried to enter by sea, their experience of ports and harbours immediately set alarm bells ringing, as we shall see in Chapter Four (The Seabord, Harbours, Ports). They attributed the country's failings to what they saw as a lackadaisical government lacking in vigorous action to repair earthquake damage or to tackle the causes of disease, little interested in pursuing the development of agriculture or trade, with a declining population sometimes at each others' throats, an uncertain rule of law, the whole bottled up at the western shore by degraded and useless harbours, and at the eastern margins by desertification. The "reckless profligacy and licentiousness which it sanctions and encourages must ever be productive of both moral and physical degeneracy." ${ }^{n}[14]$ As Olivier opined in 1803 , the locals were "d'indolens et stupides Musulmans... des Arabes indomptés... ce sont des plaines fertiles, des vallons arrosés, des coteaux verdoyans." ${ }^{\text {[15] }}$ Or as Addison remarked in 1838,

the land presented one scene of robbery, plunder, confiscation, and massacre ... no settled laws or fixed principles of justice... the annual production from employed capital gradually diminished; the wealth of the country gradually decreased, and the population with the means of subsistence. ${ }^{[16]}$

Nor were the Turkish military to be trusted, a British expedition in 1840 concluding that "how utterly useless and unavailing was any attempt at co-operation with a set of ignorant and prejudiced barbarians." ${ }^{[17]}$ Brocchi even developed a theory that the fertile lands around Baalbek were left uncultivated because central government was afraid the Pasha of Damascus would seize them. ${ }^{[18]}$

13 Aldrich 1996. 
Some travellers, however, were "cautious of charging to the character of a people what the nature of their government seems to require," ${ }^{[19]}$ and it was equally true that the prosperity of Syria depended at least in part on that of its European trading partners. ${ }^{14}$ It was not only travellers who observed Syria, of course, since there were plentiful data on the country gathered during Western occupation from the Crusades onward through settlement, trade and diplomacy. ${ }^{[20]}$

Also very noticeable was what Farren called "the total want of public spirit in the Government," which simply did not work, so that taxes were not well collected, "national works and public establishments fell into decay, and the country was left to its own local administrations." ${ }^{\text {[21] }}$ For Reid in 1840, it was the Turks who were to blame who, "after they conquered a rich and fertile country, abandoned in a great measure their predatory habits; preferring ease and idleness in the enjoyment of their conquests ... and with sloth, consequently, the Turks increased in apathy and indolence every generation." ${ }^{[22]}$ Because of the dearth of planning and oversight, even fertile regions such as the Bekaa were inadequately worked: "This arises from the indolence of the Mussulmans, who are sedentary Arabs; the oppression to the Christians; the enormous rents levied by the holders of the property which, belonging principally to the Sultan, is farmed out to inhabitants of Damascus." [23] But as Lindsay remarked, while casual visitors were obliged to record what they saw, "the springs of evil, the sources from which the tides of misery flow, are remote and inaccessible to him without the assistance of a guide." ${ }^{[24]}$ For many travellers, then, the Ottoman government was the cause of a general malaise. Buckingham visited a village near Bosra in 1825 , largely inhabited by Druze:

The industry of these people was apparent, in the superior order and neatness every where conspicuous, as well as in the more cultivated state of the land. In this instance, as in a thousand others I had witnessed, it was easy to be perceived how much the whole country might be benefited by a change of government. Wherever the despotism of the Turk extends, every motive to improvement is taken away, and every exertion paralysed. ${ }^{[25]}$

14 Issawi 1988, 56-59: Problems of Development of Syria, 1878. See 56: "The decay since 1865 ... civil government... occasional bad harvests, low prices in Europe... stagnation and want of confidence engendered by war at home and abroad." See Pamuk 1987 for the consequences of European economic penetration on agriculture and manufacturing. 
Because of his ability to exert authority and improve civility, matters improved but only temporarily under Ibrahim Pasha (1759-1848), the ruler of Syria 1831-40, and son of Muhammad Ali (1769-1849) pasha and then viceroy of Egypt ${ }^{[26]}$ of whom even desert-dwellers as far as Palmyra stood in awe. ${ }^{[27]}$ As Caraman wrote in 1841, his son's achievement included "l'établissement d'un pouvoir unique, dont la conséquence immédiate a été une sureté complète sur les routes, tant pour les transports du commerce que pour les voyageurs."[28] But safety did not last: in 1843 Millard flagged the change, with the Christians claiming they needed to be governed:

The Arabs in the Holy Land go armed with pistol and sabre, while robberies and bloodshed are frequent. Frank travellers not only need to go armed themselves, but to hire armed escorts for their personal protection, in passing certain dangerous sections. ${ }^{[29]}$

Nobody should have been surprised, for the Egyptian troops had been badly beaten in 1838 by the Arabs in the Hauran. Tischendorff, writing in 1847 , suggested most unrealistically that the European powers should have "obtained from the Porte the requisite guarantees, or at least a constant military escort for travellers in that country, who are always under their combined protection."[30] The plain fact was that Constantinople was too far away to offer reliable help.

In 1878 Farley wrote a chapter on The future of the Ottoman Empire, detailing administrative corruption, with "no interest in government except so far as they can make it minister to their cupidity and lust." He stated (against plentifully available evidence to the contrary) that "Turkish rulers do not want reform, and they would not introduce anything worthy of the name even if they could." [31] Such judgments by travellers are harsh, but can be part-forgiven because, as already noted, they contrasted Syria with what they same back home - namely increasing prosperity stemming from agricultural and town development, and improved communications, with development undertaken by both private individuals and government. If seeing Syria as a land unchanged since biblical times was something of a topos, as we shall see, the frequent comparisons made by travellers underline how ripe was Syria for development in the western manner, for she was easily defensible, and could be very productive. ${ }^{[32]}$ Yet by the $1830 \mathrm{~s}$

it is poorer, less peopled, less cultivated, and possesses fewer natural resources than at any period in its history since the time of Solomon... plains, possessing a fine cultivable soil are now desolate and 
neglected ... the country generally is deprived of inhabitants... the small population at present existing, is collected in thinly scattered villages and towns. ${ }^{[33]}$

Bar-Yosef reasonably suspects that one motive for Europeans was that "travellers based their claim that the land, once flowing with milk and honey, had deteriorated under Muslim rule."15

The government of the country attracted consistent criticism. Not only were considerable parts dangerous, but "the whole is exposed to equal inconvenience and wretchedness by the tyranny and despotism of the Pashahs." Each local official

appropriates to himself whatever he can lay hands on, and oppresses those below him; while, for the sake of securing his ill-gotten plunder, he propitiates his superiors by bribery and adulation... The country has thus been robbed of its wealth, and a tax imposed on industry. ${ }^{[34]}$

What is more it was unenterprising, for "cultivation is carried on no farther than necessity compels the inhabitants to attend to it."[35] If local rulers were a problem, so was central government, which conscripted soldiers, hence "the fields had been left uncultivated, and famine was added to the calamities from which his unhappy subjects had to suffer." ${ }^{[36]}$ Land tenure was a further problem, and badly managed. ${ }^{[37]}$ Nor did government solve the antagonism between settled populations and nomadic or semi-nomadic bedouin, ${ }^{[38]}$ who robbed them (as well as travellers, as we shall see), and were a brake on any farming development beyond immediate needs. ${ }^{16}$ In other words, the fields were capable of producing large crops and heightening farmers' prosperity, but defending them against marauders meant that any such extended planting was pointless.

Fear and distrust of the Bedouin was long-standing, Ibn Khaldun underlining in the later 14th century that where they held sway, towns were abandoned and civilisation disappeared: "De nos jours, la Syrie est ruinée; l'Ifrîkiya et le Maghreb souffrent encore des dévastations commises par les Arabes."[39] Plaisted in $175^{\circ}$ could not "see how they can be trusted; for they make a trade of robbery, and are brought up to it from their infancy."[40] They were still a

15 Bar-Yosef 2005, 82.

$16 \quad$ Karpat 1985, 61. 
problem in the 19th century, ${ }^{17}$ and De Vogüé quite properly defined the central part of the country as a desert:

l'espace parcouru par le nomade et dévasté par ses troupeaux. Quand, par suite de la faiblesse du gouvernement turc, les tribus envahissent le territoire cultivé, la population et la culture disparaissent, les villages abandonnés tombent en ruine, les champs se couvrent d'une végétation parasite, le désert gagne. ${ }^{[41]}$

A consequence of poor Ottoman governance was their inability to control tensions between their diverse populations. Their policy from the 1840 of divideand-rule was directed against the turbulent Druze, as a way of containing them in their mountains. This eventually stirred up hatred against Christians, who had been safe under the rule of Muhammad Ali. ${ }^{[42]}$ Some 11,0oo Christians were massacred in 1860, including about 2,00o in Damascus, and more in Aleppo, ${ }^{[43]}$ although the Druze claimed they had killed 22,00o. ${ }^{[44]}$ Tobler in 1859 recounted stories of Mohammedan fanaticism in Jerusalem, and murder at Jaffa. ${ }^{[45]}$ Sections of Damascus lay in ruins for several years. ${ }^{[46]}$ Without the intervention of the Algerian hero and French bugbear Abd-el-Kader (who lived in Damascus), the death toll would have been much higher ${ }^{[47]}$ The deaths culminated (too late) in armed European intervention, the French occupation of Lebanon, and a continuing conviction amongst Europeans in Damascus that "a scent of fanaticism, lust, and bloodthirstiness is on the very air. Uncaged tigers would not quicker leap to carnage than, dared they, would these tigers of Allah." ${ }^{[48]}$ To which Walpole in 1851 responded "Is there none among ourselves? High Churchman and Evangelical; Roman and Protestant; Greek and Armenian; Nestorian and Maronite; - have they toleration?"[49] Yes, but not the deadly fanaticism which caused such massacres, provoking the intervention of the European powers. By 1865 Paul could count their continuing seaboard presence, with nearly 600 troops and " 56 canons très-respectés des Turcs et des Druses."[50]

\section{Earthquakes and Disease}

Dangerous, dreadful, and terrible earthquakes often take place, not only in the kingdom of Jerusalem, but also in the countries round about, especially by the seaside... cities, with their walls and towers and other

Issawi_1988_59-61: Tribes in the Syrian Desert, 1880. 
buildings, suddenly fall down, and, taking the people unawares, smother and overwhelm them. ${ }^{[51]}$ [early 13 thC]

Syria is prey to earthquakes, ${ }^{18}$ and several of these devastated monuments and population, often occasioning decades of ruin and disease, as perhaps the Bible accounts of the destruction of Jericho, Sodom and Gomorrah. Even fortresses, and sturdy temples such as Baalbek, retain evidence of earthquake damage. ${ }^{[52]}$ For if the fortress at Banias was strongly built, "how much more powerful that hand which, in a single moment, destroys the most colossal of human productions!"[53] Here is a listing of just a few of the fixed dates and generic results from Late Antiquity onwards:

315: Aréopolis [Moab, Rabbat-Moab, er-Rabbah]; [54]

551: all of Palestine, especially the seaboard, with tidal waves, ${ }^{[55]}$ sunken ships and a retreating sea; ${ }^{[56]}$

723: throughout Syria, drought followed by storms and earthquakes; ${ }^{[57]}$

1115: Antioch region; ${ }^{[58]}$

1170: Aleppo, Antioch and the coast, its effects described by William of Tyre; ;59]

1759: columns are brought down at Baalbek;

1822: Aleppo region: completely ruined the town, including fortress and walls, ${ }^{[60]}$ plus 40,000 houses. ${ }^{[61]}$ Beirut still clearing the mess in $1833-40$, with only a single jetty to the vulnerable and clogged up harbour; ${ }^{[62]}$ Antioch also ruined, its inhabitants living in light and low houses for fear of being crushed; ;63]

1837: Palestine, demolishing Safad (killing over 5,000 ) and devastating the coast from Acre up to Aleppo. At Tiberias, ${ }^{[64]}$ the town wall was much damaged: "The ancient city is scattered promiscuously along the shore of the lake, but there isn't enough of it to make more than half-a-dozen hogyards." [65] At Seleucia, the port for Antioch, "the columns which had been seen still erect by former travellers, had been thrown down by the great earthquake ... destroyed many other remains of ancient buildings which had existed not many years before."[66] At Antioch there were some colossal rock-cut sculptures on Mount Silpius, but these disappeared as a result of the quake. ${ }^{[67]}$

If earthquakes devastated buildings, they also had consequences for prosperity, and induced the decline of Aleppo. Thus after the 1822 earthquake, the

Ambraseys 2009, passim. 
European merchants moved outside the town and built wooden houses. ${ }^{[68]}$ Over a decade later, the town was still full of piles of rubble, some as high as the crumbling walls, ${ }^{[69]}$ and "à chaque instant, on trouve la voie publique encombrée par des ruines de mosquées et d'autres édifices renversés."[70] Robinson mourned in 1838 that "elle est tombée aujourd'hui dans un état tout-à-fait insignifiant, tant sous le rapport de la localité que sous celui de la politique, en la comparant à son ancienne splendeur."[71] Layard visited in 1839, and found "some portions of the city were entirely deserted, the houses for the most part falling to ruins, the bazaars, although extensive, poorly provided, the inhabitants in general with a hungry, impoverished look."[72] There were mosques, empty or filled with rubbish, in 1880 , and the population was down by twothirds to $100,000 .{ }^{[73]}$ In other words, the earthquake set the seal on the decline of Aleppo's commercial prosperity. Robinson had noted the same effect from the identical cause at Lattakia in 1838 . ${ }^{[74}$

Even the Europeans could not blame the Ottoman government for earthquakes, but they saw and expressed their bewilderment at the resultant living conditions when steps were not taken to mitigate their results. Disease was the constant spinoff of earthquake damage unrepaired for decades or even centuries. Stagnant water was a constant problem in the coastal towns. And, as Ibn Khaldun implied, decadence encouraged disease. ${ }^{[75]}$ Volney in 1792 reported that a third of ships' crews spending summer at Iskenderun/Alexandretta would die, with only lesser problems at Tripoli, Acre and Larnaka. ${ }^{[76]}$ At Iskenderun, which awkwardly had the safest bay on the coast, the problem was a pestilential marsh: "Under any other Government this swamp, which is of no great extent, might have been drained with little trouble and at little expense." As a result, the port "had gradually dwindled down to a mere collection of native huts, mingled with the more pretentious houses belonging to the few Europeans who were compelled, by their official positions, or from their business as merchants, to reside there." ${ }^{[77]}$ By the 1870 s the port was little frequented, and the "grands marais qui entourent la ville" were still there. ${ }^{[78]}$ These were also snake-infested, and the fishermen "ont imaginé d'élever leurs maisons à une hauteur de 8 ou 10 pieds, pour éviter les miasmes pestilentiels et les morsures des reptiles" [79] - or, in another report, to protect them and their provisions from jackals. ${ }^{[80]}$ In other words, they were living with the problem instead of solving it.

It was impossible for Europeans to live at Iskenderun, and in 1881 it was misleadingly reported to the Committee in the House of Lords on the Euphrates Valley Railway Scheme: "and that if they only slept one night in the town certain death would follow after fifteen days." ${ }^{[81]}$ However, its location does bring to mind the several variations on "Beware beware, the Bight of Benin: one comes 
out, where fifty went in!" Just down the coast was Lattakia, where in 1759 it was noted that "it is strange that a town should be erected in so unhealthy a situation, amidst morasses and standing waters, the effluvia of which must naturally corrupt the air." ${ }^{\text {[82] }}$ Of course, disease also affected travellers, Guérin in 1859 using his companion's "malencontreuse maladie" as the reason for not completing his mission, "originally intended to include Arabia Petraea, Palestine and Syria." ${ }^{[83]}$ And in 1876 , Mislin missed a visit to Baalbek because of false reports that there was cholera. ${ }^{[84]}$

Plague was endemic in Syria, and towns were frequently closed against travellers, and quarantine enforced. "Arrived at Aleppo," wrote one traveller in 1669, "where there died at that time seventy or eighty in a day of the plague, and thus ended our journey." ${ }^{\text {[85] }}$ Mariti's first task, landing at Haifa in 1791, was to check for plague in the region. ${ }^{[86]}$ During Napoleon's 1799 invasion (and separate from Gros' Plague House at Jaffa), plague took five hundred of his troops, and "not less than twelve thousand of their best troops having, according to authentic accounts, perished either by the sword, by disease, by hunger, or by fatigue., ${ }^{[87]}$ In 1816 Bankes encountered fleas in a church where his party slept, and then smallpox at Caesarea. ${ }^{[88]}$ Disease was also related to trade, since incubation under quarantine (the British Parliament passed an act in 1753) meant that nations less scrupulous in enforcing such rules gained trade which other countries lost. ${ }^{[89]}$ Westerners could help, since many of them had medical knowledge, and on at least one occasion (in 1816) vaccinated a group of locals at $\mathrm{Al}$ Qaryatein. ${ }^{[90]}$

\section{Trade}

Trade provided the sinews of ancient prosperity, ${ }^{[91]}$ and it was the premier channel by which 19th-century western countries prospered. Knowing it was ancient Rome's conduit for goods from India, ${ }^{[92]}$ travellers viewed Syria in the same fashion. ${ }^{19}$ They assessed its profitability, and potential for European intervention and hence profit. This could be far greater than that provided by a few factors and middlemen along the coast and, especially, at Aleppo, wealthier if with fewer monuments than Damascus, ${ }^{[93]}$ where foreign merchants were subject to tiresome restrictions, ${ }^{[94]}$ and even spat upon. ${ }^{[95]}$ At Tyre, stones were thrown by children in 1858 , without adults reproving them in any way. ${ }^{[96]}$ Competition was rife, especially between Britain and France,

19 Hachicho 1964, 22: "The main interest of English trade in Syria was to exchange English wool for Persian silk and the galls of Mosul and Diarbakr. Syria was only the scene of this mercantile activity, and Tripoli was the only port open to European ships." 
Drummond estimating in 1754 that the Levant trade supported over 100,000 people and, that, "in a word, the French are intent upon undermining us."[97]

Of course, such competing interests were much wider than commerce, and were long-lasting. ${ }^{20}$ For Houry in 1842 the central government (the Porte) was "ennemi du commerce et de l'industrie, habitué à vivre de rapines, de pillages et de crimes," with plague and barbarism responsible for transforming ports and cities into ruins. ${ }^{[98]}$ Europeans were well aware of the part played by their merchant navies in bringing goods via the Cape of Good Hope (from 1486), and thereby cutting out the trans-shipment on which Syria had once thrived. From the 14th century, even Crete was taking advantage of Syria's relative decline. ${ }^{21}$ Aleppo was "autrefois l'abord de toutes les marchandises qui se transportoient de Perse \& Indes Orientales en Europe, ${ }^{,[99]}$ and a straw in the wind was Venice's difficulty in inducing their civil servants to go to Damascus. ${ }^{[100]}$ In 1841 Poujoulat re-iterated the reasons for Aleppo's fall: the Cape of Good Hope, English competition, Smyrna and Erzerum. ${ }^{[101]}$ With the growing importance of sea-born trade, Stewart in 1857 suggested a British consular presence at Acre, Sidon and Tyre, ${ }^{[102]}$ at least in part to counter the perennial and predatory pressures of French trading. French policies toward Syria around the time of the First World War were also tied up with trade. ${ }^{22}$

Browne believed that Aleppo was still flourishing at the end of the 18th century, especially in silk and cotton, ${ }^{[103]}$ but by the 1830 ser port of Alexandretta was in steep decline, with poor and tedious connections with Aleppo herself, and exportable goods in such a dribble that "aucun bâtiment, à moins d'être particulièrement nolisé, ne peut espérer obtenir un chargement entier dans un seul port de la côte." ${ }^{[104]}$ In 1896 Masson charted Aleppo's decline from the first rank of Levant trade ${ }^{[105]}$ at the beginning of the 17 th century: it fought for its premier place in the $17^{\text {th }}$ century, as the Dutch and British encroached, ${ }^{[106]}$ so that it housed 40 French merchants in 1630, 15 in 1653 and 16 in 1693, of whom five were about to leave. ${ }^{[107]}$ As a result of Napoleon's unsuccessful incursions, French trade diminished as Britain's grew, ${ }^{23}$ but she had already been

20 Nevakivi 1969, 4-16: outline of British and French interests in Syria early in the 2oth century.

21 Fusaro 2015, 40 Crete: From the fourteenth century, taking advantage of the decline of Syrian and Egyptian production, sugar had been produced, but cotton and wine also were widely exported from the island.

22 Andrew \& Kanya-Forstner 1981: pre-war, wartime and post-war policies toward Syria.

23 Laidlaw 2010, 223, Levant Company: "financial responsibility for representation in the region was removed from the company, which had borne the burden of it for more than two centuries, and assumed by the crown." 
undercutting Britain drastically in a pricing war. ${ }^{24}$ By the mid-19th century, because of her modernising port facilities, "Beyrout est devenue la place la plus importante de tout le littoral, l'entrepôt de tout le commerce de la Syrie,"[108] partly under increased British trade..$^{25}$ And in spite of the danger of pirates at sea and brigandage on land, Europeans would continue to buy those products from the East brought overland by increasingly rare caravans. ${ }^{[109]}$

If Europe had started by wishing to purchase exotic items from the East, and was importing grain from Syria in the 17 th century, ${ }^{26}$ by the 19 th century the boot was on the other foot, for she needed the East to purchase her manufactured goods. Nomadic ravages destroyed agriculture, and sent peasants into the towns, while cheap European goods devastated the less mechanised local manufacturing. ${ }^{[110]}$ Hence Gallois in 1907 could not only cringe before the dirt of Damascus markets, but also complain that not only was there a lack of the picturesque, but that "l'on ne voit guère aux étalages que des marchandises européennes fabriquées en Angleterre, Autriche, Italie, Allemagne trop souvent, et en France trop rarement, hélas!" [111] Such imports changed the complexion of the country: if in the 1870 os Conder could visit communities where his was the first western face, by 1882 "Western fabrics, Western ideas, and even Western languages, meet the traveller at every point." ${ }^{[112]}$ Enterprise on the part of the Syrians could also have fed the markets of Europe, but "è la inerzia eccessiva de'coltivatori suoi, che non aiutando la natura coll'arte, non allettano i commercianti colla facilità di trovare immensa quantità di oggetti da esportare."[113] In 1861 the Comte de Paris noted the lack of prosperity, lowered agricultural productivity and consequential decline in population, concluding that

la ruine du commerce et de l'industrie rend la Syrie dépendante de l'Europe; et l'Occident, qui ... avait longtemps commercé avec lui sur un pied d'égalité, se trouve aujourd'hui chargé de l'approvisionner. ${ }^{[14]}$

24 Göçek 1987, 98B: "The French gained superiority over the British in the Ottoman market through reducing prices by ten percent. By 1740 , while the number of trade vessels the British sent to the Mediterranean was around ten, the French sent as many as seven hundred."

25 Issawi 1988, 163-172: British Trade and the Rise of Beirut, 1830-1860.

26 Fusaro 2015, 277: "from the 1620 s they [the Flemish] provided a steady flow of grain from Palestine and Syria into Tuscany." 
Westernisation provoked a preference for Western goods, amd saw the decline of local crafts, while land under the control of waqfs (there was little private owndership) was frequently abused by entrepreneurs. ${ }^{27}$

\section{Circassians and Other Settlers amongst the Monuments}

The fact of low population over large parts of Syria was demonstrated to our travellers by abandoned houses and even completely deserted villages, as well as good agricultural land lying uncultivated. Baalbek's village was frequently visited, and Lucas reckoned it had some 8,00o inhabitants in 1714. ${ }^{[15]}$ Addison thought there had been 5,000 in 1751 , but he found only 200 in 1838. ${ }^{[116]}$ Buckingham counted 500 in $1825 .{ }^{[117]}$ As Butler noted with astonishment, it was reckoned that once the whole region "more than 20,000 square miles was more thickly populated than any area of similar dimensions in England or in the United States is today if one excludes the immediate vicinity of the large modern cities." [118]

Of course, ruins were all around and, although there was 17th and 18th century evidence of some movement into towns, ${ }^{28}$ these were ipso facto proof of depopulation. In the late 18th century, in the pachalik of Aleppo, 3,200 villages were on the tax rolls, but only 400 survived, because "les paysans avaient fui dans les villes ou dans les montagnes." ${ }^{[119]}$ As late as 1918 Smith wrote of one abandoned settlement every mile from Antioch inland. ${ }^{[120]}$ Griffiths, travelling from Antioch in 1805, "passed the ruins of several villages and fountains, that established additional proofs of the depopulation we had frequent occasion to notice."[121] Kelly in 1844 thought that "the inhabitants may be considered, on the most moderate calculation, as reduced to a tithe of what the soil could abundantly maintain under a wiser system of administration." He thought the whole country contained less than two million people, yet "they form an assemblage of tribes rather than a people; for they are not only destitute of every principle of national association, but denaturalised from such a relation by the reciprocal antipathies of their respective castes." ${ }^{[122]}$ The Lebanon, wrote Laurie in 1866, had about 400,000, and town populations were not high: 50,000 for Beirut, 120,000 for Damascus, Aleppo 70,000, Antioch 20,000, and

27 Rafeq 2002, 107: attempt by industrial Europe to control the markets of Syria; ibid. 116 for the exploitation of land for profit.

28 Nour 1982, 367-397: La ville et les ruraux. Baram \& Carroll 2002, 85: "The end of settlement was part of a massive abandonment of villages in Greater Syria during the 17th and 18th centuries, attributed to economic and political instability (Hütteroth 1975)." 
Jerusalem $18,000 .{ }^{[123]}$ Munk took a different approach in 1845 , estimating four million at the time of Titus; ${ }^{[124]}$ and Smith in 1918 pointed out the depopulation of Moab since Byzantine times, and the absence of the vines praised by Arab geographers. ${ }^{[125]}$ In 1875 Hamilton thought there must be a lot to be found in Moab, "though I should decline (with thanks) to go digging among these Bedouins;"; ${ }^{[26]}$ while in mid-century Bunel remarked on the desolation all around Jerusalem. Was there life inside that city? "Triste déception! à peine en a-t-on franchi le seuil, que l'on n'y retrouve qu'un désert au milieu d'un

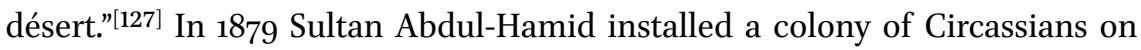
the territory of Baalbek, "et ces colons eurent tôt fait de remployer les pierres des monuments antiques." 29

One solution to depopulation, and a precondition to economic development, was to import settlers from other parts of the Empire under advantageous terms. This had of course happened for centuries, as when Harun al-Rashid introduced settlers to Tarsus in the 8th century, or when certain groups were moved from military sensitive areas. ${ }^{[128]}$ It happened on a very large scale in Syria, ${ }^{30}$ and such movements often had devastating effects. ${ }^{31}$ Caesarea was settled by a Bosnian colony about 1880, where the ruins were quarried, delivering "immense quantities of building material, which they have shipped on little steamers to the towns up and down the coast." ${ }^{[129]}$ Between 1880 and 1914 Circassians came in large numbers from the north-western part of the Caucasus to Aleppo, Damascus and Palestine, ${ }^{32}$ with some fleeing first to the Balkans, and then further east and south. ${ }^{33} \mathrm{~A}$ foretaste of the problems came in the 186os, with their settlement on the plains near Antioch:

29 Goosens 1943, 27; 22-29: historiography and archaeological exploration. The accounts of Rey (1864), Smith (1876) and Sachau (1879) tell of surviving monuments - but later authors record their swift disappearance.

30 Karpat 1985, 62: "The Ottoman government... [decree of 1857] declared that migration into the Ottoman state was open to anyone who was willing to give his allegiance to the sultan, to become his subject, and to respect the country's laws... religious freedom ... The government promised to give the settlers, without any charge, the best arable lands owned by the treasury and to exempt them from all taxes and military service... for twelve years, if they settled in Asia." [NB Syria was considered part of Asia.]

31 Quataert 2005, 116-118: migrations from 18th century and their effects.

32 Karpat 1985, 70: Circassian immigration to Aleppo, Damascus, Adana etc, plus Palestine: "at least half a million people were involved in the Caucasian immigration of 1881-1914." [not all of them into Syria/Palestine].

33 White 2011, 41: Karpat notes that some of the Circassians fled twice: from the Caucasus to the Balkans in the 186os, and from the Balkans to Anatolia and the Levant in the 1870 s. James Meyer argues that the Russian Empire generally tried to keep hold of its Muslim 
Robbery seems to be their present pursuit, while preparing to form agricultural settlements. It would surely have been wise to reflect whether or not the authorities, under whose rule they are intended to establish themselves, are in a position to preserve order before thus adding to the number of a disorderly population. ${ }^{[130]}$

Administrators might have forseen the problems the immigrants would cause, given that they were the very ethnic group who provided centuries of Mamluk rule in Egypt. They were often tough no-nonsense fighters, therefore prized members in the Ottoman military, and described in 1910 as "walking arsenals." ${ }^{\text {[131] }}$ They were to be used as soldiers during the French Mandate, and Vichy instituted a Circassian cavalry, the Gardes Tcherkesses. ${ }^{34}$ For, of all Syrian minorities, they identified closely with the French. ${ }^{35}$ Mamluks were in vogue. Napoleon had Roustam Raza, a Georgian slave boy presented to him in Cairo, and always dressed as a Mamluk; and then Ali as a faux-Mamluk bodyguard from 1811, in fact a Frenchman named Louis-Étienne Saint-Denis, born in Versailles.

The authorities must have known that they were sending settlers to lands with agricultural potential. They should also have known, but evidently did not care, that the only way such settlers could survive was by vandalising the ancient monuments they found there to build shelter and farms. As the French learned during the 19th century both at home and in North Africa, modernising development frequently entailed the death of the monumental past. Occasionally, it could also create new monuments, as with Damascus, where the Monument to the Hidjaz Telegraph, in Marja Square was a triumphal column, with mosque and ship, celebrating the Istanbul-Damascus-Mecca link, which freed them from using the European-controlled system. ${ }^{36}$

population, and notes that some (though not many) migrants returned to Russia temporarily or permanently.

34 Gingeras 2009, 2: "From the first centuries of Ottoman expansion, Circassians and Albanians were counted among the highest-ranking officials and officers as well as the most insidious bandits and rebels." Ibid. 28, of Anatolia: "Reports from local Ottoman officials consistently mention the prevalence of paramilitary activity among rural Circassians."

35 White 2011, 52: "not identified with a neighbouring state or with neighbouring populations. Rather, like Syria's Christian communities it was often identifed with the French High Commission; for example, because of the latter's heavy recruitment of Circassians into its armed forces, and the willingness of Circassians to be recruited."

36 Weber 2009, Figs 1, 82-5, 583-4. 
As settlers, the Circassians were methodical and organised, "perfectly fearless in attack or defence," and acting in the Amman area (where they paid no taxes) as a substitute for the military in keeping the Bedouin subdued: "they have succeeded in inspiring their neighbours with respect or, perhaps, awe."[132] They were generally just dumped in their new locations and left to fend for themselves, building settlements by preying on any ancient monuments they could find (the French dumped new settlers in Algeria under similar conditions, and with the same results). Around Jerash and Amman they certainly sanitized areas of Bedouin insurgents, because they were settlers but also threw the Beni 'Abbad off their ancestral lands, so that in 1884 these supposedly fierce Bedouin warriors actually contemplated bribing the Circassians to clear out. ${ }^{[133]}$ Enterprising traders as well, they also cut down forests, and carried the wood "on their horrible squeaking two-wheeled carts, drawn by oxen, to sell as timber."[134] (Wheeled transport was not common, and travellers generally went by camel- or horseback, especially in the mountains. ${ }^{[135]}$ ) Industrious and persevering, around Kuneitra (in the Jaulan/ Golan) they "built villages, cultivated the fields, bred cattle, dried grass for the winter, and drove the Bedawin out of their neighbourhood." ${ }^{[136]}$ At Nawa in the Hauran, for example, they also supplied the locals with wooden roofing to complete their houses: "ancient building-stones, of which there is an abundance, are used for the side-walls, the roofs being formed of tree-trunks brought from the forests of Northern Jaulan." [137] The re-used stones were not only Roman, but some with Jewish symbols. ${ }^{[138]}$ Had there been no wood supplied, some monuments might have survived, since the locals presumably did not have the expertise to replace their original stone (sometimes vaulted) roofs. The distinction between the Hauran houses and the Dead Cities was clear to Finati in 1816: "there occur large ancient towns in ruin, but they differ from those of the Hauran in being roofless, ${ }^{[139]}$ this being one explanation for a now-treeless landscape.

However, the Circassians did immense damage to the ancient monuments, which they re-used as building materials. There were few illusions about the danger to what remained, Burton writing in 1872 of a 35 -day journey recording "the positions of some fifty ruins, which, in presence of the Circassian immigration, now a fait accompli, are fated soon to disappear from the face of earth." ${ }^{[140]}$ This also happened at Jerash: the Circassian village was six minutes from the triumphal arch, but we will never know what antiquities might have survived there, for "Le sol couvert par les ruines est réduit en champs cultivés." ${ }^{[141]}$ Evidently the ruins did not matter, and indeed, we may suspect that the Circassians were dumped at both Jerash and Amman not simply because of the known fertile land. Inevitably, the Circassians at Jerash were 
reported to have found a pot containing "countless gold coins of large size, which same had not all, as yet, been delivered over into the hands of the officials of the Ottoman Government, to whom all treasure-trove is lawfully due."[142] At Amman by 1900 there were some 500 brick houses, but "it distressed us to see how rapidly the ruin of the ancient buildings was being made complete... the few stone houses are built largely of dressed and sculptured blocks." ${ }^{\text {[143] }}$ In one sense the Circassians were an antidote to nomadic Bedouin. As Gertrude Bell wrote in 1906, "their summer quarters are gradually being filled up with fellahin, and still worse, their summer watering places are now occupied by Circassian colonists." At Amman the Circassians ("a disagreeable people, morose and quarrelsome, but industrious and enterprising beyond measure") were even denying the Bedouin access to water. ${ }^{[144]}$ Many Druze also decamped from their mountain fastnesses into the plains of the Hauran, in search of cultivatable land. ${ }^{[145]}$

The settlers noted by Burton at Amman were early arrivals (there was a spurt $185^{8-1862^{37}}$ ), and more arrived in subsequent decades, to the continuing distress of the monuments. In the Jaulan, Kuneitra (between Madaba and the Dead Sea) was at the centre of a group of villages, and was described by Burckhardt as having a strong wall, a good khan and a fine mosque:

Within the last sixty years the wall, the khan, and the mosque have all disappeared, and the place has been abandoned until a few months before our arrival, when three thousand Circassians arrived to people it. On the north side of the village are the remains of an ancient city - perhaps Canatha - but the ruins consist of little more than foundations. ${ }^{[146]}$

As early as 1885 , Le Strange gave up on sites by the Jordan:

It would be waste of time attempting to recall the wonders of Greek architecture that have hitherto lain peacefully entombed beyond the Jordan, but which are now given over by the Ottoman Government to be a habitation for Circassian colonists. ${ }^{[147]}$

37 Karpat 1985, 65-70: The Crimean and Circassian immigration. 67: "The Russians occupied Circassia for the good military and strategic reasons of the defense and security of the Caucasus... the conquest and expulsion of the Circassians from their lands... total number of of Circassians migrating in 1858, 1859, 1862, and in the summer of 1863 came to 80,000 , while in the spring of 1864 alone the number went up to nearly $400,000 . "$ 
600 Circassians were installed at Jerash, and Cuinet in 1896 noted that "plusieurs monuments sont encore debout presque entièrement." ${ }^{\text {[148] }}$ What probably happened was that the settlers filched materials from the ancient sites, and built their houses in surrounding villages, just as happened at Kuneitra, ${ }^{[149]}$ and also near Mount Hermon, where Oliphant reckoned that the Circassians carting away old stones must have given the bedouin their first sight of wheeled vehicles. ${ }^{[150]}$ The PEF Quarterly thought it would take two generations to complete the destruction of Amman, ${ }^{[151]}$ but luckily some protection of the monuments was introduced before they were all obliterated (see Chapter Eleven). They had not, for example, destroyed the theatre (too bulky and dangerous for them?), but housed their families in the vomitoria. ${ }^{[152]}$

At the same time as new settlers were cultivating the land and destroying monuments in the process, and at least in part as a reaction to the rapid annihilation of antiquities, the Palestine Exploration Fund developed into an important part of British interest in Syria from its foundation in 1865. Its aims were "the prosecution of systematic and scientific research in all the branches of inquiry connected with the Holy Land, and... the illustration of the Bible which might be expected to follow such an investigation."[153] It was an important element in European appreciation of the Holy Land, via scientific exploration and some digging. ${ }^{[154]}$ Mislin in 1876 marked the date as important for the country, for the Fund's aim was "dans le but de faire des fouilles régulières à Jérusalem et dans toute la Palestine pour l'étude des questions topographiques et archéologiques."[155] They would promote scientific research, including excavation, with the help of officers of the Royal Engineers. It was not, emphasised the Archbishop of York in his opening address, to be a religious society ${ }^{[156]}$ there were plenty of those. It was to deal as far as possible in facts, not opinions, although "conclusions as to identifications and topography" were welcomed by the subscribers. ${ }^{[157]}$

As well as in then-deserted plains further south, settlers also devastated ancient sites along the Mediterranean seabord, as Pickthall confirmed in 1918 when he visited an unnamed village:

The village on the headland took shape rapidly - a few cube-shaped, whitewashed houses perched amid what seemed at first to be great rocks, but on a close approach revealed themselves as blocks of masonry, the ruins of some city of antiquity. ${ }^{[158]}$

Flinders Petrie, writing specifically on the prospects for eastern exploration and digging, instanced the churches of Northern Syria as being "largely wiped out of existence by Circassian colonists, who quarried them to pieces... Are all these splendid remains of the early Christian period to be left as quarries for 
every squatter that takes to exploiting a free and civilized Syria?"[159] Ruined towns might frequently be occupied by squatters, as at Caesarea in the $1630 \mathrm{~s}$, where three or four hundred robbers lived in huts, and some would pounce on passers-by along the coast road, or even swim out to attack boats. ${ }^{[160]}$

Flinders Petrie sounded the alarm, expecting action to preserve what remained, and suggested a travelling inspector to "summon the headmen, proclaim that digging or damage will be punished, and leave a rough large-scale plan in bold writing, defining the Government reservation." ${ }^{[161]}$ He was far from the first to be alarmed by the disappearance of monumental remains.

As the PEF wearily noted in 1889, looking back over twenty years since their foundation, "several other instances could be named where grand old ruins are being torn down for building material since the Survey was completed." [162] This was perhaps displacement therapy, being a survey undertaken at least in part because permits for digging into the soil of Jerusalem were difficult to obtain. They knew whereof they spoke, since two years earlier they had listed new buildings in the plain around Caesarea where new buildings were being built from old, which had outdated the accuracy of their Palestine Map. ${ }^{[163]}$ But the rapine continued, and Baedeker noted in 1898 that "the work of destruction progresses rapidly; the Bosnians still do a brisk trade in the stones."[164] Hence Adolf Michaelis' 1908 listing of towns like Bosra and Jerash which were still disappearing fast, and scheduled to go even faster with the railway nearby: "the value of the old ruins for building material is increasing, and the reports of the disappearance of old buildings are most alarming."[165]

\section{Nomadic Arabs}

[On] the borders of Arabia and Syria... inaccessible except to the Bedawin and those who journey under their protection, fortunately "the desert tribes who have had undisputed possession for at least 1200 years are not given to architecture, and never were."[166] [1868]

Here Porter identified a characteristic much remarked upon by travellers in North Africa as well: the nomads lived in tents, and generally left the monuments alone - so they survived. Their fierce reputation probably helped: they protected their land, though not in any UNEsco sense the sites thereon.

If the borders were given over to the Bedouin, who owned and controlled Syria? Perhaps those who governed it? Westerners might naturally assume that the central government had control over the country and its monuments, which could then be visited safely. This was far from the case, not only because of local governance and the tenuous-to-non-existent impact of central 
authority, but also because the locals usually thought they "owned" their own territories, the more so when they were controlled by rapacious pashas. An Empire is not a nation, and such sentiments were tribal and ancestral, and nothing to do with nationalism. As we shall see in Chapter Two, travellers frequently came across nomadic arabs, of whose customs and way of life they had no prior knowledge. Nomads acknowledged no central authority beyond that of the tribal grouping, and controlled access to routes and sites in their areas, which could cover vast tracts of territory. Again in Chapter Two we shall see the exactions they made - robbery, according to the travellers; tribute according to the nomads, for safe conduct in their lands. However, as several travellers remarked, nomads were uninterested in monuments except for constructing walled enclosures for their flocks, ${ }^{38}$ or as camping grounds (and keeping travellers away in the process); hence they did little damage to ancient monuments.

Nomads were a continuing problem for travellers, but an immense one for central government. In the Middle East and North Africa, their characteristics had been studied and the problem endemic since well before the Romans. ${ }^{39}$ Enemies to Byzantium, it had been nomads who had extended Islam from Mecca to the Pyrenees, before most adopted the sedentary life. ${ }^{[167]}$ Ibn Khaldun deprecated them as the antithesis of the civilised, not least for their ability to provoke the abandonment of settled life. ${ }^{[168]}$

In Syria, Henniker in 1823 found Bedouin company boring, for "their conversation rests upon gunpowder, firearms, sheep, corn, water, feuds, murder, and tobacco," as well as an avaricious love of gold. ${ }^{[169]}$ From the mid-19th century, efforts were made to extend a cordon sanitaire around Damascus, to force the plundering Bedouin back into the desert, ${ }^{[170]}$ stopping their persecuting and feeding off the sedentary population. As late as 1881 government soldiers were no use against them: "the Turkish soldiers have, moreover, such fear of the Bedouins that in the event of any hostile attack they would not make a stand," so protection had to be purchased from them. ${ }^{[171]}$ Travellers learned to fear Bedouin, Lithgow likening them to jackals who would flee at the sound of a shot "as if the fiendes of the infernall Court were broken loose at their heeles." ${ }^{[172]}$ Seetzen ${ }^{40}$ in 1810 was not overawed by similar reports, "I had too good an opinion of the nomade Arabs to permit myself to be deterred," and survived. ${ }^{[173]}$ Some travellers gradually learned the cadence of their lives, with

38 Fortin 1999, 138: enclosures for their beasts using stone lying around.

39 Kennedy 2004, 43: 8thC Jordan: "The forces needed to police and guard against the nomads had in any case been largely replaced generations before the Battle of the Yarmuk by putting the control of the steppe and desert in the hands of nomad chiefs."

Schienerl 2000: overview of his travels. 
a search for pasture in the summer and then the purchase of provisions for the winter, "reviennent après les premières pluies dans l'intérieur du désert."[174] Such knowledge could help with avoiding encounters. Just as in Asia Minor, they were frequently seen as destroying settlements and occasioning the desertification of areas once fertile and prosperous, for example to the east of Hama, "the rich lands which the twin curses of Syria, the Bedawin and Misrule, have converted into the Great Syrian Desert."[175]

\section{Agriculture and Desertification}

Lorsqu'on parle des Arabes, on doit distinguer s'ils sont cultivateurs ou s'ils sont pasteurs... vivant sedentaires, attachés à un même sol, \& fournis à des gouvernemens réguliers, ils ont un état social qui les rapproche beaucoup de nous... dans le second cas, ne tenant à la terre que par un intérêt passager, transportant sans cesse leurs tentes d'un lieu à l'autre, n'étant contraints par aucunes lois, ils ont une manière d'être qui n'est ni celle des peuples policés, ni celle des sauvages... Tels sont les Bédouins ou habitans des vastes déserts qui s'étendent; depuis les confins de la Perse jusqu'aux rivages de Maroc. ${ }^{[176]}[1792]$

Volney's division in the above quote might well have been written by Ibn Khaldun in the later 14th century, for little had changed in the interval, and the latter's parameters for civilisation and its decline were still recognised. ${ }^{[177]}$ Also painfully evident was the country's erstwhile fertility, the Duc de Raguse noting of the Hauran in 1839 "où Job possédait de si grandes richesses: aujourd'hui, elles ne seraient pas moins fertiles, si la culture venait les mettre en valeur."[178] Volney confessed to how great was the contrast with France, after spending nearly three years in Syria:

Au lieu de ces campagnes ravagées \& des vastes déserts auxquels j'étois accoutumé, je me suis vu transporté comme dans un immense jardin... l'aspect opulent \& soigné de nos villes, à l'aspect de ruine \& d'abandon des villes turkes; l'état d'abondance, de paix, \& tout ı'appareil de puissance de notre Empire, à l'état de trouble, de misère \& de foiblesse de l'Empire Turk. ${ }^{[179]}$

Indeed, central government evidently did not think it their duty to help farmers through bad years to ensure continuation of crops, ${ }^{[180]}$ and this in lands of great fertility and potential: "I hardly know which has surprised me most, the 
exceeding fertility of the country east of the Jordan, or the wonderful ruins which dot its surface. ${ }^{[181]}$ The Lebanon was also fertile:

The plain has become a solitude, and a soil rich enough to supply all Palestine with food is in great part untilled. On this account an effort has been made of late to colonize the district with Germans, there being not only the best of land and an abandance of water, but also many walls and arches which would afford a temporary shelter. ${ }^{[182]}$

If the actions of Circassian settlers discussed above made a desert of several antique settlements, passive desertification was a much wider problem, linked to water resources and fertility. ${ }^{41}$ This was also to be sheeted home to underpopulation, to the actions of the bedouin, and to the impoverishment or disappearance of the soil anchored by olives and terraces, leading to the steep decline in forests with their water-retention. ${ }^{[183]}$ Ibn Khaldun believed that the nomadic life had coarsened Arabs and, contrary to civilisation, they degraded buildings and ripped off roofs for their fires: "ils sont hostiles à tout ce qui est édifice; or, construire des édifices, c'est faire le premier pas dans la civilisation." ${ }^{[184]}$ The situation was especially bad in North Africa, where neary the whole population were nomads, whereas in Syria and Iraq he believed that most people lived in towns. ${ }^{[185]}$ This might well have been the case in the 14th century, but travellers in later centuries reported desertification without always being able to document depradations by Bedouin. In 1825 on his way to Jerash Buckingham noted reports of 366 ruined towns and villages, "now entirely deserted, and not even occasionally visited by Bedouin Arabs in the course of their wanderings." ${ }^{[186]}$ In 1838 Addison wondered whether good farming land around Baalbek would soon be given over completely to wild animals:

Strange it is, one is tempted to exclaim, that human industry does not avail itself of a fine soil and plentiful supply of water, and that the population should thus decay; but it is only necessary to recollect the nature of the government and the state of parties for many years past to comprehend all. ${ }^{[187]}$

Down in the Hauran, Porter wrote of deserted cities near Bosra ("Their ramparts, their houses, their streets, their gates and doors, are nearly all perfect") and especially toward the east:

41 Gatier et al., 2010: Marges Arides project, which studied 10,00osq.km to SE of Aleppo, where the team found life constrained by rainfall, soil fertility, and water resources. 
All, without exception, deserted; the soil is uncultivated, and "the highways lie waste." In the whole of those vast plains, north and south, east and west, Desolation reigns supreme. The cities, the highways, the vineyards, the fields, are all alike silent as the grave, except during the periodical migrations of the Bedawin, whose flocks, herds, and people eat, trample down, and waste all before them. ${ }^{[188]}$

Indeed, the Ottoman Empire contained so many groups moving here and there that a recent study is entitled "A Moveable Empire."42 Again, there were deserted cities without names, such as the one Teixera skirted on his way to Aleppo: his companions "assured me that there are there altars, stone crosses, and remains of buildings wonderfully wrought."[189]

The deserts of Africa were created by God, claimed Dandolo in 1854, whereas "in Siria invece quest'altra maniera di deserto è tutta opera dell'uomo," and "nello scorgere neglette e mutate in rovina siffatte larghe profferte della natura l'osservatore si sente più sconfortato che contemplando le imponenti solitudini del deserto."[190] They certainly caused problems for travellers and explorers. ${ }^{43}$ In 1882 Porter saw forests devastated rather than husbanded by bedouin making charcoal for the Damascus market. Asking a local why the ruination of an oak forest was permitted, he was told:

Should we attempt to preserve these oaks, or to plant vineyards and olives, or to spend labour and money on fields or houses, we would only be working out our own ruin. The Bedawin would be attracted in clouds round the tempting fruit; and the Turks would come, drive us out with their cannon, and seize our whole property. ${ }^{[191]}$

Similar deforestation happened not only around Damascus, for Meistermann travelling from Salt to Jerash noted damaged oaks, this time destroyed not by Bedouin but by Circassians: "Les plus robustes sont tombés sous la cognée des Tcherkesses, qui déboisent ces montagnes sans pitié."[192]

In the Ledja, Thomson in 1886 reckoned there had been more trees earlier in the century. ${ }^{[193]}$ This accords with Norman Lewis' conclusion that whereas in 1800 steppe areas were almost entirely uncultivated, agriculture

\footnotetext{
$42 \quad$ Kasaba 2009.

43 Grant 1937, 79-124: Travellers and explorers of the Syrian desert; 159-187: Eighteenthcentury travel across the desert; 205-218: Difficulties and dangers of the desert crossing.
} 
began to bloom beginning in $1850 .{ }^{44}$ Changes were also noticed in the wider Hauran, where in 1881 the much slower upturn was compared with the state of affairs nearly thirty years previously: "then most of it was desolate, now it was almost entirely under cultivation. Signs of industry and growing prosperity were everywhere visible."[194] Even in the early 2oth century, as population grew, Butler could write of northern Syria that "mile after mile of this barren gray country may be traversed without encountering a single human being. Day after day may be spent in traveling from one ruined town to another without seeing any green thing save a terebinth tree or two." ${ }^{[195]}$ Nor were deserts fixed because, as Butler found in the Hauran, the dessicated state of the soil was belied by the once prosperous towns and villages that covered the region. ${ }^{[196]}$ In 1918, Flinders Petrie made a guess, but a good one, for deserted towns in "an astonishing state of preservation:"

The insecurity of the nomad raids on the empire of Justinian, culminating in the Arab conquest, drove out the population which bordered on the desert, and their houses and churches were left almost complete. ${ }^{[197]}$

A half-way house to settlement was transhumance, and in the 1880 s some tribes divided their time between summer with their flocks in the high parts of Lebanon, and winter on the coast. ${ }^{[198]}$

The opposite of desertification is the careful cultivation of the land, of which plenty was available. ${ }^{45}$ Olivier's assessment of 1800 was still valid in 1842 , "ce sont des plaines fertiles, des vallons arrosés, des coteaux verdoyants, des montagnes couvertes d'arbres qui se perdent dans les nues." [199] So also was Seetzen's 1810 estimate of the great fertility of the Hauran. ${ }^{[200]}$ Buckingham (sceptical though he was of what he called Turkish apathy) reckoned in 1825 that one area by the Jordan could support "a million of human beings to form a new colony; and so far from doing injury to their surrounding neighbours, they would enrich every country that was on their borders, and form a centre from which industry, arts, science, and morals might extend their influence, and irradiate regions now the prey of ignorance, rapine, and devastation."[201] Areas around Damascus were equally suited to intense cultivation. ${ }^{[202]}$ Olin in 1843 thought there were too many areas of Palestine where the soil had been washed away for easy reclamation; but

44 Lewis 1993, 45-6o: population of the Syrian steppe, 1800-1920. More broadly Geyer 2001, with sections on Bronze Age, and on II-VIIC.

45 Issawi 1988, 290-336: Agriculture in Syria. 
I do not recognise any permanent and invincible cause of barrenness, or any physical obstacles in the way of restoring this fine country to its pristine fertility... The soil of the whole country has certainly deteriorated, under bad husbandry and the entire neglect of the means of improvement. But a small degree of skill and industry would generally be sufficient to reclaim it. ${ }^{[203]}$

Bad husbandry was certainly one key to low productivity. Richardson on his way to Tiberias found harvesting under way, but "the sight of one or two reapers in a large field of ripe grain, is like poverty grinning in the face of abundance,"[204] and at El-Hussn in 1838 Lindsay "the Sheikh's son visited us, and inquired whether our English books mentioned the existence of any spring there; - such an opinion have these orientals of Frank learning., [205]

Indeed, it was agreed by mid-century that agriculture could support a population ten times as large as the present one, ${ }^{[206]}$ but the peasantry was downtrodden, conscription was a continuing problem, and governance was unjust. ${ }^{[207]}$ An 1855 report identified the Potential for Agricultural Development in Syria around Homs, Hama and Muarrah, areas "turned to wastes by the Bedouins who overrun them and rule paramount over the land and its inhabitants." ${ }^{[208]}$ Farmers frequently tilled their fields well-armed in order to beat off the nomads whose depradations would ruin them. ${ }^{[209]}$ But, as already mentioned, they did not necessarily do it efficiently, Le Strange noting the yoked oxen on his way to Amman, but also yoked camels, who "evidently loathed the business, and to judge by the objurgations of their drivers - who were continually calling heaven to witness that their (the camels') clumsiness was the natural consequence of a dissolute life and a disreputable ancestry."[210]

Travellers identified suitable areas for cultivation all over the country. Laorty-Hadji46 said Mecca pilgrims reported on the fertility of the soil around Apamea. ${ }^{[211]}$ Porter noted that the whole area of the Ledja "was at one time densely populated; every available spot... bears the marks of former careful cultivation, ${ }^{[212]}$ and that the adjacent Hauran was once one of the granaries of the (Roman) Empire, and continued prosperous until the Muslim invasion. ${ }^{[213]}$ Farley listed several "vast tracts of fertile land" where cotton could be grown amongst others, the Euphrates, the Bekaa, and, the plains watered by the Orontes and the Jordan. ${ }^{[214]}$ For Till in $185^{1}$ the reason for the disparities in uptake was simple: in the mountains of Lebanon "the husbandman is comparatively secure from oppression... while in Syria, generally, there has been,

46 His invented name is an anagram of "Taylor," with "Hadji" intended to suggest he had made the pilgrimage to Mecca. 
till of late years, a great insecurity of property, and one of the finest and most fruitful countries in the world has languished under its weak and short-sighted rulers." $[215]$

Fertility could sometimes survive even complete abandonment, as Farley remarked in $1858 .{ }^{[216]}$ In the north of Syria, the great limestone massif near Aleppo had so many deserted towns and villages, with splendid buildings, and wine and olive presses ${ }^{47}$ which demonstrated that "The country was thickly populated, fourteen centuries ago, by a people who lived in comparative luxury... this means that there was soil covering these bare hillsides in those days." ${ }^{[217]}$

By the 186os wheelbarrows had been imported from Germany, but it was better ploughs that were needed, ${ }^{[218]}$ and more people on the land as opposed to in the towns: "agriculture languishes from the want of hands necessary to till the soil."[219] Agriculture should also be ramped up to supply a growing population in Syria and further afield (with new railways and roads), rather than just to feed the locals. Farley instanced the fertile plain around Iskenderun, with its port: "thus a plain capable of supplying many of the largest cities of the United Kingdom with corn, does not at present produce sufficient to feed 2,0oo people." ${ }^{[220]}$ So if the government were stable, "how much good might be effected if two or three thousand skilful and industrious Germans were sent to this favoured land, instead of being exiled to America with precarious prospects." [221]

\section{Conclusion: Impact of Ottoman Decline on Antiquities}

Si l'empire ottoman décline, c'est moins par ses propres vices que par la faiblesse et l'imprévoyance de l'Europe qui avait un intérêt vital à le consolider. La guerre de 1877 et le traité de Berlin ont assurément porté à la Turquie un coup désastreux, dont les conséquences, aggravées par l'aveugle hostilité des républicains français, peuvent être irréparables; mais on se repentira un jour d'avoir laissé affaiblir et démembrer cet empire qui, malgré ses imperfections très supportables et sa faiblesse apparente, restait la seule défense effective des intérêts politiques et religieux de l'Europe. ${ }^{[222]}[1883]$ 
As this quotation indicates, Europe's responsibility for a likely breakup of the Ottoman Empire was a death foretold, and an optimist in 1835 predicted that a European takeover would be "le remplacement de la mort par la vie."[223]

All the elements discussed in this chapter, through years when population and land use changed greatly, ${ }^{48}$ impacted in diverse ways on the survival or otherwise of the art and architecture of Syria (preponderantly the latter ${ }^{49}$ ), because each one had consequences for the others. On the plus side, earthquakes (a continuing problem in Syria and adjacent Asia Minor) brought down monuments which most locals had neither the desire nor expertise to restore. Hence small blocks were pilfered, but those too large to shift simply lay where they fell. As Robinson remarked in 1838 ,

quoique ces monumens offrent aujourd'hui les marques d'une négligence qui date de loin, on n'y fait cependant aucune des réparations nécessaires, et on souffre leur destruction comme s'ils n'appartenaient à personne."[224]

Many monuments were reconstructed on paper, and the plans and elevations published; but no more than in Europe was there ever any thought of physically rebuilding them, for this must await the later 2oth century.

Again, low population levels and little ploughing kept some sites underground; disease and disinterest in hydrology kept sites around Lattakia (for instance) unexplored within their malarial miasma. On the minus side, the Ottoman Empire (just like nations in the West) was slow in evincing any desire to protect monuments. But it was very quick to see how Circassians could be imported at near-zero cost and then left to ravage sites such as Amman. Other sites were likewise demolished for barracks and eventually factories, including a Roman tower outside the east gate of Damascus, ${ }^{[225]}$ and the remains of a Byzantine church discovered at Arga, in Asia Minor. ${ }^{[226]}$ It might have been a plus in governmental eyes that the Circassians were Sunni Muslim, whilst the awkward Druze were an abstruse sect that could not even be called shia. Central government had continuing problems with the Shia, and also with the Druze. ${ }^{50}$

48 Philipp \& Schaebler 1998, 1-154: essays on 18th-2oth century changes.

49 Hitti 1959, 89: "The cultural remains of Roman Syria, from Baalbek to Petra, are indeed largely architectural; the other visual arts marked time, while hardly any Syrian contribution to Latin literature is worth mention."

Abu-Husayn 2004; Winter 2010. 
In a broad perspective, the 19th century sees a gradual modernisation of life in Syria (keeping pace with that in the rest of the Ottoman Empire), much of it dependent on European influence and prompting, and accompanied by an increasing prosperity which would prove itself fatal to the survival of many monuments, just as happened elsewhere in the Near/Middle East. ${ }^{51}$ There is irony in the fact that those very elements which generated a developing tourist industry were the same ones that obliterated so many of the monuments the tourists would surely have liked to admire. Its governance dictated whether travellers could travel safely, and even export their finds until the State took a grip in the later 19th century, and banned a practice that was more to the advantage of European museums than of the local polity. Safe travel and the problems of robbery and other "contributions" required of travellers by everyone from government, local officials (really official, or just local sheikhs) and marauding nomads will be dealt with in detail in Chapter Two, because these were the brakes on travelling, identification and reporting of antiquities.

After earthquakes did their work, piles of ancient architecture were the least of Syria's ruins but, unfortunately, little attention would be given to the practicalities of water supply, and when water is not channeled it creates unhealthy marshes, as travellers well knew. This could mean that some areas rich in antiquities were left alone and survived usually because of problems of road transport; but by the sea even ruins in ports blocked to moderately-sized vessels could be carried away in smaller craft for building purposes elsewhere, so that, as we shall see, coastal towns could lose many antiquities while for decades remaining closed to international trade.

Movements in population and fluctuations in settlement affected agriculture all over Syria, and travellers were often startled by the depopulation of areas with excellent fertility by no crops in the ground. Bad for the country's prosperity, such deserted or semi-deserted areas (such as the famous Dead Cities) were a boon for the monuments because there were never enough inhabitants to remodel or destroy them. Conversely, repopulation was deadly, and the populating of ancient towns such as Jerash and Amman destroyed innumerable monuments of which we have no knowledge, and this toward the end of the 19th century when the Ottoman government from 1884 actually had monuments protection legislation in place.

$5^{1} \quad$ Yapp 1987. 
[1] Stanley_1856_117

[2] Brünnow_\&_

Domaszewski_III_ 1909_249-360

[3] Flinders_Petrie_1918_6

[4] Luynes_I_1874_111

[5] Elliott_1838_II_216

[6] Campbell_1758_179

[7] Farren_1838_245-246

[8] Rey_1867_329

[9] Reid_1840_67

[10] Wortabet_1856_I_ 166-167

[11] Millard_1843_343-344

[12] Curtis_1903_204

[13] Conder_III.II_1830_87

[14] Porter_1855_I_113-114

[15] Olivier_IV_1803_118

[16] Addison_II_1838_248

[17] Napier_I_1843_vii-viii

[18] Brocchi_1842_169

[19] Wood_1757_4

[20] Wright_1925_294

[21] Farren_1838_250-251

[22] Reid_1840_66-67

[23] Walpole_I_1851_78-79

[24] Lindsay_I_1839_viii

[25] Buckingham_1825_ 191-192

[26] Perrier 1842

[27] Lindsay_I_1839_40

[28] Caraman_1841_5-4

[29] Millard_1843_335

[30] Tischendorff_1847_126

[31] Farley_1878_204

[32] Olivier_IV_1803_119

[33] Addison_II_1838_246

[34] Porter_1868_I_xxxvi

[35] Griffiths_1805_314

[36] Layard_I_1903_226

[37] PEFQS_1891_99-125

[38] Guys_1855_352

[39] Ibn Khaldun_I_1863_312

[40] Plaisted_1929_98
[41] Vogüé_1865-1877_I_3-4

[42] Lindsay_I_1839_44-45

[43] Edwards_1862_177

[44] Spoll_1861_16

[45] Tobler_1859_V

[46] Marquise_de_L_1866_79

[47] Roederer_1917_19

[48] Tiffany_1896_341-341

[49] Walpole_III_1851_ $77-78$

[50] Paul_1865_157

[51] Vitri_1896_LXXXIII

[52] Hitti_1959_13-14

[53] Van_De_Velde_1854_ II_426B

[54] Saulcy_1853_I_46

[55] Hall_2004_69

[56] Hall_2004_70

[57] Dimashqi_1874_100-101

[58] Michaud_\&_Poujoulat_ VII_1835_119B

[59] Guillaume_de_Tyr_ 1880_336

[60] Michaud_\&_Poujoulat_ VII_1835_179

[61] Poujoulat_1841_II_13

[62] Hanssen_2005_32

[63] Michaud_\&_Poujoulat_ VII_1835_119

[64] Wortabet_II_1856_63

[65] Knox_1879_340

[66] Layard_I_1903_223B

[67] Layard_I_1903_231-232

[68] Blondel_1840_281

[69] Robinson_1838_338-339

[70] Blondel_1840_278-279

[71] Robinson_1838_336-337

[72] Layard_I_1903_233 1839

[73] Ellis_1881_I_39

[74] Robinson_1838_411

[75] Ibn Khaldun_I_1863_ 66-67

[76] Volney_II_1792_92

[77] Layard_I_1903_215-216
[78] Lycklama_a_Nijeholt_ 1875_336-337

[79] Bunel_1854_300

[80] Guys_1855_322-323

[81] Ellis_1881_I_14

[82] Egmont_\&_Heyman_ 1759_II_329

[83] AMS_VIII_1859_6o-66

[84] Mislin_1876_I_450-451

[85] R.B_1759_93

[86] Mariti_1791_I_271-2

[87] Wittman_1803_193

[88] Finati_1830_II_153

[89] Laidlaw_2010_26

[90] MacMichael_1819_265

[91] Farley_1858_21-26

[92] Wright_1895_104-105

[93] Green_1736_1

[94] Coote_1780_211B

[95] Coote_1780_211

[96] Osborn_1858_192

[97] Drummond_1754_ 129-130

[98] Houry_1842_12

[99] Boullaye-Le-Gouz 1653_335-336

[100] Lammens_1921_II_44

[101] Poujoulat_1841_II_15

[102] Stewart_1857_454-455

[103] Browne_1799_386

[104] Robinson_1838_374-375

[105] Masson_1896_371

[106] Masson_1896_130

[107] Masson_1896_378-379

[108] Laorty-Hadji_1854_39

[109] Houry_1842_12-13

[110] Skene_1864_182

[111] Gallois_1907_177

[112] Conder_1891_21

[113] Pierotti_1866_6o

[114] Paris_1861_52

[115] Lucas_I_1714_180

[116] Addison_II_1838_49

[117] Buckingham_1825_483 


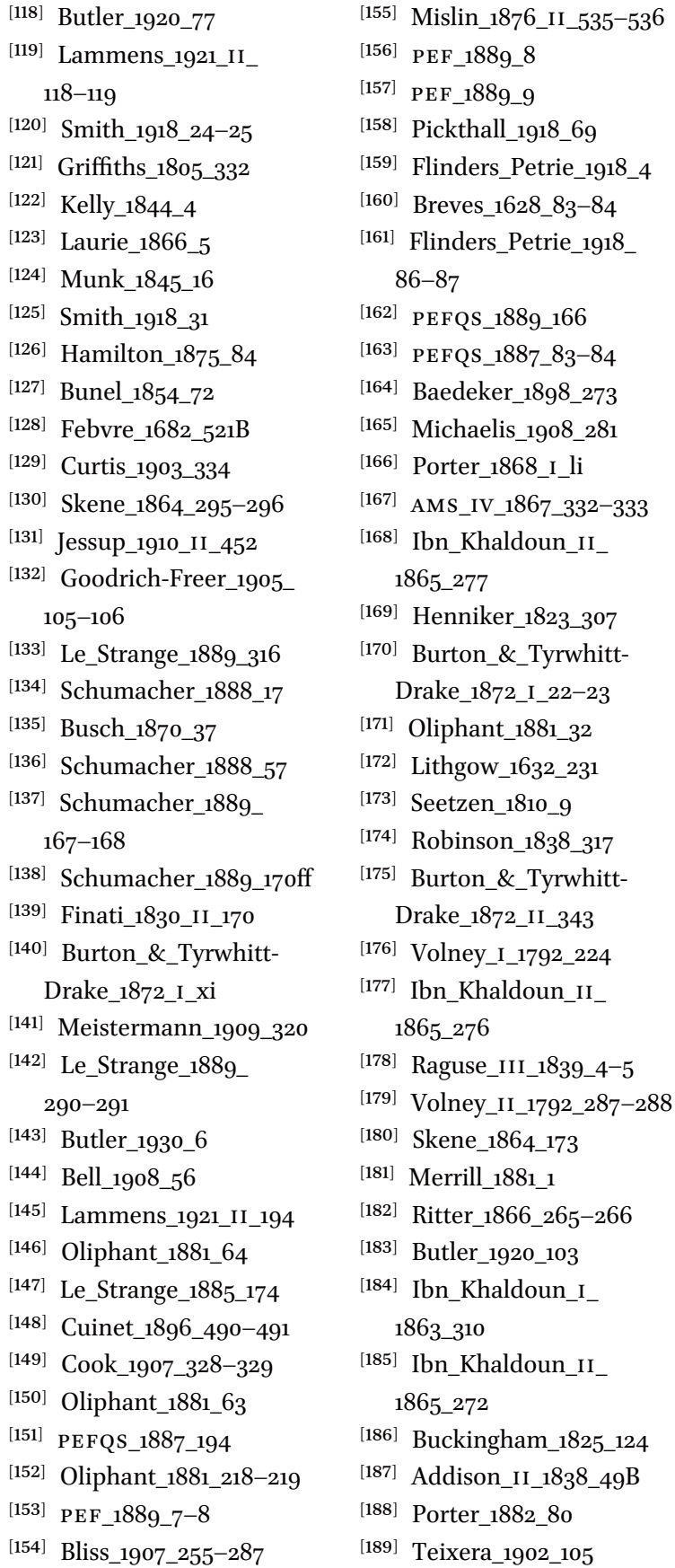

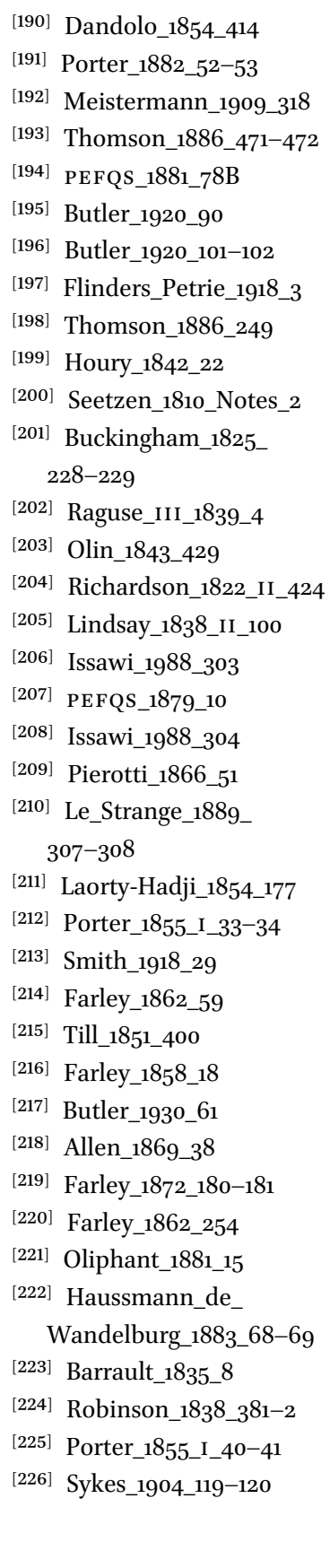

[191] Porter_1882_52-53

[192] Meistermann_1909_318

[193] Thomson_1886_471-472

[196] Butler_1920_101-102

[197] Flinders_Petrie_1918_3

[198] Thomson_1886_249

[199] Houry_1842_22

[200] Seetzen_1810_Notes_2

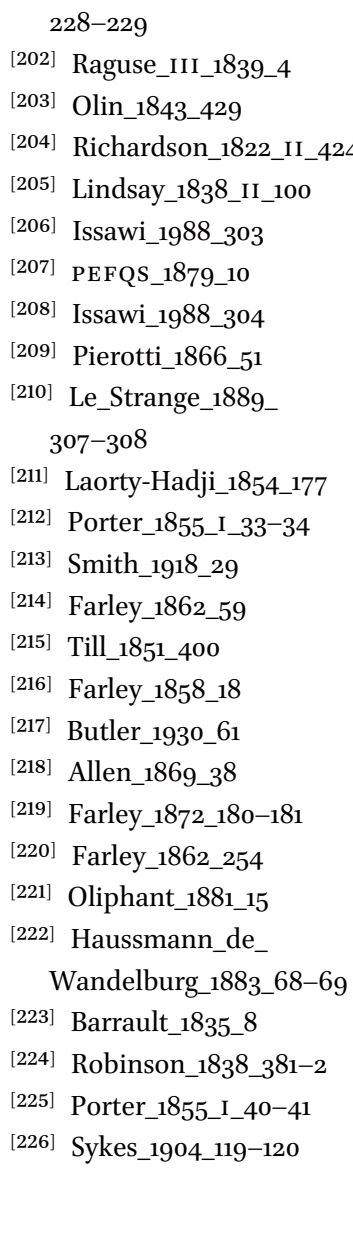




\section{Travel throughout Syria}

En effet, tandis que sur le littoral et dans les grands centres de l'intérieur les monuments antiques, utilisés comme carrières, ont été livrés à une destruction d'autant plus active que la prospérité était plus grande, dans la région centrale, au contraire, les édifices ont été sauvés de la ruine par l'abandon et la misère. Restés debout quand tout disparaissait dans les autres parties de la Syrie, ils nous font connaître l'état de cette province pendant les premiers siècles de notre ère. ${ }^{[1]}[1865]$

How and why would a Western traveller decide whether to visit Syria, perhaps in conjunction with Asia Minor ${ }^{1}$ or Egypt? ${ }^{2}$ And how would he (or she - plenty of women travelled there ${ }^{3}$ ) pick his way amongst the delights mentioned by De Vogüe in the above quotation? Where to go and how to get there naturally varied with the years, the rise and fall of trade, and the development of archaeology, but a constant was pilgrimage from the early centuries of our era, ${ }^{4}$ and the monuments thereby produced. ${ }^{5}$ With the growing pressures of modernisation during the course of the 19th century, travellers, tourists and pilgrims increased, as did trade with those Western countries which could supply modern goods (some of which, as already mentioned, undercut local production). ${ }^{[2]}$ Archaeology, the growing understanding of the past through its physical artefacts, initially as an off-shoot of the study of art and architecture, helped paint a picture of monumental and lesser survivals which encouraged travelling.

1 Salmon 2010 for earlier 19thC travel in Syria; Salmon 2013 for earlier 19thC travel in Asia Minor.

2 Berchet 1985, 589-816: 19th-century travellers to Syria and Palestine.

3 Hodgson 2006: the practicalities of travel for women - dress, harems, baths, etc.

4 Bowmann 2011: visiting the Holy Land in the fourth-century Itinerarium of the Bordeaux Pilgrim.

5 Farioli Campanati 2008: late antique and Byzantine Syria, by site, with a bibliography for each important one. 


\section{Where to Go and How to Get There}

Down the centuries, the Ottoman Empire attracted Westerners, ${ }^{6}$ and the types of traveller to Greater Syria changed. In the 14th to 16 th centuries these were (in descending order) state functionaries, religious, nobles, businessmen, bourgeois, and littérateurs, with the reasons for travel being official missions, pilgrimage, commerce, military expeditions, and science. In this period, $25 \%$ of itineraries went to Jerusalem. ${ }^{7}$ Remission of sins was one impulse for pilgrims, and Guylforde asserted that "to euery pylgryme at the firste fote that he setteth on londe there is graunted plenary remyssion." ${ }^{[3]}$ Subsequently scholars and students travelled, as did more traders ${ }^{8}$ and, from the 19th century, with easier communications, sightseeing became popular, as again did pilgrimage, soon organised into the kind of group tour we have today. The Venetians had control of the organised pilgrim trade until the conquest of Cyprus by the Turks in 1570, after which they generally made their own arrangements, often via Tripoli. ${ }^{9}$

Ben-Arieh divides the 19th-century rediscovery of the Holy Land from 1799 to 1877 from travellers in disguise $(1799-1831)$, then the short period of liberal Egyptian rule, when exploration was safe, next the return of Turkish rule, and finally the beginnings of modernisation (1865-1877), with some healthy exploration funds and expeditions by scientific teams. ${ }^{10}$ Such exploration continued into the 2oth century, but much of it was concentrated in Palestine, not in other areas of Syria. Tourists often combined travel to Syria with visiting Egypt, and could reach Palestine either across Sinai or via Suez, or take the steamer from Alexandria to Beirut. ${ }^{[4]}$ It is indeed likely that it was the steamship which resuscitated pilgrimage, which had been in decline for centuries, although "Palestine/Israel has also been viewed as a part of the romantic, chivalrous medieval tradition that began with the first crusades."11

Chateaubriand, writing in 1812, gives very low figures for pilgrimage when he made his journey, ${ }^{[5]}$ and the (re)development of such religious travel has its beginnings in the 186os, prepared by the work of scholars such as the American

$6 \quad$ Pignot 2007: the 17th century.

7 Yerasimos 1991, 9-22 for overview of travellers in the Ottoman Empire, 14th to 16thC: nationalities, social class, reasons for travel, itineraries with exact dates (where available), and adventures along the way (such as imprisonment).

8 Gharaybeh $195^{\circ}$.

9 Yerasimos 1991, 69-72.

10 Ben-Arieh 1979, 19-64, 65-108, 109-156, and 190-228.

11 Rogers 2011, 125. 
Edward Robinson (1794-1863), sometimes called the Father of Biblical Geography, who studied Palestine in the late 1830s, and published important books in 1841 and $1856 .{ }^{12}$ As we shall see, the development of the Holy Land (in all senses) had several consequences good and bad which might cancel each other out. The region became more prosperous because of pilgrimage, and archaeological attention (and money for digging) focussed on the area. In 1865, at the Palestine Exploration Fund's first meeting, the Archbishop of York stated that "there can be little doubt that under the sacred city, monuments of the greatest value and importance would be found in every foot deep of the ground."13 On the other hand, an expanded population meant pressure on antiquities which were frequently used as building materials, and whole sites thereby obliterated. Again, if the attention, expertise, digging and funding dedicated to "proving" the Bible true had been spread evenly around all of Syria, many more antiquities would have been preserved - for outside the Holy Land, pressure of population into the 2oth century spelled disaster for many sites.

In the later 18th century the Grand Tour extended beyond Italy to Greece and, for the intrepid, further east and south, so educated travellers with money (for such projects could be expensive) could take their choice at the eastern end of the Mediterranean. ${ }^{14}$ As a result, many travel books were published, ${ }^{15}$ and largely unregulated publication, undermined by frequent translation, meant that travel writing developed into an industry to service those who went abroad for leisure, health or religion. Each area had its advantages and disadvantages. Asia Minor offered a Westernised town and trading centre at Smyrna/Izmir, in a safe bay, but the interior was large, and badly supplied with roads (let alone maps), though not necessarily dangerous. Syria had Aleppo, which had prospered with its European traders; but this town, for various reasons, was in decline by 1800 , and access was via an unhealthy port. Indeed, until the 1870 s there was no port down the Syrian coast for even moderatesized ships to dock (passengers for Beirut were carried ashore piggy-back, or in small rowing boats). As explained in detail below, Syria suffered greatly from

\footnotetext{
12 Aiken 2010, 18-56: A History of Scriptural Geography.

13 Bar-Yosef 2005, 178: "The idea that the 'real' Jerusalem was not the city which appeared on the surface, but rather the one hidden beneath it, underground, soon became current, manifested in titles like Warren's Underground Jerusalem (1876) or George St Clair's The Buried City of Jerusalem (1887)."

14 Mansel 2011: The Grand Tour in the Ottoman Empire 1699-1826. Excellent overview, including Syria.

15 Hachicho 1964 for detailed, accurate and informative accounts of 18th-century English travel books in the Arab Near East, with routes and short biographies.
} 
wandering robbers (usually nomadic bedouin); and its inhabitants also suffered from fixed robbery in the form of taxation from a government distant and also local, interwoven with endemic corruption, nonchalant and disorganised, and in most decades unwilling to do anything decisive about crime.

Further south, Alexandria was easily accessible and, like Cairo, Europeanising during the later part of the 19th century, incurring an immense debt, and occasioning the British occupation from 1882. Reaching Syria was often done by travelling south from Asia Minor, sometimes overland but usually by sea; or by combining Syria with a visit to Egypt. In 1843 Napier noted that "Omnipotent steam has now so completely destroyed the glorious uncertainty of navigation, ${ }^{,[6]}$ so that from the mid-185os the traveller could take a steamer from Smyrna and stop at several ports down the Syrian coast, although how they got from ship to shore depended on the ship's size. Or they could stay on board and arrive at Alexandria eleven days later. ${ }^{[7]}$ By 1862, a mailship arrived in Beirut twice a week, and steamers ran regularly between Liverpool and Beirut, which received 113 British ships in 1855 , against a mere 39 two years previously. ${ }^{[8]}$ Another route was from Egypt, either overland by camel, or by steamer. ${ }^{[9]}$ For British travellers, this part of the world was often (and especially before the digging of the Suez Canal) a stop-off point on the way to or returning from India. Just as happens today, 19th-century authors tried to persuade their readers that, with all this modernisation, nothing had changed in the East. ${ }^{[10]}$

For those specifically interested in monuments and Antiquity, Egyptian architecture was outside the classical canon, and neither Syria nor Asia Minor boasted Greek architecture of the classical period, considered the acme of stylistic excellence. But Roman architecture was in evidence in all these three destinations, because her empire was broad and her monuments strongly built. ${ }^{16}$ Egypt was easy to visit, because everything clung to the Nile. The majority of towns and sites in Syria were nowhere far from the coast, the majority accessible via passes through the mountains, until the area marked on old maps as Arabia Deserta (with Palmyra) was reached. In Asia Minor plenty of sites (Ephesus, Didyma, Pergamon) could be accessed from the sea, but strenuous trekking was required for some inland sites such as Aphrodisias, Sardis or Ankara. ${ }^{17}$ Few of these had been extensively investigated before the mid-19th century, but many sites were large and very splendid, making full use of the extensive marble quarries, often nearby (as at Aphrodisias). And apart from a few villagers, most such sites were deserted. What is more, unlike the situation

\footnotetext{
16 Ulrich \& Quenemoen 2014 for an overview.

17 Apostolou 2009, 103-123 Les voyageurs français et les monuments de l'Asie Mineure; ibid., 149-16o A la recherche de l'Asie Mineure.
} 
in Syria, what nomads there were in Asia Minor were neither aggressive, nor at war with themselves and the world.

Few Syrian sites could compete with those in Asia Minor in splendour, such as Ephesus, which probably re-used materials from the Temple of Diana for the Church of S. John, as Gédoyn suggested. ${ }^{[11]}$ Asia Minor had several marble quarries, exploited to full effect for the building of Roman cities. Syria, however, had no native marble; some stones were imported, along with granite from Egypt; but the main building stones were limestone (some of which could be stained and polished to look marble-like) and basalt, which was solid but dour and un-prepossessing. We shall find many travellers comparing what they saw with monuments back home; but until almost the 1870 f few learned much about Muslim religious architecture, because infidels were forbidden from entering (or, in some instances, even gazing upon) the main holy sites, if not more modest mosques. Egypt was an adjacent country also without native marble, but with many imports re-used in her mosques, as Ariosto observed in the 15th century in Memphis. ${ }^{[12]}$ In 1653 Boullaye-Le-Gouz observed the same use of column shafts as through-ties (for strengthening fortification walls) as were seen in Syria, ${ }^{[13]}$ and in 1855 at Alexandria Prime reported digging for materials under way: "disclosing beautiful Corinthian capitals and handsome white marble columns... laborers, men, women, and children, were at work; some of them with barrows, and others with baskets, even little children who could carry but a few handfuls being as busy as the rest."[14]

The Egypt/Syria combination (which fed the growing interest in antiquarianism, as well as in biblical lands ${ }^{18}$ ) attracted more travellers once Egypt was established as a chic wintering destination for rich Westerners, with antiquities an added bonus. This combination increased again from the 1870 , when Biblical tourism became very popular, and pilgrimage revived with (naturally) Jerusalem and area as a focus, although Northern Syria was also attractive, not least because of the westernised Aleppo. ${ }^{19}$ All here was explicable (or at least explained) by reference to the Bible and the landscape, towns and acts it described. Pilgrimage ${ }^{20}$ and associated tourism were responsible for the renewed prosperity of Jerusalem, and revived some of the formalised excursions of devotees of previous centuries. ${ }^{[15]}$ Part of the charm of 19th-century

18 Hachicho 1964, 142: "They saw, therefore, every place and corner of the Near East through the eyes of classical and biblical authorities."

19 Tchalenko 1953, I: map of archaeological explorations in N. Syria, from De Vogüé to Lassus in 1936 .

20 Uggeri 2013, 79-83: Syria and Phoenicia. 
accounts lies in the description of largely empty landscapes, and of sites today either radically depleted or completely destroyed. ${ }^{21}$

\section{Languages, Dress and Descriptions}

The European traveller, who wishes to visit these countries in safety, and see things to advantage, must dress himself in the fashion of the country, let his whiskers grow, and endeavour to learn a little of their language, or else they will impose upon him. ${ }^{[16]}[1783]$

These three apparently disparate elements are in fact intimately linked in the work of the successful traveller. Speaking their language naturally helps intercourse with the locals and, if they are not necessarily charmed by Westerners wearing local dress, the device often got the stranger along the route without being molested or robbed. A traveller blending more-or-less into the landscape might then be expected to produce more cogent, accurate and even detailed descriptions of the sites visited. In 1815-1816 Richter told of the death of a Frenchman along the Orontes, but he was not fully equipped: "Il prenoit l'habillement des gens du pays, dont il ne savoit pas assez la langue." ${ }^{\text {[17] }}$ Born 1792 in Livonia, Otton-Frédéric de Richter, like Burckhardt died young (Smyrna 1816), and had Greek, Persian and Arabic, all of which helped his writings.

An important element in dealing with any country is a knowledge of its languages $^{22}$ (in Syria, principally Arabic, Turkish and Greek), without which one was thrown on the unassessable talents of interpreters and guides. Whereas most travellers were thus dependent, a few shine because they know languages, can interact with the locals, and often transmit more cogent and detailed reports with authoritative information locally gathered, which could lead them to near-invisible ruins buried in the sand, as Breuvery noted in 1848. ${ }^{[18]}$ Whereas universities in Paris and Berlin taught oriental languages, in Britain such formal education was sparse. Fortunately, most earlier travellers learned their languages through trade and extensive residence abroad. In Syria Turkish was the language of the rulers (used by merchants as well in Asia Minor); but south of Antioch Arabic was the current language, understood

21 Kennedy 2004, 21-22: the history of exploration in (Roman) Jordan. 21: "development has transformed almost everything and destroyed many sites." Ibid. 23B: "many of these 19th century scholars [mentions Seetzen, Doughty and Tristram] are a delight to read for their own sake... evocative as well as informative."

Kappler 1988: travellers, languages and interpreters. 
by everyone including the Greeks. ${ }^{[19]}$ The best-equipped travellers, such as the Chevalier d'Arvieux understood "la Turque, l'Arabe \& la Grecque vulgaire. Je n'étois point embarrassé, j'entendois \& je répondois à tout le monde dans la Langue qu'on m'avoit parlé,"[20] an accomplishment which was very useful when dealing with Bedouin. Burckhardt, in Arabic dress but without requisite papers, had to be careful of his route; but it was talking to the locals that highlighted monuments: "I was particularly desirous of visiting Wady Mousa [Petra], of the antiquities of which I had heard the country people speak in terms of great admiration."[21]

Ill-equipped travellers such as Van De Velde (1854) had to rely on language experts, confessing "the difficulty that I myself have experienced from ignorance of the language" and considering "two such men as Eli Smith and Robinson as the most auspicious circumstance that could have happened for Biblical geography. We may well thank God for its occurrence."[22] Van De Velde was correct, and the Palestine Exploration Fund confirmed Robinson's importance: "he went, therefore, knowing what to look for and what had been already found." ${ }^{[23]}$ Evidently not reducing his reliance on the Bible, Van De Velde in a sense increased it by now taking Robinson's account around with him, for example at Beersheba, where he examined "the important antiquities which Robinson has so copiously described," ${ }^{24]}$ but also the fortress, which he described elegantly as "a heap of rubbish." ${ }^{\text {[25] }}$ Even with the language, Baedeker reckoned that travellers "will speedily be wearied in the East... by the stereotyped questions and artificial phraseology of the people with whom he comes in contact., ${ }^{[26]}$ Language fluency enabled travellers such as Edwin Palmer ${ }^{[27]}$ and Colonel Tyrwhitt Drake ${ }^{[28]}$ "to travel without escort, or servants, or baggage, to "mess" with the people, to do everything for themselves, and to talk their language as the Bedawin talk it," as the Palestine Exploration Fund (a beneficiary of their work) put it in 1873. But the PEF evidently considered such travellers as freebooters, trampling on the sacred turf of archaeology, and they discouraged

small expeditions into that tempting country east of the Jordan, where so many treasures lie hidden... They result in a small amount of plunder, and each one makes the next more difficult and costly. ${ }^{[29]}$

Arabic dress could also help the acquisition of knowledge. ${ }^{23}$ Some foreign consuls evidently thought so, for Bankes met one at Jaffa "wearing powdered hair,

23 Rodenbeck 2011: as well as being useful and comfortable, it was often a statutary requirement to wear local dress. 67: in 1838-9 David Roberts allowed to work in a mosque only 
and a gold-laced cocked hat, with the flowing oriental habit, a grotesque combination that afterwards became more familiar to me in the consular houses at Aleppo."[30] If we are to believe the story, Claudius James Rich [1787-1821, consul in Baghdad] succeeded in entered the Umayyad Mosque in Damascus because "his knowledge of the Turkish language and manners was so thorough that while in Damascus not only did he enter the grand mosque in the disguise of a Mameluke, but his host, an honest Turk, who was captivated with his address, eagerly entreated him to settle at that place, offering him his interest and his daughter in marriage." ${ }^{\text {[31] }}$ Richardson also dressed as an Arab, got onto the Haram al-Sharif in Jerusalem twice, into the al-Aqsa and the Dome, and even up the latter's wooden stairs to view the wooden beams from up close. ${ }^{[32]}$

Buckingham in 1822 seems to have covered all bases for his travels:

We were now all dressed in the costume of the country; Mr. Bankes as a Turkish soldier, Mohammed in his own garb as an Arnaout, and I as a Syrian Arab. Our guides wore their own dresses, as Bedouins of the desert. ${ }^{[33]}$

Who would dare to attack such a group ${ }^{24}$ And Seetzen ${ }^{[34]}$ travelled light, wearing "the habit of an Arab Shech of the second rank," but also packing a gun and two pistols. ${ }^{[35]}$ Hospitality was to be accepted, and there was sometimes a certain stoicism required, as when Schumacher was in a Bedouin tent in 1884:

The night was bitterly cold, and - what between the wind and the fleas, and the extremely confiding nature of the ewes, who, for warmth's sake, were always trying to insinuate themselves beneath our blankets - sleep was fitful. Further, and as usual, till far into the night, our Arab friends discussed in strident tones politics and finance. ${ }^{[36]}$

These were evidently not the kind of locals Baedeker was so sniffy about. Travelling light was part of Schumacher's success: no tents or servants, little baggage, shabby horses, and triumph that he had paid nothing to the importuning local sheikhs, "both personages generally but too well known to those who have left Jerusalem for a trip into the Land of Gilead." ${ }^{[37]}$ The fleas were

if he wore Turkish clothes and did not use hog's-bristle brushes. $75^{-76}$ for Westerners in Eastern dress in earlier 19 thC, then $85^{-6}$ for later. $80-81$ : improvements in safety, and use of European dress, under Mehemet Ali.

Rée 2011, 169-178, for Buckingham's travelling biography. 
part-conquered by slinging a string hammock high up, which fascinated the locals. ${ }^{[38]}$

Detailed descriptions of sites were also easier for the well-equipped. The well-read Prussian Consul in Damascus, Wetzstein, tried to help local agriculture in a scheme which failed, ${ }^{25}$ but was much more successful in his 44 days of travels, and told his readers that he had taken 880 pages of notes in four notebooks, and written down 30 Bedouin songs, so that (here a pat on his shoulder) "ein grosser Theil meiner Zeit auf die Untersuchung von fast hundert Ruinenorten und die namentlich in weitläuftigen Städten zeitraubende Aufsuchung von Baudenkmälern und Inschriften verwendet werden musste." And his work encompasses several disciplines: "Die Ergebnisse dieser Reise umfassen mehrere Zweige der Wissenschaft, wie Geognosie, Geographie und Archäologie (Baugeschichte und Inschriftenkunde)." How did he manage to do it all? Answer: by writing while on horseback, and also at night. ${ }^{[39]} \mathrm{He}$ claimed a lack of architectural knowledge, but drawings and notebooks were the answer: "nur durch eine Menge Zeichnungen erzielen können. Ich verspare mir daher die weitere Behandlung dieses Gegenstandes für den Druck meines Tagebuchs." ${ }^{[40]}$ Such serious scholars were miles apart from most tourists. In 1855 Kennard mocked the enthusiasm of incompetents for drawing what they saw, each "seems to consider it his duty to carry with him a great box full of black lead pencils, a twelve month's supply of india rubber, and such reams of drawing paper as would enable him to make a panorama of his whole tour"; but Egypt would exhaust his enthusiasm, and by the time he reached Palestine, "he will have become disgusted with his multitudinous abortive efforts, and will have consigned his paper, pencils, and india rubber to the lowest depths of his portmanteau." ${ }^{[41]}$

A knowledge of local languages also helped travellers fix a better picture of the needs and attitudes of the locals. When Walpole was strolling through Byblos he exclaimed aloud in Arabic (NB one-upmanship) "Curse these people; why do they use these columns in such a way?" a Turk responded "I curse them, too, for making them so large; had they been smaller, we might have put them to a hundred uses."[42] The main opportunity for using them vanished after the Crusades, D'Estourmel noting their used as tie-bars in the town's towers, a device he had also seen in Greece and Asia Minor:

Nous remarquâmes, le long du chemin, de belles colonnes de granit rouge et gris; un plus grand nombre est encastré dans la maçonnerie des tours.

25 Hudson 2008, 45-49. See 45: his experience "illustrates the terrain of the Damascene agricultural system and the obstacles to a direct transformation through the infusion of Western capital." 
En Grèce et dans l'Asie Mineure, nous avions vu souvent de riches débris employés pêle-mêle comme matériaux; en Syrie, il semblerait que c'est à titre d'ornement qu'on a placé, en travers et symétriquement. ${ }^{[43]}$

\section{Scholars in the East}

One of the charms of Eastern travel consists in the constant appeal which is made to the historical conscience and archaeological instinct of the pilgrim...there is always something new to be seen amongst the remains of so long a sequence of centuries, and where so many and various populations have passed and repassed over the historical field of view. ${ }^{[44]}[1891]$

The best way to appreciate scholars' qualities is to read extracts from their books; some of these are included here as endnotes, and occasionally commented in the bibliography of sources. More recent scholars are also looking back at the achievements of their forbears, such as Waddington, who published plans and elevations of Hauran buildings. ${ }^{[45]}$ A glance at this will reveal several authors whose works are merely imitative, or which plagiarise what has gone before, as plaintive footnotes make clear. ${ }^{[46]}$ But there are several scholars whose published work set both the tone of enquiry and the breadth of knowledge of Syria and the Holy Land in the 18th and 19th centuries. Some, such as Abraham von Noroff, offered succinct and decent summaries of the sites he visited, especially down the coast. ${ }^{[47]}$

Their backgrounds were varied, and short biographies of the most important amongst them appear in the Appendix. Arvieux' father was French Consul at Sidon, and was at one time Consul at Aleppo, which made it easier for the son to learn Arabic, Persian, Turkish, Hebrew and Syriac. Baron Taylor was interested in archaeology, and travelled in the East as Laorty-Hadji. Volney was a French philosopher and politician, pondering the decline of empires as he saw them in the East. Burckhardt, a meticulous Swiss writing in English, dressed in Arab robes and disguised as an Arabic-speaking Muslim, would have produced larger quantities of valuable material had he not died aged thirty-three. His itineraries and notes were published in 1822 . The naval officers Irby and Mangles produced the next thorough account of the region the following year. Christian antiquities were also noted by some travellers, ${ }^{[48]}$ but by surprisingly few of them.

Divines could also numbered amongst the scholars, as for example Pococke, who ended up as a bishop, and whose Description of the East (1745) was very 
popular, and translated into French, German and Dutch, rightly so, for he visited sites omitted from most accounts. ${ }^{26}$ By the mid-19th century, excellent accounts of the landscape and its relation to the Bible were published by the Americans Robinson and Smith, who travelled and wrote extensively, equipped as they were with the necessary languages, to cater for a growing American readership and tourism. ${ }^{27}$ Robinson was said to have prepared himself by studying for fifteen years, and "he it was who first conceived the idea of making a work on Biblical Geography, to be based, not on the accounts of others, but on his own observations and discoveries."[49] Several missionaries also wrote of what they found in the region, notably Porter, an Irishman, who produced three important books and numerous encyclopaedia entries. Indeed, Porter in 1868 produced the best and most careful guide to Syria for its date for our purposes. In the two volumes, there are 280 mentions of columns, 104 of marble, 73 of limestone, 242 of churches, 159 of mosques, 795 of ruins, 39 of danger, and 453 of temples (although there can of course be several mentions for each monument).

The best 19th-century assessment of these and other scholars is by Vivien de Saint-Martin, General Secretary of the Société de Géographie, and a vigorous and detailed publisher of travel accounts, especially his own study of Asia Minor, in which he includes those travellers who also visited Syria proper. (Burckhardt's contribution to knowledge was covered by a colleague. ${ }^{[50]}$ ) Scanning the work of earlier centuries as well, ${ }^{[51]}$ he assesses Seetzen and Botta as well as the scholars noted above, ${ }^{[52]} \mathrm{He}$ showcases proudly the French contribution to oriental knowledge, praises the initiative shown by the French government in funding scholars' journeys, and laments the inevitable problems which caused delay or failure, such as the 1830 revolution, ${ }^{[53]}$ and the death of one scholar in Aleppo, which left his companion, Callier, with work for three years. ${ }^{[54]}$ He recommends reading Volney's travel account, and leaving on one side "les regrettables écarts de ce qu'on nommait alors l'esprit philosophique."[55]

\section{The Bible as a Guidebook}

Even to a casual traveller in the Holy Land the Bible becomes, in its form, and therefore to some extent in its substance, a new book. Many an

\footnotetext{
26 Hachicho 1964, 38 for the area around Lake Tiberias, and Safad; Christian antiquities around Ma'arrat-en-Nu'man; trade between Aleppo, Urfa and Diarbakr etc.

27 Long 2003, Chap 2, 43-87: Starred and striped Holy Lands.
} 
allusion which hitherto had no meaning, or had lain unnoticed, starts into prominence and throws a light over a whole passage. ${ }^{[56]}[1865]$

Palestine, both east and west of the Jordan, may be fairly regarded as the divinely prepared tablet whereon God's messages to men have been graven in ever-living characters. This fact invests even the geography and topography of the Holy Land with special importance. ${ }^{[57]}$ [1886]

The title to this section is ironical, since today few would think of using the Bible as a guidebook, any more than they would rely only on Pausanias or Herodotus for parts of the region. But it is historically accurate for the 19th century, and many accounts give the strong impression (some state it explicitely) that travelling to some parts of Greater Syria without the Bible is to be satisfied with a lesser experience. Similarly, the focus of archaeology was on Palestine, not on other parts of Greater Syria. ${ }^{28}$ Porter asserted in 1864 that the Bible "when rightly interpreted, must be in absolute accordance with fact."29 In other words, although the Holy Land occupies but a small proportion of Greater Syria, this account of the Bible and its uses appears early in this book because its use and influence structured the travels of many visitors. Large numbers would not have arrived had it not been for the Bible's influence, and dangerous regions such as Moab were first explored by scholars eager to elucidate that text and its references to physical locations. Peer pressure was certainly important, and many authors catered to readers' desires by featuring a profusion of Biblical quotations. One reason for this is the overwhelming number of published accounts of the area. As Bliss wrote in 1907:

To those acquainted with Röhricht's Bibliotheca Geographica Palaestina, with its 3,515 names of writers on the Holy Land, from AD 333 to 1878 writers who were for the most part actual travellers - we need not say that we have attempted no comprehensive bibliography. ${ }^{[58]}$

In 1836 Laborde, who had travelled widely in Asia Minor as well as in Syria, ${ }^{30}$ attempted to link the Bible with the countryside by tabulating prophecies

28 Díaz-Andreu 2007, 147-166: The search for the Holy Land: the archaeology of Palestine.

29 Aiken 2010, 95: "This is a typical piece of polemical Scriptural Geography. Earlier didactic Scriptural Geographers would not have felt the need to make an apologetic argument like this, and later contextual Scriptural Geographers would have tended to question the absolute accordance of the Bible with fact."

30 Maupoix 2013; Cotinat 2010, with numerous extracts from his account; Laborde 2013, 108285: catalogue of 138 plates from Laborde's book. 
against travellers' accounts which would confirm them. ${ }^{[59]}$ Naturally, he found what he was looking for, ${ }^{31}$ triumphantly declaring "Let the words of the prediction be compared with the reports of those who have borne testimony to its fulfilment." ${ }^{\text {[60] }}$ Delight in biblical vengeance seems antithetical to delight in ancient ruins, yet several authors indulged in such incantations. One writing in 1852 said little about the ruins of Amman, noting only that "every step which a traveller advances in that devoted land is confirmative of the truth of the Bible history." ${ }^{\text {[61] }}$ Tristram corroborates this view in 1865, convinced that "every investigation of even the minor details of the topography and the natural character and features of the land has tended to corroborate the minute accuracy of the Inspired Record." ${ }^{[62]}$ This applies even when he visits the Umayyad Mosque for, seeing a Greek inscription referring to the Kingdom of Christ, he exults:

There stand the words, unread by the Muslim. We will take them as a silent prophecy that the day is coming when this dark land shall be Christ's once more, and He shall reign for ever and ever. Even so, come, Lord Jesus! ${ }^{[63]}$

Just how this could be done by Beke, for example, looking to confirm the location of Harran, is indeed a sacred mystery. ${ }^{[64]}$ It was evidently in vain that Stanley in 1856 could protest that biblical prophecy was misunderstood, missing the important truth that "the warnings delivered by "holy men of old" were aimed not against sticks and stones, but then, as always, against living souls and sins, whether of men or of nations." ${ }^{\text {[65] }}$ But little changed, Porter in 1882 still harping on ruins as a result of the "graphic details of the Record," and "I could not resist the conclusions which a careful comparison forced upon me."[66] Little changed even in the early 2oth century, when one author noted for Tyre that "the piratical attacks of the seventeenth and eighteenth centuries at length fulfilled the words of the Hebrew prophet."[67]

Fixation on the Bible, and its use as a guidebook, leads to egregious errors in consideration of the country of Syria. The misplaced delight in finding ruins just where the Bible says they are is compounded by ignorance of the fact that many places have been ruined over and over again, and others abandoned. Blinkered Biblical vision, however, suggests to the (too many) authors unaware of history that the country has been in ruins since Biblical times, which is not of course the case. The end result is that the many mid- and late-19th century authors search for and see only the Biblical past, thereby abolishing over

31 Hachicho 1964, 150-161: The use of Near Eastern travel for the interpretation of the scriptures and of Homer's poetry. Obenzinger 1999, 39-6o chap 4: Reading and Writing Sacred Geography; ibid. 22-38 Chap 3: "Christianography" and Covenant. 
1,500 years of history. If reading the Bible might be expected to broaden the mind, the reactions of many travellers to the landscape demonstrates that, on the contrary, it encouraged tunnel vision, making them mindless of historical context, and incurious about events since Jacob herded sheep. Thus do the monuments on which they concentrate bear more weight than they are able to stand. Curiously, few of them are interested even in the plentiful remains of churches from the first centuries of Christianity although surely they were aware of the importance of Syria in the development of that religion, and had the opportunity to study surviving monuments and their decorations many of which were soon to disappear. In other words, they near-ignored what they could see in the landscape, as well as centuries of history, in favour of what the Bible related. They were, therefore, far more fixated on Jewish themes, and where possible tried to attribute buildings to David or Solomon, even complexes such as Baalbek, let alone the Haram al-Sharif in Jerusalem, the immense substructures of which are Herodian. An index of this perverted focus is the dearth of references to S. Simeon Stylites, surely one of the most famous of sites in the Mediterranean, and a large complex with a still-standing church and surrounding monastery buildings. There were plenty more. ${ }^{32}$ (Another entertaining fixation, equally revealing of historical ignorance, is on ruts in ancient roads, identified in several quotations through this book as due to chariot wheels rather than heavy carts.)

Concentrating on the importance of Biblical times truncates the past, so that those authors who refer even to the long period of the Crusades let alone visit their monumental remains are few and far between until the later 19th century. The Crusades form an important part of the fortunes of Christianity in the West, and their writings, deeds and relicts demonstrate that Syria formed an integral part of Western consciousness for centuries. It is all the more surprising, therefore, that so little impacts on 19th-century travellers. The main deeds and battles are of course mentioned, but there is little interest in the physical remains. That might be satisfactory for American travellers and tourists, whose "fix" on the Bible is perhaps understandably a direct one; but it is strange that the historical context informs so few French, German or even British accounts, given that Crusade-period fortifications were an unavoidable feature of their home landscape, as indeed they are in Syria, which (in its largest configuration, including Jordan) boasts over thirty of them, the majority naturally very conspicuous.

$3^{2}$ Castellana 2011, 125-146: Antichi monasteri nella regione nord-occidentale della Siria; ibid,. 37-61 Una chiesa bizantina a 'Alia nella regione dell'Oronte - with two reliquaries, Tav VIII \& IX. 
If travel without languages could spell danger, those who stayed at home often got even their information at third hand, which the French call (haute) vulgarisation. Thus was knowledge filtered down to schools. In 1907 Eugène Gallois (1856-1916), chargé de mission par l'Instruction publique, and already the author of books and articles on Spain, Portugal, New Zealand, Burma, Indo-China and Japan, as well as Algeria and Tunisia, claimed knowledge of Asia Minor and Syria by virtue of "divers voyages accomplis en cette contrée, que nous avons parcourue pendant de longs mois." This task, "sans la moindre prétention, cela va sans dire, nous ne faisons que poursuivre l'oeuvre de vulgarisation à laquelle nous nous sommes voués depuis des années." ${ }^{[68]}$

If many acquired knowledge of Syria from school books (some of which included intensive biblical question-and-answer sections ${ }^{[69]}$ ), and others such as Buckingham from looking at site illustrations in printed books, ${ }^{[70]}$ the majority did so via their reading of the Bible which, offering Gospel truth, diverted and dissipated accurate and detailed investigation of the landscape of Syria for decades, as we shall see. For some, just as being English allowed them to feel superior to the locals, ${ }^{[71]}$ so did the Bible, since the Koran was said to have borrowed heavily from it, and to have "the cunning to discern that the Christian revelation contains a system of morality and of order infinitely superior to all the boasted ethics of the heathen or of infidel philosophy." ${ }^{\text {[72] }}$ And many would have echoed Turner's endorsement of 1820 , that "I genially carry the Bible in my hand, and read the history of the places as I visit them." ${ }^{\text {[73] }}$ In 1877 Potter asked whether it was worth visiting the Holy Land because "very much of what one sees in Palestine is so painful and disillusionizing," and "is it not something more to be able to preserve our ideal Holy Land unspoiled by any rude disclosures of a degenerate age and people?"[74] In other words, he was fixated on one version and one element of the past. He answered his own question:

Everything in Palestine that at all shocked me, or jarred upon my sense of reverence, has, somehow, faded out of my memory, while Olivet, and Bethany, and the hill-sides of Bethlehem are to-day a living vision of luminous and beautiful reality. ${ }^{[75]}$

For American divines such as Harman, visiting Europe and the Orient was essential: "I felt that my education was incomplete, that there was a vacuum that must be filled up. ${ }^{[76]}$ His experience in the Holy Land enabled him to throw around vacuous then-and-now Eternal Orient comparisons with the best of them. ${ }^{[77]}$ Other authors were more judicious (or cunning), Jahn suggesting in 1823 that his own book would help "in throwing one's self back into the age, in which the writers lived, and into the situation of those, for whom they wrote."[78] 
For in an inversion of travel- or guidebook-writing, the Bible stood for centuries not just as a vade mecum of religion, but also as a guide to the Old and New Testament sites, monuments and deeds in Palestine. Thus when Jahn in 1823 placed the sources of biblical archaeology as first, the scriptures, and second, the ancient monuments, ${ }^{[79]}$ surely he got his priorities wrong. What is more, as the pair of quotations at the start of this section reflect, this belief (for it was not a fact) did not diminish but actually increased in reaction against the waves of scientific rationalism espoused by evolution, archaeology, and various sciences. ${ }^{33}$ Such beliefs were bolstered by centuries of pilgrimage, and by the huge amounts of blood and treasure expended during the Crusades, although some were indeed undermined by changing attitudes to the sacred texts. ${ }^{34}$

Belief in the continuing existence of biblical sites is understandable, not only because of the book's importance, but also because the Bible so often associates geography with deeds, and because there are no other similar books of such acknowledged antiquity or authority such as (for example) Pausanias could provide for Greece. ${ }^{[80]}$ Forgetting that belief had nothing to do with landscape ("I believe because it is absurd," wrote Tertullian), the aim of devout travellers was to prove that the Bible was true by bolstering its accounts with the very sites it mentioned (as misguided an enterprise as would be using similar means to prove the truth of the Arabian Nights). This usage is nevertheless an inversion, occasioned of course by faith, of any accurate modus operandi for such work, which should start with the sites, and then write the book. The mistake, inevitable in any text taken as gospel truth, is not only to privilege the text over the site but (even more dangerously) to allow travellers to scramble over the countryside to link a heap of remains or a building with the text, and sometimes to extract a souvenir. Certainly, many travellers write with the aim of illustrating the Bible from towns and monuments on the ground; what they should have been doing was investigating the landscape and its monuments and only then seeing what sites might match biblical descriptions.

Since travel books feed on each other as well as on predecessors, writers encouraged this mis-use of the Bible. In D'Estournel's words, approaching Nazareth in 1844, and of course catering at least in part to expectations back home, "à dater de ce jour, je commençai à voyager la Bible à la main: elle devint mon guide."[81] And Macbrair near Beirut in 1839 complained of the roads, and (perhaps the allusion is ironic?) "several passages of scripture came to my

33 Bar-Yosef 2005, Cf Chap 2, 61-104: The Land and the Books - "exploring the production, construction, and consumption of this distinct discourse - 'academic Anglo-Palestine Orientalism."”

Lee 2013 . 
mind, as being here finely illustrated." ${ }^{\text {[82] }}$ For Herschell in 1845 his publication was to help those at home who lacked the leisure to peruse the mountain of available publications: "I feel it right, for their sakes, to mention something about those places that are interesting to every one who loves the word of God." [83] And places should be interesting even if not yet located: thus Porter's 1868 A handbook for travellers in Syria and Palestine contains an Index of places mentioned in scripture, but not yet identified. Presumably anyone identifying them all could then shout "Lotto!" - but verification would always be a problem.

As the above paragraphs indicate, the use of the Bible as a guidebook is both partial and blinkered. Travellers (some of them pilgrims) thereby spend so much time trying to identify its sites that other piles of ruins go unexplored except by those who either take heed of information in classical texts, or are interested in ruined monuments for their own sake. To be sure, pilgrims were schooled since at least the Renaissance to follow strict days of visits in Jerusalem and surroundings, so that sites (naturally) took on a ritualistic aspect, with visitors concentrating on those sanctified by the characters of the Bible. When we throw into the mix the common belief (see below) of the Unchanging East, then biblical sites become that much more alive, because nothing has changed (has it?) in nearly two thousand years! $!^{35}$ Literal belief in the words of the Bible led to a traveller "considered as an infidel, or at least a rationalist," because he explained that "where the healed paralytic takes up his bed, and explaining that the bed was, probably, nothing more than the carpet or light mattress" and got the triumphant retort, "We believe our Bible."[84]

In spite of the problems detailed above, it is certain that without such a strong focus on the Bible there would have been far less scholarship directed at Palestine. This is clear from the original 1865 Prospectus for the Palestine Exploration Fund. Herein it was acknowledged that "no country should be of so much interest to us as that in which the documents of our Faith were written, and the momentous events they describe enacted." Ancient sites were to be identified, especially those associated with Holy Writ, but also "the course of the ancient roads ... the discovery of coins, inscriptions, and other relics."[85] Although they were not specified in the statement mentioned above, it cannot be said that the PEF neglected Roman remains, any more than it can be maintained that the Society would have been established (let alone funded)

35 Rogers 2011, 14: "Pilgrims could view Arabs as unchanged and living history, easily ignoring the dramatic political, social, and cultural changes that had swept across the Palestine landscape over two thousand years. The posited lack of development was thought to only enhance the grim views, or overall tourist experience, wherein one could view an unchanged landscape." 
without the draw-card of Holy Writ. Hence some scholars today can accuse the PEF of skewing research directions in order "to restore faith in the Bible, which was being eroded by Darwinism." 36 Its publications continually expressed alarm at the speed with which antiquities were disappearing, in part because improved sanitation led to lower mortality rates and hence a pressure on building, among other consequences. ${ }^{37}$ Confusingly, even in mid-century excellent accounts of topography such as that by Graham are produced to further the Bible: "we may be quite sure that every certain extension of our knowledge in this respect will afford us additional conviction of the scrupulous accuracy of the Holy Scriptures." [86]

\section{Changing Horizons Meet the Unchanging East}

One remark especially, which occurs to the reader, and which is the more striking as it results from all our researches in the East, is the slightness of the difference, or rather the resemblance, the perfect conformity, that exists between all the details of that [Biblical] period, and those of our own time...the stationary nature of the usages and habits which form the general character of the East. ${ }^{[87]}[1836]$

As the bibliography of source materials for this volume demonstrates, there were plenty of knowledgeable authors writing about Syria and her antiquities without being misled by biblical excursions. Their works dealt with the impact of Crusaders, Muslims and Turks on the country, and did not privilege the period of Christian origins. Just as did archaeologists, so biblical scholars found what they expected to find: blessed were they who saw and believed, and wrote it all down; more blessed still were those back home who had not seen - only read - and yet believed. Of course, without the attractions provided by Jerusalem, Bethlehem and the Bible, there would have been fewer eyes to scrutinise the monuments and towns of Palestine, and less funding for serious exploits such as the Palestine Exploration Fund; but a more balanced

36 Pollock \& Bernbeck 2005, 66: "But the bond between the Bible and the Middle East goes back far beyond the 19th century. Religious attachments of Jews, Christians, and Moslems to the holy places have long been a primary motivation for the exploration of the Holy Land and its antiquities."

Rafeq 2002, 119: "The expanding population, however, became a major threat to public order, as social tension between the poor majority and the rich minority increased in the nineteenth century in the wake of the integration of the Syrian economy into the world market." 
appreciation of the country might have been achieved without such a focus. If we need further convincing that this was indeed the case, compare the adjacent countries of Asia Minor and Egypt, where it was knowledgeable travellers who wrote the guidebooks, and where attention to the monuments depended on access and climate rather than on religion.

Archaeology was perceived as helping the Bible, as when Layard "had brought home evidence that the Old Testament was based on real people, places, and events." ${ }^{38}$ However, the financials indicate that, whereas the British and Foreign Bible Society attracted plenty of funding, the PEF did not: belief did not at first require excavation, and was triumphant over those Doubting Thomases who wished to dig; but then the Bible Society had a revenue of some $£ 100,000$ per annum, against the $£ 2,700$ of the PEF. ${ }^{39}$ Only with the cohorts of Darwin were the "biblicals" forced to support digging, in order to bolster their position, using science as their shield. Even accepting the energy, knowledge and dedication of Biblical scholars, we might wonder why serious work on the startling number of Christian churches to be found in Syria was not started until the mid-2oth century - by which time, of course, many had already disappeared.

Cartography was often the key to unmuddled exploration, including the mapping of the Holy Land itself, ${ }^{40}$ with new expertise in surveying, instruments, and topographical mapping and printing. This was a great improvement on 18th-century and earlier 19th-century mapping, ${ }^{41}$ and relieved scholars, for example those doing research on the Crusades, from the "pauvreté des renseignements recueillis jusqu'à ce jour sur la géographie intérieure des principautés chrétiennes en Orient." ${ }^{\text {[88] }}$ But just what names should sites and settlements have? Certainly, 19th-century travellers had no secure answer.

38 Murray 2007, 210, Layard in Mesopotamia: "Here was proof that the Bible was the truth, and its veracity was the subject of continual debate during the mid-Victorian age. Layard had brought home evidence that the Old Testament was based on real people, places, and events."

39 Bar-Yosef 2005, 167: "In its heyday, the PEF had about 120 local societies in the UK, with an average of ten members per society; and the total receipts from 1865 to 1914 were $£ 138,65^{\circ}$. By comparison, the British and Foreign Bible Society (established in 1804) had, by midcentury, 460 auxiliaries, 373 branches, and almost 2,500 local associations, with annual revenue of well over £100,000."

40 Long 2003, Chap 5, 165-202: Mapmakers and their Holy Lands.

41 Gavish 2005, 3: "Explorers, travellers, and military officers began to delineate the land by modern surveying methods rather than from their impressions, secondhand reports, or interpretations of the sacred texts." Ibid. 5 for a sketch of earlier surveying and mapping in Syria. 
Nevertheless, Conder could protest in 1887 that travellers were muddying the waters especially about ancient topography:

The confusion caused by Crusading and early Christian traditions which have been engrafted in a precisely similar manner, forms already a most serious difficulty; and if in addition we are to have modern foreign theories disseminated among the peasantry, identification will be impossible. ${ }^{[89]}$

There were just a few doubters of the efficacy of the Bible as a guidebook, and if some earlier travellers were sceptical (as severe a fault as credulity, we are reminded ${ }^{[90]}$ ), why drive away readers and reduce royalties by saying so? Who, after all, was going to tell readers back home that there was little left of recognisable biblical sites, because the world had indeed changed? Thomas recommended in 1900 that travellers should look to the Crusader castles which were a panacea for Biblical dodgings: "the mind, tortured and wearied with perpetual contradictions as to the traditional sites of Biblical places, gladly takes refuge in the contemplation of the more trustworthy relics of their exploits." [91] But for the majority, "the nagging uncertainties created by Modernism seemed soothed by the historical "proof" provided by pilgrimage narratives written by contemporaries. ${ }^{\left[{ }^{92]}\right]}$ Best keep off the subject of religion, counselled Baedeker, "as expressions of opinion on these subjects too often lead to serious misunderstandings and even quarrels." [93]

One might suggest that in earlier centuries, given the absence of guidebooks let alone of concepts of archaeology and factual exactitude, such misuse of a sacred text was inevitable. Even in the 2oth century and today, the Bible retains some prestige for the information it provides on early life in Syria, not least because its very existence as a centrepiece of Judaism and Christianity promoted the travel and tourism which helped bring some prosperity. Archaeology must of course take hints from whatever sources it can find over where to dig and what it expects to unearth; yet frequently 19th century and later excavations seem intended, or are interpreted, as attempts to prove the veracity of the Bible, a long-lived notion still an article of faith. Under such a dispensation, every link between sites on the ground and words in the Bible helps this process. As already noted, the amount of attention lavished on the Holy Land and its monuments by travellers and authors was greater than that accorded the rest of Syria, and biblical connections certainly increased funding for research and excavation; but these were directed to (supposedly) biblical sites at the expense of pagan ones, and authors were feeding a known and identifiable market for biblical material back home. Thus when Guérin confessed that after fifteen years studying ("en Italie, en Grèce, en Asie 
Mineure, en Egypte, en Tunisie et en Algérie"), "j'ai été attiré comme invinciblement vers l'antiquité biblique, dont la Palestine possède les restes les plus précieux, ${ }^{,[94]}$ one might be permitted to wonder whether this had something to do with available funding. Cynics may be assured that no such base motives affect academic trajectories today.

Because it was believed that the Bible was under attack, affirmation of its complete veracity was very much alive in an age pushing ever backwards the date of Creation, and also when believers themselves tried to "make use of the prestigious sciences of cartography, archaeology, history, and photography." ${ }^{\prime 2}$ (The last fed myriad popular magazines before they were technically able to reproduce actual photographs. ${ }^{43}$ ) But without excavation (of houses, field patterns, garments - all then impossible), the Unchanging East was simply a leap of faith. ${ }^{44}$ When Thomson wrote in Lebanon in 1886 that "the manners and customs of the peasants and farmers appear to have changed but little from very ancient times... and the stall of the ox and the manger were then, as now, in the house, ${ }^{,[95]}$ this was simply guessing. But the unstated corollary was that, if ox and manger were indeed still in the house, then the Bible was true! Just how far such comparions can stretch is demonstrated by comparing bedouins with Homer's writings. ${ }^{45}$

One reason for treating Bible Lands as exact versions of the Old and New Testaments was the common belief in the Unchanging East:

Elsewhere we can but dimly discern the actors and the scenery of the Elder World through the curtain of obscurity drawn over it by Time; but

42 Rogers 2011, 32: "The "fifth gospel" (i.e., the Holy Land) became a way to skip centuries of ecclesiastical corruption and excess (a crucial theme for Protestantism) to return to the basic, original, and undeniable truths of the Gospel, and at the same time make use of the prestigious sciences of cartography, archaeology, history, and photography." Camp $185^{2}$ for 125 photographs, largely of Egypt, but Jerusalem and Baalbek are included.

43 Lagarde 2006: Le Tour du Monde, founded by Edouard Charton in 186o. He also looked after Le Magasin Pittoresque (founded 1833) for over 50 years, and helped create L'Illustration in 1843 .

44 Bar-Yosef 2005, 83: "While the indigenous population was not entirely absent even from the dominant Orientalist discourse, its role was constructed to conform to the English perception of the Oriental space: in the changeless East, the natives functioned as a living museum."

45 Hachicho 1964, 108 on Robert Wood's Essay on Homer: "In Syria, he finds many characteristics among the Bedouins, which, according to him, remaining constant throughout the ages, very much correspond to Homer's utterings on Oriental manners. In Wood's opinion, this fact verifies Homer's characterization to a great extent, and speaks much for his veracity and precision." 
here, the Past is so faithfully reflected in the Present, that the drama of ancient life seems never interrupted. ${ }^{[96]}$

Or again, in a precious expression of Western arrogance:

C'est qu'en effet ces contrées, berceau de l'humanité, antique rendezvous de tous les peuples, et théâtre des plus augustes mystères, recèlent pour l'observateur, tant par la richesse de leur passé historique que par l'immobilité séculaire de leurs moeurs et de leur physionomie, une mine inépuisable de trésors archéologiques aussi précieux pour l'historien que pour le théologien. ${ }^{[97]}$

Whereas innovation ruled in the West, and old manners and customs were swept away,

the curious traveller will observe among these people the most wonderful and intact preservation of ancient manners... he finds himself, as it were, carried back to the earliest ages of which we have any record ... and observes a faithful transcript of many customs described in the Old Testament, and many copies of pastoral scenes there vividly depicted. ${ }^{[98]}$

There was more sense in contrasting imported Turkish attitudes with those of desert dwellers. Graham affirmed in 1858 that "no European element can be detected amongst the Muslems of Damascus," but that

Among the Druzes such is not the case, nor amongst the Arabs of the Desert. These are totally unchanged. They have the same black tents, the same curtains to fence off the woman's portion of the tent, the same period for crossing the great Desert, the same order of march, the same feuds, and even the same arms and utensils that they had in their father Ishmael's day. ${ }^{[99]}$

To some, it appeared that church architecture was as unchanging as liturgy and vestments. ${ }^{[100]}$ Pilgrims were in a dilemma about the locals: "sometimes they saw them as dirty and uncivilized, while at others, they found them to be conveniently biblical-looking and providing useful authentic scenery."46

46 Rogers 2011, 3: "enhancing the tourist experience by posing for a multitude of remarkable photographs labeled as Bible scenes that have survived to this day. They are at the very heart of these popular pilgrimage narratives." 
Unfortunately, the East was not as clean as the West, so Hamilton in 1875 concluded that "one such trip did away with all the grandeur one was wont to associate with the Holy Land, and that religious fervour soon subsided after witnessing the dirt and misery accumulated there."[101] Distance did indeed lend enchantment to the view. In 1898 Baedeker let fly on the sordid effects of Jerusalem:

The combination of wild superstition with the merest formalism which everywhere forces itself on our notice, and the fanaticism and jealous exclusiveness of the numerous religious communities of Jerusalem form the chief modern characteristics of the city...the contempt with which the orthodox Jews and Mohammedans look down on the Christians is only too well deserved. ${ }^{[102]}$

But the view was also hindered by later accretions, so that Pigeory could suggest in 1854 that the Via Dolorosa should be returned to its early state, as an inspiration for artists and architects. ${ }^{[103]}$ However, the distaste Baedeker evinces in 1898 for the current corruption of the Holy City is goes back at least decades. Midshipman Anderson, for example, travelled there in 1837: "You see pedling Jews, beggars, and Turks as in every other place and the sanctity of ones feelings is marred very much by the fatigue necessarily incurred in getting there."[104]

Poujade, in 1860, having noted both the supposed Tomb of Noah (guarded by no less than a descendant of the Prophet) and the spot on which the whale disgorged Jonah, explained:

Ce sont partout des Musulmans, des descendants du Prophète qui ont la garde de ces marabouts et qui en marchandent rentrée aux Chrétiens ou aux Israélites. Ces traditions locales ne sont-elles pas de véritables commentaires de la Bible, ce livre d'où sont sortis le judaïsme, le christianisme, l'islamisme, si profondément dissemblables dans leurs conséquences, malgré leur point de départ commun? ${ }^{[105]}$

In other words, he did not disbelieve the legends, instead using them to prove the veracity of the Bible. The Tomb of Noah was "occupied by a stone trunk or sarcophagus, upwards of twenty feet long, which they hold to have been the dimensions necessary for containing the body of the restorer of the human race."[106] Such Muslim veneration was the mirror-image of pilgrim management by Christians in Jerusalem (a town which lived off nothing else), where the itineraries often read like the cunning setup by some early Heritage 
Management organisation. Here, indeed, from the Middle Ages the visitors were provided with enough biblical sites hallowed by mass acceptance and millenial convention, to prolong their time there to well over a week. Such arduous itineraries were necessary to full up local coffers. Getting and spending, they did indeed lay waste their powers.

\section{Biblical Monuments "Identified"}

The villages [on the way to Jerusalem] are also, in general, a collection of huts of recent origin, and seldom connected with any interesting point in ancient or modern history. When, however, it may chance that they relate in any wise to the facts of the Scriptures, I have endeavored to make accurate mention of everything of a kind which I supposed would be worth your attention. ${ }^{[107]}[1857]$

Certainly, as already observed, travellers to Palestine would have been fewer (and our knowledge of Syria therefore the poorer) had many of them not gone armed with the Bible, for this was "a fresh and fertile field ... for the operations of our Christian missionaries." [108] (Indeed, a version of biblical archaeology had operated in earlier centuries. ${ }^{47}$ ) And as Spencer's quote above indicates, sites were only interesting when they are mentioned in the Bible. Yet again, reliance on the "pictures" in the Bible helped visitors view the country as fixed in aspic for many centuries, and later additions, such as Muslim buildings, as destructive intrusions into the biblical landscape. This closed eyes to important Muslim architecture, such as those the Ayyubids, studied in detail by Korn. ${ }^{48}$ This is not a constructive attitude with which to visit any country, although it is reflected in supposed connections between aggressive horse flies and the destruction of Sodom and Gomorrah, ${ }^{[109]}$ and even in the reports of H.C. Butler's archaeological work in the first decade of the 2oth century, writing of Tarba with creaking academic humour that "conditions here are still similar to those described in the Book of Job."[110] Indeed, the locals were easily disparaged: when Porter in 1868 saw donkeys carrying stone to Jerusalem,

47 Tigay 2000, for biblical "archaeology" in earlier centuries, and the material finds, many of these accidental, and recorded as such.

48 Korn 2004, 15-19 for a survey of information from early travellers; $75^{-89}$ for palaces, waterworks and baths; keyed plans of Jerusalem (103-108), Damascus (108-118) and Aleppo (118-122), vol II for catalog of Ayyubid buildings: Jerusalem 61-78; Palestine/S Syria 79-98; Damascus 99-169; Mid-Syria 171-208; Aleppo 209-258; N Syria 259-282. 
he uses the Bible as a measure of decline, commenting "What a change from those days of prosperity and power, when Solomon laid the foundations of his palace and temple with "costly stones, even great stones; stones of 10 cubits, and stones of 8 cubits!" ${ }^{[111]}$ He has of course never seen a Solomonic building - he has simply ready about them in the Bible. In 1862 Beke set out to find the place where Jacob had kept Laban's flocks:

we could not but be struck by the sight of some large flocks of sheep, with their lambs only a few days old... As Abraham's servant must have approached from Damascus, which lies west of Harran, he would have met the women as they went out to draw water. ${ }^{[112]}$

It is possible that the eternal Protestant-Catholic enmity produced light as well as heat, including some teaching in Ireland of Catholics in Protestant schools. ${ }^{[113]}$ Indeed, it was suggested that the "emissaries of the Papal Power in Syria" were buying up Bibles from the Bible Society in order to burn them, ${ }^{[114]}$ but then the Protestants could be presented as sceptics flooding into Syria with theodolite, chronometer, barometer, and thermometer. Hahn-Hahn tried to characterise their attitude. They

always begin their researches with the preconceived notion that they must meet with what is false, and they of course do meet with much that is false, and more that is questionable; but whether they themselves arrive at the true and correct decision, remains to be proved.

A good example supporting his criticism was the "Protestant clergyman who disputes the locality of the Holy Sepulchre without ever having been at the place!"[115] Certainly, there was dispute over the status of some sites, but Guérin believed that problems could be solved by archaeology. ${ }^{[116]}$ If, for some "treading in the very footsteps of Christ and the Bible worthies" made them better evangelists, ${ }^{[117]}$ for others more was needed, namely "also the further and more sacred interest in everything which can help to illustrate and make more plain the language, customs, allusions, and history of the Bible."[118]

Scepticism was painful but necessary. Fuller did the sites of Damascus in 1829, found "not a vestige" of Greek or Roman antiquity there, but also chased up the S. Paul connection:

A window in a tower in the eastern wall is said to be that from which he was let down in a basket and made his escape; although a lion and fleurde-lis, which surmount the arch, may seem to refer its construction to the romantic rather than the apostolic age. ${ }^{[119]}$ 
Yet apparently those who "had determined that the sacred histories themselves were but a collection of myths and fables" were to be converted, because

the ancient eastern world has been reawakened to life by the spade of the explorer and the patient skill of the decipherer, and we now find ourselves in the presence of monuments which bear the names or recount the deeds of the heroes of Scripture. ${ }^{[120]}$

Yes, but the spade of the digger (in this case Guérin in 1872) did not hesitate to divide the sites of Jerusalem into three: "les uns étant vrais, les autres douteux et les troisièmes apocryphes."[121]

For the Bible-equipped, monuments and ruins were often seen with the eyes of faith. In the 116os, John of Würzburg saw at Tyre the "the large marble stone upon which Jesus sat, which remained uninjured from the time of Christ to that of the driving out of the heathen from the city, but was afterwards broken by the Franks and Venetians."[122] This was but one of several traditions taken over by the Muslims. ${ }^{49}$ In the late 15th century, Brother Felix Fabri visited Gaza, where he saw "the ruins of a great house or palace," the temple of Dagon, "which Samson threw down by breaking the middle pillars on which it stood, and killed himself, together with the lords of the Philistines." Of course, "we saw two marble pillars, exceeding great, of a gray colour, which once supported the whole building; it was by breaking these that Samson overthrew the temple and laid low his enemies."[123] Jacques Goujon also saw them two centuries later: "ces deux colomnes qui le soustenaient." ${ }^{[124]}$ Two decades later, Thévenot was shown the site, but "ce n'est plus qu'un monceau de terre."[125] At an ancient monastery in the Hauran, "an ancient menhir was shown as the stone against which Job rubbed himself," ${ }^{n[26]}$ while another menhir played a part in Jewish superstitions. ${ }^{[127]}$

Other sites were equally blessed. D'Aramon, travelling 1549 and French Ambassador to Constantinople in the 1550s, saw on the way to Damascus the well in which Joseph was thrown by his brothers. ${ }^{[128]}$ And he also admired Jacob's bridge over the Jordan, with "quelques vestiges de la maison dudict Jacob." ${ }^{[129]}$ At Beirut in the early 150os, Varthema saw "an ancient building, which, they say, was inhabited by the daughter of the king when the dragon

49 Talmon-Heller 2007, 188B: "Syria was indeed saturated with Jewish and Christian memories and holy sites, many of which were adopted by the Muslims... Some medieval historians openly admit that the aura of sanctity of quite a few pilgrimage sites in Syria originated in pre-Islamic times. A big marble seat from Hammam Mughan in Northern Syria, revered as the chair of Jesus, is one example." 
wanted to devour her, and where St. George killed the said dragon." ${ }^{[130]}$ Two 18th-century travellers, however, were inclined to quibble: their guide showed them two pillars near Damascus, where S. Paul had his vision; but the argument was with distance, not with fact:

but herein I believe he was greatly mistaken; for, at a small distance, we found several burial-places, to which these pillars probably might have belonged; for, according to the common tradition of European divines, the place where St. Paul had his vision, was about fifty paces nearer the city. ${ }^{[131]}$

Nor was this quibbling over slight distances a joke, but rather a demonstration of a desired (pseudo-scientific) accuracy, for the same author records seeing on the road to Baalbek "a small ruined building, having near it a pillar, said to be the grave of Abel, and the spot where he was slain by his brother." ${ }^{[132]}$ In the early 17th century at Tyre the "Moores" brought William Lithgow Sampson's Pillar, which he rejected only because Sampson died elsewhere, and "I think the auncient Tyrians, sayd I, could not transport that Pillar so far hither: But they the more constantly affirmed it." ${ }^{[133]}$ This smart Scot was not going to be tricked by any locals! Lusignan in 1783 was told at Ashdod that in that town "was the house that Sampson pulled down; and to the south east, just out of the town, the water in which the eunuch Candakys was baptized by the apostle Philip." ${ }^{[134]}$

Even less of a joke was when Louis-Félicien de Saulcy, the French archaeologist, visiting in $185^{\circ}$, believed he had nailed the true location of the ruins of Sodom and Zoar, because of his fieldwork measuring the distance between them, which "rendait parfaitement compte de toutes les circonstances du récit que la Bible nous donne, de la fuite de Loth, fuite qui dut s'accomplir dans le temps écoulé entre l'aube et le lever du soleil." ${ }^{[135]}$ Again, the Book proves the sites, and the sites confirm the Book.

Biblical history has more episodes of destruction than of construction, and these were capable of turning Syria's monuments into a morality tale. Sites are often contemplated with apparent pleasure by travellers who we might expect to concentrate on any survivals. Thus the ruins of Tyre demonstrate in 1701 "the instability of things here below,"[136] while in 1696 Maundrell noted "how God has fulfilled his word concerning Tyre, viz. That it should be as the top of a rock, a place for fishers to dry their nets on - Ezek. xxvi. 14." ${ }^{\text {[137] }}$ The monuments of Jerash, conceivably the city noted in the Prodigal Son, impressed Buckingham in 1822 as "a city built only for luxury, for splendour, and for pleasure."[138] Indeed, the whole of Palestine was affected, because "chaque 
pierre est un symbole de la révélation divine, chaque ruine un monument de la colère céleste."[139] After reading several such accounts, the reader becomes fatigued. Tyre is promoted as "a monument of prophecy; one of the strong proofs of the truths of the Bible,"[140] while the whole of Bashan "was an ocular demonstration of the literal fulfilment of the curse pronounced on the land by Moses, more than three thousand years ago." ${ }^{[141]}$ Even if a modern scholar can see general poverty and disarray as "a sensible interpretation for these verses," 50 this was not the case in earlier decades.

Literal-minded travellers seem often to delight in such destruction as a proof of the Bible. This is puzzling, for we might have expected them rather to be disappointed by heaps of ruins, to view which they had made such a long journey. Yet, as Shaw remarked in 1808, "every heap of ruins points out to us the weakness and instability of all human art and contrivance," whereas Christians are "seeking a city not like these, subject to the strokes of time and fortune, but which hath everlasting foundations." ${ }^{[142]}$ As a result of searching for that Eternal City, actual ruins rarely get examined with assiduity. Or, rather, their ruination is exulted, especially if referred to directly or even allusively in the Bible. Van de Velde in 1854 actually welcomed the destruction and dispersal of Tyre's remains by speculators, for such diggings "serve to throw a new light on the judgments of God on Tyre, and add their testimony to the Lord's having performed all that he had spoken."[143] Amman also fulfilled God's word; "I will stretch out mine hand upon thee, and will deliver thee for a spoil to the heathen."[144] Biblical prophecies were fulfilled at a time when "Syria was a great, rich and powerful country."[145] Again, monuments do not have to be mentioned in the Bible for travellers to exult at their downfall, for handy quotations are always available. The "idol's temple of Baalbec" was brought down by a succession of earthquakes, yet Van De Velde in 1854 still recollects the words, "The Lord will destroy (tear down) the house of the proud." ${ }^{[146]}$ Petra gets the same treatment from Porter in 1868, where "who can fail to recall the words of Scripture; and who can hesitate to hear testimony to their truth?"[147]

Tourists simply using the Bible as a guidebook were no blight on the landscape, but attempts to explore biblical and other sites by unearthing them (a blight already mentioned) certainly were, and such private enterprise drew

$5^{0}$ Rogers 2011, 112 on Biblical prophecies: "The general poverty and disarray offered a sensible interpretation for these verses, and even when conditions improved, Palestine still lacked what was taken for granted in Western countries. Phillips Brooks noted in 1915 that in Samaria countless columns lay in ruins and the population was tortured by swarms of fleas, so that "the prophecy seems strangely fulfilled." 
a reproof from the Palestine Exploration Fund in 1873 in italics for emphasis, that "Nothing is useful, for Biblical purposes, but a scientific exploration." In any case, such actions upset the natives and put up the prices for any antiquities they wished to sell:

Some additions it may make to our geographical knowledge, some illustrations of ruins; but what is gained in this way is lost in another, for the cupidity of the natives is aroused, prices are raised, jealousy excited. ${ }^{[148]}$

As time went on, indeed, the archaeologists took over, destroying sites professionally.

The PEF was by definition (because of the nature of its readers) probably preaching to the converted, not to say treading very carefully, and culled the experiences of many travellers when it reported in 1873 from "a country where enthusiasm so often endangers accuracy, and a man perfectly and entirely truthful and honest sees what he wishes to see."[149] We might also imagine that those travellers writing about matters biblical were doing likewise, in an effort to sell as many copies of their books as possible.

Archaeology presented many challenges to traditional religion. William Robertson Smith (1846-94) Professor of Oriental languages and Old Testament exegesis at the Free Church College, Aberdeen, from 1876, was thrown out of his chair in 1881 . This was because

he began that series of theological investigations which, characterized as they were by learned research and the use of the most scientific methods, were destined to make his name famous. He was the pupil and personal friend of many leaders of the higher criticism in Germany, and from the first he advocated views which, though now widely accepted, were then regarded with apprehension. ${ }^{[150]}$

Smith was a proponent of new methodologies, and "archaeology's increasingly vocal claims for evolution rather than creation) addressed the core of Evangelical belief in the literal revealed truth of biblical texts long seen as essential to Jewish evangelism." ${ }^{51}$ His lectures on the criticism of the Old Testament were well attended, and from 1883 he occupied a chair of Arabic at Cambridge, and became University Librarian. Clearly, the tide was turning. 


\section{Other Guidebooks: Baedeker, Cook \& Murray}

Molti scrittori di viaggi fidandosi troppo alle menzogne altrui... La miglior cosa per un viaggiatore, è quella di scrivere tutto ciò di cui egli è stato testimone oculare, ne mai fidarsi alle voci d'un altro anco, se fosse amico sincero. ${ }^{[151]}[1828]$

As an antidote to the above, this section considers those guides which, without of course omitting references to the Bible where appropriate, give a more balanced account of the whole territory of Syria. None of these was written from scratch; all depended to some extent on earlier travellers acknowledged to be accurate as well as detailed, such as Burckhardt, praised by Lindsay in 1838 as "indeed a model for travellers, so accurate and precise... so cheerful, so uncomplaining under hardship and privation, that one cannot but love him."[152]

John Murray produced the first modern guidebook to distant points abroad in $1840 .{ }^{[153]}$ His Hand-book for Travellers on the Continent appeared in 1838 , and there were available plenty of reliable books to the whole of Syria from the late 1850s. These supplied practical details (steamers, roads, food, consuls, hotels) as well down-to-earth descriptions of towns and sites. Baedeker's 1876 610-page volume is for Palestine and Syria (not the converse), with 56 references to the Bible in it, nine to the Old Testament, ten to the New Testament. With its no doubt captive audience, it nails its colour to the masthead when describing the literature available, 122-123:

The Bible supplies us with the best and most accurate information regarding Palestine, extending back to a very remote period, and should be carefully consulted by the traveller at every place of importance as he proceeds on his journey. The Handbook contains references to many texts, but it has seldom been thought necessary to make quotations.

By 1910 (German edition), references to the Bible are down to 22 occurences, and it is assumed a Bible will be taken (xcv: "Als selbstverständlich wird die Mitnahme einer Bibel vorausgesetzt.")

Baedeker guides catered for the individual traveller, not for package tourists. His Palestine and Syria (editions in English 1876, 1894, 1898, 1906, 1912) alerted travellers in 1876 to the poor state of the roads, noting that they would have to ride - there was no alternative. ${ }^{[154]}$ The focus on individual travel was underlined by the nine pages of advice for suggested contracts for hiring 
guides, guards, animals etc (needing a consular attestation and stamp) with a dragoman, including extensive notes. ${ }^{[155]}$ The advice survives in a shorter form in Baedeker's 1898 handbook, and these stipulations persist in the 1910 German edition, indicating clearly that Baedeker guides were for individual travellers, not shepherded groups. There is no mention of conducted tours in the 1876 edition, although this was the year Thomas Cook produced their own guide, wherein they offer independent tours, personally-conducted tours, Nile tours (and others for Egypt), and Palestine itineraries, which are their own tours, from 10 days in length upwards to 30 and 40 days. Baedeker does deign to notice conducted tours in the 1898 edition, advising the independent variety, for otherwise (and sniffing at the prospect) with conducted tours "the traveller who joins the party is tied to society which he cannot choose for himself and must resign all claims to be master of his own time or to determine his own route." Unstated was the long-standing assumption that PLUDs (People Like Us, Dear) do not go on group excursions. The clinching argument from Baedeker was that it was no more expensive to do the trip on one's own. ${ }^{[156]}$ This author may have read, without necessarily believing it, Cook's statement that "The most enjoyable way of visiting Palestine is by joining a party. The interest of camplife is thereby much enhanced."

Cook's tourists' handbook for Palestine and Syria (London 1876, with only "Palestine" in bold), emphasises that this is indeed a guide for tourists (pushing the "benefits of associated travel"), and "it does not, therefore, attempt to give exhaustive information, or to unravel the multitudinous threads of controversy woven around nearly every sacred site. It points out all that is to be seen, and endeavours to give concise information upon all subjects in which the Tourist may find interest." (iii). Nor is it necessary to take along a Bible, for the guide contains "the full text of Scripture references, so as to avoid the inconvenience of having to turn to the passage in the Bible." ${ }^{[157]}$ It contains 186 references to ruins, 72 to destroy/destruction, 33 to the Bible, 46 to scripture, and 32 to the Old/New Testaments.

Murray's Handbook for travellers to Syria and Palestine (London 1858, revised 1868, re-written 1875) was by J.L. Porter, and therefore antedates both Baedeker and Cook. ${ }^{[158]}$ It mentions the Bible forty times, and the first line of its Preface (VI) reads "The Bible is the best Handbook for Palestine; the present work is only intended to be a companion to it." And then:

Palestine is the stage on which the most wondrous events of the world's history were enacted. Every nook and corner of it is "holy ground." I have, therefore, made an attempt to group on the old sites the chief actors in the 
sacred dramas. I think no known Scripture locality has been overlooked, and no incident of Scripture history, which would tend to enhance its interest, omitted.

But then Porter was a missionary, ordained in 1846 , and spending ten years in Syria from 1849, with further visits. In any case, such guidebooks were evidently for a niche market, for they did not sell well. ${ }^{[159]}$ This one devotes the first volume to the Holy Land and the second to Northern Palestine and Syria, the publisher's calculation perhaps being that most would buy the first volume, which covered the majority of the holy sites. The second volume contains 19 references to robbers, 16 to danger, and 31 to safety. At this date there were several hotels listed in Beirut, but only one in Damascus, and none in Aleppo. Murray was evidently ecumenical in what he published, recognising different constituencies for different books: for he also published Darwin's highly controversial Origin of Species. ${ }^{[160]}$ Guidebooks such as his were convenient for those numerous travellers who visited the sites, but did not wish to write their own descriptions: thus Berners in 1876 did indeed enter the Umayyad Mosque in Damascus, but contented himself with citing Murray's description, rather than composing his own. ${ }^{[161]}$

The rivalry between Murray and Baedeker was fierce, because there was money to be made and prestige to be guarded. The former firm later claimed plagiarism for Baedeker's adopting the same red cover, and for substantial use of text without acknowledgment. ${ }^{[162]}$ Certainly, the word "Murray" is not mentioned in the 1876 or the 1898 Baedeker's Palestine and Syria volume. Murrays then played the "continentals" card, disdainfully noting that European Baedekers were filled in "with such information as he thought useful to Germans, as for instance by sedulously pointing out where the best Bierstuben were to be found."[163] But then Murray did not publish in German, and Baedeker did publish in English, providing competition. Murray's son, provoked by a Pall Mall Gazette article suggesting Baedeker had invented the travel-guide typology, wrote an account of the Murray business demonstrating their primacy. ${ }^{[164]}$ He indicated the firm's success by his father's purchase of a country house; ${ }^{[165]}$ but he gives no figures detailing copies sold, let alone income book by book, presumably because this was commercial in-confidence information.

One indication of the Murray's guides' likely success was Murray's financing of Layard's Discoveries in the Ruins of Nineveh and Babylon (London 1853), and he paid the author $£ 1,500$ in the first year. ${ }^{[166]}$ (Babylonia and Mesopotamia were popular and much written about, in France as in Britain. ${ }^{52}$ ) Layard's

Maupoix 2006 for accounts in Le Tour du Monde. 
finds at Nineveh were spectacular. He had visited Mosul in 1840, and "as I wandered over and amongst these vast mounds, I was convinced that they must cover some vestiges of the great capital." ${ }^{[167]} \mathrm{He}$ discovered that indeed they did, thanks to Stratford Canning, who also funded the exploration of the Mausoleum of Halicarnassus, and ensured that the finds went to the British Museum. ${ }^{[168]}$ Ibn Hawqal wrote in the later 1oth century about the ruins of great buildings at Babylon, ${ }^{[169]}$ and his mention of Samarra ${ }^{[170]}$ eventually led to aerial photography of the site and then to excavation. The existence of antiquities around Mosul was well known to 18th-century English travellers, Plaisted suggesting the town as a good place to await the next caravan, "for there are many remains of antiquity which will yield you an agreeable amusement, especially if you have a taste that way." ${ }^{\text {[171] }}$

From the above, we unfortunately cannot tell just how popular any of the guidebooks to Syria and Palestine really were, for production run numbers and sales figures are lacking. A PhD topic beckons on the takeup of guidebookfuelled tourism to the East (including French series such as the Guides Joanne), based on whatever hard facts are available from publishers' archives. Other travel accounts deserve to be better known, such as those of Evliya Çelebi. ${ }^{53}$ It is startling that, of the ten volumes surviving in manuscript, in Turkish, only the first two (plus extracts from the rest in these cited Selections) have been translated into English, plus other languages by geographical criteria, into Arabic, Armenian, Greek, Hungarian, Romanian, Russian and Serbian. Extensive travel accounts in Turkish are not so common that they can be ignored in this way, so surely their copious editing could entice yet more $\mathrm{PhD}$ theses in posse?

We have seen above that Cook wrote guidebooks for groups, and Murray and Baedeker for individuals. But for what kind of people they naturally do not try to specify. The Abbé Mariti, writing on Cyprus, Syria and Palestine in 1791, was sure that his work would appeal to all classes of society:

Elle offre à l'homme de lettres des recherches curieuses; au publicité, des idées neuves \& approfondies sur les gouvernemens; au voyageur, des connoissances locales qui dirigeront plus sûrement sa marche; à l'artiste ou à l'amateur, des ruines précieuses à étudier; au négociant, d'utiles instructions \& des encouragemens sur le commerce; à l'homme du monde quelques délassemens agréables. ${ }^{[172]}$

Porter was another author who wrote for individuals, counselling his reader not to hire a dragoman, because of the likelihood of being tricked. In his preface he presents the facts of travelling life, including dragoman rake-offs and 
percentages, stories of robberies, and implores his readers not to be taken in by the rose-laden scents of the east:

Another hint may be useful for poetical travellers, who, becoming enamoured of their dragoman, deem him the very embodiment of truth, honesty, and devotedness. It may be very charitable and pleasing to entertain these feelings, but it is very dangerous to act upon them. ${ }^{[173]}$

\section{Confected Guidebooks: An Example}

The innocent might, even today, expect that a guidebook's author had trekked over the ground proclaimed in the title and shown in the maps, in order to offer accurate descriptions and timely advice. However, modern examples where authors have clearly not visited what they are describing are not hard to come by; so that some guidebooks are more like a coral reef with the dead thoughts of other authors supporting a few live blooms. With the exception of pilgrims' handbooks, most travellers' accounts in centuries past were for armchair consumption only, and their readers were hardly ever expected to go to the country in question, let alone to use such accounts as guidebooks, a genre which is a 19th-century invention intended to cater for actual visitors. This fact alone should help ring alarm bells about how 19th century divines thought the Bible might be used in the Holy Land. It was not difficult for scholars to recognise which travellers had actually travelled, and which travel books were confected, but whether the general public knew when they were being fed rehashed material can only be guessed. Even some famous books of travels were largely invented, such as Sir John Mandeville's book, written in French between 1357 and 1371; his true identity is a problem but, as the Britannica (1911, q.v.) avers, so is "the equally complex one whether the book contains any facts and knowledge acquired by actual travels and residence in the East."

The demand for travel books was voracious, pirated editions and translations frequent, and publishers' lists will demonstrate that by the 19th century there appeared to be more such books than likely travellers. This was indeed the case, and at a lower level than scholarly publications squabbling about site identifications, we find many books stitched together from the works of acknowleged travellers, with the sources named, sometimes quoted at great length, and often slightly disguised as if the current author was doing the writing. An example of the "honest" proclivity in Eyriès, who lists his sources on the title page (Voyage pittoresque en Asie et en Afrique, résumé général des voyages 
anciens et modernes, d'après - then long list of his sources, Paris 1839), who simply strings together long quotes from Sestini, Volney, Wood, Chateaubriand, comte de Forbin, Lamartine, etc.

Straight description is the order of the day, without practical travel hints, accounts of meeting the locals, Bedouin, etc. There are also many travel books where the author has evidently visited some of the sites, but not others, filling them into the narrative from previous works. Anyone reading in detail several of the sources given in the bibliography will soon come across variations on the seen-it copied-it spectrum, and I have added comments to some entries indicating where caution might be required.

Here is an example from Russell's Palestine, or the Holy Land; from the earliest period to the present time (1832), which contains no indication anywhere that he actually travelled himself to the Holy Land. It is confected from previous descriptions, and naturally there are no personal accounts by the author of travails, excitement, food, etc. The content is very dry and circumspect, for obvious reasons. The text demonstrates how the description of one site, in this case Gamala in the Southern Golan, can be confected:

The portals of the eastern gate remain, from whence a noble street appears to have run through the whole length of the city, lined by a handsome colonnade of Ionic and Corinthian pillars. The pavement is formed of square blocks of black volcanic stone, and is still so perfect, that the ruts of wheel-carriages are to be seen in it, of different breadths, and about an inch in depth, as at the ruins of Pompeii and Herculaneum in Italy. ${ }^{[174]}[1832]$

And here is Buckingham's 1822 description, from which it was taken (and acknowledged) almost verbatim, but without any quotation marks:

The eastern gate of entrance has its portals still remaining ... From hence a noble street ran through the whole length of the city ... it had a colonnade of the Ionic and Corinthian orders, at intervals lining it in avenues on each side... The street was paved throughout with fine squared blocks of the black volcanic stone, and this pavement was still so perfect, that the ruts of carriage-wheels were to be seen in it, of different breadths, and about an inch in depth, as at the ruins of Pompeii in Italy. ${ }^{[175]}$

Hence when we read Russell on the theatre at Gamala, ${ }^{[176]}$ we are really reading an almost verbatim transcription of Buckingham. Some kind of chain reaction 
has Garnier adapting Russell's title in his La Judée. Description de Palestine ou Terre Sainte, Considérations sur l'histoire de ce pays depuis les premiers temps jusqu'à nos jours, where part of the Gamala account reads:

La porte de l'est subsiste encore: elle conduit à une grande rue qui traverse la ville dans sa plus grande largeur, bordée par une belle colonnade d'ordre ionique et corinthien; le pavé est formé de blocs de pierre volcanique; il est tellement intact, qu'on y remarque la trace des roues, comme à Pompeii et à Herculanum. . $^{[77]}$

Guérin, on the other hand, actually visited this dangerous area, and gave precise notes on what he found there:

Elle était environnée d'un mur d'enceinte, dont quelques parties sont encore debout. Plusieurs beaux édifices l'ornaient; ils étaient décorés de colonnes monolithes, soit en basalte, soit en granit, aujourd'hui gisantes à terre avec leurs chapiteaux, les uns ioniques, les autres corinthiens. On y rencontre aussi les vestiges d'une ancienne basilique chrétienne à trois nefs, mais aucune trace de mosquée, ce qui m'incline à conclure que Gamala a cessé d'être habitée à partir de l'occupation musulmane. ${ }^{[178]}$

It is often difficult to discover what works are original seen-with-my-own-eyes, and which are confected from earlier accounts, because much work can be required to uncover such devices. Muslim authors were not of course immune from the practice, and an analysis of Ibn Battuta's account of his time in Syria was uncovered several untruths. ${ }^{54}$

\section{Travel then Tourism: The Agony and the Ecstasy}

Setting out upon a journey in Syria is far different from anything you have ever known...I think a Syrian missionary would make a very good Western pioneer. / This morning we had no railroad tickets to buy, no depot to reach, no carriage to put in order, no harness to perplex us, and no smooth plank road before us to effeminate our tastes and unfit us for the steep ascents of life. ${ }^{[179]}[1856]$

54 Allouche 1990, 287: "he may have stretched his imagination a bit too far." 
Thus Jessup, an American missionary, wrote to his father near the beginning of his Fifty Three Years in Syria, as he entitles his book. The subtext is that travel conditions in America were far in advance of those in Syria, where a missionary was indeed a pioneer, perhaps with the locals taking the place of Indians. As Rogers notes, such men were influential and, "Over time, the natives of the land were thought to make up a pleasant, historical, and biblical backdrop that served to enhance what became the modern tourist experience." 55 In the early 19th century, travelling in Syria was uncomfortable, and "the want of inns, theatres, museum, picture galleries, libraries, promenades, evening parties, and the ever handy and comfortable caffé, are privations which an European must ever regret." ${ }^{[180]}$ But conditions continually improved, Carne noting in 1838 that lodgings were "no longer so precarious or repulsive," and travel itself faster. ${ }^{[181]}$ Yet instructions on mounting a camel were still thought necessary half a century later. ${ }^{[182]}$ This could be uncomfortable, it being suggested that rather than riding, it was better to take refuge in a panier, the other one balancing either with a companion (for conversation) or with one's luggage. ${ }^{[183]}$

The usual method of travel by mid-century was to hire a dragoman who looked after all details and provisions, ${ }^{[184]}$ at a cost of more than $£_{1}$ a day. By 1875 this had risen to $£ 2$ a day, but the expenditure was worth it, for "he will give you the minutest details of memorable places and events, and is not unequal to the feat of indicating the exact spot where the Cock crew." ${ }^{\text {[185] }}$ Sites were not yet getting crowded, but tourists could count on seeing several companies of travellers, as Robinson found at Baalbek in $1856{ }^{[186]}$ In 1872 Farley counselled headquartering at Beirut, praising the wandering life, but noting that this "is only suited to those who are in the enjoyment of vigorous health, and not at all adapted to ladies or invalids."[187] Package tours were not for the rich: demonstrating the point, in 1885 Madame Le Ray set out with an entourage of 26 people including soldiers, and 36 horses and baggage animals to carry her five tents; even so, "sachant que le voyage était très pénible pour une femme, je l'avais abrégé d'un jour en me rendant en voiture à Atneh, situé à l'entrée du désert, où m'attendait mon campement."[188]

It was travel books and also museums which fuelled tourists, and already in 1861 Joanne's guidebook was publishing itineraries, neatly calculated to the arrival and departure of steamers. ${ }^{[189]}$ By the 188 os large organised groups,

55 Rogers 2011, 148: “Travel narratives were likewise small worlds unto themselves, crafted by religious leadership for widespread consumption that exerted a tremendous influence upon politics and culture in America for decades to come... enduring patterns for visiting and viewing the East were established by these early pilgrims, and their influence endured for decades." 
many organised by Cook's, were clogging Jerusalem's approaches with "flowing kefiyehs, horses, mules, tents, baggage, bundles without number, dragoman, muleteers, guides, cooks, servants, and all the rest." Indeed, between 1869 and 1885 Cook took 5,000 to Palestine, the total rising to 12,000 by $1891 .{ }^{56}$ Travel was already subject to intercontinental pressures: in 1881 , for example, fewer reached Jerusalem because

the great Centennial Exhibition is attracting the attention of every nation, and very many people, who otherwise would have visited the Holy Land, are turning their faces to the far West, while Americans, on their part, are staying at home. Jerusalem of to-day is bound to be represented there, and thousands of articles made of olive-wood are already on their way thither. ${ }^{[190]}$

And Walt Disney was not to be born until 1901.

\section{Taxes and Robbery}

These two topics go naturally together, and not just in Syria, where some travellers were afraid that death and taxes were sometimes well-nigh simultaneous. The crux of the problem was an impoverished country with ill-paid functionaries and soldiers, profiteering local dignitaries, and a downtrodden peasantry, the settled areas fringed with threatening nomads who exacted their own form of taxation in the form of robbery from whomsoever they could overawe. Nomads we have already met in Chapter One. They were pastoralists, so naturally they exacted crops from the peasantry whenever they could, the more so since they often claimed to have owned the lands being settled since time immemorial. And central government and their ramshackle oversight and collection methods also added to the problem: "it is not the taxes of the Turkish government that are burdensome, but the rapacity of the understrappers in office."[191] These "understrappers" included contentious locals at the sites, as Kinnear discovered at Petra in 1841, when "we soon found that there had been a design either to exclude us from the valley altogether, or to hurry us away before we had time to examine any of the ruins in detail."[192] Travellers were proportionately less at risk than natives, but robbery was frequent enough not only to deter visits to some sites, but also to ensure that much of the note-taking was sparse, as the Europeans were hurried along by apprehensive guides.

Bar-Yosef 2005, 64. 
Robbery was a big problem in Syria due in part to the disparity between the desert and the sown (in Bell's book title) - that is, between nomadic Arabs and traders and farmers in town and country. To be fruitful, a settled life in a house, with agriculture and commerce, required stability through the seasons. Bedouin tribes, however, of which there were large numbers usually on the fringes of settled regions, moved with their animals where fodder or its lack dictated. Many lived by robbing travellers, and sometimes by scaring them simply by appearing on the horizon, ${ }^{[193]}$ but it was easier and more profitable to raid towns and villages for food supplies, rendering agricultural investment and toil pointless if it could not be protected. In many areas, then "le pays plat est la région la plus fertile, mais la plus mal cultivée," because its farmers had taken to the hills. ${ }^{[194]}$ Resettlement amongst the ruins of towns where settlers tried to scratch a living was still impossible in the 1850 around Homs, because "cernés par les Bédouins, ils sont obligés de se racheter chaque jour du pillage par des contributions volontaires ou forcées." ${ }^{[195]}$ As well as around Damascus, at Apamea the fellahs were at the mercy of marauders, described as "le fléau qui dévaste toute cette zone."[196] At one village between Homs and Hama (and surely at others), there was no sign of vegetation, because "les habitants m'apprirent tristement que leurs récoltes seraient infailliblement détruites et pillées par les Arabes des montagnes, s'ils avaient l'imprudence de les attirer par l'espoir du butin.. [197]

Perhaps dangers were, for some, part of the attraction of travelling in Syria? Porter in 1868 noted the interesting places, "all rose-tinted by a dash of danger and romance." ${ }^{[198]}$ In earlier years things seemed much more insecure. Perry in 1743 reckoned travelling Sidon-Damascus put travellers "not only in Danger of

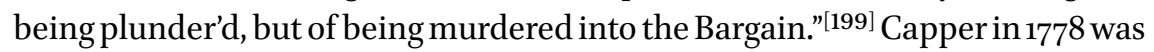
importuned on the way to Palmyra by Bedouin, but they only wanted to try and sell him some camels. ${ }^{[200]}$ Beke in 1862 , about to travel to Harran, was alarmed when the severed heads of chiefs from the region were brought to Damascus, but "at length it was decided that the Consul should apply to Emin Pasha, Wali or Governor of Damascus, for an order to the Commandant at Kiswe to furnish us with an escort as far as Eshmiskin, the residence of Sheikh Ahmed-et-Turk, which he obtained for us just before our departure for Harran."[201]

Yet the revenge of the persistent traveller could be sweet: Tristram recounts in 1865 a robbery near Caesarea, at which the wronged gentleman obtained a special firman (a laissez-passer from a competent authority) from the Porte, in execution of which the Pasha of Acre had to act, sending troops to the miscreant village: "Without trial the three chiefs were put in chains, and upwards of fifty men shipped off as conscripts to join the army in Asia Minor. The Pasha thus succeeded in raising his quota of recruits." ${ }^{[202]}$ The first defence was 
always a firearm and a willingness to deploy it. The Druze were enterprising, and Butler and his American team in 1904-5 were about to be attacked but "they had changed their minds when told of our rifles, which could shoot ten shots to their one, and had retired to consider the matter. In reports of this kind our muleteers and even our servants took particular delight."[203]

Westerners, obviously rich because of the way they generally travelled (horses, tents, baggage train and servants), were a target for semi-legal exactions as well as for robbery; and locals, even given the traditions of hospitality, needed to be kept sweet with presents freely given or exacted. In 1829 Madden recommended maintaining "an unruffled temper and a cheerful demeanour," but also pointed out that "it is a notorious fact, that English travellers are often particularly unfortunate, and this is but too frequently owing to a haughty carriage and uncompromising manners," ${ }^{204]}$ no doubt in part because they did not understand or were unwilling to abide by the local rules of the travelling game. For guns were needed. Lindsay's expedition to Palmyra in 1838 was wellarmed, and kept the Bedouin away: "seven gentlemen, four servants, two muleteers, five soldiers, and four camel-drivers - bestriding twenty-one horses and mules, two donkeys, and five camels." [205] One 1866 traveller needed 40 camels to get herself and her baggage from the coast to Jerusalem. ${ }^{[206]}$

However, even regular soldiers as tourist guards were an unknown quantity: in 1860 Skene was sent "a captain and two sergeants of the Sultan's regular cavalry," but they had to be bribed to execute their protection duties, "and we were obliged to purchase, at an exorbitant price, the freedom of the Sultan's highway." [207] The scent of treasure could, however, double the size of an escort, as Fuller found in 1829: expecting eight men to accompany him to Jerash, he found sixteen waiting: "the villagers were persuaded that we were going in search of treasure; and as all were anxious to share the benefit of our discoveries, our escort was thus unnecessarily augmented. A more ferocious-looking set of fellows I never saw collected together."[208]

Do-it-yourself was an option for the confident, such as Edward Montague, a member of the us Expedition ship [Expedition to the Dead Sea] Supply, which arrived in Syria in 1848: "We have determined souls, enduring constitutions, plenty of provisions, lots of ammunition, swords, bowie-knife-pistols, Colt's revolvers, carbines, and a blunderbuss which is able to scatter some fatal doses among any opposing, hostile tribe."[209]

At Iskenderun Drummond was taxed in 1754, being told "it was a tax laid upon the English a great many years ago, with their own consent, for the privilege of going to Aleppo ... a most scandalous indulto," ${ }^{[210]}$ only to be held up again and again at every pass until he paid a toll. ${ }^{[211]}$ Visas were and continue to be a revenue-raising exercise; Berners got his passport back at Beirut in 
1876 only by paying a fee: "This system is a regular trap to get money out of Europeans, for I learnt afterwards, that none of the officials could read anything but Turkish and Arabic." ${ }^{[212]}$

When travellers saw deserted villages with their ancient houses, they certainly linked such desertion with the exactions made upon the locals. It is to this that Browne in 1799 attributed the desertion of villages in favour of towns, where "the property is not tangible, so to speak; it is veiled from the eye of government, so as to be safe from the excessive exactions imposed on the peasants, whose property is of the most unwieldy and self-apparent description." ${ }^{[213]}$ Griffiths in 1805 wrote of the pashas, "these temporary extortioners," tax-farmers who had purchased their position from the Porte, and then proceeded to profit from it - no wonder the peasants fled to the towns! ${ }^{[214]}$ The pasha had troops with him, "a licensed banditti" who made their own exactions, so that

the state of agriculture is at the lowest ebb, commerce is fettered, and, indeed, nearly annihilated by a thousand restrictions and oppressive acts; their armies consist of an undisciplined and ferocious rabble, and their contempt of the arts is sufficiently apparent in the destruction of the finest monuments of antiquity. ${ }^{[215]}$

The Hauran was not safe, because plunderers visited the settlements regularly, and the protection of the sheikhs did not extend "even a mile beyond their dwellings." ${ }^{[216]}$ Another dodge was where possible to avoid main routes. Here the 183 os were even worse, as added to feeding the soldiers and paying the Bedouin tribute, the amount to be paid to the pasha "depends on the sum at which the whole village is rated in the pasha's books, which must be paid so long as the village is inhabited, be the number of fedhans employed few or many" - a decided trigger for depopulation. ${ }^{[217]}$ As late as 1895 the government decided on a new tax for the Hauran:

The people had risen in their wrath and slain two of the sheikhs, and the governor had saved himself by flight. The people then wreaked their vengeance on any emblems of Ottoman rule they could find. They tore down fourteen miles of the telegraphic wires, and all the officials fled for their lives. ${ }^{[218]}$

In 1838 Addison himself saw what happened when villages were raided: "excitement, terror and agony ... when a press for soldiers is going on ... horses and mules are seized for the use of the government, and... grinding exactions 
made for an arrear of taxes."[219] Such raids could empty whole villages, as Layard saw riding from Antioch to Aleppo in 1839:

owing to the conscription and the tax-gatherer, the villages were everywhere deserted, and we had much difficulty in discovering at some distance out of the high road some miserable huts, in which we could find a night's lodging and food for ourselves and our horses. ${ }^{[220]}$

The result was agricultural paralysis, as Baron Taylor explained in 1854, describing the results of Ottoman exactions in the pachalik of Aleppo. ${ }^{[221]}$ Lortet was still fulminating against tax-farming in 1881, suggesting Europeans should intervene against "ces tribus de bandits," and proposing - to no-one's surprise that "le devoir de protéger ces paisibles et aimables populations qui seront pour elle, et surtout pour la France, une source sérieuse de richesse et de puissance." ${ }^{[222]}$ The results of such apparently inevitable intervention will be dealt with in Chapter Eleven, where the French Mandate to Syria will be discussed.

Travellers were therefore clear that several causes were involved in the physical survival of complete and usually deserted ancient towns and villages in Syria. One was the insouciance of the Government and its failure vigorously to promote agriculture in a land of rich and well-watered soils. Another was Government-imposed taxation, which sometimes made it uneconomic for peasants to function, and they supposedly percolated to the towns. At some periods there was conscription, another form of taxation, for labour was taken from the soil, and the conscripts were frequently to be fed by the peasants. A fourth was the age-old tension between settlers and nomads, with the latter "taxing" the former for protection money, otherwise leaving the countryside unsafe. Government inability to deal decisively with nomadic incursions blighted agricultural development, and left many travellers anything from apprehensive to duly "taxed" by the nomads until the later 19th century when, as we shall see several towns are permanently repopulated. It also blighted archaeological research: Conder, a military man, writing in 1891 about his survey of western central Jordan (Moab), expatiates on "the perils of our position," being plagued by lawless Arabs and attacks by thieves, which showed "how difficult it was to carry through even that small portion of the great task which we completed, and how utterly impossible it was to do any more."[223]

The "nomad problem" for settled communities is documented by European travellers from the 17th century. De Vogüe in 1865 asserted with some reason that the nomad problem was endemic since the Muslim invasions. ${ }^{[224]}$ 
It is certainly much older, and probably perennial, for we have already noted that some settlements required protection in Roman times. ${ }^{[25]}$ Even travelling Damascus-Aleppo was dangerous in 1851, for "the Arabs were plundering and at open war with the Pasha." The problem was solved by accompanying a whole regiment, on its way to Homs. ${ }^{[226]}$ Nomads were sometimes at the root of a wider malaise: Europeans were amazed that a country with such rich and well-watered soils produced so little food; and they marvelled at the abandonment of large numbers of towns and villages amidst such potential richness. Thus in 1829 the Hauran "n'est presque plus habitée, parce qu'elle est exposée aux incursions des Bédouins." ${ }^{[227]}$ Porter reported in 1855 that in the spring everyone in Bosra lived in the fortress, "that they may protect their flocks and their property from the nightly depredations of the Bedawin. A massive gate, covered with heavy plates of iron, serves to secure them against all plunderers." A company of soldiers once garrisoned Bosra, "but now there is no garrison, and the rapacious Bedawin roam freely over the fields of the poor peasants, who have to pay them black mail." ${ }^{[228]}$ The territory around Bosra was still infested with marauding Bedouin in the 188os, confirming Porter in his reading of S. Luke about the man who fell among thieves. ${ }^{[229]}$ Just as the Bedouin raided agriculture, so also they were on the look-out for clothing. In the early 1840 a traveller joined a caravan at Jerusalem, but fell behind and was stripped by robbers: "he was in some little difficulty how to return to Jerusalem, as the only article of dress which the Bedouins had left him was his hat, of which they could make no use."[230]

No doubt the Bedouin were on occasion correct to be exasperated, for example in the 1820 s by "Rev. Mr. S.," an English clergyman, who toured Syria, "in the course of which, being little skilled in any language but his own, and moreover of an extremely warm and passionate temperament, ill-suited to the tedious progress of travelling in that country, he was involved in perpetual quarrels with almost every person with whom he came in contact, and was frequently reduced to circumstances of great embarrassment." He was robbed at Baalbek, abandoned by his servant, left his horses and baggage on the way to Aleppo, and eventually "Mr. S. presented himself at the Consulate, with scarcely any dress but a Mashlakh of the coarsest materials, a large straw hat on his head, and a bag containing his provisions slung between his legs." ${ }^{\text {[231] }}$ Once again the Bedouin seem to have left little more than his hat.

Lack of a controlling authority which could deal effectively with nomad depradations, and often crippling taxation, was also a contributing factor to the abandonment of many settlements and a consequent decline in agricultural provision and development. The locals took the brunt of active robbery, 
and naturally of taxation, which often appeared to them another form of robbery. Keeping marauding Arabs out of villages in the 17th century involved, around Samaria, digging ditches rather than erecting walls, and then planting them with crops, to ensure a horseman would break his own or his horse's bones. ${ }^{[232]}$ Protection money was another type of robbery. At Homs in 1736 a traveller noted devastation and ruins, attrributing it to "the Arabs of the neighbouring Desarts of Syria, or Arabia, who extort large Sums of Money from time to time from the Inhabitants." ${ }^{\text {[233] }}$ In the 185 os settlements in the Hauran were being attacked weekly, and all Muslim villages paid blackmail, whereas the Druze made the Bedouin pay for watering their flocks. ${ }^{[234]}$ In 1838 Robinson was scared off some sites near Bosra because "on nous assura que le pays qui l'environne était très-dangereux." He was naturally sorry to miss an area where there were "d'innombrables villages bâtis en pierre, mais tombant en ruine, ayant été abandonnés à cause des exactions des Arabes du désert auquel ce pays est contigu." ${ }^{[235]}$ Those towns and villages around Aleppo will be dealt with in Chapter Five, and those in the south in Chapter Seven.

Robbery also contributed to the agony of travel, and it is not surprising that Deschamps in 1678 was convinced that Arabs were people "qui ordinairement ne vivent que de volleries \& de rapines." ${ }^{[236]}$ Wittmann in 1803 agreed, with settled folk and nomads equally culpable. ${ }^{[237]}$ War (such as that involved in the expulsion of Muhammad Ali in 1840) also made the roads unsafe. ${ }^{[238]}$ At Acre in 1875 , in the courtyard of the monastery, Hamilton had to spend his time throwing stones at the muleteers trying to steal his grain, for "plunder, plunder is the order of the day throughout Syria, and you have to be perpetually on the alert to prevent it in every department of life."[239]

How, therefore, were travellers to proceed? Was it better to disguise oneself as a local, or to wave official papers and claim access that way? Reports varied. As we have seen, Eastern dress was less obtrusive and, for some, more comfortable. Cassas, for example, in the East in 1785, got to Tripoli and "se hissa, vêtu en Arabe, avec un interprète, sur un chameau, au milieu d'une caravane à destination de Bagdad." [240] Seetzen, travelling in 1809, disguised himself as an Arab, as did Burckhardt (as Sheikh Ibrahim). The latter was the first European to visit Wadi Mousa (Petra). But there was a disadvantage:

Both these travellers, indefatigable as they were, performed this trip alone and in disguise, and were consequently obliged to conceal their papers, and make all their observations by stealth, which must necessarily have rendered their remarks very brief and cursory, compared to what they would have been had the writers being unrestrained. ${ }^{[241]}$ 
Seetzen had a passport from Abdallah, Pasha of Damascus, but it was the conduct of his bullying guide ("taken for a soldier and a Mohammedan") that smoothed his passage. ${ }^{[242]}$

Eschewing disguise, another way of perhaps proceeding safely was to utilise laissez-passer papers obtained in Constantinople, necessarily assuming the locals could read, and the traveller speak sufficient Arabic. Thus in 1697 Maundrell thought it politic "to get license of the governor" before he entered Baalbek:

Being taught this necessary care by the example of some worthy English gentleman of our factory; who visited this place in the year 1689, in their return from Jerusalem, and suspecting no mischief, were basely intrigued by the people here, and forced to redeem their lives at a great sum of money. ${ }^{[243]}$

In 1822, Buckingham had to bolster his letter's effect with the local sheikh by presenting a soldier who "was in the service of the Pasha himself, and had been sent from Jerusalem to protect and accompany us to Sham [Damascus]."[244] But by the mid-19th century local pashas were probably fed up of seeing such documents from afar:

j'étais muni d'un firman du sultan, et je le croyais assez efficace pour m'ouvrir toutes les portes; mais il n'en a pas été ainsi: les pachas font peu de cas de ces lettres, qu'ils voient, d'ailleurs, entre les mains de presque tous les Européens. ${ }^{[245]}$

Near Mount Carmel in 1808, Shaw's group had twenty armed servants, but still to avoid trouble "we then travelled through as many by-paths as our conductors were acquainted with; riding in this manner, without halting, sometimes twelve, sometimes fifteen hours."[246]

By the mid-19th century, many travellers went in groups, which was safer. Even visiting the Dead Sea in 1868 without an escort was dangerous: "it would be madness for ordinary tourists to attempt the journey." The Consul in Jerusalem would provide advice, and "the usual and best plan is to contract with a local chief, who guarantees the safety of person and property, procures requisite guards, pays all bakh-shish under every name and form, provides competent guides and in return is paid a fixed sum." ${ }^{[247]}$ We have already read Baedeker's warning against the horrors of group travel. As Skinner pointed out in 1837 that even most individual travellers "move through the East so well attended by 
guides, servants, and escort, that I think they must lose much of the pleasure for which they go."[248] Several areas of Syria were difficult or dangerous right up to the end of the 19th century. In 1895 a Canadian cleric offered up a prayer that "we would have no difficulties or unpleasantness in travelling; native porters not being the most pleasant and agreeable of folk." [249]

\section{Profiteering Sheikhs}

Local sheiks were usually convinced they owned the land over which they roamed; and who except a distant government was to deny this? They provided notional protection according to the age-old demands of hospitality. There were various ways of dealing with paid contracts and presents. For whenever sheikhs demanded it, travellers were obliged to take an escort, and this could turn into an opportunity for extortion, or extended bargaining. ${ }^{[250]}$ Graham's in 1858 with a Druze sheikh lasted more than a day. ${ }^{[251]}$ Contracts were common, such as Capper's for an escort from Aleppo to Basra. ${ }^{[252]}$ Laborde took along "as presents, a spy-glass, a remarkably fine Albanian gun, a double-barrelled English gun, a watch, and a Cashmere shawl," and suggested instruments be lacquered black so the locals would not think they were gold. ${ }^{[253]}$ Negotiating could be drawn out and ultimately unsuccessful: near Jerash in 1864, the sheikh's suave diplomacy quickly degenerated "to the coarse laconism of a garotting ticket-of-leave man, and he told us simply to hand over our money."[254] Nor was this exceptional: merchants in 1678 on the way to Palmyra had to negotiate with a sheikh, who demanded $\$ 500$ or he would hang them. ${ }^{[255]}$

For his trip to Bosra, Burckhardt bargained a fee down from thirty to three piastres [about six British pence], ${ }^{[256]}$ but then he spoke Arabic. He had other bargaining coups, in one case swinging the favour his way by making a present of a pen-knife, remarking that such a gift

worth two shillings overcomes the fanatism of a peasant; increase the present and it will have equal effect upon a townsman; make it a considerable sum, and the Mufti himself will wave all religious scruples. ${ }^{[257]}$

And in the Ledja he won the day by blustering and swearing, and waving "an old passport from Soleiman Pasha." ${ }^{[258]}$ Richter also spoke Arabic, but rejected an offer to visit Jerash and Amman without letting the pasha know: "je serois resté fidèle à mes principes, qui étoient d'éviter tout ce qui pouvoit me rendre suspect aux autorités du pays, et même de ne pas faire un pas sans leur agrément."[259] Maundrell had also been cautious at Baalbek in 1697, obtaining 
a licence from the governor before visiting, because a decade previously English travellers had been shaken down and nearly lost their lives. ${ }^{[260]}$

Sheikhs were well aware of the going rate for protection, and had details of what it had cost previous travellers. Tristram negotiated in the Jordan Valley in 1865 , and moaned that "we felt here as we did also some months later in the East, how little cause travellers have to thank the evidently well-funded M. de Saulcy for his lavish expenditure on both his visits." ${ }^{[261]}$ As Graham pointed out in 1858, the first protection bargain struck in an unvisited region would set the standard for later tavellers, hence the need to be parsimonious:

No one, however, has done so much mischief in this way as M. De Saulcy, who has literally closed the road for some time to travellers east of the Dead Sea. If you wish no one to follow in your footsteps, you cannot attain your purpose more effectually than by giving a great sum to the Arabs who accompany you. They are sure to double the demand on the next traveller. ${ }^{[262]}$

Unfortunately Lady Stanhope, who we shall meet again, and who was in various ways a 19th-century version of the Getty Museum, had paid an enormous price to get to Palmyra, and this was not only remembered, ${ }^{57}$ but queered the pitch for everyone else. As Richter noted in ${ }^{1815^{-1816}}$ of now-grasping Arabs, "tous avoient été rendus exigeans par les prodigalités de lady Stanhope."[263] In 1818 Irby and Mangles bargained hard to get the price reduced, but still "it was deemed expedient to assume so humble an appearance, in order to hold out no temptation to either pilferers or plunderers." ${ }^{[264]}$ No doubt some sheikhs were free of white lies when setting an acceptable sum, but one group of travellers combined joyful vandalism with helping the next party along, with graffiti in a place they were bound to find it. In 1844 Measor at Petra had inscribed on an ancient wall just how much he had paid to sheikh, and his friends later quoted this to get the price down, without avail: "This appeal to the litera scripta availed not, for they were compelled to pay the full "bucksheesh," and old Abou sent immediately one of his men to erase the obnoxious inscription from the rock, I hope those at the Khuznee will not share the same fate."[265] Where there were no entrance charges, travellers could nevertheless leave

57 Turhan 2003, 146 on Stanhope's expedition to Palmyra: "Stanhope sent the bill for the expedition to the British ambassador. Although the funds to finance the expedition were not immediately forthcoming, the reciprocally respectful relationship established between her and the Porte kept her in good stead for the next twenty-four years." $158-160$ : Stanhope as a second Zenobia. 
their mark. Pride in their Princeton association generated an inscription on an ancient monument at Ummal-Quttayn. ${ }^{58}$

Difficulties could arise when the travellers wished to traverse the lands of more than one sheikh; Richardson met with this problem in 1822, and had to abandon his planned visit to Jerash. ${ }^{[266]}$ In 1860 Taylor also missed Jerash, as the relevant sheikh demanded he take an escort costing $\$ 150$, so he headed for Bosra carrying a firman from the Pasha of Jerusalem. ${ }^{[267]}$ Another frequent problem was the Bedouin at war amongst themselves, ${ }^{[268]}$ or in revolt against the government: Richardson, again, missed Palmyra for this reason. ${ }^{[269]}$ Toward the end of the century the "Honorable Mrs. Digby" was "rescued from danger in travelling to Palmyra by her escort, a fine-looking Sheikh, and chief of a tribe of Bedouins," and solved the problem by marrying him. ${ }^{[270]}$ She was lucky: Elliott in 1838 decided against making for Palmyra from Baalbek because a group had just been "attacked by the Bedouins; their horses were taken from them; one of their party was killed; and all their property plundered."[271]

Travellers could also be imprisoned by locals in search of a handout. At Palmyra in 1817, Bankes was kept in the local village (within the Temple of Bel) for over two days because the sheikh wanted more money. ${ }^{[272]}$ The site's track record was bad: English merchants were plundered in 1678 and never got there, and Burckhardt, although clothed as an Arab, was robbed at his first visit. ${ }^{[273]}$ Burckhardt also kept well away from the sheikh at Shahba, "who some years ago compelled M. Seetzen to turn back from hence towards Soueida," and therefore did not see the complete town. ${ }^{[274]}$

Even at the end of the 19th century, a local sheik was nervous about helping travellers to visit Qanawat, stipulating the need for an escort of one hundred soldiers. This was reduced to twenty when the traveller refused to pay for them; and Gertrude Bell implies that this was some kind of fiddle, for this was countryside "through which, as I know well, a woman can ride with no escort but a Druze boy, and might ride alone, even if she had her saddle-bags full of gold." ${ }^{[275]}$ Fiddling was endemic, Porter pointing out in 1868 that the dragoman often colluded with the local sheikh to screw as much as possible out of the traveller. ${ }^{[276]}$

Not all profiteering sheikhs were necessarily local, for the Holy Land attracted foreign settlement, and that often meant money. Enthusiasm for the territory attracted entrepreneurs: in 1867 one American promoted the "Church of the Messiah," and encouraged his followers to found a colony in Palestine near Jaffa, where "that land, or town lots, purchased near there, must so increase in value that the possessors would speedily become rich. The

$5^{8}$ MacAdam 1986, 369 pl.15, Ornamented lintel at Ummal-Quttayn - "Princeton" has been written on a block to the left. 
enterprise, as he represented it, was to possess the double character of religion and speculation - the first, to help the coming of the Messiah, the second, to help themselves."[277]

\section{Haram/Forbidden: Access to Muslim Sites ${ }^{59}$}

As we shall see later in this chapter, disparaging the available monuments was a parlour game played by many travellers, who compared Syria's structures with those in Greece and Rome. But this was distinct from the longing to visit those which were out of bounds, such as the Dome of the Rock and the Umayyad Mosque. The former was compared to Córdoba, and Laorty-Hadji in 1854 could only relay to his readers what the ambassador had learned about the interior. ${ }^{[278]}$ In 1835 Michaud had been convinced that Christians would never be allowed in the Umayyad Mosque, ${ }^{[279]}$ but the situation changed in both Jerusalem and Damascus. Indeed, in the 185 os the visitor to Damascus "can, under the most favourable circumstances, only get a peep into their courts through a window or half-open door." ${ }^{[280]}$ By 1876 a fee gained entrance and (unnecessarily in this case) "the Consul's janissary accompanies the party, in order to protect them from any fanaticism on the part of the Mahomedans."[281]

Just as many Westerners were curious to experience sights such hot baths and bazaars, so the architecturally aware were interested in mosques and other Muslim religious buildings, and were able to visit many in small towns. But for centuries Christians were barred from those at Cairo, for example the Sultan Hassan, the Sultan Qalawun, and the Al Azhar, Bankes evading the prohibition by adopting Arab robes and growing a beard. ${ }^{60}$ The same embargo operated at Jerusalem, including the Dome of the Rock and the al-Aqsa Mosque, both on the platform of the Haram al-Sharif, the "Noble Sanctuary," on which they sat, and also the Great Mosque at Damascus. It is curious that the Dome of the Rock, probably built in competition with the Church of the Holy Sepulchre, was not open to Christians for their admiration, ${ }^{61}$ but perhaps it was open in the earlier centuries of Islam?

59 Turhan 2003, 107: "The first definition refers to that which is forbidden and unlawful and also that which is sacred, inviolable, taboo. It is used to refer to places that are considered a sanctuary (e.g., the cities of Mecca and Medina are themselves haram) and that therefore are restricted to limited access and certain kinds of behavior."

6o Seyler 2015, 101.

61 Peri 2001, 74: "Muslims, from the outset, chose to respond to the religious challenge posed by the Christian holy sites with a competitive act rather than with violence and destruction, or expropriation and functional conversion." 
Those who knew mediaeval Arabic authors must have been sorry to miss such structures: Edrisi (c.110o) considered the Umayyad Mosque in Damascus "la plus curieuse qui existe dans l'univers, tant sous le rapport du dessin, du plan, que sous celui de l'art qui préside à l'exécution des ornements. ${ }^{\text {"282] }}$ And in the late 1oth century Al-Muqaddasi wrote of the Haram al-Sharif in Jerusalem that "in the ceilings of its various edifices there are 4,000 wooden beams, supported on 700 marble columns; and the roofs are overlaid with 45,000 sheets of lead." ${ }^{283]}$ Since he provides the earliest surviving detailed description of the Dome of the Rock, we may perhaps assume that he had visited the site, in which case his quantities are surely a poetic exaggeration. Mosques elsewhere were also often rich in marble columns, also taken from earlier structures, but not as rich as those on these two sites. Buckingham in 1822 encountered one on his way to Gadara, "and within the walls, the capitals of two Doric columns, in white marble, and some scattered shafts of the same material," plus sarcophagi in the adjacent khan, "and several large hewn stones were seen in different parts of the town, which, with the marble columns in the ruined mosque, induced us to conclude that this also had been the site of some ancient settlement." [284]

This long-lived restriction meant that accurate accounts of these buildings (especially of their interior) did not reach the West until after the middle of the 19th century. Travelling in the early 1480 s, Fabri gives a long description of the Dome of the Rock, but he makes mistakes, such as that the mosaics were "of palm-trees or olive-trees, or figures of cherubim." ${ }^{[285]}$ ) This was silly, because he stated honestly that he could indeed describe only a part of the Haram al-Sharif:

All these things I saw with my eyes from the outside, but what it is like within I have not seen, though I have been able to guess with some probability from the outward form of the temple, and from the other mosques which I have entered. ${ }^{[286]}$

In 1714 Cornelius Le Brun believed one could be burned for even setting foot on the Haram al-Sharif, ${ }^{[287]}$ though travellers could contrive to view it from a distance. Although he does not say where he stood, Hasselquist in 1766 could get no closer than Mount Sion, and "no Christian can approach nearer to this most principal of holy places, than Sion, which is at two gunshot distance."[288]

Christians were recognised as such by their clothing, and it was reported in the late $1^{\text {th }}$ century that "the infidels will not endure that Christians should enter their cities and towns riding on beasts, unless they come in the dark: by daylight they cannot do so." ${ }^{[289]}$ It was also said that such sumptuary laws were 
enforced to enter Damascus, and that even foreign consuls obeyed them. ${ }^{[290]}$ Christians in disguise fared differently, as we shall see. Even close approach to such sites was forbidden, on pain of death ${ }^{[291]}$ or, as Thévenot noted in 1689 , of turning Turk and becoming a Muslim. ${ }^{[292]}$ One fanciful explanation is given for the embargo on infidels in such sacred areas, relayed in 1624, namely that wishes made there were granted by the Almighty, so that "il accorderait tout ce qui luy seroit demandé en ce lieu: \& pourtant que si les Chrestiens y entroient, ils le pourroient prier pour l'avancement du Christianisme, \& pour la ruyne de leur Religion, ce qu'ils obtiendroient infalliblement."[293]

So travellers could report little about the Dome of the Rock, and we have no full description of the Haram al-Sharif until ${ }_{1873},{ }^{[294]}$ although Father Doubdan (recognised as a reliable source ${ }^{[295]}$ ) gave an adequate account of its external appearance after his visit in $1651 .{ }^{[296]}$ Arvieux in 1735 noted that "Les Turcs en ont fait leur principale Mosquée, l'ont orné autant qu'ils en sont capables," which is not very helpful. ${ }^{[297]}$ Even less helpful were sheer guesses about the interior: Beauvau asserted in 1608 that "le dedans du Temple est tout blanc; hors mis quelque peu de Mosaicque, qui reste du vieux temps," ${ }^{[298]}$ and this misinformation is repeated by Deshayes in 1624, with a baroque variation: "tout blanchy, hormis en quelques endroits, où le nom de Dieu est escrit en grands caracteres Arabiques."[299] These are obviously garbled variations on information provided by local Muslims. There was a short interregnum in 1831-1839, when the modernising Mehmet Ali ruled Palestine and allowed Christian access to Muslim holy sites; after which, supposedly because of "the conduct of Prince Puckler Muskau," Christians were again barred. ${ }^{[300]}$ In later decades a stiff entrance fee ensured admittance. ${ }^{[301]}$ Perhaps Curtis was exaggerating in 1903 when he described the approach via filthy streets, and the need to be accompanied by a guard. ${ }^{[302]}$ In a sense Christians, especially American Protestants, targetted new holy(-ish) sites, such as Robinson's Arch, which "became a Protestant answer for Christians and Jews to the restricted access imposed by Muslims to ancient Temple Mount, and a monument to American scholarly achievements." ${ }^{22}$ This area was still out-of-bounds in 1843 , when Williams could recommend only "careful enquiry among the Muslim inhabitants, or by a survey from the exterior, aided by a telescope, or by employing as proxy an intelligent native dragoman."[303]

Wortabet got into the Dome of the Rock in $185^{6,{ }^{[304]}}$ and in 1864 Guérin, under the auspices of the French Consul, entered not once but twice ("interdite naguère encore aux chrétiens"), and also the Al-Aqsa as well. ${ }^{[305]}$ Vetromile 
entered both buildings in 1871, with the French, Spanish and Italian consuls, and explained his lack of interest in what he saw with a burst of disdainful one-upmanship: "I was not very anxious to see the Mosque, but I wanted to visit the spot on which the famous Temple of Solomon stood." ${ }^{[306]}$ In 1874, however, the Duc de Luynes could only get as far as the stairs to the site ${ }^{[307]}$ which, given his architectural knowledge and the full descriptions of other important monuments in his books, was a pity. Under the protection of men from the consulate, Vicomte Savigny de Moncorps entered the Umayyad Mosque in 1873, aware of how recently that had been forbidden:

On retrouve la trace de ces origines dans une masse de belles colonnes grecques en pierre et en marbre, et des fragments de mosaïques épars un peu de tous les côtés. La cour est immense; elle renferme sa fontaine et un petit pavillon octogonal, supporté par de vieilles colonnes qu'on dit provenir de l'ancien temple. ${ }^{[308]}$

The platform in Jerusalem was easily protected because of its height, but the Umayyad Mosque in Damascus was in the midst of a confusion of streets, the "Street which is called Straight" being the exception. Maundrell viewed the exterior in 1697 , but could not enter ${ }^{[309]}$ Yet one might spring out by a door, stick one's head inside, and get a vague impression, as did Perry in $1743 \cdot{ }^{[310]}$ Hill did likewise in 1866: "I stepped out a few paces, and arriving safely at the proper door, I put my head, at least, within, without pulling off my shoes."[311] Bare-faced (or rather, bearded) cheek could also work, as Buckingham recounts in 1825:

when we had arrived, we shook off our slippers and walked boldly through. By the aid of our beards, white turbans, and a certain conformity to Turkish or Arabic movements only to be acquired by habit, we passed undiscovered, and without even being regarded, as mere strangers generally are, though known to be of the same faith. ${ }^{[312]}$

In Thévenot's day (1689) a nearby house with a balcony gave a good view into the courtyard, which he describes: "La cour est pavée de belles pierres, la plupart de marbre luisant comme des miroirs. A l'entour de cette cour sont plusieurs colonnes de marbre, porphyre \& jaspe, fort délicatement travaillées qui soutiennent une voûte qui règne tout autour, peinte de divers ouvrages à la Mosaïque."[313] This was evidently before the columns of the courtyard were encased as square pillars. In 1833 Catherwood, Arundale, and Bonomi entered supposedly to make repairs, and their sketches were the best available for forty 
years. ${ }^{[314]}$ Even in 1840 Damascus was described as "the most intolerant and the most fanatic," and an exasperating place for Christians to visit; ${ }^{[315]}$ but this was the reaction of one visitor, and Christians had lived there comfortably for centuries. ${ }^{[316]}$ Nevertheless, in 1861 the Comte de Paris was admitted by the Pasha only at night, "pour ne pas exciter un fanatisme contre lequel il n'aurait pu nous protéger." [317] Admission was available by 1879 when Knox gave a short description, ${ }^{[318]}$ and Guérin's only complaint in 1884 was that entrance cost 20 francs. ${ }^{[319]}$

And what of the Roman portico to the west of the Mosque, which today frames a small square before one entrance? In earlier centuries this was not visible from ground level. In 1853 De Saulcy tipped a bazar owner: "on grimpe par un escalier fort obscur, au-dessus du bazar, et l'on se trouve en face de quatre énormes colonnes corinthiennes que surmonte un fronton gigantesque, surchargé d'ornaments." ${ }^{[320]}$ This structure was so cluttered by shops that the following year Van De Velde had to be led to (presumably) the same shop: "We went into a house and climbed up to the flat roof, where I had the pillars close before me. The columns are almost entirely hidden by the mason-work of the adjoining houses."[321] From this we can speculate that little of Roman Damascus was visible in its crowded streets. Elsewhere, Bankes obtained permission in 1816 to enter the mosque at Acre and, as a bonus, was able to use the baths. ${ }^{[322]}$

Not all monuments forbidden to foreigners were religious ones, for many fortresses seem to have been out-of-bounds. Drummond complains in 1754 that the citadel at Aleppo was forbidded to Christians, but he still learned what it contained: "there are thirty cannon, of different sizes, mounted, and three hundred in their arsenal ready for use. It contains above one hundred houses, and about one thousand people." ${ }^{[323]}$ De Saulcy complained about both mosques and fortresses:

Or, nos anciennes églises ont été presque toutes converties en mosquées, et les châteaux sont encore maintenant occupés par des garnisons turques. Il résulte de là qu'il est presque impossible de pénétrer à l'intérieur. Quand donc on voudra se procurer des notions détaillées et completes sur ces édifices, il importera qu'on se munisse préalablement à Constantinople de lettres de recommandation particulières, contenant la mention expresse des bons offices que l'on aura à réclamer des gouverneurs de Beyrouth et de Jérusalem. ${ }^{[324]}$

At Bosra Burckhardt was allowed in the fortress in 1812, when it was defended by only six soldiers. He climbed to the top, and described a peculiarity: 
What distinguishes it from other Syrian castles, is that on the top of it there is a gallery of short pillars, on three sides, and on the fourth side are several niches in the wall, without any decorations; many of the pillars are still standing. ${ }^{[325]}$

In other words, he did not recognise that he was looking at an almost buried Roman theatre; this is one of several occasions when his meticulous descriptions are let down by his lack of architectural knowledge. In 1904, Bosra was more thoroughly manned, and had a commandant, on whom Butler paid a visit: "A flight of narrow and very steep steps, made of the ancient columns which once lined the streets of Bostra, took us up to a flat roof where was the door of the Commandant's chamber." [326]

At Shobak (in present-day Jordan) in 1864, de Luynes was prevented from entering the fortress, but apparently only because he refused to pay for the privilege. ${ }^{[327]}$

\section{Architectural Quality: Is Syria Worth Visiting?}

Comparisons may sometimes be invidious, but formed an important part of many travel narratives, less we would hope to burnish the credentials and display the look-where-I've-been knowledge of the writer, than to situate unknown monuments vis-à-vis more familiar ones for the prospective reader. Because of a decided European preference for Greek architecture and sculpture, and a tendency to disparage things Roman as clumsy and inferior, the monuments of Syria often suffered, except in terms of scale and sometimes profusion, from such comparisons. Indeed, the study of Roman art and architecture struggled against prejudice for decades after the Second World War. In part it was archaeology which swung admiring attention more toward Rome, since far more Roman than Greek sites survived: they built more, and further afield throughout Europe and North Africa. ${ }^{63}$ Islamic art and architecture also stood in the shadow of Western percetions. ${ }^{64}$

63 Pentz 2002 for comparative purposes: Towns 29-75; Rural organisation: 77-101; Fortifications: 103-137; Interaction and exchange: $139-165$.

64 Vernoit 1997, 1: "One of the principal reasons for this delay [viz Islamic archaeology only at end of 19 thC] can be found in Hegel's portrayal of the historical evolution of art, in which Asia was relegated - following the ideas of Winckelmann - to a significance only in preGreek times, with ancient Persia credited with the first historical consciousness." 
The rise to prominence of Roman architecture was at least in part because of a demonstrable connection between monuments and politics, recognised for centuries. ${ }^{65}$ For, as Ibn Khaldun wrote, "La grandeur des monuments laissés par une dynastie est en rapport direct avec la puissance dont cette dynastie avait disposé lors de son établissement." ${ }^{[328]}$ Other Muslim commentators were well aware of the impact architecture could make, because they admired antique monuments in Syria, such as Baalbek, Jerash and Amman. ${ }^{[329]}$ They were also proud of the likely prestige of their own structures, as for example the well-known opinion relayed by Al-Muqaddasi that the Umayyad Mosque in Damascus was the best target for large expenditure (even more so than roads or fortresses!) because it would outshine Christian buildings. What is more, like the Dome of the Rock it was "unique and a wonder to the world,"[330] itself praised by one visitor for its glass windows rather than its architecture. ${ }^{[331]}$ And Martin in 1876 acknowledged the beauty of the structure, but then compared it unfavourably ("flimsy") with Solomon's Temple, the details of which he naturally took on trust. ${ }^{[332]}$

La Roque in 1723 thought Baalbek the most beautiful remains from all antiquity, "sans en excepter même les ruines qui sont en Egypte." ${ }^{[333]}$ He thought neither the Greeks nor Romans had ever done anything more superb, or in better taste. ${ }^{[334]}$ Wood, however, writing in 1757 , though Baalbek merely bold. ${ }^{[335]}$ In ${ }_{176} 67$ Thompson covered both bases by declaring that at Baalbek "In a Word, the fine taste of Greece and the Magnificence of Rome are united here." ${ }^{[336]}$ Hill in 1866 stated that only the Acropolis at Athens could compare, ${ }^{[337]}$ and Knox in 1879 found Baalbek "grander and loftier than anything at Rome or Athens."[338] Dubious comparisons were also made by divines such as Robinson, who apparently had no special knowledge of architecture: "They are like those of Athens in lightness, but surpass them far in vastness; they are vast and massive like those of Thebes, but far excel them in airiness and grace." ${ }^{[339]}$ This was the man who identified the church at Keniset-El-Awamyd as Greek architecture; ${ }^{[340]}$ he should have read Burckhardt, who found that its decorated doorway stood comparison with Baalbek. ${ }^{[341]}$ In 1885 Le Strange added Arak el Emir to the list of awe-inspiring structures. ${ }^{[342]}$

But the standard opinion was that Greece and Egypt were the measuring sticks by which Syria would be judged. ${ }^{[343]}$ They were better in sculpture and architecture, whereas Baalbek had "a peculiar sameness in the decorations;" ${ }^{[344]}$ and as Renan stated in 1860, shuddering at the non-Greek columns at Baalbek, "je suis loin de les placer au premier rang parmi les monuments de l'antiquité."[345] Yet it was the decoration of Baalbek that

65 Díaz-Andreu 2007, 29-59: 2: Antiquities and Political Prestige in the Early Modern Era. 
made the site (and especially the huge colonnade) more imposing even than Karnak. ${ }^{[346]}$ Grandeur, of course, was not the same as interest, and by 1900 we meet the divide between part-excavated sites (such as the Roman Forum) and untouched ones such as Baalbek, ${ }^{[347]}$ where the Germans were closing in. D'Estourmel yawned at Baalbek in 1844, and recommended that "les architectes de notre temps peuvent rester dans la belle Italie et se dispenser de venir étudier en Syrie des monuments romains. ${ }^{\text {[348] }}$ Petra fared little better because it was viewed as decadent: "The architecture is florid and corrupt."[349]

Nor did Jerash please the aesthetes, because the monuments (for a visitor in 1852) were "constructed of a dark sombre-coloured stone, which gives them an air of heaviness, and destroys the light and shades of their architectural decorations." [350] D'Estourmel's opinion of Roman architecture in Syria was already stated by Lindsay in 1838 , his eye being "perpetually offended by the want of harmony and proportion." In other words, he had seen Rome, and how architecture was executed there; so that his final verdict (and a true one) was that Jerash was "a very fair specimen of a second-rate provincial Roman town." ${ }^{[351]} \mathrm{He}$ was of course writing before excavation was possible or even thought of; and subsequent occupation by Circassian settlers eventually translated this virgin site into something less attractive to the spade.

Palmyra was another site that astonished visitors. Addison in 1838 discounted the opinion of a fellow traveller who thought Palymra inferior to Baalbek in part because of the lesser height of the columns, and noted that the effects of wind had eroded the sculpture at Palmyra ${ }^{[352]}$ In 1848 Yanoski \& David switched their preference to Palmyra, because Baalbek was overgrown and more confusing. ${ }^{[353]}$ Palmyra, on the other hand, was comparable to other towns with colonnades, such as Jerash, Damascus and Apamea, ${ }^{[354]}$ and modern scholars have identified more such colonnades. ${ }^{66}$ Aleppo also had a colonnaded street, some of the columns of which are re-used in the ash-Shuabiya riwaq. But their mere extent did not compensate for the greater beauty of

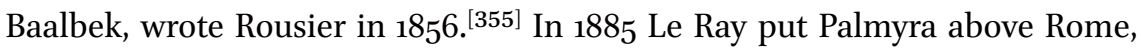
Greece and Paestum. ${ }^{[356]}$

European travellers naturally compared the monuments they found in one part of Syria with those they had seen in other parts, or sometimes with conspicuous buildings back home, inevitably with dubious results. A comparison of Baalbek with S. Paul's in London ${ }^{[357]}$ was probably intended as a joke, and reference to the obelisk in the Place de la Concorde to underline just how large

66 Milwright 2010, 30: colonnades in Syria, and Sauvaget's contribution to their understanding. Klinkott, 2008: colonnades in their urban context. 
were the monoliths at Baalbek ${ }^{[358]}$ Yet Thompson could declare that the Great Temple was "very much like the Church of St. Paul, Covent Garden," but conceded that Baalbek was bigger ${ }^{[359]} \mathrm{A}$ much more serious comparison, evidently intend for in-the-know scholars, was between the Great Court at Baalbek and the great quadrangle of Christ Church, Oxford. ${ }^{[360]}$

However, an unattractive trait of some travellers is a told-you-so and seenit-all boredom with what they saw. Such tedium vitae is yet another weapon of one-upmanship or ignorance, for example Berners at Acre in 1876 avoiding visting the Great Mosque because he would need to don slippers and discard some of his riding gear. ${ }^{[361]}$ Thus Scholz condemned Syria, commenting that there are "few countries so abounding in traces of a former great population, but few also where they are so uninteresting as in Palestine." ${ }^{[362]}$ Blondel never got to Palmyra, but ruled that the site could not compare with Baalbek, and that "C'est sa position dans le désert et la difficulté d'y parvenir, qui rehausse l'intérêt de Palmyre et qui à fait souvent exagérer le mérite de ses ruines."[363] Damoiseau visited Merdj-el-Sultani in 1833, where "je trouvai un assez grand nombre de colonnes encore debout; d'autres, en plus grande quantité, gisaient par terre à moitié ensevelies sous le sable;" but he evidently did not bother to count them, and "un assez grand nombre" means little. ${ }^{[364]}$ And if marvels were on their schedule, some monuments could be skipped, such as the Umayyad Mosque in 1915, because Smith had seen the Dome of the Rock and was en route to Haghia Sophia, so that "we did not think that this one could present any special feature of importance to us." ${ }^{[365]}$ What happened was that "we came to the door, but we did not enter, as we were not disposed to pay the entrance fee required."[366]

Because there was nothing similar to be seen further west, it was the "dead cities" around Aleppo and in the Hauran (dealt with in detail in Chapters Five and Seven) that attracted even greater amazement than Palmyra or Baalbek, because Europeans were not used to encountering completely deserted settlements (although there were plenty to be seen throughout Europe, if not with untouched Roman stone houses). Here the inevitable comparison was with Pompeii. ${ }^{[367]}$ The difference was that the buried town had been excavated and was on the tourist schedule from well before 1800 , whereas the villages/towns in Syria had never been buried, were just as intact and, in some instances, still sparsely inhabited, "closed by their original doors, and sheltered by their original roofs, and the horses eating out of the same mangers as they did sixteen hundred years ago." ${ }^{[368]}$ As Flinders Petrie wrote in 1918, "south of Hebron I have walked through a town, still inhabited, where the houses were obviously Roman, and have seen a large hall with the stone roof 
still perfect over it." ${ }^{[369]}$ There were plenty similar towns to be marvelled at. Pompeii won in terms of surviving frescoes and sculptures, whereas on the limestones massif

they are much more imposing, in their structure of solid stone, with their lofty colonnades and richly ornamented doorways, than any other ancient private residences that we know of, more beautiful than the houses of Pompeii, for example, with all their wall-paintings and mosaics. ${ }^{[370]}$

As La Salle wrote rather neatly in 1840 at Deir-Semaan, "Je nommerais volontier cette cité la Petra de cette Syrie pétrée." ${ }^{[371]}$ Further south, in the Hauran, the extensive deserted towns and villages with ancient standing houses also called for comparison with Herculaneum and Pompeii. ${ }^{[372]}$

However, by those who knew their history of art, many of the monuments of Syria were condemned if of the later Roman Empire. For Irby and Mangles, writing in 1823, "we passed many sites of ancient towns, castles, tanks, temples, \&c. all of the lower empire, and very uninteresting."[373] The same pair luckily avoided sites near Aleppo and S. Simeon, "all of the lower empire, and, as we have since learnt, totally uninteresting;"; $[374]$ other sites in Lebanon received the same appellation: "every thing much dilapidated and uninteresting."[375] Why did they bother travelling? Nor did they take pleasure in ruins for, at Eleethias on the Nile, they came across "the ruins of a small temple, and other buildings much dilapidated and consequently uninteresting., ${ }^{[376]}$ But reading on, it becomes clear that they pan everything, including Palmyra:

Take any part of the ruins separately, and they excite but little interest; and altogether, we judged the visit to Palmyra hardly worthy of the time, expense, anxiety, and fatiguing journey through the wilderness, which we had undergone to visit them. ${ }^{[37]}$

Nothing they saw would have coaxed even one star from Michelin, and with their formulaic phrases they soon begin to sound like Sellar \& Yeatman's 1066 and All That.

\section{One-upmanship and Verbal Wars in Travel Narratives}

A gazelle captivated me so much, that my attention was so riveted by this singularly beautiful animal, that Tyre received only a transient glance. ${ }^{[378]}[1845]$ 
An entertaining if unedifying aspect of travel accounts, over and above the usual pieties of citing earlier accounts, ${ }^{67}$ and making comparisons to display one's knowledge, is the overflowing measure of one-upmanship and backbiting they sometimes contain. These are addressed to the cognoscenti back home, rather than to ordinary readers, who were more likely to be impressed by the boredom and monuments fatigue outlined above. For serious scholarly authors, credibility and hence sales figures, money and sometimes academic respectability were involved. Australia is notorious for the Tall Poppies Syndrome (local reaction being to cut prominent people down to their own size and importance), but they got it from Britain in the first place. Thus Drummond castigated Pococke for his inaccuracies (he "travelled through part of Asia in the night"), and as for some identifications, "charity bids me suppose he was not there."[379] For Baalbek, Wood set his own work above that of La Roque, "which contains so much ignorant admiration, and so little intelligible description." ${ }^{[380]}$ Some travellers were indeed ignorant, but confident with it, Breves asserting in 1628 that mosques "sont les temples, bastis tous presque d'une forme spherique, ornez de marbres de diverses couleurs, \& de riches colomnes, ${ }^{[381]}$ when he could not possibly have seen more than a handful of such structures. Easiest of all to enter was the biblical arena, where there are plentiful accusations of absurdity and credulity, not to mention only very short visits to the sacred sites. ${ }^{[382]}$

Against the prevailing trend to privilege Greece against Rome (and oneupmanship always went against such trends) some travellers averred that sites further west had been visited and comprehensively described, so visits further east were in order. Already in 1819 Forbin was complaining that everything in Greece, Syria and Egypt had been seen "par de savans voyageurs, sous les aspects les plus divers et les plus remarquables. Cependant quelques-uns d'entre eux ont négligé d'ajouter des dessins à leur ouvrage." ${ }^{[383]}$ Similarly, Walpole in 1851 explained he went to study the Assassins because everying else was filled in:

If I bought tape in a shop on Ludgate-hill, ten to one if the person who served me, had not taken a return-ticket by the steamer, rushed in a

67 Bar-Yosef 2005, 67: "This interplay between texts and real-life experience is typical of all travel, but it is particularly typical of travel writing, as the readers-cum-producers enter the literary tradition which shaped their expectations in the first place. Virtually every travel account or geographical study contained the obligatory list of those celebrated travellers who had visited Palestine previously, as well as long citations from their work." 
fortnight over Syria and Egypt, and knew as much, at all events, as his dragoman thought he ought to know for his money. ${ }^{[384]}$

Strong impressions were what counted, writes Durbin, so from his book "I have excluded from these pages such portions of my journals as I found, upon reading them after the lapse of a considerable time, to have escaped my recollection,"[385] evidently not considering that it would be descriptions of lesser-visited sites which would prove valuable. Quick tourism, what is more, produced inadequate results, as the Edinburgh Review noted in 1829:

It is only after considerable residence in a country where every habit is so unaccountably opposite to our own, and where no single channel of direct communication can be said to exist, that a knowledge of any thing beyond the surface can, except by singular accident, be procured. ${ }^{[386]}$

Thus Oppenheim (the excavator of Tell Halaf, and supposedly a spy for the Kaiser ${ }^{68}$ ) assures us in 1899 not only that he has travelled widely in the Islamic world, but has spent several months in the Arabic quarter of Cairo (i.e., not in the Europeanised section). ${ }^{[387]}$ For most travellers, however, time constraints were all: in 1841 Egerton's party "determined upon an expedition to Baalbec" not because they especially wanted to visit the site, but to fill in time until the steamer sailed a week later. ${ }^{[388]}$

Buckingham struggled against the calumnies of the Quarterly Review, "the unfounded aspersions of the late Mr. Burckhardt," and "the unparalleled conduct of Mr. William John Bankes,"69 the whole explicated in a long doublecolumn appendix. ${ }^{[389]}$ The matter revolved around stealing another scholar's work. ${ }^{[390]}$ Buckingham sued Bankes, and won. Finati had judged Buckingham (a prolific author) as a useless companion from Jerash to Nazareth in 1816, "in our company, bearing, however, no part in it either with his purse or with his pencil."[391]

The tall poppies syndrome also applied, Napier elevating his own book by complaining that Burckhardt ("generally so observant of everything") nodded

\footnotetext{
68 Gossman 2013.

69 Lewis 1996 for William John Bankes. He was in the Orient 1815-1820, in Egypt, Nubia, Syria, Asia Minor and Greece. The first to do drawings of Petra and Jerash, and the first to visit Umm al-Jimal 39 years before Graham, the supposed discoverer of the site. Bankes was the unrecognised co-author of Irby \& Mangles, published 1823, some of it dictated by Bankes to Irby, another part written by Bankes himself. Bowsher 1997: Bankes' accounts of Qanawat, Gadara, Jerash, Amman, Baysan and Abila.
} 
at Bysan, didn't get up what was probably the acropolis, and therefore missed "some splendid remains of a Roman amphitheatre."[392] Robinson in 1856 also attacked Burckhardt for apparently missing the ruins at Apamea. ${ }^{[393]}$ Supposed mis-identification could also create storms, as De Saulcy discovered when in $185^{1}$ he read a paper on the structure he named the Tomb of the Kings at Jerusalem:

Ce fut le signal d'une guerre ardente qui me fut déclarée, et dont le but évident était, d'une part, de réduire à néant les résultats de mon voyage, de l'autre, de me faire passer aux yeux du monde savant pour un homme d'imagination, dont les érudits n'avaient pas à s'occuper, et qui, par sa légèreté et son ignorance, ne méritait pas qu'on prît au sérieux ce qu'il ne publiait qu'au prix de tant de peines de toute nature. ${ }^{[394]}$

The Jews were not happy, and petitioned Constantinople to have the excavation stopped because, like all biblical archaeology, it desecrated holy sites. ${ }^{70}$

An excellent satire on silly scholars is provided by Richard Burton, who focusses on the quarrel between Porter's Five Years in Damascus (London 1870) and Freshfield's Travels in the Central Caucasus \& Bashan (London 1869), who averred that the sites in Bashan were not, as Porter believed "giant cities," but merely provincial towns of the Roman Empire. Burton set it up as a court case before the Athenaeum (the magazine):

The suit ended magno cum risu by a verdict of the jury of Reviewers, duly charged by Mr. Chief-justice Fergusson, that defendant and his party had "disproved the existence of any such giant cities whatever;" and furthermore, that "the so-called giant cities of Bashan were in fact no giant cities at all, but mere provincial towns of the Roman Empire."[395]

Another elegant put-down is Tristram's reference to "some valuable hints from Dr. Thomson, the well-known author of "The Land and the Book," and the oldest missionary in Syria" - a venerable source indeed. But he goes on to reveal that this supposed authority "longed for an excursion across Jordan, where he had never yet been."[396] This hint on page 26 of Tristram's book is then hammered home in comments throughout the text: "scarcely fulfils the conditions of the history... somewhat laughable hypothesis... has not recognised... Thomson mistook... erroneously asserts," and so on. Thomson declared in his book that he had "incorporated into it many important and

Shaw 2003, 37. 
interesting observations derived from the publications of eminent writers and travellers," ${ }^{[397]}$ so perhaps he was as slippery as Tristram was snide. Statements such as "we shall meet in our travels" ${ }^{[398]}$ surely suggest but do not explicitely state that he has covered the ground himself.

Because sites were not signposted, and only contained useful inscriptions in a minority of sites ${ }^{71}$ travellers sometimes described the wrong place. ${ }^{72}$ This could be embarassing, and reminiscent of the poignant story of the Viking Hastein, who supposedly sacked Luna/Luni, thinking it was Rome. Thus Roberts in $175^{\circ}$ assessed Palmyra as "a palace situated in a most delightful and spacious plain... has its walls of the finest free stone, and the best I ever saw;" but his 2oth-century editor thinks he never got there, and really visited Taiyibe. ${ }^{[399]}$

Primacy of visitation and the publication of results also raised academic profile. Here the crown for one-upmanship goes to Victor Guérin (1821-91), a serious archaeologist, who spent several years in North Africa and the Middle East, and wrote at length and very sensibly about the sites he visited, and what they meant for the understanding of the past. ${ }^{[400]}$ Much of this was done with funding from the French Government, and the necessary reports read like Little Jack Horner, who believes his paymasters should be equally enchanted with his plums. In Syria he claimed in his 1864 report to have visited 106 sites, ${ }^{[401]}$ and goes on to list 81 of these, which he claims to have been the first to visit, ${ }^{[402]}$ and then nine which he claims to have discovered. ${ }^{[403]} \mathrm{A}$ later report lists 280 localities in Upper Galilee, 44 of which did not appear on maps and (ahem) had escaped previous researchers. ${ }^{[404]}$ Industrious though he assuredly was, he never explains the point of this kind of archaeological stampcollecting, when it is not accompanied by large-scale maps and topographical details. (The pertinent words here are "large scale," for he certainly did publish maps to accompany his adventures, but on a small scale.) Age evidently did not slow Guérin down, for his 1877 report states that he often travelled eight or ten hours each day without stopping, "et j'ai examiné environ 300 localités, les unes détruites et abandonnées depuis longtemps, les autres encore habitées. Un certain nombre d'entre elles n'étaient marquées sur aucune carte."[405]

In 1875 the Rev. Selah Merrill went to Umm al-Jimal, "into the genuine desert," listed the travellers who had viewed the area through a telescope, and noted with pride that "although two or more of these made the attempt, they

71 Sartre 2011 includes historical introductions and visitors to some of the Hauran villages, e.g. 139-140 Jmarrin, 153 Kharaba, 221 Kerak (where he saw lots of spolia in the modern houses), 233 Deit Al-Khuleif Umm Walad, 287 Hrayyek. 
did not succeed in reaching them. Mr. Cyril Graham and Mr. Waddington were the only Europeans who had visited the place previous to ourselves."[406] This might have been what made Le Strange take an insinuating shot at him and, at the same time, at the meagre fruitfulness publications-wise of the American Palestine Exploration Society. ${ }^{[407]}$

Unfortunate results of one-upmanship and Franco-German rivalry were evident in the sad story of the Moabite Stone, discovered in 1868, and not only the oldest Semitic inscription then known, but also "cette découverte est la plus importante qui ait jamais été faite dans le champ de l'épigraphie orientale." ${ }^{[408]}$ Its discoverer, Klein, a Frenchman, kept the find secret from Clermont Ganneau (he "could have got up the stone, whole and uninjured, for a few napoleons, because the Arabs were wholly unacquainted with its value") and instead went to the German consul. Klein's manoeuvres and various indiscretions persuaded its Arab owners of its true value, and he then returned to Berlin, and became a German citizen. Clermont Ganneau took a squeeze, but its owners,

terrified at the prospect of another raid, angry at the probable loss of a stone which possessed supernatural powers in their eyes, lit a fire under the priceless relic, threw cold water on it when it was red-hot, and so smashed it into pieces. ${ }^{[409]}$

Name-calling continued, and "the Franco-Prussian war tended not a little to embitter antiquarian rivalry in the matter of the Moabite Stone." ${ }^{[410]}$ This sad tale, recounted in detail by Sayce ${ }^{[411]}$ and the PEF, ${ }^{[412]}$ underlines both the thirst for treasures to showcase national prestige, but also the intricacies of dealing with alert if vandalistic locals. In 1895 Heber-Percy reasoned with some locals who persisted in believing that inscriptions held to the key to buried treasure; so why write the instructions on a stone? "They laughed and said I was right, but clearly remained convinced that I could not take all this trouble except for some prospective material gain."[413]

The too-many-monuments disease was rife with less meticulous tourists, whose numbers increased as travel became cheaper. We might call it onedownsmanship, for it is still active today, and blends effortlessly with authors' one-upmanship by knocking off as many monuments as possible in a limited time-span. From 1900 Michelin continued the rot by classifying monuments and sites with stars (so that the discerning could aim only for les trucs troisétoiles, vaut le détour, vaut le voyage, etc) just as it did from 1926 with restaurants. Towns less antiquities-rich felt the full force of travellers' disdain. "Where you have done Rome and Athens, and half the cities of Europe and Asia, you 
won't linger long over the antiquities of Beyrout," wrote Knox in $1879 .{ }^{[414]}$ This was because so many of her monuments had been destroyed in building the modern town, including bungling by European consuls who tried in the $1830 \mathrm{~s}$ to lift a mosaic which stood comparison with those at Pompeii. ${ }^{[415]}$

\section{Modernisation Changes Travelling in the Unchanging East}

If, as discussed above, modernisation could be a two-edged sword for travellers, it could also make visits safer and quicker, if sometimes less interesting because of the monuments it destroyed. For Syrian agriculture and commerce, railways controlled much organisation and development. ${ }^{73}$ One noticeable advantage was speed. At Baalbek in 1840, La Salle was amazed by the daguerrotype, which could achieve in a few minutes what it would take more than four days to draw by hand. ${ }^{[416]}$ At Tyre, in 1840, Layard reports that "M. Vernet was provided with a Daguerrotype - then only recently discovered, and the first I had seen - and was able with it to take views of the principal monuments and scenes which he visited." ${ }^{[417]}$ Vernet had shown the device to Mehmet Ali, the great moderniser. But there were others, such as the sheikh Porter encountered at Qanawat in 1855, who "questioned us until he got a full explanation of the principles of locomotion and electricity," and then pressed him on contemporary politics. ${ }^{[418]}$

A more clinical defence weapon and evidently a normal piece of equipment for hardened travellers was a telescope, which allowed travellers to scan the horizon for lurking robbers. It was carried along with compass, maps, and surveying instruments. ${ }^{[419]}$ In 1882 Robinson rode along a Roman road near Bosra, "stopping occasionally to examine with our glasses the deserted towns away to the right and left ... and scan suspicious ruins, and peer into valleys, in the fear or hope of discovering roving Ishmaelites." They were right to be wary, since they passed Druze ploughmen sporting rifle and pistols, just as did the French colons in 19th-century Algeria, and for the same reason. ${ }^{[420]}$ If the telescope could keep travellers out of danger, it also allowed travellers to examine sites

73 Lantz 2005: Syria and the Hijaz. 15 with the 1856 line Smyrna-Aidin, "Pour la première fois de son histoire, l'Islam se vit imposer un réseau dont il n'était pas lui-même à l'origine." Similar to the printing press, author notes. ${ }^{176-186}$ De la Caravane aux Chemins de Fer - in Syria. The rails stay where they are, so (177) "Il était donc nécessaire de déterminer a priori les régions les plus fertiles et conduire les rails là où léconomie augurait la rentabilité de leur exploitation." 179: between Beirut and Damascus, cheaper by one quarter to transport goods by rail. 
without visiting them. This then allowed authors to write about them without incurring any danger, but one must wonder how many monuments were isnpected in close-up. Using a telescope, in 1844 Kelly viewed the Dome of the Rock from the Mount of Olives, ${ }^{[421]}$ while Porter scanned a host of towns from the fortress at Bosra, "and their walls and houses appeared to be in even better preservation than those I had already visited." ${ }^{[422]}$ The same device allowed Porter to count "sixty walled cities, besides unwalled towns," a great many in the southern section of Jebel Hauran. ${ }^{[423]}$ Butler was still doing likewise in 1905: "the Djebel Sim'ân, with the exception of a few sites, was unexplored, although distant telescopic observations had shown it to be full of deserted cities and towns."[424]

Telescopes also fascinated the locals. Van De Velde was viewed by them suspiciously when taking measurement in 1854 , but "I likewise allowed some of the old shechs to look through the telescope, in order to familiarise them with the harmless instrument; and thus I contrived to come away with a whole skin.." ${ }^{[425]}$ Porter wrote of a sheikh who had taken a telescope off a Turkish officer, replaced the brass tubes with cardboard, used it a lot, and Porter promised to try and get him one in Damascus. ${ }^{[426]}$ Near the Dead Sea in 1856 , "many of the peasants gathered around us, and seemed gratified to hold our telescopes," ${ }^{[427]}$ while by the Nile in 1866 , the natives "all petitioned at the same moment to be allowed to look through it." ${ }^{[428]} \mathrm{A}$ telescope (or a revolver, rifle or compass) formed a suitable gift to ensure a sheik's co-operation, ${ }^{[429]}$ and some refused to accept cash: "they are also very generous to travellers with consular recommendations, or with consular influence, but they are thereby building up a debt of obligations which they will take good care shall be cancelled by the consul.". $[430]$

If Ottoman modernity sometimes startled sensitive travellers (such as "un tapis européen aux couleurs criardes" in the Umayyad Mosque ${ }^{[431]}$ ), it also impressed them, such as the request by the Moutselim to Walpole in 1851 "to beg he would cut him out a pair of European trousers, at the same time sending the calico." ${ }^{[432]}$ Yet rather than tailoring, modernity generally meant speed of urban development, or of travel, and some signal of government getting a grip. ${ }^{74}$ In 1862 Farley marvelled at the new town of Beirut, and the ships that sailed there. ${ }^{[433]}$ He had already written on how to travel in Syria, taking the

74 Hanssen 2005, 9: "Particularly under Sultan Abdülhamid II (1876-1909), many Ottoman cities and towns received 'face-lifts' and public health regulations. Railway, port, and telegraph networks criss-crossed the empire, while the increasingly mobile members of the new Ottoman mass bureaucracy became omnipresent bearers of state power in the provinces." 
visitor from landing at Jaffa, then dragoman, servants, mules and donkeys, luggage, locals, costs. He recommended Beirut as the most suitable HQ. ${ }^{[434]}$

In 186o Poujade noted how Baalbek would be a magnet for artists and antiquarians, "si une bonne route conduisait au milieu de ces ruines dont un gouvernement intelligent s'empresserait d'arrêter la destruction."[435] Farley was still reminding his readers in 1878 that "well-made roads, good canals, and inexpensive railways are desiderata for Asiatic Turkey," and that these are "civilizing agents of the highest order, while, on the other hand, their absence restrains enterprise, diverts trade, and lessens cultivation."[436] But things were improving: already by 1879 there was "excellent road, equal to the best turnpikes of America, and the diligence roads of Europe" between Beirut and Damascus, ${ }^{[437]}$ and twenty years later Tiffany noted that "the march of modern improvement" was greater in Syria than in Kansas, with the splendid new Beirut-Damascus road:

Close beside this triumph of modern engineering runs the old trail from Damascus, torn and gullied almost out of recognition, over which are painfully laboring great caravans of heavily burdened asses and camels... already is a mountain railway from Beyrout to Damascus in rapid advance before the eye. ${ }^{[438]}$

To complement the efficiency of the new road, plans were also announced for the modernisation of the walls of Acre, ${ }^{[439]}$ but this did not happen because trade was attracted instead to Haifa.

\section{Conclusion}

The traveller treads at every step on the remains of perished cities, and of monuments of art and industry that testify the vast population, the wealth, energy, and grandeur of the land in days gone by ... here was prepared, developed, and consummated, that stupendous series of events on which he rests his hopes for eternity. ${ }^{[40]}[1844]$

Here Kelly explains in a nutshell why Syria was attractive to travellers for a variety of reasons from ancient monuments to the towns and scenes of the Bible. This chapter has surveyed the panoply of attitudes and responses to what they saw, explaining why some sites were visited more than others, and demonstrating the various ways in which attitudes to the Bible dictated which sites received more than their fair share of attention, while other sites languished. 
We may assume that many sets of ruins disappeared without trace, consumed in later buildings, while funding went to proving the truth of the Bible.

The accounts above have also demonstrated that travelling was a sometimes dangerous and generally imprecise pursuit, reliant on locals for safety, and no doubt on earlier books for some of the information some authors set down as their own - an occupational hazard for guidebook readers. Since travellers often visited sites with earlier books to hand (some of them mention the fact), we can never be certain that some sites really were seen by the narrator, let alone examined in detail or even (as a counsel of fear, laziness or despair) distantly through a telescope. We may suspect that several sites were written up from chunks of detail reworked and elaborated from earlier sources, the author generally omitting to mention the fact. As Allen wrote in 1855, "I have availed myself of all the information I could gather from other writers, in order to support my own views."[441]

We have now completed an outline briefing of the state of Syria, the beliefs and attitudes of the locals, and the delights and dangers travellers were to face there. The following chapters form a gazetteer, and will examine sites area by area, relaying accounts of Syrian monuments which will allow us to assess survival and destruction, and underline how little information we would possess about changes over the centuries to the rich treasures the country still guards were not Westerners so attracted to the region and its treasures.
[1] Vogüé_1865-1877_I_4C
[2] Sepp_1863_IX-XXXI
[3] Guylforde_1506_16
[4] Bement_1858_9
[5] Chateaubriand_1812_II_ 135
[6] Napier_I_1843_51
[7] Wortabet_1856_I_8
[8] Farley_1862_209
[9] Busch_1870_32
[10] Wilson_IV_1881_2
[11] Gédoyn_1909_148
[12] Ariosto_1878_86
[13] Boullaye-Le-Gouz_ 1653_371
[14] Prime_1855_II_399-400
[15] Guérin_1868_359
[16] Lusignan_1783_203

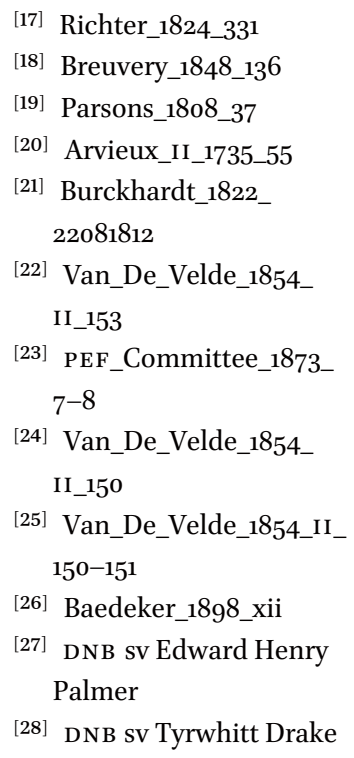
[29] PEF_Committee_ 1873_221C
[30] Finati_1830_II_131-132
[31] Hilprecht_1903_26
[32] Richardson_1822_II_211
[33] Buckingham_1822_II_50
[34] Seetzen_1854_I_iii-xlii
[35] Seetzen_1810_14
[36] Le_Strange_1889_304
[37] Le_Strange_1889_322
[38] Le_Strange_1889_164
[39] Wetzstein_1860_4-5
[40] Wetzstein_186o_6o
[41] Kennard_1855_334-335
[42] Walpole_III_1851_27B
[43] D'Estourmel_I_1844_ 263-264
[44] Rendel_Harris_1891_1 


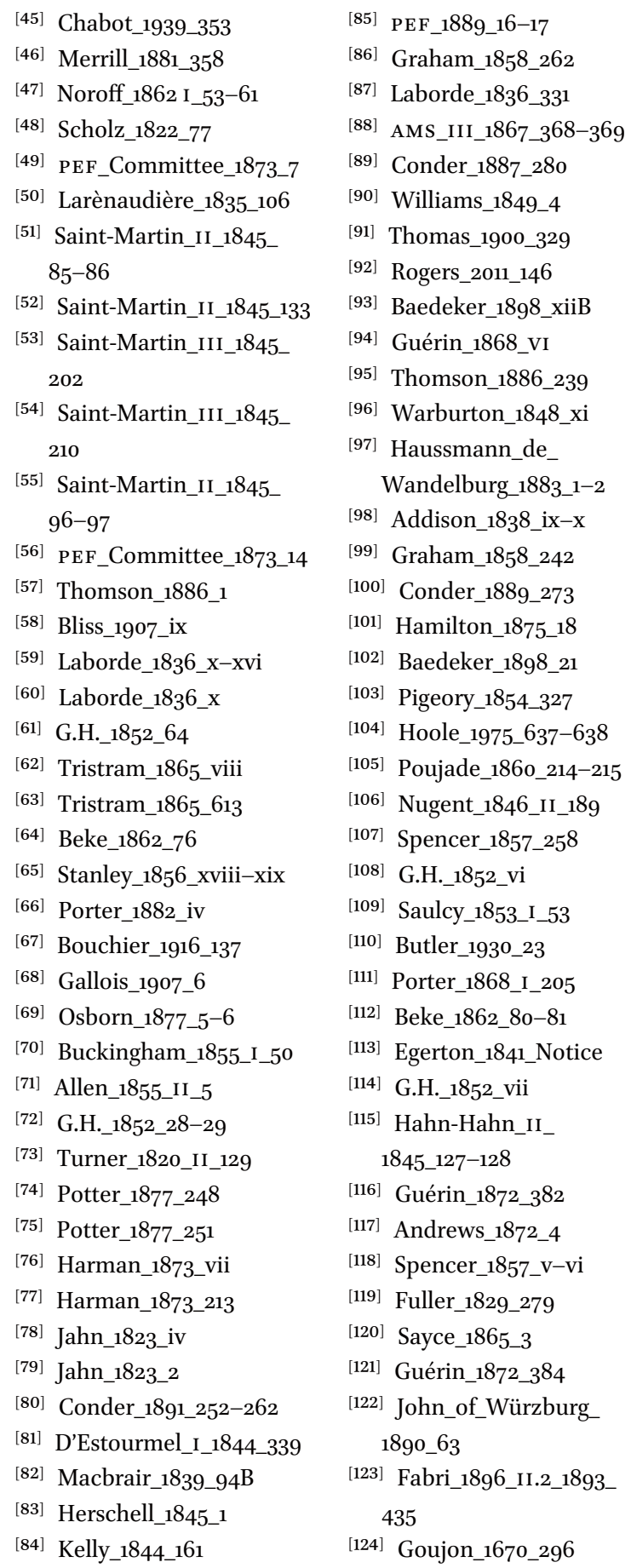

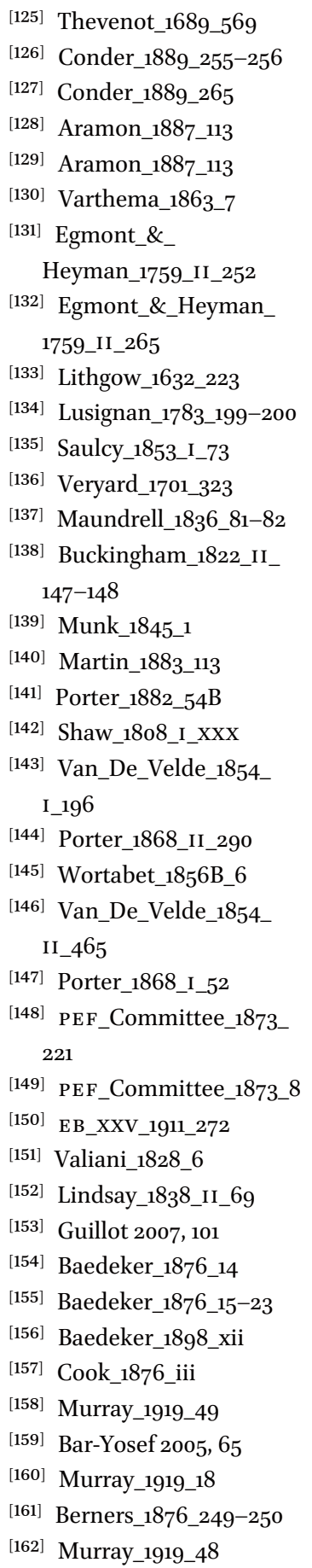

\begin{tabular}{|c|c|}
\hline & \\
\hline & ] Lithgow_1632_223 \\
\hline 34 & ] Lusignan_1783_199-200 \\
\hline & ] Saulcy_1853_I_73 \\
\hline & ] Veryard_1701_323 \\
\hline 137 & ] Maundrell_1836_81-82 \\
\hline & Buckingham_1822_II_ \\
\hline & $147-148$ \\
\hline & ] Munk_1845_1 \\
\hline & ] Martin_1883_113 \\
\hline & Porter_1882_54B \\
\hline & ] Shaw_1808_I_Xxx \\
\hline & ] Van_De_Velde_1854_ \\
\hline & I_196 \\
\hline & ] Porter_1868_II_29o \\
\hline & Wortabet_1856B_6 \\
\hline & Van_De_Velde_1854_ \\
\hline & II_465 \\
\hline & ] Porter_1868_I_52 \\
\hline & PEF_Committee_1873 \\
\hline & 221 \\
\hline & ] PEF_Committee_1873_8 \\
\hline & ] EB_XXV_1911_272 \\
\hline & Valiani_1828_6 \\
\hline & ] Lindsay_1838_II_69 \\
\hline & Guillot 2007, 101 \\
\hline & ] Baedeker_1876_14 \\
\hline & Baedeker_1876_15-23 \\
\hline & ] Baedeker_1898_xii \\
\hline & ]Cook_1876_iii \\
\hline & Murray_1919_49 \\
\hline & Bar-Yosef 2005, 65 \\
\hline & Murray_1919_18 \\
\hline & Berners_1876_249-250 \\
\hline & Murray_1919_48 \\
\hline
\end{tabular}




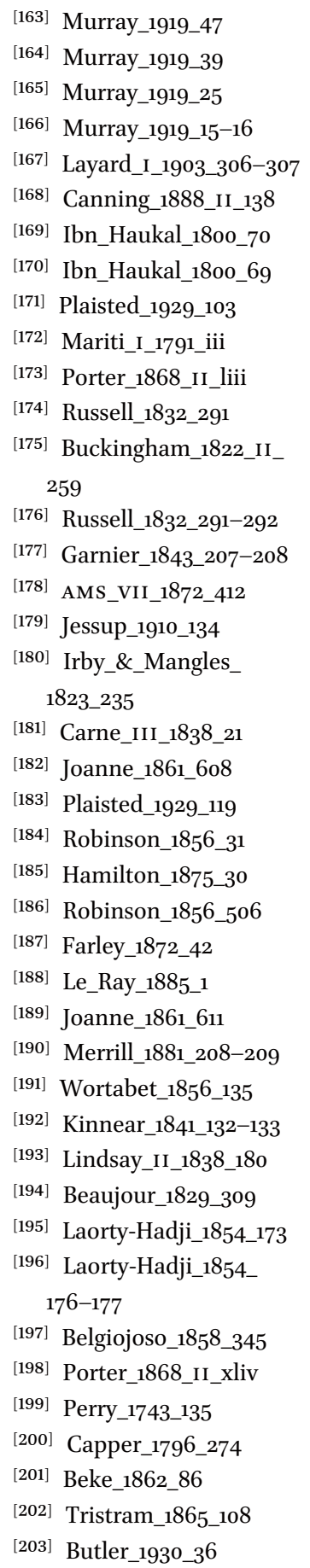

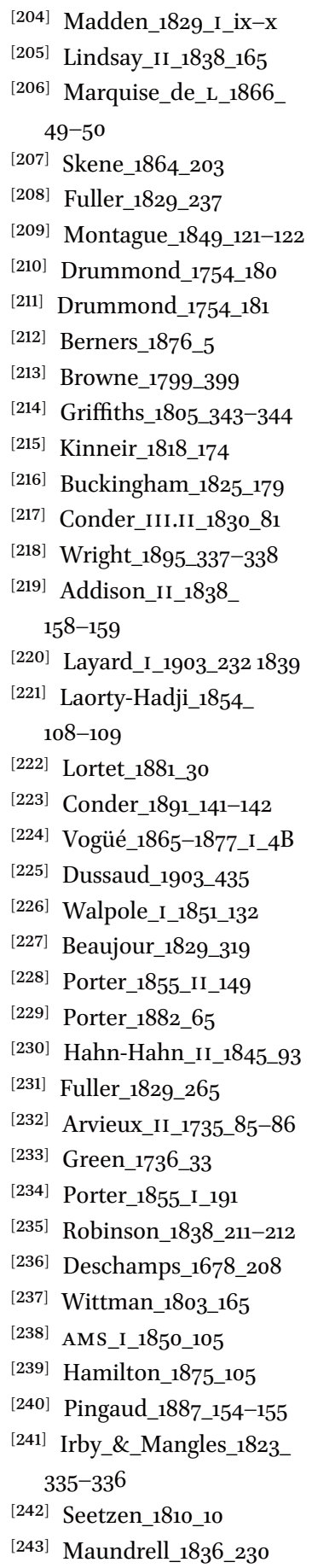

[244] Buckingham_1822_

$$
\text { II_248 }
$$

[245] AMS_I_1851_199

[246] Shaw_1808_I_xxviii

[247] Porter_1868_II_280

[248] Skinner_II_1837_199

[249] Moore_1895_7

[250] Lindsay_II_1838_16-22

[251] Graham_1858_246-249

[252] Capper_1796_26o-263

[253] Laborde_1836_47

[254] Skene_1864_206

[255] English_merchants_ 1678_134-136

[256] Burckhardt_1822_ 15101810

[257] Burckhardt_1822_ 30041812

[258] Burckhardt_1822_ 24041812

[259] Richter_1824_331

[260] Wright_1848_495-496

[261] Tristram_1865_193

[262] Graham_1858_253

[263] Richter_1824_293-294

[264] Conder_1830_1-2

[265] Measor_1844_164

[266] Richardson_1822_II_ 419-420

[267] Taylor_186o_87

[268] Measor_1844_16o

[269] Richardson_1822_II_496

[270] Warren_1883_147

[271] Elliott_1838_II_268

[272] Lewis_1996_61

[273] Conder_III.II_1830_3

[274] Burckhardt_1822_ 14111810

[275] Bell_1908_164

[276] Porter_II_1868_507

[277] Freese_1869_31

[278] Laorty-Hadji_1854_156

[279] Michaud_\&_Poujoulat_ VI_1835_171 


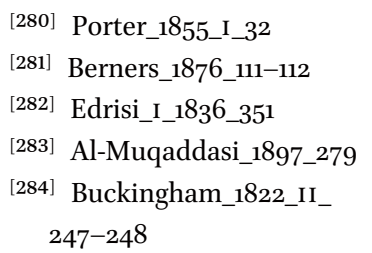

[285] Fabri_1893_II.1_243-244

[286] Fabri_1896_I.1_245

[287] Le_Brun_1714_298

[288] Hasselquist_1766_123

[289] Fabri_1896_I.1_246

[290] Edwards_1862_167

[291] Lithgow_1632_251

[292] Thevenot_1689_689

[293] Deshayes_1624_367

[294] PEFQQ_1873_34-47

[295] Russell_1832_7

[296] Doubdan_1661_366-374

[297] Arvieux_II_1735_207

[298] Beauvau_1608_157

[299] Deshayes_1624_368

[300] Layard_I_1903_279

[301] Porter_1868_II_458

[302] Curtis_1903_452

[303] Williams_1849_295-296

[304] Wortabet_1856_II_285

[305] AMS_I_1864_374

[306] Vetromile_1871_I_231

[307] Luynes_I_1874_217

[308] Savigny_de_

Moncorps_1873_168-169

[309] Maundrell_1836_214

[310] Perry_1743_137

[311] Hill_1866_408-409

[312] Buckingham_1825_307

[313] Thévenot_1689_

689-69o

[314] PEFQ S_1873_36

[315] Geramb_1840_II_172

[316] Edwards_1862_167-168

[317] Paris_1861_15-16

[318] Knox_1879_284

[319] Guérin_1884_I_414

[320] Saulcy_1853_I_587B
[321] Van_De_Velde_1854_

II_458-459

[322] Finati_1830_II_155-156

[323] Drummond_1754_184

[324] AMS_I_1851_199B

[325] Burckhardt_1822_ 27041812B

[326] Butler_1930_15

[327] Luynes_1874_II_149-153

[328] Ibn Khaldun_I_ 1863_359

[329] Dimashki_1874_35

[330] Al-Muqaddasi_1886_ 22-23

[331] Depelchin_1877_130

[332] Martin_1876_65

[333] La_Roque_1723_I_98

[334] La_Roque_1723_I_86

[335] Wood_1757_6

[336] Thompson_I_1767_134

[337] Hill_1866_425

[338] Knox_1879_271

[339] Robinson_1856_517

[340] Robinson_1837_66-67

[341] Burckhardt_1822_ 13031812_2

[342] Le_Strange_1885_176

[343] Guérin_1868_VIB

[344] Addison_II_1838_47

[345] Renan_1930_229

[346] Castlereagh_II_ 1847_278

[347] Thomas_1900_312

[348] D'Estourmel_I_1844_ 286

[349] Robinson_\&_Smith_ 1856_II_136

[350] G.H._1852_47-48

[351] Lindsay_1838_II_106-107

[352] Addison_II_1838_159160

[353] Yanoski_\&_David_ 1848_44

[354] Porter_1855_I_235-236
[355] Rousier_1856_182

[356] Le_Ray_1885_6

[357] Rousier_1856_157

[358] Bourassé_1867_500

[359] Thompson_I_1767_129

[360] Bouchier_1916_128

[361] Berners_1876_46

[362] Scholz_1822_60

[363] Blondel_1840_175-176

[364] Damoiseau_1833_69

[365] Smith_1915_249B

[366] Smith_1915_249

[367] Vogüé_1865-1877_ I_-7 -88

[368] Buckingham_1825_644B

[369] Flinders_Petrie_1918_3B

[370] Butler_1930_70

[371] La_Salle_1840_I_187

[372] Rey_1861_56

[373] Irby_\&_Mangles_ 1823_231

[374] Irby_\&_Mangles_ 1823_231-232

[375] Irby_\&_Mangles_ 1823_242

[376] Irby_\&_Mangles_ 1823_130

[377] Irby_\&_Mangles_1823_ 268-269

[378] Hahn-Hahn_II_1845_92

[379] Drummond_1754_243

[380] Wood_1757_19

[381] Breves_1628_34

[382] Williams_1849_7

[383] Forbin_1819_15

[384] Walpole_I_1851_V

[385] Durbin_1845_I_iii

[386] Edinburgh Review Oct

1829-Jan 1830, 439

[387] Oppenheim_1899_VI

[388] Egerton_1841_97

[389] Buckingham_1825_vi

[390] Lewis_1996_6o

[391] Finati_1830_II_152 


\begin{tabular}{|c|c|c|}
\hline [392] Napier_II_1847_203-204 & [409] PEF_1889_16o-163 & [426] Porter_1855_II_116-117 \\
\hline [393] Robinson_1856_55oB & [410] Burton_\&_Tyrwhitt- & [427] Robinson_\&_Smith_ \\
\hline [394] Saulcy_1855_1-2 & Drake_1872_II_341-342 & 1856_II_496 \\
\hline [395] Burton_\&_Tyrwhitt- & [411] Sayce_1865_88-91 & [428] Hill_1866_174 \\
\hline Drake_1872_I_191-192 & [412] PEFQS_1871_138 & [429] Porter_1868_471 \\
\hline [396] Tristram_1865_26 & [413] Heber-Percy_1895_163 & [430] Wright_1895_257 \\
\hline [397] Thomson_1886_iv & [414] Knox_1879_256 & [431] Paris_1861_17 \\
\hline [398] Thomson_1886_v & [415] Addison_II_1838_17 & [432] Walpole_I_1851_196 \\
\hline [399] Roberts_1929_47 & [416] La_Salle_1840_I_142 & [433] Farley_1862_209 \\
\hline [400] Guérin_1877_65-67 & [417] Layard_I_1903_262-263 & [434] Farley_1858_59-65 \\
\hline [401] Guérin_1864_381 & [418] Porter_1855_I_93-94 & [435] Poujade_186o_217 \\
\hline [402] Guérin_1864_397 & [419] Van_De_Velde_1854_I_5 & [436] Farley_1878_130 \\
\hline [403] Guérin_1864_376-377 & [420] Porter_1882_74-75 & [437] Knox_1879_261 \\
\hline [404] Guérin_1877_75 & [421] Kelly_1844_382 & [438] Tiffany_1896_335-336 \\
\hline [405] Guérin_1877_78 & [422] Porter_1882_69 & [439] Lortet_1881_44 \\
\hline [406] PEF_1876_49-50 & [423] Porter_1855_II_206-207 & [440] Kelly_1844_3 \\
\hline [407] Le_Strange_1889_272 & [424] Butler_1930_1 & [441] Allen_1855_I_vi \\
\hline [408] Mislin_1876_III_ & [425] Van_De_Velde_1854_ & \\
\hline
\end{tabular}




\section{The Life and Death of Monuments}

\section{Superstitions and Monuments}

Near [Cana] they pretend to shew the field where the Disciples of Jesus Christ plucked the ears of corn upon the Sabbath-day. The Italian Catholics have named it the field "degli Setti Spini;" and they gather the bearded wheat, which is annually growing there, as a part of the collection of relics to be conveyed to their own country. ${ }^{[1]}[1817]$

The first three sections of this chapter deal with the mysterious question of who built the monuments of Syria (some older than Adam, apparently ${ }^{[2]}$ ), with inscriptions leading to treasure and as a source of superstition, and finally with the vandalism involved in ransacking ruins.

For the Christian traveller the distinction between superstition and veritable truth might have been clear: what I believe is justifiable faith; whereas what you believe (especially if you are a Muslim!) is mere superstition. However, as well as amongst Muslims, accounts of miracles and miraculous discoveries abounded in the Christian sphere, such as the 16th-century discovery, while looking for building stone, of the body of Joseph, "tout resplendissant de grâce et de beauté, et il s'exhala de l'endroit des parfums de musc."[3] Such accounts proved that treasures were to be found when digging in ruins (although in that instance the workmen replaced everything as they found it, taking the hint offered by a violent wind).

The locals cottoned on quickly to the fact that many Western travellers were looking for biblical links, and they were often happy to provide them, sometimes for a useful fee. Therefore to the gullibility of those travellers who took the words of the Bible as a literal guide to the ruins they encountered (rather than testing the ruins as perhaps a guide to the Bible), we may add those of the locals which might both help and hinder the work or pleasure of travellers. Tall stories were often the order of the day, such as for Turner who, in 1820, was shown "the spot where St. George killed the Dragon, and showed me, still running down the walls, what he called the soap with which the saint had washed off the blood of the dragon."[4] Similarly, Nazareth showed the column against which Gabriel had leant for the Annunciation, ${ }^{[5]}$ straight competition for the Dome of the Rock, between two of the columns of which Gabriel stood 
for the same task. ${ }^{[6]}$ Jolliffe was at Nazareth in 1819 , and reported the location of the "interview between the angel Gabriel and the wife of Joseph." The artefacts (including Joseph's house) seemed suitably antique, but "the monk who attended to point out the different objects usually held sacred, injured the effect of his narrative by intermixing a fabulous statement of the flight of one part of the edifice to Loretto!" ${ }^{[7]}$ Here was a man not disposed to accept Biblical truth because there were sheep in the Bible and he had seen sheep in Palestine; his analogy was with the stone jars he saw:

As relics of antiquity they are entitled to some attention; but the authenticity of the gospel narrative cannot, surely, be affected by any such evidence: the author, even of a work avowedly fictitious, would hardly describe the usages of any known country otherwise than they were universally recognized to exist at the period of his writing. ${ }^{[8]}$

Nor were Old Testament heroic deeds omitted from the pilgrim round, for Damer in 1841 sought the "brook from which David is said to have selected the five stones, when he went against Goliath. ${ }^{\text {[9] }}$ Stretching anyone's credulity (and certainly that of Lindsay in 1838) was a visit to the tomb of Noah himself, ${ }^{[10]}$ and Macleod ascended Mount Gerizim, but found questionable the "twelve stones which Joshua brought from the Jordan." ${ }^{[11]}$ Fiske in 1857, going from Jerusalem to Bethlehem, remarked on "the identical tree, (possibly two hundred years old,) on which Judas hanged himself."[12]

Sites with supposed biblical connections were still being shown in the 1870 s. Thus at Nazareth, which had "scarcely any remains of antiquity," they conjured up "no end of traditional sites into a real existence, for the benefit of such travellers as are inclined to be sentimental. Among these are the 'Fountain of the Virgin,' 'Joseph's Workshop', and many others of a similar nature., ${ }^{[13]}$ As Saewulf wrote in 1102, the fountain there, still rich in marble, was where Jesus "often drew water for the use of his mother."[14]

But what about large complexes of ruins? According to Dimashqi the Pyramids were designed as they were in order that they be safe against earthquakes, and were erected before the Deluge specifically "d'y renfermer les manuscrits et les trésors qu'on craignait de perdre à cette occasion."[15] Treasure was also available at other Egyptian sites, the same author writing of one discovered which filled one hundred date-sacks for transport to Cairo. ${ }^{[16]}$ If most mediaeval and later Muslims were clear about which monuments they had not built (cf. section on Locals and Antiquities later in this chapter), they were splendidly ecumenical about who did so, and also about 
sharing other religions' holy sites and objects. ${ }^{1}$ Solomon was a favourite with everyone, especially for Baalbek. ${ }^{[17]}$ Yakut, writing in 1225 , notes that he built Baalbek, "consisting of palaces with marble columns," and that it was the dowry of the Queen of Sheba. ${ }^{[18]}$ In 1701 Veryard heard about Solomon from Baalbek's inhabitants, and he described the site as "the Rests of divers stately Buildings, and the Ruins of an ancient Castle."[19] The stones of Baalbek were so large who but a devil could have raised them into place? ${ }^{[20]}$ Fermanel in 1670 heard the story, but thought Baalbek was Roman. ${ }^{[21]}$ Wood related that everyone in Syria thought Solomon built both Baalbek and Palmyra. ${ }^{[22]}$

Of course, Solomon did not build Baalbek on his own: he commanded the djinns/genii to do it for him, the aim being to conceal immense treasures (still there!) in the structures' underground vaults. ${ }^{[23]}$ What about the famous monolith in the nearby quarry? The djinns carried the stones but, "being one day offended at something, this stone was dropped in the quarry, and no human strength has been found capable of lifting it since."[24] Solomon's father King David was also a builder but, according to Maqdisi, so punctilious about attribution that he inscribed the following on a monument of the Ad people: "Nous y sommes descendus, mais nous ne l'avons pas construit; nous l'avons trouvé ainsi bâti. Notre ennemi de Persépolis, nous l'avons culbuté; puis nous le quitterons pour la Syrie, s'il plaît à Dieu."[25] Ibn Khaldun countered such notions of djinns and building because "dans ce (faux calcul), on ne tient aucun compte du secours de la mécanique, du treuil et d'autres machines dont l'emploi, en pareil cas, est exigé par l'art de l'ingénieur." ${ }^{26]}$ And, in any case, look around:

nous voyons beaucoup de monuments élevés par des hommes qui ont appartenu à des nations dont la taille nous est parfaitement connue, et ces monuments cependant égalent et surpassent même en grandeur ceux (qu'on attribue aux Adites). ${ }^{[27]}$

According to Maqdisi, the same people were responsible for the ruined towns and villages to be seen far to the north east of Syria. ${ }^{[28]}$

Some 19th-century Syrians had a sometimes good, sometimes hazy understanding of their country's past. In 1858 Graham met the Imam of the Druzes at Qanawat, and together they talked of history:

He told me that in olden times Abraham had lived, and that he spoke Hebrew, then came Izaac who spoke Syriac, then in our Lord's time Greek

1 Khalek 2011, 85-134 Chap. 3: Icons: John the Baptist and Sanctified Spaces in Early Islamic Syria. 
was the language of the country, and now all speak Arabic... He told me that Job had been a native of his city, and he took me to Job's house. I asked him who Job was. "O," said he, "Nabi 'Ayub (the prophet Job) was a great sheikh, who had, oh! such numbers of oxen and sheep, oh! kitar, a very great number, and he ruled this country." He seemed to know nothing of Job's misfortunes; nor did he know the names of Job's friends or anything about them. ${ }^{[29]}$

He also claimed English was not a (separate) language: it was in fact Turkish.

People like Lady Stanhope seemed to breed superstitions. Walpole was assured in 1851 that "the Bint el Vizier, the vizier's daughter, four times every year, sent them [her relations] a ship-load of silver." ${ }^{\text {[30] }}$ According to her doctor, there also came into her possession a manuscript, "written in Italian, and disclosed the repositories of immense hoards of money, buried in the cities of Ascalon and Sidon, in certain spots therein mentioned." ${ }^{\text {[31] }}$ She dug in both cities, as we shall see.

At the fortress of Merkab by $185^{\circ}$ the local governor (whose father had bought an old 18-pounder from an English merchant ship), wanted an explanation of the contents of a sarcophagus lid built into the walls, and relayed to Walpole "a tradition that huge stores of treasure are hid over the door, where they are kept by magic spell."[32] Probably the lid was inscribed, so this is one of many examples of a local believing that inscriptions gave directions to hiding places; but that only Westerners could decipher them and thereby retrieve the treasure. Seetzen met the same belief in the Hauran in 1805, when a sheikh offered to lead him to a site rich in antiquities, including inscriptions, but Seetzen declined: "Man sprach häufig über meine Absicht, und Manche glaubten, ich würde ihnen nachher alle Inschriftensteine durch Zauberey stehlen." [33] From the context, it is evident that such sheikhs were convinced Seetzen also believed that inscriptions led to treasure! Another superstition collected by Schumacher in the Jaulan was that inscriptions were holy, because once (re-)built in mosques, which was no less than the truth:

The Fellah who gives any stone of a mosque to a foreigner will be punished for it by Allah, either by death or by a misfortune in his house; and as they consider all architectural remains to have formed portions of old mosques, they decline to give any information about such stones unless they happen to be found in the sites of deserted houses. ${ }^{[34]}$

Ancient designs needed explaining, and talismans perhaps took the place of tutelary deities. Thus Baalbek had one in the form of a mirror ${ }^{[35]}-$ a widespread 
mediaeval magical device. Again, in the 11th century a gate at Maarat al-Numan (73 km south of Aleppo) bore an unreadable inscription. This was interpreted as a talisman to prevent scorpions entering the town. ${ }^{[36]}$ At Jerusalem a column decorated with snakes protected inhabitants even after they had been bitten, so long as they did not travel far. ${ }^{[37]} \mathrm{A}$ similar talisman worked at Tripoli, wrote Boullaye Le Gouz in 1653, because no scorpion entered the town although outside there were plenty. ${ }^{[38]}$ The idea of such talismans is pagan, going back to ancient magicians and the symbols they had sculpted, to guard against scorpions and mosquitoes. ${ }^{[39]}$

In 1909 a Bedouin met what he thought was a djinn, as recounted by Butler. He was in the Ledja, "Msekeh, a most interesting deserted ruin where there were many hours of work in measuring buildings and copying inscriptions. There was no sign of inhabitants, and we went about our task in the peace and comfort that only deserted ruins afford." But then a Bedouin leapt over a wall brandishing a club, but was calmed somewhat by hearing the Expedition's guide speak Arabic. Why, then, the agression? A misunderstanding:

He had been in search of a stray sheep and, without having seen any sign of human beings in the vicinity, had leaped over a wall to find a creature in strange garb mysteriously examining a written stone. He took this creature for a djinn and, being unable to retreat, had thought best to attack him, fully expecting to be killed. ${ }^{[40]}$

\section{Treasure-hunting and Locals' Knowledge of the Past}

On n'oseroit aller visiter par curiosité les anciennes ruines des Villes Chasteaux \& Eglises à la campagne, de crainte d'estre soupçonnez qu'on $\mathrm{y}$ va chercher des thrésors. Quelques Turcs amis me voulant un jour mener dans un lieu souterrain, qu'ils disent estre une Cité abismée... d'autres m'en dissuadèrent pour la raison que je viens d'alléguer, afin de ne donner point de prise sur nous aux Magistrats, qui venant à le sçavoir ne manqueraient pas de nous mettre en peine, \& de nous faire payer une avanie. ${ }^{[41]}[1682]$

Another common belief amongst locals was that sculptures and inscriptions, as well as just pointing to its location, could sometimes actually contain treasure, and that Westerners came to Syria to search it out. This seems to have been perennial, merchants in 1678 recording the astonishment of a local at 
seeing Franks, the more so "wondering that we travelled thus in the Desart, only out of Curiosity."[42] No, exclaimed a local at another unnamed site, built by Solomon, that "we understanding the writing on the Pillars, came to seek after Treasure." ${ }^{\text {[43] }}$ Several years later, returning from Palmyra, other merchants recorded the same notion in the heads of the locals, "that the Franks go to see old Ruines, only because they there meet with Inscriptions which direct them to some hid Treasures."[44] At Jerash in 1829, Fuller was shadowed everywhere by the Bedouin, "and never allowing me to be a moment out of their sight, lest I should appropriate any thing unobserved by them. This perpetual surveillance I found very irksome; and I now took the opportunity of stealing out, as I hoped unnoticed, to make another tour of the ruins by myself, and at leisure. But in this I was disappointed: I had scarcely reached the fountain, when my persecutors overtook me."[45]

The worst illustration (and part-confirmation) of the belief associating Westerners with treasure was Lady Stanhope, niece to William Pitt the Younger, who lived in the Lebanon. She confirmed that treasure-hunting was the Western aim by allowing her workmen during excavations for antiquites at Ascalon to destroy a handsome colossal lion they uncovered for precisely this reason. ${ }^{[46]}$ The dig, employing 150 workmen for a fortnight, was on the supposed site of the Temple of Astarte, where it was believed a treasure lay buried. ${ }^{[47]}$ There are further details in the account of Ascalon, in Chapter Four. Everyone must have known that digging amongst ruins could and did unearth treasure. Fabri, writing in the 1480 s, knew that this had happened at Athlit, to a set of knights evidently uninterested in old coins and medals, but very well aware of their straight bullion value:

While [the Crusaders] were laying the foundations thereof, an ancient and thick wall was laid bare, into which they dug with iron tools, and found a great plenty of certain golden coins, the inscription and figure whereof was unknown to the moderns, which coins they melted down, and paid their soldiers' wages with them. ${ }^{[48]}$

In spite of cogent explanations of the stupidity of announcing the location of hidden treasure, ${ }^{[49]}$ any traveller copying inscriptions was constantly shadowed by locals who thought him "a confirmed lunatic, if he goes out sketching, and spends his time in spoiling good paper with scratches and hieroglyphics; and a magician when inquisitive about ruins, and given to picking up stones and shells, gathering sticks and leaves of bushes, or buying up old bits of copper, iron, and silver." ${ }^{[50]}$ Burckhardt guarded against such nuisances by 
sallying forth with a very small notebook he could conceal under his Arab robes, and enter his memoranda when nobody was looking - but "these restraints were, however, extremely unfavourable to fullness, accuracy, or method in arrangement." ${ }^{[51]}$ Drummond, in fact HM Consul at Aleppo in 1754-6, sketched at Lattakia to the wonder of the locals who, perhaps mistaking his scarlet coat and sword for the garb of a soldier, did not interfere. ${ }^{[52]}$

Further east, near Burj el Abiadh [the White Tower, not far from Hama], a Westerner copied Greek inscriptions in peace, and these survived, because "happily these Fellahin have not the organ of destructiveness so fully developed as their brethren in Palestine."[53] On the seabord, however, such foreigners were known for their skill in sniffing out treasure. At Lattakia, Lucas recorded that "Les Francs en ce païs ont la réputation de les sçavoir trouver," and he refused to get down into a likely underground vault in case he was kept there. ${ }^{[54]}$ So strong was the belief about treasure-hunters at Lattakia that a landowner would not let an inscribed pillar be unearthed:

Qui sait, avait-il dit, si ces Chrétiens, dont les connaissances leur viennent du diable, ne trouveront pas dans cette écriture l'indication de quelque trésor caché dans mon champ, qu'ils ne manqueront pas de m'enlever furtivement? Qui sait s'ils ne feront pas quelques maléfices qui porteront préjudice à mes plantes et à mes fruits? ${ }^{[55]}$

One explanation could be that the landowner was suspicious that such a fine piece of building material could disappear, for this town had a whole colonnade incorporated into its modern houses: "des rangées de belles colonnes de granit gris encore sur pied, mais tellement embarrassées dans la maçonnerie des maisons qu'on y a adossées, qu'il est impossible de juger à quelle sorte d'édifice elles peuvent avoir appartenu." ${ }^{[56]}$ There had of course been Christians in Syria from the early years of the religion, and locals were clear that churches, just like pagan structures, might contain treasure. When Fletcher visited Idana, near Aleppo, in 1850, and investigated the ruins of the church, the villagers "asked if we were looking for gold, and whether there really were any treasures buried below."[57]

Columns certainly contained treasure if they were in drums (witness the iron pins frequently retrieved from such shafts at Baalbek ${ }^{[58]}$ ), and such shafts were often disfigured or even ruined for very little return. In 1853 the Turkish general Tadmour Pacha blew up a shaft at Baalbek, but only retrived some $20 \mathrm{~kg}$ of lead from it; he probably needed the metal for bullets to use against insurgents. ${ }^{[59]}$ According to Ellis, "the drums of the columns are so huge that these miners were unable to get up to the first joint, or many more would have 
been lying prostrate., ${ }^{[60]}$ He noticed exactly the same gougings at Palmyra, and for the same reason. ${ }^{[61]}$

Monuments built by the djinns/genii (that is, most large buildings on most sites?) were frequently held to contain treasure. In 1822 Buckingham was greeted by a peasant at Jerash "who insisted that we were come to take away the hidden treasures of the genii who had built these palaces and castles."[62] But he was assured the riches were safe, for "a guardian genius, or demon, under the form of an immense bird, held the whole in too great security for it to be taken away by mortals, unless some magic arts were used to charm him into consent."[63] In the same year Burckhardt was warned at Petra that he would not be allowed to take treasure from "the ruins of the city of your forefathers," and that they knew his measuring and noting was because he was a magician: "we know that if you are a skilful magician you will order it to follow you through the air to whatever place you please.,[64] One problem was that many of the locals could not read, and so were naturally suspicious of the written word, even declaring at Medjel that Burckhardt's firman was a fake, so he gave up: "while coffee was roasting I left the room, finished copying some inscriptions, and rode off in a torrent of rain." [65] Burckhardt did indeed employ "magic," using a dream to get himself out of an awkard spot: "They greatly applauded my prudent determination, accustomed as they had been to look upon me as a person who had a secret to insure his safety, when travelling about in such dangerous places."[66]

Again, the locals were correct to suspect that ancient sites could contain treasure. Sections of the ruins of Jerash had been cultivated by peasants from the village of Sûf since well before the Circassians arrived in the 1880s. When this happened they evidently acquired finds from them, including "a pot said to have been dug up in this neighbourhood, and reported to have contained countless gold coins of large size." Such treasure was naturally the property of the Ottoman government, but little was handed over, and "the finding of hoards is of by no means rare occurrence in Palestine., ${ }^{[67]}$ Indeed, the PEF speculated in 1871 that following Bedouin footsteps into Moab could lead to "further interesting discoveries," because they have "at various times undoubtedly found relics of antiquity - gold coins, and even a small idol - when ploughing in the neighbourhood of the ancient cities." From such thoughts, and Frankish willingness to spend big money to find them, any Bedouin reading such a report in his tent (perhaps not in the reading room of the Athenaeum) would rightly have concluded that the PEF were just as interested in treasure as the locals, since "the Arabs indeed narrated to us several instances of gold coins and figures having been found by them while ploughing, and sold to jewellers at Nablous, by whom they were probably melted up."[68] 
Ruined towns, such as Ar Rastan near Hama, ${ }^{[69]}$ seem to have attracted treasure-hunters. Likewise large burial vaults such as one near Sidon where, so the Grand Vizier was told, "inconceivable treasures were hid in them."[70] (There were myriad burial chambers at Sidon, where so many great sarcophagi were discovered; but most had probably been thoroughly looted by midcentury.) Much the same was reported near Baalbek, where a body was found with a piece of unstamped gold in his mouth, together with inscribed sheets of lead, which were melted down. ${ }^{[71]}$ Monumental tombs also suffered: the (in fact Byzantine) remains at Khirbet el-Medieh (which Guérin thought to be the Tomb of the Maccabees) were being dug, and the locals "se répètent les uns aux autres qu'un trésor doit être caché en cet endroit, puisqu'un étranger y pratique des fouilles avec tant d'ardeur." ${ }^{\text {[72] }}$ Whatever the origin of the site, the locals were taking materials for re-use, and considerable quantities disappeared within five years. ${ }^{[73]}$ Only by purchasing the land (he suggested the French Government should do so, but concedes that would have been difficult) did Guérin believe he could prevent the cut stone disappearing "pour être transportés à Lydda ou à Ramleh comme matériaux de construction."[74] (Presumably the town - Lydd - that Goujon in 1670 had said was deserted, ${ }^{[75]}$ was now rebuilding.) He was surely correct.

The previous year the PEF had reported a vaulted building (perhaps a tomb) made out of hewn stone from the quarry less than a kilometre distant from Ramleh, but a local put them right:

the rest of the vault had been demolished by the people of Ramleh for the sake of the ready-hewn stones, as they found it much easier to carry them that distance than to quarry them nearer at hand. This deportation of stones has spoilt many a ruin.

Nor was it only the locals who destroyed antiquities. In 1816 Bankes visited Lady Stanhope at Mar Elias, and entered and drew a recently discovered tomb: "Copies of all in detail were added to the store of drawings, and even some of the originals successfully sawed off and removed during this visit." ${ }^{[76]}$ Ramleh was a town much shrunken and in ruins by the 16 th century, ${ }^{[77]}$ and was a centre for cutting marble. ${ }^{2}$ Further examples were provided in the PEF account:

The site of Khalasah in the Negeb, for instance, is left almost stoneless by the pilfering of the Gaza folk. The shaykh of this village tells me that

2 Petersen 2001, 32. 
his father and others built their houses entirely of the stones which they brought from the ruins of El 'Amayziyeh, some two miles distant. In fact, wherever a ruin is handy, the fellahin prefer digging up the well-cut seasoned stones to the toil of cutting them afresh. ${ }^{[78]}$

\section{Vandalism}

On auroit de la peine à les croire \& à se les imaginer, si on ne les avoït veuës. II n'y a pas long-temps qu'ils brisèrent \& mirent en pièces à grands coups de marteaux une tres-belle colomne de marbre d'une hauteur \& grosseur prodigieuse trouuée dans les ruines d'une ancienne Ville pour en tirer des pierres. ${ }^{[79]}[1682]$

While we wait [antiquities] are being carelessly or wantonly destroyed! One explorer tells of an Arab who found an entire black statue, and because it was too heavy to carry away bodily, broke off its head and carried that away first. Palaces and temples, when unearthed, are used as quarries for the building stone. ${ }^{[80]}[1892]$

The two quotes above are separated by over two hundred years, suggesting that vandalism continued unabated. Febvre, in his 1682 philippic against the destruction wrought by the Turks, should have included Western travellers amongst his examples. So should St Clair, author of the 1892 quote, in a chapter entitled "The vandalism of the Orientals." Mislin, writing in 1876, placed most of the blame on Western thirst to fill museums:

Les Anglais, les Français, les Allemands, se donnent réciproquement et à bon droit les noms de vandales et de dévastateurs; hélas! la question n'est plus aujourd'hui que de savoir si les débris des plus beaux monuments de l'Orient font meilleure figure dans les musées de Berlin que dans ceux de Londres ou de Paris.

He also writes of an American:

Depuis, un Américain du nom de Jones [no further details] s'est donné la mission de mutiler tous les monuments qu'il ne peut emporter. Il exerce en grand ce genre d'industrie et de dévastation, dont il a choisi pour centre les deux villes de Beyrouth et de Jaffa, afin de pouvoir démolir à la 
fois le peu qui reste sur place des anciens monuments de la Phénicie et de la Palestine. ${ }^{[81]}$

Pilgrims and tourists down the ages have indulged in practices well-known today, occasioning agony for the monuments but ecstasy for the tourists. Felix Fabri (c.1480-3) warned against chipping fragments off the Holy Sepulchre (excommunication), or "scratching columns and marble slabs, or boring holes in them with iron tools, to make marks of their having visited them."[82] Buckingham, a member of several learned societies, knew no better at Baalbek in 1825:

We tried to get a small piece from off one of them, but could find no stone hard enough for the purpose, and were obliged to content ourselves with two or three very little bits, which the Arabs made many objections to our taking away at all. ${ }^{[83]}$

Nor did De Saulcy who, upon seeing HYDE inscribed in large letters on a wall at Beit Kerm, applauded his companion, who "a eu l'idée d'écrire son nom au-dessus de celui que nous avons trouvé, et de le faire suivre des mots: Venu avant!!! Inutile de dire combien cette bouffonnerie nous a mis en gaieté."[84] This practice extended to the famous Cedars of Lebanon, where squares of bark were cut out "pour écrire des noms que nul ne retient," and was in full swing by $1827{ }^{[85]}$

Evidently, important locations deserved marking with the visitor's presence. So when Damoiseau visited the cave of the Prophet Elias in 1833, he was gratified to find so many French names on the walls, and “j'osai graver le mien à côté de ces noms respectables, pour laisser au moins une trace de ma vie sur un monument que les hommes et les siècles ne détruiront pas." ${ }^{[86]}$ Egypt was equally blessed by such inscriptions. At the Pyramids in 1856, Bromfield kept up the honour of the British by cutting his name "at full length, and in large Roman letters" over the name of Prince Puckler Muskau, "who has left no memorial of the date of his visit." ${ }^{[87]}$ At Baalbek by the mid 19th century, "the walls and the columns are covered with the names of visitors." ${ }^{\text {[88] }}$ Robinson visited Seleucia in 1838 , and was disappointed by the few column stumps surviving; but this was where Paul and Barnabas embarked for Cyprus, so "tout-àcoup ce lieu acquit à mes yeux un intérêt que les restes de l'art payen auraient été peu capables d'inspirer."[89]

Either vandalism simply continued through the 19th century, or it increased; or, at least, it was reported more frequently, and often with outrage. Burton in 1872 mentions a colossal female statue at Baalbek still lying in a back street 
there, bought but abandoned perhaps because its purchaser could not carry it away (Joyeau was a Prix de Rome artist, not an engineer). ${ }^{[90]}$ The following year the PEF notes the collecting of large quantities of antique architecture from a site near Jericho, and in their yard "had been accumulated a great quantity of ancient cut stones taken from excavations made in the surrounding Tells, and intended to serve for a new building projected by the Russians." ${ }^{[91]}$ Not far from here, Conder records that frescoes of the 12 thC in a monastery he had previously visited had completely disappeared by 1881: "Russian monks from Marsaba had settled there, and had rebuilt the monastery. Every fresco had been scraped from the walls, in order, they said, that new and better might replace them.. ${ }^{[92]}$ At Athlit, for example, even the act of dismantling damaged the stones: "Inhabiles même à détruire, ils peuvent à peine jeter à terre ces blocs immenses que d'autres mains avaient su élever jusqu'au ciel." But then, this was the man who said Djezzar Pasha had destroyed all the temples of Syria to build his mosque. ${ }^{[93]}$ Egypt continued to suffer from European museum vandals, as Flinders Petrie emphasised in 1918, writing of "the vicious demand for fragments of monuments, mainly by the tourist, but also fostered even by national museums."[94]

\section{Roads, Milestones, Bridges}

Remains of a noble, large Causeway, on the Road betwixt Aleppo and Antioch; which was made by the Romans. We travell'd upon it for about a Mile. It is made of large, flat, hewn Stones, which are yet in pretty good Order and Repair, for the Space above-mentioned. ${ }^{[95]}[1743]$

European travellers expected to find serviceable roads in Syria, and until the later 19th century were mostly disappointed. Even then, there was no metalled road between Aleppo and the east. Thus when Oppenheim had Tel Halaf excavated in the years following 1911, all materials had to come from Aleppo on nearly 1000 camels, and this was a 20-day journey. Over half a century later, in the 1980s, there was "no direct paved road from Palmyra to Deir ez-Zor."

Many were well aware that the Romans developed and maintained an impressive network all over the Empire, ${ }^{4}$ and frequently remarked on their milestones and remains as they came across them. There were many survivals in Syria. ${ }^{[96]}$ In 1818 Irby \& Mangles followed just such a road in eastern

3 Oates 2013, 7 .

4 E.g. MacAdam 1986, 19-33, Roman province of Arabia: Road system and Peutinger Table. 
Jordan, finding the remains of forts along the way, and a Roman bridge over the river Arnon. ${ }^{[97]}$ Throughout the Hauran were some near-perfect stretches, as for example between Suweida and Bosra in 1855: "The pavement is in some places quite perfect, and the line of the road, extending across the fine plain as straight as an arrow, is clearly marked." ${ }^{[98]}$ At Bosra, Lindsay in 1838 was shown a section of road, and told that it ran "as straight as a gun" as far as Baghdad. ${ }^{[99]}$

Sections of road near Tyre survived because "where the road runs along the beach, concrete was used instead of stone to form the roadway, and the remains of this, set in hard white or pink cement, are still to be found in parts." ${ }^{\text {[100] }}$ In other words, there were no re-usable blocks to plunder. North of Byblos, Allen moaned in 1855 that he liked neither the scenery nor the road: "dreary, stony hills; on the other the sea; and under us a road so bad as to have defied the powers of Macadam. Thus we had all the monotony which could weary the mind, and the difficulties which fatigue the body."[101]

Drummond in 1754 (on the coast) decided not to visit either Antioch or Aleppo because of "the tedious manner of travelling; a day's journey never exceeding thirty miles, though one must be on horseback from the rising to the setting of the sun." ${ }^{[102]}$ Much of the way was over the old Roman road, which was

infamously out of repair, a very considerable proportion of the Roman stones being here and there absent, and causing a hiatus, into which your jaded beast never fails to stumble; and yet the habitués of Alexandretta were wont to rejoice in this old voie Romaine, though part of it, at most seasons of the year, is fathomless mud. ${ }^{[103]}$

Nothing appears to have changed by 1903: "an all day's ride over a wretched road which was built twenty centuries ago by the Romans and looks as if it had not been repaired since." ${ }^{\text {[104] }}$ Yet how else was one to get from the coast to Aleppo?

The Roman road along the coast was in parts in much better condition, with several milestones surviving. ${ }^{[105]}$ Newman travelled this road between Tyre and Acre in 1864, and came across French soldiers "excavating a buried city which has neither name nor story, ${ }^{\text {[106] }}$ perhaps to build defences. Ward followed the same route (there were "numerous traces") in the same year, "but the road has not been used for wheeled carriages for centuries past, so that the present inhabitants ... can find no fault with their road assessments, for, judging from what I could see, their highways are never repaired."[107] On the Beirut-Sidon stretch, Van De Velde remarked on milestones which Maundrell had seen 
150 years before. ${ }^{[108]}$ Further afield, many more Roman roads ${ }^{5}$ were to be recorded: in the Hauran, by Porter; ${ }^{[109]}$ between Petra and Hebron; ${ }^{[110]}$ and in present-day Jordan by Tristram ${ }^{[111]}$ and Butler. ${ }^{[112]}$

The Duc de Luynes was also an aficionado of Roman roads, mentioning several in his account, and clearly travelling on rather than beside at least one of these. ${ }^{[113]}$ It was usual, however, just to follow the line of the Roman road, as Tristram recounts for Moab in 1873, "which had formed a paved way from the Callirrhoe to the Herodian fortress, but which is now merely a rugged line of upturned squared stones." ${ }^{[114]}$ Conceivably these were flanking kerbstones, or just possibly stones prised up ready for re-use elsewhere, but most probably simply the chaos of a millennial non-maintained surface.

For our travellers, therefore, transport throughout Syria was not of the best. ${ }^{6}$ The road network had probably not been maintained since the time of Justinian; its blocks had been filched for building. Even if camels and donkeys could have used such roads when in perfect condition, in a broken state they presented hazards even for horses, so that tracks tended to develop alongside them (since they naturally went from town to town), and to be used by all. "Whenever I came to a remnant of any extent," wrote Skinner in 1837, "I was able to trot briskly on; but where it is broken, it affords the vilest path in the world."[115] Lortet echoed the sentiment in 1881: "ces larges pavés hexagonaux, absolument privés du remblais dont les anciens avaient soin de les recouvrir, sont horriblement glissants pour les chevaux et désagréables pour les cavaliers." ${ }^{\text {[116] }}$ Schumacher, during his prospecting for a railway, ${ }^{[117]}$ sometimes described with precise measurements the Roman roads he encountered, ${ }^{[118]}$ made many useful archaeological comments, and observed that the modern road frequently ran alongside the Roman one. ${ }^{[119]}$ This was no doubt because of the bone-shaking consequences of actually using the ancient road, as Allen claimed above.

Ancient ruined towns were often seen by travellers precisely because they were close to Roman roads. ${ }^{[120]}$ If an area was dangerous, then other arrangements were made: in 1669 travellers sailed between Tripoli and Jaffa - they did not go by road, which was not continuous. ${ }^{[121]}$ Blondel in 1840 was puzzled by the disappearance of roads inland, between Palmyra and Baalbek and the coast: "Des villes aussi considérables devaient nécessairement entretenir des rapports journaliers et importants avec Tyr, Sidon, Bérythe, etc., et elles devaient posséder entre elles des moyens aisés de communication."[122]

5 Bauzou 1988: Roman roads from Damascus to Amman.

6 Issawi 1988, 224-246: transport in Syria. 
And he was disgusted by the state of the roads within Beirut, because "personne, de temps immémorial, ne s'étant soucié d'y faire la moindre réparation, le tout était dans un état détestable."[123] However, he did find a very wellpreserved Roman road in the Galilee. ${ }^{[124]}$

Roman bridges met with a similar fate, sometimes useless because the river had changed its course, ${ }^{[125]}$ sometimes repaired with spolia (such as granite columns at Gebala ${ }^{[126]}$ ) or even with wood, but often replaced by a ferry. Thus in 1714 Lucas admired on the Orontes "un tres-beau Pont, qu'on ne repare point, \& qui tombe en ruïne., ${ }^{[127]}$ The uncharitable opinion was that the Arabs destroyed them deliberately, so as to gain custom for their ferries, perhaps then to plunder those who stepped into their boats. ${ }^{[128]}$ Such ferries were the only boats on Syrian rivers, Al-Muqaddasi pointing out this fact: ${ }^{[129]}$ therefore no river commerce. In the Hauran, so rich in ancient remains, Porter followed a Roman road to Wady Zedy, where "a fine Roman bridge of three arches here spans it, crossing which we rode up to the village."[130] Near Tyre, Conder and Kitchener counted two more Roman bridges. ${ }^{[131]}$ This was Horatio Herbert, later Field-Marshal Viscount Kitchener, at this date a subaltern in the Royal Engineers, in 1883 to be attached to the Egyptian army.

Arguably the technology was not available to reconstruct Roman bridges: just north of Beirut, on the Dog River, Émir Beschir built a stone bridge in the 1830s, not far from the old Roman bridge. ${ }^{[132]} \mathrm{He}$ might have included Roman blocks in its construction (for Thomson in 1886 said he "erected his on the ruins of one more ancient, built probably by the Romans"); but no matter, for "it soon gave way before the violence of the stream." [133] It was still standing when Fuller passed by in 1829, to admire the several rock-cut inscriptions next to the Roman road. ${ }^{[134]}$ Other bridges, even Roman ones, went because of war. Lieut-Colonel Napier, fighting against Ibrahim Pasha in 1842, admired a bridge over the Jordan (the span of which he had measured ${ }^{[135]}$ ), and "if the powder I have sent for has arrived at the bridge, I mean to send the latter into the air. 'Tis a pity, too - a fine old Roman structure - but it cannot be helped."[136]

How did modern roads and bridges fare in comparison with their ancient counterparts? Modern roads were fine if properly constructed, to take account of the weather. The Grand Vizir built one in six months in the plain of Antioch during the reign of Sultan Achmet, and included a 24-arch bridge. ${ }^{[137]}$ Another across the Jordan was the (15th century?) Bridge of Jacob. Here Jacob (and his daughters - sometimes included in the bridge's name) crossed the river on his return from Mesopotamia. ${ }^{[138]}$ Even a bridge built by Faccadine near Sidon in the early $17^{\text {th }}$ century was left to go to ruin. As Lortet explained in 1881, traffic over the bridge was hindered, particularly during spring flooding, when 
even caravans could not cross the swollen rivers. ${ }^{[139]}$ In 1820 even the road from Ramla to Jerusalem "became worse as we advanced." ${ }^{[140]}$ In the 1830 s the Beirut-Damascus road was traversed by camels, not carriages, although Jones (who thought that in Indiana, and this in the 1830s, "I had seen the very worst roads in the world") tells of the British Consul's employment of sixty men to drag a carriage over the mountains (the camels disdained to carry it in pieces) so he could travel over the great Damascus plain. ${ }^{[141]}$ The roads around the Sea of Galilee were declared by a guide in 1838 to be absolutely impassable, but Lindsay discovered that "there is as beautiful and easy a footpath along the whole eastern shore of the lake as across a meadow in England." [142]

In 1872 Farley was lamenting that Turkey was being held back by "the injury caused by defective appliances for the transport of merchandise,"[143] and in the following year Savigny de Moncorps, stuck in Damascus, complained that rain had made the road to Baalbek impassable, so he never saw the site. ${ }^{[14]}$ Roads around Beirut were described in 1839 as narrow, and in a "shocking state of disrepair." ${ }^{[145]}$ However, the Beirut-Damascus road (off which the road to Baalbek branched to the north) was indeed passable, and of high quality. Built by two Frenchmen 1850-1860, it was described in 1875 as "une route carrossable, la seule de toute la Syrie,"[146] helping explain the despair of travellers marooned elsewhere. Farley explained that the construction was done "at a cost which makes the working of the road a highly remunerative business to the shareholders," the more so since the French company "have the monopoly of all wheeled conveyances over the road for a term of fifty years," and traders can transport their goods in the company's wagons. ${ }^{[147]}$ Here is but one example of the grip Western enterprises had on Syria and the wider Ottoman Empire.

Roman roads were marked by milestones, and large quantities survived in Syria, some reused and built into newer structures, but many in their original location and, where the road was bad, the only indication that the reporting traveller was indeed following an antique road was provided by milestones ${ }^{[148]}$ and, along the coast, by bridges. ${ }^{[149]}$ At Jubah, Tristram cantered along the side of the old Roman road (but not on it), "and came across two mile-stones, one broken, the other still in situ." ${ }^{[150]}$ From Rabba he saw the Roman road straight as an arrow, found three milestones, and "followed its course by its side the greater part of the day... in many places the pavement remains exposed, though, for the most part, its stones have become displaced by the action of time and weather." ${ }^{\text {[151] }}$

The Duc de Luynes was an avid collector of sightings of milestones, but they were only incidental to his narrative (he does not try to identify sites 
via them), for travel by time not by distance indicated both the difficulty and lack of well-kept roads, as well as the dearth of maps with reliable distances marked. Indeed, because of the absence of reliable maps, not to mention any documented culture of reading Roman milestones, travel was usually computed by time elapsed, not by distance. ${ }^{[152]}$ Travelling in 1864 near Kerak, Luynes found three milestones and a stretch of Roman road, noting the times when he found them; ${ }^{[153]}$ in the same region and following the Roman road, he came across four milestones, ${ }^{[154]}$ then 15 milestones in just over one half hour of travel, ${ }^{[155]}$ of which the 12 fallen ones must have been gathered for transport to the ruins mentioned, because they could not all be still in place and spaced each a mile apart. There were three upright ones (he does not say whether they were of different periods), perhaps marking only a single mile division, unless roads crossed here, with the possibility of milestones from two roads, and not just from one. Given the frequent practice of erecting a new stone for a new emperor, no wonder the stones Luynes encountered in Syria were bunched together (cf Sardinia: 51 inscribed milestones found for the first 12 miles Olbia to Carales). So he notes milestones, but does not seem inclined to use them for their clear purpose, namely by reading off distances; at one point he notes one milestone with "une inscription très-fruste et impossible à déchiffrer," [156] suggesting that others were indeed readable. Irby \& Mangles, travelling in 1818 in Moab, reported many milestones, most of them readable. ${ }^{[157]}$ One gentleman travelling Aleppo-Basra in 1780 amused himself by measuring distance according to camel strides, noting these varied depending on any available pasture. ${ }^{[158]}$ More canonical was the practice of marking distance between waypoints or landmarks by the hours and minutes between them, which is a practice common in military itineraries. ${ }^{[159]}$ Unsurprisingly it is Rennell, a major, who gives an excellent account of his distances were calculated in our region, in his A treatise on the comparative geography of Western Asia, (London 1831).

\section{Railways}

Here the next European development may be introduced: the railway. ${ }^{7}$ It had already demonstrated in Europe its ability to sidestep roads, and even to lower their importance. Networks were to be designed by Western engineers, which were to assume such importance archaeologically (in Asia Minor ${ }^{8}$ ), politically (the Hijaz Railway) and commercially, all over the Middle East. Already in the

7 Oppenheim 1899, 21-24: Syrian railways.

8 Greenhalgh 2013, 196-197, 298-300. 
186os the railway route to India was being considered, perhaps with a terminus at Iskenderun, set against navigation down the Euphrates, and the completion of De Lesseps' Suez Canal in 1869. If some sensible solution were not taken, "we [Britain] shall awake some morning with the whole Indian trade monopolised by others, and Napoleon's fleet on its way from Toulon to Bombay by the Red Sea, while ours may have to go from Portsmouth round the Cape of Good Hope to defend our Indian possessions." [160]

By 1881 some were dreaming of a line Tripoli-Homs to the Euphrates, ${ }^{[161]}$ and Acre was being talked up as "très certainement tète de ligne d'une voie ferrée destinée à amener à la côte les riches produits de la vallée du Jourdain."[162] By 1890 engineers from an English company were surveying for a Haifa-Damascus railway, ${ }^{[163]}$ and a concession was accorded in 1891 to build a railway AcreDamascus. And would not a railway connection along the coast be an antidote to "the bad harbours and dangerous anchorages of Southern Palestine"? [164] For Tiffany, writing in 1896, it had been the Damascus massacre of 1860 that gave the French such a foothold in the country: "This led to French intervention, and thus did the blood of the martyrs become the seed of the railway church." ${ }^{[165]}$ Indeed it did, and it was French engineering which built the difficult Beirut-Damascus line. ${ }^{[166]}$ Tiffany was not alone in his prediction that a foothold could become a stranglehold, Miller writing in 1894 that the railway would revolutionise the whole country, revivify the Holy Land, and "only another evidence that the semibarbarism of the Mohammedan religion must in the end give way to Christian civilization. The Jaffa and Jerusalem Railway is a great object lesson to the natives, and it is doubtless the beginning of the end of Muslim rule in Syria."[167]

Little was quickly solved railway-wise for Aleppo, for still in 1906 they had no railway connection with Iskenderun, and both Beirut and Mersin were equally impractical for their import-export trade. What is more, a coast-to-Aleppo line should not be built, the Sultan determined, "lest the troops of the foreigner, and particularly of England, should find it perilously easy to land from their warships and march up country."[168] (Blocking likely landing places was an age-old device down the Syrian coast, as we shall see in the next chapter.) Antioch was in the same position: with Seleucia as the port, "Antioche reprendra de l'importance le jour où l'on songera à exécuter le projet du chemin de fer de l'Euphrate qui doit ouvrir la route de l'Inde."[169]

Europeans were probably more accustomed to railways than to Roman temples, so in 1881 Wilson explained the vaults under the Great Temple at Baalbek as follows: "Beneath this great platform are vast vaulted passages like railway tunnels, of massive architecture and beautifully constructed." [170] Syrians understood very well what railways portended. When Schumacher visited the 
Western Hauran in 1889 to survey the best route for a Haifa-Damascus railway, the Sheikh of the Anazeh's response was as follows:

I see well that with the great iron road we cannot remain long in Hauran; but we know that this country is not for ever to be ours, for we have heard how the descendants of those, whose bones lie under the ruins of this land, are to come back and rebuild once more its cities, even as they were in the times of their forefathers. ${ }^{[171]}$

He would retire with his tribe to the fastnesses of the Ajlun. Much earlier, in 1816, the local sheikh's first question to Thomas Legh at Kerak was "Are you come to see the country of your forefathers?"[172]

Building a railway entails much smoothing out hills and valleys, and digging for hardcore; and it was inevitable that antiquities would be discovered and destroyed in large quantities (for the necessary hard core) in the process. In 1910, during the extension of the Hijaz Railway, the government tried to halt the practice. ${ }^{9}$ They began by translating existing laws from Italy and Britain in an attempt to halt "smuggling activities of local tribes reflect their collusion with European forces who would later lay claim to Ottoman territories and also their dire need of money and supplies."10 The task was urgent, since the railway could pass very close to vulnerable ancient sites, as it did at Amman, ${ }^{[173]}$ and there seems to have been little hesitation in using ancient stones to make stations. ${ }^{[174]}$ Butler made the same point about Amman in 1904-5, deploring the fact that "the modern spirit with its lack of reverence for the ancient buildings prevails everywhere." $[175]$

The railway inevitably but perversely brought in its train the desire to get away from such modernisation, and to visit sites not touched by the new technology, as Gallois did from Aleppo in 1907, going for example to Apamea and points east, confronting local not European life, which was certainly not like life in France: "Il était là, de plus, des promiscuités quelque peu désagréables, gens et bêtes vivant sous le même toit, mais un vrai voyageur n'en est pas à cela près."[176]

9 Shaw 2003, 133: "foreign officials and various travelers working with the Hijaz Railway have, with the assistance of some locals, acquired antiquities... measures for their protection as well as an investigation have been ordered." 


\section{Aqueducts}

En Syrie, on rencontre sur les chemins, de distance en distance, de petits réservoirs ou grands vases remplis d'eau, ayant chacun à côté un pot dont les passants se servent pour boire. Ces monuments sont dus à des fondations pieuses en faveur des voyageurs; mais la plupart tombent en ruines, et la piété ne vient plus à leur secours. ${ }^{[177]}[1814]$

Water supply was essential to life and settlement, but many later travellers remarked on lack of maintenance, even when this would have been easy, and the inevitable consequences of neglect. For parts of Syria had indeed been wellsupplied with canals, and cadastration as well." ${ }^{11}$ At Rastan Abulfeda (d.1331) noted the town was in ruins, but its aqueducts were still standing (if not necessarily working?). ${ }^{[178]}$ Boullaye-Le-Gouz at Tripoli in 1653 reckoned that its fountains fed each house in the town, ${ }^{[179]}$ while at Tyre in 1658 Arvieux noted a well which simply voided into the sea, when "avec un peu de travail \& de dépense, on le pourroit conduire à la Ville comme il y alloit autrefois; mais les Turcs sont trop indolens pour penser à ces sortes de commoditez." ${ }^{[180]}$ In 1745 Pococke reported on water turning mills near Antioch, the water "then carried towards Antioch in the same manner," but he does not report on what happened when the channels arrived there. ${ }^{[181]}$ However, by that date the small population was gathered by the river, so it is likely that was the only source of their water. Fountains were also a source of water, provided without human intervention, although the Romans often beautified them. In 1825 Buckingham came across one such near Salkhad, and "around the fountain-head of this source of the Zeady were scattered fragments of some ancient building erected over it, with Roman sculpture on many of the blocks, though not sufficient for us to trace any particular design; neither was there any inscription met with."[182]

The sea coast towns were usually fed by aqueducts from the adjacent hills and mountains. Byblos had an ancient one, apparently repaired by the Muslims, and part negotiating a valley on tall arches. ${ }^{[183]}$ Irby \& Mangles visited Caesarea in 1823 , found that the wells had poor water, and thought they recognised the remains of aqueducts which once brought a better quality to the town; ${ }^{[184]}$ they were correct, for one aqueduct had brought water from a great distance, and another still functioned for part of its length, according to locals in $1864{ }^{[185]}$ Conder \& Kitchener thought one such aqueduct was Herodian, and had been repaired by the Crusaders, ${ }^{[186]}$ and others were described and

11 Dodinet et al. 1990 for cadastration/centuriation with irrigation canals, perhaps originiating in Hellenistic times; very well illustrated. 
mapped. ${ }^{[187]}$ Monro found initiative under way at Tiberias in 1835 , where the pasha was building a private bath, fed from a spring by a subterranean aqueduct, "the digging of which was in progress when I was there, and several remnants of statues and other marble remains were thrown out, while in places portions of pavement were visible at the bottom of the trench." ${ }^{[188]}$ This is clearly not new work, but the refurbishment of perhaps a villa, with Roman pipes already in place.

Such initiative seems to have been rare. Perhaps the pasha at Tiberias should have taken charge at Samaria where, in 1837, a broken aqueduct cascaded down the town, "and rushed down the streets: tearing them up in every direction, and sweeping its way into the houses, it leaped in cataracts over the ruined walls." ${ }^{\text {[189] }}$ Banias was in exactly the same state in 1854 , and "the ancient aqueducts, roads, and bridges, are all destroyed; the water from the rich fountain of the rock of Pan, runs in all directions through the village, so that one cannot even walk through its streets with dry feet." This astonished Van De Velde, for "This water is turned to no account whatever." [190] At Acre, Djezzar had built an aqueduct, but this was broken by 1856 , with the consequence that "water was brought in from a fountain a mile distant."[191] Worse, the town had large vaults which Robinson reckoned had indeed served as cisterns, "but being now full of stagnant water, they added to the unhealthiness of the place."[192] At Sidon in mid-century, an aqueduct was still feeding the gardens and keeing things green, but "the aqueduct not being kept in good repair, a part of the city is deprived of any benefit from it, and a large quantity of water runs to waste in the gardens, and along the road." [193] Inland, Homs was fed by a dammed lake, which Abulfeda said was built by Alexander the Great, and which was kept in poor repair in the $1880 .^{[194]}$

\section{Temples}

Unlike theatres, ${ }^{12}$ amphitheatres and broken aqueducts, temples were structures easy to modify into a church ${ }^{13}$ or a mosque; and even, thanks to the destructive earthquakes which dismatled them, capable of providing materials

12 Frezouls 1953; Frezouls 1989; Segal 1995, 32-34 for the decoration of theatres: stones are marble, granite, limestone. Lots of statues discovered in Caesarea, Beth-Shean, Neapolis and in smaller theatres, mostly of marble. The corpus is short, concentrates on description, and does not address the post-antique fate of the structures.

13 Callot 1997 for the christianisation of Zeus Madbachos et Sélamanes in the Dgebel Sheikh Barakat; Zeus Tourbarachos in the Djebel Srir; and Zeus Bômos at Burdj Baqirha. With 
which could be re-used elsewhere. There were large numbers of temples in Syria. ${ }^{14}$ Pococke's 1745 book, which also covers Mesopotamia, uses the term "temple" 444 times (sometimes, of course, to denote churches). Some of them are now being studied by the Marges Arides Project, surveying the area east of Hama. ${ }^{15}$ Even east of Aleppo, "the Americans discovered in 1904 numerous temples, partly remodelled into churches and private houses, which could be dated." ${ }^{[195]}$ All over Syria were temples converted into churches. ${ }^{[196]}$ Ancient temples in inhabited towns were usually converted into churches and then sometimes into mosques, and hence were often effectively disguised. Those in ruined settlements, however, could stand unaltered, but generally earthquakes had collapsed the columns and their entablatures. Seetzen encountered a large one near Beit-er-Ras in 1810, and "the outside of these ancient walls I found also a great many columns, two of which were of extraordinary magnitude, from which I concluded that there must have been formerly in this spot, a considerable temple., ${ }^{[197]}$ These were still there, reported Merrill in 1881, with multitudes of sarcophagi nearby. ${ }^{[198]}$ At Qanawat, ${ }^{[199]}$ in the Hauran (where there were plenty of temples, and with statues ${ }^{[200]}$ ), in 1810 Burckhardt saw the remains of a statue in one of the deserted town's temples. ${ }^{[201]}$

In the Lebanon, near Tripoli, Burckhardt came across a ruined town and the temple called Kenyset el Awamyd, or "the church of the columns." This was in a deserted town (called Naous, perhaps as a folk-memory from the Greek) with two temples "which are worth the traveller's attention. The smaller one is very much like the temple of Hossn el Forsul, near Zahle, which I had seen on my way to Baalbec; it is an oblong building of about the same size; and is built with large square stones." ${ }^{[202]} \mathrm{He}$ thought the decoration excellent:

In the S. wall are several projecting bases for statues. The door and its soffit, which is formed of a single stone, are ornamented with beautiful sculptures, which are not inferior to those of Baalbec. Before the entrance

reconstruction drawings showing what happened to each site at the Roman, Proto-Byz, mediaeval and Islamic occupation.

14 Krencker \& Zschietzschmann 1938. Contribution française 1989, 181-186: Les temples romains du massif calcaire de Syrie du Nord.

15 Gatier \& Rousset 2010, 149-158: temple at Arfa, in the middle of rich soils (due to the basalt). Temple converted into church, and now within an Ottoman house. Lassus described the temple in 1935, and the authors identified its destroyed elements in the ruins of the village. A collapsed arch and columns of the church, limestone, lie on the ground. Two basalt chancel screens are in a neighbouring house. Chretien-Happe 2004 for temples represented on coins. 
was a portico of four Ionic columns, of which three are standing; they are about eighteen feet high, and of a single stone. ${ }^{[203]}$

But an earthquake, (perhaps the very destructive 1822 one) evidently toppled much of the portico, because in 1838 Robinson reports that the larger temple "n'offre plus aujourd'hui qu'un amas de décombres; colonnes, chapiteaux et frises, gisent pêle-mêle, entassés les uns sur les autres." ${ }^{\text {[204] }}$

Also on the Lebanon at Husn Niha, Thomson in 1886 saw two temples, the one near the village "so thoroughly demolished, and the materials carried away, that neither its dimensions nor its architectural character can now be distinguished." The other was better preserved, and large:

It stood on a wide platform, facing the east, and had a portico in front, with a flight of steps leading up to it, more than thirty feet broad, and still in good preservation... The temple was nearly one hundred feet long, and over forty feet wide, but the interior is much choked up with fallen stones and broken columns. ${ }^{[205]}$

Near 'Afka, ancient Apheca, in the high Lebanon, Thomson visited a temple famous for its inscription, and marvelled at the stones of which it was made:

Some of the stones are large, and all are limestone, quarried from the rock in this region. One is surprised to find under the rubbish a column of red or Syenite granite, like the one in the village of 'Afka, which must have been brought from Egypt to Jebeil, and then transported up and down these mountains with incredible toil. ${ }^{[206]}$

Syenite is a variety of granite, so called after Syene (Aswan), where it was mined, and much used in ancient architecture. Near Wady Afka Porter visited what he thought was a Temple to Venus (where "were practised the grossest impurities and licentiousness of heathenism"), recorded that it was therefore destroyed by Constantine, saw two large granite columns from it, and thought that "By what means such blocks were conveyed up the mountain side from the coast it is not easy to understand."[207]

In Moab, well south of Madaba, in today's Jordan, Burckhardt came to arRabba (Areopolis), with two temples in the vicinity, one at Reil Kerm with an eight-column portico: "Within the temple, a great part of the walls of which are fallen, there are fragments of smaller columns. The stones used in the construction of the walls are about five feet long, and two feet broad." The one 
within the town "of which one wall and several niches remain, by no means distinguished for elegance... There are many remains of private habitations, but none entire." ${ }^{[208]}$ Seetzen had already visited the site in 1806 , remarking not only on the Christians who lived there, but also on "die Ruinen eines uralten Prachtgebäudes, das entweder ein Pallast oder ein Tempel war."[209]

Burckhardt's meticulous descriptions are admirable because of their length, and they often include rough measurements. Thus he describes the ruined temple called Heusn Nieha, SE of Baalbek, which had

a grand flight of steps, twelve paces broad, with a column three feet and a half in diameter at each end of the lower step, formed the approach to a spacious pronaos, in which are remains of columns: here a door six paces in width opens into the cella, the fallen roof of which now covers the floor, and the side walls to half their original height only remain. ${ }^{[210]}$

Then again, at Habbariyyah, on the western slopes of the Hermon, stood a ruined temple: "On the outside of the temple, at the east corners, are badly wrought pilasters of the Ionic order. The roof has fallen in, and fills up the interior. The stone employed is of the same quality as that used at Heusn Nieha and Baalbec."[211] So good were his descriptions that several authors simply quoted him. Robinson, for example, with a firman from Constantinople, was equally equipped with "notes extracted from Burckhardt's excellent work, to prepare us for what we were to see and inquire for; and that no mistake might occur from our mispronunciation of names, we had them annexed in Arabic characters," ${ }^{[212]}$ just as Burckhardt had done. Several of his passages (such as describing the ruins near Deir Demitry ${ }^{[213]}$ ) simply gut Burckhardt's accounts. Some temples were sufficiently weatherproof for camping, as Carne found near Banias in 1830: "This ruin stood quite aloof and utterly neglected; there were many niches in the walls within, where statues, no doubt, formerly stood. It served us as a refuge and a refectory; the most useful purpose, perhaps, it had served for many ages."[214]

Close to the coast were several temples, and even groupings. Near Beirut, at Deir El-Khalah, Renan in 1861 saw "d'énormes colonnes monolithes, que je ne puis comparer qu'à celles des Thermes de Dioclétien à Rome, indiquent la place du portique et en marquant l'étendue." ${ }^{[215]}$ Redding in 1873 noted the same temple, and remarked that Burckhardt had found the ruins of four similar temples on the same mountain. ${ }^{[216]}$ Further south, near Gaza, and heading for the village of Haneunis, Irby \& Mangles passed "a temple of considerable magnitude; two pillars of grey granite are standing, with several prostrate 
fragments, and a large wall constructed with antique remains." They guessed that the site was once important, because "there are many marble fragments of columns, \&c. which mark the site of a town of Roman antiquity."[217] We in our turn might guess that this was one site from which Gaza obtained some of the marble so evident in the town in the 19th century.

Further north, at Rukhleh, near Hermon, there were several ruined temples, already described in 1856 as "once splendid,"[218] but for one "its massive walls and noble columns have been wholly overthrown; and the huge blocks of stone lie scattered around in utter confusion." It was admired for its sculpture (and measured) by Porter in $1868,{ }^{[219]}$ but by 1874 it was no more than heaps of jumbled stones. ${ }^{[220]}$ Another temple was to be seen at Thelthatha, but already in 1856 "in a very dilapidated state; only a part of the northern wall is standing. The northeast corner, with its pilasters and entablature and a fragment of the pediment, remains yet erect, and towers above all the rest. Standing thus alone, it forms a very striking and picturesque feature."[221] Robinson, indeed, was astonished that "the whole of Hermon was girded with temples," naming several and exclaiming that

These all lie directly upon and around Hermon. The Buka'a and its borders are full of like edifices; to say nothing of the crowning glory of the temples at Ba'albek. Who were the founders of all these costly and magnificent structures? ${ }^{\text {[222] }}$

The PEF echoed the sentiment in 1891:

One wonders at the erection of such costly buildings in so lonely a spot. Such, however, is very commonly the case in the East, where men seemed to seek for retired sites for their shrines, far from the centres of population and worldly business. ${ }^{[223]}$

To the south east of Rukhleh was another temple, at Burkush, a temple platform with, on it, "foundations of a large Byzantine building, and small hovels of the modern Druze village are built against the eastern wall." ${ }^{[224]}$ It was recommended by Baedeker in 1876, having "several chambers, one of which seems to have been used as a bath... Many capitals of different forms lie scattered around." ${ }^{[225]}$ In the Bekaa Valley, Baalbek vied with Palmyra for the admiration of travellers, some of whom found it picturesque. ${ }^{[226]}$ On their way there they passed "des débris considérables d'édifices isolés, de villages et même de villes,"[227] including Deir el-Ashayir, with its hewn stones, "many of them 
being ten or twelve feet long." ${ }^{[228]}$ Nahleh, near Baalbek, displayed "the foundations and portions of the walls of a massive temple, simple and chaste in its style, ${ }^{[229]}$ located in the middle of the village and, like that at Deir el-Ashayir, stood on a masonry platform. ${ }^{[230]}$

East of Hama and Homs, on the edge of the desert, Perthuis in 1896 wrote of the remains of a temple near Assalamiyeh, "sur le sommet d'un petit monticule, un amas de fûts de colonnes monolithes, des chapiteaux sans sculptures, des fragments de portiques et beaucoup de débris enfouis dans le sol, restes d'un ancien temple romain," and column shafts and capital fragments all around the town, plus a mosque built from a church, ${ }^{[231]}$ itself perhaps also made from earlier remains. Under four hours' ride to the east of Damascus was Haran al-Awamid, the Village of the Columns, with three immense basalt Ionic columns still standing today. The same columns had been standing in 1855 , and in the streets of the village Porter observed "large numbers of broken shafts and hewn stones, showing that some important structures once stood in this place." ${ }^{232]}$ Close it might have been to Damascus, but when Thomson visited in 1886 "The villanous-looking Arabs and Bedawin in and around the village caused our guides great uneasiness, and they requested us not to remain there any longer than was necessary."[233]

Up in the snows (and ski slopes) of Lebanon is Fakra, the main focus of a large collection of ruins, ${ }^{[234]}$ with fine workmanship and some large columns, ${ }^{[235]}$ and in the vicinity the remains of what Warburton thought was a large city. ${ }^{[236]}$ The temple has now been rebuilt, and its enclosure tidied up, but in 1842 it was "un cumulo di rovine. Veggonsi nell'interno rottami di colonne della calcaria de'monti del diametro di piedi tre e mezzo."[237] Porter visited in 1855 , and near to the temple saw "the ruins of a bath, fragments of the marble pavement of which, I was informed, still exist beneath the rubbish. In the rocks around are some excavated tombs, and there are likewise the foundations of several other buildings." ${ }^{\text {[238] }}$ Just like Hosn Suleiman, this temple is remote from growing population centres, so its blocks remained undisturbed, as did most of those at Qasr Namrud, also in the northern Lebanon, "and the traveller in Syria and Palestine will soon find that Namrud and 'Antar represent the Devil and Julius Caesar of Western Europe."[239]

Not far from Banias was the temple of Hibbariyeh, a beautiful ruin standing in a ploughed field when Robinson saw it in 1856 :

This is one of the best preserved and most beautiful specimens of the many ancient temples, with which Lebanon, Anti-Lebanon, and the valleys between, are thronged. Their number is not yet known; but I visited 
no less than thirteen during my present journey; and that without varying my intended course except slightly in one or two instances. ${ }^{[240]}$

Warren and Condor went to measure the temple in 1884, but "we here got into the midst of a Muslim funeral, and after it was finished we were troubled in our measurements by being surrounded by the rabble of the village." Evidently they thought they had more rights than the people who lived there. ${ }^{[241]}$ Further north, in 1839 Layard went to visit the summer house of Barker, the retired Consul at Aleppo, high up on Mount Rhossus; this was a lovely spot, and evidently the Romans who built here thought likewise: "Near the house were the ruins of a Greek temple, which at one time had been converted into a Christian church. The ruins of other edifices were strewed around, and where the rain had washed away the soil were the remains of Roman mosaics."[242] At Bait Lahiyyah, near Damascus, a temple converted into a church became a mosque for the villagers: "It was of old the temple where the father of Abraham made his idols and kept them. But Abraham came and broke them to pieces."[243]

South of Damascus, in the Hauran, Hebran boasted a fine temple, of which today little remains, ${ }^{16}$ because the town was occupied from the later 19th century. When Buckingham passed by in 1825 , and apparently did not examine it closely, it was in ruins and deserted. ${ }^{[244]}$ In 1865 Porter described the temple as "beautiful," and the town was now inhabited. He was attracted to "the simple, massive, primeval houses were to us objects of greater attraction. Many of them are perfect, and in them the modern inhabitants find ample and comfortable accommodation." ${ }^{[245]} \mathrm{He}$ also wrote of the town a decade earlier. Here he could sate his interest in stone doors:

A once fine temple, which appears at a later age to have been converted into a church. A low stone door, evidently transported from some other building, gives admission to the interior. On the east was a portico, but it is now completely prostrate. ${ }^{[246]}$

The town and its temple were on Baedeker's list in $1876,,^{[247]}$ and Wright in 1895 thought that several of the churches in the town were simply converted temples. ${ }^{[248]}$ At Slim were two temples, drawn in the early 19 th century, but

16 Dentzer-Feydy 1997, 161 for Hebran, 2ndC temple: "Ce temple, dont la construction est clairement datée en 155 ap. J.-C. par une inscription, a été progressivement détruit à partir de la deuxième moitié du XIX ${ }^{\mathrm{e}}$ siècle, mais de nombreux blocs sont encore visibles dans le village." 
already largely destroyed and under collapsed blocks by 1900. ${ }^{17}$ At Suweida Robinson in 1838 saw a large temple with eight standing Corinthian columns, their entablature and cella; ${ }^{[249]}$ seven columns are still standing, probably because they were of little use for the barrack-building of the early 2oth century, which devastated other remains in the town, and a large tomb outside it.

\section{Degradation}

Les Turcs disent en commun proverbe, qu'ils ne sont venus que pour ruiner, \& non pour édifier, ce qui n'est que trop véritable, \& manifeste à tous ceux qui ont voyagé dans leur pays. Il n'y a qu'à le voir pour en estre convaincu, dautant qu'on n'y apperçoit par tout que des ruines de quelque costé que l'on se tourne, de vieilles mazures, de tristes débris, d'Eglises, de Villes, de Chasteaux \& de Bourgades, dont ils ne sçavent pas mesme les noms. ${ }^{[250]}[1682]$

Unfortunately, much of the evidence we have of ancient buildings in Syria concerns their continuing degradation, and some reports allow us to understand the speed at which this sometimes happened. This is against a background of believing Turks destroyers not builders, as Febvre affirms above. Yet just as seriously (and this was an attitude that puzzled many Westerners) many structures were left without maintenance, for eventual ruin. This happened even to conspicuous monuments at Constantinople, and fortresses on the Black Sea were robbed of their lead. ${ }^{[251]}$ The Turks were condemned for causing the destruction of agriculture as well as of towns and monuments:

Il ne croist plus d'herbe au pré où le cheval des Turcs met le pied, pour donner à entendre qu'ils ruinent \& désolent tous les païs par où ils passent, semblables à un torrent impétueux qui entraîne tout, \& qui ne laissé rien apres soy. ${ }^{[252]}$

Robbing out essential materials could quickly destroy buildings. In 176o Mariti admired at Acre in the Palace of the Grand Master a large room held up on tall granite columns; but it had gone by $1767 \cdot{ }^{[253]}$ And when Parsons visited Seleucia in the early 1770s, he referred to Pococke's plan of 1739: "things must

17 Dentzer-Feydy 1997, 163 for Slim's 2ndC temples. 161: “D'après les vérifications que l'on peut faire aujourd'hui sur certains bâtiments mieux conservés, Bankes a dessiné exactement ce qu'il a vu et il n’a rien restitué." 
have altered greatly in thirty-three years, since I cannot discover a fourth part of what he mentions to have seen then, and I very narrowly examined every thing worth notice." ${ }^{[254]}$ From what he saw visiting ruinous khans in 1814 Ali Bey (in fact a Spaniard) reached the inevitable conclusion:

Ceux que j'ai visités sont bien construits en pierre, quelques uns même avec le luxe de l'architecture; mais, comme ils sont déjà fort anciens, plusieurs tombent en ruines, et je pense qu'on ne les rétablira pas; ce qui fortifie mon sentiment, c'est que l'époque de la gloire musulmane est entièrement passée. ${ }^{[255]}$

Speedy degradation at two sites will indicate the wider effects of neglect.

Acre was especially battered by war. Along with Tyre (reported by Ibn Battuta as a mass of ruins in $1355^{[256]}$ ), Beirut and Sidon, Acre fell to Sultan Melik-el-Aschraf in 1291, and seems to have been left in ruins. Certainly, travellers in later centuries appear not to have visited it, "and those who mention it, speak of it only from hearsay, or as seen from the vessel as they sailed by." ${ }^{[257]} \mathrm{In}$ the 17th century, Acre was already a town of massive ruins, with no more than 300 inhabitants, indeed "a vast heap of magnificent ruins, partly covered by the sand driven up by the winds." [258] With a population in 1830 of 12,000, the town was attacked in 1831 by Ibrahim Pasha, son of Muhammad Ali, and the Egyptian cannon destroyed Djezzar's mosque. ${ }^{[259]}$ Under 2,00o remained by 1840, living in the greatest misery. By $185^{1}$ Acre had suffered three sieges in the previous century, but cannon balls and bomb fragments still littered the streets, ${ }^{[260]}$ and in the same year the town walls were being repaired by stripping a Crusaderperiod church at Athlit. ${ }^{[261]}$ And by this date, there were scarely any old ruins left, ${ }^{[262]}$ presumably plundered to build housing for the garrison.

Baalbek, immense thought it was, also degraded, helped by the Turkish garrison who broke up interstices between column drums to extract the iron. ${ }^{[263]}$ Since all the sculptured bas-relief faces in the Temple of Jupiter at Baalbek in sections nearly $20 \mathrm{~m}$ off the ground have also been destroyed, Ellis surmised that this must have been the work of idle soldiers when the structure was part of a fortress. ${ }^{[264]}$ Indeed, Baalbek was known by its 19th-century villages as The Fortress (which it was), but according to Huart in 1879 "il ne viendra à l'esprit d'un indigène qu'il y eut là autrefois un temple païen." ${ }^{[265]}$ Whether by earthquake or by such plundering, columns were falling: Wood drew nine at the Large Temple, but in 1840 la Salle counted six, ${ }^{[266]}$ the same number that are standing today. In the early 1870 s Burton attempted to get the small temple cleared out, and "applied to the Govenor-general of Syria for official permission to clear away the hideous Saracenic wall which, pierced for a wicket, masks the 
smaller temple of Ba'albak, called of Jupiter or of the Sun." ${ }^{[267]}$ But the work could not be completed because the Pasha objected to the cleared material being given away, and he stopped the work. A letter to The Builder explained that such a way of clearing sites was in any case dangerous:

I should discountenance demolition; especially demolition paid for with the materials removed. This is a most dangerous course in such a case; and, with such people as the Arab population of the neighbourhood, not to be thought of; not a stone in the place would be safe. ${ }^{[268]}$

Whatever the weight of such published objections, pilfering blocks at Baalbek continued, and in 1881 Ellis recorded that material continued to disappear to build the town, acting as a veritable quarry: "Almost any day some native may be seen with donkeys or mules carting off the stone." Sheer size protected the megaliths, of course, because "luckily the blocks in the finest parts are far too huge for 'draughting,' and it is too much trouble and expense to blast them.."269] Already in 1871 Tyrwhitt-Drake had raised the alarm, writing to The Times about how much damage had been done in the previous fourteen months. He suggested raising a small amount by subscription, and "would not some architect or civil engineer, intending to visit Palestine during the ensuing tourist season, volunteer to stay a few days and see the thing done? I fear that if it be not set about within a year, it will be too late."[270] Here, as elsewhere in Syria, Christianity made use of existing structures to build its basilica. ${ }^{18}$

\section{Locals and Antiquities}

[At Athlit] Women milk their cows on the steps of an amphitheatre; flocks of sheep jump one after another through the architecturally ornamented window of the palace of an emir, or of a Gothic church of the epoch of the Crusades; cross-legged Scheiks smoke their pipes under the sculptured arch of a Roman arcade. ${ }^{[271]}\left[183^{2}\right]$

The Christian population of Syria had been building with antiquities long before Islam arrived, and some of their productions were both coveted and dismantled when the Muslims ruled the roost. After the invasion, the Christians

18 Callot 1997, 743: "Enfin, tous les blocs qui n'ont pas pu être réutilisés ont été concassés pour servir de remblai autour de la basilique." Other examples include Sheikh Barakat and Qal'at Kalota. 
became a tolerated but downtrodden minority. For example, building the 8th-century mosque at Ramleh evidently required columns; the Christians were said to have columns buried, and "Hishâm informed the Christians that they must either show him where the columns lay, or that he would demolish their church at Lydda, in order to employ its columns for the building of his mosque." ${ }^{[272]}$ For Dimashqi (b.1256) the town must still have been rich in antiquities, for he records that after an earthquake "la ville de Lydda s'éleva sur d'anciens monuments." ${ }^{[273]}$

The widespread European belief in vandalistic orientals who simply destroyed what they did not understand is misplaced, as examples throughout this book demonstrate. But there were rumoured to be focussed reasons for some destruction. The Moabite Stone, for example, the oldest Semitic inscription was destroyed in 1871 by the Bedouin supposedly because either they hated the Turkish governor who asked for it, ${ }^{[274]}$ or because they were "terrified into believing that the Stone was the record of some treaty or law by which the Turks would seek to claim special jurisdiction over them." ${ }^{[275]}$ But this might have been too sophisticated an explanation, as it was reported in 1872 that "they destroyed or buried every other fragment of antiquity in their neighbourhood."[276] De Saulcy reported in 1853 that the locals at Baalbek broke up a sarcophagus which a foreigner wished to carry off to England, but does not explain why. ${ }^{[277]}$

The misconception of some travellers that Syrian locals knew nothing and cared less about antiquities was just that. Certainly, few before the 1880 s espoused any "academic" interest in dates and styles, and there are few imitations of antique forms, ${ }^{19}$ but many locals lived cheek-by-jowl with antique buildings, lived in them where convenient, and re-used their materials. Some, indeed, claimed descent from crusading families. ${ }^{[278]}$ Many old structures were also built into the narrative of the country's history, sometimes as a justifying anchor for Islamic buildings. Thus when the Umayyad Mosque in Damascus was built, the strength of the existing foundations was checked (so the builders were evidently aware of the possibility of earthquake damage), and a granite slab, inscribed in Greek, was found, part of which read:

And the worship of the Creator of created things shall be instituted here, when the lover of horses commands the building of this Temple of his own monies; and this shall be after the passing of seven thousand and

19 Al-Tabba 1982267 for Aleppo, Qastal al-Shu'aybiyya, of 1150, which looks antique, but was probably mediaeval. Ibid. 269: "It is possible that Nur al-Din saw and admired the magnificent Roman ruins in Apamea, which he had only very recently conquered, and wanted to express his military victories against the Crusaders with the same vocabulary." 
nine hundred years since the days of the People of the Column, And if the builder live to enter therein, the building will be named as the best of acts. ${ }^{[279]}$

Dimashqi, quite clear about the pre-eminent place of the Greeks and Romans in learning, ${ }^{[280]}$ also notes that the town of Balis in the Euphrates valley was built over "d'anciennes ruines grecques." ${ }^{[281]}$ Great antiquity in a building's origins was evidently prized, for example by attributing the original building of the Umayyad Mosque to a race of giants, ${ }^{[282]}$ or to Ad, who "transported thither a great number of columns of marble and alabaster," and called the result Iram of the Columns. ${ }^{[283]}$ Other great men to whom (erroneously) was attributed the construction of some Syrian buildings were Chosroes and Tamburlane. ${ }^{[284]}$

Indeed, mediaeval authors seem to have been bewildered by the surviving numbers of marble columns and capitals, Khosrau (travelling 1035-42) claiming that more than 500,000 survived, but that "personne ne sait à quoi ils ont servi, ni d'où ils ont été apportés." ${ }^{\text {[285] }}$ One servant in 1851 in the citadel of Aleppo, upon his master being shown some antique guns, asked "What is antique?" and was satisfied with the response "From Stamboul." ${ }^{[286]}$ Guys in $185^{\circ}$ interrogated locals about whether they knew any ruins, châteaux, churches, or large stones, and was frustrated as a result: "Et l'on me menait voir des blocs de rochers qui, à la vérité, avaient reçu un commencement de travail, mais dont la vue ne me faisait pas oublier la fatigue qu'ils m'avaient coûtée."[287] He was quite correct to ask about large stones, which were surely a sign of antiquities older than the Middle Ages, or in later re-use. Such stones are to be seen at (for example) Byblos, Marra Castle (inhabited by eleven families in $185^{[288]}$ ), Lattakia, Baalbek, Rukhleh, Umm al-Jimal, Mejdel, Ruad, Caesarea, and Jerusalem.

It seems just possible that some ruined churches and the like were called "Mother of Columns" and other places "of the columns" because, like Khosrau, the locals did not know their source. ${ }^{[289]}$ Yet if this was the case, it suggests a rather vague knowledge of ancient buildings ${ }^{[290]}$ - the same vagueness that named columnar structure "palaces." ${ }^{[291]}$ Certainly, locals were quite clear that using columns was a very old method of construction. Thus when La Roque met the sheikh of Baalbek in 1723, and told him why such monuments were no longer built like the temples, he responded with reasons that form the précis of Ibn Khaldun's rationale: after progress, matters decline - but "les Arts pourroient aussi se rétablir avec le temps, pourvu que les Maîtres du monde, c'est-à-dire les grands Empereurs, s'attachent à les protéger."[292]

Naturally, it was the locals who knew where ancient ruins were to be found. For example, Wilson tells of the shore of the Sea of Galilee in 1881, where there was nothing but earth and stones near the surface, "but the peasants knew that even underneath this there was material, marble and limestone, which 
they could convert into lime." ${ }^{[293]}$ Some locals also knew something of their history, for example amongst the Dead Cities. Sunnuhar, to the west of Aleppo, had "ancient remains, showing its former greatness," wrote Yakut in $1225 \cdot{ }^{[294]}$ Arethusa (Restan, Ar Rastan, Er-Roustan), between Homs and Hama, was stated by Ibn Jubair ${ }^{[295]}$ and Abulfeda to have been ruined in the early days of the Muslim conquest, and "each of the houses here is so large as to be almost like a village, with ruins everywhere round of buildings and walls. Some of the arches, too, remain, also some of the city gates, and its walls in part, and its water channels." [296] The ruins were still there in 1865 , with "traces of walls, and gates, and streets, and churches"[297] - indeed, a site worth excavating. ${ }^{[298]}$ When Gertrude Bell visited Bara, the sheikh and his son showed her around, and named three previous travellers there, so the town had evidently been occupied, and the visitors remembered; and

at Serjilla, a town with a sober and solid air of respectability that would be hard to match, though it is roofless and quite deserted, he presented me with a palace and its adjacent tomb that I might live and die in his neighbourhood. ${ }^{[299]}$

The locals with whom many travellers would inevitably come into contact were the dragomans, often necessarily hired to take care of all arrangements from camel hire and food to site location. Cyril Graham pointed out in 1858 that travellers (usually short of time) were in their hands, although they were often lacking in knowledge of sites:

In the majority of instances he has but a very confused idea of the purport of their questions, but he always has cunning enough to give some apparently satisfactory answer, which the deluded traveller carefully notes down, and thinks he has obtained some valuable information. ${ }^{[300]}$

The results, he noted, were to be "read so frequently in books of 'Eastern Travel,' things which have evidently been palmed off on the writer."[301]

Of course, the locals built with nearby antiquities when these were available. But it is also possible that sheikhs recognised some prestige value both in living in old houses, with decorated antiquities, and deliberately building them into their more modern structures. Rey in the Hauran in 1861 came across the sheikh at Majdel surviving in a two-storey house but with the staircases replaced by ladders; ${ }^{[302]}$ while at Hit the sheikh lived like everyone else in a house built from spolia. ${ }^{[303]}$ In the same region, at Suleim, antiquities were still available all around, and in 1895 Wright met the sheikh, very proud of his 
new dwelling: "Into the walls he had built stones with inscriptions and bits of Greek ornaments, as he naively said, to save Englishmen from ranging through the town to look for them." [304] This was, indeed, an on-site museum! But was the sheikh's comment naiveté, or rather irony which the traveller did not recognise? Burton visited Hama in 1872 , and recommended a visit to the palace of Muayyad Bey, the interior of which had "such a mixture of Persian writing, painting, and gilding, with granite pillars, porphyry, marbles of all colours, and infinite variety of decoration, all gorgeous in the extreme, but tasteful."[305] Some locals, of course, were indeed ignorant; Bell at Hama in 1908 met the station-master, who announced that his passion was archaeology, and annoyed her by attributing "every antiquity in Hamah to the Hittites, whether it were Byzantine capital or Arab enlaced decoration."[306]

One of the differences between Westerner and Turk was of mentality: they had different concerns. Thus the Turks could not understand "des gens parmy nous si passionnez des choses de l'antiquité qu'ils achetèront des sommes considérables une idole de marbre trouvée dans quelque vieille masure, ou dans dans les sepulchres des Moumies d'Egypte., ${ }^{[307]}$ Halifax, questioned in 1691 by a local emir on his way back from Palmyra about whether he had found any treasure, had the greatest difficulty in convincing him that the notion of Franks finding treasure because its location was marked on inscriptions was completely false:

We assured him we went with no such Expectation, but only out of a desire to see ye place; neither had we brought any thing away wth us but a piece of Porphyry stone wch upon his request we shewed him: we let him see, too, a rude draught, wch we had taken of ye place wch he seemed to like. ${ }^{[308]}$

Again many locals could not understand how Westerners could argue hotly and loudly about antiquities without coming to blows: "they gravely stroked their beards and came to the conclusion that Franks were universally mad, and made more noise about a piece of old stone, than all the inhabitants of Turkey would be guilty of, if there was a general massacre of their wives and children."[309]

The locals, knowing the terrain, had often to be consulted to help travellers find interesting sites. Van De Velde wrote in 1854 that so many were obscured by brambles and needed pointing out:

I could see from this instance how impossible it is to discover ruins in this land without assistance from the natives; and at the same time how very 
probable it is that, by exploring the country with their assistance, most of Israel's lost cities may again be found. ${ }^{[310]}$

When Coote travelled east of Aleppo in 1780, to Hagla, he counted fifteen mounds which the locals assured him were "the burying places of my ancestors, but they did not appear to me to have been catacombs, but towers or forts to protect the towns near them from the incursions of the Desert Arabs." Fuller met with the same belief at Palmyra. ${ }^{[311]}$ Whatever the truth, the locals were clear that the sites were ancient (and pre-Muslim). ${ }^{[312]}$ As for the three temples near Tripoli, Michaud \& Poujoulat reported in 1835 that "ces ruines sont connues dans le pays sous le nom de Naous; je présume que ce mot n'est qu'une corruption du mot grec neos qui veut dire temple." [313] At Qanawat in 1855, the local sheikh was fascinated by "numbers of statues of men in armour, female figures, and equestrians, the fragments of which are lying about among the ruins, and with much eagerness asked what they were intended for. ${ }^{n}{ }^{[314]} \mathrm{We}$ can forgive the frequent mis-attribution by travellers of temples as churches because so many of the latter were based on and reused the former. ${ }^{[315]}$

As for observation, mediaeval Muslim travellers sometimes tried to locate chronologically what they saw. Dimashqi was quite clear that some Muslim structures were built on top of Roman ruins. ${ }^{[316]}$ Similarly Masudi (travelling 915-940) assures us that bronze doors in the Umayyad Mosque were adapted from a much older structure. ${ }^{[317]}$ Mis-attribution for reasons of prestige also occurred. Yakut (c.1225) wrote of a temple in a village near Aleppo, which once held three tablets predicting the arrival of Mohammed - an example of "proving" Islam by interpreting an old inscription. ${ }^{[318]}$ This is an "historical" device already seen at the Umayyad Mosque in Damascus.

Sorting out the chronology could sometimes be difficult: Buckingham met a jeweller in 1825 who "thought the early Christians far more ancient than the Greeks or Romans, and considered Alexander of Macedon, and the twelve Caesars, quite modern personages compared with the Christian emperors of Constantinople., ${ }^{[319]}$ Such misplacement was common: Dimashqi (b.1256), who described monuments from the Tower of Babel onwards, ${ }^{[320]}$ believed that Egyptian temples were the "habitations des sages parmi les Coptes," and that each one contained a throne from which the priest could teach. ${ }^{[321]}$ If Ad was one of the great ancient builders, then so too was Solomon, to whom was attributed by the Muslims (and not a few European travellers) the building of Palmyra and Baalbek. ${ }^{[322]}$ In similar vein, one mausoleum at Petra was known as the Kaszr Bent Faraoun, or the palace of Pharaoh's daughter. ${ }^{[323]}$ And another famous tomb was known as The Treasure, because Pharaoh's treasure 
was supposedly in the urn at its summit; ${ }^{[324]}$ climbing up to it was apparently impossible, but evidently pot-shots were taken "in the hope of breaking it in pieces, and thus obtaining the imagined treasure."[325] Chronology could often be a problem for Western travellers as well. Just when were things built? Burckhardt was told at El Kefeyrat that the paved causeway was Muslim work prepared for the Haj, but he thought it Roman. ${ }^{[326]}$

Locals were often (but not always) very clear about the later fate of Syrian monuments. They knew about Crusader castles (such as Merkab/Margat ${ }^{[327]}$ ) and their fall during the Crusades. Fortresses, then, were well within their experience, but theatres were not, so the one at Amman was called the King's Palace, and its ring of seats steps for its users ("persons of much greater stature than the present race") to climb up and take the breeze. ${ }^{[328]}$ Similarly, a strong belief in Syria as well as in North Africa held that Europeans still held deeds for local land, and came to the country intent on reclaiming it. ${ }^{[329]}$ Since ancient inscriptions were often held to contain details of such holdings (or indeed to point the way to buried treasure), it is not surprising that they often fared badly. For this reason they were no doubt sometimes deliberately destroyed: no inscription, no land deed! The problem was that most of the locals could not read Greek: Robinson noted in 1837 at Ezraa that Greek inscriptions were "frequently placed as lintels over the doors, by way of ornament, and sometimes reversed, for the language is perfectly unknown to the modern inhabitants. ${ }^{[330]}$ Merrill found the same at Gadara. ${ }^{[331]}$ The basic reason for this re-use was presumably their suitable shape, and reports of such transformations are plentiful. ${ }^{[332]}$ As for the value of earlier monuments, locals at Lattakia actually living in them sometimes refused admittance to travellers, while other took the money and ushered them inside. ${ }^{[333]}$

Sculpture could also suffer, a usual explanation from Muslim locals being that devils resided in them to do harm, but would flee elsewhere if they were broken. ${ }^{[334]}$ (A variation is the common mediaeval trope of artworks' eyes which follow the spectator around the room. ${ }^{[335]}$ ) Locals may also have recognised much of the sculpture unearthed as funerary - a usage that Mohammed had discouraged. ${ }^{[336]}$ Lucas relates how a man in Lattakia fell into what was perhaps an extensive mausoleum, and his rescuers broke all the statues, Lucas seeing the results. ${ }^{[337]}$ This happened in 1713 or 1714 , well before everyone knew that such objects could be sold for a good price, such as happened in 1898 to a Jewish sarcophagus at Lydd, where hard bargaining over the years eventually won the vessel for the Louvre. ${ }^{[338]}$ Two years earlier Clermont-Ganneau saw desirable antiquities with dealers in the town, and two of them were later acquired for the Louvre. ${ }^{[339]}$ 
If throughout the century tourists had been plagued by robbers on the highway, by the turn of the century some of these sat in antique shops, in Damascus. ${ }^{[340]}$ As Rendell-Harris noted in 1891 , "one has to be a 'trusty moneychanger' who knows how to tell good coins from bad, the fabricated antiques of the modern trader and stone-mason from the genuine legacies of ancient days." [341] Even good coins were not necessarily what the travellers wanted: Bovet bought all that were brought to him at Samaria, hoping to find among them some Greek or Asmonaean coins. But they are all of the date of the Roman emperors. ${ }^{[342]}$ Much earlier in the century, Clarke was unsporting enough to believe that no decent coins and medals survived in Syria because the French had already cleaned up the best. ${ }^{[343]}$

Ordinary people could destroy or reuse common-or-garden antiquities, but their rulers were alert to the value of prestigious material items, and important names here are Hussein Pasha, governor of Gaza in the 166os, and Djezzar Pasha, Governor of Acre from 1777 until his death in 1804, who halted Bonaparte's advance in 1799. Hussein dug on the site of the Temple of Dagon, and recovered sufficient to decorate the whole town "with beautiful and precious marbles" - but then allowed the people to pay a small sum and carry off items. ${ }^{[344]}$

Djezzar, noted for his brutality and cruelty, built a mosque at Acre. He enthusiastically collected marble antiquities to beautify it. This survived into the 1850 , its dome ruined by bombing ${ }^{[345]}$ (presumably during Ibrahim Pasha's 1831 siege of the town) but supposedly repaired in the early 1880 s. $^{[346]}$ Djezzar is reported to have sought antiquities at Ascalon but (an unlikely story?)

had been prevented by the inhabitants, who are exclusively of the race of Arabs, and who manifested, by their obstinacy on this occasion, the stubbornness of their nation, rather than the value they attached to these fine vestiges of antiquity. ${ }^{[347]}$

He is also said to have re-used mosaics, perhaps wall veneer from earlier churches or temples. Two large red granite shafts remained at Tyre, however, because his engineers could not shift them. ${ }^{[348]}$ Presumably he knew they must have been imported from Egypt. These had belonged to a church built by the Venetians, so that was also perhaps the source of the mosaics. ${ }^{[349]}$ Perhaps it was his love of the past that had him build an aqueduct on arches from mountain to town, for this cannot have been built for strategic reasons. ${ }^{[30]}$ Djezzar's inability to shift heavy columns finds an echo in Bunel's 1854 account of Muslims attempting to retrieve a heavy block from the grounds of the Sœurs 
de la Charité in Beirut but, in spite of invoking Allah, "le câble se rompit et le bloc retomba avec fracas dans la terre, où il s'enfonça plus profondément qu'auparavant."[351]

By the end of the 19th century, Rendel Harris reported the emir of a Lebanese village incorporating a section from "a beautiful carved sarcophagus" into the front of his new house: this included heads and decorative garlands, with a central inscription. ${ }^{[352]}$ At Gaza, however, a colossal seated statue of Jupiter discovered in 1879 had its face hammered by the locals before the Governor was persuaded to guard it. ${ }^{[353]}$ This went to the museum in Constantinople. ${ }^{[354]}$ In 1888 the Governor promised to "protéger les inscriptions du Wadi-Brissa contre la cupidité des chercheurs de trésors et des marchands d'antiquités de Beyrouth,"[355] but no general promise to protect all inscriptions (and not just such early ones) seems to have been issued.

\section{Columns as Structural Tie-bars}

Travellers used to seeing marble and granite columns supporting splendid churches and palaces were fascinated (as we shall see) by their re-use by the hundred as breakwaters in harbours, and equally by their re-use in mediaeval fortresses and town walls as tie-bars. Here they served a purpose similar to that of the modern RSJ (Reinforced Steel Joist) in securing stability for large walls against both earthquakes, projectiles and (in the case of foundations) sapping. The circular ends were often left proud of the wall, and eventually their purpose was replaced by make-believe substitutes: these were mere bosses, which could be decorated with figures or inscriptions. Jerusalem was surrounded by walls, strengthened with through-columns so sumptuous that some travellers thought they must be from the Jewish Temple. ${ }^{[356]}$ It was on one such shaft, protruding from the walls of the Haram al-Sharif, that Mahomet would sit to judge the world. ${ }^{[357]}$

Such tie-bars were to be seen throughout Syria, especially in the fortresses down the coast. In 1820 Turner thought the tie-bars he saw at Tyre (of red and grey granite) were simply repairs; ${ }^{[358]}$ but Brocchi, at Tyre in $1823-4$, was quite clear that the granite columns he saw in wall foundations (including one of the towers) were for strengthening, and as tie-bars. ${ }^{[359]}$ Guérin described them at Tripoli; ${ }^{[360]}$ at Caesarea Monro recognised the area near the inner harbour as containing mediaeval ruins, ${ }^{[361]}$ which included forts strengthened with through-columns, ${ }^{[362]}$ one of which contained several mosaic floors. ${ }^{[363]}$ Irby \& Mangles, also at Caesarea, noted "on a promontary" (presumably within the 
Crusader citadel) a large edifice which they thought started as a temple, and with "immense pillars of granite forming the foundation of the former, placed on a bed of rocks." ${ }^{\text {[364] }}$ Like many others, Conder and Kitchener noted the column through-shafts at Caesarea strengthening the walls, and suggested the Crusaders had brought them to the town. ${ }^{[365]}$ Ascalon was similarly protected. ${ }^{20}$

Given their frequency in Syria and Asia Minor, tie-bars must in origin have been a Muslim device, used long before the Crusades, and making re-use of the staggering numbers of mostly useless column shafts lying amidst ancient ruins. The Crusaders surely learned of their use actually in Syria and on the way there through Asia Minor; for there were surely no marble antiquities for such re-use back home, whereas the Eastern Mediterranean abounded in them.

\section{Mosaics and Veneers}

On this road [Bethany to Mount of Olives] we found scattered about many small pieces of squared and polished marble of divers colours, and a friar led us out of the modern road to a place where we found a field all paved with polished marble of divers colours. ${ }^{[366]}[\mathrm{c} .1480]$

In the quotation above Fabri reports what was probably the remains of a church floor, or perhaps a Roman villa, plenty of both of which were to be uncovered throughout Syria, and reported by travellers. The majority quickly disappeared, helped by foreigners who took handfulls of tesserae as souvenirs. It was not until about the 1860 os that anyone though preservation was warranted, either on-site or through translation into a European museum. Recent research has uncovered many spectacular floors, some fragmentary, such as the Church-martyrium of S. Babylas at Antioch (the fragments are mostly in the museum). ${ }^{21}$

20 Pringle 1984, 144: "In the late nineteenth century, traces of walling bonded with granite through-columns were seen built upon it and were described as a jetty by the Survey of Western Palestine ... It seems more likely, however, that this structure represented simply an extension of the town wall, intended to protect the beach area against a landward attack from the south. As a jetty it would have been hazardous to approach; and as a harbour mole it would have provided little or no protection against the prevailing westerly winds."

21 Donceel-Voûte 1988, 411-420 for the mosaic floor at, Qabr Hiram, S. Cristophe, which went to the Louvre in 1862; ibid. for a catalogue of Byzantine mosaic pavements. Over half the pavements listed are fortuitous finds and from rescue digs. Many pavements fragmentary, and some are spectacular. 69-86: Dibsi Faraj; 90-116: animals \& vine scrolls in two 
Mosaics for Westerners are designs (sometimes forming figured scenes) built from tesserae the size of a finger-nail or smaller, usually in a variety of colours, generally made from marble, other stones, glass or pottery, for the decoration of floors, walls and sometimes vaults. Veneers are large sheets of marble or other hard and glistening stone, used for the decoration of walls. Both were manufactured in Roman and Byzantine times, hence mosaics and wall veneers are often abundant in areas occupied by the Romans. In the Middle East, the term "mosaic" was sometimes more broadly applied, and used sometimes in the Western sense, but also to indicate patterned marble veneer, halved or quartered and opposed in mirror fashion, to be seen in Haghia Sophia and in the Ummayad Mosque in Damascus, ${ }^{[367]}$ the latter once displaying mosaics in the prayer hall as well as in the courtyard. ${ }^{22}$

Decorative wall panels, often cut from column shafts sliced vertically, were also a popular Islamic form, plentiful in Syrian mosques and palaces but especially in those of Cairo. A variation is the "jigsaw" arrangement of contrasting stones and marbles extravangantly and expensively cut from solid blocks, not thin slices of veneer; and used structurally, often as joggled voussoirs. When Moudjir-ed-dyn (died 1521) wrote of the Dome of the Rock, he interchanged terms, writing on one occasion that "Les murs de la coupole, ainsi que le sol, sont recouverts de marbre, tant à l'intérieur qu'extérieurement, et ornés, dans la hauteur, de mosaïques de diverses couleurs, en dedans et en dehors;"[368] and on another that "Jérusalem est redevable à Baybars de plusieurs bonnes œuvres: il s'occupa avec ardeur de la restauration du Masdjed et renouvela les mosaïques de la Sakhrah qui sont au dessus des plaques de marbre, à l'extérieur." ${ }^{[369]}$ The following account uses "mosaic" in the strict sense of small tesserae, but this does not necessarily help interpreting such descriptions (in the Greek epic) as the palace built by Digenis Akritis. ${ }^{23}$

The use of mosaic is taken up with a vengeance for the decoration of Christian churches, along with frescoes, ${ }^{24}$ and there are survivals in Syria, ${ }^{25}$

churches at Haouarte; 191-202 Oum-El-Khalakhil; 395-406: Nebha; 450-454: mosaic with camels in S. Georges at Deir El-Adas; 424-439: Zahrani.

22 Gauthier-van Berchem 1970-71.

23 Fowden 2004, 313: "The ceilings - every one of them - he covered in mosaic work of costly marbles all made up, and gleaming in their glory. / The floor he brightened, paving it in patterns made of stone work."

24 Schmidt \& Westphalen 2005: fragments survive from what must have been very extensive decorations - the authors deal only with Qara and Kloster Mar Yakub, plus Ma'arrat Saydnaya.

25 Lassus 1947, 297-299 for survivals of mosaic pavements in Christian churches in Syria. Ibid. 299-302 for survival of fresco fragments in churches. Mayer \& Allen 2012: church in 
although iconoclasm damaged or destroyed many. ${ }^{26}$ Whether the Dead Cities had many churches with mosaics seems unlikely, but S. Simeon still had the remains of a floor in Opus Alexandrinum in the mid-19th century. ${ }^{[370]}$ Floor mosaics are plentiful, both because there was little point in destroying them (except for iconoclastic reasons), but wall decorations in marble less so, because walls fall down, and also because marble veneer found ready re-use in churches and in some later mosques and domestic settings. Indeed, thousands of square metres of mosaics survive in Syria, ${ }^{[371]}$ and in 2014 there were quantities sufficient to cover a football pitch waiting to be restored. ${ }^{[372]}$

Mosaic tesserae, of which very large areas were available for re-use, appear in many prestigious Muslim religious buildings, such as in Damascus and Jerusalem, and many more wall veneers survive in Cairo than in the whole of Syria. Just what quantity and style of mosaic and marble decorations were to be seen in palaces and upper-class houses in mediaeval Syria is obscure, although their use in Cairo mosques and the Citadel palace ${ }^{[373]}$ can probably give us some clues. Such decorations were certainly in vogue in Syrian secular buildings (including khans as well as palaces and private houses) by the 17th century, and many have survived. There must have been plenty of mosaics available from earlier monuments (villas and standing or ruined churches) when in the mid-6th century Chosroes plundered Syria, including Jerusalem, and took materials for his building program back home, as Masudi ${ }^{[374]}$ and William of Tyre relate. ${ }^{[375]}$ William tells of a temple built by Herod (evidently converted into a church) in Caesarea, "de trop riches euvres fez, touz peinz à or musique," ${ }^{[376]}$ but by 1876 all Berners saw at the site, on what he considered to be the road leading to the harbour, was "a portion of very handsome mosaic pavement. The colours were blue and red, and seemed to retain their pristine brightness." [377]

Mosques when refurbished sometimes lost some of their earlier decoration: the Great Mosque at Homs had in 1871 in its courtyard "a number of grey and red granite columns and a few mutilated capitals," presumably from an earlier state; and "In this prayer-niche some mosaic has been used, relics of the former building." ${ }^{\text {[378] }}$ De Saulcy in 1853 was convinced that "les gros cubes de mosaïque grossière, noire, blanche et rouge" found in the environs of Jerusalem

Seleucia Pieria, figs 79-132, had splendid mosaic floors, and lots of marble adornments, including frieze blocks (58-64 for catalogue entry).

26 Shiyyab 2002 for iconoclasm: suggests 225 that Christians damaged mosaics "under duress of Muslims' or Jews' attitudes rather than of their own accord." But many mosaics survived intact, suggesting they were out of use by date of Yazid's 721 iconoclasm decree. And damage difficult to date. 
"appartenaient incontestablement au temple de Salomon, temple dont les portiques étaient sans doute garnis de ce genre de pavé." Showing his servant these, he sent him onto the Haram al-Sharif:

Il m’en rapportait une énorme provision, ramassée sur le plateau même du Moriah. Ils n'ont pu être apportés là d'ailleurs, puisque ailleurs on ne les retrouve pas. Ils n'appartiennent pas à une mosaïque du temps d'Hérode, et encore bien moins à une mosaïque romaine; il faut donc, vu leur abondance, les faire remonter au temple de Salomon. ${ }^{[379]}$

Thus are convictions reinforced when scholars are unwilling to accept the much simpler explanation, namely that not only had nobody ever identified Solomonic mosaics, but that these tesserae were Muslim, conceivably reused Roman. For there were plenty of tesserae available in 1850s Jerusalem: "Fragments of polished marble are often picked up here; and especially the small cubes of marble of different colours, not much larger than dice, which were employed in the construction of the ancient tesselated pavements."[380] Had some of the tesserae fallen off the Dome of the Rock, perhaps?

Mosaics were evidently seen from the early centuries of Islam as a Christian specialty technique. Their reputation can be deduced from the import of Byzantine craftsmen to decorate the Umayyad Mosque in Damascus, from Masudi's assertion that the mosaics redecorating the Kabaa at Mecca came from a church, ${ }^{[381]}$ and from Al-Muqaddasi's assertion that artisans from Syria and Egypt were "specially imported for the work," and their names recorded thereon. ${ }^{[382]}$ Justinian II was also asked for mosaics and workmen for the refurbishment of the Prophet's mosque at Medina. ${ }^{[383]}$ Naming towns (as well as gods, people, animals and rivers) on mosaic floors often occurred in churches. The slight use and re-use of mosaics under Islam, and then apparently just for prestigious buildings, is something of a mystery. Mosaics can be very colourful, and are easy to take apart and reconstitute in different patterns, without figures if necessary. But this does not seem often to have happened, except for prestige buildings such as the Umayyad Mosque in Damascus, and the Dome of the Rock, where William of Tyre mentions them. ${ }^{[384]}$ For the former, in one story soldiers supposedly collected tesserae and marble veneer (presumably from Roman or Byzantine ruins) when on campaign; and in another, the Greek Emperor was asked for workmen and materials. ${ }^{27}$ And Caliph Omar is supposed to have said he would sell off the mosaics if he could get his money back $^{[385]}$ - so there was evidently a market for tesserae. And of course, it is a 
commonplace that the Dome of the Rock was built to compete with the Holy Sepulchre. Al-Muqaddasi gives a description of the mosaics in the Umayyad Mosque, writing that "figures of trees and towns and beautiful inscriptions, all most exquisitely and finely worked. And rare are the trees, and few the wellknown towns, that will not be found figured on these walls!" [386] But no towns are named (as they are on the famous Madaba Map), and the depictions do not seem specifically different enough for that ever to be the intention of the designer or the craftsmen.

European travellers saw plentiful remnants of mosaic floors as they travelled around Syria, but in sufficiently bad condition to indicate how little they had been prized and re-used in previous centuries. In 1697, Maudrell saw remnants around Beirut, together with "other poor relics of this city's ancient magnificence."[387] But the sea-level was changing, and Robinson in 1838 noted that "sur le rivage, vers l'ouest, on remarque les restes d'un pavé en mosaïque, d'un assez bon goût, mais qui est aujourd'hui presque recouvert par les eaux de la mer., ${ }^{[388]}$ At Antioch, presumably on the higher ground within the town (since some sections were deeply silted), "after heavy rains, antique marble pavements are visible in many parts of the town, and gems, cornelians, and rings are frequently found." ${ }^{[389]}$ Browne was at Sidon in 1799, where he saw a large pavement "representing a horse, festoons, \&c. and in some places tolerably perfect: for ten feet in length, remains, close to the sea, on the northern extremity of the city; a proof of marine encroachment."[390] Baron Taylor saw the same pavement in $1854{ }^{[391]}$ North of Jerash, Buckingham in 1825 in the village of Ajlun (which houses a Muslim Crusades-period fortress) was shown mosaics in "what was justly considered to be the greatest curiosity in the place," now in use for cattle, but in his opinion an ancient bath-house. ${ }^{[392]}$

Walking along roads outside towns offered many sightings of mosaic remains, the majority probably from villas flanking or near Roman roads. Lamartine, travelling from Carmel to Galilee in 1832, "all day marched upon fragments of walls, the sand being continually broken by patches of mosaic, and the whole route bespread with ruins which attest the splendor and prodigious population of these shores in by-gone times." ${ }^{[393]}$ As Walpole noted in 1851, "a tesselated pavement shows itself here and there, particularly after rains, on the road between Beyrout and Rars Beyrout." ${ }^{\text {[394] }}$ Further north, at Lattakia, Drummond came across "a good deal of mosaic work remaining upon the common road, which must be part of the pavement of the houses that stood thereabouts." ${ }^{[395]}$ Similar amounts of débris were to be seen travelling Tyre to Sidon along the erstwhile Roman road, where "je trouvai sur la route même un pavage en mosaïque, accompagné de tronçons de colonnes en beau marbre; c'étaient les traces de riches salles de quelques palais."[396] 
Such ruins outside towns and along roads would inevitably disappear, like those in the Roman baths at Hama: "the fine mosaic spoken of by travellers had already disappeared, and in a few years the place will be a mound of earth."[397] Bathing continued, and new baths developed, in Islamic mode. ${ }^{28}$ Presumably the same happened to the remains Bell saw in 1908 in a beehive village north of Kefr 'Abid, not far from Bara:

Fragments of other mosaics are to be found scattered through the village, some in the houses, and some in the courtyards, and the whole district needs careful exploration while the new settlers are turning up the ground and before they destroy what they may find. ${ }^{[398]}$

Such destruction happened even in semi-deserted towns such as Serjilla, where Butler reported the mosaic floor of a bath largely destroyed between its discovery in 1900 and his visit in 1909: "The inscription was gone completely; but we set to work to take up the parts which were still intact, in order to send them to the Imperial Museum at Constantinople."[399] This work was stopped, apparently because authorities had learned of thefts of antiquities in Babylonia; the local gendarme gave the order to stop work, and then "returned, partly destroyed the mosaic, and covered it with stones and earth." ${ }^{\text {[400] }}$ Such destruction has increased over the past years, for example around Ramleh, because of the increase in population. ${ }^{29}$

Most mosaics sighted in earlier centuries have indeed disappeared, with mosaic floors surviving intact only when they lay deep in soil and silt, as at Daphne, near Antioch. In 1858 Belgiojoso saw a fountain at Daphne, plus "des colonnes de marbre blanc; quelques-unes étaient couchées sur le sol; d'autres, quoique tronquées, étaient encore debout; de nombreux débris jonchaient la terre."[401] And the Roman road from Antioch was near-perfect: "On jurerait aisément que depuis les Romains on n'y a pas apporté une seule dalle."[402] Yet Baedeker noted in 1876 that "there are few antiquities here,"[403] although it was well known that "les principaux habitants d'Antioche avaient leurs maisons de plaisance dans les environs de Daphné, également riches en belles sources." ${ }^{[404]}$ An earthquake in the earlier 6th century then destroyed both the town and this obviously upper-crust suburb. Between 1932 and 1939 a consortium of foreign museums dug there, uncovering over 300 3rd-century mosaic floors. Most of these were complete, some were very large, and they are now to be seen in Antakya Museum and in America and Paris.

\footnotetext{
28 Grotzfeld 1970.

29 Al-Houdalieh 2009: rising population and destruction of buildings in Ramallah Province.
} 
Larger mosaics were also to be found elsewhere, such as at a site by the eastern base of Mount Gerizim, clearly a Roman villa: "A fellah who had been employed to dig by Mohammed Said Pasha, told me that the mosaic extended over a space some fifty yards square. In one place a small tank (bath or impluvium?) had been found lined with marble."[405] This might just be the complex described in 1283 as "quia ruine magne sunt ualde ex palaciis marmoreis et columpnis mirabilibus." ${ }^{[406]}$ Guérin notes in 1877 that material unearthed when the English excavated the Byzantine church on the summit went to Nablus (visible from the site) as building materials; ${ }^{[407]}$ so perhaps this is what happened also to the remains of the villa. Not that Nablus was interesting:

Except a spacious Saracenic doorway, now the portal of a mosque, a marble sarcophagus, now a water-trough, and a few prostrate columns of granite, limestone, and marble, there are no antiquities worthy of a moment's attention. ${ }^{[408]}$

\section{Quarries and Marble}

[Returning to Beirut from Egypt] The custom-house inspectors in Beirut were full of amazement at my bringing so many stones. They said, "Are there no stones in Syria?" I might have reminded them that the old Phoenician emperors, and the Greeks and Romans, brought granite and porphyry columns to Syria from Assowan in Upper Egypt. ${ }^{[009]}$ [1910]

Since everyone knew marble was a material prized by the Romans, and imported and exported all around the Mediterranean, it was snobbishly preferable, if and where possible, to have a columned and marble-embellished building rather than a limestone one, the exotic always trumping the local stone. If not necessarily recognised, most travellers knew that (for example) Paros produced the whitest marble. ${ }^{[410]}$ There was indeed marble in Syria - but it was all imported, ${ }^{30}$ just like Jessup's stones in the above quote. Much of the marble used by the Romans in ancient Syria was to be recycled by Christians in their churches, then by Muslims in their mosques and occasionally by Crusaders and later princes in their palaces. Lazzarini and others have plotted Roman marble quarries around the Mediterranean, and then locations where the

30 Fisher 1988: use of marble imports and local stone in Roman Palestine. Ibid. 162 for division into two levels, namely imported marble details, and architecture and its decoration based on local stones. 
varieties of stones were first used, and then re-used. ${ }^{31}$ Sometimes this would happen nearby, but sometimes valuable stones were transported elsewhere for their re-incarnation in later buildings.

In any accepted modern definition, there are no true marbles in Syria, although there are hard limestones which can be polished to look like marble. ${ }^{32}$ Earlier authors had a broader definition of marble, so that Dimashqi, writing in the 1320s, noted near Lattakia "une carrière de marbre blanc, vert et rayé,"[411] and Al-Muqaddasi affirmed that there was indeed marble in Palestine, near Bait Jibril [Gibelin]. ${ }^{[412]}$ For Masudi, granite seems to have been spewed out by volcanoes, ${ }^{[413]}$ perhaps because he had never seen a quarry for that material. European travellers who knew nothing of the granite quarries in Egypt thought the stone was somehow confected, and some evidently thought that columns noted at Tyre had been cooked up on the spot, thus avoiding any suggestion of quarries or transport difficulties. ${ }^{[414]}$ Arvieux, writing in 1735, relayed the belief that granite was a manufactured stone, namely that

elle est de pierre fondue, parce qu'elle est tachetée de plusieurs couleurs. Je crois que cela est faux, d'autant que si le secret de fondre les pierres avoit été connu des Romains, il ne se seroi pas perdu, \& seroit venu jusqu'à nous. ${ }^{[415]}$

The idea was an old one, Boullaye Le Gouz reporting in 1653 the same of Pompey's Pillar at Alexandria: "Elle est de marbre pastiche ou fusible, comme l'on dit allez improprement, dont l'on prêtent auoir perdu le secret."[416] Burton reported that "columns of granite and syenite are found profusely scattered about the ruins of Syria, extending even as far as Palmyra. The modern inhabitants invariably declare them to be Masnu'a - of made stone."[417] Again, locals could have had no experience of granite quarries, for there were none.

Nor were most of our travellers rock-solid, as it were, in their identifications of various stones. Bishop Arculf in 700 wrote that the Holy Sepulchre

31 Lazzarini 2004. 73: Roman quarries of coloured stones, followed (figs 2-50) by listing of characteristics; 101ff for diffusion of rocks throughout the Mediterranean, source, use and reuse, only those mapped for several occurences in Syria cited in the following tables: 1: sienite; 2: diorite; 6: porphyry; 7: giallo antico; 9: granito violetto (a lot in Syria!); 13 cipollino rosso; 17 rosso antico; 22: cipollino verde.

32 Petersen 2001, 31. Wright 1985, 339: "virtually all the formations quarried for building stone are limestones of various qualities-some extremely hard and crystalline verging towards marble, some softer and friable. The one variant to this prevailing usage is the basalt, which from late м в times was used in monumental building because of its hardness and for its striking chromatic effect." 
was "covered with choice marble to the very top of the roof,"[418] which seems unlikely.

Casola in 1494 admired the paving of the Haram al-Sharif, which he declared was marble. ${ }^{[419]}$ Arnold von Harff, for example, travelling 1496-1499, misses no opportunity to comment on marble he has seen; but of course we do not know whether he could recognise that stone and distinguish it from close approximations. In 1549 Aramon declared the walls of Antioch to be "presque toutes de pierres de marbre."[420] In 1586 Teixera admired Aleppo's souks, and her paved streets, identifying the pavers as marble slabs. ${ }^{[421]}$ Thomas Legh, travelling in 1816, reckoned he found marble monuments at Jerash, as well as at Palmyra and Baalbek. ${ }^{[422]}$ In 1838 Lindsay noted the "countless columns of white marble" at Palmyra, ${ }^{[423]}$ and Poujoulat in 1841 located the "belle carrière de marbre qu'on trouve dans le flanc de la montagne, à une lieue et demie de Palmyre."[424] This might have encouraged Pertuis to report villages near the Euphrates built entirely of white marble. ${ }^{[425]}$ Similarly, in 1851 Pardieu wrote of the "marbre blanc mélangé, très-crevassé" at Baalbek, ${ }^{[426]}$ and many 19thcentury travellers made the same mistake, ${ }^{[427]}$ leading the exasperated Wright to remark in 1895 that "tourists generally speak of 'the marble ruins of Palmyra white as snow.' There is no marble in Palmyra, and the ruins are not white."[428] Near Baalbek, Walpole came across the remains of the temple at Ainete: "The stones used were quarried around; but I found two or three finer pieces of a coarse marble: one small piece I carried off, but it was stolen by one of the villagers, who accompanied me."[429]

Other travellers were more discriminating. Porter nailed the Palmyran stones in 1855: "White limestone of a fine texture from the neighbouring mountains has been universally employed, and the only other species found is Sienite granite, a few shafts of which may still be seen near the long colonnade."[430] Hard limestones were to be found in various parts of Syria, "almost marble," as Burton remarks. ${ }^{[431]}$ In 1881 Ellis offered one explanation for the confusion: he thought the stone at Palmyra "has been carelessly chosen as regards the strata; the weathering shows it tilted in all directions in the drums of the columns. The cracks so formed give somewhat the appearance of marble."[432] Already in 1848 Yanoski \& David pointed to the consequences of such stone poverty: "le luxe lui est interdit, à moins qu'il n'ait recours à ses voisins, puisque son sol ne lui fournit ni marbre, ni porphyre."[433] Russell, who lived in Aleppo, gave a good summary of the various stones available, and called several of them "marble":

They have an inferior kind of yellowish marble, which takes a tolerable polish, and is used for the ornamental parts of building, and for 
paving the court-yard. But a variety of other marble is brought from parts more distant. From Damascus they receive a red marble; thence also, and from Khillis, a coarse black sort; a fine white sort is imported from Italy; and from Antioch they procure various ancient fragments. The common Aleppo Marble is brought to resemble the Damascus red, by rubbing it with oil, and letting it stand some hours in an oven moderately heated. ${ }^{[434]}$

Plenty of trickery occurred to make limestone look like marble. Kenney tells of Tankiz al-Nasiri (1312-1340) who was enamoured with marble veneer, and naturally had to take the material from older buildings. He tried to requisition sone yellow-green marble from near Beirut, but had to give up because it turned out that the offering was not marble, but simply painted stone. ${ }^{33}$

The Aleppo quarries were well-known to travellers, because they were immense. ${ }^{[435]}$ Those near Damascus were described by Burton as "a reddish porphyry, and a pudding-stone, which, somewhat like the giallo antico of Egypt, takes a high polish." ${ }^{[436]}$ It was the polish which made other stones look like marble, Pierotti in 1865 noting how widespread was such polishing: "Les brèches rouges, blanches, jaune pâle reçoivent le poli aussi bien que le marbre. Le pavé de beaucoup d'églises à Jérusalem, les colonnes de la mosquée El Aksa, celles de la basilique de Bethléem et une foule d'autres ornements, dans quelques autres villes, en sont la preuve évidente."[437]

Stone was also quarried not far from Jerusalem, at Anata, as Robinson \& Smith described after visiting the Biblical site of Bethel, near Ramallah:

From the vicinity of Anata a favourite species of building-stone is carried to Jerusalem; and we met several troops of donkeys loaded in this manner with the materials of future dwellings; a hewn stone being slung upon each side of the poor animal. Larger stones are transported on camels. ${ }^{[438]}$

This stone, a variety of limestone, was perhaps often mis-interpreted as marble, as for example by those who believed the Temple of Solomon to be of marble. ${ }^{[439]}$ They were presumably confused by seeing columns from what was actually Herod's temple which, following his normal building practice, was indeed rich in marble. 
In the Christian village of Arayeh, in the Lebanon hills, Ellis in 1881 saw that stone building, and including vaults made of large blocks without mortar, was being practised:

Large blocks of stone are frequently used, the tops of windows and doors being of one piece. No machinery is employed to raise them, but there are strong men who have trained themselves to carry weights, and these do the work. It often happens that the carrying of one piece of stone from the ground up to its resting-place, constitutes a whole day's work. For the man is so exhausted from the tremendous exertion, lasting only a few minutes, that he has to spend the rest of the day in repose to enable him to work the next day. ${ }^{[440]}$

Large blocks were always laid without mortar, because their weight ensured they would not move. As we have seen, then, stone was certainly quarried in Syria, perhaps simply continuing earlier practice, but why so much re-use of ruins if this were the case? After all, re-cutting such blocks must often have been more laborious than quarrying itself, and there are plentiful reference to masons, so appropriate skills were not necessarily lacking. In 1825 Buckingham, while condemning "the unskilfulness of the Arabs, and their want of proper implements adapted to their labour," then mentions the enormous costs of transport from the quarry:

The expence of carriage from the quarry to the place of sale, each stone requiring a single camel, wheel carriages and good roads being entirely unknown, occasion an advance above the prime cost, at which they might be hewn in England, of at least 500 per cent, each pair of stones costing from ten to fifteen and sometimes twenty pounds sterling. This is the only produce that the stony tract of Ledjah now yields, almost all its towns being deserted. ${ }^{[441]}$

Finally, perhaps there was a propensity to regard prestigious buildings as marble-built, whether or not this was the case. Le Strange picks up Josephus' description of Iraq al-Amir, which he says is white, whereas this is not the case; but perhaps because visitors found what they expected, Le Strange's explanation is that "as Josephus had himself never visited this place, the error is probably due to his having been misinformed by the hearsay report of contemporary tourists." ${ }^{[442]}$

One possible reason for eschewing quarries (and there must have been plenty of Roman quarries available) was that the masons did not know how 
stone, especially limestone, would survive after weathering for years in the open air. In favour of re-using antique blocks was that they could see just how well such antiquities had survived, hence the common practice of recycling, to which we now turn.

\section{Re-use}

The same rapacity and vandalism continue their work of destruction, and, what is the more distressing, is that the so-called Europeans, representing certain great Powers at Saida, in their own interests and the most mercenary spirit, head these devastations. We are assured that, not content with this clandestine speculation, they patronize a manufactory for articles of antiquity and false inscriptions, which is in a village in the outskirts of Saida. [1887]

This quote is Hamdi Bey reporting on the Sidon sarcophagi, translated from the Revue Archéologique, deploring vandalism and celebrating the discovery of almost untouched chambers, which "had happily escaped the greed of the desecrators of the burial places. I must state, to my great regret, that these today are no less terrible than those of preceding ages."[443] The same applied all over the Middle East, and when Poujoulat opined in 1841 that "les saintes et grandes ruines de la vieille Athènes sont respectées; on n'a touché à aucun monument pour en faire des matériaux de construction, ${ }^{,[44]}$ he was talking nonsense, misled perhaps by the mirage of an independent Turk-free Greece working on Western principles (did he really believe they existed?) of respect for the past.

Such vandalism was indeed a continuing reason for the depletion of ancient monuments in Syria. - as Burton describes the practice of their dismantling and re-use in later structures:

the same incongruous heaping together of stones to form a shelter, without much reference to their former use; lintels used as pillars, stone doors as lintels, ornamented cornices and bits of inscriptions built in wherever they fitted best. ${ }^{[445]}$

Ibn Khaldun explained such recycling as a marker during the decline of civilisations, as older elements were moved and moved again, eventually ceding to "la civilisation grossière qui est propre aux nomades." ${ }^{[46]}$ Some centres may have specialised in the recutting and reworking required. Ramleh was certainly a centre for marble-work as early as the 11th century, and there were 
so many varieties named ${ }^{[447]}$ that they must have come from local buildings, or been imported by sea. At Gaza in 1689, Thevenot reported "car tout y est plein de colonnes de marbre de tous cotez, \& même j'y ai vu des cimetières dont tous les sepulcres étoient entièrement de marbre," obviously with the materials taken from the ancient monuments. ${ }^{[448]}$ Mediaeval and later Syrians often had no interest in re-using antique members as they had been intended. Columns would frequently be used upside-down, and capitals or even cornices employed as bases, as De Saulcy observed near Baalbek in $1853 .{ }^{[449]}$ The largest mosque at Baalbek was built with 100 columns from the old monuments and, as Ellis affirmed in 1881, "is only worth a visit on account of its size, and as showing details of the architecture of the temples."[450] Often, the locals knew just where to find antiquities and how deep to dig.

Tombs and sarcophagi were prime targets for re-use because there were plenty of them, and few with owners' descendants to protest, the more so if they were antique and not Muslim. Cemeteries were always outside towns and (if the rock was suitable) often in a series of underground or cliffside chambers. Such locations were not hidden Tutankhamen-wise, except by vegetation and the like. At Sidon, for example, the existence of large burial caverns was well known even to travellers by the mid-18th century. Egmont \& Heyman visited in 1759, finding sarcophagi of marble and lead, and a lot of bones: "Among others was one of beautiful marble, hewn out of one single block: and round the niche in which it was deposited, were paintings of birds, trees, \&c." [451] One attraction of sarcophagi was that they were fairly easy to break down into usefully flat slabs. In 1887 the PEF noted large sandstone vessels at Haifa, in slabs, and workmen "were busy in destroying these ancient remains and cutting them into building stones of such size as to be transportable on camel's back." ${ }^{[452]}$

Ancient marbles were frequently re-used in later tombs, as Rey discovered at Kharbet-er-Ram, on the Hebron-Jerusalem road, in 1861, at a construction completely built from spolia:

Servant de cippe à une tombe arabe, un magnifique fût de colonne d'une seule pièce de granit rose d'Egypte que les Bédouins ont dû trouver en ce lieu; car, à coup sûr, ce ne sont pas eux qui l'y ont amené. Or que devons-nous en conclure, sinon qu'il y a eu là une ville ancienne d'une assez grande importance? ${ }^{[453]}$

Only superstition kept locals away from tombs, such as that reported at Ascalon, containing what appeared to be an embalmed corpse, but "frightened by the 
glare from his eyes they reclosed the tomb, and as the violator died soon after they concluded it was a prophet, and built a rude tomb above the slab." Conder thought it might have been a crusader mummy, "but there seemed many objections to touching a place held sacred, and close to modern tombs, which were sufficient to deter us."[454]

Christian buildings could also be targeted for re-use. In 1836 Delaroière tells of a convent on Mount Carmel, near Acre, where the Pasha Abdala obtained a firman allowing him to knock down a convent using the fallacious argument that it was a fortified site that threatened Acre. The French consul wished to go to Constantinople to get the firman revoked, but the Pasha locked him up. The convent was too far from Acre to threaten the town, was in no sense a fortress, and "c'était donc des pierres que le pacha voulait. Il a eu ces pierres; il a élevé sa maison pour laquelle la violence avait fourni les matériaux, et que l'iniquité a bâtie. Maintenant elle est abandonnée; le vent et la pluie y pénètrent partout, et en vain elle attend son maitre."[455]

Occasionally, however, travellers were surprised to find villagers living amidst stone ruins, but in makeshift huts rather than in rebuilt houses. Pierotti observed that poor government offered no encouragement to build, and he provided an explanation for reluctance to do so, together with a dollop of prejudice:

Leur nature sauvage, cupide, indolente fait qu'ils préfèrent habiter dans une chaumière ou dans une ruine plutôt que de se donner leurs aises, sachant bien que le gouvernement leur ferait payer ce confortable et aussi parce qu'ils craignent les combats continuels des différents partis, qui portent partout la destruction. ${ }^{[456]}$

In areas perhaps short of extensive ruins we nevertheless find column shafts in re-use, rolled over flat earth roofs to keep them watertight (a common practice in Anatolia as well). Huart, on the slopes of Mount Hermon in 1879, spent the night in just such a house: "Une sorte de cylindre en pierre, foré au centre, qui est souvent un fragment de colonne antique, sert de rouleau pour aplanir cette terre battue et fermer les fissures qui s'y produisent souvent pendant les grandes pluies de l'hiver."[457]

It was not only locals who made constructive use of earlier buildings. Noting masons' marks on parts of the walls of Aleppo, Clermont-Ganneau suggested that stone cut by crusading Franks had been re-used, the locals saving themselves trouble "by transporting ready-hewn stone from some of the towns and castles near Aleppo, when they had won them back from the Crusaders."[458] 
But remarking on the huge number of stones cut by the Crusaders in a relatively small period, he suggested very reasonably that these were already re-cut by them from earlier monuments:

we soon call to mind that their task was greatly assisted by the ancient ruins which they used as quarries... they seem to have taken a sort of pride... in setting their mark upon their inheritance from bygone ages, the materials which they found all ready to their hands for their new buildings, by re-working them after their own fashion. ${ }^{[459]}$

He thought he could identify such re-use by characteristic tool marks. ${ }^{[460]}$ Conder and Kitchener thought otherwise, believing that (at least at Caesarea) the Crusaders cut afresh the ashlar for their fortifications, perhaps thinking this more efficient and less-time consuming than reworking older materials. ${ }^{[461]}$ The Crusaders certainly brought sappers from Europe, to help destroy buildings; and also masons, some of whom presumably made the marks about which Clermont-Ganneau writes. But since it would be the locals who would know where the best sources of suitable re-usable stone were to be found, perhaps they were co-opted as well.

Mediaeval Europe was certainly alert to the gains to be made from older buildings, not least at S. Mark's, Venice, which was "comme une église de Justinien transportée au milieu des lagunes."[462] Clermont-Ganneau was alert to such transfers, identifying a bas-relief from the Holy Sepulchre re-used in a later house. ${ }^{[463]}$ Inevitably, some Crusader fortresses were themselves dismantled to provide housing in the village they protected. This was the case at Khisfin, in the Jaulan, where Oliphant thought the village looked like a quarry,

so thickly piled were the blocks of hewn stone which enclosed the courtyards and formed the walls of the houses, while they were strewn, or stacked in heaps, over all the neighbouring fields. The lintels of the doors of the modern huts consisted frequently of large stones, some of which possibly had served the same purpose in old times, and on these were tablets, rosettes, crosses, bosses, and other crusading devices. ${ }^{[464]}$

In the same region, Oliphant came across "many stones on which were carvings and pictorial representations," laid bare when locals were excavating an ancient site for materials for their houses. ${ }^{[465]}$

Travellers who visited Syria to view monuments, found many of them scattered around towns and villages like pieces of a jigsaw. Already in the $1750 \mathrm{~s}$ materials were being carried from Tyre to Sidon for re-use there, ${ }^{[466]}$ while 
at the same date there were few columns to be seen at Byblos/Jebilee because the best had already been carried away. ${ }^{[467]}$ But extracting the best left the remainder to be maltreated: gunpowder had been used in the theatre there presumably to bring down the scenae frons, and "the great quantity of marble, of which it consisted, converted to build a mosque and a bath." ${ }^{\text {[468] }}$ By 1836 the theatre remains were only about $7 \mathrm{~m}$ high. ${ }^{[469]}$ At Hama in 1872 the theatre was being excavated "for the sole purpose of removing the stones." ${ }^{[470]}$ Further up the coast, by 1800 Seleucia Pieria was being denuded of stone, packed on floats and carried up the river to Antioch. ${ }^{[471]}$ Nearby Lattakia (Laodicea) had already lost its marble in 1188, when Saladin and his troops apparently carried off the marble they stripped from churches they destroyed: "les musulmans détruisirent tous les édifices, surtout les églises, et emportèrent les marbres."[472] What remained of columns did so because they were built into more recent structures. ${ }^{[473]}$ According to Aramon in 1549, the Turks coveted a church in Bethlehem and ruined it, "à cause que les Turqs en ont osté et ostent journellement le marbre et aultres pierres qui leur peuvent servir pour enrichir leurs mousquées." Damage was certainly done to the Church of the Nativity, but its colonnade still stands. ${ }^{[474]}$ An imperial rescript dated 1532 orders the looting of lead and columns from Bethlehem to cease, the culprits be detained, and the monks be allowed to rebuild "a ruined wall." ${ }^{[475]}$

In 1268 the inhabitants of Jaffa displeased the Sultan, and marble and wood was consequently carried off to Cairo for re-use in the Mosque of Sultan alZahir Baybars (or Bibars), then building. ${ }^{[476]}$ But the town got material from Caesarea in the 1840 s, a period when boats were selling blocks at towns up and down the coast. ${ }^{[47]}$ There, Christians could rejoice when blocks from Herod's great showpiece had been converted into a church to the True God:

Though entirely new-built, the monastery of Jaffa, which has cost a great deal of money, is like all the monasteries of the Holy Land: it exhibits the appearance of a fortress, of a castle of the tenth century; a heap of stones piled one upon another, and that is all. ${ }^{[478]}$

In earlier centuries, Christians could sometimes build if they paid money: see the re-building of a monastery at Haifa, on Mount Carmel, in a contract of 1631, whereby the emir included in the deal not only the Grotto of Elijah, but also "buildings and the ruins next to the Chapel of the Greeks on the terrace... together with the stones of the ruins that were lying around and which were used for the building of a monastery, a church and walls." ${ }^{34}$ Re-use

Carmel 2011, 28. 
was second nature, as it was in Constantinople where, for example, a lavish summer palace was built in 1722 using spolia, which was much quicker than tedious quarrying and transport from distant parts over inadequate roads: "the ancient 'tower of dogs' in Çengelköy on the Asiatic shore provided the blocks of fine marble for the wall along the canal and for the columns sustaining a portion of the roof of the palace."35

Indeed, even mediaeval buildings in Caesarea were being plundered in the 1860s, for the town was "comme une carrière que l'on exploite continuellement pour en extraire et en exporter des matériaux de construction." ${ }^{[479]}$ Because of successive re-use and refurbishment, the resultant structures can be confusing, for example with some churches as secondary and mosques as tertiary re-use. In 1847, travelling from Beirut to Tyre, Napier came across "some remarkable ruins of antiquity in the shape of [modern] excavations," but did not investigate because dinner called. ${ }^{[480]}$ At Samaria in 1867 , Bourassé reckoned that all the houses were built from ancient materials; ${ }^{[481]}$ this could well be the case, since for example a church is recorded as disappearing in the 17th and 18th centuries. ${ }^{[482]}$ Nor were tombs or their contents safe: as late as 1881 Lortet predicted that necropoleis near Beirut would soon entirely disappear, because "elles constituent une véritable carrière pour les habitants des villages voisins qui viennent y chercher des abreuvoirs et des matériaux pour la construction de leurs demeures." ${ }^{\text {[483] }}$ At Tell es Semak on the seabord of Western Palestine, towns were disappearing in the same year, and "quantities of the ashlar blocks have been taken away, the holes remaining whence they were dug out."[484]

Although told that the government had forbidden any more materialhunting, in 1886 Ascalon was alive with sawing:

Every suitable marble piece is transported as it is, or, in case of considerable weight, sawn into portable slabs and sold to Gaza and Jaffa, to be placed over the entrances of private buildings.

The PEF saw one which had been retrieved from nearly $5 \mathrm{~m}$ below ground, "and measured 4 feet 5 inches in every direction; it had an unfinished cornice on its upper part, which was to be worked all round the block, as well as other uncompleted ornaments in the middle, in its central, and lower part." ${ }^{[485]}$ They noted that at El Jish, in the Galilee, substantial remains of the ancient town survived in the 186os, but that materials had been taken away, some to build a church. ${ }^{[486]}$ On many sites, pottery and mosaic tesserae survived, as they did at Amoas, between Jerusalem and Jaffa - but a lime-kiln signalled "comment ont 
disparu les beaux marbres blancs, provenant des statues et des monuments anciens."[487] Evidently, government edicts did not count for much, perhaps especially when the government also destroyed monuments. The temple of Musmieh, in the Ledja (later a church, then a mosque), described by Baedeker in 1876 as "one of the finest ruins in the Hauran," ${ }^{488]}$ was redescribed in the guidebook's 1898 edition as "said to have been recently pulled down to make room for barracks." [489] In 1903 Dussaud described the structure as completely destroyed, and "devant ce monument moderne gisent quelques morceaux de sculpture gréco-romaine,"[490] though the builders had thoughtfully incorporated the odd inscription into the barracks' verandah.

Antiquities from other cultures presumably suffered as well: in 1889 Conder found no Hittite pieces at Kadesh (on the Orontes), but noted that a traveller in 1846 had found the natives "breaking up ancient columns at this spot, and the work of destruction at an inhabited site goes on with frightful rapidity."[491] Already in 1879 he had visited the site with Kitchener, and "we were disgusted to find that the marble sarcophagi and the Temple ruins were being broken up and demolished, to fill the yawning trenches that the Fellahin navvies had dug for the foundations of a sugar-factory."[492]

Of course, selling off the old for profit was perennial: on Rhodes Gédoyn in 1624 that the Palace of the Grand Master (much later restored picture-perfect, yet accuracy-doubtful, by the Italians) "est grandement détruit et s'empire tous les jours par le consentement du Gouverneur qui en permet la démolition et vend ses ruines à très vil prix."[493]

\section{Ancient Towns and Villages and Their Houses}

Close by is a house or rather a large room with a perfect stone door, window shutters, and cupboards... All doors and shutters, some plain, some carved in panels, are made on the same principle, the doors varying eleven to seven inches in thickness, aecording to their height and width. The stone pivots are made of the same block as the threshold and lintel, and the doors and windows are so hung that notwithstanding the centuries that must have elapsed since they were put up many still swing easily. ${ }^{[494]}[1896]$

Heber-Percy's description of an obviously ancient house at Bosra echoes the fascination of many travellers with the stone doors they found in Syria, especially in the Hauran. The only thing missing was the lock, which Heber-Percy suggests Bedouin would have removed for their metal: "In one or two instances 
we observed that the pivots of stone doors having become worn from long use, stone rings had been cut and put round the worn pivot. Some doors and gates are double." Nor were mediaeval Muslims ignorant of a technology they perhaps could not implement. Dimashqi, born in 1256, was amazed at Baalbek by the size of one room with a stone roof, an eagle and other decorations; what is more, "la porte qui ferme ce sanctuaire est de pierre; cette maison est une merveille."[495]

Today in our Architectural History lectures we are used to discussions of monumental architecture. This is built in long-lasting stone, and travellers today concentrate on such monuments to the exclusion of the relicts of ordinary life, which have mostly disappeared. While it is certainly true that everyday life and its housing did not seem interesting to previous centuries, one undoubted reason is that so little physical evidence of its buildings survived in Europe, so there was nothing to provoke such an interest. Before the dawn of investigative archaeology, little was therefore known about the look and use of ancient housing. Pompeii and Herculaneum were exceptions, and their discovery came as a decided shock because both sites had been preserved in volcanic aspic, and neither had to contend with survival above ground since 79AD. The two towns formed a suitable comparison for Syria: as Bankes wrote in 1820 ,

à l'exception de Pompéi, où peut-on trouver des habitations romaines? Nous en avons ici en grand nombre encore habitables ou inhabitées, fermées par leurs portes d'origine et couvertes par les toits d'époque, les chevaux mangent dans les mêmes mangeoires qu'ils le faisaient il y a 1600 ans. ${ }^{[496]}$

Elsewhere, most ordinary housing usually decayed away, in part because of recourse to materials which did not last, or which burned, like the wooden upper stories of some insulae in Rome. Compare Angkor and Borobudur (or Dacia on Trajan's Column), where we only know about the houses of ordinary people because they are depicted in bas-reliefs on these very structures. Porter might be thought to have been joking (he wasn't) when he wrote that they were the work of a race of giants, but accurate when he noted that "they form, I believe, the only specimens the world can afford of the ordinary private dwellings of remote antiquity."[497]

In the Hauran, as we shall see in Chapter Seven, "many of them are still found uninjured, but very many are mere heaps of ruins." ${ }^{[498]}$ Travellers often observed ancient villages used not for permanent residence, but just as nomads would use campsites: "The Haouran peasants wander from one village to another; in 
all of them they find commodious habitations in the ancient houses... and find every where large tracks to cultivate. ${ }^{[499]}$ As Porter observed at Shuka, in the Hauran, there were so many houses and so few would-be inhabitants that they could pick and choose: "The present inhabitants, Druzes, have taken possession of such chambers as had their roofs and doors perfect, but I did not observe anywhere a new erection or even recent repairs; indeed, this would be quite unnecessary, for there are far more houses still habitable than there are people to occupy them."[500]

Syria's old housing is therefore highly unusual, surviving in profusion, unique in both quantity and state of preservation. This happened for a mix of reasons still not completely understood. The first reason is that such housing was stone-built without much or any wood, with vaults and roofing in stone, although perhaps large-span temples had wooden roofs. (There had been forests around Aleppo, so the houses there had fewer vaults because timber was available.) Yet monumental buildings were also of stone, and few survived intact, probably because nobody needed pagan temples, baths or theatres any more, at least for their intended purpose. Hence another reason must be that houses were useful; and, indeed, we shall see that many ancient houses were occupied in later centuries. But no stone houses seem to have survived from Antiquity in continuously occupied towns (the lower stories of insulae in Rome, already mentioned, are of tile), so we are left with searching for long-lasting triggers which saw the near-abandonment of many hundreds (and probably in the low thousands) of walled towns and smaller settlements throughout Syria. A further peculiarity is that several settlements were probably abandoned, reoccupied, abandoned again, and so on, in cycles which may have depended on various factors from rainfall and nomadic depradations to government taxation schemes. And some settlements were occupied only in the odd year, perhaps by nomads substituting stone houses for tents (see below).

The plentiful survival of abandoned stone towns in Syria, especially in the inland areas of the Hauran, Ledja and around Aleppo, is indeed unique, and thus fascinated European travellers. Both France and parts of Britain were Roman, and a few monuments survived for scholars to enthuse about; but there were no complete and abandoned towns to be seen above the earth in later centuries, because most Roman settlements had been built over or quarried for their re-usable building materials, and hence mostly disappeared. The same applies in Britain to the devastation caused by the 14th-century Black Death: plenty of villages were abandoned, but if anything survived above ground it was usually only the church, and perhaps the manor house.

Villages were of course abandoned throughout Europe, often for the rearrangement of the landscape by large landowners. Oliver Goldsmith's 1770 
poem The Deserted Village ("Even now the devastation is begun, / And half the business of destruction done") rails against the enclosure movement and parkmaking (which simply wiped whole villages off the map because their survival would disturb milord's view), and rural depopulation at the expense of rising towns. But most destroyed European villages would have been mediaeval in origin, not ancient, and usually amounting to grass-covered mounds in a few fields, or sometimes to almost complete obliteration from ploughing. There were simply no ancient towns to be seen anywhere in Europe clearly at least a thousand years old, largely or completely deserted, with few later additions, yet with walls, roofs and roads still standing. Instead, by the later Middle Ages most erstwhile Roman settlements in Europe had been completely built over. Because most such structures were late antique (and now the subject of intensive study ${ }^{36}$ ), what visitors to Syria found was a profusion of sites completely outside their experience. Many of these were graced by still standing if ruinous churches, some with dated inscriptions, which meant that the years of their prosperity and subsequent disrepair could be estimated. In 1840 La Salle reckoned there were fifteen towns south of Bosra, and the ruins of more than two hundred towns and villages on Jebel Hauran itself. [501]

Some abandoned towns were large, and not completely abandoned in the 19th century. Shahba ${ }^{[502]}$ (nearly 3 miles round) in the Hauran (named after a family who settled here in the $7^{\text {th }}$ century), had a sheikh who gave lodging to Porter in 1855 . The ramparts and paved streets were in places near-perfect, and those "to the east and south are, in a great measure, free of stones; and they now present a singular aspect running straight and smooth through the wilderness of ruins, and terminating at five triple gateways still almost perfect." [503] Cook found little changed in 1876: the streets looked as good as new, and he found erstwhile temples with inscriptions in place, and a theatre, "the most perfect monument of antiquity in Shuhba" as well as "the remains of a large Roman bath can be observed, with portions of an aqueduct in connection." ${ }^{[504]}$ Much has since disappeared. ${ }^{37}$

Ezraa was about the same size as Shahba, and fully described by Burckhardt in $1810 .{ }^{[505]}$ During these years there were few locals around, "and Lord Lindsay [writing 1838] walked through whole streets of them, seemingly in good repair, but almost all untenanted." ${ }^{[506]}$ But by 1837 there was also a separate inhabited section, with some 200 families installed. ${ }^{[507]}$ Some of the houses there

36 Eichner 2009, 82-86: late antique and Byzantine houses and building materials.

37 Darrous 2004, Figs 1 \& 2 for plans of the town, the second of what was still visible in 1991: Il fallait cependant y ajouter les vestiges antiques attestés mais aujourd'hui disparus ou recouverts - a lot has gone. 
had "plain thick slabs, fixed into their sockets at the time the houses were built," ${ }^{\text {[508] }}$ so presumably they were original, for it must have been difficult (or dangerous or impossible) to remove them without dismantling adjacent jamb blocks. Similar fine touches survived at Musmieh, sporting a Doric portico. ${ }^{[509]}$ Suweida was a little larger, having a main road with houses and shops still standing on both sides. ${ }^{[510]}$ Nejran was described as two miles around, and "has still a large population of Druzes and Christians in about equal numbers, who occupy what remains of the ancient buildings," with a large church converted into a mosque. ${ }^{[511]}$ At Shahba, in the Jebel Hauran, "The flat stone pavement of this town still continues perfect, though the edifices forming the streets are mostly ruined. Among those that are least demolished, is a large bath, and an aqueduct, with a Corinthian temple, of which five columns, each three and a half feet diameter in their shafts, are still standing,"[512] and "the first edifice that presented itself, after our entrance at the small angular gate, was a theatre."[513]

Lindsay was also impressed by the state of preservation at Shahba where, "entering by the southern gate, [we] rode for ten minutes up a broad handsome street, better paved, and the pavement in better preservation than any in London... up the principal street of. the city; the public buildings lie on each side of it." [514] At Shuka, nearly two miles in circuit, was "once probably the abode of 20,000 inhabitants, now sheltering a few Christians and Druses in the ancient houses."[515] At Buserar, also in the Hauran, Madox in 1834 found

a church or mosque, with a belfry or minaret, having twenty plain columns, with capitals of different orders. Some are of marble, and some of lava, and they appear to have been put up at different periods. Close by are the noble remains of a church.

Little seems to have been done to improve living quarters: "The sheik's room in which I lived had only a doorway, with air-holes at the back, and the fire, as usual, was in the middle of four pieces of stone."[516]

Two reasons for the survival of so many ancient houses were evident to all travellers: not only were the structures sturdy, with no wooden parts to rot, but some were still occupied, either permanently or periodically, depending on the growing seasons. Many ancient houses were very solidly built, some with walls nearly $2 \mathrm{~m}$ thick:

Long thick slabs of stone rest upon projecting cornices, and form the roof. The very doors are of massive stone, with pivots working in sockets above and below... The wandering Arabs prefer dwelling in their tents 
to occupying these houses, and the traveller can take possession of any house he fancies for the night, and apportion the rooms at pleasure, to himself, his horses, and his attendants. ${ }^{[517]}$

So undamaged were many of the houses encountered that visitors (in what became another common trope) imagined that the original owners had walked out only yesterday, while other had built in the open countryside, fearing no enemies. Bell saw such a mansion much further north, near Ruweiha, apparently an owner who "built his dwelling far out in the country and guarded it only with a garden palisade." ${ }^{[518]}$ Lindsay came across a Roman mansion at Nedjraun, near Ezraa, spacious and occupied: "Nothing could exceed the courtesy of the owners in shewing us their dwellings, and allowing us to pry wherever we liked." He noted the sense of continuity: "a beautiful stable, with mangers of stone... The Arabs stable their steeds this very day where the old Romans did."[519]

Travellers were fascinated not only by the use in housing of arches ${ }^{[520]}$ but, especially in the Hauran, by stone roofs and doors, which were not to be seen in houses in modern Europe, although reading their Bible they might have remembered "the great stone to the door of the sepulchre" (Matt. 27.60). Near Salkhad in 1825 Buckingham found a fifteen-inch-thick folding door, and stone beams for the roof; ${ }^{[521]}$ en route to Bosra he saw similar fixtures replaced in wood, ${ }^{[522]}$ indicating that these ancient houses had been re-inhabited. Stone doors were also to be found further north. Ancient tombs, often constructed like houses, were also occupied and with stone doors. Lindsay examined one at Gadara / Umm Qais: "These doors are usually five or six inches thick. The best specimen seen by Lord Lindsay was beautifully carved in four deep pannels, with a pseudo-knocker; a wreath between two roses was sculptured on the lintel, and the sarcophagus still retained its place within." ${ }^{\text {[523] }}$ Stone doors, in the local limestone, were naturally to be seen as well in Jerusalem, one being reported in 1835 as still perfect,

half a foot in thickness: the panels were as nicely cut as in the finest mahogany doors in this country, and the whole highly polished. It had originally turned upon tenons of one piece with itself, resting on sockets in the solid rock, so that no extraneous matter was used for hinges, fitting most exactly in the door-frame, shutting apparently with its own weight, and requiring pressure to push it open. ${ }^{[524]}$

Travellers were clear that many of the houses the Druze occupied in the Hauran were old for, even if they could not date them exactly, many of the churches 
in the same settlements bore inscriptions. De Vogüé thought nearly all earlier than Islam, many of the Christian period, and others earlier because (conveniently) they were not decorated with Christian symbols. ${ }^{[225]}$ Bankes thought the houses all Roman:

As to the temples and larger buildings, there cannot remain a doubt upon any body's mind that is conversant with antiquities; the same applies to the theatres and the baths. With respect to the private dwelling houses, we have less means of comparing them, but the inscriptions fix the aera of many of them, and wherever there is any ornament it is purely Roman. ${ }^{[526]}$

What was disconcerting was the evidence that the population had decreased from the thousands and then hundreds and, by the mid-19th century, to the tens. Kelly, from his reading, counted up 446 such settlements east of the Jordan, a region that appears "both from ancient testimony and from its still existing ruins, to have been one of the most fertile and thickly-peopled countries on the face of the earth." ${ }^{[527]}$ Leary in 1913 wrote that "all seem centuries old: many have been occupied for more than a thousand years, for the hard basalt seems never to crumble."[528] Indeed, basalt was very strong; and if houses in northern Syria could be planked by wood because there were forests on which to draw, in the south basalt, cut into smallish blocks, would be used even for window frames as well as vaulting. ${ }^{[229]}$

However, the townscapes were changing fast, as new settlers arrived, and agriculture, railways and new buildings helped erase many ancient remains. In 1861 Waddington had remarked how, with his own drawings and those of De Vogüé,

Nous avons de quoi faire toute l'histoire architectonique de ce pays, et en fait de monuments chrétiens, nous avons relevé des basiliques et des églises d'un grand intérêt; plusieurs sont datées, entre autres une église octogone à coupole et intacte de l'année 520 de l'ère chrétienne. ${ }^{[530]}$

Unfortunately, this was not done either systematically or completely, so that by 1920 Butler reported that

each village marks the site of an ancient town; but only the more massive of the ancient buildings have survived generations of rebuilding, and these are almost hidden in modern work; 
and especially in the Hauran "the ruins here have been inhabited by the Druses for about a century, and the ancient remains are being gradually broken up."[531] This was at least in part because communications were improving: in 1905 Butler "reported interesting buildings all along the route of the direct journey through the plain, and an important field for research in the lava-covered region of the Ledja," - but other members of his party "boarded the train for Damascus at half past eight, leaving Butler to follow after us with the camp." ${ }^{[532]}$ This was the area where, a quarter-century before, the tourist would have found "Oriental life and manners existing in primitive vigour to a far greater extent than in other portions of Palestine, which have come so largely under European influences, and where European customs, and even European fashions, are often ludicrously copied."[533]

If the Roman Empire in Greater Syria brought many stunning monuments to life, those same European travellers who visited them were distressed by their steady dilapidation and the insouciance of locals who cut up and re-used them where possible, preferring (except in the case of old stone-built houses) to build anew rather than to maintain or upgrade the old. If building such monuments confirmed political power and prestige, then abandoning them could also be viewed as a harbinger of the decline of the Ottoman Empire. That the Empire stood in need of reform was undeniable, although its efforts at modernisation (in several areas with European help) were often forgotten, usually with the aim of bolstering European intervention.

Nothing like Greater Syria's monuments (complete grid-plan town layouts, colonnades, temples huge to bijou-size, ancient villages, aqueducts) survived in Europe, hence the astonishment of travellers. But their condemnation of Ottoman destruction was unfair, for worse was happening in the only site comparable to those further east, namely Rome herself. Yes, she is famous today for her surviving monuments; yet large swathes of the city intra muros were destroyed from the later 19th century, with little to show architecturally except the Ara Pacis and a few underground rooms. As in Syria, it was archaeology, provoked by such radical alterations to the landscape, which developed apace and recorded a level of destruction too extensive to be halted.
[1] Clarke_1817_IV_189
[2] Maqdisi_II_1901_136
[3] Moudjir-ed-dyn_1876_ 22-23
[4] Turner_1820_II_61
[5] Bagatti_1857_I_150
[6] Paul_1865_68
[7] Jolliffe_1819_25
[8] Jolliffe_1819_28
[9] Damer_1841_I_275
[10] Lindsay_II_1838_232-233
[11] Macleod_1866_236-237
[12] Fiske_1857_163
[13] Berners_1876_202-203
[14] Wright_1848_46
[15] Dimashki_1874_32
[16] Dimashki_1874_328
[17] Laorty-Hadji_1854_81 

[18] Le_Strange_189o_297
[19] Veryard_1701_324
[20] Tristram_1865_620
[21] Fermanel_1670_310
[22] Wood_1757_6B
[23] Volney_II_1792_142-143
[24] Beaufort_1874_191
[25] Maqdisi_III_1903_109
[26] Ibn Khaldun_II_1865_ 242
[27] Ibn Khaldun_II_1865_243
[28] Maqdisi_II_1901_138
[29] Graham_1858_259
[30] Walpole_II_1851_363
[31] Stanhope_1846_III_87
[32] Walpole_III_1851_ 290-291
[33] Seetzen_1854_I_43
[34] Schumacher_1889_223
[35] Huart 1879_23B
[36] Khosrau_1881_34
[37] Moudjir-ed-dyn_1876_31
[38] Boullaye-Le-Gouz_1653_ 338

[39] Bouchier_1916_58-59

[40] Butler_1930_99

[41] Febvre_1682_150

[42] English_merchants_ 1678_132

[43] English_merchants_ 1678_134-135

[44] English_merchants_ 1691_155

[45] Fuller_1829_241

[46] Damoiseau_1833_ 195-196

[47] Conder_\&_Kitchener_ 1883_242

[48] Fabri_1896_II.1_1893_354

[49] Robinson_1838_235

[50] Neale_I_1851_202-203

[51] Buckingham_1825_ 195-196

[52] Drummond_1754_189B
[53] Burton_\&_TyrwhittDrake_1872_II_200-201

[54] Lucas_I_1714_163

[55] Olivier_IV_1803_130

[56] Olivier_IV_1803_129

[57] Fletcher_1850_362

[58] Wood_1757_23

[59] Saulcy_1853_I_6o7-6o8

[60] Ellis_1881_II_108B

[61] Ellis_1881_II_83

[62] Buckingham_1822_ II_152-153

[63] Buckingham_1822_ II_238-239

[64] Burckhardt_1822_ 22081812B

[65] Burckhardt_1822_13111810

[66] Burckhardt_1822_ 23111810B

[67] Le_Strange_1885_167

[68] PEFQS_1871_72

[69] Le_Strange_189o_519

[70] Egmont_\&_Heyman_ 1759_II_243

[71] Browne_1799_407

[72] AMS_VII_1872_409B

[73] Guérin_1884_20-21

[74] AMS_VII_1872_409

[75] Goujon_1670_107

[76] Finati_1830_II_158

[77] Moudjir-ed-dyn_1876_ 204

[78] PEFQS_1871_176-177

[79] Febvre_1682_185

[80] St Clair_1892_376

[81] Mislin_1876_II_620

[82] Fabri_1896_I.1_249-250

[83] Buckingham_1825_483B

[84] Saulcy_1853_I_345-346

[85] Renan_1930_234

[86] Damoiseau_1833_250

[87] Bromfield_1856_122

[88] Van_De_Velde_1854_ II_464
[89] Robinson_1838_392-393

[90] Burton_\&_Tyrwhitt-

Drake_1872_II_239

[91] PEFQS_1873_85

[92] Conder_1891_44-45

[93] Mislin_1876_II_84-85

[94] Flinders_Petrie_1918_

84-85

[95] Perry_1743_144

[96] Thomsen_1917_9-12

[97] Saulcy_1853_II_56

[98] Porter_1855_II_141

[99] Lindsay_II_1838_138-139

[100] Conder_\&_Kitchener_ 1883_435

[101] Allen_1855_II_168

[102] Drummond_1754_124

[103] Neale_II_1851_142

[104] Curtis_1903_27

[105] Olivier_IV_1803_50

[106] Newman_1864_440

[107] Ward_1864_213-214

[108] Van_De_Velde_1854_ I_76

[109] Porter_1882

[110] Durbin_1845_I_205-206

[111] Tristram_1873_124

[112] Butler_1930_34

[113] Luynes_III_1874_133

[114] Tristram_1873_271-272

[115] Skinner_I_1837_315

[116] Lortet_1881_14

[117] Schumacher_1889_iii

[118] Schumacher_1889_19

[119] Schumacher_1889_48

[120] Burton_\&_Tyrwhitt-

Drake_1872_I_33

[121] R.B._1759_74

[122] Blondel_1840_131

[123] Blondel_1840_12

[124] Blondel_1840_187

[125] Lynch_1849_249-250

[126] Irby_\&_Mangles_1823_ 205 


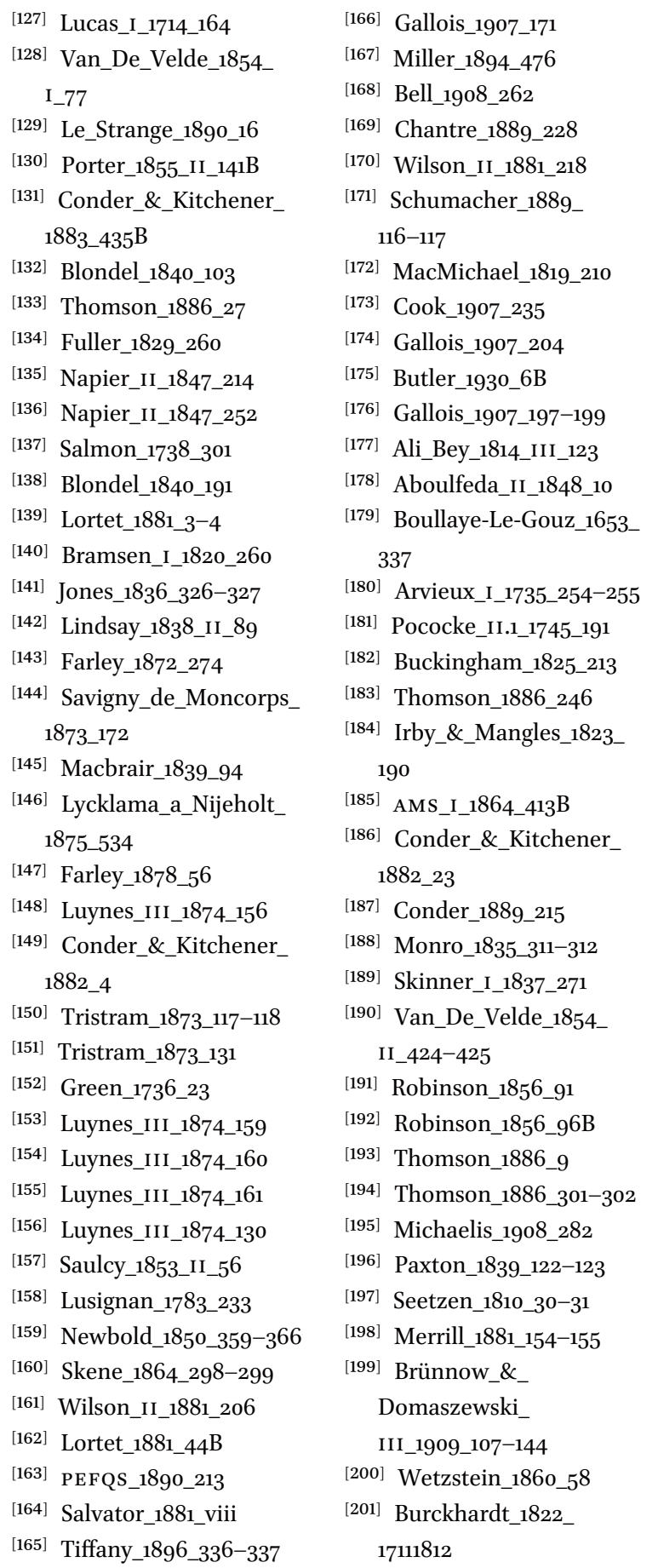

\author{
[202] Burckhardt_1822_ \\ 13031812 \\ [203] Burckhardt_1822_ \\ 13031810 \\ [204] Robinson_1838_77 \\ [205] Thomson_1886_

$$
\text { 203-204 }
$$ \\ [206] Thomson_1886_242 \\ [207] Porter_1868_II_554 \\ [208] Burckhardt_1822_ \\ 15071812 \\ [209] Seetzen_1854_I_411-412 \\ [210] Burckhardt_1822 \\ 07101810 \\ [211] Burckhardt_1822_
} 12101810

[212] Robinson_1837_146

[213] Burckhardt_1822_ 13031812

[214] Carne_1830_31

[215] Renan_1930_200

[216] Redding_1873_16o

[217] Irby_\&_Mangles_1823_ $175^{-176}$

[218] Robinson_1856_435-437

[219] Porter_1868_432

[220] Beaufort_1874_274

[221] Robinson_1856_426

[222] Robinson_1856_438

[223] PEFQS_1891_163

[224] PEFQS_1873_53

[225] Baedeker_1876_456

[226] Henniker_1823_304

[227] Bourassé_1867_497

[228] Robinson_1856_529B

[229] Porter_1855-II_319-320

[230] Robinson_1856_529

[231] Perthuis_1896_32-33

[232] Porter_I_1855_376

[233] Thomson_1886_415-417

[234] Renan_1864_337

[235] Lycklama_a_Nijeholt_ 1875_622

[236] Warburton_1848_241 


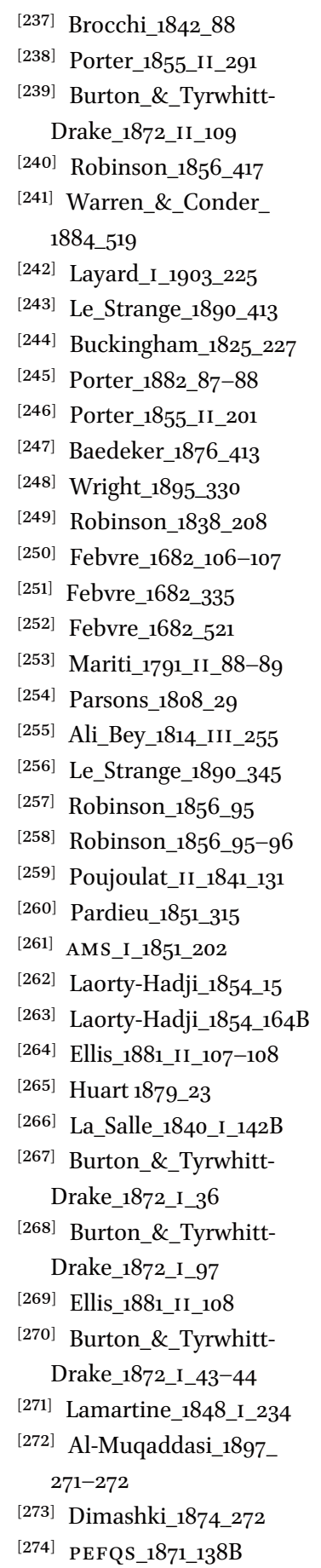

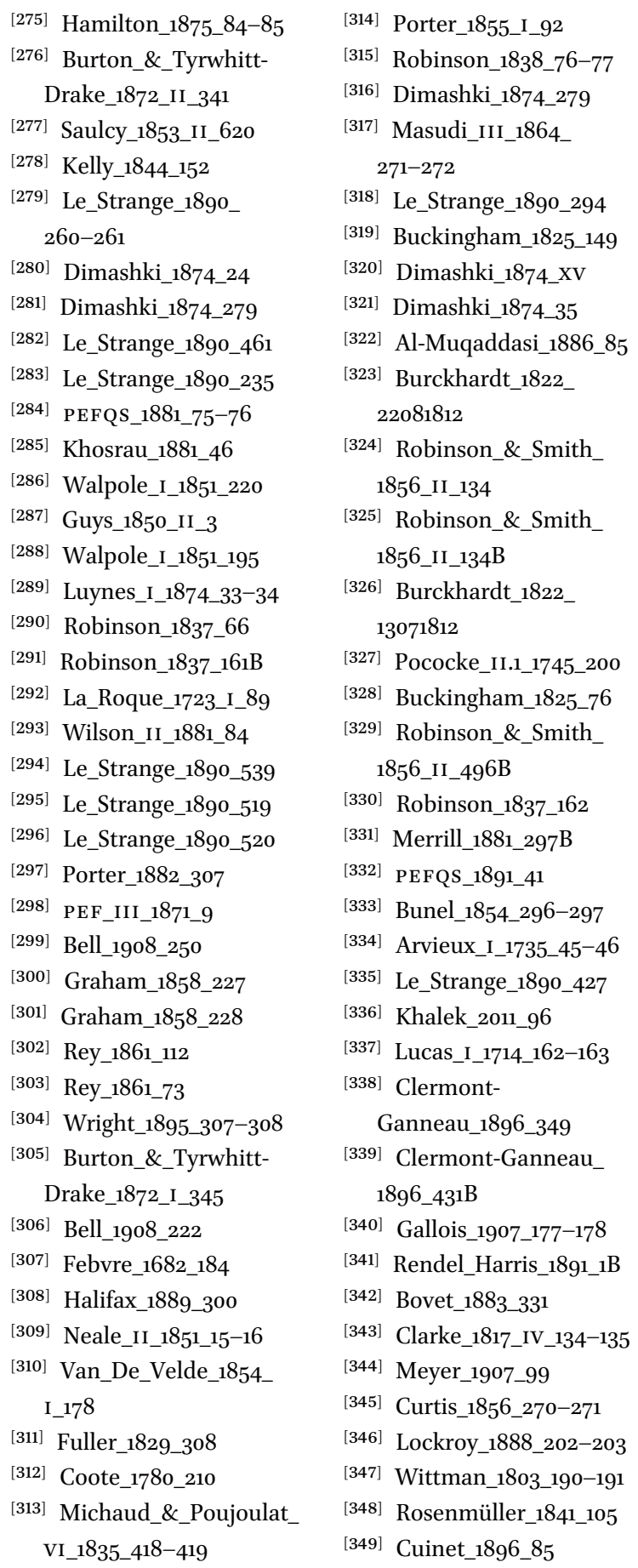




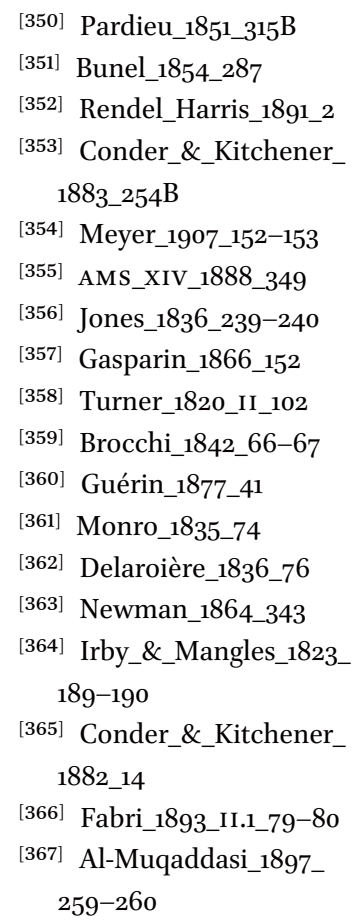

[368] Moudjir-ed-dyn_1876_ 105

[369] Moudjir-ed-dyn_1876_ 238-239

[370] Vogüé_1865-1877_I_152

[371] Al-Azm_2014_335

[372] Al-Azm_2014_335B

[373] Pococke_1814_19o

[374] Masudi_II_1863_ 198-199

[375] Guillaume_de_Tyr_I_ 1879_4-5

[376] Guillaume_de_Tyr_I_ 1879_351-352

[377] Berners_1876_69-70

[378] PEFQS_1871_8

[379] Saulcy_1853_II_217

[380] Robinson_\&_Smith_ 1856_II_240-240

[381] Masudi_V_1869_192-193

[382] Al-Muqaddasi_1897_115

[383] Al-Muqaddasi_1897_129
[384] Guillaume_de_

Tyr_I_1879_268

[385] Dimashki_1874_262

[386] Al-Muqaddasi_1886_ 17-18

[387] Maundrell_1836_71-72

[388] Robinson_1838_5-6

[389] Kelly_1844_274

[390] Browne_1799_373

[391] Laorty-Hadji_1854_29

[392] Buckingham_1825_147

[393] Lamartine_1848_I_231

[394] Walpole_I_1851_52

[395] Drummond_1754_189

[396] Pardieu_1851_319

[397] Burton_\&_Tyrwhitt-

Drake_1872_II_282B

[398] Bell_1908_26o

[399] Butler_1930_44

[400] Butler_1930_57

[401] Belgiojoso_1858_132

[402] Lycklama_a_Nijeholt_ 1875_330-331

[403] Baedeker_1876_58o

[404] Lycklama_a_Nijeholt_ 1875_331

[405] PEFQS_1871_190

[406] Laurent_1873_55

[407] Guérin_1877_50

[408] Newman_1864_310

[409] Jessup_1910_II_618

[410] Casola_1907_196

[411] Al-Dimashqui_1874_ 284-285

[412] Le_Strange_189o_20

[413] Masudi_II_1863_27

[414] Monconys_1665_330

[415] Arvieux_I_1735_190

[416] Boullaye-Le-Gouz 1653_373

[417] Burton_\&_Tyrwhitt-

Drake_1872_I_170-172

[418] Wright_1848_2

[419] Casola_1907_249
[420] Aramon_1887_144

[421] Teixera_1902_114

[422] MacMichael_1819_248

[423] Lindsay_II_1838_167

[424] Poujoulat_1841_II_149

[425] Perthuis_1896_155

[426] Pardieu_1851_361

[427] Wilson_II_1881_235

[428] Wright_1895_171

[429] Walpole_III_1851_

442-443

[430] Porter_1855_I_238

[431] Burton_\&_Tyrwhitt-

Drake_1872_II_52

[432] Ellis_1881_II_88

[433] Yanoski_\&_David_ 1848_12

[434] Russell_I_1794_52-53

[435] Browne_1799_387

[436] Burton_\&_Tyrwhitt-

Drake_1872_I_171-172

[437] Pierotti_1865_166

[438] Robinson_\&_

Smith_1856_II_438

[439] Munk_1845_553

[440] Ellis_1881_II_117

[441] Buckingham_1825_ 283-284

[442] Le_Strange_1889_ 313-314

[443] PEFQS_1887_14-15

[444] Poujoulat_I_1841_8

[445] Burton_\&_Tyrwhitt-

Drake_1872_II_195

[446] Ibn Khaldun_II_1865_ 277

[447] Khosrau_1881_64-65

[448] Thevenot_1689_568

[449] Saulcy_1853_II_638

[450] Ellis_1881_II_110-111

[451] Egmont_\&_Heyman_ 1759_II_243B

[452] PEFQS_1887_104

[453] Rey_1861_234-235 


\begin{tabular}{|c|c|c|}
\hline [454] PEFQS_1875_156-157 & [478] Geramb_1840_I_48 & [505] Burckhardt_1822_ \\
\hline [455] Delaroière_1836_72-73 & [479] AMS_I_1864_413-414 & 09111810 \\
\hline [456] Pierotti_1865_165 & [480] Napier_II_1847_44 & [506] Kelly_1844_437B \\
\hline [457] Huart 1879_32 & [481] Bourassé_1867_389 & [507] Robinson_1837_16o-161 \\
\hline [458] Clermont-Ganneau_ & [482] Munk_1845_39 & [508] Kelly_1844_437 \\
\hline 1899_30 & [483] Lortet_1881_2 & [509] Porter_1855_II_244 \\
\hline $\begin{array}{l}\text { [459] Clermont-Ganneau_ } \\
\text { 1899_46-47 }\end{array}$ & $\begin{array}{l}\text { [484] Conder_\&_Kitchener_ } \\
\text { 1881_352 }\end{array}$ & $\begin{array}{l}\text { [510] Burckhardt_1822_ } \\
15111810\end{array}$ \\
\hline [460] Clermont-Ganneau_ & [485] Conder_\&_Kitchener_ & [511] Porter_1855_II_215 \\
\hline 1899_40 & 1885_172-173 & [512] Buckingham_1825_258 \\
\hline [461] Conder_\&_Kitchener_ & [486] Conder_\&_Kitchener_ & [513] Buckingham_1825_257 \\
\hline 1882_25-26 & 1881_226 & [514] Lindsay_II_1838_156-157 \\
\hline [462] AMS_IV_1867_440 & [487] Conder_\&_Kitchener_ & [515] Cook_1876_436 \\
\hline [463] Clermont-Ganneau_ & 1883_68 & [516] Madox_II_1834_166-167 \\
\hline 1899_115 & [488] Baedeker_1876_422 & [517] Cook_1876_433 \\
\hline [464] Oliphant_1889_ & [489] Baedeker_1898_197 & [518] Bell_1908_254 \\
\hline $25^{8}-259$ & [490] Dussaud_1903_415 & [519] Lindsay_II_1838_ \\
\hline [465] Oliphant_1889_245 & [491] Conder_1889_33 & $15^{8-159}$ \\
\hline [466] Egmont_\&_Heyman_ & [492] Conder_\&_Kitchener_ & [520] Lindsay_II_1838_131-132 \\
\hline 1759_II_238-239 & 1881_Preface & [521] Buckingham_1825_ \\
\hline [467] Egmont_\&_Heyman_ & [493] Gédoyn_1909_151 & $221-222$ \\
\hline 1759_II_312 & [494] Heber-Percy_1896_116 & [522] Buckingham_1825_ \\
\hline [468] Egmont_\&_Heyman_ & [495] Dimashki_1874_35 & $176-177$ \\
\hline 1759_II_313 & [496] Lewis_1996_63 & [523] Kelly_1844_437 \\
\hline [469] Maundrell_1836_25-27 & [497] Porter_1855_I_197 & [524] SPCK_1835_81-82 \\
\hline [470] Burton_\&_Tyrwhitt- & [498] Porter_1855_II_23-24 & [525] Vogüé_1865-1877_I_52 \\
\hline Drake_1872_II_282 & [499] Robinson_1837_163 & [526] Buckingham_1825_644 \\
\hline [471] Parsons_1808_33 & [500] Porter_1855_II_63 & [527] Kelly_1844_443 \\
\hline [472] Michaud_1829_226 & [501] La_Salle_1840_I_367 & [528] Leary_1913_83 \\
\hline [473] Robinson_1838_417 & [502] Brünnow_\&_ & [529] Bouchier_1916_28o \\
\hline [474] Aramon_1887_125-126 & Domaszewski_ & [530] Dehérain_1914_276 \\
\hline [475] Aramon_1887_261 & III_1909_145-179 & [531] Butler_1920_88-92 \\
\hline [476] Michaud_1829_503 & [503] Porter_1855_II_76 & [532] Butler_1930_40 \\
\hline [477] Blondel_1840_245-246 & [504] Cook_1876_437-438 & [533] Cook_1876_431 \\
\hline
\end{tabular}




\section{The Seabord: Harbours and Ports North to South}

[Coast of Phoenicia:] Qu'y a-t-il encore? des tours antiques le long du rivage, sur les rochers; tours aux trois quarts écroulées, dont la base sert de muraille à quelque masure; des entassements de pierre taillées dans les champs et sur le rivage, mêlées avec des colonnes enterrées ou brisées. ${ }^{[1]}$ [1866]

From the European perspective, it was the Syrian seabord and ports which were the key both to access and to trade, and Shaw's was the general opinion, that the ancients had put up magnificent harbours, but that later rulers "out of avarice, or want of public Spirit, have suffered them to become either altogether useless, or else of very little service to the trade and navigation of this rich and plentiful country."[2]

The Middle East was an entrepôt between East and West and, before the circumnavigation of Africa, Venice and Genoa grew prosperous from that trade. Enormous camel trains brought goods westward, most finishing in Asia Minor (at Smyrna and Bursa) and some in Syria, at Aleppo. Syrian ports were therefore important for mediaeval trade and military incursions, ${ }^{[3]}$ but in subsequent centuries these had mixed fortunes, either lacking the maintenance necessary to keep them working, or being deliberately blocked off to prevent naval surprises, even before the Crusades. ${ }^{1}$ Natural harbours down the coast of Syria were rare, so artificial ones had to be built, many of the surviving remains in various locations being Roman, others marking attempts down the centuries to open up the coast for trade. Such harbour works, together with the necessary fortresses, took a large toll on the ancient monuments. Since there were so few natural harbours, Herod's great constructions at Caesarea were essential. In later centuries, the virtual abandonment of once-working ports meant that only small ships (and hence small trade) could be welcomed. In any case, the majority were too small for large 19th century sailing ships, not to mention steamers, ${ }^{[4]}$ which were offering regular services by the $1850 \mathrm{os} .{ }^{[5]}$ As we saw in Chapter Two, affairs inland were little better during the same centuries: a declining population, abandonment of country towns and villages, desertification, marauding Bedouin, neglect of agriculture, and a European trade through Aleppo that was on its last legs by 1800 .

1 Richard 1998 for the key importance of the ports for both sides. 
This chapter examines seabord towns one by one, both to underline the problems with which they presented Syria up to the 2oth century, and to reflect the lack of development inland, but also because before the Middle Ages they had been thriving towns with important monuments, and were visited for this reason, and also because of biblical connections, by later European travellers. Inland were hills or mountains so, if robbers were discounted, the coast road could be used. It was flat, and there were always a few settlers along its length.

The towns are examined north to south, almost as if the reader were a middlesized ship looking for a place to anchor or to dock: Alexandretta/Iskenderun, Seleucia, Lattakia, Tripoli, Byblos, Beirut, Sidon, Tyre, Acre, Caesarea, Haifa, Athlit, Tortosa, Jaffa, Ascalon, and Gaza. There were some landing-places available by the mid-19th century, especially Beirut and Jaffa; earlier travellers either braved Lattakia (the port for Aleppo), or travelled overland from the north or south - from Asia Minor or Egypt. Many travellers' accounts parcel Syria together with Asia Minor or Egypt, and the latter grouping becomes the more popular as Egypt develops as a winter travel destination, and pilgrimage to the Holy Land develops in part into a group concern, commercially managed. Many of the following towns formed part of the Crusader Kingdom of Jerusalem, and their antiquities were usually re-used in their building of town walls, in eleven towns on the coast, and three inland. ${ }^{2}$

In many of the ports discussed below we shall come across large numbers of columns thrown into the sea for use as breakwaters, and it will become clear that their numbers diminished over the years, because it was evidently not over-difficult to dredge them up into boats, dry them off, and re-use them elsewhere. Casola, travelling in 1494, relates that Saladin was said to have re-used columns from Jaffa, some on land, some lifted from the water:

Our magnificent captain assured me that this was true, because a few years ago he was obliged with his boats to help to raise certain columns which were in the water there at Jaffa, and which were afterwards dried and taken to Jerusalem to be used in the building of the new Mosque. ${ }^{[6]}$

\section{Iskenderun}

D'ailleurs personne ne regrettera Alexandrette, avec son port dangereux, son climat malsain et la traversée de l'Amanus, difficile en tous temps et périlleuse en hiver. ${ }^{[7]}[1889]$

2 Pringle 1995. 
In the knee-bend between Cilicia and Syria sits Alexandretta, or Iskenderun. This is the northern port for Antioch a few kilometres to the south, the other being Seleucia Pieria (see below). The name indicates its founder. Nearly deserted at the Ottoman Conquest, ${ }^{3}$ in 1669 traces of luxurious churches still survived there: "di tre ò quattro Chiese, e dalle colonne, capitelli, basi, cornici, e pietre, marmi bellissimi, s'argomenta fossero fabriche di considerazione."[8] Ruins of a temple and a city were to be seen on the road hence to Aleppo. ${ }^{[9]}$ Traces of its ancient harbour at Arsous ("the foundations of strong edifices, from which two keys have run out, so as to form a pretty little mole or harbour") were visible in $1754^{[10]}$ This part of the coast was marshy, certainly by $17388^{[11]}$ and a breeding-ground for malaria; this affected Drummond who, when he recovered, went "in quest of such antiquities as had escaped the blind fury of those wretches who are now in possession of Asia., ${ }^{[12]}$ The Aleppo merchants in the 1770s suggested to the Pasha of Tripoli that they would pay to refurbish the harbour if duties on their goods were forgiven for ten years, and otherwise would carry their trade to Lattakia. But he refused:

"But what signifies it to me," replied the Pasha, what may happen in time? I was yesterday at Marash; to-morrow, perhaps, I shall be at Djeddah. "Why should I deprive myself of present advantages which are certain, for future benefits I cannot hope to partake of?"[13]

This might have been a common argument, for the Aga of Gaza advanced it when Volney suggested to him in 1792 that he should repair his palace at Ramleh: "Pourquoi, disois-je un jour à un de ses sous-Agas, ne répare-t-il pas au moins la chambre? Et s'il est supplanté l'année prochaine, répondit-il, qui lui rendra sa dépense?" [14] Porter's explanation in 1868 was that Syrians were concerned only about their own house, selfishness reigning supreme:

The consequence is, that there is not a road in the whole country except the one recently made by a French company... It sometimes happens that a roué pasha takes a pious fit, and spends a tithe of his ill-got gains in building a bridge or adorning a mosque; but the moment the work is finished the process of dilapidation begins, and nobody thinks of repairs.

3 Nour 1982, 298-299: Antioche et la renaissance d'Alexandrette. 
The result was a country that looked as if it had been hit by a continuing earthquake:

There are so many broken bridges, ruinous mosques, and roofless caravansaries. It is emphatically a land of ruins, and ruins are increasing in number every year. ${ }^{[15]}$

One area of the marshes was drained about 1830, and an opinion in 1836 was that "for less than $1000 \mathrm{l}$ all the land might be efficiently drained, cleared, and rendered fit for cultivation." [16] This is but one of several examples of Europeans seeing just how easily and cheaply improvements could be made to the land of Syria. Squire in 1820 indicted the Turkish government with ignorance and imbecility, for not draining the marshes, cultivating the land, and introducing commerce to this, "one of the finest bays in the world." [17] In $183^{2}$ Aucher-Éloy stated the obvious: this was the best port for Aleppo, and suitable for the Sultan's navy. ${ }^{[18]}$ In fact, Ibrahim Pasha [ruler of Syria 1831-40] cut a canal to channel a spring, which "finding no adequate outlet, have created those baneful marshes which surround the town, extending over nearly the whole plain." ${ }^{\text {[19] }}$ But in 1840 there were still no harbour services: ships had to unload using their own boats, and there was no accommodation to be had. ${ }^{[20]}$ What is more, in 1854 Laorty-Hadji suggested that it was not only difficult docking that caused the problem, claiming that visiting sailors were dying because of its climate: "Des fièvres du plus fâcheux caractère, accompagnées d'obstructions au foie et compliquées d'hydropisie, enlèvent le tiers des équipages qui viennent y charger pendant l'été."[21]

According to Neale in $185^{1}$ the government was paranoid about spending on harbour works, sending "some soi-disant engineers to form an estimate of what the cost would be." Hence work was stopped short of completion because it was thought the Franks "when the work was completed, would probably lay claim to the recovered land. This was the Turkish dog in the manger, at the same time that they were perishing from fevers, and never dreamt of turning the marshes to any account themselves." ${ }^{[22]}$ As a result in 1855 "it requires a strong act of faith to believe that wealth and luxury have once been in all their pomp and pride where now not even a bat or an owl resides," ${ }^{[23]}$ while in 1856 the town was still "dirty, miserable, marshy, and unhealthy" yet also potentially (as several travellers remarked) "the best harbour on the coast of Syria." ${ }^{[24]}$ The town had been devastated by the 1822 earthquake, and not yet rebuilt, for in 1859 "quelques cabanes éparses au milieu de roseaux et de palmiers composent le village de Scanderoun."[25] In 1844 the British consul here got acclimatised, but only after fifty attacks of fever. ${ }^{[26]}$ Things were looking up by 1918 , 
but fever was still a problem. ${ }^{[27]}$ The import/export trade had grown, perhaps because efforts had been made to fill in and drain the marshes. ${ }^{[28]}$ The spoils reverted to the new Turkey, to the detriment of Aleppo. ${ }^{4}$

\section{Seleucia Pieria}

To the north of Lattakia were Iskenderun, sitting in its own bay; and Seleucia Pieria (or Suweida), just north of the River Orontes. Both are now in Turkey. Seleucia was founded by Seleucus I Nicator, who gave it important ancient harbour works, including a 1350m tunnel intended to divert the river and keep the harbour from silting. This was one of the ports for Antioch. In the early 19th century, Iskenderun was the winter port for Aleppo, and Lattakia for the summer, but neither was in good condition:

Le port d'Alexandrète n'est pas tenable dans l'une de ces saisons, à cause de son insalubrité, et celui de Laodicée ne l'est pas dans l'autre, parce que la jetée en est rompue et qu'il ne peut recevoir que de petits bâtiments. Il faudrait réparer le port de Laodicée et assaillir celui d'Alexandrète, en donnant un écoulement aux eaux. ${ }^{[29]}$

This site, modern Al-Sweidiyeh, ${ }^{[30]}$ a town near the Mediterranean coast serving Antioch, is not to be confused with the Suweida in the Hauran. Our travellers call it some variation of Suedia. Griffiths visited the area in 1805 , determined to find the remains of Seleucus' famous port, but could see only "the remains of two moles indicated where this famous port had once received the innumerable but diminutive vessels of the eastern monarchs." ${ }^{[31]}$ The following account will explain why viewing the ancient harbour works was so difficult.

Seleucia was already in bad condition in 1754 , the large blocks of its quays tumbled down:

One of them is perfectly intire for above thirty feet, and is forty-five feet in breadth; the basin may be about eight hundred feet wide; but how large the entrance was, or how far from the land, I could not pretend to judge. ${ }^{[32]}$

The town walls were still traceable at this date, but within them "no intelligible ruins could I find." [33] By 1772ff, when Parsons was travelling, silting (pre-

4 Fedden 1955, 213: after wwI "the arbitrary seizure of Alexandretta fatally compromised the already reduced possibilities of Aleppo." 
sumably) meant that he only saw corn fields on the site. However, its former greatness was remembered by the locals: "pointing to the old port, they said their fore-fathers had left it on record, that that was the port of Antioch when it was a great city." ${ }^{[34]}$ The port works (including a tunnel and canals) were still visitable in 1838 , when Robinson noted the iron cramps uniting the large blocks of the jetty projecting into the sea; ${ }^{[35]}$ but there was nobody there except himself. ${ }^{[36]}$ In 1839 Layard marvelled at the "great tunnel and water-course, cut with extraordinary labour and skill through the solid rock, to carry off the waters of a torrent which threatened to fill up the port with the mud and stones that it brought down from the mountains, and which were thus diverted to the sea." ${ }^{[37]}$ The dimensions of this cutting were extraordinary. It was broad enough for seven or eight horses abreast, ${ }^{[38]}$ and demonstrated an ancient attempt to keep the port free of the effects of winter rains. ${ }^{[39]}$ By the 1870 s, the port which Pococke had described over a century beforehand

n'est plus qu'un marécage, la mer s'étant retirée à une distance de près de cent cinquante mètres. Son énorme môle existe en partie, montrant encore la terrasse qu'il supportait, et, dans le bas, de spacieuses cavités qui probablement étaient des magasins pour les besoins du commerce. ${ }^{[40]}$

Nevertheless, there survived some ancient remains, perhaps of a temple, plus a statue of the seated Neptune. ${ }^{[41]}$ In 1860 Bourquenoud described the topography of the harbour and of the town, plus the walls of the upper town (with a tower "revêtue de belles pierres de taille"); he saw marble débris in the town, and noted the recent discovery of a marble statue. ${ }^{[42]}$

Here as at other erstwhile harbours, the port was a swamp in 1851 , yet still with lions surviving at its entrance. ${ }^{[43]}$ In 1825 Buckingham found in the area "the remains of a curious edifice, apparently once encompassed by a square of twenty columns, five on each face. There are still ten of these columns standing, ${ }^{,[44]}$ and went on to inspect a Roman tomb, with bas-reliefs of helmets, shields and armour. ${ }^{[45]}$ Both were still there in 1838 , visited by Lindsay, who walked down the ancient pavement, "but the street is in many places choked up with rubbish, and we then clambered over the roofs, and through the apartments of the old houses; fig-trees grow wild among them."[46] In 1834 Madox found another colonnade near Suweida, this one oval, near the Druze village of Garnavate:

The ruins here are beautiful. Magnificent temples or palaces, with columns, all of great strength and beautiful workmanship, greet the eye. Round one door the vine in clusters was sculptured; and floral ornaments appeared on others. All is in a state of ruin: part of the ground is paved: 
water gushes down in all directions, forming cascades amongst these once well-built houses. ${ }^{[47]}$

For European visitors in the earlier 19th century, the must-see in the valley of Suedia was the garden of John Barker, long-time British consul at Aleppo, where "les arbres et les plantes d'Europe y sont mêlés aux arbres et aux plantes d'Orient," ${ }^{[48]}$ and where he built himself a villa, ${ }^{[49]}$ which included marble basins and flowing water. ${ }^{[50]} \mathrm{He}$ also promoted local industry, namely silk production and cotton weaving. ${ }^{[51]}$ There appears to have been a spurt of cottagebuilding by English merchants, but these were untenanted by 1861, perhaps as a result of the decline of the Aleppo trade including, as Skene writes, "the dilapidated villa of a late British consul, where we had taken up our quarters." He returned to the sea, and admired "a fine colossal statue, representing the river Orontes, lately dug up, and a curious tunnel constructed in the rock to prevent a winter torrent from flowing into the basin, with a great many sepulchral caves of considerable interest." [52]

The ancients had done so much work on the complex that it should be restored, thought Captain William Allen R.N. in 1855. A Fellow of both the Royal Society and the Royal Geographical Society, Allen described the setup thoroughly, making a survey "in the hope of finding that this port is capable of being restored to its original purpose." ${ }^{[53]}$ His sketch appears in the 1898 Baedeker, but everywhere was still in ruin, without any active port. ${ }^{[54]}$ Thus it remained in 1919, with little hope of being cleared: "The ancient dock or port which was excavated from the rock is now partially silted up, and considerable rock excavation would be required to convert it into a modern harbour, as the limestone in the old basin is only 12.5 feet below sea level."[55] In other words, either the sea floor had risen, or the land had sunk.

\section{Lattakia}

Surrounded by the sea on three sides... Its buildings are very ancient... The port of Al Lâdhikiyyah is a most wonderful harbour, and one of the most spacious, so that it never ceases to lie full of large ships. There is at its mouth a great chain which protects the ships that are inside from the enemies' ships without. ${ }^{[56]}[$ later 13 thC]

During the Middle Ages, some of Syria's Mediterranean ports were evidently kept in good condition. Lattakia/Laodicea is a few kilometres north of Byblos and, in the 13th century, Dimashqi notes the marble quarries in the area, and the port, as in the above quote, and "on y voyait des marbres 
de toute espèce."[57] Although some of its buildings were dismantled during the Crusades, ${ }^{[58]}$ Ibn Battuta (d.1368) describes Lattakia as closed with a chain (as it was in Dimashqi's day), it being "un des plus beaux ports de mer de la Syrie." ${ }^{\text {[59] }}$ In the later 17th century Lattakia was refurbished, "being cherished, and put in a way of trade by Coplan Aga, a man of great wealth, and authority in these parts, and much addicted to merchandise,"[60] and a man whose name was still known and revered in the area in the mid-18th century. ${ }^{[61]}$ Such accounts refer to the inland town, and it is not clear what alterations he made to the port.

In the 18th century the town of Lattakia was still rich in ancient remains. In 1714 Lucas saw a splendid church said to have been built by S. Helena, with a fallen vault, and the environs used for animals:

L'on voit encore ces belles colonnes qui soutenoient le comble. Au dessous de l'Eglise sont de grandes voûtes fort longues, qui servent aujourd'huy à retirer des bœufs, des chèvres \& des moutons. ${ }^{[62]}$

There were "hundreds" of columns along the shore. ${ }^{[63]}$ Outside the town to the north, Shaw saw several decorated sarcophagi, ${ }^{[64]}$ and in 1743 Perry noted a triumphal arch as "tolerably perfect (abating for the Abuses and Alterations, which those barbarous People the Tuks have made.) ${ }^{n[65]}$ Drummond teased out some columns ("from a number of broken fusts which are buried in the walls of mean houses"), thinking them part of a grand building, ${ }^{[66]}$ but they were actually part of a colonnade, with grey granite shafts, like those of the arch. ${ }^{[67]}$ Buckingham realised this, what he saw surmised to be "remaining portions of colonnades to some public edifices which still remained standing after the general destruction of the buildings to which they belonged; and advantage might thus have been taken to build the walls of the modern dwellings in a line with them." ${ }^{\text {[68] }}$ As Robinson neatly put it in 1838 , "Les restes de l'ancienne ville offrent des matériaux tout prêts pour construire des habitations modernes."[69] Colonnades were not uncommon in Syria, and travellers to Jerusalem would have come across the eighty columns of a long road surviving at Samaria. ${ }^{[70]}$ In 1874 Beaufort noted that

there is still enough to show that a double row of granite columns once made an approach the whole way from the quay on the harbour up to the Corinthian Temple, whose remains are now quite at the back of the town, and at the distance of 1500 yards from the harbour. Numbers of these columns still remain, but the greater part have been broken off and rolled down to the sea, to be built into the foundations and walls of the castle in the harbour. ${ }^{[71]}$ 
Capper, travelling in 1778 , noted that the town "doit avoir été un ouvrage aussi magnifique que dispendieux; il n'en reste aujourd'hui que des débris.."72] The arch (there were comparable structures elsewhere in Greater Syria ${ }^{5}$ ) was then part of a mosque. ${ }^{[73]}$ To the south of the town, Parsons saw still better antiquities, "consisting of pieces of granite pillars, capitals, broken pedestals, and among them many larger fragments of columns than are to be met with at present in any part of Syria." ${ }^{\text {[74] }}$ Such survivals were difficult to examine, because they were built into later structures, ${ }^{[75]}$ Buckingham writing of "ranges of granite columns still erect, and incorporated with the modern buildings." ${ }^{[76]}$ In 1840 La Salle wrote of the fort protecting the port, which "a des fondements tout feutrés de colonnes, rouges, noires, blanches, en basalte, en granit, en marbre, posées droites, horizontales, obliques, sortant du mur comme des canons." ${ }^{[77]}$ In 1846, Stanhope wrote extended descriptions both of the arch, ${ }^{[78]}$ and of the other antiquities he saw in and around the town. ${ }^{[79]}$ There were still plenty to be seen in $1874,{ }^{[80]}$ and in 1877 Guérin reported on the arch, the remains of a temple with four surviving columns, and on other shafts to be seen in the mosques as well as the harbour walls. ${ }^{[81]}$ Digging for materials was already in train in 1835, when Michaud \& Poujoulat noted the ruined monuments above ground, pointing out that "les fouilleurs ne creuseraient point en vain dans l'enceinte de la cité rivale d'Apamée et d'Antioche."[82]

In 1851 Walpole got news of "the opening of a sepulchre of extraordinary beauty, and covered with inscriptions," with nearby a later drain or aqueduct, where more inscriptions were to be found: "rest by some barbarian from their original holy use: they had thus, perhaps, been preserved, where their fellows in their proper places had perished."[83] $\mathrm{He}$ also admired the ruined house of the governor: "The bath, fitted with marble, is small, but very handsome."[84] There might have been plenty of splendid sarcophagi in the area, for Corancez reported one in 1816, "chargé au dehors d'ornemens encore bien conservés. Il y a quelques années qu'on déterra aussi dans les environs un beau groupe de la même matière, représentant un homme de haute stature qui tient un lion enchaîné."[85]

By the end of the 19th century few antiquities were visible above ground, but "en creusant des fondations ou même en cultivant les jardins, des

5 Kader 1996 sets the tetrapylon at Lattakia in context of the Temple of Jupiter at Jerash, plus the arches at Petra and Bosra, plus east gate of market at Damascus. Author then discusses city gate monuments at Gadara, Tiberias, Tyre and Petra. Lattakia tetrapylon now freed from later accretions. All stonework is friable, and damaged. 108-114: early knowledge of the arch at Petra, but no digging until 2othC. 
statues de marbre mutilées de l'époque grecque" were found. What is more "une ancienne église byzantine, convertie en mosquée, garde encore des traces de peintures murales où l'on reconnaît des figures de saints. A l'extérieur, ses murs sont ornés de sculptures représentant des casques et des boucliers romains, faisant présumer que cet édifice était, lors de sa fondation, un monument triomphal." ${ }^{[86]}$ With so much decoration, this was evidently a different arch from that recorded by Perry in 1743, and mentioned above.

Travellers could no doubt consider themselves experts on Mediterranean harbours, and perhaps studied their fittings with a nervous eye or, in the case of Lattakia, with a jaundiced one. For they would have sailed or steamed in and out of several on their way to Syria, and would know the dangers. By 1738 the harbour complex ("capacious enough to receive the whole British navy") was in ruins, recognisable as "a work and structure of great labour and design, though at present it is so much filled up with sand and pebbles, that half a dozen small vessels can only be admitted." ${ }^{[87]}$ Pococke visited Lattakia in 1745 , when the harbour basin was already badly silted. He examined the canal, which he thought once had gates to control the water flow, and saw signs of abandoned habitation:

Near a mile to the west of this bason there are ruins of several houses along the river, which do not seem to be of any very great antiquity, but probably were houses of merchants, and warehouses, when Antioch flourished in the middle ages, at which time it was called the port of St. Simon. ${ }^{[88]}$

Ferrières-Sauveboeuf first entered the harbour in 1783 , noting the protecting tower which, crumbling, made entry more and more difficult. ${ }^{[89]}$ Once in, the harbour was choked with sand, so that, still shamefully neglected, in 1808 "none but barks and small ships can get so far into it as to lye secure from hard gales of wind."[90] What is more, by this date it was known to be unhealthy, and Europeans avoided it for that reason:

Ce n'est pas que l'air de cette ville ne soit en lui-même très-sain, mais depuis que les Mahométans en ont fait disparaître la majeure partie des habitans, les terres se trouvent en quelques endroits abandonnées et couvertes d'eau une partie de l'année. ${ }^{[91]}$

Size requirements had changed by 1823 , when two naval officers noted that "The port ... is very small, but it is better sheltered than any we have seen on this coast." ${ }^{[92]}$ 
If the surrounding land was badly maintained, and a breeding-ground for mosquitoes, nor was the port cared for. The crumbling tower and its walls were to be recognised as mediaeval constructions, with through-columns to strengthen them, looking like "une rangée de gros canons;" ${ }^{[93]}$ capitals and other antique débris were also built into them. ${ }^{[94]}$ Dilapidated walls were still causing difficulties in 1816, as were the large blocks of stone from the old quay which littered the basin. ${ }^{[95]}$ Magazines were built for the port sometime before 1850, and Walpole remarks on a large khan, where "a few columns and a few handsome marble pillars attest its antiquity." ${ }^{\text {"[96] }}$ Allen reported in 1855 that it was still silted, but "could be cleared out so easily, and with such incalculable advantages for the maritime population as well as to the government., ${ }^{\text {, } 97]}$ And by 1860 , one of the would-be improvers who wished to update the whole of Syria's commerce, thought it "could, with a little expense, be made an excellent harbour for both steamers and sailing vessels, as the holding-ground is trustworthy, the entrance favourably situated, and it is well sheltered by closely surrounding hills." ${ }^{[98]}$ Earthquakes had struck in 1799 and 1822, and according to Eyriès writing in 1859 further damaging the port; he also reported that through-commerce had gone down, not up, in the previous half-century. ${ }^{[99]}$ Trade recovered somewhat by the 1860 s, when the aromatic Lattakia tobacco, smoked in peasant huts (where the dwarf oak was burned), was exported to Egypt. ${ }^{[100]}$ The trade was still "considerable" in 1918. ${ }^{[101]}$

\section{Banias $^{6}$}

In Dimashqi's day in the 1330s, Banias had plenty of springs, but "son sol et son air sont insalubres," ${ }^{[102]}$ presumably because the water supply was no lon ger managed. She also had ancient monuments, the fortress on the above hill with "des substructions de beaux blocs taillés en bossage; les Romains, ces maçons acharnés, ont passé par là." ${ }^{[103]}$ Van De Velde agreed, thought the foundations even older, and was amazed "at a sight of these gigantic stones, gates, vaults, tanks, and so on." ${ }^{\text {[104] }}$ By 1714 when Lucas passed by, the bridge was in ruins, and the fortress as well. ${ }^{[105]}$ Seetzen in 1809 found twenty poor huts there, and the line of the town walls was clear, but no traces of Herod's temple to Augustus survived. ${ }^{[106]}$ By mid-century the bridge appears to have been rebuilt, and "in every direction there were broken shafts and capitals of marble pillars scattered upon the ground."[107] Ibrahim Pasha had repaired the

6 Wilson 2004, 38-55: Roman Banias; ibid. 162-176: European "rediscovery" of Banias. Pl 1 for plan of ancient city. 
fortress, and so perhaps the bridge as well as the small port. ${ }^{[108]}$ De Saulcy in 1853 concluded that the harbour works were not antique, because

Les belles pierres de taille qui en constituent les parements, ont été empruntées a tous les monuments antiques d'alentour, et au-dessus de l'archivolte est encastré un véritable tarikh [inscription] arabe, que je n'ai pas le temps de déchiffrer, mais dont je lis assez pour me convaincre que je suis devant l'oeuvre d'un soulthan mamlouk Baharite. ${ }^{[109]}$

\section{Tortosa/Tartus \& Ruad}

Tortosa became a stronghold for the Crusaders from 1099 and, although not held continuously, they survived there until 1291, building a fortress and a cathedral. To the north, at the artificial port, granite columns had been used in the breakwater, which Walpole saw in $1851^{1,110]}$ while to the south a decade later the locals were at work digging down seven or eight metres "à extraire de belles pierres; entremêlées à des colonnes de granit gris de dimensions moyennes." ${ }^{[111]}$ The blocks in the fortress were too heavy to move, Rey marvelling in 1866 at what he thought was their great age:

J'ai tout lieu de croire que les ruines phéniciennes de Rouad, d'Amrit et de Carné durent être mises à contribution pour élever ces gigantesques murailles, composées d'énormes blocs taillés à bossages. ${ }^{[112]}$

Just offshore was the island of Ruad, surrounded by double walls containing some huge blocks of stone ("in size and appearance are Cyclopean, resembling those in the foundations of the temple at Ba'albek"[113]), and a jetty likewise. ${ }^{[114]}$ There was a temple platform, on which were to be seen column shafts, and also the remains of decorated sarcophagi. ${ }^{[115]}$ Just like Tortosa, Ruad was also punctuated by defensive towers, but these were destroyed and replaced by "les petites forteresses ridicules" to meet the threat of the Greek War of Independence. ${ }^{[116]}$

\section{Tripoli}

First it was overwhelmed with water; Secondly, it was sacked with Cursares, and Pirates; Thirdly, it is like now to be overthrowne with new made mountains of sand. ${ }^{[117]}\left[163^{2}\right]$ 
Lithgow in the above quote does not predict a prosperous future for Tripoli, and indeed its future would mirror its past. The peninsula of Tripoli was protected by strong stone walls. ${ }^{[118]}$ Little survived above ground in Tripoli and its port of Al-Mina was older than Crusader times. Captured early by the Crusaders, it was one of the last fortresses to be relinquished. Projecting into the sea and lacking maintenance, it silted easily. Goujon still recognised port installations in 1670, "quoy que un peu ruiné."[119] The name the locals gave to the town in 1835 was El-Karah, the Ruins, because stone was removed in order to build up the harbour. ${ }^{[120]}$ Its great walls survived in parts in 1745 , when Pococke saw "several pieces of large pillars of grey granite" near it. ${ }^{[121]}$ Robinson saw large numbers of granite columns near the defending towers and in the sea, ${ }^{[122]}$ but it is unclear whether these were part of a breakwater, or placed as obstructions to prevent ships from docking. Both these uses will be found further down the coast. The towers themselves were also "fortified with fragments of grey granite columns, placed horizontally in the building." ${ }^{\text {. }}{ }^{223]}$ Seetzen, in 1805 , thought the towers Crusader, not Saracen. ${ }^{[124]}$

By the early 18 th century, the town was not completely inhabited, ${ }^{[125]}$ and its most noticeable features were the series of very large stones built into its walls. ${ }^{[126]}$ In 1743 the "many Fragments of Granite and Porphyry Pillars" between town and port, ${ }^{[127]}$ and the Crusader sculptures to be seen on the façades of some houses. ${ }^{[128]}$ Burckhardt reported in 1812 that the plain between town and port had in part been drained, and converted into gardens. ${ }^{[129]}$ Still in 1854 that same area was "plein de débris d'habitations et de colonnes ensablées," and we might wonder whether any of the houses were indeed ancient; ${ }^{[130]}$ Spoll thought the same in ${ }^{1861} .^{[131]}$ The mosque was formerly a church, and adorned with marble columns and Corinthian capitals. ${ }^{[132]}$ Antiquities also survived in the surrounding countryside, such as the eight-metre-high tower near the village of $\mathrm{Cir}^{[133]}$ Its population increased, rising to some 35,000 by 1917 , according to Roederer.

Volney in 1792 noticed that south of Tripoli the plain was "plein de vestiges d'habitations \& de colonnes brisées \& enfoncées dans la terre ou ensablées dans la mer," and that "Les Francs en employèrent beaucoup dans la construction de leurs murs, où on les voit encore posées sur le travers." ${ }^{[134]}$ Indeeed, close by was the village of Arca, site of another ancient town, with a temple dedicated to Alexander, and plenty of ruins surviving into the $188 \mathrm{os}$. Thomson in 1886 thought the columns had been brought down by earthquake, "or they have been thrown down by the equally destructive Saracen and Turk. I counted sixty-four lying on the bank of the river, one-third of which are of red Syenite, the rest of gray granite. ${ }^{[135]}$ Hence this was once a prestigious site, for these were imported, not Syrian stones. Not far away was a temple at Harf es Sphiry, 
but this time of hard white limestone, with walls still standing, but only two or three columns amongst its ruins. ${ }^{[136]}$

\section{Byblos}

Malgré ses grandeurs éteintes, Djébaïl n’a guère que six mille habitants; mais sa baie gracieuse, son pont élégant sur sa jolie rivière, les colonnes de marbre doré qui restent de son ancien théâtre ... toutes ces ruines pittoresques. ${ }^{[137]}[1848]$

Byblos (Jebilee, Galaba, Giblet, Djebail, Jubayl), with only six thousand inhabitants in 1848, had been an important Phoenician city, its early treasures first unearthed by Ernest Renan in $1860-61,{ }^{7}$ but with as yet nothing coherent to inspect. But in this book we shall deal only with the Hellenistic and Roman city visited by travellers. Already in 1697 Maundrell wrote that the town had nothing remarkable, but had noted the "many heaps of ruins, and the fine pillars that are scattered up and down in the gardens near the town." ${ }^{[138]}$ Laroque in 1723 saw substantial remains of what he called a palace, built by the Genoese. ${ }^{[139]}$ Pococke in 1745 (who claimed that "there are very little signs of the antient harbour"[140]) remarked on some huge stones in the foundations of the [Crusader] castle. ${ }^{[141]}$ Of course these (rivalled only by a few blocks at Baalbek) are still there, since the locals concentrated on plundering smaller blocks. The only other item of note seems to have been a fountain, set up with marble entablature and other elements, one apparently Egyptian, ${ }^{[142]}$ so perhaps taken from the Royal Necropolis. Renan in 1864 thought the fortress "parait, quand on l'examine pour la première fois, l'oeuvre des géants de la primitive antiquité."[143] Modern giants, the British, had battered it when it was in the hands of Ibrahim Pasha. ${ }^{[144]}$

Maundrell also visited the theatre, where the Turks were using gunpowder to blow it up so as to re-use the stones. ${ }^{[145]}$ The interior was then cluttered with houses, yet "on the west side the seats of the spectators remain still entire, as do likewise the caves or vaults which run under the subsellia all round the theatre. ${ }^{[146]}$ He dubbed this the best of the antiquities at the town, also mentioning "great many pillars of granite, some by the water-side, others tumbled into the water." ${ }^{147]}$ Some time after his visit the theatre was evidently partdestroyed to build modern structures. Egmont \& Heyman in 1759 called it an

7 Salibi 1988, 167-181: Phoenicia Resurrected. 171-172: Renan and his Mission en Phénicie. 
amphitheatre, but gave it the same dimensions as Maundrell, so surely the same building:

the whole exhibits but a wretched appearance, and has been greatly abused; all that remains now consists of a semi-circle, in the inside of which are some small houses built of the ruins, a great part of it having been blown up designedly by gun-powder; and the great quantity of marble, of which it consisted, converted to build a mosque and a bath. ${ }^{[148]}$

The destruction had perhaps been bad enough to confuse visitors: Salmon wrote in 1738 that

le Muraglie non sono in oggi più alte di venti piedi, avendo li Turchi fatto volare in aria il piano per servirsi de' Marmi nella fabbrica della Moschea, e del Bagno, che vi hanno fatti. ${ }^{[149]}$

Robbing continued, for Michaud \& Poujoulat in 1835 found only half the theatre surviving, including the seats, and wished:

quel bonheur pour l'histoire des arts si nos chroniqueurs pèlerins se fussent donné la peine de tracer une description complète du théâtre! mais, vous le savez, les croisés traversaient l'Orient, s'inquiétant peu des chefsd'œuvre de l'architecture antique. ${ }^{[150]}$

Robinson in 1838 found "les restes d'un beau théâtre romain,"[151] yet in $185^{\circ}$ Neale claimed he could find no trace of it (although it part-survives today as a re-build), and that

probably its stones have been used for the Construction of more modern buildings; for Gibili is now a town of considerable size, and is much frequented by small vessels, owing to the excellent shelter its little harbour affords. ${ }^{[152]}$

Walpole had no difficulty finding the structure the previous year, when "Between the arches are now a colony of Arabs, whose flocks are driven into the town at night." ${ }^{\text {[153] }}$ So was cannot always trust supposed eye-witness reports.

As at Tyre and elsewhere, at the port of Byblos Maudrell identified an extensive mole, Madox noted that "a great many broken columns lay about in the water," ${ }^{[154]}$ and Porter not only some large blocks in its construction (which he thought Phoenician), but counted over 40 columns in the water. ${ }^{[155]}$ By 1855 
it was "now nearly filled with ruins and sand. Many grey granite columns are lying on the shore and in the water. It now has shelter for boats only." ${ }^{\text {[156] }}$ Renan in 1860-1 observed that few old buildings survived, and said the town had been used as a quarry to build elsewhere; ${ }^{[157]}$ but described column shafts set symmetrically in the town's north walls, and "de toutes parts se voient de beaux fûts brisés de colonnes de granit d'Egypte, apportées à l'époque romaine."[158] In 1881-2 the town was still half-deserted, its streets "lined with great shafts of grey syenite from Egypt, some supporting verandas and trellises for creeping vines." ${ }^{[159]}$ Much remained at the end of the century: "On voit encore à Djébail le port que les Romains y avaient construit, et on rencontre au bazar beaucoup de débris de colonnes et de fragments d'antiquités d'époques diverses."[160]

Some visitors were confused by the stones of which the fortress was built, because they tried to date them by size, bevelling and apparent masonry tools. In 1876 De Vogüé called it a "construction arabe entée sur de belles assises de grandes pierres à refends qu'on a longtemps appelées cyclopéennes ou phéniciennes, mais qui, d'après les derniers arrêts de l'archéologie contemporaine, paraissent devoir être restituées simplement aux Romains." ${ }^{\text {[161] }}$ Other antiquities were to be seen around the town. To the south, where red granite columns were plentiful, was "un vieux château, de construction rustique, et dont les pierres sont d'une grosseur énorme," and a Maronite convent the walls of which "sont ornés de sculptures adaptées dont quelques unes portent des inscriptions grecques."[162] To the east, the chapel at Mar Seman had at its centre "une énorme colonne de marbre de quatre mètres cinquante centimètres de circonférence. Le tronçon a cinq mètres de haut, et il s'enfonce profondément dans le sol." ${ }^{\text {[163] }}$ The Convent of Deir-el-Kullah, not far from Beirut, was "built over the ruins of a very large temple, of which some huge columns and stones are still standing. A great many Greek and Latin inscriptions have been fixed in the modern walls (most of them upside down)."[164]

\section{Beirut}

The only habitable place in Syria for an Englishman. ${ }^{[165]}[1838]$

The Persian traveller Nasir-i-Khosrau visited Beirut ${ }^{8}$ in 1047, and noted the survival of only one ancient building, of large blocks, which he was told was the gate of Pharaoh's garden, though "all the plain around this spot is covered with marble columns, with their capitals and shafts." ${ }^{\text {"[66] }}$ If the building was the

8 Dentzer-Feydy 2007; Hall 2004: Beirut in Late Antiquity. 
baths, then it seems it was thoroughly dismantled in the earlier Middle Ages, just like those at Carthage. Columns were still scattered around in $1670 .{ }^{[167]}$ These remains and other ruins discovered underground convinced Volney that Beirut had once been much larger. ${ }^{[168]}$ No doubt some ancient materials were re-used by Emir Faccadine (Fakhr ed-Din, 1584-1635) to build himself a palace, but this had been stripped of its marble by the time Pococke visited in $1745,{ }^{[169]}$ "now running to decay, or else were never finished by their first Master" [170] by 1767 , and in ruins by the 19 th century. ${ }^{[171]}$ Brocchi in $1823^{-1824}$ was sniffy about these remains, but described others within the town. ${ }^{[172]} \mathrm{A}$ later emir, Bashir (1788-1840), built himself a palace at Beiteddine and, according to Brocchi, not only used marbles from the nearby mountains, and from near Damascus, but also from the ruins of Beirut. ${ }^{[173]}$

Just what survived into the late 17th century is difficult to determine. In 1697 Maundrell reckoned he visited the ruins of Faccadine's "palace," but it seems just possible that what he actually saw were the remains of the Roman baths, because he also saw there "several pedestals for statues, from whence it may be inferred that this emir was no very zealous Mohammedan," ${ }^{[174]}$ drawing an incorrect conclusion. A few antiquities still to be seen around the town in 1825 included a sarcophagus near a public fountain, "and remains of ancient buildings are constantly found wherever excavations are made." ${ }^{[175]}$ In 1803 Olivier saw three standing granite columns in the town, and a fallen one nearby, ${ }^{[176]}$ perhaps part of a temple, and still there in mid-century. ${ }^{[177]}$ To the north of the town, Light noticed "a range of buildings" which by 1818 were converted into a rope-walk, and "said to be that part of the amphitheatre of Augustus allotted for the reception of wild beasts." ${ }^{[178]}$ In 1829 Fuller found the town "a dirty disagreeable place," its palaces and gardens "now totally gone to decay."[179] Thompson walked outside the south walls (built from spolia) in 1767 , and came across what might have been baths: "some Remains of Mosaic Pavements, several Pillars of Granite, Pieces of polish'd Marble, and other Tokens of the former Magnificence of the City." ${ }^{\text {[180] }}$ But these did not last long. In 1835 Michaud and Poujoulat still discerned what they thought were the remains of baths, and of a theatre, and believed many other structures were hidden under the sands to the south-west of the town. ${ }^{[181]}$ But by 1844 , these were but "a faint trace," yet mosaic pavements were also discovered, and the columns at the harbour (see below) championed: "Though these remains are of little value in the eyes of the antiquary, they may, as old Sandys has it, 'instruct the pensive beholder with their exemplary frailtie." "[182]

For Blondel in 1840 , ruins were everywhere, including the amphitheatre, bridges and aqueducts, and "on découvre à chaque instant des fragments de colonnes de granit, des tombeaux, des médailles, des mosaïques superbes." [183] Columns and sarcophagi were in evidence in $1856,{ }^{[184]}$ and mosaic pavements 
were still visible in 1872 , but by then any traces of baths and theatre had vanished. ${ }^{[185]}$ To discover anything else, one would have to dig, ${ }^{[186]}$ encouraged by the plentiful fragments of pottery, rich marbles and mosaic tesserae ("which are always signs of occupation by wealthy people"[187]). In 1842 Hunter tried to follow Buckingham's "interesting remains ... but which, I believe, are now no longer to be found." $[188]$

Reflections of the ancient town's splendour were the remains of the port, which was claimed in 1835 to be safe even for warships, ${ }^{[189]}$ but presumably only for small ones. In winter, ships used to anchor in the bay to the north, but in summer they lay off the town in the open sea ${ }^{[190]}$ The wharf included many grey granite shafts, which were used for mooring small craft. ${ }^{[191]}$ There were also columns scattered along the shore, visible at low tide, ${ }^{[192]}$ and perhaps the relicts of attempts to export them for re-use elsewhere. In mid-century the port received a make-over ${ }^{[193]}$ which was to seal Beirut's ascendancy over other more precarious harbours up and down the coast. This seems to have been a slow process, however: in 1861 only small boats anchored in the port, larger ones in the roads, and passengers were carried ashore piggy-back from ships' boats. ${ }^{[194]}$ Hence even the quay, described by Paxton in 1839 as consisting of "an immense number of old, broken pillars... Most of them are more or less broken," ${ }^{[195]}$ was no longer of use for larger ships. The British bombardment of 1841 largely demolished the once-prominent fortress-towers by the shore. ${ }^{[196]}$

New installations were evidently needed, for traffic was increasing, and so was the population. In $185_{1}$ Walpole reckoned the town had doubled in size since his previous visit eight years ago, and "each Christian merchant has now his villa." [197] Darboy in $185^{2}$ put the current figure at 30,000, up from 12,000, and noted that it was the poverty of other towns that brought fortune to Beirut, "qui pourrait, avec l'industrie de ses habitants, ressusciter les splendeurs dont elle fut environnée sous les Romains." ${ }^{[198]}$ Beirut was fast becoming a modern city. ${ }^{[199]}$ Baedeker reckoned the population at 20,000 in $185^{\circ}$, then 80,000 in 1876 , and finally 150,000 with a 2,000 -man garrison in 1910, rising to 180,000 in 1917 , according to Roederer. By 1862, indeed, there was part of a proper road to Damascus, as well as an electric telegraph between the two towns, ${ }^{[200]}$ plus a distinct "Western quarter,"[201] so that Guérin in 1877 claimed not to recognise the town he had seen fifteen years earlier. ${ }^{[202]}$ By 1910 one author could write nostalgically of "Old Beirut" on his frontispiece showing a photograph of the town "in 1856, before the historic castle was removed to make way for the railway and the port." ${ }^{[203]}$ Later conflicts have promoted the modern concept of memorycide, which can apply to monuments as well as politics. ${ }^{9}$

9 Naccache 1998. 


\section{Sidon}

Le bassin a été malheureusement en partie comblé, et ne pourrait être réellement utile que si l'on y exécutait des travaux sérieux pour enlever tous les débris qui ont facilité l'ensablement. Que de richesses archéologiques ce curage mettra au jour lorsqu'il sera entrepris au grand avantage des laborieuses et intelligentes populations de cette côte! ${ }^{[204]}$ [1881]

Sidon was designed with a port sheltered by a mole and protected by a sea castle. Underwater exploration here and at Tyre by Poidebard was to provide to the 2oth century much information on the ancient harbours. ${ }^{10}$ Emir Faccadine, who had been to Florence, returned at an appropriate period, because "the state of the empire then enabled an ambitious and resolute man to extend his power: and this governor encroached on that of the governors of Damascus." ${ }^{205]}$ Maundrell in 1697 noted the pillars lying around, but no other antiquities, for "they are now all perfectly obscured and buried by the Turkish buildings," [206] so the town evidently was prosperous at that date. In 1767, "some Latin inscriptions are to be found in the neighbouring Fields and Gardens."[207] Certainly, Faccadine built himself a splendid palace here, but this was ruinous by the end of the 18 th century, ${ }^{[208]}$ and was perhaps "the ruinous and neglected remains of a palace" with a courtyard paved in marble where Madox stayed in 1834. ${ }^{[209]}$ Faccadine had plenty of local antiquities to choose from: for there were large numbers of columns scattered around above ground even later in the 17 th century. ${ }^{[210]}$

The French manoeuvred to gain trade access, ${ }^{[211]}$ but Faccadine, fearing a Turkish invasion by sea to unseat him, filled in the harbour, just as he did at Acre, and he probably included rock-hard antiquities. (In earlier centuries, it had been Christian pirates, harassing Muslim shipping, that were dangerous along this coast. ${ }^{[212]}$ ) This was done, writes Maundrell, "to prevent the Turkish gallies from making their unwelcome visits to this place." Hence the harbour remained in ruins: in 1745 Pococke noted "great ruins of a fine port... now choaked up," and it was still current knowledge that Faccadine had done this, so that "they might not be harbours for the Grand Signor's galleys to land forces against him." ${ }^{213]}$ Such fill-ins were much older, and "the fear of renewed

10 Viret 2004: Poidebard at Tyre and Sidon. Poidebard 2004, 190-191: Les fonds photographiques de la Bibliothèque Orientale de l'Université Saint-Joseph; according to their website, nothing digitised. Ibid., 292-319: Actualité de sites archéologiques découverts par Antoine Poidebard. Poidebard 1939: aerial and underwater archaeology at Tyre. 
crusader attacks was the rationale behind the destruction of the coastal cities of Palestine."11 The Tyrians had indeed tumbled large blocks into their harbour to prevent Alexander the Great attacking from the sea. ${ }^{[214]}$

In 1702, Naud saw on the site only "quelques colomnes abbatuës," and "plusieurs petits morceau d'ouvrages travaillez à la Mosaïque" in the gardens and along the roads. ${ }^{[215]}$ Paradoxically, the 16th to 18 th centuries were prosperous here, with an inn for strangers and some paved streets, ${ }^{[216]}$ until a decline in the later 18 th century. ${ }^{12}$ Some of the gardens were surely outside the walls, and in the surroundings Leandro reported finding not only coins but also "alcune colonne, statue, ed iscrizioni spezzate da quei barbari. Se potrò dare alla luce la collezione delle monete, e degl'Idoli, da me fatta nello spazio di più anni."[217]

By the early 19th century, the harbour was completely sanded up, and trade went to Beirut. ${ }^{[218]}$ At that period, repeating Maundrell, "whatever antiquities may at any time have been here about, they are now all perfectly obscured and buried by the Turkish buildings." ${ }^{\text {[219] }}$ Although the port was already in a bad condition in $1670,{ }^{[220]}$ the earthquake of 1688 caused ruination and fire, ${ }^{[221]}$ and this probably affected Baalbek, because Sidon was its entrepôt. In 1798 Djezzar expelled the French merchants from the town, and Marcellus reported in 1820 that in the previous seven years the French consul had seen but one French ship, and that thrown into the harbour by a storm; ${ }^{[222]}$ the English had a similar experience. ${ }^{[223]}$ And yet Sidon was capable of containing over twenty small vessels, ${ }^{[224]}$ and could easily have become the main port for Damascus, because there was a better road between them than that from Beirut. In 1840 Suleyman Pasha was persuaded to clear out Faccadine's large stones; he had got rid of 200 "when he was dissuaded from the undertaking by the janizary Aga, and other Turks who had houses on the sea-side, which they feared would be carried away by the water."[225] Coasting vessels could anchor behind a ridge of rocks, but even approaching the area was dangerous. ${ }^{[226]}$

Sidon declined, as already noted, in favour of Beirut. She was described in 1829 as "l'entrepôt de la vallée de Balbek et de celle de Damas."[227] And as an optimist wrote quite correctly a decade later, "avec très-peu de frais, on débarrasserait l'ancrage de Saïda des sables qui l'ont comblé, et on obtiendrait un port bien préférable à la rade de Beyrout." ${ }^{[228]}$ But it was not to be, and Ward in 1864 was still lamenting "its present fallen condition" due entirely to the nearblocked harbour. ${ }^{[29]}$ Because the state of the harbour prevented large cargoes of exports, manufacturing declined at Sidon, and commerce consequently

\footnotetext{
11 Petersen 2007, 506-7.

12 Weber 2010: "This was a boom period, with buildings charted on several maps; followed by late 18 th century decline, linked to the waning stars of its leading families."
} 
developed at Beirut, ${ }^{[230]}$ so that by 1875 the unmaintained harbour of Sidon was completely useless:

When a large vessel, or a steamer, arrives off the city... she must lie off the entrance to the harbor, and be ready to stand out to sea the moment the north wind begins to blow. ${ }^{[231]}$

By the 1840 s her decline was reflected mockingly in the substantial stone houses, now lost to commerce because French merchants had decamped to Beirut, ${ }^{[232]}$ and it was no wonder the local French Consul was described as lethargic. ${ }^{[233]} \mathrm{A}$ few French families remained behind, but Eyriès predicted in 1859 that unless something was done "la côte entière de Syrie finira par devenir entièrement inhospitalière, et ses villes perdront le reste d'existence qu'elles doivent encore au commerce." ${ }^{[234]}$ Its population was 10,000 in 1876, and 12,000 in 1910, but 18,00o by 1917, according to Roederer.

Scavengers might have cleared the harbour, but the shafts were "so perforated and honeycombed by the water, and by the boring-shells"[235] that they were evidently useless for recycling, given an evident lack of technical expertise to refurbish and polish them. Joanne could report in 1861 that all to be seen in the area was a few broken columns and fragments of mosaic ${ }^{[236]}$ - surely testimony to how thoroughly the ground had been worked over by scavengers and treasure hunters, for in 1799 the remains were already described as "so much injured, and so scattered."[237] Treasures were certainly there to find, hence the continual upturning of the soil: for in the late 19th century workmen digging a house foundation

unearthed several copper pots containing about $\$ 12,000$ worth of gold coin issued by Alexander the Great and Philip of Macedon. They appeared to be fresh from the mint, and some of them were as bright as the day on which they were coined,

which caused hundreds of people to turn up with shovels. ${ }^{[238]}$

There were probably several villas surrounding the town. In 1820 , Turner noticed Roman walls, and a mosaic, and "a large palace, fancifully called that of Cleopatra." ${ }^{[239]}$ Little was to survive Djezzar's scavenging, for "from its [Sidon's] remains of ancient splendour, however, the Pacha Jezzar procures his principal pedestals, columns, and capitals, for the embellishment of his mosque and palace [at Acre]."[240] Whether much of these villas survived for long is doubtful. Osborn mentioned a mosaic found in 1819, but no longer visible: "perhaps it lies buried beneath the sand." South of Sidon he also saw "half-filled excavations 
and sarcophagi partly exposed;" these were for looting, the local Arabs being reluctant to let him open any tombs. He also thought "from the desire exhibited on the part of the inhabitants to trade, that a plan might be adopted to exhume or purchase larger relics than those offered in the streets." ${ }^{\text {241] }}$ Other mosaics were also spotted in 1828 , together with remains three miles inland abutting the hills. ${ }^{[242]}$ Granite tie-bars were noted in the Crusader-period twin castles, ${ }^{[243]}$ and "great quantities of granite pillars lying under water, and others built into the mole," ${ }^{[244]}$ some, no doubt, Faccadine's underwater defences.

Plenty of objects were retrieved from Sidon, especially from the many tomb chambers. Glass was also discovered, of high quality, and unmatched by any in Western museums. ${ }^{[245]}$ It seems likely that several tomb chambers here served as dwellings, being cooler than houses in or around the town. Beaufort in 1874 camped in a now-Muslim shrine by the sea shore, but evidently built from classical remains: "a small square whose arched roof is supported by sixteen columns and is raised on steps at each side: such are most of the welys in Syria, and they are often a very agreeable resting-place."[246] Tombs were also suitable for sheltering flocks, as Butler noted in 1907 when he visited Brad, and "found families of Kurds temporarily settled in tents within the ruins; for there was an old cistern here, which the recent rains had filled with water." ${ }^{[247]}$

Sidon is now famous for the splendid sarcophagi discovered there (one in 1855, and a further seventeen in 1887), all now to be seen in the Archaeological Museum in Istanbul. ${ }^{[28]}$ The cemeteries around the town had long been known, and sacked: indeed, plundering continued well into the 2 oth century. ${ }^{[249]}$ In 1864 Renan noted "le spectacle de la dévastation dont ils ont été l'objet. Pas un sarcophage qui n'ait été violé," with unwanted objects left scattered around. A main aim of the looters was marble: "L'empressement avec lequel les marbres qui en sortent de nos jours sont recherchés par les indigènes, montre dans quelle proportion ce genre de destruction a dû s'exercer autrefois." ${ }^{[250]}$ One main looter was Péretié, who discovered the Esmunazar sarcophagus, presented by Luynes to the Louvre; ${ }^{[251]}$ other activities of that helpful man are given in Chapter Eleven.

Luckily, in 1887 the spectacular find of sarcophagi was made in an almost unplundered necropolis, ${ }^{[252]} 1.5 \mathrm{~km}$ north east of the town. ${ }^{[253]}$ Near the town a local landowner excavated "with the object of recovering from the debris the ancient buildings, out of which the inhabitants of the country for the most part construct their houses," and the necropolis was discovered 11m below the surface. A rare occurrence, indeed, as the law was obeyed, and "by the end of the month all the tombs of any value were drawn out from their vaults, cleverly packed, and ready to convey by sea." ${ }^{[254]}$ Hamdi Bey, Director of the Constantinople Museum, followed European traditions and ordered up a 
Turkish warship to take the finds north. ${ }^{[255]}$ This was no doubt done to forstall any filching, for which Europeans were at the forefront, as the correspondent for the Revue Archéologique complained at Sidon in 1888. The famous sarcophagi

escaped the greed of the desecrators of the burial places. I must state, to my great regret, that these today are no less terrible than those of preceding ages. The same rapacity and vandalism continue their work of destruction, and, what is the more distressing, is that the so-called Europeans, representing certain great Powers at Saida, in their own interests and the most merenary spirit, head these devastations. ${ }^{[256]}$

This assessment was rigorously accurate. In 1873 , for example, Massenot found a Christian chapel south east of Sidon, retrieved "de très gracieuses fresques représentant des oiseaux, dont la collection de M. Lycklama possède des spécimens détachés par moi," and then, digging deeper, "trois magnifiques sarcophages en pierre antérieurs à l'ère chrétienne et même à l'époque romaine ou grecque." These went to Beirut for onward conveyance to Holland. ${ }^{[257]}$ In 1869 another traveller, Baron Lycklama a Nijeholt, dug around Sidon and "j'ai eu la bonne fortune de recueillir quelques pièces qui sont l'orgueil de ma collection." ${ }^{[258]}$ Foreign officials seem to have considered it part of their duties to help wandering scholars, such as Alcide Leroux, and in 1882 the French Consul took him around the digs and recent discoveries. ${ }^{[259]}$ In the 1880 s the Vice-Consul, Edmond Durighello "nous en montra une grande collection qu'il a réunie dans une salle du khan franc: on y voit des sarcophages antiques, des restes de statues et de sculptures, ${ }^{, 260]}$ some of which eventually found their way into the Louvre. As Curtis remarked in 1903,

The tomb chambers, however, have been looted of everything of value by vandals. The robbery probably began at the time of the Crusades. Here were found the sarcophagus of Alexander the Great, which is now exhibited in the museum at Constantinople, and other burial urns and cases of great artistic beauty, which have been shipped to museums in almost every great city. ${ }^{[261]}$

Settlements around Sidon also lost their antiquities during the course of the 19th century. Between Tyre and Sidon, reported Jowett in 1826, "are very extensive ruins of towns, which once connected these two cities: but, of these ruins, there is now scarcely one stone left upon another,"[262] and these La Salle in 1840 described as nearly continuous. ${ }^{[263]}$ Digging was needed, as Massenot remarked in 1873: 
Il faudrait des mois entiers pour explorer tout cet emplacement de l'ancienne Sidon, qui cache, sous les blés et les arbustes, tant de choses ignorées et tant de belles choses; chaque champ a sa légende et garde enfouis de véritables trésors archéologiques, qu'ont fait disparaître les terres entraînées des montagnes voisines par les pluies de vingt siècles. ${ }^{[264]}$

The nearby village of Aiha was once a substantial town, and in 1825 Buckingham found here "a considerable number of fallen columns." ${ }^{[265]}$ Yet by 1876 Baedeker reported that of the temple near the village "few remains are left, as the stones have been carried off for other buildings."[266]

\section{Sarepta}

Between Sidon and Tyre, Sarepta was nevertheless close enough to Beirut to have her antiquities looted, and sat on a small port (a natural harbour) which allowed access. ${ }^{[267]}$ Rosenmüller, who visited in 1841 , recorded that antiquities had disappeared since Richter's 1815 visit. ${ }^{[268]}$ Prime noted diggings in 1855 , together with capitals and broken columns strewed around, ${ }^{[269]}$ and "where literally not one stone had been left upon another."[270] The explanation is simple: Ward in 1864 wrote that the town's "foundations have lately been dug up and carried to Beirout, to be employed in the construction of modern edifices." ${ }^{[271]}$ Thus did tombs and also mosaics disappear. ${ }^{[272]}$ Because even the foundations were dug out, all that remained were cisterns and the hard concrete of aqueducts. ${ }^{[273]}$

Tyre $^{[274]}$

Partout l'affreux tableau de la dévastation, de la misère et du désespoir vient déchirer le cœur de l'étranger, déjà ému par le souvenir d'une gloire et d'une puissance qui furent fondées sur l'agriculture, les arts, la navigation et le commerce. ${ }^{[275]}[1803]$

Olivier, in the above quote, was saddened that such a town, famous for Alexander's siege as well as for its monuments, was brought to the level of a village. In ${ }_{176} 67$ Thompson had called the site "a melancholy Scene of Ruin and Desolation, consisting of decayed and broken Walls, Fragments of Pillars, Pieces of antique Marble, and great Heaps of Rubbish." ${ }^{[276]}$ Even in the Middle Ages, there was more to be seen, including column shafts galore. Burchard 
of Mount Sion was impressed by the columns he saw in 1283, but does not say whether these were on land or in the sea. ${ }^{[277]}$ Perhaps some shafts were sliced up and fired into the town during the siege of 1124, thought Stevenson in $1907 .{ }^{[278]}$ Ibn Battuta says the town was a heap of ruins, with a village outside it. ${ }^{[279]}$ Mocquet saw large columns in 1696, noting those used as tie-bars in the walls. ${ }^{[280]}$ and dismissing the notion that "one of a wonderful length and breadth, very smooth, and almost Seven Fathoms about" was one that Sampson brought down - he knew that this had happened at Gaza. ${ }^{[281]}$ By the mid-19th century the port of Tyre, like that of Sidon, was in a bad state. ${ }^{[282]}$ The port at first attracted more attention from travellers than the town, especially the column shafts, which visitors (most of whom would never have seen such quantities) probably saw as proof of the old-time greatness of the city. Just as at Caesarea, Tyre had moles (to the town's main harbour, which was considered safe, ${ }^{[283]}$ if only for small vessels, ${ }^{[284]}$ and the southern "Egyptian" harbour) formed in part from ancient column shafts. Rogers, at Caesarea, thought that buildings had simply toppled into the sea, and Bertou thought likewise for Tyre, conjuring up a Hellenistic double portico, ${ }^{[285]}$ and decoration for the agora and the harbour itself. ${ }^{[286]}$ With the help of local divers, he also traced broad and long walls submerged at the port. ${ }^{[287]}$ Sandys believed much the same in the early 17 th century, ${ }^{[288]}$ as did Nugent in $1846^{[289]}$ and Kennard a few years later. ${ }^{[290]}$

There were certainly plenty of columns still on dry land and in the port, as Leandro observed in $1753 \cdot{ }^{[291]}$ Quantities are not generally given, and it is likely that those on land were taken away for re-use before those in the sea. According to Olivier in 1803, many had already gone: "on sait que divers sultans en ont fait transporter à Constantinople, et que dernièrement encore Dgézar s'y en est procuré de fort belles." [292] In 1826 Jowett counted about one hundred shafts at the main harbour, ${ }^{[293]}$ and Olin in 1843 counted over 200, perhaps at the "Egyptian" harbour, "of all sizes and of various materials, but, for the most part, large and handsome." ${ }^{[294]}$ Lithgow had admired a large quantity of them in $1632,{ }^{[295]}$ while Le Brun noted on land "plusieurs colonnes qui étoient encore entières, et une infinité d'autres qui étoient rompuës." ${ }^{[296]}$ Under water were also to be seen capitals, ${ }^{[297]}$ presumably there for infill, which might indeed have misled some travellers into believing that a complete portico had collapsed. Some of these capitals "were carved with exquisite beauty not entirely destroyed by the action of the water." ${ }^{[298]}$ These were still obstructing the port in 1861 , for the port was shallow, and accessible only to small boats. ${ }^{[299]}$ This had prevented the accession of European imports since the previous century. ${ }^{[300]}$ Does such a large number of survivals suggest that some ancient structure (building? colonnade?) was standing in the Middle Ages, or perhaps collapsed like dominoes, for the Crusaders to employ in their projects? 
For the biblically minded, such as Deschamps in $1678^{[301]}$ or Stewart in 1857 , the granite columns under the water fulfilled the prophecy of Ezekiel: "They shall lay thy stones and thy timber and thy dust in the midst of the water."[302] The next year Osborn thought likewise: "naught but supernatural design and mysterious energies could have swept so thoroughly from the surface of this plain and island the remains of so much grandeur." ${ }^{[303]}$ De Hass in 1887 , observing the survival of "piles of beautiful granite columns, some of vast dimensions; substructures of pagan and Christian temples," nevertheless returned to Ezekiel. ${ }^{[304]}$ Prophecy, after all, required fulfilment. ${ }^{[305]}$

The column-moles (plus large cemented blocks ${ }^{[306]}$ ) were evidently an attempt to abate the force of winds and currents so that ships could dock safely, and it seems likely that they were placed in post-mediaeval times, when the technology espoused by al-Muqaddasi's grandfather in 9th-century Acre for building walls in the sea had been lost. The fact that, as Newman observed in 1864, many columns were "imbedded in the solid rock, or cemented together by some powerful agent, ${ }^{,[307]}$ should have alerted everyone to the fact that these were indeed constructed breakwaters, rather than just a collapsed portico. Luynes could not make up his mind whether the materials under water were deliberately placed there, or the result of earthquake. ${ }^{[308]}$ But what was the date of the ensemble? Newbold went out in a boat in 1850, but thought the "from the numerous columns and foundations that are now covered by the sea" were evidence of "oscillation," or bradysism, apparently not realising that these were harbour installations. ${ }^{[309]}$

Robinson and Smith observed in 1856 that the foundations of the harbour walls themselves were of large stones resting on marble columns, "a proof that these portions of the walls at least, if not the whole port in its present form, cannot probably be much older than the middle ages" ${ }^{\text {[310] }}$ - so were any of the breakwaters here so constructed? Renan states that all the columns seen lying by the sea at Tyre were brought by the Crusaders, and goes on to condemn the poor quality of their use as tie-bars, apparently unaware of Muslim techniques. ${ }^{[311]}$ Certainly, Lortet in 1881 described the mole "qui s'étend très loin sous les eaux du côté du cap Ras el-Abiad," and "on voit de vastes amoncellements de pierres de taille, et une quantité incroyable de fragments de poterie" ${ }^{n[312]}$ - but he also counted some fifty columns in the water, and believed that "ces colonnes étaient très certainement encastrées dans un mur d'enceinte, dont l'éboulement les a précipitées dans la mer."[313]

Whatever the original constitution of the moles, their existence (although still misunderstood by some as late as the $1880 \mathrm{~s}^{[314]}$ ) evidently meant that the port of Tyre was preferred to Sidon and Acre, and French merchant ships, for example, could in 1766 "find shelter here in the winter season, when they cannot have it elsewhere." ${ }^{[315]}$ Mariti in 1791 said the port was blocked, and 
accessible only to ships' boats because (he thought) tumbled ruins lay on the sea bed and would foul larger ships; he was told that this was deliberate, and that the columns used "venoient de plus loin, \& que les Arabes les avoient transportés dans cette darsine, pour la rendre inabordable aux galères \& autres bâtimens." [316] This does not quite contradict Olivier's 1803 observation that "La facilité que la mer offre pour le transport des colonnes, des statues, des inscriptions, des bas-reliefs, a été une des principales causes de la dévastation qui a eu lieu sur toutes les anciennes villes de la côte," because he does not actually say he saw materials exported by sea from Tyre. ${ }^{[317]}$

It seems possible that the Tyre moles have in fact sunk over the centuries thanks to repeated earthquakes, and movements in sea level, namely bradysism/bradyseism: the land along this coast (it is on a geological fault line) seems to have dropped, as 19th century reports relate, ${ }^{13}$ so this would have left the moles lower in the water, and hence eventually unable to act as moles at all. At Caesarea, for example, the caissons sunk by Herod are today more than $5 \mathrm{~m}$ under water, and seismic activity here has also been studied. ${ }^{14}$ However, just how the ancient land and sea levels have changed relative to one another is a question for experts.

In 1758 Campbell noted that the town walls were in ruins, ${ }^{[318]}$ Volney thought the surviving town wall was built about 1766 , and Bertou in 1843 suggested that the port was repaired at the same time "à l'aide de magnifiques fûts de colonnes en granit, ce qui restait encore de la formidable clôture." But the north wind pushed sand into the port, "qui tend à le combler; aussi les plus petites barques ne peuvent y rester à flot, quand les eaux sont basses." ${ }^{[319]}$ Indeed, most of the columns could be rowed over in a skiff "as they lay at an inconsiderable depth," as Van De Velde did in 1854, which suggests either that an earthquake had sunk the sea bed, or that upper layers of column shafts (which also formed a pavement to the head of the harbour) had been filched for re-use elsewhere. ${ }^{[320]} \mathrm{In}$ any case, by mid-century the harbour suffered severely from silting. ${ }^{[321]}$

What antiquities were to be seen at Tyre during the 19th century? Much had already gone, for Tyre was a focus of conflict during the Crusades, ${ }^{15}$ not least in 1291 when Al-Malik Al-Ashraf broke the siege, and "he sent men to organize its demolition, to pull down the walls and buildings, and he gained from this a good quantity of marble and salvage."[322] Browne in 1799 writes only of "three fragments of granite columns," so presumably did not visit the columnmoles, ${ }^{[323]}$ and perhaps there had yet been no extensive scavenging to recover

\footnotetext{
13 Greenhalgh 2012, 123.

14 Mart \& Perecman 1996, including a list of earthquakes and tsunamis $23^{-24}$.

15 Chehab 1979 for Tyre during the Crusades.
} 
materials from under ground. Failoni's 1833 account also suggests that little was then to be seen above ground. ${ }^{[324]}$ Massive granite columns ("dix-huit coudées en hauteur" - c.9m) survived in the ruins of the old cathedral, ${ }^{[325]}$ the ruins of which "paraît servir de nid à des huttes de Turcs" ${ }^{\text {"[326] }}$ or, in Tristram's words, "devoted to the filthiest purposes, and with miserable Muslim hovels plastered like swallows' nests in all its comers and transepts." ${ }^{[327]}$ Conder and Kitchener suggested that such shafts must have been taken from a Phoenician temple on the site, because "the Crusaders are little likely to have imported such stones, as they were always on bad terms with the Egyptian Saracens." ${ }^{[328]}$ This was certainly the case: at any date the Crusaders controlled little more than the coastal strip, so perforce their materials would usually have been local, even if imported from along the coast by boat.

In 1843 Olin counted some fifty granite and marble columns near the sea wall, and surmised that these "seem to have been collected here from the field of ruins for the purpose of being transported to some rising city, a design which was for some cause abandoned." ${ }^{[329]}$ He may have been correct, for Van De Velde in mid-century wrote that "for many feet under the present surface, the ground is a complete mass of building stones, pillar shafts, and marble, porphyry, and granite rubbish, ${ }^{[330]}$ suggesting he had seen scavengers digging for materials. In 1842 Brocchi saw several excavations searching for building materials, ${ }^{[331]}$ as did Till nine years later; ${ }^{[332]}$ and Seetzen in 1806 had seen red as well as grey granite shafts, perhaps also uncovered by scavengers. ${ }^{[333]}$ Newbold in $185^{\circ}$ found near the town "the remains of baths with tessellated pavements, and the foundations and pillars of a small temple, had been recently dug up, as well as the mutilated torso of a marble statue of Minerva, as large as life."[334] Van De Velde in 1854 had really wanted to see a proper exploratory dig, not just the search for re-usable blocks, ${ }^{[335]}$ but this was not to happen for decades, because all excavation was devoted to the search for materials, and "des restes intéressants de maisons, de colonnes, de statues" noted in 1861 presumably disappeared, ${ }^{[336]}$ so that scholars like Porter had to rely on scavengers as substitutes for proper digs. ${ }^{[37]}$ By 1882, however, German archaeologists "ont déjà fait de sérieuses tentatives."[338]

As early as 1839 Paxton had pointed to the cathedral as the town's "most remarkable and interesting relic of antiquity, with its great granite pillars."[339] But as late as 1883 Conder and Kitchener were still calling for "a complete excavation of the cathedral by shafts sunk to rock," for it was here that the suspected the Temple of Melkarth was to be found. ${ }^{[340]}$ For Thompson the temple stood "stood in the centre and highest part of the island," and he suggested the bases he found when diggers were searching for stone for the new barracks at Beirut fixed the site of the temple. ${ }^{[341]}$ Here again, the scavengers obviously 
got first pick. The red granite pillars (nearly $8 \mathrm{~m}$ long) were still to be seen in 1889, and were often photographed with tourists sitting upon them; Conder believed these to be Phoenician rather than mediaeval. ${ }^{[342]}$ Perhaps they were still there in 1915, unless Fleming was quoting from an earlier account. ${ }^{[343]}$ Bromfield in 1856 writes of the "wanton destruction by the Turkish government of the remains of a fine Christian church, to serve for building materials at Beyrout." ${ }^{[344]}$ This was almost certainly the cathedral, like other buildings perhaps comprehensively destroyed in the earthquake of 1837 , although already ruined. ${ }^{[345]}$ In the same year Wortabet gives further details, climbing up what little remained of a spiral staircase, "which still stands, but could not ascend high, as the government has been pulling it down, carrying off the stones to build a hospital at Bayroot with them for its troops."

The new cathedral and archbishop's palace in 1839 were very different from the mediaeval stone construction, being simply a "chaumière attenant à une chapelle." ${ }^{[346]}$ Wortabet noted by the sea wall the destruction of a tower, "whose stones were being pulled up for government purposes," and "broken columns, hewn stones and cornices, lined the sea-beach," evidently ready for export by sea. ${ }^{[347]}$ Osborn reports that in 1858 that "the interior of what was once a splendid building is now completely filled up with little huts with mud roofs; and several fig-trees grow in the ancient nave and transept," and that the debris was some sixteen feet deep. ${ }^{[348]}$

In 1865 Tristram called the whole place "a deplorable rubbish-heap," the more so because of the chaotic way in which workmen trenched here and there for building stone to send to Beirut: "It is small wonder if, after ages of such quarrying, the ground-plan of Tyre be difficult to trace." ${ }^{[349]}$ Guérin had visited in $185^{2}$, but when he returned 25 years later, the cladding of the town walls had been removed, "et pour arracher les nombreux fûts de colonnes engagés transversalement dans l'épaisseur de la construction, on détruit jusqu'au blocage même, qui finira par disparaître complètement." ${ }^{[350]}$ And as late as 1897 Baedeker noted that "numerous ancient hewn stones have been, and are still in course of being removed hence to Acre and Beirut." [351] They were also disappearing along the coast at Cape Ras el-Nakoura, where a splendid temple (drawn by David Roberts) had already gone in mid-century. ${ }^{[352]}$

What antiquities survived did so either because they were useless for building at Beirut, or simply too large to move. Thus the small Greek church at Tyre, perhaps built in the 1820s, did not use columns because, so Mislin was told, there was nobody who could move them. ${ }^{[353]}$ In 1872 "a magnificent column of red Egyptian granite... formed the best part of a native garden wall" because it was too large for export elsewhere. ${ }^{[354]}$ Lasseurs recounts his 1921 discovery of part of a sarcophagus; but he was then in a hurry, returned to it the 
following day, and found that already workmen had built it into a nearby dyke. ${ }^{[355]} \mathrm{He}$ also uncovered "un énorme sarcophage de marbre gris à couvercle en dos d'âne, orné aux quatre angles d'acrotères non sculptés," which he wished to carry to Beirut. However, he could not move even the lid with his deadlegs, which broke, and so "il fallut y renoncer et laisser là ce beau morceau de marbre qui sera vite réensablé, s'il n’est pas auparavant débité par les maçons du pays."[356]

Such depradations happened because Tyre continued to be sparsely inhabited. In 1766, Hasselquist found five families here, all living by fishing, and estimates are c.2,500 in $1850,3-4,000$ in mid-century, ${ }^{[357]} 5,000$ in 1876 , 6,000 in 1898, and 6,500 in 1910; Roederer reckoned 15,000 in 1917. In 1854 it was described as a village which "n'a plus ni monuments, ni navires, ni port, ni marchandises, ni population."[358] By 1868 the harbour was "now nearly filled up with sand and rubbish," ${ }^{[359]}$ and by the 1870 os only fragments were to be seen. ${ }^{[360]}$ Even in 1883 , inhabitants filled only a part of the ancient city; Bovet noted how the Tyrians "sell [the remains] to any one who wants materials for building," and correctly predicted the complete ruin of the cathedral (as noted above), because "the pacha of Beyrout, who is building barracks, has given an order for as many stones as can be got out of the ancient buildings belonging to the government."[361]

Clearly, then, local authorities had no conception of the value of antiquities either in themselves or as an attraction for tourism. This is curious in an area through which so many pilgrims passed on their way to Jerusalem, a town which could not have survived without such visitors. What is more, it was not force majeure which occasioned the re-use of antiquities, because in the region of Tyre were sandstone quarries acknowledged "dans la contrée comme la meilleure pierre à bâtir." And, what is more, "ces carrières sont exploitées de temps immémorial pour la construction des édifices de Beyrouth et autres villes de la Phénicie et du littoral syrien comprises dans ce vilayet." ${ }^{[362]}$ Evidently, marble and granite were widely prized as prestige materials.

Several travellers remarked how rich in antiquities were the roads north and south of the town. Toward Sidon were to be seen "fragments of tesselated pavement; while prostrate columns, and remains of masonry, and occasionally a single pillar rising amidst the confused heap of ruins." ${ }^{\text {[363] }}$ Some of these were probably the remains of late antique villas. ${ }^{16}$ The retrieved antiquities were also sometimes recycled, as in the fortress at Geser Casmie where in 1823-4 Brocchi described "una grande pietra paralellopipeda di granito rosso Egizio,

16 Badawi 1997, 82-94: opus sectile in late antique Tyre. Very well illustrated, and the colonnaded street was indeed paved in various patterns of marble - see figs 2, 3, 5, 6 . 
la quale serve di architrave alla porta." ${ }^{[364]}$ East of Tyre, a church was excavated by 1864 , and a large mosaic pavement unearthed, but only column bases, for the shafts themselves had already been taken away. ${ }^{[365]}$ The remains of aqueducts were visible around the outskirts of the town, and again to the north, ${ }^{[366]}$ but these were "now gone to Decay," as Thompson wrote in $1767 .{ }^{[367]}$ The road itself was the Roman road, with many of its paving stones in place, and milestones as well. ${ }^{[368]}$ Equally, antiquities were exported from Tyre and Ascalon south, to Gaza and vicinity. ${ }^{[369]}$ In 1838 Stephens came across an Arab village built on top of Roman ruins, with two ancient buildings still standing, "and the stones which once formed the foundations of palaces were now worked up into fences around holes in the rocks, the burrowing-places of the miserable Arabs."[370] Going south, between Tyre and Acre, Renan remarked on standing columns, "Oum-El-Awadid, la Mère des Colonnes."[371] But by 1845 Durbin noted that the population seemed to have vanished into the hills:

Once this plain was carefully cultivated, and thickly studded with towns and villages; now it is badly tilled in patches here and there... a fine aqueduct, in a leaky condition, still conveys water from the mountain to the town. ${ }^{[372]}$

All that remained were antiquities:

Everywhere the traveller stumbles upon shafts, capitals, and bases of columns, scattered among the rocks, indicating the populousness and wealth of former centuries; and frequently he sees the broken-up pavements and fallen bridges which mark the imperial highway of the Caesars. ${ }^{[373]}$

Unknown to the 19th century were further riches discovered over the past century: more rich cemeteries, used for centuries, with many decorated sarcophagi; the façades of funerary platforms, decorated with imported marble and granite; and a broad road flanked by tall cipollino columns and porticoes. ${ }^{17}$

17 De Jong 2010, 607, 623; 599: "The date of the paving and colonnade is unknown but lies well before the fourth century CE, when black-and-white mosaic floors covered the road. Slabs of Proconnesian marble obscured the mosaics in the final excavated phase, possibly dating to the fifth or sixth century CE." 


\section{Acre}

In the Town there are not above two or three hundred Inhabitants, who dwell here and there in the patch'd-up ruines; only a new Mosque they have, and a strong square Cave [i.e. cellar] (built where once was the Arsenal for Gallies) in which the Franck Merchants securely dispose of themselves and their Commodities. ${ }^{[374]}[\mathrm{c.1610}]$

In earlier centuries Acre ${ }^{18}$ increased in importance when Caesarea declined, and Ibn Tulun (870-892) improved its harbour, for which the grandfather of Muqaddasi (himself writing in 985) developed techniques for laying foundations for the port structures under water using sunken wooden rafts, cement and columns as tie-bars. ${ }^{[375]}$ With these facilities and the European commerce they attracted, the town thrived. It also attracted crusaders ${ }^{19}$ who took it in 1104 and, after surrendering to Saladin in 1187 (leaving only the toe-hold of Tyre), revived the European grasp in 1191 under Richard the Lionheart for exactly a century, until its recapture in 1291. After this the town lay in ruins, with remains of "de belle franche pierre taillée et moult richement édifiée," but no inhabitants, ${ }^{[376]}$ or just a few houses at one end of the town. ${ }^{[377]}$ Such was the dire gift of the infidels, writes Mariti. ${ }^{[378]}$ It was deliberately levelled, ${ }^{[379]}$ and in the early 17 th century Faccadine filled in the port to discourage attacks from the sea, ${ }^{[380]}$ as he did at Tyre. In 1600 there appear to have been fewer than three hundred inhabitants. There was a short revival in commerce (and presumably in inhabitants) under Daher el-Omar from 1749 until he was assassinated (approaching the age of 9o) in 1775. However, he had built two hotels specifically for Europeans, to encourage trade. ${ }^{[381]}$

Djezzar ("the Butcher") replaced him, and with the help of the Royal Navy defended the town against Napoleon in 1799. He ruled Acre and also Sidon 1785-1805. The conjunction between Djezzar and Sir Sydney Smith was as strange as any coalition, ${ }^{[382]}$ but essential to keep out Napoleon, who knew that access to the harbour was essential to his success. Bramsen, travelling 1813-15, said Acre was "esteemed one of the best ports in Palestine, and is frequented by ships of considerable burden" ${ }^{[383]}$ - hence, of course, the desire to attack it so that troops might be resupplied from the sea. By 1840, ship sizes had increased, and nothing larger than coasters could dock there. ${ }^{[384]}$

18 Petersen 2001, 68-91, in his gazetteer of buildings in Muslim Palestine: Acre, including Mosque of Djezzar Pasha.

19 Gertwagen 1996: the port in Crusader times. 
These several batterings and ruinations down the centuries did much damage to its monuments, which also suffered for the building of her walls. ${ }^{[385]}$ Attacked by the Crusaders, "King Philip of France battered the city walls, towers, and battlements incessantly, both by day and by night, with huge stones, breaking the enemy's machines, houses, and buildings within the city." ${ }^{[386]} \mathrm{We}$ might imagine some of the stones were cut from the handiest available material, namely column shafts. In 1355 Ibn Battuta had found the town in ruins, ${ }^{[387]}$ as a result of the Crusades. It was still ruined when Doubdan visited in 1651, and the port difficult, because "il est tout remply de roches \& d'écueils, qui font fort à craindre en la moindre tourmente. ${ }^{[388]}$ Large stone projectiles lay around the streets in 1658 and still in 1667 , indicating desolation rather than nonchalance. ${ }^{[389]}$

Desolate though it was in the later $17^{\text {th }}$ century, ${ }^{[390]}$ the Palace of the Grand Master [of the Knights of S. John] was very ruined but still recognisable, because embellished by Faccadine, "\& plusieurs autres fort beaux restes."[391] By 1697 there was a mosque and some cottages, and a khan with French factors, but still were "scattered up and down upon the ground several large balls of stone, of at least thirteen or fourteen inches in diameter; which were part of the ammunition used in battering the city, ${ }^{[392]}$ date not given. Arvieux wrote that he saw even larger ones (some over $1 \mathrm{~m}$ in diameter) inside and around the town; ${ }^{[393]}$ he also described five structures, of which Robinson found only three in $1856,{ }^{[394]}$ so extensive was the continuing demolition. Jolliffe set out in 1819 "to explore what vestiges of antiquity are yet remaining," and the best he could come up with were "a few mutilated arcades" of the cathedral. ${ }^{[395]}$ Lack of maintenance meant that sections of the town had fallen into the sea, ${ }^{[396]}$ while two large columns had been appropriated for the baldacchino of the Maronite church. Mariti thought these were porphyry, ${ }^{[397]}$ but it is more likely that, as Buckingham wrote in 1822 , they were red granite, like the ones taken for the Franciscan Convent. ${ }^{[398]}$ Delaroière found the town still a pile of ruins in 1836 , with no intact monument, "les nombreux travaux qui se font pour la restaurer s'exécutent plutôt pour rétablir les fortifications que pour relever les monumens en ruine," so that only ruins were there to be defended. ${ }^{[399]}$ The streets were perhaps cleared of their projectiles, but as late as 1836 the town was still largely in ruins, and evidence of shot from the 1799 siege was everywhere. ${ }^{[400]}$ Nor did the British bombardment of 1840 help, after which the inhabitants of Tyre, who had found "magnificent wall of finely-cut rusticated masonry," "were busily engaged in transporting the materials of this portion of their ancient city to repair the breaches made by Sir R. Stopford and Commodore Napier in the walls of St. Jean d'Acre."[401] 
Acre differs from most of the towns along the coast in that later 18th- and early 19th-century travellers found it occupied and thriving, thanks to its local despots Daher and then Djezzar. Daher fortified the town (badly according to Volney ${ }^{[402]}$ ), and annoyed the Porte by conspiring in robbery (including a Mecca caravan) and piracy, ${ }^{[403]}$ presumably because the harbour could still handle the shallow-draft vessels involved. In contradistinction Djezzar, as well as making war on Beirut, ${ }^{[404]}$ also cultivated the arts of peace, as we have already seen in Chapter Three. For example, he built two public baths, and decorated them with marble; ${ }^{[405]}$ but he was also condemned in 1823 by Spilsbury for having no interest in Antiquity, the proof being that he cut up so many of its marble remains. ${ }^{[406]}$ This was simply Western prejudice, for he collected marbles from up and down the coast, and Seetzen noted their effect when he visited in $1806 .{ }^{[407]}$ Clarke visited his monuments in 1817 , and names verde antico, syenite, and also "some pillars of yellow variegated marble, of extraordinary beauty; but these he informed us he had procured from the Ruins of Caesarea." ${ }^{[408]}$ If the last-named was indeed giallo antico, then he had captured examples of the stone (from Tunisia) prized above all others by the Romans. And his sumptuous bath was enjoyed by travellers, containing as it did "every kind of antique marble, together with large pillars of Egyptian granite."[409]

In 1824 Richter was very impressed by Djezzar's still-standing buildings, including several khans, one of which was supported on 23 columns taken from Caesarea, and which might have been the establishment occupied by Jews two decades later. ${ }^{[410]}$ But Djezzar had died in 1804, and his successor Soleiman-Pacha abandoned his aqueduct and was in the process of building a new one. ${ }^{[411]}$ Obviously the baths were fed with water, but in 1828 there was insufficient from any aqueduct to fill the town's encircling ditch. ${ }^{[412]}$ Nevertheless, Stanhope in 1846 was describing these buildings as if they still stood, ${ }^{[413]}$ although another visitor a decade later describes the mosque as a complete ruin, ${ }^{[414]}$ when Bagatti specified that only the lateral walls of the mosque were standing, and only one room of his palace survived. ${ }^{[415]}$ In 1887 De Hass was also writing of the mosque and tomb of Djezzar in the present tense, ${ }^{[416]}$ prompting the reader to assess just how much in travellers' accounts to believe, the more so since he says Djezzar's columns sported bronze capitals and bases. ${ }^{[417]}$ Five years previously Chauvet \& Isambert wrote likewise:

Des plaques de marbre tapissent les parois intérieures du monument et en dallent le sol. Le mihrab est également en beau marbre de différentes couleurs. On remarque les fines sculptures du member. ${ }^{[418]}$ 
We may imagine that such authors did not visit the site in question (at least thoroughly), and simply copied or plagiarised an earlier account without realising that buildings had changed or deteriorated.

In spite of Djezzar's collecting, even in the mid 19th century there were plenty of antiquities around to be cannibalised: "Ici ce sont des colonnes de marbre de Paros dont vous poussez du pied une brillante parcelle, ruines grecques; là ce sont les gradins circulaires d'un cirque immense, ruines romaines." ${ }^{[419]}$ This was also the case along the road to Sidon, but the remains were "so much injured, and so scattered, that it is impossible to guess their destination." [420] Presumably so many remained because, even in 1868 , the harbour was still silted up. ${ }^{[421]}$ Perhaps for this reason the population increased only slowly, from 8,000 in 1876 to 12,000 in 1910.

\section{Haifa}

19th-century Haifa sat to the south of Acre on a promontary across the bay. The new settlement was near the site of an old town built in the 1760 os by "Daher el Omar, who destroyed ancient Haifa because that position was too much exposed to the invasions of Bedawin.. ${ }^{[422]}$ The ancient town was said to be Sycaminum, and "quelques-uns des plus anciens habitants d'Haïfa se souviennent que leurs pères leur ont montré la place de leurs premières habitations dans la vieille ville."[423] Because it was nearby, the new town served as the French base for the siege of Acre, while the old site provided stones for the energetic Dahar / Zahir al-Umar (r.1730-1775) to build defences and a customs house. ${ }^{20}$ This new Haifa quadrupled in size from 4,00o in 1876 to 16,000 in 1910 , so that ruins in the area went quickly. As Tristram wrote in 1865 ,

the whole area is constantly quarried for building stone, being one mass of foundations, fragments of columns, and sculptured marble. The extent of these ruins is considerable, the importance of the buildings being evident from the size of the substructures. ${ }^{[424]}$

20 Carmel 2011, 9-14 for early accounts of the town; 33-59: Dahar al-Umar and the Destruction of Ancient Haifa. 
Modernisation took its toll, with the extension of water facilities by Schumacher in 1886 , then building of a new port from 1905 , to help service the railway. ${ }^{21}$

\section{Caesarea}

On ne vit jamais rien de mieux fortifié que le port, ni de plus commode. Il était flanqué de plusieurs grandes tours et orné d'un rang de superbes édifices... Mais, ô caducité des villes aussi bien que des hommes! Toute cette splendeur est aujourd'hui ensevelie sous un vaste monceau de pierres et de sable! ${ }^{[425]}[1862]$

Herod the Great (37-4 BC) built a magnificent city at Caesarea, which became the capital of Palestine from 6 AD, with sewers, an immense harbour, a grid plan and Roman buildings including a palace, theatre and amphitheatre, ${ }^{[426]}$ using lavish amounts of imported marble. ${ }^{22}$ In spite of the extensive robbing out, to be discussed below, its splendour in town and harbour has proved a magnet for today's archaeologists, ${ }^{23}$ just as it did for 19th-century travellers, who spotted plenty of Herodian evidence in the remains. ${ }^{[427]}$ Al-Muqaddasi, writing in 985, thought its fortress impregnable and its water and local food produce good, ${ }^{[428]}$ but Yakut, writing in the 13 th century, notes its decline: "It was of old a fine, grand city, the very mother of cities, with broad lands and wide domains; but now it is more like a village."[429] It ruinous state was confirmed a century later by Abulfeda. ${ }^{[40]}$

The Byzantine walls, encompassing more than the Herodian ones, were abandoned during the occupation by Crusaders, who simply improved the fortifications erected by Ibn Tulun in the late 9 th century. These were pulled down in their turn by Saladin and re-erected by Louis IX in 1251-2. Baybars flattened the city in 1265 , and in 1608 Beauvau noted that "à ceste heure il n'y a plus rien d'entier que certaines grottes \& voultes, ou se retirent les Mores."[431] By 1661 to these had been added "quelques chetives cabannes pour des pecheurs."[432]

21 Carmel 2011, 36-37. 126: "Schumacher extended [the stone quay] by a construction of columns and iron bars in the form of a bridge for the anchorage of ships, which allowed water to stream through and so prevent the sand accumulating."

22 Fischer 1996; Fischer 1988: marble imports and local stones.

23 Raban 1989: the Ancient Harbour Excavation project 1980-1985; Raban \& Holum 1996; Boas 2010, 292-302: Crusader housing in Caesarea, including use of spolia. Turnheim \& Ovadiah 2002 for public and private art. Holum 2008: statuary; Holum 2004: temples and churches; Horton 1996: baths and bathing in late antiquity. 
In 1669 Morone could find here only "ruine, e Colonne innumerabili,", ${ }^{[433]}$ but at the same date the walls were "entourées de beaux fossez à fond de cuve y sont encore presque toutes entières."[434] Pococke investigated the ruins in 1745 , finding the castle (which he correctly attributed to Louis Ix) "full of fragments of very fine marble pillars, some of which are of granite, cippolino, and a beautiful grey alabaster,"[435] to which Mislin in 1876 added porphyry seen elsewhere on the site. ${ }^{[436]}$ So perhaps this was built as a luxury palace, like the Ibelin structure at Beirut. The walls and their ditches survived because of their evident strength, ${ }^{[437]}$ until parts of the walls were dismantled in mid-century to provide building materials for Acre. ${ }^{[438]}$

Caesarea remained a semi-desert (1834: "pas un être vivant!![439]), and had a bad reputation as a den of robbers. Chateaubriand, on shipboard in 1812, saw scarcely any traces of cultivation, but noted lugubriously that

the Arab, roving on this inhospitable shore, pursues with eager eye the vessel that scuds along the horizon; he lurks in expectation of the plunder of the wreck, on that very shore where Christ gave the injunction to feed the hungry and to clothe the naked. ${ }^{[440]}$

By 1837 the Bedouin were grazing their animals nearby, and using the city as a cemetery; Skinner was sure they hung about "for no very honest purpose, if my Christian guide is to be credited, who did all he could to dissuade me from lingering among the ruins." ${ }^{\text {[441] }}$ The coast was still dangerous in mid-century, Belgiojoso recounting a mid-century shipwreck of pilgrims that she though was a put-up job, with the unfortunates massacred as soon as they reached land. [442]

Ashore, Stanhope in 1812 writes of "being in a great measure ignorant of the existence of these several heaps of stones, which were now so overgrown with grass and weeds as not to be visible,"[443] so perhaps very little of the town's extent was sown. By mid-century, however, there may have been more people around, for the land inside the walls was now sown with crops, planted over and therefore obscuring any surviving ruins. ${ }^{[444]}$ Lynch in 1849 saw that "the whole area within the walls is full of pits, where hewn stones have been dug from the earth accumulated over them in the lapse of ages,"[445] though how such debris managed to live with any agriculture is unclear. Mislin's 1876 claim that the town had only one inhabitant, apart from shepherds drawing water from a well, was surely incorrect. ${ }^{[446]}$ Were they working in the fields, perhaps? For the farmers evidently lived somewhere outside the walls, where perhaps they had better access to water, even if this came (along with malaria) from some leaking ancient aqueduct. 
Some refugees from Bosnia settled here in $1878,,^{[447]}$ but it was surely an exaggeration to say the site was totally deserted: at mid-century there were a few living "où le marbre et le granit gisent épars, où se dressent quelques pauvres cabanes." ${ }^{\text {[448] }}$ Certainly, large quantities of ancient materials were re-used in the mediaeval city, ${ }^{[49]}$ and also in the modern town. For Straton's Tower, supposedly there before Herod began his new town, and a tall ruin in the 19th century, was brought down using gunpowder, "and a modest Government building, the seat of a Moudir, replaces it partially."[450]

The port, however, built because of the need for secure anchorage along the Syrian coast, became dangerous by Late Antiquity because its breakwaters had sunk. ${ }^{24}$ One index of its decline (supported by archaeological evidence ${ }^{25}$ ) is the use by the Crusaders of Jaffa and Acre, rather than Caesarea, for berthing their ships. In 1678 Deschamps declared its port narrow, silted and dangerous, ${ }^{[451]}$ and over a century later Mariti found only the débris of walls and temple, and

je n'ai pu reconnoitre la place de l'ancien port que plusieurs historiens ont vanté comme une autre merveille du monde. Il est probable qu'il n'a pas subsisté long-tems, puisque Guillaume de Tyr n'en dit rien dans la description de cette ville. ${ }^{[452]}$

Yet he could conjure up what the city once looked like, by citing Josephus. ${ }^{[453]}$ Doubdan believed that when the Crusaders assaulted the city in 1102 the defenders withdrew to "un très-beau \& magnifique Temple qu'Herodes avoit fait faire en honneur d'Auguste César, lequel estoit encore sur pied, et pouvoit servir de citadelle, ${ }^{[454]}$ although it is unknown whence he derives such certainly. The area, known today as the Temple Platform, overlooked the inner harbour, and was later replaced by a church and then a cathedral. Elsewhere were ruins which would remain indeterminate until they were dug: thus Carne in 1830 noted that "of the temple, forum, amphitheatre which it formerly possessed; it is difficult now to discover the sites."[455] Obviously, digging was needed to discover anything more.

Buckingham in 1822 described the fortress as "evidently a work of the Crusaders," and dismissed Pococke's belief that "the mounds in which he thought he could recognize the sites of the tower of the Drusus, Caesar's temple, the colossal statues of Augustus and of Rome, the forum and the theatre, are mere masses of indefinable form." ${ }^{\text {[456] }}$ In 1864 Guérin wrote that "en dehors

\footnotetext{
24 Sperber 1998, 172.

25 Raban 1996: inner harbour basin.
} 
de l'enceinte des Croisades, j'ai découvert un vaste hippodrome," the French phraseology being flexible, but implying here that he did indeed discover that site. This he certainly did not do, although he might be using the latitudinarian meaning of "découvert" in French, beating down the bushes and brambles to discover some seats. In 1864 the hippodrome had a pink syenite obelisk, and two two-metre-plus markers in the same material, ${ }^{[457]}$ of which Kitchener found only one, and in pieces, eighteen years later. As for the famous aqueduct, “j'en ai retrouvé un second au milieu d'épaisses broussailles,"[458] wrote Guérin, demonstrating the loudness of the trumpet to be blown in order to impress the paymasters back in Paris.

Conder in 1889 reckoned excavations near the cathedral would reveal the temple in honour of Augustus, just as digging at theatre and hippodrome "would be of great interest and not difficult to accomplish." ${ }^{[459]}$ Seven years earlier he had seen large red granite blocks cut into sections, obviously for reuse elsewhere along the coast, but some reworking was unsuccessful, because "the granite is so hard that the cutting has been abandoned after penetrating a few inches only". [460]

There were plenty of column shafts, both in the town and around the harbour. In 1735 Arvieux noted large numbers of granite columns, ${ }^{[461]}$ and large quantities were still there in $1822,{ }^{[462]}$ "columns by the hundreds on the seashore one above another, or lying close together in the water," although many had already been carried off to Acre and Jaffa. ${ }^{[463]}$ But perhaps these then disappeared, since Lamartine was intrigued by this "labyrinth of stones or half open caverns, of ruined edifices, of fragments of marble and porphyry." He collected sculpture fragments, and spent the night underneath the aqueduct. ${ }^{[464]}$ In the same year of 1848 Yanoski and David identified "quelques colonnes de porphyre" as from Herod's Temple. ${ }^{[465]}$ These were surely those of red polished granite, which Van De Velde measured as having a diameter of c2.5m, plus a block in the same stone over $10 \mathrm{~m}$ in length. ${ }^{[466]}$ Baron Taylor supposedly visited Caesarea in 1838, and certainly La Syrie, la Palestine et la Judée. Pèlerinage à Jérusalem et aux lieux saints, (first published 1838, 16th edn, Paris 1854, making 16 editions in 15 years) was very popular. However, he conjured up a vision (which he cannot have believed had he seen the place) of an intact deserted town from what he actually saw elsewhere in Syria (there were plenty of these). But certainly not in Caesarea, which he affirmed "a presque tous ses monuments debout, toutes ses places conservées, où l'on peut, comme autrefois, circuler dans ses rues, loger dans ses maisons." And he goes on to write that "on dirait que ses habitants sont partis d'hier pour aller à quelque fête ou à quelque pieux pèlerinage" ${ }^{\prime 467]}$ - a common notion which we shall meet again concerning several abandoned towns in the interior, with streets and houses intact. 
Just how much similar padding and outright confabulation there was in such published travellers' accounts is only occasionally quick and easy to determine.

Distinct from ruins within the town were "the countless columns that lie by hundreds in the sea," correctly believed by Van De Velde to be a substitute for Herod's breakwater, ${ }^{[468]}$ and picturesquely compared by one traveller to the mole at St. Andrews (Scotland). ${ }^{[469]}$ This is perhaps what Kinnear described in 1841 ("Immense blocks rising above the waves"[470]) although Rogers in 1865 believed the shafts and the large blocks had simply fallen into the water from the land. ${ }^{[471]}$ The previous year Newman described the shore by the southern gate as "covered with prostrate columns, fallen pendentives, broken entablatures, and marred cornices," ${ }^{[472]}$ so perhaps some land buildings had indeed collapsed. He went on to write of a ruined marble pier:

Its hundred prostrate columns lie as they fell, most of them parallel to each other, with now and then one lifting its head in silence above its fellows, worn by the tireless surges which roll over it, careless of its former grandeur. ${ }^{[473]}$

We should forgive Rogers his mistake (if indeed it was one), for he had surely not seen the same jetties formed further up the coast, and probably reckoned that some of the columns were so splendid that part of the adjacent land must simply have collapsed. Forbin did not count the columns, but did note that some were pink granite, and with inscriptions too indistinct to be deciphered. ${ }^{[474]}$ Monro in 1835 identified some of the columns as giallo antico, and others as granite and syenite. ${ }^{[475]}$ He was probably mistaken, since stone quarried near Damascus (called "Fat and Flesh") was "a pudding-stone, which, somewhat like the giallo antico of Egypt, takes a high polish."[476] The water-bound column shafts were evidently filched for use elsewhere, as in 1882 Conder and Kitchener estimated their number at only sixty or seventy. ${ }^{[47]}$

\section{Jaffa}

Des pans de murs renversés, de larges pierres couchées sur le côté, ensevelies dans le sable, couvertes de broussailles, marquaient encore le plan de Jaffa ... la mer y bat aujourd'hui de façon à n'y rien laisser, quand elle est dans sa fureur. ${ }^{[478]}[1651]$

When Doubdan visited Jaffa in 1651 , the town was a ruin, as the above quote indicates. Her ditches were filled with rubbish, walls fallen down, blocks of 
stone half-buried in the sand, and the town covered with brushwood. He thought nearby caverns had perhaps been dug to assist landing on this fierce coast; this could not be done at the town itself, where "on découvrait à fleur d'eau les débris de travaux gigantesques qui soutenaient les terres et servaient de môle pour rompre les vagues et fermer le port." Jaffa remained the most perilous port on the coast, well-known for its shipwrecks. ${ }^{[479]} \mathrm{He}$ was not alone in finding the ruins confusing: Casola in 1494 noted the "numerous marbles," and "has a fine circuit of ruins, but one cannot understand what they were."[480] In 1840 "its roadstead in winter is altogether unsafe,"[481] and even at the end of the century the harbour was still described as the worst in the world, and missed by ships which were forced to carry on to Beirut or even Port Said. This made for a very uncertain mode of commerce, ${ }^{[482]}$ in one case causing a cargo of sheep from Iskenderun to miss the town because of stormy weather, and consequently to be carried on to Alexandria, and then back again. ${ }^{[483]}$ In midcentury Westerners were already explaining (a common refrain up and down the coast) how easy it would be to refurbish the port, ${ }^{[484]}$ with Farley still pushing its advantages in $1872 .{ }^{[485]}$ Change evidently happened slowly, Macleod still explaining in 1866 just how tricky a landing could be. ${ }^{[486]}$

Because of the dangerous coast, little is heard of the town in the 18th century. Jaffa had once been larger than it stood in the 19th century, with a mound of ruins outside the current settlement pointed out in the 17th century. ${ }^{[487]}$ Expansion from a small town obliterated these remains, and materials for building were being imported from Caesarea well before the mid-19th century. ${ }^{[488]}$ The Governor was already beautifying the town in 1812, having "enriched his masonry from the ruins of Caesarea, Ascalon, and other cities along the coast, whence he had drawn abundant supplies of granite, marble, and stone, ready shaped to the hand."[489] Unusually, even Christian establishments profited, for in 1834 the Franciscan convent had been rebuilt there with material from the ruins of Caesarea, ${ }^{[490]}$ which had also provided materials for Djezzar's mosque at Acre. ${ }^{[491]}$ In 1865 Rogers noted materials which he thought came from Ascalon:

Des fragments de colonnes de granit, de piédestaux de marbre et de chapiteaux sculptés... Ces débris servent maintenant de marchepied pour monter à cheval et en descendre. ${ }^{[492]}$

The quay was repaired with material brought from Caesarea, and "de là proviennent sans doute plusieurs fûts de colonnes monolithes que l'on observe sur divers points."[493] Of ancient Jaffa itself not a fragment survived, except for "quelques fûts de colonnes brisées et de gros blocs de pierre, encastrés çà et 
là dans le mur d'enceinte."[494] Richardson, in 1822, saw nothing: "There are no antiquities in Yaffa." ${ }^{[495]}$ In the 185 os Jaffa $^{26}$ had some 5,000 inhabitants (as against 10,000 at Acre and 15,000 at Jerusalem) and 8,000 by 1876. By 1910, Jaffa housed 47,000 people (Acre 12,000, Jerusalem 24,000), and it was the thriving port for Jerusalem. ${ }^{[496]}$

For European not local reasons, celebrity tourism was easy to exercise here: in 1841 Damer stayed in the quarters occupied by Napoleon, converted into the plague-house of painted fame:

Although forty years had elapsed since the bodies of these unfortunate pestiférés were thrown into the well of the convent, I could not feel at my ease about the water used for our tea, till I ascertained it was taken from the spring. ${ }^{[497]}$

But of course celebrities far antedated Napoleon. In 1876 Berners was taken to see the house of Simon the Tanner [Acts x.6]. ${ }^{[498]}$

\section{Ascalon}

A medley of pieces of wall, huge building stones, fragments of columns, marble, granite, porphyry, and limestone rubbish, in prodigious heaps, in the midst of which some poor-looking huts have been put together. ${ }^{[499]}$ [1854]

Ascalon impressed Van De Velde in the above quote, for it was another city endowed by Herod with marbled magnificence. ${ }^{27}$ Muqaddasi, in 985 , wrote that Ascalon was a fine city, but that its harbour was unsafe and its water brackish. ${ }^{[500]}$ The town was refortified by Richard of Cornwall in $1239,{ }^{[501]}$ then ruined by Saladin and destroyed by Baybars in 1270 . When Ibn Battuta visited, the Great Mosque had only its walls standing, but "il y a aussi des colonnes de marbre sans pareilles pour la beauté. Les unes sont debout, d'autres couchées à terre." Showing just how special such marble columns were, one had been carried off by the Christians, but had returned of its own accord. ${ }^{[502]}$ Columns had also been re-used for monuments in nearby towns. ${ }^{[503]}$ Arvieux in 1735

26 Petersen 2001, 161-175: Jaffa, including history of the town.

27 Fischer 2008: the great basilica. 
noted the town's thick but fallen walls, with granite through-columns, ${ }^{28}$ and the vestiges of a temple within the town. ${ }^{[504]}$ Whether there was ever a harbour here seems in dispute, although Chauvet \& Isambert in 1882 thought collapsed walls indicated a mole:

Ils sont construits avec des pierres de toute sorte et renferment dans l'épaisseur de leur masse des colonnes de granit ou de marbre. D'autres colonnes de granit gris, en très grand nombre, sont couchées sur la plage on dans la mer. ${ }^{[505]}$

At Ascalon in 1820 Jolliffe found many column shafts, including a couple of porphyry, and the remains of Hester Stanhope's recent dig (see below), which uncovered what he thought was part of the gallery of a bath. ${ }^{[506]}$ But he couldn't find "the smallest vestige" of a port. ${ }^{[507]}$ In the same period Forbin identified what he said was a Temple to Venus, and counted forty very large pink granite columns, with capitals and friezes. ${ }^{[508]}$ Details of discovery are confused, Duray affirming that Ibrahim Pasha (who occupied Syria 1831-40) discovered the columns, associated ruins and a church when digging a redoubt; ${ }^{[509]}$ in which case there were more columns underground than Stanhope had found. In any case, by the 1850 , some of these had apparently already disappeared. In 1885 Conder and Kitchener refer to "several large granite columns of 14 and 18 feet in length," but evidently far from forty. ${ }^{[510]}$ Baedeker in 1876 and then 1898 mentions no complete columns, only fragments. ${ }^{[511]}$ Porter provides an explanation in 1868: Stanhope (see immediately below) discovered part of a theatre (the source of the statue she had destroyed?), and available antiquities were exported in large numbers for building Jaffa and Acre. ${ }^{[512]}$ By the end of the century digs ("qui ne pourraient être faites sans une autorisation préalable de la direction du musée impérial de Constantinople") had stopped, and only small objects and coins were recovered. ${ }^{[513]}$

Lady Hester Stanhope (1776-1839) was the decidedly eccentric niece of William Pitt who travelled (expensively) to Palmyra, and then settled for life at Joun, near Sidon. Her caravan to Palmyra was widely believed to have caused a permanent hike in the rate the Bedouin thought they could charge Westerners for travel protection. Profligacy makes waves, similar to those occasioned by the purchase of the Hot Pot by the Metropolitan Museum of Art, or in the minds of dealers servicing the splendid Getty Museum, sitting so picturesquely near the San Andreas Fault.

28 Pringle 1984, 140 \& Table I: through-columns (of granite and marble) at Ascalon; 141: the chronology of their use. 
Stanhope's Ascalon dig ${ }^{29}$ was evidently a treasure hunt, and certainly not informed by any desire to study, let alone resurrect, the ancient glory of the town. The reasoning for the happening is both convoluted and unsatisfactory, since we have only the detailed account of her doctor (Meryon) for what happened, and why. The dig might have been triggered by several large and conspicuous columns. The town was known in 1667 for its remains, and Naud mentioned what he thought was a church, with "de grosses \& hautes colonnes, d'une espece de marbre gris, qu'on nomme Granete, dont plusieurs sont encore de bout \& dans leur ordre."[514] Two years later Morone noticed tie-bar shafts set in the walls, ${ }^{[515]}$ and thought the standing columns (perhaps those Naud mentioned) might be the remains of a loggia. ${ }^{[516]}$ In the middle of the 17 th century apparently only seven or eight granite shafts were visible. ${ }^{[517]}$ In 1819 Forbin set down the same remains as a Temple to Venus, and counted forty columns, ${ }^{[518]}$ many presumably uncovered by Stanhope's dig in 1815 . This was effected with the indulgence of the local aga, and using workmen press-ganged by the government. A large headless statue was discovered, and Meryon illustrated this.

The foundations of a building were uncovered only on the fifth day of digging, and "Mohammed Aga found his own purposes answered in the number of marble slabs that were discovered. These he shipped, in a coasting boat, for Jaffa." ${ }^{[519]}$ The doctor was righteously puzzled by her reaction when he mentioned to Stanhope that "her labours, if productive of no golden treasures, had brought to light one more valuable in the eyes of the lovers of the fine arts." To this she responded that "malicious people may say I came to search for antiquities for my country, and not for treasures for the Porte: so, go this instant; take with you half a dozen stout fellows, and break it in a thousand pieces!"[520] Did this actually happen, or is it simply a story to improve in the telling? Further digging produced only two granite columns, and Stanhope affirmed without any known evidence that

when Gezzar Pasha embellished the city of Acre, by digging for marble and other materials in the ruins of Ascalon, he was fortunate enough to discover the treasure. That Gezzar enriched his coffers by wealth so got was generally affirmed: and it is probable that his pretended mania for building was no more than a cloak to conceal this real motive for excavating. ${ }^{[521]}$ 
Apparently, materials from the town were still heading for Medjdel, near Gaza, in $1823-4 \cdot{ }^{[522]}$

This distasteful episode (which was famous, and was still being cited by Michaud \& Poujoulat in $1834,{ }^{[523]}$ and also in mid-century ${ }^{[524]}$ ) apparently uncovered many antiquities for later travellers to view. In 1841 Kinnear noted not only that the Pasha intended to clear out the harbour, but also the site of the temple

of large dimensions, the pillars of which, although all prostrate, are still entire; each shaft being of one piece of grey granite. The capitals and entablature are of white marble, of the Corinthian order, and in the purest taste. / Near this, a very beautiful colossal female figure, of white marble forms part of the substructure of a building, and might be easily removed from its present situation. Friezes and entablatures, and fragments of marble statues, lie scattered about in every direction. ${ }^{[525]}$

This was evidently a different statue than the one shattered by Stanhope, perhaps left in place because of its lack of reuse value when there were so many other stones much more easily cleared out. Not much clearance had happened by 1851 , when Senden reported many columns on the beach, and the sand encroaching; ${ }^{[526]}$ this was still happening over a decade later. ${ }^{[527]}$ Bankes was at Ascalon in 1816, and saw the fruit of Stanhope's exertions: "nothing besides a headless statue, which was broken to pieces by her order, and was still lying in fragments on the spot." [528] If we are to believe Richardson, who may not have been a very conscientious observer, this had already disappeared six years later, fragments and all. ${ }^{[529]}$

Stanhope's dig evidently cleared only a small section of the site, which was soon recognised to extend outside the walls. For in 1864 Newman remarked that "beneath mounds of sand there must be other remains, perhaps of temples and palaces, but at present not even the outlines of a building can be traced."[530] In 1875 quarrying was in progress, and "marble pillars, inscriptions, and bits of architectural ornamentation, are constantly dug up, and all the good stones are carried to Jaffa or Gaza, and sold for modern buildings." [531] Industry was needed for such excavations, for a decade later Conder noted that up to ten feet still covered the ancient levels, "and the natives find fragments of fine masonry, shafts, capitals, and other remains of the old city, by digging in this." ${ }^{[532]}$ In 1857 Tobler found the site extraordinarily interesting, for its Crusader fortress, granite columns and huge quantities of debris, ${ }^{[533]}$ even after Stanhope's depradations. Caesarea was similarly rich: "so darf ich dennoch die 1821 gemachte Behauptung bestätigen, dass am ganzen Meeresufer von Ghaseh bis Berüt die 
Ruinen von Askalon und Kaisarieh die beträchtlichsten sind." ${ }^{[534]}$ In 1886 on the site of what might have been baths (was this where Stanhope had dug?), the locals found two colossal statues, each a monolith,

but as the Government had strictly forbidden to excavate, they immediately filled the pits up again, fearing that Europeans might come... and show them to the Government, which would be a confiscation of their property. ${ }^{[535]}$

This had not stopped the inhabitants at nearby Medjdel from plundering the site: "Les maisons sont en pierre; les matériaux précieux d'Ascalon sont entrés dans leur construction comme dans celle de la mosquée."[536]

\section{Gaza}

[Gaza] rivals Ascalon in this abundance of columns. They are dug up in every yard and garden, and they form every threshold and most of the lintels. From the narrow street you step over a puddle on to a marble column lying across a doorway ... a passage into the inner courtyard, large and paved with marble fragments, the open arcaded rooms on each side of it flanked by marble columns, dug up on the premises, with capitals Corinthian, Herodian, or Late Byzantine, the relics of church and temple together. ${ }^{[537]}[1881]$

Gaza, near to the sea and with an associated port, sat at the junction of trade routes, and was a prosperous and well-appointed city where, famously, Sampson brought down the columns of the Temple of Dagon. ${ }^{[538]}$ His supposed tomb was revered by Muslims, and the location of the gates which he carried away on his shoulders was pointed out to travellers. ${ }^{[539]}$ Its Great Mosque, we are informed, was built by Solomon, ${ }^{[540]}$ and other monuments were marble-rich, ${ }^{30}$ including a number of Christian monasteries. ${ }^{31}$ Its walls, wrote William of Tyre, showed it had once been a great city. ${ }^{[541]}$ From being the largest city in Palestine in the 17 th century (far larger than Jerusalem), it declined

30 Humbert 2000, 78-86: Gaza à l'époque musulmane. 82: the minbar of Ibn Othman mosque, built from planks of marble spolia. The exhibition naturally concentrates on portable items. 
to a population of some 16,000 in the mid-19th century. ${ }^{[542]}$ By this date Neale could complain of the degradation of buildings in the town:

Its houses are strangely constructed, consisting of a confused mixture of ancient and of the rudest modern architecture: ruins of magnificent palaces dating from the times of the Caliphs, rudely patched up with mud and brambles to shelter their present uncouth tenants; in the intervals appear the Bedouin's hut plastered with cow-dung, and the well-smoked tents of the Zingari or gypsy tribes. ${ }^{[543]}$

Marble was being unearthed at Gaza in the $15^{\text {th }}$ century, ${ }^{[544]}$ and in the later

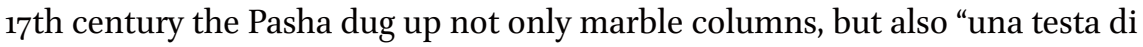
Porfido, elegantemente da mano eccellentissima lavorata, e con gli occhi di cristallo forto argentato, a guia di specchio, con parte del busto." ${ }^{[545]}$ Arvieux in 1735 was enthusiastic about the antiquities there: "la quantité prodigieuse de beaux marbres de toutes les espèces" was to be seen on every hand, and people could take what they needed, for little money. ${ }^{[546]}$ In 1673 Sandys noted modern roofs supported "with goodly pillars of Parian Marble, some plain, some curiously carved. A number broken in pieces, do serve for Thresholds, Jaums of doors, and sides of Windows, almost unto every beggarly Cottage." Little seems to have changed by the mid-19th century:

Occasional columns of marble or gray granite, scattered in the streets and gardens, or used as thresholds at the gates and doors of houses, or laid upon the front of watering-troughs. One fine Corinthian capital of white marble, lies inverted in the middle of a street running from north to south along the eastern foot of the hill. ${ }^{[547]}$

On the nearby hill were the walls of the old town, which were still traceable in the mid-19th century. ${ }^{[548]}$ Here was the governor's palace, and by 1783 the army barracks, "which was formerly the hotel of the knights, and a very excellent structure." ${ }^{[549]}$ Also here had been columns so large they had to be sawn before being shifted, to adorn a mosque on the plain. ${ }^{[50]}$ These perhaps came from the ruins of a palace Affagart identified there in $1533 \cdot{ }^{[551]}$ Columns of Africano were also reused to grace the main mosque; ${ }^{[552]}$ this was once a church, and there were others, also built from or decorated with spolia. ${ }^{[553]}$ Meyer writes of the spolia in (perhaps) a separate church. ${ }^{[554]}$ In 1861 Duray counted seven mosques, and reckoned they were all built largely from the remains of ancient monuments. ${ }^{[555]}$ Chauvet \& Isambert viewed the Great Mosque in 1882, with 
its blue-veined white marble columns, several with a (nearly effaced) cross on them. ${ }^{[556]}$ Wittman was told in 1803 that a now ruined mosque had been built in the previous century with materials carried to the site. ${ }^{[557]}$ These were frequently used as thresholds, as Sandys had noticed. ${ }^{[558]}$ Such diverse type of reuse attested, as Darboy observed in $185^{2}$, "à la fois la magnificence de l'ancienne ville et la pauvreté de la nouvelle."[559] Stephens came across similar ruins in 1838 ,

a mingled exhibition of ancient greatness and modern poverty... and the sculptured stones which once formed the ornaments of Roman palaces were now worked up into fences around holes in the ground, the poor dwellings of the miserable Arabs. ${ }^{[560]}$

Antiquities must have been plentiful, for Kinnear in 1841 came across one house where the roof of the apartment was supported by five Corinthian capitals of white marble, placed one above another. ${ }^{[561]}$

Anyone requiring more materials than were available at or very near the modern town could get them from ruins to the south as well as to the north, for example from Khan Neby Yunas, which still displayed various spolia as late as the 1880 s. $^{[562]}$ In every village he passed, Kinnear saw a similar re-use of antiquities, finding "the fragments of granite and marble pillars used in the construction of modern houses." ${ }^{\text {[563] }}$ There were even some inscriptions. ${ }^{[564]}$ The most fruitful Roman site was probably El Harish, south-west of Gaza, with Roman remains built into the fortress, ${ }^{[565]}$ as well as into the houses and cemetery; the remains of a temple were also to be seen, ${ }^{[566]}$ and an Egyptian sarcophagus was given to Bankes in $1816 .{ }^{[567]}$ In 1882 there were still plenty of spolia in evidence, some just lying on the ground together with large quantities of pottery, others built into modern houses. ${ }^{[568]}$ Gaza also sported marble shafts in one of its cemeteries, as well as some reused as posts on the race course. ${ }^{[569]}$

There was apparently little available to tempt collectors in the earlier 19th century ${ }^{[570]}$ Later in the century owners were still re-using inscribed stone slabs, still to be found, as Pickard writes in 1873, "in one of the numerous sandpits where excavating is carried on by the natives to obtain stone for building purposes." He chased down one to its new owner who

coolly told me that he had scraped the two largest! and the other, I suppose, not being large enough for the purpose required, was thrown aside, to share the same fate at some future time. However, after some difficulty I succeeded in getting it; this is the whole history of the stone. ${ }^{[571]}$ 
Statues were also to be found, one rescued upon its discovery in 1880 by a missionary, and sent to Istanbul, ${ }^{[572]}$ another perhaps built into a house wall, the owner wanted money before extracting and showing it, so nothing was done. ${ }^{[573]}$ Surely much remained to be found for, as Meyer wrote in 1907, "a site so well determined as this, in so promising a locality, where even surface finds have been more abundant than in most parts of Palestine surely suggests itself as a desirable one for excavation." ${ }^{[574]}$ Recent excavations have revealed a villa maritima, a Roman temple, and mosaics. ${ }^{32}$

Sailing down the Syrian coast in Antiquity must have presented a nearcontinuous spectacle of temples and colonnades, as well as luxurious villas outside the towns, known to us today in Roman frescoes of the Campanian seabord. From the amounts of antique material re-used by Muslims and then Crusaders, much must still have been visible on the surface, still standing if not earthquake-collapsed, or easily available under soil or sand. Apart from some lavishly decorated rooms, the Crusaders appear to have taken little interest in what they found, except as building materials, although it is possible that the Venetians (remembering the mis-labelled "pilastri acritani" which came from Constantinople) extracted Syrian antiquities to beautify their city.

32 Humbert 2000, Gaza: Archaeological remains include a villa maritima, a Roman temple (117-120) and a Byzantine church at Jabaliyah, with several mosaic floors, discovered and rescued in 1996-7, found during road work (121-135). Splendid mosaics survive, and allow the drawing of a plan of the various buildings, because the walls have been robbed out.
[1] Gasparin_1866_287
[2] Shaw_1808_II_11
[3] Beaujour_1829_374
[4] PEFQS_1881_182
[5] Wortabet_1856_I_8
[6] Casola_1907_253
[7] Chantre_1889_228B
[8] Morone_1669_I_402
[9] Neale_II_1851_140
[10] Drummond_1754_218
[11] Salmon_1738_300
[12] Drummond_1754_226
[13] Farley_1872_181-182
[14] Volney_II_1792_194
[15] Porter_1868_I_xxvii
[16] Kelly_1844_276
[17] Squire_1820_352
[18] Aucher-Éloy_I_1843_80
[19] Neale_II_1851_142B
[20] Smith_1840_24
[21] Laorty-Hadji_1854_118
[22] Neale_II_1851_143-144
[23] Prime_1855_II_331
[24] Wortabet_1856_I_20
[25] Eyriès_1859_336
[26] Oberhummer_\&_ Zimmerer_1899_103
[27] Smith_1918_16B
[28] Naval_Staff_1919_687
[29] Beaujour_1829_347
[30] Murray_1917_8-11
[31] Griffiths_1805_314

\footnotetext{
[32] Drummond_1754_225

[33] Drummond_1754_225B

[34] Parsons_1808_30

[35] Robinson_1838_392

[36] Robinson_1838_393

[37] Layard_I_1903_223

[38] Aucher-Éloy_I_1843_83

[39] Lycklama_a_Nijeholt_ 1875_327

[40] Lycklama_a_Nijeholt_ 1875_326-327

[41] Lycklama_a_Nijeholt_ 1875_327-328

[42] Bourquenoud_186o_ 11-13

[43] Neale_II_1851_74-75
} 


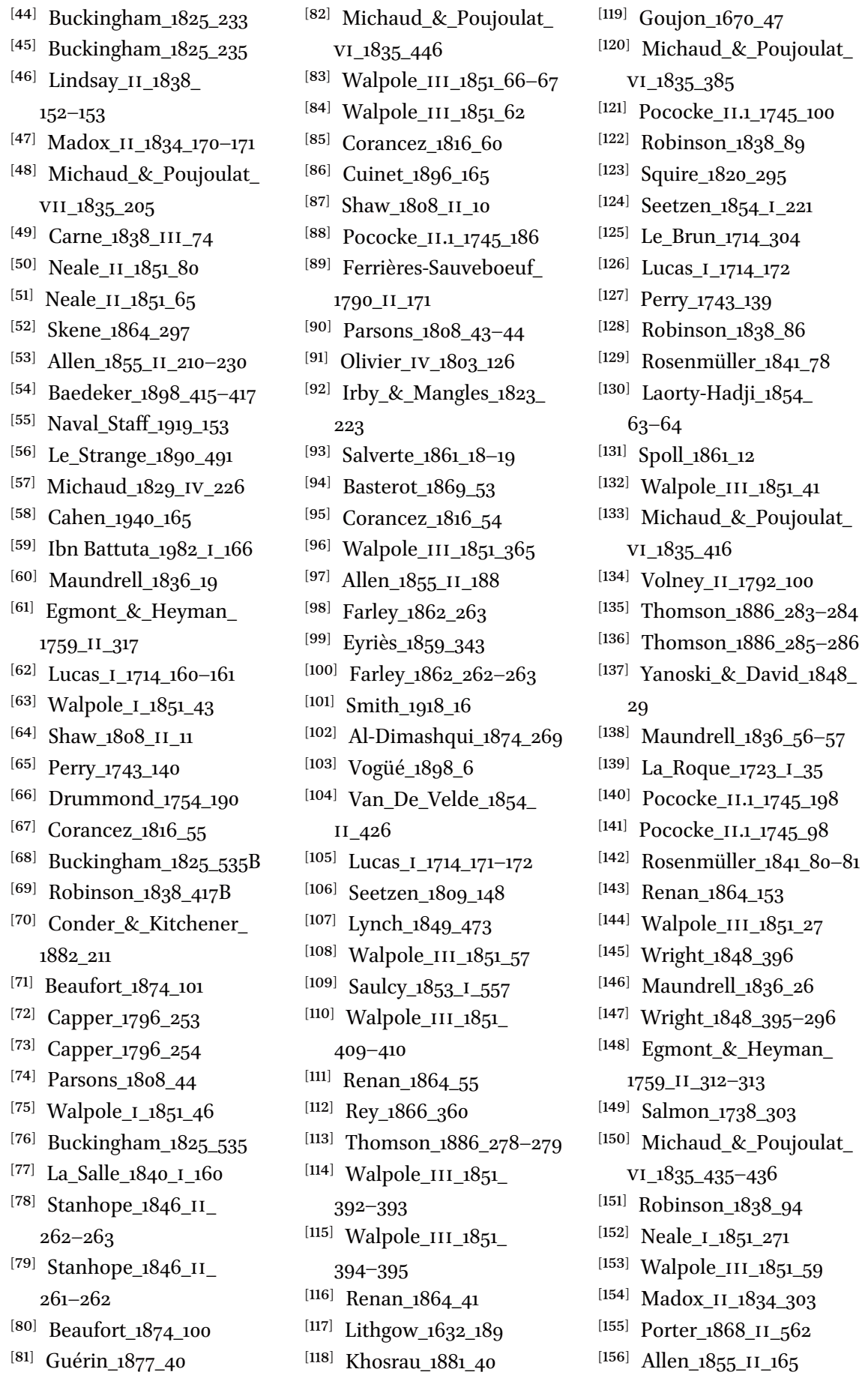




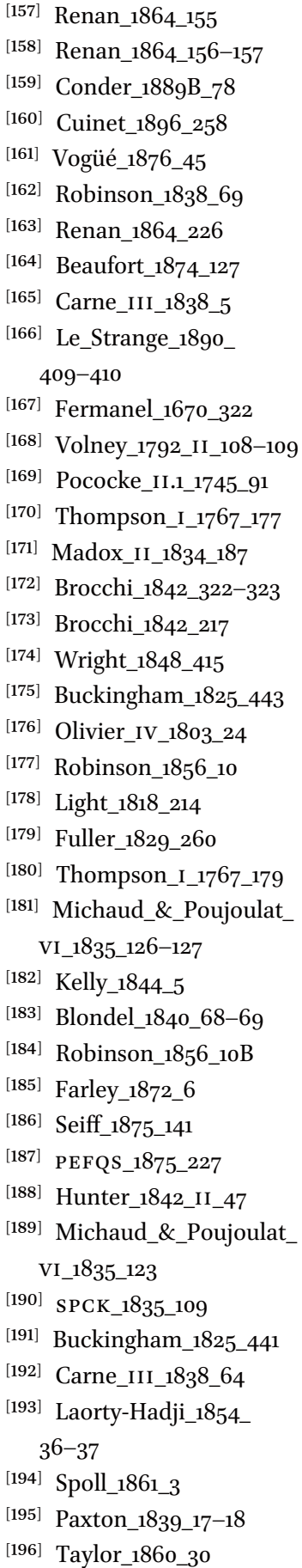

[197] Walpole_I_1851_50

[198] Darboy_1852_385-386

[199] Marquise_de_L_1866_75

[200] Beke_1862_77

[201] Seiff_1875_138

[202] Guérin_1877_41b

[203] Jessup_1910_

Frontispiece

[204] Lortet_1881_6-8

[205] Skene_1864_192

[206] Wright_1848_420

[207] Thompson_I_1767_182

[208] Browne_1799_373

[209] Madox_II_1834_354

[210] Goujon_1670_54

[211] Lortet_1881_5

[212] Broquière_1892_ xxxvi-xlii

[213] Pococke_II.1_1745_86

[214] Fleming_1915_59-6o

[215] Naud_1702_535

[216] Lusignan_1783_174-175

[217] Leandro_1753_43

[218] Richter_1824_363-364

[219] Maundrell_1836_76

[220] Fermanel_1670_326

[221] La_Roque_1723_I_6

[222] Marcellus_1839_I_389

[223] Jones_1836_314

[224] Rosenmüller_1841_88

[225] Turner_1820_II_95

[226] Light_1818_208

[227] Beaujour_1829_339

[228] Blondel_1840_254

[229] Ward_1864_226-227

[230] Cuinet_1896_72

[231] McCabe_1875_1082

[232] Kelly_1844_303

[233] Wilson_1848_412

[234] Eyriès_1859_345

[235] Tristram_1865_43

[236] Joanne_1861_718

[237] Browne_1799_370

[238] Curtis_1903_189B
[239] Turner_1820_II_90-91

[240] Spilsbury_1823_15

[241] Osborn_1858_153

[242] Valiani_1828_43

[243] Brocchi_1842_72

[244] Stewart_1857_468

[245] Merrill_1881_521

[246] Beaufort_1874_144-145

[247] Butler_1930_70B

[248] Curtis_1903_189

[249] Contenau_1920_20-21

[250] Renan_1864_409

[251] Luynes_1874_I_21

[252] PEFQS_1888_9-15

[253] PEFQS_1887_202

[254] PEFQS_1887_201

[255] PEFQS_1887_254

[256] PEFQS_1888_14-15

[257] Massenot_1873_29

[258] Lycklama_a_Nijeholt_ 1875_353-354

[259] Leroux_1882_54

[260] Haussmann_de_ Wandelburg_1883_ 253-254

[261] Curtis_1903_188-189

[262] Jowett_1826_129-130

[263] La_Salle_1840_I_257

[264] Massenot_1873_32

[265] Buckingham_1825_393

[266] Baedeker_1876_456

[267] Richter_1824_362-363

[268] Rosenmüller_1841_91

[269] Prime_1855_II_325-326

[270] Prime_1855_II_324

[271] Ward_1864_222

[272] Howe_1854_138

[273] Guérin_1872_427

[274] Seetzen_1859_IV_ 293-299

[275] Olivier_IV_1803_54

[276] Thompson_I_1767_194

[277] Laurent_1873_25

[278] Stevenson_1907_115 


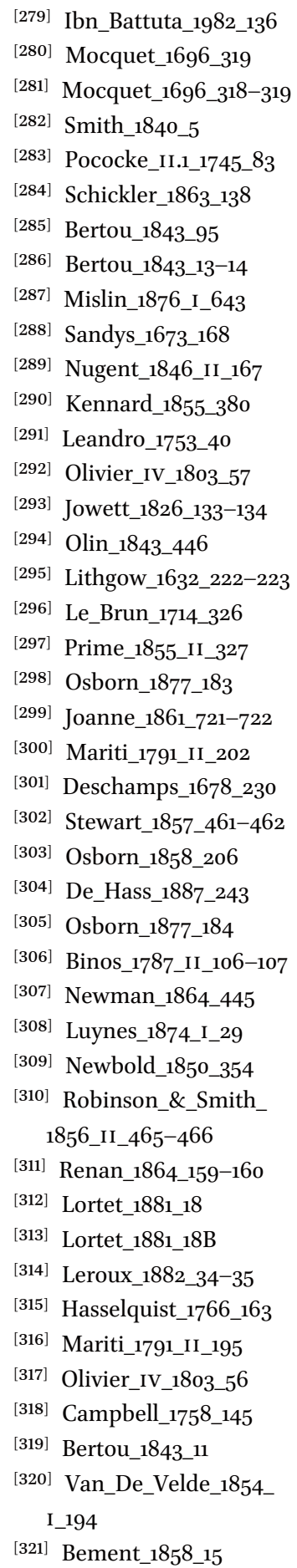

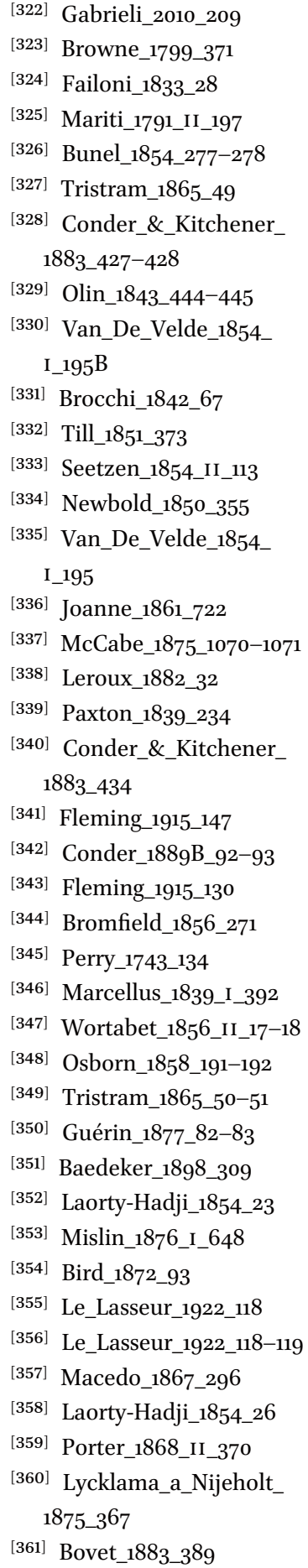

[362] Cuinet_1896_27

[363] Kinnear_1841_233

[364] Brocchi_1842_69-70

[365] Newman_1864_453

[366] Prime_1855_II_330

[367] Thompson_I_1767_196

[368] Howe_1854_136

[369] Tobler_1859_32-33

[370] Stephens_1838_II_108

[371] Renan_1930_215

[372] Durbin_1845_II_43

[373] Durbin_1845_II_43-44

[374] Sandys_1673_16o

[375] Le_Strange_189o_328

[376] Broquière_1892_28

[377] Broquière_1892_27-28

[378] Mariti_1791_II_83

[379] Niccolò_1945_69

[380] Robinson_1856_96

[381] Lusignan_1783_179-180

[382] Pigeory_1854_472-473

[383] Bramsen_I_1820_292

[384] Smith_1840_12

[385] AMS_VII_1872_418

[386] Vitri 1896 XCIX

[387] Le_Strange_1890_334

[388] Doubdan_1661_522

[389] Naud_1702_641

[390] Goujon_1670_62

[391] Thevenot_1689_669

[392] Maundrell_1836_91-92

[393] Arvieux_I_1735_270-271

[394] Robinson_1856_100

[395] Jolliffe_1819_20

[396] Le_Brun_1714_314

[397] Mariti_1791_II_91

[398] Buckingham_1822_I_148

[399] Delaroière_1836

\section{$133^{-134}$}

[400] Jones_1836_309-310

[401] Newbold_1850_354-355

[402] Volney_II_1792_57

[403] Volney_II_1792_6o-61

[404] Lammens_1921_II_

$$
113^{-114}
$$




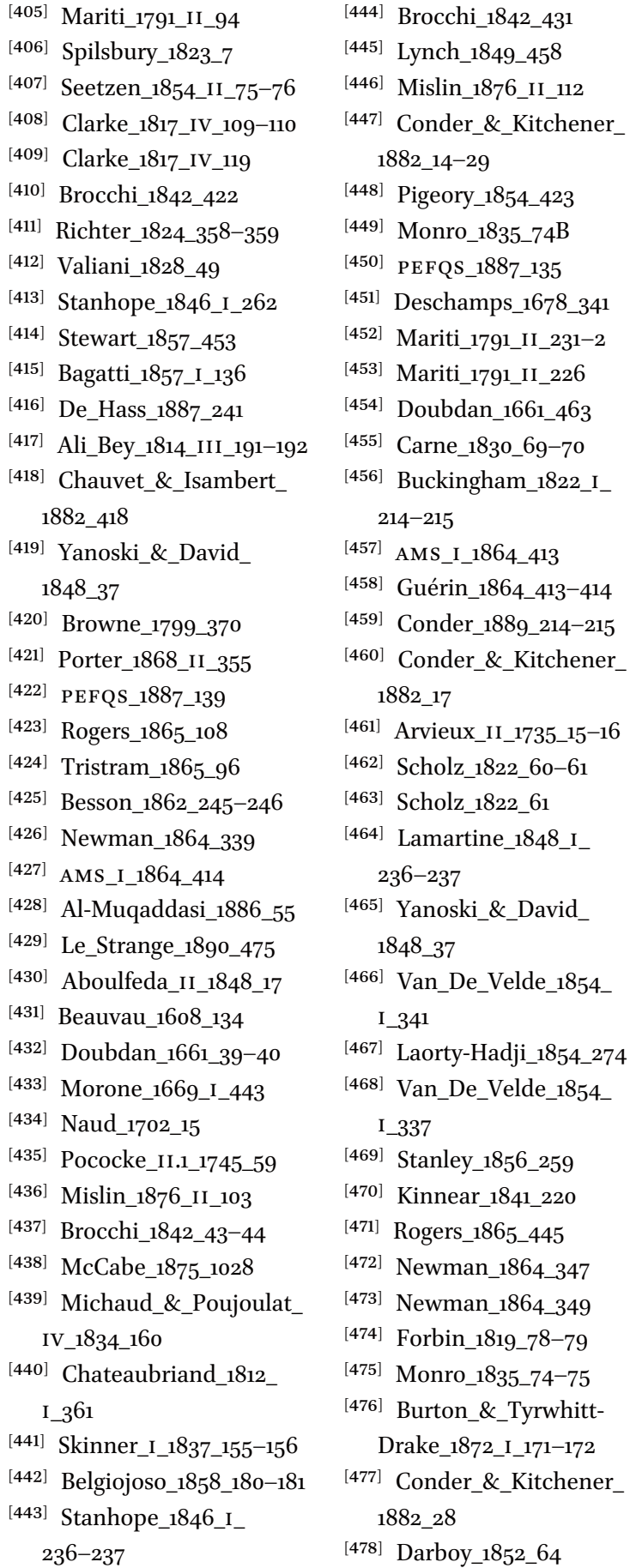

[479] Laorty-Hadji_1854_272

[480] Casola_1907_235

[481] Smith_1840_9-10

[482] Terhune_1896_308

[483] Terhune_1896_308

[484] Marmier_III_1852_31

[485] Farley_1872_328-329

[486] Macleod_1866_77

[487] Naud_1702_22

[488] Brocchi_1842_437

[489] Stanhope_1846_I_195

[490] Saint-Aignan_1864_16

[491] Michaud_\&_Poujoulat_

IV_1834_162-163

[492] Rogers_1865_18

[493] Guérin_1868_6

[494] Jollivet-Castelot_ 1878_12

[495] Richardson_1822_II_155

[496] Smith_1918_15

[497] Damer_1841_I_268-269

[498] Berners_1876_79

[499] Van_De_Velde_1854_ II_178

[500] Le_Strange_1890_401

[501] Pringle_1984_143

[502] Ibn_Battuta_1982_ 133-134

[503] Naud_1702_508-509

[504] Arvieux_II_1735_72

[505] Chauvet_\&_Isambert_ 1882_217

[506] Jolliffe_1820_212-213

[507] Jolliffe_1819_134

[508] Munk_1845_62-63

[509] Duray_1861_15-16

[510] Conder_\&_Kitchener_ 1885_173

[511] Baedeker_1898_144-145

[512] Porter_1868_I_256

[513] Cuinet_1901_675

[514] Naud_1702_510-511

[515] Morone_1669_I_471

[516] Morone_1669_I_471B 


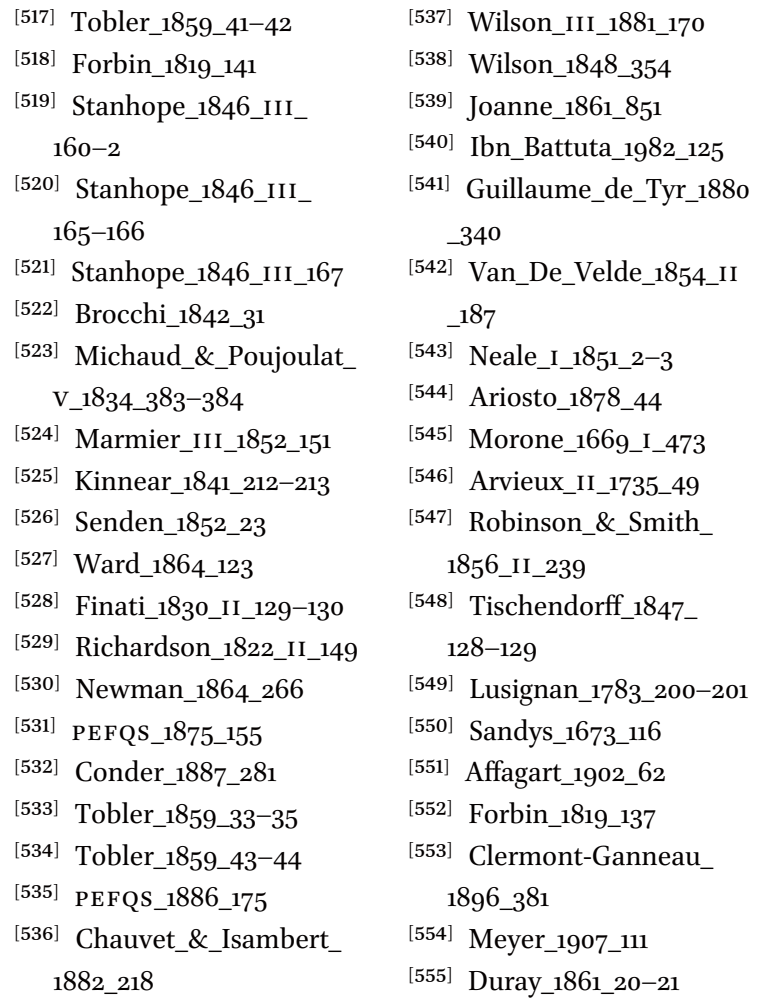

[556] Chauvet_\&_Isambert_ 1882_205

[557] Wittman_1803_192-193

[558] Brocchi_1842_28

[559] Darboy_1852_71

[560] Stephens_1838_II_109

[561] Kinnear_1841_209

[562] Salvator_1881_62

[563] Kinnear_1841_205

[564] Hamilton_1875_47

[565] Salvator_1881_36

[566] Salvator_1881_40

[567] Finati_1830_II_126

[568] Chauvet_\&_Isambert_ 1882_206

[569] Meyer_1907_154

[570] Michaud_\&_Poujoulat_

V_1834_412

[571] PEFQS_1873_157

[572] Conder_\&_Kitchener_ 1883_254

[573] Clermont-Ganneau 1896_431

[574] Meyer_1907_152 


\title{
Aleppo and the North
}

\begin{abstract}
Aleppo
I have seen, at times, as many as one thousand camels leave Alexandretta for Aleppo in one day, bearing high aloft upon their backs two thousand Manchester iron-bound bales of twist and manufactures, a proud sight for the Englishman to meet. ${ }^{[1]}[1851]$
\end{abstract}

Aleppo, ${ }^{1}$ with some $90,000-100,000$ inhabitants in 1876 , and perhaps 250,000 in 1910, and "a town so Europeanised that it would be superfluous to describe it," ${ }^{[2]}$ was and still is the most populous city in Syria, and on the routes of many travellers. ${ }^{2}$ It possessed many fine buildings, most built from the local stone,$^{3}$ and developed from an ancient into an Islamic town. ${ }^{4}$ And although some Westerners saw it as a town plan degraded since Roman times, ${ }^{5}$ in the 18th century they appreciated both its architecture and its easy-going atmosphere. ${ }^{[3]}$ Because it was an entrepôt between East and West, ${ }^{6}$ this commercial hub was also the most westernised 7 before the rise of Beirut toward the end of the $19^{\text {th }}$ century. ${ }^{8}$ Its buildings (with mostly Christian masons, as

1 Gaube 2007.

2 Yerasimos 1991, 72-76 for internal route for travellers, 14th to 16 th C via Aleppo and Damascus. Hadjar 2000 for ten illustrated walking tours, with ground-plans and fold-out maps. Highly recommended.

3 Watenpaugh 2004 235, for the Ottoman reorientation of the Mamluk city centre.

4 Neglia 2009, 175-207: La città spontanea. La medievalizzazione bizantina e la nascita della città islamica.

5 Watenpaugh 2004 18: "Sauvaget's work assumed the Hellenistic-Roman grid-plan city as an ideal type and ascribed a moral superiority to this type... his history of Aleppo demonstrated the slow and inexorable degeneration of this ideal type, which reached its lowest point during the Ottoman period. As such, Sauvaget viewed the history of Aleppo as a moral parable which demonstrates, ultimately, the superiority of the European cultural ideal."

6 Fusaro 2015, 79: "the key to trade with Persia and beyond." Ibid. 209 for English merchants and their organisation.

7 Raymond 1985; Raymond 1998; Eldem 1999.

8 Marcus 1989 for 18 thC cultural, religious, economic and political history, but scarcely anything on architecture. 
throughout Syria) were of the local limestone, ${ }^{9}$ and the town's cleanliness was frequently remarked upon by visitors. Christians were well-treated here, ${ }^{[4]}$ and Drummond exclaimed in 1754 that it was "the fairest and best built town I have yet seen in the Turkish dominions."[5]

This was a town with 272 mosques, 64 bath-houses and 77 bazars in the mid18th century. ${ }^{[6]}$ Aleppo's commercial prosperity, part dependent on foreign establishments, some of which shipped home antiquities, ${ }^{10}$ declined (along with the Levant Company) in the 19th century. ${ }^{[7]}$ The consequence was that by mid-century the twenty British trading houses of the $1770 \mathrm{os}$ had declined to two. ${ }^{[8]}$ The 1822 earthquake devastated the city. The physical devastation was not cleared for several years, ${ }^{[9]}$ but the effect on administration lasted much longer. ${ }^{11}$ Note that the quotation heading this account writes of imported manufactured goods from the West, rather than exporting exotic goods arriving from further east, hence the decline in foreign trading houses as trade switched around. After World War I, prosperity declined again as France, "seeking to remold its new Syrian colony into an economic appendage," strangled local textile production. ${ }^{12}$ These events are well documented in the archives. ${ }^{[10]}$

No ancient building survived in the city. Aleppo's most prominent landmark was its citadel, ${ }^{13}$ with more than one commentator suggesting it had antique fortifications improved in the 1oth century. ${ }^{[1]}$ The site boasted a domed Mamluk throne hall, built after 1400, with floor mosaics and ablaq wall decoration, largely destroyed in the 1822 earthquake, with parts rebuilt in the course of the last century. ${ }^{14}$ When Walpole entered in 1851 he found "nothing standing save a mosque and the powder magazine. One sarcophagus I saw, and the remains of several columns; some thrown about, others that have been ruined,

9 Nour 1982, 137-154 for buildings; ibid. 145: "Aleppo limestone is easily worked, and compact, and acquires over time a polish and an ivory tint."

10 Laidlaw 2010, 114, Levant Company: "In the 1740s, Alexander Drummond writes of shipping home as a gift to the Duke of Argyll an inscribed stone that had been picked up near Palmyra and later presented to Drummond by a fellow Scot... clearly many other such artefacts were brought to Britain during the lifetime of the Levant Company in the personal collections of officials, merchants and chaplains alike." Ibid., on the trade and eventual decline of the Levant Company.

11 Knost 2010: administration of waqf endowments.

12 Quataert 2005, 127.

13 Gonnella 2007; Rabbat 2010, 59-71: militarisation of taste in medieval Bilad al-Sham including citadel of Aleppo.

14 Gonnella 2005, Gonnella 2006 for Ayyubid, Mamluk and Ottoman architecture in the Citadel; Gonnella et al. 2007, Gonnella 2012; Behrens 2012, 330-331 for bibliography of Mamluk architecture in Syria and the Hijaz. 
having been built a second time into the modern buildings." ${ }^{[12]}$ Twenty-five years later, nothing had improved: it was now "un triste amas de décombres, de maisons ruinées, de petits cimetières dévastés" - a whole town within a town devasted in 1822 , and not rebuilt. ${ }^{[13]}$ Robinson explored the site in 1838 , noted in the stores several thousand arrows, plus helmets and armour, suggesting that they might date back to the Crusades. ${ }^{[14]}$ Michaud \& Poujoulat had explored there three years earlier, and confirmed the ruination within, and the uselessness of the citadel for defence:

La même insouciance des Turcs pour tout ce qui tend à conserver et à réparer, a été un obstacle à faire enlever les décombres du château et à sa reconstruction. Dans son état naturel, il ne peut plus être considéré comme une forteresse, ne présentant plus que des ruines et des débris. ${ }^{[15]}$

Disinterest unfortunately continued, and Gallois in 1907 witnessed the continuing destruction, especially of the glacis, for building materials:

La vieille citadelle... dont les pentes maçonnées servent aujourd'hui de carrière, sans que le gouvernement intervienne en quoi que ce soit; il est vrai qu'il laisse même prendre des matériaux dans la forteresse elle-même. ${ }^{[16]}$

One of the puzzles surrounding our travellers is how few set out to visit the Muslim antiquities of the town, which Burns quite correctly divides into ten itineraries (which "only touch the surface") taking a minimum of three days. ${ }^{15}$ He indexes eight khans, ten madrasas, and twenty-two mosques. This was a city nearly always assessed as safe and friendly; it had paved streets and some pavements; there were plenty of European merchants, plus a whole range of consuls. The khans were certainly popular with foreigners, but we learn little about their architecture.

\section{Antioch}

Antioch was one of the great cities of the Byzantine Empire, ${ }^{16}$ and its magnificence was already described by a native, Libanius (314-ca.392, and writing

15 Burns 2009, 37.

16 Todt 2004 for Antioch in the Byzantine period; Cahen 1940, 127-133 for Antioch in the Middle Ages; Carita 2004, 69-82 for Antioch, including layout, and some Byzantine descriptive sources; Ten Hacken 2006 for a mediaeval description. 
355 ff). Thanks to the marble "from all the corners of the world," the city had "beautiful buildings which illumine our city like stars." [17] There were colonnades of gleaming marble sufficient for three cities, ${ }^{[18]}$ "separated by an uncovered street, paved all the way across," and because of the size of the city a carriage would be needed to go from one end of the city to the other. ${ }^{[19]}$ The city and its territory boasted prestigious churches. ${ }^{17}$ Even discounting the hyperbole, Antioch was once a magnificent city, but would become, like Apamea, a clear case of urban recession. ${ }^{18}$ Much was known of it in Antiquity, and it featured prominently in the Crusades (falling to Islam in 1289), although little is known of the city other than via literary sources. ${ }^{19}$

When our post-mediaeval travellers visited Antioch, she was landlocked because there was then no serviceable port. Both port and town were in ruins, with a very small population (perhaps $5,000-6,000$ in $1841^{[20]}$ ). Most of her monuments were deeply buried, and with the population occupying "un petit espace dans l'enceinte de l'antique cité."[21] Already in 1743 one traveller found it a "wretched scurvy Hole,"[22] and 19th-century plans of the city show only a small section within the walls occupied, with a larger section given over to orchards. Gone are the great straight streets and the colonnades. As late as 1919 "the narrow streets, many of which are impassable for wheels, have comparatively broad side-walks, separated by a deep depression for the reception of garbage. There are some streets, however, through which wheel traffic can pass." ${ }^{[23]}$ Nothing had changed since 1881, when Ellis reported on the general dilapidation. ${ }^{[24]}$

Antioch was devastated several times by earthquakes, its monuments stripped (marble went to Damascus, according to Masudi ${ }^{[25]}$ ), and never rebuilt, while some columns and blocks were (as usual) built into later houses. ${ }^{[26]}$ Thus Veryard in 1701 could write that it "at present hardly merits the Name of a Village."[27] In 1856 it was "a small dilapidated place, with few ruins to mark its former splendour," and the small population where once had lived "upwards of a quarter of a million" ${ }^{[28]}$ was gathered along the banks of

17 Mayer \& Allen 2012: churches of Syrian Antioch. 261-267 Table with chronology 284-641. There were some large churches, e.g. cruciform at Qausiyeh near Antioch, figs 7 \& 57, with remains of some spectacular mosaic floors; impressive floors at Machouka, figs 6o-78.

18 Wickham 2005, 620-621: "several earthquakes, and a Persian sack... the eclipse of the city in the early Arab period... the weakening of the eastern Mediterranean exchange network as a whole... The maritime cities of the north of our region are thus the best candidates for an overall picture of early deurbanization, by $65^{\circ}$ at the latest." Castellana 2011, 245-256: La strada diretta tra Antiochia e Apamea.

19 Edmund Spenser Bouchier's A short history of Antioch $300 B C-A D$ 1268, (Oxford 1921) was written from literary sources, and was not interested in its later history. 
the river, ${ }^{[29]}$ a good indication of what had happened to the aqueducts. If the inhabitants were reported in 1745 to be dismantling a Christian basilica, ${ }^{[30]}$ by the late 18 th century they were apparently living in mud and straw houses, ${ }^{[31]}$ evidently not willing or able to find and reuse the stones in the ground, instead building with light materials which Robinson in 1838 thought were used specifically to mitigate the effect of earthquakes. ${ }^{[32]}$ (Merchants at Aleppo decamped to lightweight structures when they thought another earthquake was imminent.) An earthquake had struck the previous year, in 1837, and Fletcher compared its almost deserted, still and silent streets to a Pompeii, "abandoned by all living beings except a few travellers or sight-seers." [33]

After the 1872 earthquake "permission was then granted to the inhabitants to use the fine limestone of the ancient town-walls in rebuilding their houses, so that little is now left of the wall in the plain." ${ }^{[34]}$ This might well have happened, but Neale reported in 1851 that already Ibrahim Pasha "in his attempts to beautify the modern city" blew up "almost every particle that remained of the original walls of the city." He built a ten-thousand-man barracks and a palace for himself, from the plentiful spolia, and Neale recorded with indecent delight that "these modern fabrics, built not fifteen years ago from the spoil of monuments destined to commemorate the prowess and piety of the Crusaders, are already in a tottering and dilapidated state."[35]

The walls had indeed been whittled away, probably for centuries, Ibn Battuta for example saying Baybars dismantled them. ${ }^{[36]}$ Michaud counted $5^{2}$ towers in them in 1835 , but originally there were $130,{ }^{[37]}$ and some of these were splendid: "celles de la partie méridionale ou grandes tours ont quatre ou cinq étages; quelques-unes possèdent jusqu’à vingt chambres réparties avec un art admirable." ${ }^{[38]}$ Hence were lost "perhaps the very finest specimen extant of ancient crusading fortification," which the PEF reported in 1886 as a freefor-all: "Every one who wants a hewn stone goes to the ancient walls for it, as the Turkish authorities make no sign of prohibiting the spoliation.. ${ }^{[39]}$ The PEF summarised the situation the following year:

When perfect these walls enclosed a space of seven miles. Now, under Turkish auspices and Turkish rule, the whole of the walls on the slopes or face, as distinguished from the top of Silphius, with their towers and bastions, have altogether disappeared. Multitudes of the finest stones have been transported across the river, and appear as gravestones in the great Turkish cemetery; others have gone to construct a modern barrack ... So the work of destruction begun years ago is still going on, and ere long what might justly have been regarded as one of the wonders of the world will be matter of history only. ${ }^{[40]}$ 
The old strong walls were no use for the modern village, although "on pourrait former avec les murs de l'ancienne un camp retranché, pour servir d'asile à une armée qui voudrait conquérir ou défendre le pays." ${ }^{[41]}$ Neale reported that after a storm small children would fish in the gutters with sticks, "sweeping up and clearing away the mud, and earnestly occupied in hunting for antiques,"[42] so evidently antiquities were washed from higher ground down to the villagetown by the river. In 1682 Febvre recounted the effect of a recent storm (not an earthquake) in which nearly 200 died, and which revealed "dans les ruines \& à travers les pierres quantité de médailles anciennes fort curieuses \& de divers métaux d'or, d'argent, \& de cuivre que les Turcs vendent pour l'ordinaire aux Francs." ${ }^{[43]}$ Two hundred years later, heavy rains were still revealing marble pavements and small antiquities, ${ }^{[4]}$ and sarcophagi were being retrieved from the adjacent lake. ${ }^{[45]}$

\section{Cyrrhus \& Menbij}

$76 \mathrm{~km}$ north of Aleppo, and nearly at today's Turkish border, Cyrrhus was founded by Seleucus I Nicator as part of the division of Alexander's empire, and was important in Roman and Byzantine days, when it was the seat of a bishop under Menbij/Manbij/Bambyce, 88km from Aleppo. Both sites were fortified by Justinian, but the latter has lost most of her monuments, because the town stood at a busy set of several crossroads. Cyrrhus, on the other hand, is on no main road, certainly not on any popular route between Asia Minor and Syria, which is why its monuments survived and those of Menbij did not. Neither site is on any of the standard 19th-century or early 2oth-century guidebook itineraries. When Maundrell visited in 1697 it was part of a round tour from Aleppo, first across the Euphrates to Beer, and then back and north-west to Cyrrhus.

Both sites were well known from ancient accounts, so travellers knew what to search for. Menbij was well known to mediaeval Muslim authors. ${ }^{[46]}$ It was described by Drummond in 1747 as having "miserable vestiges," but he did admit that it three miles of walls were "extremely well built of finely polished stone, six feet thick, with square towers and bastions in the old manner," and that the whole area was characterised by impressive subterranean aqueducts [qanats]. ${ }^{[47]}$ Volney, half a century later, was peeved there was no remaining trace of the Temple of Atargatis about which he had read in Lucan, and also mentions the extensive water supply. ${ }^{[48]}$

In 1699 Maundrell visited the site, noting only several "fragments" of the walls, and at the east gate "another piece of eighty yards long, with towers of large square stone extremely well built." He also found "a stone with the busts 
of a man and woman, large as the life; and, under, two eagles carved on it. Not far from it, on the side of a large well, was fixed a stone with three figures carved on it, in basso relievo,"[49] which was still there when Drummond arrived. Pococke had already given a better account fo the town's walls (stairs, towers, chemin de ronde ${ }^{[50]}$ ), so it seems that Drummond did not inspect their whole extent, because his account implied that the circuit of walls was complete. He identified "the walls of a superb square building" as the temple, and in it found the base of what he called an altar ${ }^{[51]}$ (is the wish here father to the deed?). He then took Maundrell to task for writing of a "deep pit," and castigated him as ignorant of architecture:

Any man, the least conversant in drawing, will at once perceive that this must have been a theatre. Almost all the benches remain, and the arena now produces very good pot-herbs for the convenience of a farmer and his family. ${ }^{[52]}$

Menbij was settled with Armenian and Circassian refugees early in the last century and, if true to the form reported elsewhere, helped destroy what antiquities then remained.

To the north-west of Menbij was Cyrrhus, with, as Yakut wrote c.1225, "many remains of antiquity lying near it. It is ruined now, but there are many fine relics of the past." [53] And so it remained when Maundrell assessed it in 1699, for there were no large towns nearby and the site ("a wild and romantic setting," writes Burns) is still not on a main road. It was "walled very strongly with huge square stones," and inside were to be seen the "pillars, \&cc., of many noble buildings," including what he thought was the cathedral (since he knew the town was the seat of a bishopric). He also described amidst other smaller tomb monuments the hexagonal Roman tower tomb ("a fine architrave all round just under the cupola, having had heads of oxen carved on it"[54]), and taken over in 1303 by al-Nabi Huri, which gives the site its current name. He only "conjectured" one building complex as a cathedral, while Drummond, enthusiastically contrarian, identified a basilica, claiming Maundrell was wrong because he identified no altar, nave or cloister. Yet his foe might have meant the adjacent complex to the west, which Drummond did not bother with: "A noble row of pillars, of great length, has led to another grand building, but I really do not know of what sort, and I will not trouble you with idle conjectures."[55] Perhaps he stubbed his toe (or head) somewhere, for to the south he disparaged "the bridge that consists of six mean arches, which will, probably, foon go to ruin." There were in fact seven arches, and another Roman bridge close by, both described by Maundrell: 
A bridge of seven arches, of a very old structure, over the river Sabon; and about a quarter of a mile further we came to another bridge of three very large arches... They were well paved on the top with large stones. ${ }^{[56]}$

\section{Dead Cities}

The abandoned villages of Syria are innumerable; hardly ever is the traveller out of sight of their ruins; on the maps of Palestine no designation is more frequent than "Khirbet," which means a ruined, forsaken hamlet. Ancient or recent, these fragments of desolation are the most damning witnesses to the insecurity of the land under Oriental rule. ${ }^{20}$ [1918]

The Dead Cities is the accepted modern name for groupings of towns and villages deployed on the three groups of hills on the limestone massif to the west and south of Aleppo, between Cyrrhus and Apamea, the Jebel Semann, Jebel al-Ala and Jebel Riha. ${ }^{21}$ They were placed on the World Heritage list in 2011, and the citation explains their importance. ${ }^{[57]}$ Apparently first settled in the time of Christ, the main expansion is in the mid-4th to mid-6th centuries, with decline from the 8th century. ${ }^{22}$ Ali Bey, travelling from Aleppo toward Antioch in 1814, fell over antiquities at every step, "des fragments de corniches et d'autres ornements d'architecture, amoncelés avec des pierres brutes, qui servent à présent de clôtures aux terres, ainsi, que des fragments de colonnes employés à couvrir les puits." ${ }^{[58]}$ Callier covered the same ground in 1835 , noticing "quelques villages disséminés qui présentent l'aspect de châteaux en ruines; de hautes tours délabrées servent aux habitans de forteresses," and apparently concluding that close approach could be dangerous. ${ }^{[5]}$

Early travellers read the plentiful Greek inscriptions, but De Vogüé in the 186os was perhaps the first to use church inscriptions to intuit the decline of these settlements, because that was when inscriptions ceased. But he also helped along the hare that it was the Muslim invasion that caused such decline:

\footnotetext{
$20 \quad$ Smith 1918, 39.

21 Strube 1996, on the Dead Cities, 72-75: Hausbauten in der Antiochene und Apamene.

22 Castellana 2011, 147-175 Alla ricerca di antichi villaggi nella Siria Settentrionale; Strube 1996, 24-29 for the Roman period 1-3rdC; ibid. 30-34 for late antique and Byzantine period 3-4thC; ibid., 76-89 for prosperity and decline - Blütezeit und Beginnen der Niedergang - 6thC. Gerster 2003, 35-51: aerial images of some of the sites.
} 
mais la population elle-même paraît avoir brusquement abandonné ces montagnes pour se concentrer dans quelques villes. Cette révolution subite ne peut avoir été amenée que par l'invasion musulmane. ${ }^{[60]}$

Butler also found in these towns "buildings in a simple form of polygonal masonry with heavy moldings at the top of the walls and massive door frames," and struggled hard to believe that these could be much older than the datable temples and churches. ${ }^{[61]}$

As for such sites' decline, invasion is an answer to everything, of course: but De Vogüé and other invasionists do not stop to wonder why Muslims should drive people out of productive settlements. There were further villages to the east of Aleppo, described by Sir Eyre Coote in $1780^{[62]}$ and, indeed, all around that city. Baron Taylor wrote of them in 1854, noting that the débris "se composent presque tous de blocs énormes qui rappellent Balbeck et Alexandrie de

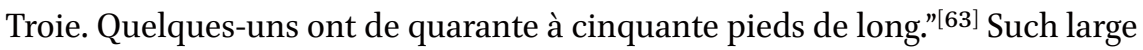
blocks in one of the dead cities, possibly Khirbet Hass, "had been arranged so as to form inclosures for herds of sheep and goats, which were now spread over the plain grazing, under the protection of armed villagers from the surrounding villages."[64]

Scholars continue to argue about the reasons for the decline in population, which left hundreds of houses and churches looking (as was frequently remarked by travellers) as if their occupants had just walked out of the door, ${ }^{[65]}$ and as if the sculpture was carved only yesterday. ${ }^{[66]}$ These sites have been the object of extensive research since World War II, Tchalenko printing plans, and with details of houses, sanctuaries, towers, baths, quarries, cisterns etc., dealing with possible reasons for decline, and noting that currently inhabited villages are mostly out on the plains, and abandoned antique sites on the massif.. ${ }^{23}$ He has also compiled a catalogue of convents, and analyses. ${ }^{24}$ Georges Tate has continued this tradition of exacting scholarship, with a very well illustrated survey of 700 villages, subtitled Un exemple d'expansion démographique et économique à la fin de l'antiquité, but not solving the question of the reason(s)

23 Tchalenko 1953, profusely illustrated with maps and plans. I.1-54 for antiquity; I.377-438 Une civilisation rurale. 431ff for 7 thC decline, and depopulation with Arab conquest, explained 435: les relations maritimes sont définitivement rompues, la Méditerranée est fermée au commerce syrien. Rodinson 1961: examination of Tchalenko's work. Castel et al. 1997 for housing in Syria up to Islam. 
for abandonment. ${ }^{25}$ His recent book on Serjilla extends this documentation by cataloguing every building. ${ }^{26}$ For Callot, who has catalogued the evidence for the olive oil industry in the dead cities, the abandonment was not because trade was cut off, but to enjoy an easier life on the plains. ${ }^{27}$ Perhaps, indeed, more excavation will modify the parameters of decline and prosperity, as in the Jebel Ansariyya. ${ }^{28}$

Travellers were told about these sites by locals, and passed near to some of them when going from Aleppo to Hama or the coast. Pococke, travelling in 1737 , inspected several over the course of three days. He saw buildings that "appear like very magnificent palaces; some of them are built round several courts," dated them correctly, and saw plenty of evidence of churches: "I was astonished to see such buildings in a place so retired, and in the midst of rocky hills, where there is no view or prospect of any thing delightful."[67] And indeed, these uplands are today grim and large tracts are treeless. Pococke explored Bara, and listed its attractions, but did not like the inscriptions: "there are two or three Greek inscriptions, which seemed to be Pagan, but in such barbarous unintelligible Greek, that they were hardly worth transcribing." ${ }^{[68]} \mathrm{He}$ particularly liked the houses and churches at Ruweiha: "The houses are built round courts with porticos all round within supporting a gallery, which communicates with the rooms above, there being a door from it to every room.."[69]

Drummond followed Pococke in 1754, copying Christian inscriptions and illustrating churches. ${ }^{[70]}$ At Bara, he particularly liked and drew "many

25 Tate 1992 writing against the standard view of stagnation and decline and pauperisation at hands of state and owners. The evidence on the ground, with rich houses and so many villages, contradicts this view. 13-84 Identification et classement des constructions; 85-166 La datation des maisons (in the general absence of inscriptions); 273-342 Conquête des terroirs et enrichissement paysan (with graphs); 303-332 Une seconde expansion (330550); 333-342 Crise ou stagnation? (550-610) - he suggests stagnation. Tate 1997: summary; Tate 1988: discussion of strong expansion 4th-6thC.

26 Tate 2013, with 241 plates. I.17-28: history of the site and its exploration; I.559-567: development of the village, together with details of reoccupation. Wickham 2005, 449: "The limestone villages are at an extreme in their density and in their architectural and decorative ambition, but they are not unique, as indeed Tate stressed. Nearly all the sectors of Syria and Palestine that have been studied show a high point in the fifth or sixth centuries, which often extends into the seventh and eighth."

27 Callot 1984, 115-128: Les huileries, les villages, la région; 128: the plains were "dépeuplés par les guerres antérieurs et tellement plus facile à exploiter."

28 Milwright 2010, 62: "The widespread abandonment of these settlements prior to the Islamic conquest is now questioned by results from Dehes/Dayhis, where excavations show probable evidence of occupation through to the eighth or ninth century." 
pyramidical monuments, some of which are now almost intire.,[71] Such tombs (like the one at Dana) had long before fascinated mediaeval Muslim writers. ${ }^{[72]}$ Walpole visited Bara in 1851 , and wrote that one of the larger structures was called the King's Palace, yet of which "nothing remains but a confused mass of columns, shafts, capitals, and stones."[73] Monasteries were also easy to recognise, Aucher-Éloy remarking in 1835 between Antioch and Aleppo: "un vaste monastère avec une tour carrée, dont tout un côté est encore debout: ces ruines, placées au milieu de solitudes, sont toujours un objet d'étonnement."[74] Waddington, travelling in 1861, noticed there were few inscriptions, yet sufficient to date churches; and he declared the need for a plan of work that would be executed only in the following century:

Il faudrait à la fois la photographie, et un architecte dessinateur qui relèverait les plans et étudierait les détails d'ornementation et les procédés de construction; ce serait une monographie des plus intéressantes et des plus neuves, portant sur un très grand nombre de monuments. ${ }^{[75]}$

Volney had remarked in 1792 that "sur toute la route d'Alep à Hama, ce ne sont que ruines d'anciens villages, que citernes enfoncées, \& débris de forteresses \& même de temples." ${ }^{[76]}$ Burckhardt described Bara in detail, comparing the buildings to those he had seen in the Hauran. ${ }^{[77]}$ He visited Jebel Riha, he says, because "as I had often heard the people of the country mention them, I thought it worth while to take this circuitous road to Hamah" - a good advertisement for knowing the language. By the mid- and later 19th century, descriptions are frequent. ${ }^{[78]}$ Thus Walpole in 1851 , near Khan Sheikhun, found a large town where "many plain shafts of columns were standing; excavated vaults," but in this area "the villages are now deserted, and the people encamped out on the plain in order to pasture their cattle." ${ }^{\text {[79] }}$ In 1881, travelling from Antioch to Aleppo, he passed over sixty mounds "marking the sites of towns or castles," but "as far as I could learn no one has yet made excavations with a hope of finding antiquities."[80] Sykes went the same route in 1904, passing through "many ruined towns and villages of the Christian period." However, "these require a specialist's description, which, being unable to provide, we will omit, as an Irish editor remarked of his leading article."[81]

If so many once-prosperous villages still stood on land once fertile, why should desertion continue?29 The reasons are complex and serious (see

29 Lewis 1987, 12-23: Village desertion and population movements. Notes how travellers were shocked by uncultivated high-quality land and deserted villages. Maps 4-6: inhabited and deserted villages - generally the further east and south, the more deserted they become. Some villages very small, other inhabited only on occasional years. 
Chapter One), and much the same happened in the Hauran. In both north and south, there was some re-occupation, sometimes just for part of the year. At Dana, among some "noble ruins" and a cistern "covered with logs of marble from ten to twelve feet long," Drummond found some inhabitants:

Arabs, among whom I saw a scene of industry that far exceeded any thing I had ever observed in Syria; for the Turks are a lazy people, and choose to gain their livelihood by robbery, fraud, or murder, rather than by honest toil. ${ }^{[82]}$

One reason for desertion was the insecurity occasioned by Bedouin incursions. Aucher-Éloy, travelling in 1832, thought he could proclaim that brigandage was over, because "Ibrahim [Pasha] a fait une expédition pour les punir: ils ont abandonné le pays pour s'enfoncer dans le désert."[83] This was a very temporary fix, and thirty years later Tilley wrote of the devastation around Aleppo:

that in a large fertile district near Aleppo, which twenty years ago possessed 100 villages, there are now only a few fellahs to be seen; that he had passed over towns in the desert, having well paved streets and houses still in good repair, but totally uninhabited; that thousands of acres of land, showing signs of former irrigation and extensive culture, now hardly afford a scanty bite to the Bedouin's sheep or camels. ${ }^{[84]}$

As was to happen soon in the environs of Jerash and Amman, here in the Dead Cities near Aleppo (and also further north near Hierapolis) some Circassians (numbers unknown) were settled by 1870 . They did not shrink from conflict, and conceivably they were brought here both to repopulate deserted villages and control the Bedouin. Burton was in no doubt what this would mean for the monuments: he "sketched and fixed the positions of some fifty ruins which, in presence of the Circassian immigration, now a fait accompli, are fated soon to disappear from the face of earth." ${ }^{\text {[85] }}$ And rescue archaeology is much older than the 2oth century, for Tyrwhitt Drake soon returned "laden, not only with sketches, plans, measurements, but also with Greek inscriptions, of which there are a great number lying about. These would, of course, if left uncopied, soon have perished with the stones on which they are inscribed."[86]

\section{Apamea \& Qalaat Mudiq}

Of the eighteen hundred or two thousand shafts necessary to fill out this immense design, every one had fallen, and lay as if with its face to the 
earth, in an eternal woe of desolation. Every edifice, also, was prostrate, exhibiting no other sign of its former beauty than a confused wreck of hoary stones. ${ }^{[87]}[1856]$

Apamea, $55 \mathrm{~km}$ north of Hama, and on an important Roman road, is today a spectacular site with colonnaded main streets (the columns re-erected in the 1990s) and many other pagan and Christian ${ }^{30}$ remains. However, it is easy to conclude from the accounts below that some travellers visited only the fortress on the hill, and others only the site; what is more, perhaps they were not on the lookout for colonnades, since presumably the main roads were encumbered with ruins and blocks. Apamea probably appeared to travellers in earlier centuries as a common-or-garden (there were plenty of them) field of ruins overlooked by the fortress of Qalaat Mudiq, probably without much of interest visible among the tall grass and scrub, perhaps because any population had deserted it for the fortress. ${ }^{[88]}$ It was once surrounded by walls. ${ }^{31}$ Usama Ibn Munqidh encountered the enemy cavalry there during the Crusades (the Crusaders occupied the overlooking fortress), but "it is a place where horses cannot easily move because of all the blocks and columns and ruined foundations, so we were unable to dislodge them from the area." ${ }^{\text {[89] }}$ Green visited the site in 1736, and wrote of "the Remains of the famous, ancient Apamea, formerly one of the most splendid Cities of Syria" - and that is all he writes. ${ }^{[90]}$ Without its colonnades vertical, this large grassy extent must have looked like many other ruin fields.

Although he often travelled very slowly (he took ten hours from here to Hama) Burckhardt does not appear to have examined the site except from the fortress, seeing to the north "several columns scattered about." ${ }^{\text {[91] }}$ Hence this intrepid traveller must have nodded for, even if he was the supposed discoverer of Petra, he did not do Apamea justice. ${ }^{[92]}$ For Beaujour in 1829 "elle a l'air d'une ville ruinée, ${ }^{[93]}$ and the impression he gives is that the majority of the colonnade columns (the cardo is $1.85 \mathrm{~km}$ long) were indeed part-buried under grass, the pasture for the famous horses, which he also mentions. However, he must have ridden past quickly, for Stanhope in 1846 describes the colonnade remains (locally quarried, he thinks) as perfectly visible, being large, and "the effects of the atmosphere were strongly marked upon them, showing them to want hardness." He did not investigate the mounds on the site, and "what buildings stood on them, or what purposes they served, I could only conjecture." ${ }^{\text {[94] }}$ De Forest in 1856 camped in the fortress, which gave him a commanding view of

30 Lassus 1972.

31 Leriche 1987: urban defences in Hellenistic Syria. 
the ruin-field on the plain: "here we paused, as it were, on the shore of a broken sea of pillars, capitals, pediments, and walls, sweeping in gray surges of ruin far away into another shore of verdure."[95] There was plenty to be discovered, because around the cardo "on observe les emplacements de grands bâtiments ruinés et des rues." ${ }^{[96]}$ These Seiff in 1875 surmised to be temples, palaces and private houses, "einem grossen Todtenfelde ... auf wenige formlose Reste und Fundamente verschwunden," the ruination due partly to earthquakes. ${ }^{[97]}$

As Sachau pointed out in 1883, the ancient city was of special interest because "seit der letzten Zerstörung im Anfang des 7. Jahrhunderts ist dies Terrain gänzlich unbewohnt und fast unberührt geblieben." This perhaps assumed the Crusaders had little impact on the ruins, for he observed that the ground level was so unchanged that "an einigen Stellen die Basen der Strassen und der Häuser offen zu Tage treten." ${ }^{[98]}$ This meant that the riches of the site were part visible without full excavation, so that, for instance, Bell in 1908 could note that "the ruins of a great church with a courtyard set round with columns lie on the edge of the main street." ${ }^{[99]}$ There were other ancient sites around such as, to the east, El-Kefr, much less splendid than Apamea but housing an estimated 30,00o people: "Eine Stadt des Luxus und der Kunst kann Elkefr nicht gewesen sein, denn ausser wohl eingerichteten Häusern und Kirchen findet man weder Prachtbauten irgendwelcher Art noch kunstvolle Säulen noch auch das geringste Denkmal antiker Sculptur."[100]

\section{Deir Semaan \& Saint Simeon}

Ceux en compagnie desquels j'estois, qui estoient des gens du pays... s'estonnoient de ce qu'ils me voyoient regarder si exactement \& avec une joye meslée de douleur \& de complaintes, l'Eglise \& les appartemens de ce grand Couvent, dont les pierres paraissent encore fort blanches, quoy qu'elles soient exposées à toutes les injures du temps. Ils sembloit qu'ils estoient sur les épines, tant ils me pressoient de sortir. Mais que regardestu avec tant d'attention, me disoient-ils? que remarques-tu dans ces mazures? y veux-tu découvrir quelque thresor: car cette simple veuë ne meritoit pas la peine que tu as pris de venir jusques icy. ${ }^{[101]}[1682]$

This complex, $36 \mathrm{~km}$ wNW of Aleppo, consists of the large church on the hill, visible from afar, and a monastery below it, with one or more monastic buildings plus several others serving visiting pilgrims. Let us set the importance of this site in perspective. If we think of the importance attributed to the plan of the monastery of S. Gall, not the much re-built structure, which has generated 
large volumes about monasticism, what an opportunity has been lost to investigate thoroughly an even larger complex - not a plan, but a monastery and church complex in aspic, almost untouched since Late Antiquity!

On the road between Aleppo and Antioch, S. Simeon was sometimes visited by Western travellers. ${ }^{[102]}$ Chantre in 1889 places the complex at the centre of a wide range of villages, "partout des blocs énormes, des pierres de taille gigantesques soigneusement appareillées, qui ont servi de matériaux. L'ornement bien caractéristique de ces ruines est toujours le portique à un et parfois à deux étages." ${ }^{[103]}$ Butler does likewise, writing of the extraordinary state of preservation of the churches around:

The buildings of this region, too, especially the churches, are in a better state of preservation than in other parts of Syria. Eight of the eighteen churches still preserve the half domes of their apses; four have both rows of columns and arches standing, and two have one row of arches still intact. Four of these buildings are almost perfect so far as stonework is concerned. ${ }^{[104]}$

In 1669 Morone stated that pilgrims going from Aleppo to Iskenderun would divert to see S. Simeon, "fra le quali si vedono inditzi di tre, ò quattro Chiese, e dalle colonne, capitelli, basi, cornici, e pietre, marmi bellissimi." ${ }^{[105]}$ There were certainly mosaics in the monastery complex. ${ }^{32} \mathrm{~S}$. Simeon was only one of several sites displaying stylites that were visited by pilgrims in Syria, but it was the most important. ${ }^{33}$ The idea of spending time atop a tall column is an idea adopted by Christianity from pagan practice; ${ }^{[106]}$ but this is on ly one of a host of adaptations. ${ }^{34}$ Visitors in both the 17 th and the 19th centuries imply that part at least of the octagon's dome was in place. Goujon semed to suggest in 1670 that a substantial part of the saint's column was still standing, ${ }^{[107]}$ but Febvre wrote in 1682 that it could no longer be seen, "à cause qu'une partie de la voûte est tombée dessus, \& l'a ensevelie sous ses ruines."[108] Walpole in ${ }^{1851}$ suggests the stylite's column had been carried off by pilgrims, perhaps because it was underneath the rubble of collapsed vaulting; although "beneath an octagon dome is the base of the pillar, a huge square block of about nine feet on either side, by five high: a rude step runs round it. In the centre of the upper surface is a round hole for the holding of the first round of the shaft."[109]

\footnotetext{
32 Donceel-Voûte 1988, 225-240: fragments of mosaic floors in the church.

33 Lassus 1947, Pl.XLV for photos of three stylite columns - S-Syméon-du-Mont-Admirable, Kafer Derian, and Kimar.

34 Milani 2001 on Christian itineraries and the classical world.
} 
Both these accounts are probably examples of loose writing, and there was no surviving dome; but they are equalled by De Vogüé's fine prints, which show greater wall elevation than survives today. Within the octagon, the pedestal for the saint's column was noted by Lycklama a Nijeholt in 1875: "La voûte et les parties les plus hautes se sont affaissées, jonchant le sol de débris, tronçons de colonnes, chapiteaux, fragments de corniches, etc,"[110] and in 1838 Robinson wrote that the remains of the column were still shown to pious pilgrims. ${ }^{[11]}$ Perhaps these appeared through a miracle, since Bankes in 1816 states that "there is no part left of the pillar on which the Saint is said to have lived so many years; but a mass of the live rock stands up square in the centre, which was probably its pedestal." A Kurdish chief had also been living in the ruins. ${ }^{[12]}$ Whether the stump today displayed on the pedestal had anything to do with the column itself we may at least doubt, but not its 19th century decay, which Butler remarked on in 1909, mistaking the limestone of the columns for imported marble. ${ }^{[113]}$ This was not the only misunderstanding, for Besson in 1862 conjures up a hilarious version of the stylite's column, from what he knew in Rome, namely Trajan's Column: "Au milieu de l'église, qui est prodigieuse en sa grandeur, mais à moitié ruinée, paraît la colonne du saint Stylite, faite à vis, au haut de laquelle on montait par le dedans." ${ }^{\text {[114] }}$

\section{Hama \& Homs}

Although these were both important cities in Antiquity, there is little that travellers had to say about them because few of their monuments survived into the 19th century, and nearly all had gone by its end.

Ibn Battuta painted an idyllic picture of Homs, with its water-wheels and barrages, ${ }^{35}$ important market, and magnificent baths, but he does not mention any other monuments. ${ }^{[115]}$ Green confirmed this in 1736 , for "within there is scarce any thing worth taking Notice of," but goes on to mention some beautiful houses and masjeds made of black and white stone, and the citadel, which "consists of the same Materials, disposed so as to form various Figures, which testify its ancient Beauty." ${ }^{\text {[116] }}$ The citadel appears to have been in working order in the early $15^{\text {th }}$ century, ${ }^{[117]}$ but when Burckhardt saw it in 1810 in the town's centre, this was already being plundered: "the materials, as well as the stones with which it is probable that the hill was faced, have been carried away

35 Calvet 1992, 41-51 Les barrages de norias (Oronte et Khabour). Used certainly from the

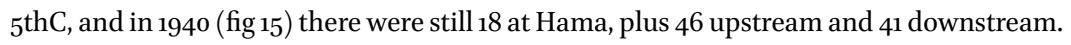


and used in the erection of modern buildings." Robinson, there in 1838 , found few surviving traces of it. ${ }^{[118]}$ Figured antiquities were already disappearing:

I enquired in vain for a piece of marble, with figures in relief, which La Roque saw; but in the corner of a house in the Bazar is a stone with a number of small figures and signs, which appears to be a kind of hieroglyphical writing, though it does not resemble that of Egypt. ${ }^{[119]}$

Using standard procedure, the inhabitants found it more convenient to destroy the antiquities inside their town, to build and refurbish their houses and mosques, ${ }^{36}$ rather than venturing outside it, where Poujoulat wrote of

un vaste plateau des pierres de taille, des murs à demi enfouis dans la terre, des colonnes brisées, des chapiteaux, des corniches d'un beau travail; un portique orné de deux pilastres corinthiens s'élève au milieu des débris de cette antique cité. ${ }^{[120]}$

Consequently old Hama ${ }^{37}$ was to be seen built into the walls of new Hama: "Von antiken Bauten hat sich in Hamah nichts erhalten, einige unbedeutende Reste ausgenommen, die man hin und wieder als Schmuck moderner Gebäude verwendet findet."[121] In all such towns in the north of Syria, wrote Burton in 1872, "the destruction of old buildings is unpleasantly rapid," and he instances even the destruction of a temple, so presumably "it had been covered by an earthslip, or had been broken up for building material. ${ }^{[122]} \mathrm{He}$ also noted important inscriptions:

I believe that the five blocks of basalt at Hamah, covered with hieroglyphs in excellent preservation, may be the opening page to a new chapter in history. These inscriptions were found in the Kala, and are now scattered about the town. ${ }^{[123]}$

By the 188 os "sind bisher auffallend wenig Anschriften und Alterthümer gefunden," but "Wer den hohen Hügel im SO und den Castellberg im Norden in grosser Tiefe durchstechen könnte, würde vermuthlich auf classische, vielleicht sogar

36 Al-Tabba 1982, 68 for re-use in the Al-Nuri mosque in Hama.

37 Ploug 1985. 
auf ältere Baureste stossen." [24] To find antiquities in 2oth-century Hama, it was indeed necessary to dig. ${ }^{38}$

One continuing problem in the region appears to have been what was wrongly called the "Great Syrian Desert" to the east of Hama, a region "exceptionally riant and fertile," but harassed by Bedouin and its many town in ruins by 1871 . The "remedy" was a forerunner of what was to be the solution in the Hauran, namely import the warlike Circassians and have them settle the area and expel the Bedouin. ${ }^{39}$ Realising what this would mean for ancient towns and their remains (destroy them):

It is, therefore, gratifying to add that Mr. Drake has returned laden, not only with sketches, plans, measurements, but also with Greek inscriptions, of which there are a great number lying about. These would, of course, if left uncopied, soon have perished with the stones on which they are inscribed. ${ }^{[125]}$

Just like Hama, Homs appears to have fed off its antiquities. In Pococke's day, in the mid-18th century, the stone-faced town walls were to be seen ${ }^{[126]}$ and, indeed, parts were still standing in $1889 .{ }^{[127]}$ It seems possible that marble materials went from the town to decorate more modern buildings. For example in 1805 Seetzen described lavish marble at a khan between Homs and Damascus, which we might imagine came from Homs. ${ }^{[128]} \mathrm{He}$ also stopped at Kteiphe, where

Es ist ein grosser viereckiger mit weissem Marmor gepflasterter Platz, in dessen Mitte ein marmornes Wasserbassin befindlich ist. Dieser Platz ist rund umher mit Arkaden von weissen Marmorquadern umgeben, aus welchen Thüren in die Ställe führen. ${ }^{[129]}$

38 Ploug 1985, for excavations 1931-8 only now published. Hellenistic architecture reused in Roman period, but replaced down to the foundations in the Byzantine period. So only one, the House of the Mosaics, survives, but destroyed in earthquakes of 1157/70. Byzantine fragments found reused in Islamic structures. 171-184: remains of mosaic floors. Pentz, 1997, 96 for the House of Mosaics "re-used from the late pre-Islamic period, was refurbished in the most sophisticated manner by the Arabs" - some later evidence of iconoclasm. Only fragments of architectural decoration have been retrieved, so presumably much went for re-use elsewhere, à la Ibn Khaldun. No complete mediaeval structures were located, either.

39 Lewis 1987, 99-110: Circassian settlement in Syria. This was a floating population, some of whom soon left. 
And just as at Homs, the once-prestigious, stone-faced citadel here was going by 1851 :

The whole hill is cased over with solid masonry, immense blocks of black, ferruginous stone, of great depth and solidity: here and there columns of the same have been worked in. Many portions of this are now in ruins, as it is much used by the inhabitants for the lower portions of their houses, tombs, \&c. ${ }^{[130]}$

Porter's description of the town in 1855 reveals just how much there once was:

Large hewn stones, and fragments of columns of granite, basalt, and limestone are seen scattered in great profusion through the streets, and bear ample testimony to its antiquity and former architectural beauty. ${ }^{[131]}$

These were to be connected with what he realised was missing from the citadel:

Not a fragment of the castle itself now remains, and the only buildings standing are a few portions of the exterior flanking towers along the northern wall, which are chiefly of Saracenic origin. The whole summit of the mound is covered with heaps of rubbish, mixed with which I observed several large fragments of red and gray granite columns, the remains, no doubt, of the splendid temple that once occupied this site. ${ }^{[132]}$

Squire inspected the citadel in 1820 , noting that "the Saracen fortifications on this height were of excellent workmanship, but are now entirely ruined."[133] The ominous word "barracks" (which generally meant a large, new building) appears in the following sentence, indicating just how antiquities (in this case surely the superstructure of the baths) disappeared into modern structures: "near the barracks, are foundations of ancient baths, and I there saw some squares of fine mosaic pavement." [134] In fact Ibrahim Pasha (ruler of Syria, 1831-40), blew up the citadel because it resisted him, and it was he who built the cavalry barracks, leaving only bits and pieces in the citadel:

Within all is grass-covered ruins, broken arches, tumbling walls. I noticed a rather well-cut Corinthian column, built into a modern mosque, and another, rudely carved in black stone in the base of the wall, still standing. The stones are of almost Cyclopean size. It has, however, evidently been patched at very different eras. ${ }^{[135]}$ 
Lycklama a Nijeholt went up the citadel in 1875 , but "n'y trouvai qu'une petite mosquée en très-mauvais état et des monceaux de ruines." ${ }^{[136]}$ Burton did a little better in 1872 , reporting

The long meurtrieres intended for archers, not for matchlock men, the arches and the domed casemates, prove its date; whilst the old basaltic pillars horizontally couched in the solid masonry, the large blocks of white stone, the imposts of snowy marble, and the columns of fine Syenite and gray Egyptian granite, show what has become of the Sun Temple's splendid remains. ${ }^{[137]}$

The dismantling of the baths was also described by Burton in 1872, "for the sole purpose of removing the stones; the fine mosaic spoken of by travellers had already disappeared, and in a few years the place will be a mound of earth."[138] Also outside the town were two pyramid-on-cube structures, the larger one called the Burj El-Somah, the Tower of the Oratory. Buckingham described it in 1825 as a tomb, and noted traces of stucco and paint in the interior. ${ }^{[139]}$ When Burton visited in 1872 , the pyramid had disappeared, and the cube was collapsing, although he could still see the decoration: "it is faced with basaltic squares, each about four inches, forming, with alternations of white limestone, diaperwork of rough mosaic." [140]

Pyramid-on-cube tombs were not rare in Syria (any more than were other types of mausoleum ${ }^{40}$ ), and one was spectacular. This was Kamu'a el Hurmul, near the Orontes, wsw of Homs. This was viewed by Robinson in $1856^{[141]}$ and further described by Thomson in 1886 :

The sculptures on its sides represent hunting scenes, and it may have been erected over the grave of some "mighty hunter" who was mortally wounded while pursuing the chase in this vicinity; but no inscriptions have been found to explain the figures or relate the circumstances, and both history and tradition are silent upon the subject.

He also notes cracks in the structure, for "it has not been able to withstand the destructive power of the earthquake."[142] 


\section{Qasr ibn Wardan}

This was a complex of Byzantine palace, church, and barracks NE of Hama. The north-south road from Aleppo to Damascus passes through Hama, and Qasr ibn Wardan is $62 \mathrm{~km} \mathrm{NE}$ of that town. Since the road is on the way to nowhere else of interest (except the site of Alandarin, $25 \mathrm{~km}$ further on, and another Byzantine settlement $t^{41}$ ), few early travellers got here. Indeed, on early maps the only place east of inhabited Syria and west of Babylon is Palmyra itself. Thus Pococke's 1745 map shows plenty of place names for the western areas, and then, for the east, north to south, "Desart of Syria," "Desart of Palmyra" and finally "Arabia Deserta," with Palmyra and only a very few other habitations marked.

Out in the desert today, Qasr ibn Wardan, dated by inscription to $5^{64}$ (on a near-four-metre basalt block as a lintel), was a complex of palace, church and barracks, although little of this last survives. Part of its purpose might have been to secure the frontier from Bedouin raids, for there were several communities in the area (see below). Indeed, it was in a region prosperous in Byzantine times, "these isolated, regal buildings on the edge of the Syrian desert" described by Butler in 1909. The church would have been highly decorated, with columns and capitals of marble, and comparable to contemporary buildings in Constantinople. ${ }^{[143]}$ He picked up some tesserae, and learned from a local that the dome had not long collapsed:

An old native whom we met later, and who seemed to know the whole region well, said that when he was a lad the kubbeh, i.e. the dome, was standing, and that there were "pictures" on the walls. It is scarcely probable that this old Bedawi had manufactured this story, because he could have had no outside experience on which to base imaginary wall-pictures. ${ }^{[144]}$

The site appears neither in Baedeker's 1898 nor in Cook's 1907 guidebook, and was apparently discovered by Baron Max von Oppenheim, ${ }^{[145]}$ who excavated Tell Halaf from $1911 .{ }^{42}$ It should be noted that the site has been extensively restored since Butler photographed it.

$28 \mathrm{k}$ NNE of the Qasr ibn Wardan complex was a large settlement, al-Anderin, described by Butler in 1905, and still impressive today:

\footnotetext{
41 Mango 2008, 73-88 for Alandarin: the site had ten churches, and a barracks.

42 Gossman 2013, chapters 7 \& 8: Tell Halaf.
} 
Sun-dried bricks, with foundation courses, doorways, arches, and colonnades of finely dressed basalt; but in blocks of unusual size... The larger churches, one of which is of proportions sufficiently imposing to have been a cathedral, contained a larger proportion of stonework; their apses, their interior system of arches, and in one case the side walls, were built of good dressed masonry. Androna possessed no fewer than ten churches. In the middle of the city, which was walled, are extensive barracks, built in the same style and of the same materials as the buildings of Qasr Ibn Wardan. ${ }^{[146]}$

Nor was this the only ruin field in the region, for Butler also described Mirâye ("a small modern village built among the ruins of an ancient town") and then Odjeh: "a modern village of a few families among the ruins of what was once a large town... Two of the ancient houses are well preserved: one of them, which was converted into a mosque at an early date, still has its roof-slabs in place." He then visited two further settlements nearby. ${ }^{[147]}$

\section{Hosn Suleiman}

Une vaste enceinte carrée de 144 mètres de long sur 9o de large. Son tracé est irrégulier et affecte la forme d'un trapèze, ce qui, comme ensemble général, donne à son plan quelque analogie avec celui du Haram eschSchérif de Jérusalem. C'est le plus beau spécimen d'enceinte sacrée ou Témenos existant encore en Syrie. ${ }^{[148]}[1867]$

Hosn Suleiman, $25 \mathrm{~km}$ north of Safita in the mountains, is a splendid Roman shrine complex, not much visited by our travellers because it is nowhere near a main road, nor on the way to anywhere, and with few nearby villages. Such remoteness is one reason for its good state of preservation; the other is the enormous size of many of the temenos blocks, which were simply too big to shift. "The country was wild in the extreme... at the head of a wild gorge, and consists of a large mass of ruins, among which are several Ansayri cottages," wrote Walpole in 1851 in his book on the Ansayrii (the Alawis), ${ }^{[149]}$ and went on to describe the site, including its inscriptions and decoration. ${ }^{[150]}$ As several scholars realised, the temple complex had almost the largest stone blocks in Syria, inferior only to those at Baalbek, which is surely why the site is called Husn ("castle"). Rey (who gives a good description of the complex ${ }^{[151]}$ ) measured the blocks, ${ }^{[152]}$ and thought (wrongly) that such cyclopean masonry 
indicated a date earlier than the Romans. ${ }^{[153]}$ He regretted not getting to the site in $1864,{ }^{[154]}$ but did so a few years later.

Walpole also visited sites in the area, and was impressed by Fuckera, a Maronite village high above the coast, with Beirut visible in the far distance, and an extensive field of ruins, with a large temple:

The walls are built of uncemented stones, one layer thick, and now greatly shaken, and ruined, seemingly, by an earthquake... The east face perfectly plain, save a few pilasters, runs north to south. This leads to an inner court: a face then presents itself, raised from the ground five steps, or perhaps seven, across which run columns whose huge pedestals alone remain - the columns and their Doric capitals lying broken about. ${ }^{[155]}$
[1] Neale_II_1851_200
[2] Sykes_1904_54
[3] Plaisted_1929_107-113
[4] Vergoncey_1615_435
[5] Drummond_1754_184B
[6] Egmont_\&_Heyman_ 1759_II_338
[7] Guys_1855_250
[8] Neale_II_1851_110
[9] La_Salle_1840_I_192
[10] Watenpaugh_2004_23
[11] Aramon_1887_100
[12] Walpole_I_1851_219
[13] Lycklama_a_Nijeholt_ 1875_257
[14] Robinson_1838_346-347
[15] Michaud_\&_Poujoulat_ VII_1835_179B
[16] Gallois_1907_203-204
[17] Libanius_200o_46
[18] Libanius_200o_48
[19] Libanius_20oo_46-47
[20] Caraman_1841_15
[21] Callier_1835_245
[22] Perry_1743_142
[23] Naval_Staff_1919_691
[24] Ellis_1881_I_19-20
[25] Masudi_III_1864_ 407-408

\author{
[26] Lycklama_a_Nijeholt_ \\ 1875_317 \\ [27] Veryard_1701_326 \\ [28] Wortabet_1856_I_24 \\ [29] Fermanel_1670_264 \\ [30] Rey_1883_327 \\ [31] Volney_II_1792_9o \\ [32] Robinson_1838_364 \\ [33] Fletcher_1850_363 \\ [34] Baedeker_1898_443 \\ [35] Neale_II_1851_11-12 \\ [36] Ibn_Battuta_1982_I_154 \\ [37] Michaud_\&_Poujoulat_ \\ VII_1835_117 \\ [38] Laorty-Hadji_1854_ \\ 120-121 \\ [39] PEFQS_1887_1-2 \\ [40] PEFQS_1887_67 \\ [41] Beaujour_1829_312-313 \\ [42] Neale_II_1851_18 \\ [43] Febvre_1682_159 \\ [44] Redding_1873_298 \\ [45] Gallois_1907_224 \\ [46] Le_Strange_189o_ \\ 500-501 \\ [47] Drummond_1754_210 \\ [48] Volney_II_1972_95 \\ [49] Wright_1848_507 \\ [50] Pococke_II.1_1745_166
}

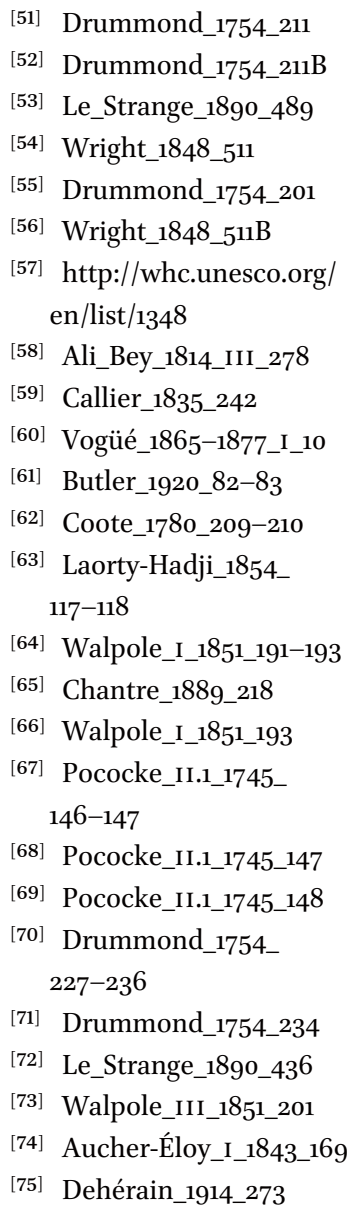




\begin{tabular}{|c|c|c|}
\hline [76] Volney_II_1792_96 & [104] Butler_1905_397-398 & [132] Porter_1855_I_346 \\
\hline [77] Burckhardt_1822_ & [105] Morone_1669_I_402 & [133] Squire_1820_322 \\
\hline 20021812 & [106] Bouchier_1916_252 & [134] Porter_1855_II_346-347 \\
\hline [78] Seiff_1875_287-303 & [107] Goujon_1670_28 & [135] Walpole_I_1851_165-166 \\
\hline [79] Walpole_I_1851_189 & [108] Febvre_1682_187B & [136] Lycklama_a_Nijeholt_ \\
\hline [80] Ellis_1881_I_26 & [109] Walpole_III_1851_233 & $1875 \_563$ \\
\hline [81] Sykes_1904_53 & [110] Lycklama_a_Nijeholt_ & [137] Burton_\&_Tyrwhitt- \\
\hline [82] Drummond_1754_216 & $1875 \_280$ & Drake_1872_II_287 \\
\hline [83] Aucher-Éloy_I_1843_85 & [111] Robinson_1838_354 & [138] Burton_\&_Tyrwhitt- \\
\hline [84] Tilley_1864_369 & [112] Finati_1830_II_183 & Drake_1872_II_282 \\
\hline [85] PEFQS_1871_3 & [113] Butler_1930_66 & [139] Buckingham_1825_ \\
\hline [86] PEFQS_1871_11 & [114] Besson_1862_17 & $495-496$ \\
\hline [87] De_Forest_1856_275-6 & [115] Ibn_Battuta_1982_144 & [140] Burton_\&_Tyrwhitt- \\
\hline [88] Robinson_1856_550 & [116] Green_1736_30 & Drake_1872_II_282B \\
\hline [89] Usama Ibn Munqidh_ & [117] Broquière_1892_78 & [141] Robinson_1856_540 \\
\hline 2008_99 & [118] Robinson_1838_326 & [142] Thomson_1886_ \\
\hline [90] Green_1736_26 & [119] Burckhardt_1822_ & $306-307$ \\
\hline [91] Conder_1824_348 & 22021810 & [143] Butler_1930_50-51 \\
\hline [92] Burckhardt_1822_170212 & [120] Poujoulat_1841_II_27 & [144] Butler_1930_51-52 \\
\hline [93] Beaujour_1829_314 & [121] Seiff_1875_270-271 & [145] Leclercq_1907_81 \\
\hline [94] Stanhope_1846_II_237 & [122] Burton_\&_Tyrwhitt- & [146] Butler_1905_395 \\
\hline [95] De_Forest_1856_275 & Drake_1872_II_288 & [147] Butler_1930_54 \\
\hline [96] Joanne_\&_Isambert_ & [123] Burton_\&_Tyrwhitt- & [148] Rey_1867_336 \\
\hline 1864_624 & Drake_1872_II_184 & [149] Walpole_III_1851_319 \\
\hline [97] Seiff_1875_286 & [124] Sachau_1883_66-67 & [150] Walpole_III_1851_ \\
\hline [98] Sachau_1883_74-75 & [125] PEFQS_1871_11 & $319-322$ \\
\hline [99] Bell_1908_241 & [126] Pococke_II.1_1745_141 & [151] Rey_1866_336-341 \\
\hline [100] Sachau_1883_89 & [127] Chantre_1889_212 & [152] Rey_1866_340 \\
\hline [101] Febvre_1682_187 & [128] Seetzen_1854_I_25 & [153] Rey_1867_339 \\
\hline [102] Lycklama_a_Nijeholt_ & [129] Seetzen_1854_I_26 & [154] Renan_1864_112 \\
\hline 1875_267 & [130] Walpole_I_1851_164-165 & [155] Walpole_III_1851_ \\
\hline [103] Chantre_1889_232-234 & [131] Porter_1855_II_347 & $45^{1-45^{2}}$ \\
\hline
\end{tabular}




\section{Damascus and the Centre}

\section{$\operatorname{Damascus}^{1}$}

C'est la plus sublime mosquée du monde par sa pompe, la plus artistement construite, la plus admirable par sa beauté, sa grâce et sa perfection. On n'en connaît pas une semblable, et l'on n'en trouve pas une seconde qui puisse soutenir la comparaison avec elle. ${ }^{[1]}\left[13^{26}\right]$

The builder-converters of the Umayyad Mosque (from the Roman Temple of Jupiter) were certainly aware that the structure they built on and modified was very old, Yakut relating how the foundations were dug out to ensure their solidity, perhaps because the masons knew that local stone needed checking, ${ }^{2}$ as must have been known when the citadel was constructed. ${ }^{3}$ In the process they discovered an inscription in Greek conveniently predicting the mosque. ${ }^{[2]}$ Al-Muqaddasi described the richness of the materials and their decoration, including the mosaics ${ }^{[3]}$ which, before the fire, were also to be seen in the prayer hall. ${ }^{4}$ Dimashqi wrote that "par sa beauté, son élégance et sa perfection est comptée parmi les merveilles du monde," lavished with marble and mosaics. ${ }^{[4]}$ Of its builder, "it is said that he expended the revenues of all Syria on this work." ${ }^{[5]}$ This occasioned restrictions on the next ruler. ${ }^{5}$ NonMuslims were for centuries forbidden access (cf. Chapter Two, under Haram/ Forbidden), which is surely why Fermanel in 1670 affirmed that the "galeries, lesquelles, comme aussi la face de la Mosquée, sont peintes à la Mosaïque representant plusieurs Saints Pères, ce qui authorise assez qu'elle a esté bastie par les Chrétiens."[6]

1 El-Hage 2000 for photographs: 6-57 for the town, its visitors and photographers; $79-85$ walls and gates; $87-98$ : Umayyad Mosque before the fire.

2 Nour 1982, 147-148: Damascus poor in building materials, with the stone of poor quality.

3 Hanisch 2007: it was built on late antique foundations.

4 Gautier van Berchem 1970-1.

5 Flood 2001, 244-5: Yazid III acceeding in 744 had to promise not to lay "stone upon stone, brick upon brick," or to dig canals. 
If the mosque was indeed built as a competitor for churches, ${ }^{6}$ then it seems strange to modern minds that Christians were not admitted for centuries, the same case apertaining for the Dome of the Rock, an obvious comparison for the Holy Sepulchre, and elevated above it. Yakût tells a good tale which illustrates an attempt, as it were, to wipe the eye of the Byzantines. When Omar became Caliph in 717AD, he reportedly found the luxury of the mosque excessive, and intended to strip off marbles and mosaics, and return to the treasury the money got by selling them off. Not very surprisingly, this did not happen because (and this is worth quoting at length) ten ambassadors arrived from the king of the Greeks:

And they begged permission to enter and visit the Mosque. Permission was granted them to enter by the Bab al Barid, and a certain attendant was sent to accompany them who knew their tongue, in order to listen to their words, and report what they should say to 'Omar, they knowing nothing thereof. The envoys passed through the court until they came in front of the Kiblah, and they raised their eyes to look at the Mosque. Then their chief began to hang his head, and his colour became yellow, and when his companions inquired of him the reason, he replied, "Verily, I had told the assemblies of the people of Rûmiyyah (Byzantium) that the Arabs and their power would remain but a brief space; but now, when I see what they have built, I know that of a surety their (dominion) will reach to length of days." When 'Omar heard report of this, he said, "I now perceive that this your Mosque is a source of rage to the infidels," and he desisted from doing what he had intended therein. And 'Omar had before this studded the Mihrâb with jewels of great price, and he afterwards hung up here lamps both of gold and of silver. ${ }^{[7]}$

From this reasoning, Omar's only justification for maintaining and enhancing the beauty of the mosque was to discomfit the Christians who, having once shared the complex with Muslims for worship, were presumably let inside to milk their admiration, just as were the ambassadors. However, this was also a town inside which Christians were not allowed to ride. ${ }^{[8]}$ Here the locals had a reputation for surliness, and so Thompson in 1767 "applied to the Governor: who gave Orders to an Officer of the Janizaries to let two of that Body attend

6 Flood 2001, 213-236: the architecture of Umayyad Mosque as competition with Christians, and also with Byzantine sources, including use of architectural elements. 219: foundation of Ramleh in Palestine, with Sulayman also going to the Emperor for antique columns. 
us wherever we went, and prevent our being insulted or molested by the Populace."[9]

Fermanel's mistake about elements of the mosque's decoration suggests (and it is certainly likely) that he got not a peep into the interior, but made it up from what he thought was likely, and would convince his Christian readers: churches had mosaics, mosaics often depicted saints, ergo, so did Damascus. Who could trust such travellers? And what did they actually visit? Perhaps Arvieux did indeed get inside the Mausoleum of Baybars in $1660,{ }^{[10]}$ and perhaps Thevenot did three decades later ${ }^{[11]}$ - so either he copied Arvieux, or haram rules were more flexible in the 17th century. Baybars it was who had built the famous Qasr al-Ablaq and its dependencies in 1266-67, designed as contrasting colours of stone in a technique which often keyed adjacent blocks together jigsaw-style. The Mosque might also have been open to Christians for periods in the 18th century, when Campbell entered in 1758, prayer-hall included. ${ }^{[12]}$ Pococke evidently walked right round the exterior of the mosque in 1745 (which was probably impossible a century later), positing a twelvecolumn portico on each of the mosque's four sides, and from his description he also saw the courtyard. ${ }^{[13]}$ He makes a lovely grab for symmetry all round - but what did he actually see, as opposed to reconstructing?? ${ }^{[14]}$ According to Green in 1736, Damascus was then "but a Heap of Houses and Walls half ruined," so perhaps restrictions were ignored. ${ }^{[15]}$

Ali Bey entered the mosque in 1814, ${ }^{[16]}$ disguised as an Arab (he was Spanish), but in 1820 Squire managed only to find the west portico, "which after great difficulty, because it was in the midst of houses and harams, we succeeded in examining., ${ }^{[17]}$ Four years later Richter evidently peeped into the courtyard, but no further, so brief is his description, but he did describe the columns in the courtyard as of granite, with Corinthian capitals. ${ }^{[18]}$ By 1838 the shutters were evidently down, ${ }^{[19]}$ and Robinson "ne me hasardai pas à pénétrer au-delà du porche," referring instead to Buckingham's description of $1825,{ }^{[20]}$ which is rather sparse. But Buckingham and his companions "by the aid of our beards, white turbans, and a certain conformity to Turkish or Arabic movements only to be acquired by habit, we passed undiscovered, and without even being regarded."[21] All Robinson could relay, visiting in $185^{2}$, was that an acquaintance "was able to clamber over the roofs of adjacent houses, and approach so near to the entablature and Corinthian capitals of the columns, as to reach them with the hand." ${ }^{[22]}$

But then matters quickly changed. Perhaps because of his rank, Monsignor Mislin entered in 1855, and described the building in some detail. ${ }^{[23]}$ And within a decade, there were no further difficulties: a fee got Christians inside. ${ }^{[24]}$ This was in part because of the French presence which resulted from the 1860 
massacres of Christians. ${ }^{[25]}$ In 1875 Lycklama a Nijeholt offered a good overview of these changing times, ${ }^{[26]}$ but in 1881 Oliphant was unable to enter. ${ }^{[27]}$ Admission still caused some problems: in 1887 Raboisson objected to being charged 20 francs entrance fee, so slipped in with a group of Americans. He then photographed the prayer hall, but again tricked the locals, and avoided paying the 500 francs they demanded. In his opinion, the complex was more a church than a mosque, so his subterfuge was permissible! ${ }^{[28]}$

Unfortunately, in spite of the easing of restrictions on admission, we still know less than is desirable about the details of the structure, let alone its various alterations, ${ }^{7}$ for example the configuration and appearance of the Christian church, ${ }^{[29]}$ or the rebuild following the sack by the Tartars. ${ }^{[30]}$ This is because of the dearth of detailed descriptions by Easterners after the mediaeval ones cited above, but also because of the great fire of 1893, which destroyed parts of the structure and much of the decoration. ${ }^{[31]}$ For example, what did the marble pavement in the prayer hall look like, and also the columns in the courtyard, encased in masonry by $1880{ }^{\text {? }}{ }^{[32]}$ What happened to the great granite pillars that supported the prayer-hall dome, and the syenite and porphyry ones? [33] "It must have been a beautiful building before the fire, and even now excites the admiration quite as much as St. Sophia or any of the mosques in Constantinople," wrote Curtis in $1903 .{ }^{[34]}$ We can answer some of the above questions. Most of the columns were destroyed, and replacement with shafts from Baalbek was contemplated, but it was then decided to quarry afresh in the nearby town of Al-Mazza. ${ }^{8}$ The old shafts, it is said, were cut up for use as paving stones. ${ }^{9}$

Apart from the Great Mosque, few other traces of the city's antique past remained, or even of early Muslim buildings, such as the Umayyad palace, ${ }^{10}$ known from early chroniclers. ${ }^{[35]}$ This is due in part to the collapse of the Umayyad Dynasty in 750AD, after which "the palaces of the Caliphs, shining with gold and marble, fell into ruins and their very graves were not spared."[36] Other structures from the same period and earlier have recently been uncovered. ${ }^{11}$ When foundations were being dug for a church in 1895 , Roman

7 Degeorge 2010, 42-59 Métamorphoses du temple païen. Greenhalgh 2009, 292-295: the fitting out of the Umayyad Mosque, including plenty of spolia.

8 Weber 2009, 87-8, fig $3^{1}$ for the special wagon built showing part-shafts slung with ropes under the chassis.

9 Degeorge 2010, 9. Cf. Richard Spiers in PEFQS_1897_296.

10 Flood 2001, 147-159: the Khadra, the Umayyad palace.

11 Saliby 1997 for a Byzantine/Umayyad palace near the peribolos of the temple; they uncovered only a part, dated end $5^{\text {th }}$ first half 6 thC, and still occupied in Umayyad period; 
remains were found some 15 feet down, ${ }^{[37]}$ indicating that discovering the Roman city could not be easy.

The town walls were in part antique, with many later repairs; ${ }^{[38]}$ and in 1854 Van De Velde found "a great many ancient hewn stones, pieces of columns, and fragments of walls and buildings," but much overbuilt with later structures, so that "I doubt whether archaeologists will be able to decypher much from these ancient relics." [39] This did not stop Porter in 1855 from speculating that the city once boasted colonnaded streets, ${ }^{[40]}$ such as were to be seen elsewhere in Syria. He was correct. Certainly Muslim interest in colonnades continued at Anjar and Ramleh. And, writes Flood, "the once-popular paradigm of Muslim invaders rupturing the continuous fabric of urban life in Syrian cities such as Damascus is becoming increasingly untenable," placing the Damascus colonnade plus tetrapylon as Umayyad royal patronage. ${ }^{12}$

The underground canals were decribed in the 14th century, suggesting the Roman sewers and drains were known. ${ }^{[41]}$ Vergoncey had admired a "fort magnifique" bath in 1615 , built with (spolia) marble and porphyry; we cannot now identify this bath, but the remains of the ancient city were disappearing into such structures ${ }^{[42]}$ as well as into the many private houses which travellers described as early as the 16th century, ${ }^{[43]}$ sometimes at length, often contrasting the squalour of the public streets with the magnificence within. ${ }^{[44]}$ (This was a characteristic to be seen also in Cairo, as Affagart explained in $1533 \cdot{ }^{[45]}$ ) Mosques with mosaics and coloured marbles were also built outside the city. ${ }^{[46]}$

Macbrair in 1839 was decidedly sceptical about the wonders of Damascus, ${ }^{[47]}$ and in 1824 Richter could find few antiquities to buy, although forgeries were already being made. ${ }^{[48]}$ As Hahn-Hahn noted in 1845 , "you may wander throughout the whole of this large wide-spreading city, without meeting with a single interesting object."[49] Damascus, like Beirut, was modernising and expanding (from 110,00o inhabitants in 1876 to 300,000 by 1910). Indeed, little of archaeological interest remained by the 1830 , ${ }^{[50]}$ let alone the $1870{ }^{[51]} \mathrm{By}$ the end of the century "Damaskus kann heute eine Touristenstadt par excellence genannt werden,"[52] but modernisation through demolitions left little of the older city visible. ${ }^{13}$

it had extensive mosaic floors, and the walls had large stones from earlier monuments, presumably the nearby temple.

12 Flood 2001, 139-147: Porter's Colonnade, which had gone by the end of the 19thC. Flood suggests this was a Muslim remodelling of the ancient town; 145 for quote.

13 Weber II 2009: the catalogue of buildings and demolitions throughout Damascus: how much survives today? 
Damascus was a natural starting place for the expedition to Palmyra. However, the state of the country varied so much that several travellers were to be disappointed. Pfeiffer and Count Zichy were blocked first by the pasha:

he had ceased for some time to allow travellers to undertake this dangerous journey, as until now all strangers had been plundered by the wandering Arabs, and in some instances men had even been murdered

and then by the exorbitant demands of various Bedouin chiefs: "Thus it became necessary to give up the idea altogether, and to proceed instead to Baalbek and to the heights of Lebanon."[53] Stories of the loss of clothing and money were frequently retailed here, often because of the lack of a sufficient escort against Bedouin depradations. ${ }^{[54]}$

\section{Baalbek}

The Mussulman quarrying material for his mosque, the Christian for his church; the Bedouin rudely pulling down whole columns for the few pounds of lead which cemented their sections; the bigot destroying for the sake of destruction; the antiquarian disturbing in his pursuit of knowledge; and lastly, repeated shocks of earthquake have strewn the area with fragments of the stately temples which once rose proudly to the sky. ${ }^{[55]}[1864]$

Palmyra was a complete city, with colonnaded streets, monumental tombs, and a fortress overlooking the site. ${ }^{[56]}$ Baalbek was a temple complex, built (as we now know) from the later first into the third century AD, parts of which were converted by Muslims into a fortress and with a village close by, ${ }^{14}$ and surrounded by walls which Maundrell thought were late, because they were partconstructed of Roman inscriptions. ${ }^{[57]}$ But even for classically aware travellers, the complex was confusing because (unlike, for example, Ephesus) it scarcely appeared in the ancient record, and inscriptions on the site were sparse. Ibn Battuta did not even mention any of the various buildings, although he praised Baalbek for its cherries. ${ }^{[58]}$ Because of the mystery, travellers like Michaud \& Poujoulat could write that "tout était vague et fantastique dans mon admiration pour les monumens de Balbek; j'aurais pu, comme les Arabes, attribuer leur construction au pouvoir merveilleux des Djins." ${ }^{\text {[59] }}$

14 Bloch 2006, 127 Baalbek: fine wares 9-16thC with majority 12-14thC. 
The complex amazed because of the enormous blocks in parts of the structure, the height of its columns (and hence of its main temple), and the extravagance of its decoration. ${ }^{15}$ In the biggest-is-best stakes, it beat Didyma and Cyzicus. Didyma also amazed travellers to Asia Minor, although earthquakes had brought much of it down. Of Cyzicus, on the Sea of Marmara, and therefore convenient for spoliation, little was left by the 19th century both because of earthquakes, and because many of its marble blocks had been carried away for reuse of its marble in Istanbul; it did not appear on many traveller itineraries.

Was Baalbek a temple or a fortress, and who built it? Al-Idrisi, writing in 1154, recorded the common story that Baalbek had been built by Solomon and, as it were, seeing through the fortifications, described the structures as temples. ${ }^{[60]}$ Dimashqi, in the 1320 s, described both the height of the columns, and also the well inside the fortress. ${ }^{[61]}$ It is conceivable that early European travellers - such as Bertrandon de la Broquière (1432), who does not mention ${ }^{i t}{ }^{[62]}$ - were kept away from the complex precisely because it was a military zone. Yet Aramon, travelling in 1549, retailed the stories of who built the complex (he preferred Romans to Solomon), including "un chasteau fort bien basty et d'une belle architecture" which he said the Cairo Circassian Mamluks had erected. ${ }^{[63]}$ Maundrell in 1697 identified the complex as originally a "noble ruin," once a heathen temple, and "together with some other edifices belonging to it, all truly magnificent; but in latter times these ancient structures have been patched and pieced up with several other buildings, converting the whole into a castle, under which name it goes at this day."[64]

When in 1758 Campbell suggested that the structures "have of late years been repaired and converted into a castle;"[65] he must have meant "updated" perhaps to deal with gunpowder weapons. As Castlereagh wrote in 1847, "Baalbec has been turned into a fortress, and bastions and batteries have been erected among her colonnades and porticoes," and one had to hunt for surviving basreliefs, because "of modern Vandals, who broke down pillar and capital, frieze and bas-relief, to construct a wretched mosque, and make a fortification that was useless." ${ }^{\text {66] }}$ Leary surely knew this in 1913, writing that

Mosques and khans, barracks and castle walls have been built out of this immense quarry of ready-cut stone, yet the supply seems hardly diminished. The cannonballs of the Middle Ages fell back harmless before

15 Schlumberger 2010, 101-174: Les formes anciennes du chapiteau corinthien en Syrie, en Palestine et en Arabie - reckons impact of Baalbek ensured free-form capitals were replaced by canonical ones. 
twenty feet of solid masonry, and only God's earthquake has been able to shake the massive foundations of the Temple of Baal.[67]

Earthquakes devastated the site, and helped bring down several members. The violence of past earthquakes might sometimes be calculated by the number of columns they brought crashing down, as at Sardis. ${ }^{[68]}$ A century ago, wrote Baron Taylor in 1854, "ces vestiges étaient beaucoup plus imposants qu'ils ne le sont aujourd'hui," [69] meaning that parts had collapsed in the intervening years. In 1549 Pierre Belon counted nine columns in the Great Temple of Jupiter-Baal, which were "plus grosses que celles de l'hippodrome de Constantinople,"[70] by which he perhaps meant the obelisks on the spina (he was wrong). We know of serious tremors in 1158, 1203, 1664 and especially 1759 , which brought down three columns of that enormous temple. ${ }^{[71]}$ In 1866 the Emir told Hill quite accurately "that a tradition existed among the Arabs here, that the temples within the walls of the citadel which we had examined were nearly entire about three generations before the present time, when they were overthrown by an earthquake." ${ }^{n 2]}$ As well as the columns already noted, nine also fell from the smaller (and incorrectly named) Temple of Bacchus. The entrance keystone slipped somewhat in 1784 , and considerably more by $1844 .{ }^{[73]}$ "There it remained suspended for nearly a century and a half, until a German engineer, by means of a most ingenious device, restored it to its former position and braced it so firmly that it may outlive many more centuries." ${ }^{[74]}$ Anyone who has stayed in Pozzuoli or the Japanese islands will know that small earthquakes can sometimes occur several times a day - hence the slippage of the multi-ton keystone amidst its unstable supports.

Although the site and its Muslim fortress featured in the Crusades, because the site is nowhere near the great roads which led north from Damascus, or west toward the coast, it appears that the temples at Baalbek first came to the notice of travel-reporting Europeans in 1507, when Baumgarten visited and admired the stones in the quarry. These "resembling for bigness a tower or a hill;" near it, he says, stand "three pillars, not unlike those that are to be seen in St. Mark's place in Venice;" these have disappeared. ${ }^{[75]}$ But the site is only $86 \mathrm{~km}$ from Beirut, which was by the mid-19th century one of the most prosperous towns in Syria, with an improving port and (eventually) road network. ${ }^{[76]}$ The nearer to Damascus, the safer the trip, especially under the rule of Ibrahim Pasha; this was a golden age for safe travel, and its end was much regretted. ${ }^{[77]}$ Carne, at Baalbek by 1838, saw an American, a Pole, a German, a Russian and a Greek. ${ }^{[78]}$ But the greater the distance, the more problems arose. Problems included not only bureaucracy, but also just getting there, Palmyra being a prime example. 
The Temple of Jupiter-Baal was immense, on foundations some $300 \mathrm{~m}$ in length, and with columns (22.9m) the tallest in the Roman world, but in drums, because these are not monoliths. ${ }^{16}$ The temple of Bacchus (really Venus-Astarte) was much smaller, but more highly decorated. Large foundation blocks (including the famous trilithon) amazed everyone, and left Burton thinking "how very superior in stone-lifting and transporting the Pagans must have been to us Christians of $1870 .{ }^{,[79]}$ Yet more remarkable was the even larger block left part-cut-out in the quarry; and an even larger stone, at some 1,650 tonnes, was discovered near it in 2014. There was much speculation about how such behemoths had been moved. ${ }^{[80]}$ Holes for inserting wooden tenons to help move them were visible on many of the stones. ${ }^{[81]}$ De Vogüe thought the immense stones were pre-Roman, which led to a standard lament about decline: "Ainsi les murs de Baalbeck semblent un défi ironique jeté à nos théories sur le progrès de l'humanité: chaque race nouvelle a apporté sa pierre plus petite et plus éphémère."[82]

The size and jointing of the building blocks impressed everyone, with the trilithon stones being so large that many of the upper blocks "would excite astonishment were they met with elsewhere; but here, eclipsed by three enormous monsters, lying consecutively in the same course of the building, about twenty-five feet from the ground, they are overlooked as trifles in comparison.. ${ }^{[83]}$ Some of the stones weighed over 1,00o tons ${ }^{[84]}-$ and how were such monsters raised some $10 \mathrm{~m}$ off the ground? ${ }^{[85]}$ Bird's 1872 comparison of one of the trilithon stones as "of the size of a small farm-house" sets the context, ${ }^{[86]}$ or for truly mechanised American travellers, "large enough to contain a Pullman sleeping-car., ${ }^{[87]}$ Nothing in Europe compared: "Les deux colonnes de Venise, les monolithes de Rome, l'obélisque de la place de la Concorde, ne sont que des jouets d'enfants à côté des pierres de Balbek."[88] Pococke thought they must have come from the quarry on rollers. ${ }^{[89]}$

Blocks for the Great Temple were cut so accurately that (in a standard comparison) "the blade of a knife [sometimes a sheet of paper] could not be inserted between them;" and the limestone so hard that it resembled marble. ${ }^{[90]}$ And what of the immense stone still in the quarry? "It is calculated by Dr. Saulcy, that the united efforts of forty thousand men would be required to put this miniature mountain in motion." ${ }^{\text {[91] }}$ Even in 1880 "all must feel that it is a monument which surpasses the capability of this age." ${ }^{[92]}$ Thomas in 2007

16 Elagabalus' temple in Rome had monolithic shafts estimated at $17.66 \mathrm{~m}$; the cipollino shafts for the Temple of Antoninus \& Faustina were $17 \mathrm{~m}$; the granite shafts of the Pantheon's pronaos were a mere $12.5 \mathrm{~m}$, although it has been suggested that taller columns were intended but for some reason unavailable. 
recalls Aristides' assessment of Cyzicus: "You might say that each of its stones took the place of a whole temple, that the temple took the place of a whole precinct, and that the temple precinct was big enough to enclose a city."17 Because of the stones still in the quarry, Monconys guessed that the complex was unfinished. ${ }^{[93]}$ Pococke was saddened that "the barbarous people of these countries continually destroy such magnificent buildings" - but the chink of light in this case was that although "they privately chip the pillars in order to undermine them, ... when they fall, the stones are so large that they can carry away but very few of them." ${ }^{[94]}$ They could, nevertheless, destroy or mutilate bas-reliefs. ${ }^{18}$

Islamic travellers of course knew about the complex and its size and quality (just as European travellers knew about their accounts ${ }^{[95]}$ ), because it was an important Islamic fortress. ${ }^{19}$ In the 1oth century it is noted by Masudi, who writes of the elements which impressed everyone else. "Les dimensions de ces monuments, leurs assises énormes, leurs colonnes élancées, leur vaste portique, tout cet ensemble de constructions excite l'étonnement." ${ }^{[96]}$ Ibn Hawqal, later in the same century, writes (correctly) that there was a palace within the complex, ${ }^{[97]}$ which was part of the fortress into which the structure had been converted. This was still called El Kala'a in the 2oth century, and was studied by the German excavators, as well as being noted by various travellers. ${ }^{[98]}$ The complex also contained projectiles ("great round chunks of marble as big as footballs") which, Carpenter reckoned in 1923, were probably cut from column drums. ${ }^{[99]}$ There were certainly plenty of re-usable elements, as Volney saw in 1792: the hexagonal court was "semée de fûts de colonnes brisées, de chapiteaux mutilés, de débris de pilastres, d'entablemens, de corniches." [100] Rousier also seems to imply that the Turks used gunpowder to bring various parts crashing to the ground. ${ }^{[101]}$

That Baalbek was built by Solomon, ${ }^{[102]}$ and was where he married the Queen of Sheba, was a story presumably picked up by early visitors from the locals, except that several large structures throughout Syria are given the same parentage. Vergoncey relays it in $1615,{ }^{, 103]}$ as in part does Breves in $1628,{ }^{[104]}$ while Beaufort in 1874 laughs at the notion. ${ }^{[105]}$ The trilithon stones ("the largest

\footnotetext{
17 Thomas 2007, 217: "The trilithon ... is comparable in dimensions to many cult buildings in the Hellenistic and Roman East." Ibid. 46-5o for an account of Baalbek.

18 Picard 1939 for the Temple of Bacchus: all friezes comprehensively hammered on the blocks, which remain in place: see his figs $5^{-8}, 11-12$.

19 Gaube 1998: Islamic Baalbek, with plentiful quotations from Arabic sources. 325: German excavators showed the whole of the interior of the citadel occupied by rural courtyard houses, two mosques, and a bath.
} 
hewn stones in the world"[106]) were perhaps laid by Solomon: "Some think they date from Solomon, others would have them ante-diluvian.." ${ }^{[107]}$ Naturally, the complex received plaudits from travellers who struggled to find comparisons further west. For Wood in 1757 it was "the most surprising structure in their empire," ${ }^{[108]}$ and he collected antiquities (including manuscripts) and sent them back home. ${ }^{[109]}$ For Geramb "nowhere in Asia are there ruins so magnificent, so vast." ${ }^{[110]}$ As for the courtyard, "La magnificenza di questa galleria sorpassa ogni espressione."[111] After comparing it with S. Peter's Pigeory was "pris à douter de l'omnipotence de Michel-Ange,"[112] while another saw nothing in Italy to equal it. ${ }^{[113]}$ For one author it was more imposing than the Acropolis at Athens or the Roman Forum, ${ }^{[114]}$ and for another "there is nothing in Rome itself so imposing, nothing which so nearly attains that spiritual elegance of impression which marks Greek architecture."[115] Lombay did not agree: they outdid the Acropolis and the Colosseum in scale, ${ }^{[116]}$ but

Malgré ses proportions colossales ce temple ne dépassait pas en beauté le Parthénon d'Athènes dont les formes idéales représentent ce que notre esprit peut concevoir de plus harmonieux; les blocs sont joints les uns aux autres avec une adresse inférieure à celle des constructeurs héllènes de la meilleure époque; la qualité même des matériaux laisse à désirer, le marbre du Pentélique n'ayant nulle part son pareil. ${ }^{[17]}$

Wilson's hilarious comparison for the large temple in 1823 is with "the church of St. Martin in the Fields, in London, and St Andrew, at Glasgow, built after that model,"[118] which would surely surprise their architects. And what about Palmyra? "By those who have seen both I was told that Palmyra is much inferior in its details to Baalbec, but superior in general effect, from the greater extent of ruins and the long avenues of columns which adorn it." ${ }^{\text {[119] }}$ Did the West ever build any monuments to compare with Baalbek? Yes, in the Middle Ages "quand nous étions chrétiens: nos cathédrales l'attestent." ${ }^{[20]}$ Lindsay was interested in the Muslim buildings, in ruin by 1838 , but with

semi-vaulted portals, scooped shell-wise, like the ceilings of the Alhambra, lead to staircases, one running down into the platform, but filled up with rubbish, - the other leading to the roof. Peeping through the chinks of a door a few steps up, I saw a large chamber with pointed arches, now used, apparently, for a magazine. ${ }^{[121]}$

There was plenty of room within the town walls for the modern village, which in the 19th century by no means filled the available space, ${ }^{[122]}$ although the 
size of the ruined mosque (made largely with spolia) suggested a much bigger population. ${ }^{[123]}$ Ferrières-Sauveboeuf in 1790 was struck by the contrast between its hovels and the grandeur of the monuments. ${ }^{[24]}$ In 1820 Squire estimated that only one-fifth of the town's area was occupied, with "a most wretched appearance, as the principal part of the hovels have been destroyed by earthquakes." ${ }^{[125]}$ Brocchi visited in 1842, and was distressed by the sparse population and other signs of ruination:

E uno spettacolo per verità rattristante quello di vedere un paese lungo tre quarti almeno di miglio, le cui case sono deserte e per metà diroccate. In mezzo ad esse ve n'ha una sessantina all'incirca di abitate, le quali costituiscono tutta la popolazione del paese. ${ }^{[126]}$

The town contained the ruins of a church, ${ }^{[127]}$ but even the Christian bishop's house was "but a sort of cottage, darker, and less roomy than that of a peasant in Europe." ${ }^{[128]}$ It was "the little huts of the poor peasants" which predominated, so the available ruins were left alone, perhaps because the locals did not possess masonry skills. ${ }^{[129]}$ This was not always the case, since Bourassé noted in 1867 that "plusieurs des cabanes du village actuel de Baalbekk sont bâties avec les fragments des temples et des palais: de simples murs de clôture ont des moellons en marbre et des sculptures que nos musées seraient fiers de posséder." [130] In the early $15^{\text {th }}$ century there might well have been inside the complex the remains of a colossal statue (perhaps a cult statue?), although the narrator only heard of it, and did not set eyes on it. ${ }^{[131]}$

Visitors did not need to stay in the village with the locals, for there was still plenty of room on the site in the 186os: they could pitch their tents among the ruins, and do their cooking there as well, ${ }^{[132]}$ although they had to beware of any brigands, ${ }^{[133]}$ and try and avoid the Saracen and Crusader additions, "walls within and without, which now remain to the extreme discomfort of the traveller." ${ }^{[134]}$ Many residents had taken short column shafts from the site to keep their earth-covered house roofs rolled flat and compact, and therefore watertight. ${ }^{[135]}$ This was a common practice throughout the Middle East. ${ }^{20}$

Visiting the complex incurred fees in cash or in kind, for the area was considered the property of the local emir, who extracted a telescope from Squire in 1820. ${ }^{[136]}$ The host to Aucher-Éloy in 1830-1 demanded he be shown where the treasure was hidden, ${ }^{[137]}$ this happening at least in part because some visitors copied inscriptions. ${ }^{[138]}$ In 1867 Macedo was relieved to find that guides had not yet arrived, "pour y dépouiller les visiteurs, comme font les Bédouins aux 
Pyramides, où ils exercent la plus arbitraire extorsion, au mépris du règlement de police du pays." ${ }^{\text {[139] }}$ Some tourists were evidently warned (cf. warnings for Jerash, or Palmyra) that it was dangerous to wander alone around the temples, but this might have been overplayed. Pfeiffer met "no one but a few curious inhabitants, who wished to see the newly-arrived Franks," and he thought travellers' tales were spiced up: "My journey was a very long one through very dangerous regions; on some occasions I travelled alone with only one Arab servant, and yet nothing serious ever happened to me."[140]

It may be the case that the dangers which kept both settlers and travellers away from ancient sites helped to protect monuments. In 1743 Perry intended to go to Baalbek, but "the Aga's [warriors] upon that Road were at Variance and Blows amongst themselves; which render'd our passing that Way impracticable, or at least dangerous." [141] In 1881 Oliphant suggested the Turks charge admission to the site and, because visitors were evidently chipping souvenirs from the ruins, also carve fragments from the quarry, label them "Baalbek," and sell them to the tourists. ${ }^{[142]}$ Such low-quality souvenirs would not have prevented the captain of the USS Constitution, visiting in 1837 from seeking and receiving permission to take down a bas-relief eagle and carry it away. Unfortunately, "the block on which it was sculptured formed the key stone of an arch and could not have weighed less than four tons, perhaps five of them. It had been displaced from its position by the jarring of an earthquake" and could not be removed without bringing down surrounding stonework. "So deeming discretion the better part of valor we contented ourselves with breaking off some round sculptured pieces from the frieze \& returning to our tents." [143] Evidently Berners, who condemned the locals who excavated columns for lead, ${ }^{[144]}$ should also have considered the toll taken by foreigners.

Inprovements were on the way: by the later 1880 os "the village, or town, of Baalbek is extensive and flourishing," which must have come from tourism and perhaps agriculture, and the governor had decorated the approach to his house with a headless colossal statue seated between colossal lions. ${ }^{[145]}$ More tourists were to arrive, because of the site's proximity to the railway. ${ }^{[146]}$ In 1892 Marquette paid an entrance fee, and reckoned that in the touristy months of April and May "il recueille ainsi de huit à neuf mille francs, que l'on devrait employer à restaurer, ou du moins à conserver ces ruines saisissantes, qui malheureusement se détériorent chaque année."[147] Organised tours also brought income, but provoked the contempt of independent visitors: "Ces brigands de Cook savent toujours bien choisir leurs places. Nous leur envoyons de nos gâteaux, qu'ils s'empressent de jeter à l'eau [they were installed near a stream] après y avoir touché., ${ }^{[148]}$ The Kaiser with his large retinue visited in 1898 on 
his way to Jerusalem, ${ }^{21}$ as part of what has been called "The political theater of the past," ${ }^{22}$ and was given carte blanche by the Sultan to excavate the site: they

laid down a rail-road track for the dirt cars to carry away mountains of earth and debris. As a result of their work and modern machinery for lifting huge stones into place we have at last a view of these most wonderful temples more as they were in their glory. ${ }^{[149]}$

There was certainly plenty of digging to do: Lamartine wrote in $183^{2}$ that "Le fer de nos chevaux glissait et se brisait à chaque pas dans les acanthes polies des corniches, ou sur le sein de neige d'un torse de femme."[150]

The materials for the temples were largely of the hard local limestone, but some visitors got it wrong: in 1823 Wilson wrote of "stately Corinthian columns, each of one solid piece of marble," when they were in drums, and of limestone. He also thought part of the complex was a theatre. ${ }^{[151]}$ Berger was still calling the columns of the great temple "marble" in $1895^{[152]}$ - and perhaps the confusion was with Roman monuments seen further west, where the columns often were of marble or granite. Lucas thought he needed more than a week to explore the ruins, but labelled the tombs he saw as marble. ${ }^{[153]}$ Jones recognised the red Egyptian granite monoliths in the square court, which had retained their polish. ${ }^{[154]}$ Paxton in 1839 saw small granite columns in the mosque, and asked "how could masses of rock three feet in diameter and ten or fifteen feet long be brought over Mount Lebanon, which is so steep and high that it is a great labour for man unloaded to pass?" ${ }^{[155]}$ Like Seetzen, ${ }^{[156]}$ he knew that Syria had no granite quarries - which increased their wonderment at the monuments. Lindsay in 1838 noted that a colonnade visible in 1688 had completely disappeared, leaving only the podium; ${ }^{[157]}$ and Measor, writing in 1844 , complained about the "confused patchwork put together in haste by the Saracens" forming an "unseemly confusion" to turn the complex into a fortress. ${ }^{[158]}$ So for some the later builders were "plutôt des vandales que de vrais architectes."[159]

As already noted, some travellers were also distressed at the continuing destruction of the temples, especially the gouging of the columns for the small quantities of iron which joined the drums ${ }^{[160]}$ - and bad luck if the whole column fell. Visitors could still "rebuild" the great temple by counting surviving

21 Scheffler 1998: the Kaiser left Oct 11, 1898 for tour of Constantinople, Jerusalem, Beirut, Damascus and Baalbek with an enormous number of tents, horses, coaches, etc.; Lemke 1998 for large number of postcards and photos recording the Kaiser's visit. 
column shafts (nine) and also bases, ${ }^{[161]}$ not all of which survived, presumably because they were easier to reuse. Just what part earthquakes played in demolition is difficult to determine. It was indeed extensive, but we must doubt Basterot's assertion that the great temple lacked scarcely more than its roofing before the great 'quake of 1709 ': [162]

\section{Palmyra $^{23}$}

There are wonderful buildings here erected on pillars. The people say they were built by the Jinns at the order of Solomon the son of David. At the present day the people there live in a castle surrounded by a stone wall. It has a double gate of stone, and there are temples, of which three remain standing to the present day. ${ }^{[163]}[1225]$

This important antique trading centre (with art and architecture that looked east as well as west $)^{24}$ saw a decline into insignifiance ${ }^{[164]}$ which helped for centuries to preserve her many monuments. ${ }^{25}$ Occupied in early Islamic times, ${ }^{26}$ Palmyra was famous with Muslim authors such as Yakut, quoted above, whose "castle" is the Sanctuary of Bel, still a stronghold in the 19th century. It was a site with so many wonders that like Baalbek its building was ascribed to Solomon, aided by the djinns - a persistent idea. ${ }^{[165]}$ If Hellenism had a list of wonders, so did Islam. "Parmi les merveilles du monde," wrote Dimashqi in the later 13th century, "est aussi la ville de Tadmor avec ses colonnes et ses murailles, ses décombres et ses ruines, dont on ne trouve pas de pareilles en longueur et en hauteur, en quantité et en qualité des carrières d'où elles ont été tirées." ${ }^{[166]}$ The site remained in very good condition, apart from sculptures where "Muslimischer Vandalismus hat alles stark beschädigt." ${ }^{[167]}$ Even the continentals agreed that the site's "discovery" was British, ${ }^{[168]}$ so that Le Brun

23 Smith 2013, 1-32: Roman Palmyra and its setting; with 21-32 for Palmyra's history and urban development. Carita 2004, 131-146 for Palmyra, with Byzantine sources; Hammad 2010, 54ff. for mediaeval and later history; ibid. 54: in 1177 walls of the peribolos of the Temple of Bel were strengthened with a large number of column drums - cf. fig. 116; ibid. 62: Diocletian's wall dismantled 745-6, and the town shrank into the enceinte of Bel, until the inhabitants were expelled under the mandate in 1929 .

24 Schlumberger 2010, 227-390: Descendants non-méditerranéens de l'art grec - deals with Gandhara and Palmyra, some of which he compares with material further east.

25 Delplace 2014 for a survey.

26 Gawlikowski 2008; Gawlikowski 1997: houses in the section dug by the Poles abandoned only toward 800 , after occupation for more than six centuries. 
wrote honestly in 1714, "quoi que ce que j'ai à en dire ne soit pas de moi, mais d'un autre de qui je l'ai emprunté."[169]

One curiosity is just how late the site was properly surveyed (was this a result of insecurity?). In spite of the deficiencies in Wood's 1753 account, "only the highest praise can be given to so magnificent a work, accomplished under such difficulties and long before archaeology as a science was born," wrote Murray in 1917. Wood himself stated his concern for the truth, ${ }^{[170]}$ aware, perhaps, of other decidedly fanciful publications. Murray wanted to know why no more than a preliminary report on the site had yet been published ${ }^{[171]}$ - an eternal question for many archaeological sites. Michaelis, on the other hand, denigrated a part of Wood's work: "what they brought back in the way of antiques does not appear to have been of great importance." ${ }^{[172]}$ But then perhaps large quantities had already been misappropriated: the mummies of Palmyra had been broken up in the hope of finding treasure, and for this reason Wood, writing in 1753 , could not locate a whole one. ${ }^{[173]}$ Nevertheless, Volney in 1792 describes the ground as strewn with antiquities:

ce ne sont de toutes parts que fûts renversés, les uns entiers, les autres en pièces, ou seulement disloqués dans leurs articulations; de toutes parts la terre est hérisée de vastes pierres à demi-enterrées, d'entablemens brisés, de chapiteaux écornés, de frises mutilées, de reliefs défigurés, de sculptures effacés, de tombeaux violés, \& d'autels souillés de poussière. ${ }^{174]}$

With its colonnades, temples, fortress and tombs, "beautified by decay," as Sykes has it, ${ }^{[175]}$ Palmyra was an important attraction for travellers, in part because of knowledge through ancient authors of its feisty Queen Zenobia, who gave the site an identity that Baalbek did not possess because it went unmentioned (which puzzled more than one traveller). However, Baalbek was near to the coast, even if the access was in early years by a track through the mountains. ${ }^{27}$ Palmyra, on the other hand, was $235 \mathrm{~km}$ from Damascus across the desert, throughout which roamed marauding Bedouin. Hence it was usually difficult and expensive to get to, and the trip could be dangerous if the various competing marauders had not been squared. The site itself was ruled by the local sheik, frequently with an iron fist, ensuring security once there and the "ransom" paid by travellers who generally had nowhere else to go but back west toward Homs/Hama, thus temporary desert captives. This distinguished it from Amman and Jerash, where mayhem ruled both on the journey and at

\footnotetext{
27 Apostolou 2009, 161-173: Palmyra and Baalbek.
} 
the sites. Strangers were to be feared. In 1691 Halifax tried to enter the settlement of thirty or forty families:

ye whole power of ye village if I may so call it, being gathered at ye door, whether to stand upon their defence in case we proved Enemies, for some of them had their guns in their hands, or meer curiosity to stare upon us I know not: however our guide being a man known among them, we had an easy admittance. ${ }^{[176]}$

The population was estimated at fifty huts in 1876 , and lived within the great temple precinct, which had probably been a fortress since the Middle Ages. ${ }^{28}$ Le Brun had reported a similar population in 1714, and in the same location: "entre les murailles d'une grande place, dans l'enceinte desquelles il y a un tres beau Temple des Payens,"[177] and Campbell likewise in $1758^{[178]}$ These huts were of antique materials cemented with mud, and the mosque was built with fragments of sculpture in its walls, ${ }^{[179]}$ but this "wch tho of a more artificial frame \& composure than many I have seen yet is not worthy to stop us in ye way to things both of greater antiquity." ${ }^{\text {[180] }}$ Baron Taylor had evidently not looked too carefully in 1854, also stating that the huts were of mud, and "c'est là tout ce qui reste de ce peuple riche et policé, de cette nation qui fut plus grande par les arts que par la guerre."[181] The mosque was the sanctuary of the temple, and the sheikh took Beaufort inside in 1874: "at each side are two small chambers with richly-carved ceilings, one of which has the signs of the zodiac, with figures of the deities still visible, despite the efforts of the Mooslims to destroy them." ${ }^{[182]}$ Certainly, several antiquities had deteriorated since Wood drew them in $1753 \cdot{ }^{29}$ Others had patently disappeared, but to where? Sachau wanted to know where the remains of the city had gone to, since there were no nearby settlements:

Wer das Ruinenfeld durchwandert, dem drängt sich bald die Frage auf: was ist aus dem gesammten Baumaterial der Stadt geworden? wo ist es geblieben, wohin gerathen? Es sind niemals in der Nähe Palmyras neue Ortschaften entstanden, zu deren Bau die Steine von dorther geholt worden wären, auch sind die Transport-mittel in der Palmyrene zu jeder Zeit die primitivsten gewesen. ${ }^{[183]}$

28 Wiegand $193^{2}$ II, 70: aerial views of the Sanctuary of Bel in 1929, with its complete Arab village, and 1930, in the process of clearing out the inhabitants.

29 Wiegand 1932 II, 45 for Camp of Diocletian in Wood's plate of 1753, and the much less left to see in a photo of 1902. 
Inhabitants had been so few because Palmyra was no longer a busy entrepôt, and was naturally called a village. ${ }^{[184]}$ It had grown by the 1880 s, presumably because of the opportunities brought by the tourists, ${ }^{[185]}$ but the temple enceinte was still the "seule partie habitée de la grande et somptueuse reine du Désert." ${ }^{\text {[186] }}$ In 1899 Oppenheim thought there were 1,500 inhabitants, and both trade and travel were on the increase, with a sheikh "welcher durch seine Begleitung verschiedener europäischer Reisenden bekannt geworden und zu grossem Wohlstand gelangt ist." ${ }^{\text {[187] }}$

In 1840 Blondel heard stories of travellers robbed and stripped on the way to Palmyra. He liked the system whereby the sheikhs left hostages at Damascus against their good conduct (a system as old as the hills), but making the necessary arrangements would have taken too much time, so he chickened out, and "nous nous vîmes en conséquence dans la dure nécessité de renoncer à cette excursion.. ${ }^{[188]}$ The identical excuse had been used by Coote in 1780 , who likewise wrote that he could not spare the time for the necessary negotiations. ${ }^{[189]}$ So many ruins, so bound to miss things if robbers were lurking - and they were! The trip was still dangerous in 1848 , if one met "une de ces bandes errantes de Bédouins dont l'état habituel est la guerre, qui ne vivent que de rapines et de brigandages." ${ }^{[190]}$ Indemnification was sometimes sought and won against tribes who had assaulted travellers. ${ }^{[191]}$

Once arrived, there could also be problems. In 1829 Fuller met with an ingenious Bedouin wrinkle in the sacred custom of hospitality, when the local sheikh resented payment being made to those overseeing the route rather than to the locals, and produced his own variation on visitors being allowed into monuments such as fortresses, but not out again:

The inhabitants themselves, the natural guardians of the antiquities, derived no benefit from their visits, but on the contrary were obliged to provide entertainment for another's guests. "The hospitality of the Arabs," continued he, "forbids me to show any incivility to strangers; you are welcome to remain in my house, and to eat with me for as long as you please; but I will not allow you to go out to visit the curiosities of the place, unless you pay me the same sum which you have paid to Nasr." ${ }^{[192]}$

By 1876 Cook was writing up twelve-day tours to Palmyra, but warning (as one might expect from a company trying to attract custom) that the site was "under the power of rapacious sheikhs, and great care has to be observed in arranging for a tour to that city of grand ruins." ${ }^{[193]}$ Yet travel there was easier, because "since the extension of the military frontier of Turkey from Aleppo to Palmyra, and along the whole margin of the Syrian desert, which took place in 1870 , 
the expedition has been freed from much of its difficulty and expense., ${ }^{[194]}$ Abandoned after 14thC Mongol invasions, control was re-established by the Ottomans with an imported population to control the margins and increase agriculture. ${ }^{30}$ Nevertheless, the half-ruinous barracks of the soldiery ${ }^{[195]}$ can hardly have inspired much confidence. By 1913, it is reported, so many caravans had passed that way that one could ride all the way by bicycle; it was easy for cars, but with no garages en route, the idea was abandoned: "Our own party traveled on horse-back." [196]

Travellers were astonished by the extent of the ruins (19sq.km including necropoleis), and by the beauty of their structure (such as the entrance to the Temple of the Sun ${ }^{[197]}$ ) and their stone. The preponderant one was "une pierre calcaire tirée des montagnes voisines, fort dure, dont la beauté égale presque celle du marbre, et dont la teinte dorée s'harmonise admirablement avec celle du paysage de sable qui entoure les ruines,"[198] but there was also some granite, recognised as having been brought here from an immense distance. ${ }^{[199]}$ Nevertheless, many people thought the colonnades and other blocks were marble, and still thought so at the end of the 19th century. ${ }^{[200]}$ Volney in 1796 described the sight as "a countless multitude of superb columns standing erect, and which, like the avenues of our parks, extended in regular files farther than the eye could reach." Invited into the enclosure of the Temple of the Sun, "I accepted the hospitality of some poor Arabian peasants, who had established their huts in the very area of the temple. Here I resolved for some days to remain, that I might contemplate, at leisure, the beauty of so many stupendous works." [201] Richter in 1824 went into the château (the Temple of the Sun) to rest, and "Hassan-Saléh, Arabe, qui se donnoit pour le cicérone de tous les voyageurs, vint me prendre pour parcourir les ruines."[202]

Because the temple precinct was the village, enclosed by high walls and packed with huts, on leaving it "the eye is at first utterly bewildered, and even at last unable, except with imagination's aid, to estimate its grandeur." ${ }^{\text {[203] }} \mathrm{As}$ for the colonnades, these were indeed plentiful. "Elles sont rangées en files tellement prolongées," wrote Volney, "que, semblables à des rangs d'arbres, elles fuient sous l'oeil dans le lointain." ${ }^{[204]}$ Breuvery emphasises the point:

Des colonnes, rien que des colonnes, voilà la magnificence de Palmyre. Plus de trois cents sont encore aujourd'hui debout au milieu des ruines, et un plus grand nombre est renversé à leurs pieds. ${ }^{[205]}$

"But I spare the reader further description the more readily," wrote Beaufort in 1874, "since I myself never got so far as to see the half of them." ${ }^{[206]}$ Clearly, for

Al-Dbiyat \& Jaubert 2006. 
this traveller it was indeed better to journey than to arrive, and "all their imposing extent and grandeur of situation"[207] did not seem to impress him: seen one column, seen them all? For others, however, Palmyra was the epitome of the picturesque: "Palmyra at sunrise, and Baalbec at sunset, are Claudes treasured in the cabinet of the memory, which neither accident can injure nor beggary deprive one of." [208] Or, as Wood has it in French translation, "l'effet le plus romanesque que l'on puisse voir." [209]

The stones of Palmyra also fascinated the locals, according to Breuvery, whom they quizzed about extracting metals. Lead or copper was used to join architectural elements, and setting fire to shafts could sometimes succeed in extracting the metal. But they were also convinced that the metallic sound the shafts made when struck meant that they were really of bronze, and nothing Breuvery could say would dissuade them. Extracting molten metal from joints would have encouraged this notion, but it does appear as if the capitals of what is now called the Temple of Bel were indeed covered with goldor silver-decorated sheet brass, so perhaps the locals had seen some on the ground, and retrieved the metal. Certainly, in 1881 Ellis states that the shafts had both bronze capitals and bases, ${ }^{[210]}$ so presumably he had been talking to the locals. He found it ironic that "presque toujours les moyens employés par les anciens pour assurer à leurs grands édifices une solidité qui pût braver les siècles, soient devenus pour ces monuments une cause de destruction," so that "partout où le fer ou le cuivre ont été employés avec le plomb pour joindre les assises des pierres ou les tronçons des colonnes, les blocs qui seraient demeurés intacts ont été brisés pour les en arracher."[211]

For Sykes in 1905, the glory days of Palmyra visiting were past, because Cook's Tours had arrived, and

the dyspeptic colonels and "Poppas" of America will be driven by chattering servants from Zenobia's bath to Zenobia's bed, from Zenobia's bed to Zenobia's temple; the young Oxford Don will write poetry in the Temple of the Sun during the vacation; the English clergy will write to the Times concerning the disgraceful charges of the hotel.

And he published the (imaginary?) advertisement:

To Palmyra and back in Five Days £1o

Ruins and Tombs!

Spots of Interest!

Hotel - Special Rates! Home Comforts!

Children half-price - Wines included!

Reliable Guides, \&c!! [212] 


\section{Anjar, Mejdel Anjar \& the Nearby Temple}

A ruined town-wall, inclosing an oblong square of half an hour in circumference; the greater part of the wall is in ruins... In the enclosed space are the ruins of habitations, of which the foundations alone remain. In one of these buildings are seen the remains of two columns of white marble, one foot and a quarter in diameter. The whole seems to have been constructed in modern times. Following the Mountain to the southward of these ruins, for twenty minutes, I came to... springs... In the wall of a mill, which has been built very near these springs, I saw a sculptured architrave. These remains appear to be much more ancient than those of Andjar, and are perhaps coeval with the buildings at Baalbec. $^{[213]}[1810]$

When Burckhardt visited Anjar in 1810, there was little to be seen inside the walls, and he correctly half-dated the site as "modern," in fact built by the Umayyad caliph al-Walid I early in the 8th century. ${ }^{31}$ Seetzen, visiting in 1805 with a Druze guide who hoped he might find treasure there, was clear that its main feature suggested that it was in fact antique, or at least based on Roman camp layouts: "man sieht noch den Umfang der Stadtmauer und viele Thürme der Mauer, aber, so wie alles Uebrige, gänzlich ruinirt. So viel sähe ich indessen aus den Mauerresten, dass dieser Ort nie ansehnliche Gebäude des Alterthums aufzuweisen hatte." ${ }^{[214]}$ Superstitions surrounded its name. ${ }^{[215]}$ The site was subsequently abandoned (it is unknown just when), but repopulated with Armenians from the Musa Dagh area in 1939. Cobb notes that the site "was built from scratch in the style of a Roman legionary camp, but is unambiguously Umayyad, with its palaces, mosque, Syrian style houses, baths and shops." ${ }^{32}$ Until the site was investigated and parts rebuilt by archaeologists from the 1950s, there was indeed little to see inside the walls of Anjar.

In $185^{2}$ Robinson visited, noting "the ruined walls and towers of an ancient fortified city or citadel, in the form of a square, about a quarter of an English mile on each side," and stating it was the ancient Chalcis. ${ }^{[216]}$ He then camped

$31 \quad$ Hillenbrand 1999: exposition of Anjar and Early Islamic urbanism. Petersen 2007 for Mamluk new towns in Palestine: Magdal NE of Ascalon - this is Magdal-Gad, now el-Medjdel [= the fortress]; a lot of sites have the same toponym. 501-505: Safad.

Cobb 2010, 248; Nicolle 2008: well illustrated accounts of Anjar, the Amman Citadel, and the Desert Castles. Milwright 2010, 76: "a startling illustration of the tenacity of Roman-Hellenistic principles of urban planning ... In accordance with classical models, the two major arteries meet at a tetrapylon and are colonnaded with lines of cubicles on either side." 
by the fountain at Mejdel, and called the temple there "one of the finest antique temples now existing... The temple is simple, massive, and beautiful, and obviously of a severer and earlier type than those at Ba'albek. Nothing can be finer than its position."[217] Just like Robinson and Burckhardt, Seetzen also went to Mejdel, the source of Anjar's water, and the natural place to camp, since presumably aqueducts no longer worked at Anjar itself. Again he was impressed by the temple above the deserted village, especially by its large stones:

die Ruinen eines alten Tempels, welcher die gewöhnliche länglicht viereckige Form hatte und aus Ungeheuern Steinen ohne Mörtel bestand. Vor seinem auf der Nordseite befindlichen Eingänge war ein Peristyl von Ungeheuern Säulen befindlich, welche alle zerbrochen unter dem Schutte umher lagen, und von keiner bestimmten Ordnung gewesen zu seyn schienen. ${ }^{[218]}$

Porter described the temple, thinking it considerably older than those at either Baalbek or Palmyra:

The foundations of the cell are composed of huge blocks of limestone; one I measured being twenty-four feet long and six high... The interior was ornamented with fluted semi-columns of the Ionic order, supporting a fine cornice. Between the columns were niches for statues. A portico of massive columns stood in front, with antae behind. These columns are now completely prostrate; but the huge fragments are scattered around, half covered with luxuriant vines. One portion of a shaft I measured was twenty-four feet long and four feet six inches in diameter. The door leading from the portico to the cell was lofty and spacious; the jambs were massive monoliths, richly moulded. ${ }^{[219]}$

No doubt in a desire simply to keep the record straight, Robinson noted that Burckhardt, although he went to the springs at Mejdel, did not mention the temple. ${ }^{[220]}$

Already by 1854 Porter saw little on the site: "the foundations of the walls alone can be traced, enclosing a rectangular space about a mile in circumference. In the interior are a few mounds covered with soil, from which some hewn stones and pieces of broken columns may be seen here and there projecting. These are the only remnants of palaces and temples." Camping by the fountain he saw "traces of an aqueduct running along the high ground toward the ruins." [221] Two years later Robinson affirmed the little interest the site seemed to hold for travellers, and at the same time indicated the motor for its further ruination: 
Although the ruins lie within fifteen minutes of the great Beirut and Damascus road, and in full view, Seetzen and Burckhardt were the first travellers to visit and describe them; and very few have done it since. ${ }^{[222]}$

By 1862 there was surely less to see on the site, when Beke reported that road works were plundering the site: "the ruins of this city are now rapidly disappearing, the broken shafts of columns, hewn stones, and other architectural fragments being either worked up for the masonry of the bridges of the new carriage-road, or else burnt into lime." ${ }^{[223]}$ Mislin in 1876 wrote:

L'enceinte de la ville, encore facilement reconnaissable, avait une demilieue de tour; on y voit les débris de quatre portes, de trente-deux tours, de belles colonnes en marbre et en granit, des sculptures, des restes de temples, des bassins, des citernes et des sarcophages. ${ }^{[224]}$

This might indicate that the walls were already being dismantled, for the town in fact originally had forty towers, not Mislin's thirty-two. In the same year Baedeker reckons that "an important town and fortress must have stood here in ancient times," and notes that the springs are "at about the same distance from the station" (a stop on the diligence route, not a railway station) as the ruined town - a clear indication of how the remains were disappearing. ${ }^{[225]}$
[1] Ibn_Battuta_1982_173
[2] Le_Strange_1890_26o-261
[3] Le_Strange_1890_227
[4] Al-Dimashqui_1874_262
[5] Ibn_Haukal_180o_42-43
[6] Fermanel_1670_315
[7] Le_Strange_1890_263-264
[8] Broquière_1892_32-33
[9] Thompson_I_1767_140
[10] Arvieux_II_1735_451
[11] Thevenot_1689_689
[12] Campbell_1758_153
[13] Pococke_II.1_1745_120
[14] Cf. Robinson_1856_462B
[15] Green_1736_39
[16] Ali_Bey_1814_III_219-220
[17] Squire_1820_315
[18] Richter_1824B_27-28
[19] Dieterici_1853_II_358
[20] Robinson_1838_299
[21] Buckingham_1825_ 307-308
[22] Robinson_1856_462
[23] Mislin_1876_I_548-549
[24] Paul_1865_144
[25] Tilley_1864_358
[26] Lycklama_a_Nijeholt_ 1875_549-550
[27] Oliphant_1881_53
[28] Raboisson_1887_289
[29] Vogüé_1876_76
[30] Lammens_1921_II_21-22
[31] Oppenheim_1899_56
[32] Wilson_II_1881_149
[33] Cuinet_1898_401-402
[34] Curtis_1903_129-130
[35] Von_Kremer_1920_155
[36] Von_Kremer_1920_182 


\begin{tabular}{|c|c|}
\hline [54] & ] Berners_1876_254-255 \\
\hline [55] & ] Tilley_1864_371-372 \\
\hline [56] & ] Thompson_I_1767_ \\
\hline & $128-135$ \\
\hline [57] & Wright_1848_499 \\
\hline [58] & ] Ibn_Battuta_1982_ \\
\hline & $167-168$ \\
\hline [59] & ] Michaud_\&_Poujoulat_ \\
\hline & VI_1835_244 \\
\hline [60] & ] Le_Strange_189o_ \\
\hline & $296-297$ \\
\hline [61] & Al-Dimashqui_1874_268 \\
\hline [62] & Basterot_1869_10o \\
\hline [63] & ] Aramon_1887_111-112 \\
\hline [64] & ] Wright_1848_496 \\
\hline [65] & ] Campbell_1758_159 \\
\hline [66] & ] Castlereagh_II_1847_277 \\
\hline [67] & ] Leary_1913_192 \\
\hline [68] & ] Bird_1872_27 \\
\hline [69] & ] Laorty-Hadji_1854_164 \\
\hline [70] & ] Aramon_1887_111-112 \\
\hline [71] & Laorty-Hadji_1854_164 \\
\hline [72] & Hill_1866_431 \\
\hline [73] & D'Estourmel_I_1844_287 \\
\hline [74] & Curtis_1903_172 \\
\hline [75] & Lindsay_II_1838_36o \\
\hline [76] & Allen_1869_56 \\
\hline [77] & Canning_1888_II_127 \\
\hline [78] & Carne_III_1838_21B \\
\hline [79] & ] Burton_\&_Tyrwhitt- \\
\hline & Drake_1872_I_38 \\
\hline [80] & ] Saulcy_1853_II_637-638 \\
\hline [81] & Lombay_1892_176 \\
\hline [82] & Vogüé_1876_58 \\
\hline [83] & ] SPCK_1835_137-138 \\
\hline [84] & ] Ellis_1881_II_108-109 \\
\hline [85] & ] Baedeker_1898_373 \\
\hline [86] & ] Bird_1872_78-79 \\
\hline [87] & Leary_1913_198-199 \\
\hline [88] & ] Mislin_1876_I_584 \\
\hline [89] & ] Pococke_II.1_1745_112 \\
\hline$[90]$ & Squire_1820_306 \\
\hline [91] & Moore_1895_26-28 \\
\hline [92] & ] Martin_1883_142-143 \\
\hline
\end{tabular}

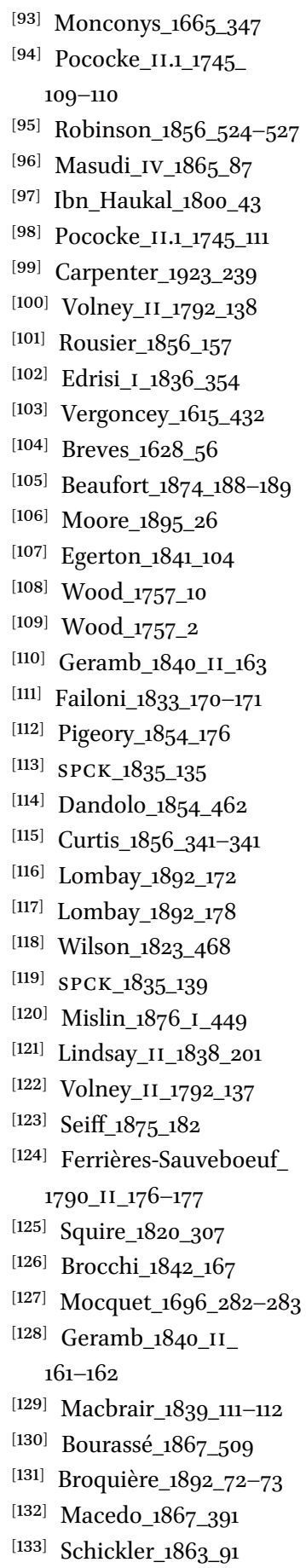

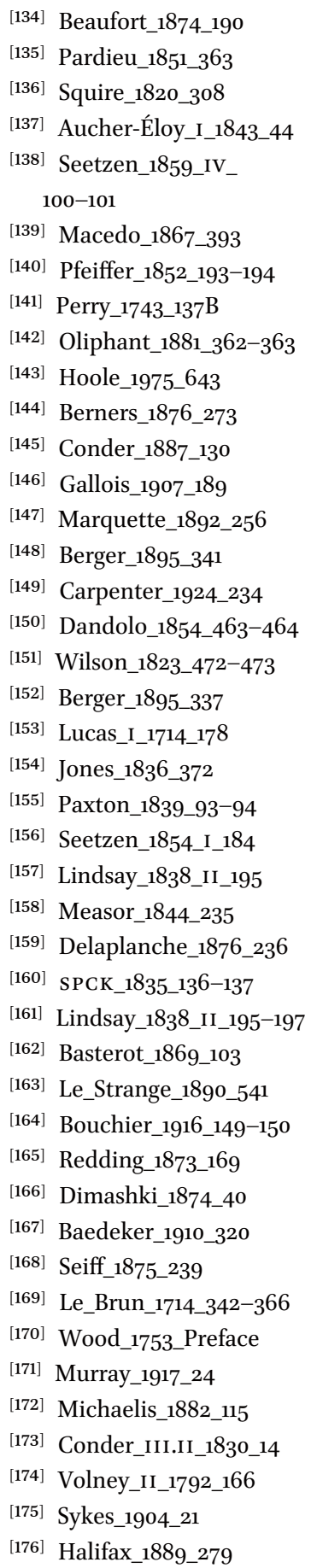




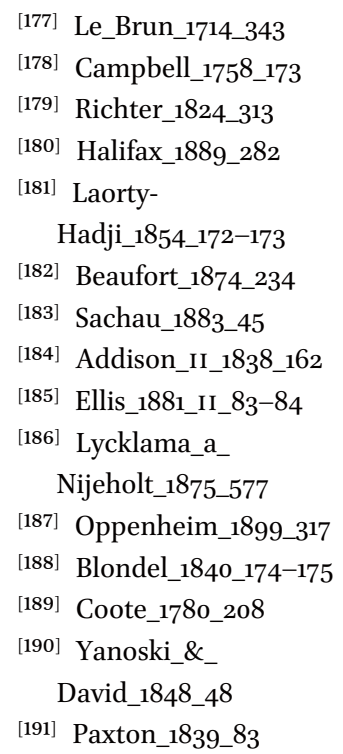

\author{
[192] Fuller_1829_307 \\ [193] Cook_1876_28 \\ [194] Baedeker_1876_517 \\ [195] Sachau_1883_47-48 \\ [196] Leary_1913_128 \\ [197] Kelly_1844_231 \\ [198] Breuvery_1848_112 \\ [199] Ellis_1881_II_86 \\ [200] Delville_1894_73-74 \\ [201] Volney_1796_3 \\ [202] Richter_1824B_310-311 \\ [203] Kelly_1844_232 \\ [204] Volney_II_1792_165 \\ [205] Breuvery_1848_97 \\ [206] Beaufort_1874_239 \\ [207] Addison_II_1838_159 \\ [208] Kelly_1844_259-260 \\ [209] Volney_II_1792_165
}

\author{
[210] Ellis_1881_II_82-83 \\ [211] Breuvery_1848_113 \\ [212] Sykes_1904_19-20 \\ [213] Burckhardt_1822_ \\ 26081810 \\ [214] Seetzen_1854_I_262 \\ [215] Burton_\&_Tyrwhitt- \\ Drake_1872_II_50 \\ [216] Robinson_1852_30B \\ [217] Robinson_1852_30 \\ [218] Seetzen_1854_I_263 \\ [219] Porter_1855_I_12-13 \\ [220] Robinson_1856_494 \\ [221] Porter_1855_I_14-15 \\ [222] Robinson_1856_496-497 \\ [223] Beke_1862_78 \\ [224] Mislin_1876_I_534-535 \\ [225] Baedeker_1876_447
}




\section{Bosra and the South}

\section{Bosra}

Roman Bozrah...was a beautiful city, with long straight avenues and spacious thoroughfares; but the Saracens built their miserable little shops and quaint irregular houses along the sides of the streets, out and in, here and there, as fancy or funds directed; and they thus converted the stately Roman capital, as they did Damascus and Antioch, into a labyrinth of narrow, crooked, gloomy lanes. ${ }^{[1]}[1865]$

Bosra, ${ }^{[2]} 140 \mathrm{~km}$ south of Damascus, the main town in the Hauran, and a site investigated by today's archaeologists, ${ }^{1}$ was in ancient times the centre of a rich and prosperous agricultural region, and well endowded with monuments including temples, theatre, hippodrome and amphitheatre, the main area protected by walls. Its towers were visible for miles around, ${ }^{[3]}$ but some travellers believed it had been more affected by earthquakes than other sites. ${ }^{[4]}$ The imprint of the hippodrome may be seen from the Ayyubid Citadel, itself built round the Roman theatre, and presumably using very large quantities of blocks from the amphitheatre, barely $30 \mathrm{~m}$ distant. This is only known to us from recent excavation, and no early travellers mention it, so either the Ayyubid builders must have stripped it to the foundations, or earlier inhabitants must have used its blocks for churches and houses. In any case, by the 2oth century, the site was covered in modern houses and gardens. Since amphitheatres were so often turned into fortresses in post-Roman times, it is likely the structure had been partly robbed out well before the Ayyubids. Abulfeda [d.1331] noted the strength of the fortress, and the dour basalt: "les maisons sont construites en pierres noires qui servent également à les recouvrir." [5] The scenae frons of the theatre was largely buried under later housing until clearance began after the Second World War. ${ }^{[6]}$

In 1812 Burckhardt saw the remains of Bosra's town walls, and noted that it was "at present the last inhabited place in the south-east extremity of the Haouran ... The S. and S.E. quarters are covered with ruins of private dwellings, the walls of many of which are still standing, but most of the roofs have fallen in. ${ }^{[7]}$ As a demonstration of his limitations in architectural history, here

1 Contribution française 1989, 133-141. 
is his description of the fortress, describing the gallery at the top, but not realising that it was a Roman theatre:

Its walls are very thick, and in the interior are alleys, dark vaults, subterraneous passages, \&c. of the most solid construction. What distinguishes it from other Syrian castles, is that on the top of it there is a gallery of short pillars, on three sides, and on the fourth side are several niches in the wall, without any decorations; many of the pillars are still standing. ${ }^{[8]}$

Richter arrived three years later, and easily picked out the theatre encased in the citadel. He got an excellent welcome, because Westerners so rarely came to the region. ${ }^{[9]}$ Buckingham was delighted by the theatre, but did not know whether the fortress which enclosed $i^{2}$ was Roman (and hence the theatre built for the garrison!), or a later addition. ${ }^{[10]}$ Not least perhaps because it had once been a church, ${ }^{[11]}$ he was confused by the Mosque of Umar, which was

a large building entirely constructed out of the ruins of more ancient edifices. In some parts of this were seen columns of white marble in one solid shaft; in others, pillars of black basalt, formed out of several distinct pieces, and curious capitals of different ages, orders, and materials, ${ }^{[12]}$

and spotted nearby a large fragment of a stone door from an earlier building. ${ }^{[13]}$ No wonder he was confused, for the structure was probably a jumbled ruin as a result of the 1822 earthquake: Lindsay reported in 1838 that only a metre or so of the colonnades was visible, with several columns

of beautiful variegated marble, and, from inscriptions on the shafts, have evidently been pillaged from some Christian church. The view from the minaret is very fine; you enter the staircase by an ancient stone door, adopted from some Roman house. ${ }^{[14]}$

Adjacent was a hamman, but its remains were not explicable until after World War II. ${ }^{3}$ In 1855 Porter must have clambered carefully around the piles of

2 Yovitchitch 2004 for the citadel; Piana 2008, 170 Abb. 3 for fortressing of the theatre at Bosra, from 12thC. to 1251, and its infill, reckoned at 1240.

3 Meinecke 1991: Hamman Manjak at Bosra, with rooms incorporating opus sectile or marble mosaic. Meinecke \& Aalund 2005 for the city's architecture and archaeology. Excavating the site required the removal of c2m fill - over 600 cubic metres of blocks, rubble, earth etc. 
columns in the mosque, for he repeated what Lindsay saw. ${ }^{[15]}$ Lindsay also admired some of the "Saracenic additions" wrapped around the theatre, ${ }^{[16]}$ the houses within which "communicate with the exterior fortress by the ancient galleries of the theatre." ${ }^{[17]}$ Seetzen didn't even realise the innards were a theatre: he thought they were "die Reste eines schönen grossen Palais."[18]

Monk visited Bosra in 1851, finding most of it "wholly deserted," with some 230 people living to the south east (i.e. with access to water in the same reservoir that fed the fortress). But they lived "in caves and underground dwellings, beneath the ruined houses, not one of which has been repaired, although abundance of materials lie scattered around." Why? This was attributed to habit, natural indolence, and lack of interest in comfort, so "they look with the greatest unconcern upon the ruined palaces of Bozra." ${ }^{\text {[19] }}$ Indeed, the place continued to be semi-deserted:

The surrounding plain is desolate, the walls are broken and ruinous, the mosques roofless, the houses shattered to their foundations; and we have to ride far in through piles of ruins, and over mounds of rubbish, ere we can find the half-dozen families who call Bozrah their home. ${ }^{[20]}$

And this was a city which once housed some hundred thousand! ${ }^{[21]}$ While the old paved streets in other centre had been cleared by mid-century, in Bosra this had not happened. In 1824 Richter's horse had difficulty picking its way "au milieu des rues étroites remplies de fragmens, de débris de siècles et de peuples nombreux, et où quelques habitans vivent dans des espèces de trous." ${ }^{\text {[22] }}$ Nothing had changed decades later, Porter writing in 1865 that "the streets are mostly covered, and in some places completely blocked up, with fallen buildings and heaps of rubbish. Over these I had to climb, risking my limbs among loose stones." Perhaps the population was so small and troglodytic because of the ever-present danger of marauding Bedouin. ${ }^{[23]}$

An important structure was the circle-in-square cathedral church of SS Sergius, Leontius and Bacchus (built 511-512). In 1812 Burckhardt wrote that "several beautiful sculptured friezes are inserted in the wall, but I was unable to discover from whence they had been taken." ${ }^{[24]}$ Richter described it accurately in 1824 , including chapels and doors. ${ }^{[25]}$ The drum to the central dome is still seen in De Vogüé's print; and Seetzen, in 1854, mentions the dome, and also frescoes in the choir. ${ }^{[26]}$ Much of the structure had collapsed by 19oo, probably due to mining of its blocks for building materials.

If Bosra was near-deserted in the mid-19th century, so was the surrounding area, and Porter, writing in 1865 , takes his usual perverse delight in proving the topicality of the Bible: 
I cannot tell how deeply I was impressed when looking out over that noble plain, rivalling in richness of soil the best of England's counties, thickly studded with cities, towns, and villages, intersected with roads, having one of the finest climates in the world; and yet utterly deserted, literally "without man, without inhabitant, and without beast" (Isa. xxxiii. 10). I cannot tell with what mingled feelings of sorrow and of joy, of mourning and of thanksgiving, of fear and of faith, I reflected on the history of that land; and taking out my Bible compared its existing state, as seen with my own eyes, with the numerous predictions regarding it written by the Hebrew prophets. In their day it was populous and prosperous; the fields waved with corn; the hill-sides were covered with flocks and herds; the highways were thronged with wayfarers; the cities resounded with the continuous din of a busy population. And yet they wrote as if they had seen the land as I saw it from the ramparts of Bozrah. ${ }^{[27]}$

An important point already made deserves repeating here. Porter directly links Hauran villages from Biblical times to 1865 . How could he believe that such settlements in a country taken over by Muslims and then invaded by Crusaders could have no history in the intervening seventeen hundred years? Surely his readers would have been better informed had he been conscious of the various ups and downs that did indeed happen to such settlements over the centuries? We cannot know what evidence his blinkered attitude missed, but we can be certain that his accounts lack detail that a greater ecumenism would have provided.

\section{Hauran}

After the original erection of these cities, an age of great prosperity seems to have ensued. Carving, decoration, and architectural embellishment became general, and lasted for a considerable period. Then a great earthquake appears to have shattered the larger and loftier buildings. Public edifices, theatres, and churches transformed from old heathen temples, have been shaken to their foundations, the roofs and upper stories crashing through the lower floors; in some places whole streets have been laid low, looking in their ruin like furrows in a ploughed field. / A period of rebuilding followed. Stones used in the old edifices were re-used in repairing and reconstructing the dwelling-houses. You see now inscriptions built into walls upside down, carved and decorated stones curtailed to fit into their new positions. ${ }^{[28]}[1895]$ 
The country itself was almost unknown to the modern world until during the last half-century; and even today it has not been completely explored. It is very rich and fertile, but thinly populated. It abounds with remains of ruined cities and towns, which testify to its former prosperity. Most of the present inhabitants live in the best preserved of these ancient houses. ${ }^{[29]}[1915]$

The Hauran ${ }^{[30]}$ is a basalt plain south of Damascus and east of the Jordan river, with desert at its eastern and southern fringes, and measuring some $100 \mathrm{~km}$ north-south by $75 \mathrm{~km}$ east-west. ${ }^{4}$ It was further divided into the Gaulanitis (Jaulan), Batanea (aroud Deraa), Trachonitis (Ledja) and Auranitis (the Hauran itself). Modern scholars have deepened and extended our knowledge of the Hauran with well-illustrated and meticulous scholarship, often by examining sites which our travellers found as heaps of ruins, as will be recounted below. Clauss-Balty has mapped villages around Deraa, and determined that, unlike the limestone plateau near Aleppo, these villages were indeed re-inhabited in the 19th century but that, with an increasing use of concrete, it is difficult to trace various changes between the Middle Ages and massive reoccupation of the 2oth century. In the same region, Dentzer-Fedy offers an examination of domestic architecture, with 169 plates. ${ }^{5}$ Guérin has examined a village in the Ledja in the $7^{\text {th }}-15^{\text {th }}$ centuries, concluding that it was founded in the 2 ndC, was given defensive towers; was intensely occupied in the Byzantine period, especially with churches. It then declined, but 12 thC and 13 thC show an economic recovery, the author suggesting that the stable Ayubbid period saw sedentarisation and repopulation of the area. ${ }^{6}$

In the two areas of villa architecture and sculpture stand-outs were flagged a century ago by Butler's Princeton Expedition of 1909. One was the Roman villa at Inkhil, which he described as "almost a palace" ${ }^{[31]}$ - as indeed it was, for Stanzl's recent account of this sumptuous complex writes of busts in the stone panels of one ceiling. ${ }^{7}$ Most sculpture our travellers encountered was either in re-use or badly damaged, but Butler came across the shrine at Sahr (a town which also possessed a theatre) tumbled but largely intact:

4 Contribution française 1989, 151-158: Prospections archéologiques dans le Hauran, époques romaine et byzantine.

5 Clauss-Balty 2004; Dentzer-Fedy 2008.

6 Guérin 1997; Guérin 2008.

7 Stanzl 2008. 
The Shekh's judgment about the ruins of Sahr was certainly excellent. Here was a Nabataean temple surrounded by a colonnaded temenoswall. In the enclosure were many inscriptions and quantities of broken statues and relief sculptures of extraordinary interest, and, rarer than all, here was a little theatre in a wonderful state of preservation. ${ }^{[32]}$

Weber has now catalogued the finds at Sahr, including state sculpture groups on a podium, reconstructed their arrangement, and also discusses the Shahba statue group with equestrian statues and a central heroic nude ruler. ${ }^{8}$ As for occupancy in the Hauran towns and villages, Braemer suggests that this was dense in the Roman period (with large cadastrated domains), probably only temporary in the Middle Ages, but with plentiful evidence of presses, watermills, canals, terraces and the rest, unfortunately difficult to date. What about the transition from the Iron Age to the Roman period? "Notre hypothèse actuelle est que l'occupation devait être essentiellement de type non permanent pendant toute cette période, et ce jusqu'au Ier siècle av. J.-C. environ, date à laquelle réapparaissent sur l'ensemble du territoire étudié les établissements construits." ${ }^{9}$ Kennedy, concentrating on water, argues that the overthrow of Roman power in early 7 thC is no longer an explanation, because some sites flourished under the Umayyads, and cisterns were repaired; yet with the decline in security and consequently a shrinking population, attempts to recolonise these marginal areas were unsuccessful until the 19thC..$^{10}$

From the large number of settlements in the Hauran, it was obvious to our travellers that it was prosperous into Late Antiquity. ${ }^{11}$ In some of the Hauran towns, travellers were especially welcomed, and the ancient structures made excellent guest-houses. At Khulkhuleh (which Burckhardt had also visited) Heber-Percy met the local Druzes, who greeted him and

led us into a capacious room built entirely of stone, with stone rafters resting on arches, and covered with a flat stone roof. Acanthus leaves were carved on the walls at the side of the room, which must have been one of the principal buildings of the ancient city. Now it is the menzul or guest-room. ${ }^{[33]}$

8 Weber 2009. Sahr: Abb. 6 \& 7 for photos of the sculptures, and Abb. $63-66$ and 120-122 for reconstructions of the arrangement. Shahba: Abb. $495^{-8}$.

9 Braemer 1993, 131-132; quote 162.

10 Kennedy 1995.

11 Sartre 1987: settlement in the Hauran 1st-4thC. Fahd 1989 for the Hauran on the eve of the Islamic Conquest; see his maps $1-5$ for settlement details. 
Here many stone doors and windows were still in use, as well as a mill-house with its aqueduct: "the mill door still opens and shuts on its stone pivots; all is so strongly built of black stone that it has hardly suffered since its last occupants left it." ${ }^{[34]}$ Near El-Hazm he found a town with an amphitheatre, determined to photograph it, and sent a Druze to fetch his kodak:

Najm explained that I was going to take a picture with the sun. This aroused immense curiosity, and, for the time, entirely diverted the attention of these wild children of the wilderness; two were persuaded to sit in the amphitheatre opposite to us. The kodak arrived; and what with the Bedouin watching me set the focus and watching the sun to see how he was going to do it, all were so quiet that I managed to get a photograph. ${ }^{[35]}$

Travellers such as De Vogüé were fascinated by the Hauran's basalt houses and vaulted roofs, ${ }^{[36]}$ a manner of building that modern scholars have traced way back before the Romans. ${ }^{12}$ As late as 1876 Baedeker was counselling travellers to take a Druze escort for the Hauran, because the region "is frequently the scene of feuds among hostile tribes, and can only be visited when the state of the country is unusually quiet." But there were treasures to be found there. The Hauran also contained inscriptions, which attracted several travellers: Waddington in $1861-2$ copied 650 , over 500 of them unknown ${ }^{[37]}$ (while such a haul would be mediocre for Roman towns in Asia Minor, it is exceptional for Syria). As Baedeker wrote:

There are still numerous uncopied inscriptions to be found here, - Greek, Latin, Nabatwan, and Arabic, - and some of them in characters still undeciphered. One or more ladders should be taken, as the inscriptions are sometimes high above the ground, and ropes and a strong iron crowbar will also be useful. ${ }^{[38]}$

Butler used inscriptions he read to paint a picture of the Hauran's inhabitants, as well-to-do, providing public buildings including churches, few settlements needing walls, and all in all a society that was peaceful and well ordered. ${ }^{[39]}$ Much has been learned about the region by energetic investigation over the last

12 Braemer \& Sorin 2010, 90: "Two social contexts appear to give a frame to these developments: egalitarian herders' communities during the 4th millennium, and building of prestige housing in the 3 rd millennium. Afterwards theses building techniques became the common ones until the beginning of the 2oth century AD." 
few decades, and their extensive publication..$^{13}$ Aerial photography has helped here, as indeed in Jordan ${ }^{14}$ and further afield under the French Mandate ${ }^{15}$ and elsewhere. ${ }^{16}$

The Palestine Exploration Fund, preparing its Survey of Eastern Palestine, gave details of the region's extent, indicating which areas featured in the Bible. ${ }^{[40]}$ For the Ledja, the towns include Burak, Musmieh to the north; Ezraa to the west; Shahba to the south east. Nearby was Sunamein (just outside to the north east), where the mosque was made from Roman materials, and "de plus elle offre des portes monolithes en pierre munies de pivots, ne nécessitant pas l'emploi d'attaches métalliques, ce qui tendrait à supposer que l'emploi du fer était inconnu jadis en ce pays." ${ }^{[41]}$ Here some materials had also been reused to build the Turkish fort. ${ }^{[42]}$

Just where one named area in this region ends and another starts can be hazy. For the Hauran proper, on the Jebel Hauran (sometimes mapped as Jebel Druze and/or Hauran) are Qanawat, Atil, Suweida and Sia; with Mejdel to the north and Bosra to the south. Sulkhad, Ezraa and Deraa are to the west of these settlements. Our travellers do not always agree on where in the above list to locate any particular settlement, so in what follows the sites will be divided simply into Hauran, Ledja and Jaulan.

This region is very fertile because of its volcanic origin, and was known in Antiquity for its cereals. The past tense is appropriate for much of the period this book covers, because of the problems (discussed in Chapter One) agriculturists faced, including taxation and, especially, ravaging nomads, warring amongst themselves but also against the adjacent Druzes. "Now it lies fallow for want of hands to cultivate it, and teems only with wild flowers," wrote Elliott in 1838, "and as corn must be grown somewhere, the pasha leaves here a few cultivators of the soil; so that the conscription presses less heavily on the Haouran than on any other part of his dominions."[43] Few people meant no beggars, wrote Seetzen in $1805{ }^{[44]}$ Sporadically the Government tried to clean up the region, taking action for example in the years following 1839 in both

13 Hauran V.I 2008, for several papers on Les aménagements hydrauliques et les bâtiments des eaux, and on La sculpture et le travail en pierre; Bessac 2008 for use of basalt in southern Syria, including quarries; Dentzer 2008 for town development.

14 Gerster 2003, 99-112: Hauran, Qanawat, Bosra; ibid. 113-137: Das Syrische Wüstensteppe; Kennedy \& Bewley 2004 for Jordan.

15 Poidebard 1937, 5: "Le Haut Commissariat de France en Syrie et au Liban, l'Armée et l'Aviation françaises du Levant, le Service des Antiquités de Syrie fournirent à ces essais de méthode aérienne un concours incessant pendant les huit années où ils s'échelonnèrent (1925-1932)."

16 Trümpler 2005: aerial photography in archaeology and its pioneers. 
Hauran and Ledja. [45] "The Hawarinah or actual tenants of the Hauran," wrote Richard Burton in 1872 , "have a very bad name, and as far as my experience enables me to judge they merit it."[46]

The various names of the region are frequently noted by travellers, and are used by them to flag the areas through which they journeyed on the way to (for example) Bosra, Jerash and Amman, all of which were great attractions, and many of the ancient towns and villages they saw en route the icing on the cake. They experienced and reported on the towns, villages and antiquities of the region, and their accounts tell of deserted settlements and nomadic dangers. We possess much more detail about these sites than about the (now more famous) Dead Cities occupying the limestone massif near Aleppo, because the latter were not strictly on the way to anywhere, and the roads were in the valleys, thereby bypassing most settlements. In the Hauran most were on the plains, easily discernable from the plentiful hills or some of the settlements upon them. Because of security concerns, most sites were little visited until the mid 19th century, but by the end of the century travellers were sounding the alarm about how fast the remains were disappearing in the face of an increasing population. ${ }^{[47]}$

For travellers the Hauran was a combination of the Wild West and Aladdin's Cave. It was often dangerous to travel there, but was teeming with ancient towns and villages, and with thousands of surviving ancient houses built with basalt stone, often stone-vaulted as well, and many with their original stone doors. Travellers were right be astonished: except for the Dead Cities further north, nothing equivalent survived anywhere else. As Thomson wrote in 1886 of the houses:

they have been exposed during long centuries to the rain and frost and snows of winter, and the blazing sun in summer, and yet they are still in such a condition that but few repairs are necessary to render them habitable. ${ }^{[48]}$

Population levels, low during the earlier 19th century, increased with higher levels of safety, and farmers prospered on the rich soil, which produced cereal crops. But this meant that the stones of many such antique sites were re-used to provide modern buildings, and some extensive sites (such as Deraa, now Syria's third-largest city) disappeared almost completely under new constructions. This is why the Dead Cities in the north are in prominence today: few people live on those hills, and they keep sheep, for whole areas have suffered from deforestation, so the soil cannot support intensive agriculture or even their original staple, namely olive groves. 
At Kereye, three hours' march from Salkhad, c.12km from Bosra, Burckhardt in 1810 noted that it was "a city containing about five hundred houses, of which four only were at this time inhabited."[49] Robinson gives exactly the same number in $1837,{ }^{[50]}$ so either these were permanent inhabitants or, which is much more likely, he simply copied Burckhardt (whom he cites a lot) and hoped no-one would notice. On the eastern side of Jebel Hauran, Burckhardt visited Zaele, which had a spring, and stone doors to its houses. He names several other sites in the vicinity,

to the distance of three days journey eastward, there is still a good arable soil, intersected by numerous Tels, and covered with the ruins of so many cities and villages, that, as I was informed, in whatever direction it is crossed, the traveller is sure to pass, in every day, five or six of these ruined places. ${ }^{[51]}$

In 1824 Richter could only reach Bosra. He had to hire 12 soldiers to get there, travelling via Sanamein (50km south of Damascus), where he saw houses built from spolia, and the remains of a temple. ${ }^{[52]}$ And, as for getting as far as Jerash and Amman, "à peine aujourd'hui deux cents cavaliers osent-ils se hasarder sur cette route." ${ }^{\text {[53] }}$ Elliott reached Sanamein in 1838, where he saw "magnificent fragments of capitals and cornices, and marbles."[54] Beke arrived in 1862, and found it so filled with ruins that he considered the town to have been rebuilt more than once. ${ }^{[55]}$ Merrill declared the temple "one of the most beautiful temples in the East." ${ }^{[56]}$ In the same year Robinson reached Suweida, $128 \mathrm{~km}$ SE of Damascus, the preeminent Druze town of the region, ${ }^{[57]}$ with a large temple, and also a large church later converted into a mosque. ${ }^{[58]}$ Lindsay, who could not travel Jerash-Bosra because, he wrote, "there being no water the whole way,"[59] and so had to approach from Amman. He saw nomads, but "during the whole day's ride, thirty-five miles at least, we did not see a single village: the whole country is one vast pasturage, overspread by the flocks and herds of the Schoor and Beni-Hassan Bedouins."[60]

\section{Shahba}

Shahba (Philippopolis), $87 \mathrm{~km}$ south of Damascus, was an important Roman town on a grid-plan (a common layout), ${ }^{17}$ and the birthplace of Philip the Arab (Emperor 244-249), hence the town's name and also its splendid buildings.

17 Schwartz 1998 for numerous street plans. 
Druze were inhabiting the town by 1805 when Seetzen visited and admired the remains; and, since he stayed with a shoemaker, presumably it was well-populated. ${ }^{[61]}$ Robinson in 1838 says it was the residence of the main Druze sheikhs, and he notes the remains of town walls, and the principal monuments, including the theatre. ${ }^{[62]}$ In 1851 Monk visited the town, which he thought larger and more magnificent than either Jerash or Bosra, with large, broad and paved streets, four great gates in the city walls, and a theatre and bath. This was like Pompeii, but on a grander scale, and

Unlike Gerash, however, many houses and public buildings are standing, while the stone doors and windows to this day move in their sockets. These old Roman houses form the habitations of the Druses of the Hauraan, who dwell peaceably in cities once renowned for beauty and splendour, now mere monuments of the instability of mighty empires. ${ }^{[63]}$

Four years later Porter described the temple, with five of its six Corinthian columns in the portico still standing, and noted the adjacent one-time church. ${ }^{[64]}$ He was welcomed by the sheikh, so presumably there was a substantial population here by the $1850 \mathrm{0s}{ }^{[65]}$ The paved Roman roads were in good condition, and evidently still in use. ${ }^{[66]}$ But the handsome Roman gates were blocked with rubbish, and the only way to enter was by scrambling over the tumbled walls, which were perhaps left that way to help deter marauders. ${ }^{[67]}$

In 1861 Rey describes the main streets at Shahba as "bordée tantôt de maisons druses, tantôt d'édifices ruinés." [68] This was evidently the posh part of town, for Rey disdained the occupied cottages to the west, "qui paraissent d'autant plus laides qu'elles sont construites avec de magnifiques débris antiques."[69] Ruins were still heaped around to a great depth, "over immense heaps of hewn stones, mingled with broken columns and fragments of richly-ornamented cornices." In the centre of town was a monumental exedra, which Porter took for part of a circus: "within several families reside."[70] He also believed that the houses with stone doors were older than Roman, "but they are in a great measure concealed or built over with the later and more graceful structures of Greek and Roman origin." ${ }^{[71]}$ One of the temples in $185^{8}$ provided the Druze chief with his summer residence. ${ }^{[72]}$

At the end of the 19th century, Shahba was still in good order, still with paved streets and the remains of its aqueduct, and "temples and columns and ruins of palatial buildings abound." [73] At the Baths "beautiful fragments of sculpture are still to be seen. Gutters for the water, and earthen pipes for conducting it to the different rooms, also still in existence. The hooks or cramps on the walls were used to secure the marble incrustation., ${ }^{,[4]}$ Rey thought these baths 
looked like those of Caracalla, at Rome, which is an apposite comparison, for they are indeed very large; ${ }^{[75]}$ what is more, there were so many columns lying around that he thought the street approach had been colonnaded. ${ }^{[76]}$ HeberPercy in 1895 was greeted there by Druze, but "the houses which lined either side of the street are heaped in ruinous confusion," and he reckoned a powerful earthquake had laid the town low: "stone seems to have been hurled from stone with titanic force; streets of stone houses lie in ranks of heaped-up ruins. Columns, capitals, and carvings lie strewn in every direction." [77] Perhaps only the main thoroughfares were clear: these appear broad and tidy in photographs labelled "1938" taken by the American Colony in Jerusalem, and now in the Library of Congress.

Near Shahba was Bshennef, with ornamented house doors and a temple, one month uninhabited, the next one occupied:

All that the Druzes had to do was to throw down a piece of matting, or those who could afford it, a piece of carpet, and to bring with them the few cooking utensils of which they had need. This formed the entire furniture of the houses; they then shut their stone doors and were secure against any sudden attacks of the Arabs. ${ }^{[78]}$

Nearby was also the village of Deir Nileh, where Heber-Percy admired fine stone doors and windows, and "those in the best repair are inhabited by the Druses... Many houses are still almost in the state in which they were abandoned centuries ago." ${ }^{[79]}$ There were plenty of other villages: Seetzen visited Mhadsche in 1805, where he saw some beautiful columns and Ionic capitals, and the remains of a church (a few Christians still lived there). ${ }^{[80]}$ By midcentury, the region was in a bad state because of governmental oppression and bedouin incursions:

Seventy villages, our travellers were told, had been destroyed or deserted within the last few years; and unless some speedy change takes place, it is likely that the Haouran will become little better than a desert, the more especially as its fruitfulness depends mainly upon regular artificial irrigation. ${ }^{[81]}$

\section{Slim, Hit, Atil}

Not two hours distant from Shahba was Slim, with its own small temple, ${ }^{[82]}$ where in 1855 Porter climbed up a larger and lavishly decorated temple (later 
converted into a church) outside the town to the north and surveyed the site: "about a mile and a half in circumference, and contains the remains of some large and important buildings; but most of them are now mere heaps of ruin."[83] Deserted at the start of the century, by 1880 it was "flourishing although not a large town,"[84] and the inhabitants "find ample accommodation in the old houses." ${ }^{[85]}$ The walls of the larger temple were still nearly perfect in the 1880 s, "with the exception of the central portion and the portico on the east side, where there has been a perfect avalanche of large stones, occasioned by the falling in of the roof and the upper parts of the walls." ${ }^{[86]}$ In 1909 Butler studied "the ruins of the very remarkable temple,"[87] but the remains today are "rather scanty," writes Burns.

At Hit, Porter was immediately led to the sheikh's house, where "the massive stone roof was supported by antique columns." ${ }^{[88]}$ He suspected the town was older than Roman, because the streets were narrow and tortuous; but "the houses are all massive and simple in plan, with stone roofs supported on arches, and stone doors. Some of the latter are finely panelled, and otherwise ornamented with tasteful mouldings. ${ }^{\text {[89] }}$ Nearby was Hiyat, where "the present inhabitants have selected the most convenient and comfortable chambers, and in these have settled down without alterations or additions. The roofs are all of stone, like those of Burak, and so also are the doors; but I observed in one or two places that the stone doors had been removed and wooden ones substituted." ${ }^{[90]}$ At Tuffas, where the mosque was built from spolia, the sheikh's house was an ancient building "which, to judge by the large well-squared stones of which its walls are built, and the style of architecture of the southern façade, must originally have been a Christian church or monastery."[91]

Slim, Atil and Suweida lie close to each other just to the west of Jebel Hauran. Atil, ${ }^{[92]} 12 \mathrm{~km}$ south of Shahba, is a settlement with fine buildings and two temples, ${ }^{[93]}$ one of which ("the portal adorned with beautifully sculptured friezes of vine-leaves, and the cornice is very handsome") was deserted when Burckhardt visited in $1812,{ }^{[94]}$ but occupied in 1838 by a Druze family, ${ }^{[95]}$ as were other houses, "encore debout en grande partie, couverts de toits en pierre et habités." ${ }^{\text {[96] }}$ One of the two temples ${ }^{18}$ was still occupied when Rey visited in 1861, so he could not make a plan, but spent his evening developing his photos instead. ${ }^{[97]}$ The temple was still a house in 1886 , "and is now the residence of the sheikh of the place," who looked after a few Druze families. ${ }^{[98]}$ (In the Ledja, Euting found in a settlement near Shahba that the sheikh had chosen the best old house. ${ }^{[99]}$ ) Merrill illustrates the temple, with the sheikh's house built into a section of it, and with the vines trailing down from the roof. ${ }^{[100]}$ 
Porter was disappointed in the few sculptural remains he came across, and infers that some had disappeared over the past decades. ${ }^{[101]}$ However, as late as 1895 Wright saw "several broken statues, some of them equestrian, are lying about, and there is one fine bust built into a garden wall." [102]

\section{Suweida}

The ruins of Suweida, $128 \mathrm{~km}$ SE of Damascus, were described by Seetzen in $1805,{ }^{[103]}$ and the houses appear to have been badly hit by earthquakes, so that little was standing intact in the 1850 s. Buckingham reported in 1825 that the town was in ruins; that 200 families lived there, and that "it was surrounded with towns and villages in every direction, and the communication between it and Bosra was over a large public road, like that between this last named city and Salghud." ${ }^{[104]}$ By the middle of the 19th century the town still boasted temples and a large church, and a mosque converted from an ancient building, ${ }^{[105]}$ while nearby Sia had an important tomb. Most of the antiquities at both sites were destroyed to provide building materials for barracks. Conspicuously the (pre-Roman, Nabatean) Tomb of Hamrath, almost complete when De Vogüé illustrated it in the 186os, was still about half-complete when Brünnow \& Domaszewski photographed it in 1909, noting how it had already deteriorated. Porter contemplated the destruction in the town, with people living only in the lower stories of the ancient houses, "and the whole surface [of the town] has become so deeply covered with the fallen structures, that most of the people seem to be residing in caves." ${ }^{\text {[106] }}$ What is more,

here are ruins heaped upon the top of ruins; temples transformed into churches; churches again transformed into mosques, and mosques now dreary and desolate. Inscriptions were here, side by side, recording each transformation, and showing how the same building was dedicated first to Jove, then to St. George, and finally to Mohammed. ${ }^{[107]}$

For Rey in 1861 the church in the main square at Suweida was "le plus beau morceau d'architecture du Bas-Empire que nous ayons rencontré dans tout le Haouran." ${ }^{[108]}$ Some town refurbishment appears to have been done. Thomson, writing in 1886 , notes that use was being made of the grand temple at the east end of the town: "When I was here, several years ago, the interior was a mass of ruins, but it has recently been transformed into the divan of the sheikh, whose humble dwelling is just east of it." ${ }^{\text {[109] }}$ The structure was also a jumble of older pieces: 
The columns are clumsy, and the Corinthian capitals in bad taste; the cornice too is poor, and is not uniform all round, and even the columns are of different dimensions and workmanship. ${ }^{[110]}$

The town was chosen by the Turks as the local seat of government; and the sheikh was, Oppenheim assures us in 1899, powerful so that, "zu meiner Zeit mögen hier mehrere Hundert Familien ansässig gewesen sein, unter ihnen auch einige Christen." [111] Brünnow \& Domaszewski gave a long and illustrated description in the early 20 th century. ${ }^{[12]}$ The town was certainly growing: the 1876 Baedeker gives the population as about 500 Druzes plus a few Christians; but by 1910 there were 4,500 inhabitants plus the military garrison, the commandatura for the whole of the Hauran, sited high above the town. Rimet Hazem is $7 \mathrm{~km}$ NW of Suweida, and with a temple that De Vogüé included in his notebook but not in the finished book; this was a pity, for the temple was destroyed and its site part-covered by an asphalt road. ${ }^{[13]}$

\section{Qanawat}

To the south-east of Slim was Qanawat, where Burckhardt described the site in $1810 .{ }^{[114]}$ Buckingham visited in 1825 , noted the temple-into-church conversions (where mosaic floors were later to be found ${ }^{19}$ ), and regretted he could not spend longer there, for "I know of no place that would furnish a richer harvest to a traveller possessed of leisure and the means of research than this." ${ }^{[115]}$ The site delighted him, for some of the buildings

stood on so elevated a position as to command the whole extent of the Hauran in one view to the westward; and from the mixture of wood and water, with the fine mountain air which it enjoyed in great purity, must have formed a delightful place of residence. ${ }^{[116]}$

In the south part of the town, Robinson identified what he thought was a palace, ${ }^{[117]}$ in fact a temple converted and extended into a church, neither of which he identified. Perhaps he found the ruins in impenetrable heaps, or perhaps he simply admired the antiquities from which the complex (indeed, it is still called the Seraya) was constructed ${ }^{[118]}$ He did recognise a temple to the south of the Seraya, admiring its "porte d'un travail exquis," and the beautiful paving

19 Donceel-Voûte 1988, 244-253 for mosaic floors in churches at Qanawat. Contribution française 1989, 142-150. 
stones en route. ${ }^{[119]}$ He noted another temple [of Zeus Megisthos] which was then in much better condition than its current state. ${ }^{[120]}$ Indeed, there were still "fragments of numerous roughly executed statues" here in the 1870 . ${ }^{[121]}$

Porter, writing in 1855, agreed that Qanawat was important, for "there are but few ancient sites in Syria that surpass it in the extent and importance of its monuments." ${ }^{[122]}$ He was particularly taken by the stone doors at Qanawat, "as most of them are panelled and have ornamental mouldings, while a few are adorned with wreaths and fruit in bas-relief." ${ }^{[123]}$ And he was especially impressed by a tower above the theatre/odeon (its remains built into a modern house):

Within it are several stone doors of great beauty, with panels and fretted mouldings, and bas-reliefs of flowers and fruit. In one of them I observed a place for a lock and also a keyhole! ${ }^{[124]}$

Riding up a hill, he scanned the town:

Temples, palaces, churches, theatres, and massive buildings whose original use we cannot tell, are grouped together in picturesque confusion; while beyond the walls, in the glen, on the summits and sides of wooded peaks, away in the midst of oak forests, are clusters of columns and massive towers, and lofty tombs. The leading streets are wide and regular, and the roads radiating from the city gates are unusually numerous and spacious. ${ }^{[125]}$

He also saw several tower tombs, which he compared to those at Palmyra, and what he believed was a hippodrome, near the Seraya, of which no trace survives:

In no other city of Palestine did I see so many statues as there are here, Unfortunately they are all mutilated; but fragments of them - heads, legs, arms, torsos, with equestrian figures, lions, leopards, and dogs - meet one on every side. ${ }^{[126]}$

There is no hippodrome, and Rey pointed out that the Druzes did indeed cultivate an oblong patch of ground, with débris piled in the middle; there was no sign of seating, and "les statues qui gisent brisées au milieu des décombres me paraissent provenir des édifices encore debout qui existent aux environs." [127]

By the 1870 os, several hundred people lived in Qanawat, ${ }^{[128]}$ and Heber-Percy remarked in 1895 that "all the best houses are now inhabited by Druses" ${ }^{[129]}$ 
that is, the ancient houses lining the main streets. He also found the odeon "with a fountain in the centre; its orchestra and tiers of seats in good preservation," and near it "a bath-house, the water still rising in the bath itself, though now surrounded with weeds and water grasses, and tenanted by clamorous frogs." ${ }^{\text {[130] }}$ Not everyone approved of repopulation, because it damaged the monuments. In 1895 William Wright wrote that Palmyra "fell under the withering blight of Islam, and then its fate was sealed." In a similar state was Burak, in the Ledja, where "seems to have fallen early under the destroying blight of Islam, and never to have recovered." And then at Qanawat, where

the blight of Islam, whose genius is destruction, fell upon it, and from that period to the present day time and man have united to make this lovely town once more like a burrowing-place of wild beasts. ${ }^{[131]}$

He need not have worried: at the end of the century most of the houses were well-preserved, but unoccupied; ${ }^{[132]}$ indeed, Oppenheim counted no more than thirty or forty families there, ${ }^{[133]}$ and the site's prestigious monuments survived into the 2oth century. ${ }^{[134]}$

Just south of Qanawat was Sia, with a small temple and its undisturbed approaches that Wilson had cleared (but not rebuilt) with a week of work by Druze labourers in $1870 ;{ }^{[135]}$ so that Heber-Percy in 1895 could admire "heaped fragments of sculptures of eagles, of horses, of a key pattern moulding, of garlands of flowers, and of capitals of Corinthian, Ionic, and Doric columns with their shafts, shattered inscriptions," and conclude that this was "the site of some gorgeous temple, shaken to pieces by a convulsion of Nature."[136]

\section{Salkhad}

Salkhad, some $165 \mathrm{~km}$ from Damascus, and which protected the grain supplies so important to that town, had a fortress prominently placed on a volcano. ${ }^{[137]}$ Early in the 19th century there were few inhabitants, but many Druze arrived as the century progressed, together with some Christians. ${ }^{[138]}$ The problem was water (although there were reservoirs), and in 1876 Baedeker reported "eight hundred stone houses, but owing to the want of water they are occupied by a few families only." Aware of the transplanted populations arriving on Syrian soil, Porter reported that "three or four hundred families could settle in this place at any time, and find ample accommodation." ${ }^{[139]}$ Riding through a deserted town was eery: 
The open doors, the empty houses, the rank grass and weeds, the long straggling brambles in the door-ways and windows, formed a strange, impressive picture which can never leave my memory. Street after street we traversed, the tread of our horses awakening mournful echoes, and startling the foxes from their dens in the palaces of Salcah. ${ }^{[140]}$

In 1876 the fortress at Salkhad still boasted Roman eagles in relief,, ${ }^{[141]}$ but one of these had fallen two decades later, because "the Druses having used it as an excellent and convenient quarry of ready hewn and squared stones for repairing their houses on the hill-side below."[142] To the south-east of the town Porter "counted fourteen towns, all of them, so far as I could see with my telescope, habitable like Salcah, but entirely deserted! From this one spot I saw upwards of thirty deserted towns!" [143] As Buckingham wrote there, the best maps were misleading, and there was far greater scope for exploration in that area than anyone had yet realised:

At Salkhad Castle, east of Bosra: In the best maps which we possess of this country, the region beyond Jordan to the east is very imperfectly delineated and described: but Bosra and Salghud form the extreme border of all that is known, and beyond this the country has hitherto been supposed to be entirely a desert. How was I surprised, therefore, to see, as far as my sight could extend to the eastward, ruined towns without number, and a country which promised a still richer harvest to the scholar, the antiquarian, and the traveller, than even the interesting region behind us to the west. ${ }^{[144]}$

\section{Deraa}

Deraa, 9okm south of Damascus and just north of the Jordanian border, was uninhabited at the start of the 19th century, although it was on Ottoman tax registers in 1596 with 120 households. Seetzen in 1810 saw only a sarcophagus, for "no remains of the beautiful ancient architecture could be found." [145] The small population of farmers, he believed, had recently been chased out by nomadic Arabs, for whom the whole area was no less than a paradise. ${ }^{[146]}$ Lindsay passed by in 1838 , admired the "handsome five-arched Roman bridge, in perfect preservation," ${ }^{[147]}$ and concluded that Deraa must have been a very large town. The President of Queen's College, Belfast visited in 1874, and found some 50 families living in houses newly built from old materials, and even with stone doors, but so overlaid with rubbish that some were like caverns, and "dangerous riding over the site, as portions of the old roofs are apt to give way 
under the horses' feet." There was one monument in the centre of the town, perhaps the Great Mosque:

A large building with an open court surrounded by rude cloisters. On one side is an old church or mosque, the roof of which is supported by six ranges of short columns and piers, all evidently taken from more ancient structures. I saw on some of the stones and shafts, Phoenician letters rudely cut, as if masons' marks, and I also found some imperfect Greek inscriptions bearing dates of the Bostrian era. ${ }^{[148]}$

By the 1880 os the town had attracted more settlers, which Schumacher in 1889 estimated at 4,000 to 5,000, but it was still a miserable place:

Everywhere are the ruins of ancient buildings and modern huts which have been abandoned, and are now fallen to decay. The building-stones used are, without exception, ancient, and the elevated site of the present city is entirely due to the debris of ancient buildings on which it stands. ${ }^{[149]}$

Merrill in 1881 thought excavation here would bear fruit:

Dra'a ought to be a rich field for excavations, because at least three cities exist there, one beneath another. The present Arab buildings and heaps of filth are, for the most part, on the top of a Greek or Roman city ... Judging from facts brought to light at certain points where excavations have been made, the second or Roman town was built on the remains of one still older. ${ }^{[150]}$

In other words, Deraa was slowly being populated; it was reckoned at the end of the century to have 800 worked stone houses in perfect condition - but with only a few families in residence because there was no spring water, only cisterns. ${ }^{[151]}$ Shortly thereafter Butler faced the same problem at Salkhad, and looked for water from melted snow. ${ }^{[152]}$

Some way outside the town Schumacher described an aqueduct and the remains of a Roman bath with perhaps a later hammam built within one section:

A ruined, spherically-vaulted building, evidently an ancient Roman bath, as is proved by the construction and the pipes which conducted the water from the roof of the building into the interior. The masonry is good and laid in white mortar; the surrounding walls are 20 feet high. A part of the 
building is now occupied by Fellahin, who have made a hut in one of the niches. These men informed me that a short time ago the building was in perfect preservation, and the interior arrangements were those which they remembered to have seen at the Hammams of Acca [Acre], to which city they now and then bring their grain. To the east of this Hammam is a well-built chamber in good preservation, the roof of which is on a level with the surrounding ground and the floor of the Hammam, while its walls are in part those of the ancient water-basin. ${ }^{[153]}$

He also described a medley of antiquities, including cornices, columns and capitals, plus a still-standing six-metre column, at Zeizun, which he reckoned "an important place in ancient times." ${ }^{[154]}$

\section{Ledja}

The Lejah is a refuge for those fleeing from oppression or danger, as in times past. Its inhabitants are chiefly Bedawins of the wildest and most predatory type, who are only kept in control by the authority of their Druse neighbours. Without a Druse escort the Lejah is indeed inaccessible. Travellers should stedfastly adhere to the advice of the escort in all particulars, and not even attempt to sketch a ruin or copy an inscription without their express permission. Otherwise, he might be suspected by ignorant and superstitious onlookers to be engaged in magical incantations; and in that case danger to life or limb would inevitably result. ${ }^{[155]}$ [1876]

In 1881 Oliphant enlarged on the above warning in the Cook's Guide quoted above, pointing out that the area was an impregnable fortress. Bankes in 1816 had marvelled at the "prodigious number of antique villages that stand scattered over it, with the dwelling-houses of a thousand years old and more, remaining quite entire," all built in basalt, "even to the very planking of the ceilings, and to the doors and shutters, which still turn upon their pivot-hinges." [156] He visited a range of settlements in the Hauran. ${ }^{20}$

Sykes in 1905 reckoned that, along with the Hauran, the Ledja had been more-or-less an independent state. ${ }^{[157]}$ Ibrahim Pasha lost 25,000 men when he tried to subdue it in 1835, and this was far from the last bloody nose given to would-be invaders. The region was earlier in the century the stronghold of 
Arabs, feuding with the Druze, and in 1858 "to trust oneself under such circumstances among the wild rocks of the Lejah would be madness." ${ }^{\text {[158] }}$ Subsequently the Druze had the upper hand, and used the area as a stronghold to avoid conscription and taxation. The area calmed down only when central government had the sense to elect a Druze instead of a Turk as the local Caimakam. ${ }^{[159]}$ Jessup reckoned that the government nailed down the problem in 1906, opening "three railway lines of approach to the Druse strongholds, the two roads from Damascus to Mezeirib from the north, and the Haifa railroad from the west, so that a future Druse rebellion in Hauran is well-nigh impossible."[160]

The Ledja really was the Wild West: "In several places the temples remain, though generally less perfect than the private houses, and in some the theatres also." ${ }^{[161]}$ Lying between Bosra and Ezraa, the Ledja was occupied before and during the Islamic period, but appears to have been given over to nomads by the end of the 17th century. ${ }^{21}$ This area has been described as a volcanic wilderness, characterised by Butler on his 1909 expedition as "a country the face of which could hardly be matched in the worst of evil dreams," but with small patches of fertile soil where are to be found "every ancient town, as well as the modern villages which have replaced a number of them." But these patches were rare, and "there are vast tracts where there is no soil whatever, and consequently no settlements ancient or modern.. ${ }^{[162]}$ Ruins were also useful for modern requirements, so that at Shaara Burckhardt reports the collection of saltpetre, essential for the manufacture of gunpowder, which is

collected in great quantities in the ruined houses... One hundred Rotolas of saline earth give from one to one and a half Rotola of salt-petre. I was told by the Sheikh of the village, who is the manufacturer on his own account, that he sends yearly to Damascus as much as one hundred Kantars. Here is also a gunpowder manufactory. ${ }^{[163]}$

Travellers visited the Ledja to see ruined towns and villages. Buckingham suggested correctly the region was once covered in vineyards, ${ }^{[164]}$ hence its ancient prosperity before soil was washed away. At this period the Druze seem to have wandered from one settlement to another, and there were plenty of houses to accommodate them:

21 Guérin 1997 for Msayké, a village in the Ledja: prosperous before the conquest: 20+ churches documented as built 547-596. Prosperity came from agriculture, artisanat, and trade with the Hedjaz. There was sedentarisation of some nomadic tribes. But by 16 thC Ottoman register says viticulture and arboriculture absent from the whole of the Hauran, and much of the region occupied only by nomads to the end of the 17 thC. 
Now and then two or three of the Druz families will leave the larger towns and form a new community in one of these long-deserted places. All they have to do is to take possession; they have not even the trouble of making a door, for they find stone doors already hung. At present the Druz population is far too small for the country: only a very small portion of the soil is cultivated. ${ }^{[165]}$

\section{Ezraa}

Ezraa is 8okm south of Damascus, and on the region's western edge. Halifax visited in 1691, and described what he thought (surely correctly) was a church built on a temple, possibly the still-surviving S. George, then a partial ruin:

Ye ruines of a fabrick in appearance very ancient, built of a hard stone, yet exceedingly worn out by ye weather: it is of an oblong figure pointing near to ye N.E. \& S.W. wth only only one door in ye E. end, wch was once adorned wth extraordinary good carvings, of wch some yet remain, but ye greatest part is either worn away or purposely defac'd, \& those markes of antient beauty yt some are very obscure; the outside of ye wall is beautified wth Pilasters quite round, wth their Pedestalls \& Capitalls regular \& handsom; but ye roof is all fallen down. ${ }^{[166]}$

By the time Buckingham arrived in 1825 , this structure appears to have been refurbished as a mosque, built with spolia. ${ }^{[167]}$ This was a town of nearly $3 \mathrm{~km}$ in circumference, with an imposing building the locals called The Palace, and a cruciform church, ${ }^{[168]}$ now rebuilt. When Richter visited Ezraa in $1815^{-16}$, it was dangerous for his horse, so covered with ancient ruins was the site. ${ }^{[169]}$ Not that the site was safe, and newly recruited soldiers were apprehensive about approaching the place. ${ }^{[170]}$ Buckingham could not decide on the style of the buildings, but thought they might be as old as the Pyramids of Egypt, for "the style and character of the buildings in question is low, square, and massive, like that of Egypt." ${ }^{[171]} \mathrm{He}$ was fascinated by the architecture, ${ }^{[172]}$ and described one house in detail "one that was unoccupied, though no part of it was destroyed or even materially injured:”

The central room of this house was large and lofty, and on each side of it was a wing, separated from the central room by open arcades at equal distances from the sides and from each other. The east wing appeared to have been the kitchen, as in it were seen two large fire-places in the 
stone wall, with hearths... with small recesses, like cupboards, around the walls. This room was low, being not more than a foot above a tall man's height: but the stone ceiling was as smooth as planks of wood, as well as the ends of the stones on which the massy beams that formed this roof and ceiling rested. In the centre of it was sculptured a wreath, the ends fastened with ribband, and a fanciful design within it, all executed in a style that proved it to be beyond question Roman. ${ }^{[173]}$

No doubt because the Druze inhabitants were used to sparring with Bedouin, Ezraa was a tough place. Its residents beat off the plundering soldiers of Mustapha Pasha in 1852 , when they wished to establish a barracks here. ${ }^{[174]}$ Such a project would inevitably have been to the detriment of the ancient buildings. Merrill camped there in 1879, "a place of great antiquity, and important now for its ruins and inscriptions," so things must have improved. ${ }^{[175]}$

\section{Burak \& Mismiye}

At the northern edge of the Ledja are Burak and Mismiye. When Cook visited Burak in 1876 he found it deserted, and described the doors as "of massive stone, with pivots working in sockets above and below. Such are the deserted habitations found in thousands in the desolate cities of Bashan." ${ }^{[176]}$ The town was evidently old, since St. Clair in 1892 described digging down some $5 \mathrm{~m}$ to find pottery, so that "while the houses seem to stand on a mound of black earth, they are in reality built on the foundations of houses of a more remote antiquity."[177] Such solid buildings were by 1895 inhabited by a few families, who no longer had to fight off Bedouin, but rather "official tax-gatherers, who are, as a rule, only legalized brigands."[178]

South west of Burak is Mismiye, where Burckhardt admired a small Corinthian temple fronted by a Doric portico, "one of the most elegant buildings which I have seen in the Haouran."[179] This was a town of well over $4 \mathrm{~km}$ circumference, approached across a labyrinth of rocks, and when Robinson visited in 1838 it was deserted (served by cisterns not springs), but clearly used by shepherds in the winter. ${ }^{[180]}$ Nearby was Shaara, with a columned structure in use as a mosque, and its inhabitants gathering saltpetre from among the many large ruins. ${ }^{[181]}$ Burckhardt slept in the ruined town of El Khelkhele, in the house of the owner of the local saltpetre factory: ${ }^{[182]}$ evidently, the ruins provided plenty of work for him. Rey visited Mismiye in 1861, and found the temple turned church turned mosque, with part of its peristyle surviving. ${ }^{[183]} \mathrm{He}$ described picturesque ruins with a temple, a large house in use as a pigeon-loft, 
a modern khan constructed from spolia, and "une foule d'autres maisons que nous trouvons bien conservées; nous y admirons de belles voûtes à linteaux soutenues par des arcs, et nous y remarquons aussi d'assez beaux ornements d'architecture sculptés en lave." ${ }^{[184]}$ Roaming brigands made the local sheikh uneasy, and a night skirmish with guns left his servant disgusted, because he had missed killing what would have been his fifteenth Bedouin. ${ }^{[185]}$ In 1864 Skene found

fine architectural remains of low Greek art, with many inscriptions in that language, highly ornamented temples almost entire, well-paved streets, houses still roofed with great slabs of stone, and their massive doors of single blocks of basalt swinging on their pivots, ready to be inhabited. ${ }^{[186]}$

The town had important inscriptions ${ }^{[187]}$ and, like Burak, Wright affirmed that "nor will it be doubted that beneath that raised mound are buried the remains of one of the "threescore cities" that once existed in Bashan. ${ }^{[188]}$

Some towns in the Ledja appear to have been abandoned during the 19th century, perhaps because they promised only hard living. Sha'arah (today Shajarah), down by the Jordanian border, and wNw of Deraa, was reported by Burckhardt to house about 100 families, yet "this once a considerable city, half an hour from the cultivated plain" was deserted when Thomson arrived in $1886,{ }^{[189]}$ and still so in the early 2 oth century, described by Butler:

There is much above ground to show that it was once a real city, not very large but having paved and colonnaded streets, one or more temples, a fine bath and a huge khan, in addition to a large number of residences. Unfortunately, Sha'arah retained its importance until some time in the Middle Ages; for its temples were destroyed to build two mosques, and the colonnades of its streets were thrown down and used in the erection of defenses. Only the bath remains in a fair state of preservation. ${ }^{[190]}$

\section{Bashan}

The area known to Biblical scholars as Bashan (which is not a "Syrian" term at all) is situated east of the River Jordan, vaguely delineated between the Jaulan/ Golan to the west, the Ledja to the north, and the Hauran to the east. It appears as a kingdom in the Old Testament, featuring as its king a giant named Og. As the Encyclopaedia Britannica has it (1910, q.v.), "In the later history Bashan became remarkable as a refuge for outlaws and robbers, a character it still retains." The 
region was said by the Bible to contain "threescore great cities with walls," and in 1865 this encouraged Josias Leslie Porter to write his Giant Cities of Bashan, as part of his crusade to prove the Bible factually true. Graham kept the faith in 1858, writing that the very size of the houses of Bashan, "built of such huge and massive stones," left him with "the strongest conviction that we have before us the cities of the giant Rephaim, the cities of the Land of Moab." ${ }^{[191]}$ However this certainty evoked scepticism in later decades. "Whether there ever was a race of men much larger than the present remains to be proven," wrote De Hass in 1887 , conceding that "True, the Bible makes mention of the fact, that 'there were giants in the earth in those days;' but we are only to understand from this that they were wicked, ferocious men." ${ }^{[192]}$ One awkward fact was that there were indeed large numbers of walled towns in Bashan, yet "a few only have been identified; of most of them nothing is left but heaps of shapeless ruins without either name or story."[193] By the 1880s, no survey of the area had been completed, ${ }^{[194]}$ and Porter could only point to the great antiquity of the towns, some massive walls, and conviction rather than proof:

When we find some of these towns bearing the very names which cities in that very country bore before the Israelites came out of Egypt, I think we cannot help feeling the strongest conviction that we have before us the cities of the Rephaim of which we read in the Book of Deuteronomy. ${ }^{[195]}$

His conviction gives context to the frequent attempts by travellers to suggest that many examples of stone housing all over Syria dated from long before the Romans, simply because the Bible offered details of "great cities with walls": they found what they expected to find. De Hass therefore squares Porter's conviction with what he saw on the ground in Bashan:

And what is remarkable, in some of the oldest buildings materials from still older edifices may be seen, indicating a remote antiquity, and showing that portions of these structures must date back at least four thousand years. ${ }^{[196]}$

\section{Jaulan / Golan Heights}

The Jaulan and Gaulanitis are names for one and the same tract of country in the middle of the now Turkish province of Syria. In the west, bordered by the Jordan fissure, it forms at the same time a part of the socalled East Jordan land, or Eastern Palestine. ${ }^{[197]}[1889]$ 
The Jaulan plateau (the Golan Heights) was little visited until the later 19th century, and scarcely mapped. ${ }^{[198]}$ It was simply too dangerous because Bedouin, even if they did not live there, came from the eastern deserts to pillage, where Roman forts suggested that they had long been a problem..$^{22}$ (Several of these forts were subsequently converted into convents. ${ }^{[199]}$ ) There were no reliable roads or settled population, so De Vogüé can recount in 1876 how a group of 50-6o pilgrims were lost without maps, firearms or food, until taken in hand by Europeans. ${ }^{[200]}$

For all these reasons, it was noted in 1881 that the Jaulan "should be thoroughly ransacked. It is easily traversed, and hundreds of ruins ... will yield us a fruitful harvest." ${ }^{\text {[201] }}$ In the same year Oliphant estimated that there were three hundred villages in the region, only ten of which had inhabitants, who for once welcomed Circassian immigrants because these "being a sedentary people, and having property to protect, might be expected to make common cause with them against the Arabs." ${ }^{[202]}$ Yet thorough exploration was not going to be easy. Schumacher in 1888 noted the locals were suspicious and cagey:

The natives from fear of new taxes took care to conceal almost everything, so that information and guides could only be reached by threats of prison, and, as a rule, the discovering of ruins had to depend entirely upon myself. [203]

A main town was Kuneitra, where Burckhardt saw "a strong wall, containing within its circuit a good khan and a fine mosque, with several short columns of gray granite." But all these had disappeared by 1880 , and the town abandoned until three thousand Circassians arrived the following year to settle there. "On the north side of the village are the remains of an ancient city ... but the ruins consist of little more than foundations, ${ }^{,[204]}$ and we may be sure these went as well, into the new houses the industrious newcomers then built. This was indeed the case at Surramân, near Kuneitra, where 900 immigrants dismantled all the antiquities: "According to the positive statements of the natives, who were acquainted with the ground before the existence of the villages, this was covered with the remains of a very ancient extended site."[205] By 1898 Baedeker wrote of Kuneitra: "1300 inhabitants, mostly Circassians. International Telegraph. Little is left of the ancient village."[206]

In the southern Jaulan Gamala (used as an example of mis-reporting in Chapter Two) was deserted, and so were other sites in the area. Schumacher 
visited Ayün (in the far south of the Jaulan) during his railway prospecting, and found both Roman and Muslim remains, and "basalt stones lie heaped up between the falling huts of a Bedawin winter village." ${ }^{[207]}$ Further south, the basalt stones at Khirbet Brikeh, near Amman, were in danger from the goahead Circassians, whose sheikh told Schumacher he "ardently desires the construction of a railway." ${ }^{[208]}$ It was clear that the immigrants "have only settled on the old ruined places where building stones lie ready to hand, and where they hoped to find treasure. According to their testimony, this last hope has not deceived them. ${ }^{[209]}$ Oliphant stayed in a house in the occupied village of El Al:

Occupying the site of an ancient ruin... in the walls and yards of the houses are many vestiges of antiquity. In the stable of the house in which I lodged was a column in situ standing to a height of 6 feet, and in the yard a draped female statue, life-size, in three pieces. ${ }^{[210]}$

Kuneitra was to become a government centre, and when Burckhardt went there he found a mosque with granite pillars, but much had gone in the course of the century:

The Khan has disappeared, and the Serai arose from its ruins. Very little is to be seen at present of the old site; most of the old building stones have been used again, and only rude, disjointed basalt wall remains are to be found in the north, not far from the windmill. ${ }^{[211]}$

Such re-use was also seen in the now-village (once town) of Nawâ, where Shumacher was perhaps eyeing blocks needed to railway work:

A village which has been built of ruins, and is surrounded by a great field of them, but yet itself contains hardly anything except modern buildings. All about lie heaps of hewn and unhewn stones. Fragments of mouldings and ancient sculptures are common in the walls, but, curiously enough, no inscription was anywhere found. ${ }^{[212]}$

There were some 300 houses and huts there in 1889 , and perhaps $700-800$ people. Most of the houses were unoccupied. Building skills were evidently deficient: "One villager holds two, three, or more of them, and will occupy one house till it gets ruined and becomes dangerous to live in, when he builds a new one at a suitable place alongside," and roofs it with logs brought in by the enterprising Circassians. ${ }^{[213]}$ 
Antiquities were no safer in the Jaulan than elsewhere. Schumacher admired a sarcophagus taken from a mausoleum at Khurbet Samakh, and his guide was present when it was first dug out:

It was then, he said, intact and covered by the stone with the circular hole in the centre. The sarcophagus was broken into by the Government officials, who found inside a jar of gold coins; these were sold, and the proceeds applied to the building of the Government flour-mill at El Mezeirib. He also stated that many stones had been taken from this place and used for building the walls of the mill. ${ }^{[214]}$

One feature of the Jaulan in the 19th century and before might well have made prehistorians (had they existed) bless the Bedouin; because just as they eschewed settlements except perhaps for winter shelter, or for watering their flocks, so they ignored the large quantities of prehistoric antiquities scattered across this wild region. Schumacher found one area with some 60 hectares of dolmens, to the south of a Roman road ${ }^{[215]}$ (were dolmens perhaps broken up for hard core?). Standing on one such, he counted over 160, and thought there were probably two or three times that number all around. The locals thought (correctly) they were tombs, so opened them:

A great many of these dolmens have already been opened by the natives, with a view of searching them for treasure, but hitherto without result, as they informed me; to the Arabs they are known by the name of Kubur Beni Israil - "the graves of the children of Israel."[216]

\section{Counting the Settlements}

How many antique towns and villages were there in the Hauran, broadly defined? There were certainly several hundred such sites, some deserted, and many with only a small population, which meant that complete towns with houses, temples and civic structures, surrounded by walls, survived for admiration of foreigners. Different visitors made differing assessments. In 1815-16 Richter met a sheikh who told him that

jadis on comptoit dans le Hauran 2,366 villages; aujourd'hui il n'y en a guère plus de cinquante qui soient habités. Le nombre des Bédouins augmente en proportion de ce que celui des Arabes sédentaires diminue. ${ }^{[217]}$ 
As Burckhardt noted in 1812:

The Haouran peasants wander from one village to another; in all of them they find commodious habitations in the ancient houses; a camel transports their family and baggage; and as they are not tied to any particular spot by private landed property, or plantations, and find every where large tracts to cultivate, they feel no repugnance at quitting the place of their birth. ${ }^{[218]}$

In the Hauran today there remain about 100 substantial sites and perhaps 800 smaller ones, the majority more-or-less uninhabited since about the 1oth century, but some housing a few farmers. "More-or-less" tries to take account of what is known about the temporary use of such towns and villages by the Bedouin, who in any case were not anchored to any place.

Counting accurately was impossible because there were no regular censuses, so even central government had no exact idea of habitations or inhabitants. Burckhardt's partial count was more than two hundred "towns in ruins, at a quarter or half an hour's distance from each other, on the eastern declivity of Djebel Hauraan."[219] Buckingham recorded in 1825 that there were supposedly 366 in the Ledja alone, but suggested that such numbers, "which are quite suited to the exaggerating taste of an Arab, only mean, however, that there are a great number of each." ${ }^{[220]}$ In 1838 Robinson saw many abandoned villages in the Ledja, and extrapolated the reasons for this to the whole of the Hauran: taxes, feeding the soldiery, and tributes to the Bedouin. ${ }^{[221]}$ Porter saw a large number in 1855 and (surely like most travellers) was equipped with a telescope. ${ }^{[22]}$ In 1844 Kelly reckoned a total of 446 villages and towns in the Hauran, Ledja, Bashan, Ajlun and Belka. ${ }^{[223]}$

East of Bosra was the desert, but Seetzen was assured that there were still ruined and abandoned villages there. ${ }^{[224]}$ Wetzstein in 1860 reckoned there were some 300 deserted towns and villages, and only 14 with inhabitants. He was clearly amazed that places like Busan had 800 houses and only a very few people. ${ }^{[25]}$ Near Qanawat in 1879 Merrill had pointed out to him by a Druze "upwards of forty ruined cities and towns, most of which he called by name," which suggests they were inhabited, and relayed Wetzstein's calculations that "this eastern section of the Lejah and the slopes of the Hauran mountains contain at least 300 ruined cities and towns. It should be mentioned that a town of ordinary size contains 600, 800, or 1,00o houses."[226]

Much the same happened to Porter in the Ledja: the local sheikh (presumably knowing inhabitants round about, and perhaps in charge of some of the 
settlements) "on my remarking the extent of this prospect and the large number of towns and villages embraced in it, he volunteered to tell me the names of them all, and I gladly wrote them down as he enumerated them." ${ }^{[227]}$ Porter compiled a list of 127 towns and villages, all deserted except for eleven; and a common "statistic" was that travellers would come across a town or village ("an important ruin") every half-hour they spent on horse-back. ${ }^{[228]}$ Even villages reported by travellers to be well-preserved, such as Saoura, were completely deserted. ${ }^{[29]}$ Schumacher wrote in 1889 that in the western Hauran "the Fellahin feel themselves more protected, and begin to risk further settlements; also the Bedawin... have now begun to settle and build stone houses in which they store their grain" - but that confidence had been destroyed (and fellahin with it) by speculation on grain prices. ${ }^{[230]}$ In 1879 one correspondent described how much fertile land was available in the Hauran (with water, fertile soil, oak forests, and a sub-tropical climate), so that European colonisation seemed a distinct possibility:

The country, though now entirely deserted, proved, as we know, once so attractive as to be preferred by some of the tribes of Israel to the Promised Land itself, and it is covered with the ruins of cities which continued to flourish even as late as the fourth century of the Christian Era. ${ }^{[231]}$

And some of the tombs were as spectacular as those at Palmyra. ${ }^{[232]}$

Re-occupation of many Hauran towns and villages in the later 19th century proved disastrous for ancient monuments, which were routinely reused and even their very location obliterated as new structures took their place. Like houses, funerary monuments also suffered, and it is suspected that tomb towers (similar to those at Palmyra) were once common here. ${ }^{23}$ Tomb inscriptions were frequently re-used in later walls, for example in the fortress at Bosra. ${ }^{24}$

23 Will 1949, 264: "Bien moins connue que la tour funéraire de Palmyre et du MoyenEuphrate est celle du Hauran. Cependant les indications qu'on peut relever dans les récits de nombreux voyageurs ne permettent guère de doutes sur son existence et fournissent une image suffisamment exacte, malgré l'extrême rareté des plans et des vues." [i.e. many of them have been destroyed!]. MacAdam 1986, 310 for Plate 10: photo by Brünnow \& Domaszewski of a tower tomb at Bosra, "long since disappeared."

24 Sartre-Fauriat 2001: see index for plenty of the tablets now in re-use. 
[1] Porter_1882_66-67

[2] Seetzen_1859_IV_43-50

[3] Seetzen_1854_I_66

[4] Rey_1861_180

[5] Aboulfeda_II_1848_31

[6] Monk_1851_II_272

[7] Burckhardt_1822_ 27041812

[8] Burckhardt_1822_ 27041812

[9] Richter_1824_47

[10] Buckingham_1825_204

[11] Rey_1861_181

[12] Buckingham_1825_ 198-199

[13] Buckingham_1825_200

[14] Lindsay_II_1838_137

[15] Porter_1855_I_151

[16] Lindsay_1838_II_136

[17] Lindsay_II_1838_135-136

[18] Seetzen_1854_I_72-73

[19] Monk_1851_II_271-272

[20] Porter_1868_II_495

[21] Porter_1882_64-65

[22] Richter_1824B_46

[23] Porter_1882_64

[24] Burckhardt_1822_ 27041812

[25] Richter_1824B_51

[26] Seetzen_1854_I_67-68

[27] Porter_1882_69-70

[28] Heber-Percy_1895_55

[29] Smith_1915_245

[30] Wright_1895_224-5

[31] Butler_1930_107

[32] Butler_1930_102-103

[33] Heber-Percy_1895_29-30

[34] Heber-Percy_1895_32

[35] Heber-Percy_1895_39

[36] Vogüé_1865-1877_I_6

[37] Dehérain_1914_272

[38] Baedeker_1876_399

[39] Butler_1920_99-100

[40] PEFQS_1881_28-29
[41] Gallois_1907_187

[42] Gallois_1907_188

[43] Elliott_1838_II_325

[44] Seetzen_1854_I_119

[45] Rey_1861_23-36

[46] Burton_\&_Tyrwhitt-

Drake_1872_I_230

[47] Van_Berchem_1895_8

[48] Thomson_1886_470

[49] Burckhardt_1822_ 23111810

[50] Robinson_1837_454

[51] Burckhardt_1822_21111810

[52] Richter_1824_39

[53] Richter_1824B_35

[54] Elliott_1838_II_319-320

[55] Beke_1862_87

[56] PEFQS_1879_49

[57] Robinson_1838_205

[58] Robinson_1838_208

[59] Lindsay_1838_II_109

[60] Lindsay_1838_II_110-111

[61] Seetzen_1854_I_92

[62] Robinson_1838_192-193

[63] Monk_1851_II_284-285

[64] Porter_1855_II_75-76

[65] Porter_1855_II_68

[66] Robinson_1838_196-197

[67] Porter_1882_36

[68] Rey_1861_83

[69] Rey_1861_86-87

[70] Porter_1855_II_72

[71] Porter_1882_37

[72] Graham_1858_241

[73] Wright_1895_364

[74] Baedeker_1898_196

[75] Rey_1861_92

[76] Rey_1861_92-93

[77] Heber-Percy_1895_59-6o

[78] Graham_1858_244

[79] Heber-Percy_1895_47-48

[80] Seetzen_1854_I_47

[81] Till_1851_412

[82] Robinson_1838_199-200
[83] Porter_1855_II_83-84

[84] Merrill_1881_32-33

[85] Porter_1882_39

[86] Thomson_1886_478

[87] Butler_1930_95

[88] Porter_1855_II_40

[89] Porter_1855_I_49

[90] Porter_1855_II_37

[91] Schumacher_1889_ 210-217

[92] Seetzen_1859_IV_65-71

[93] Porter_1882_54

[94] Burckhardt_1822_ 25041812B

[95] Lindsay_II_1838_154

[96] Robinson_1838_204-205

[97] Rey_1861_152

[98] Thomson_1886_495

[99] Euting_1896_19

[100] Merrill_1881_46-47

[101] Porter_1855_II_109-110

[102] Wright_1895_320

[103] Seetzen_1854_I_77

[104] Buckingham_1825_232

[105] Robinson_1838_206-207

[106] Porter_1855_II_123

[107] Porter_1882_55-56

[108] Rey_1861_158

[109] Thomson_1886_

498-499

[110] Porter_1855-II_122

[111] Oppenheim_1899_189

[112] Brünnow_\&_

Domaszewski_III_1909_

88-102

[113] Dentzer-Feydy 1998, 201

[114] Burckhardt_1822_

17111810

[115] Buckingham_1825_

244-245

[116] Buckingham_1825_243

[117] Robinson_1838_201-202

[118] Rey_1861_129

[119] Robinson_1838_203 


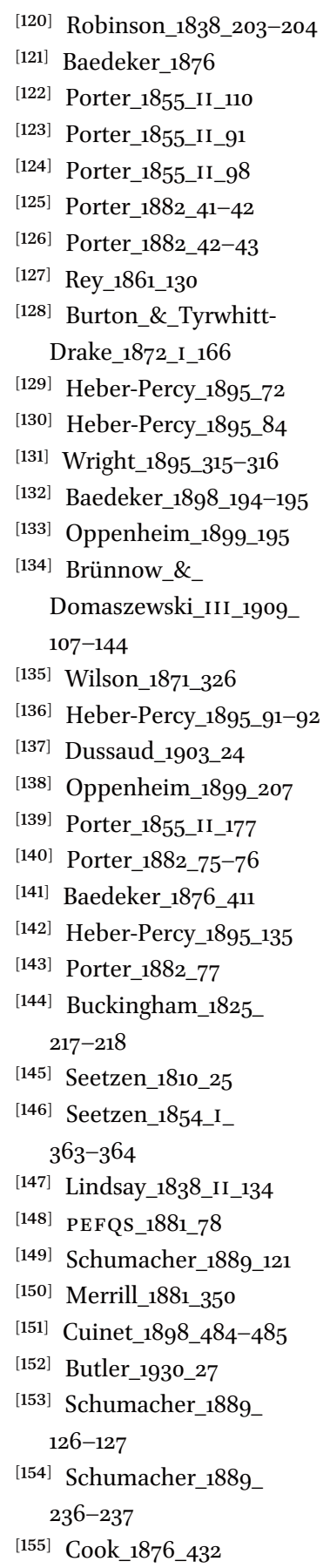

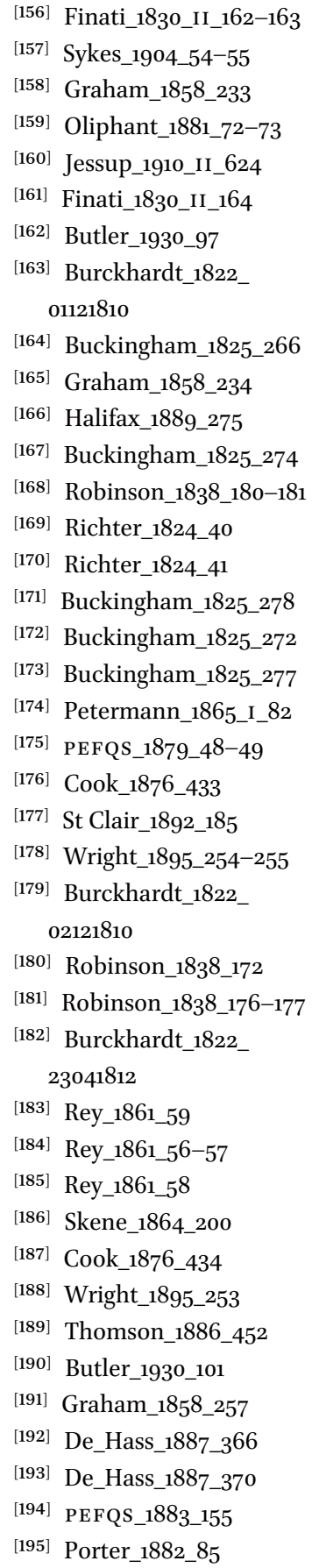

[196] De_Hass_1887_372

[197] Schumacher_1889_1

[198] Schumacher_1889_iii-iv

[199] Dussaud_1903_77

[200] Vogüé_1876_97

[201] PEFQS_1881_75

[202] Oliphant_1881_68

[203] Schumacher_1888_6

[204] Oliphant_1881_63-64

[205] Schumacher_1888_243

[206] Baedeker_1898_304

[207] Schumacher_1888_

97-98

[208] Schumacher_1888_114

[209] Schumacher_1888_114B

[210] Oliphant_1889_255

[211] Schumacher_1888_214

[212] Schumacher_1889_ 168-169

[213] Schumacher_1889_ 167-168

[214] Schumacher_1889_ 182-183

[215] Schumacher_1889_62

[216] Schumacher_1889_ 67-68

[217] Richter_1824B_43

[218] Burckhardt_1822 25041812

[219] Monk_1851_II_276-277

[220] Buckingham_1825_280

[221] Robinson_1838_185-186

[222] Porter_1855_I_33

[223] Kelly_1844_443

[224] Seetzen_1854_I_67

[225] Wetzstein_186o_42-43

[226] PEFQS_1879_151

[227] Porter_1855_II_48

[228] PEFQS_1879_151

[229] Rey_1861_67

[230] Schumacher_1889_22

[231] PEFQS_1879_116

[232] Wetzstein_186o_59-6o 


\title{
West of the River Jordan
}

\begin{abstract}
Above all other countries in the world, [Palestine] is a Land of Ruins. It is not that the particular ruins are on a scale equal to those of Greece or Italy, still less to those of Egypt. But there is no country in which they are so numerous, none in which they bear so large a proportion to the villages and towns still in existence... Western Palestine has always been the resort of a population which, however rude and scanty, has been sufficiently numerous and energetic to destroy and to appropriate edifices which in the less frequented parts beyond the Jordan have escaped through neglect and isolation. ${ }^{[1]}[1856]$
\end{abstract}

In the above account, Stanley contrasts the destruction he observes to the west of the River Jordan with across that river, where "not even in Rome or Athens, hardly in Egyptian Thebes, can ancient buildings be found in such magnitude and such profusion as at Baalbec, Jerash, Amman, and Palmyra." The disparity he suggests is because "Eastern Syria has been for the last four hundred years entirely, for the last fifteen hundred years nearly, deserted by civilised, almost by barbarian, man."

In the now-deserted areas of Judaea "there is yet hardly a hill-top of the many within sight which is not covered by the vestiges of some fortress or city of former ages." These were in the mid-19th century "mere masses and heaps of stone," unlike complete, standing towns to the east. Many of these heaps of stone, and some prosperous towns and villages, featured in the Bible, and their remains were described by travellers and investigated by scholars, ${ }^{[2]}$ often with one eye on the Book.

\section{Samaria, Janin, Capernaum}

Samaria/Sebaste, destroyed by Hrycanus in 108BC, was gifted to Herod the Great by Augustus, who lavished monuments on the site, elements of which impressed travellers. Burchard of Mount Sion (who visited the ruins in 1283) described the large number of columns around the hill and on top of it, where "regia uero erat supra in ipso monte, pulchra nimis, ubi uidentur adhuc columpne marmoree multe nimis, que sustentabant palacia et deambulatoria." ${ }^{[3]}$ Conspicuous were 
the remains of a colonnaded street (which Lortet thought would have been $1 \mathrm{~km}$ in length ${ }^{[4]}$ ), of which Niccolò, travelling ${ }_{1346-50}$, counted some fifty columns amongst the ruins of a large town but with a very small population. ${ }^{[5]}$ Morone in 1669 investigated the site more thoroughly, locating not only "grossissime colonne, piedestalli, capitelli, cornici, \&c., che vi si vedono in quantità," but also "intorno ad una piscina pure stanno ancora in piedi molte altre colonne disposte a due a due."[6] When Arvieux visited in 1735, the Church of S. John was partly ruined, with a few mosaics surviving, and supported on marble columns, with more columns supporting a domed baldacchino over the altar. Rather like the early years in Muslim Damascus, "Ce qui subsiste de cette Eglise est partagé entre les Chrétiens de les Turcs, qui ont fait une Mosquée de leur part qui est toute pavée de marbre blanc."[7] The church was still visited in the later 19th century, as an example of Crusader work. ${ }^{[8]}$

For the 19th century, the double colonnade was the main featured remarked upon, Richardson noting sixty standing shafts, and "fragments of Ionic volutes that lie scattered about." ${ }^{[9]}$ De Saulcy pretended (perhaps to make his "discovery" more exciting for the reader) that he hadn't known there was a long colonnade to be found there! ${ }^{[10]}$ Taylor gives a good description of the site in 1860 , which by that date does not seem to have been plundered, for "The hill is strewn, even to its base, with large hewn blocks and fragments of sculptured stone."[11] Perhaps this was because some of the site was under cultivation, and the rest simply wild: "Where marble walks once ran and exquisite statuary stood, venerable Nature, outliving the monuments of human greatness, has resumed her ancient sway." ${ }^{\text {[12] }}$ By this date, there was a small village (with some truculant locals) in what Tristram judged to be the middle of the site, the remainder unoccupied except by the plough. ${ }^{[13]}$ Apart from the columns, the only building Paul found standing in 1865 was part of the church: "un temple à moitié démoli, construit par les croisés et transformé en mosquée, compose l'unique édifice de la ville." ${ }^{[14]}$ The site was evidently difficult to explore because the fragments of wall were surrounded by thorn bushes. ${ }^{[15]}$ This might be why Luynes thought his visit a let-down. He found plenty of moderatelysized columns standing and on the ground, plus paving stones, but everything was clumsily done in limestone, and "si c'est à Sebastieh que l'on trouve le type de la magnificence d'Hérode, il faut croire que les historiens, et Josèphe en particulier, l'ont singulièrement exagérée."[16] Berners, on the other hand, found the same columns "enormous," and all monoliths. ${ }^{[17]}$

Janin was evidently once an important town, to judge by its ruins of palace and mosque, and "marble pillars, fountains, and even piazzas, still remain in a 
very perfect state."[18] And it was clear to Guérin that a site near Ramallah had helped build that town: "la plus grande partie des matériaux de cette ancienne cité, et notamment une dizaine de colonnes, ont été transportés à Ramallah, qui a été bâti avec ces débris." ${ }^{[19]}$ More prestigious still was the great synagogue at Capernaum, with connections to the Gospel of S. John, and recognised even though it was still a "shapeless heap of ruins" in $1903 .{ }^{[20]}$ In fact, the visible remains were so impressive that for Robinson in 1856 this was "an edifice, which, for expense of labour and ornament, surpasses any thing we had yet seen in Palestine." It was a large structure, and

Within the space thus enclosed and just around, are strewed, in utter confusion, numerous columns of compact limestone, with beautiful Corinthian capitals, sculptured entablatures, ornamented friezes, and the like. The pedestals of the columns are often still in their place, though sometimes overturned and removed. The columns are large, but of no great length. ${ }^{[21]}$

Unfortunately, an English team then came to dig at the site and, as Guérin recounts following his first visit in 1870 , what they excavated was soon destroyed or taken away, because Bedouin camping there assumed the English digging was for treasure:

N'en trouvant pas dans les fondations, ils les ont cherchés dans les colonnes, dans les chapiteaux, dans les blocs les plus richement sculptés, qu'ils ont brisés et mutilés avec un acharnement aveugle qu'enflammait une convoitise insensée. D'un autre côté, les habitants de Tibériade sont venus quelquefois extraire de ce même endroit de beaux matériaux de construction, de telle sorte qu'aujourd'hui les précieux fragments de cette synagogue ont diminué au moins de moitié depuis cinq ans, enlevés ou réduits à l'état de pierres informes. ${ }^{[22]}$

By 1883 , either the Bedouin had absconded with their treasure, or they had discovered none, for Bovet found the hovels they had built:

We force our way, not without difficulty, into one of these huts. Its walls are built of great hewn stones, gathered from the ruins of the ancient town; the roof consists of mats made of rushes resting on three posts of fig-wood, and on a fragment of an ancient column. ${ }^{[23]}$ 


\section{Jerusalem ${ }^{1}$}

On arriving at the gate [of the Haram al-Sharif], however, and not seeing it guarded, we had the presumption to pass a few feet through it. Soon there was an uproar... Shame on Mohammedanism and its ignorant barbarian minions, that a Christian must be insulted, and even his life threatened, if he advances to take a near view of the hallowed spot on which once stood the temple of the Most High. ${ }^{[24]}$ [1843]

Jerusalem is a city sacred to Muslims and Jews as well as to Christians through both Bible and Koran, and its fame, growth and prosperity were measured by pilgrim numbers, which saw the population increase from that of a small village to some 24,000 by 1876 , and 70,000 by 1910 . The problem here for Christians was that the best monuments were Muslim, Herod's Temple had left no superstructure remains (except for imaginative visitors), and the Holy Sepulchre was much altered. The journey up from the coast passed several ancient monuments, but travellers could be frustrated by finding no descriptions even of Roman structures. ${ }^{[25]}$ As early as the 185 os some visitors were prepared to describe the "sacred places" as "not worth the trouble, as no one now believes in their genuineness."[26]

The surviving monuments have been described in great detail by many travellers, including Muslims, ${ }^{[27]}$ although the Haram-al-Sharif, with the al-Aqsa Mosque and the Dome of the Rock, was difficult of access to non-Muslims, as Millard's quote above makes clear. Some travellers got confused over the sacred topography of the city, and mis-identified the Dome as Constantine's church, amongst other mis-attributions. ${ }^{[28]}$ Because so many pilgrims wrote up their visit, there are more accounts of the city from Late Antiquity than for anywhere else, although these are not always informative about the state of the monuments. Better are accounts from the later 19th century, when some of the city was explored and excavated. ${ }^{[29]}$ What follows is a very brief overview, concentrating on the fate of the important monuments within the walls and in the environs. ${ }^{[30]}$

Central was the Haram al-Sharif, ${ }^{[31]}$ an elevated platform, the erstwhile site of Solomon's Temple and of the Dome of the Rock and the al-Aqsa Mosque. ${ }^{[32]}$ The Dome, finished in 691AD, was beautified (we are told by Arvieux in 1660) by precious marbles from Bethlehem, Nazareth and the Holy Sepulchre. ${ }^{[33]}$ The al-Aqsa dates from perhaps the 120th century. For Muslims, the whole

1 El-Eini 2006, 59ff: town planning, especially Jerusalem, and preservation of sites in the Old City; Boas 2001, 16-19 for Jerusalem and its buildings following recapture by Saladin. 
platform was a mosque. ${ }^{[34]}$ This was itself enhanced over the centuries by pious donations, ${ }^{2}$ for example by Suleiman the Magnificent, who paved the whole area, ${ }^{[35]}$ and also refurbished the city's water-delivery system. ${ }^{[36]}$ Presumably the pavement was made from spolia, like at least one of Suleiman's fountains. ${ }^{3}$ Clermont-Ganneau speculates that much of the re-used marble came from the remains of Herod's Temple ${ }^{[37]}$ and, given his lavish flaunting of the material at Caesarea, this seems very likely. However, cutting down columns would have been very difficult indeed: but it certainly happened in Cairo and in Constantinople, where wall panelling was made from the relicts. ClermontGanneau was one of the few who ponders sensibly about the mechanics of disappearance and re-use. He is certainly correct about slicing shafts to make disks, but have any excavations uncovered vertically-sliced column spolia?

The Haram al-Sharif had been occupied by the Crusaders, ${ }^{[38]}$ and at least one of them, Jacques de Vitri, thought the Dome was a rebuild of Solomon's Temple, "rebuilt on the same spot by faithful and religious men in a round building, of wondrous and cunning workmanship, exceeding fair and stately," although he knew Muslims used it whenever in possession: "they set up the image of Mahomet in the Temple, and suffer no Christian to enter it."[39] (Confusingly, he gives the same name to the al-Aqsa. ${ }^{[00]}$ ) Saladin destroyed most of the Crusader additions to the architecture, ${ }^{[41]}$ but some hammered capitals have survived, if not in place. ${ }^{[42]}$ Naturally, the Haram al-Sharif was well described by Muslim travellers such as Khosrau, Edrisi ${ }^{[43]}$ and Evliya Çelebi ${ }^{[44]}$ who in the town itself, admired the white paving stones as large as kilims. ${ }^{[45]}$ The Dome of the Rock was, as Grabar wrote, "the visual rival of the Holy Sepulchre and the Nea church," and its sources are multiple. ${ }^{4}$ Because pilgrims chipped holy souvenirs off the Rock itself, the crusaders covered it with a marble slab, later removed by the Muslims. ${ }^{[46]}$

Access to the Haram al-Sharif was barred to non-Muslims (who would be routinely abused and even spat at, here as in Damascus). Niccolò, travelling in 1346-50, warned that "he who would enter it, will deny the faith or be sawn in two." ${ }^{[47]}$ Guylforde repeated this in 1506, admiring the exterior only: "a man may juge by out warde syght ye sayd temple is in largenes, hyght, and suptuousnes buyldynge fer aboue and beyonde any werke that euer we sawe in

2 Murphy-O'Connor 2008, 87-105.

3 Murphy-O'Connor 2008, 45 Jerusalem: "Part of the C1 AD street that crossed the original Herodian bridge is visible in the excavated area before the gate. The fountain was a gift of Suleiman the Magnificent in the mid-C16 AD. Economically, it reuses older elements. The trough was originally a Roman sarcophagus, and the rest is Crusader."

4 Magness 2012, 353. 
all our lyues."[48] Ali Bey entered in 1814, disguised as an Arab, rubbing it in by stating with typical one-upmanship modesty "que je n'ai pas eu le temps de faire plus de cinq visites au temple, assez longues, il est vrai, et assez bien employées pour que je puisse garantir l'exactitude de mes descriptions et de mes dessins." [49]

Rumours abounded about entry difficulties, Bramsen nervously relating an old topos (usually about fortresses) that a man obtained a firman from the Sultan which allowed entry, but did not mention being allowed out - so he was beheaded. ${ }^{[50]}$ The story still circulated, perhaps by traveller bush-telegraph, in the 1840 os. $^{[51]}$ Even approaching the gates of the Haram al-Sharif could be dangerous, as indeed it was for the Umayyad Mosque in Damascus. Same problem, same remedy: in 1840 Geramb was reduced to peeking through the blinds of a Turk's apartment simply to view the ensemble. ${ }^{[52]}$ It was therefore no surprise that Gaskin's textbook for drilling students (Dublin 1846) should have to make it all up: "It bristles with points, and little spires, and minarets, many of which have gilded crescents that flash and gleam in the sunshine."[53] Even quizzing the local gentry for information about the Muslim monuments could be unproductive, for they were tight-lipped, and "generally evade every question that might be put to them, or otherwise evince displeasure by a gloomy silence., ${ }^{[54]}$

There were exceptions to the embargo, Tobler naming various Christians who had gained access between 1753 and $1833{ }^{[55]}$ He notes some admissions following the war in the Crimea, but then exults about the mere words on a British passport: "gerade an einer der heiligsten Stätten auf der Welt ist ihr Schutz ein blosser Wortschall. An dem heil. Felsen Moriahs scheitert der brittische Stolz." ${ }^{[56]}$ Dupuis noted in 1856 that things were loosening up, because

in the present disturbed state of the Oriental world, the asperity of the law is somewhat blunted... we hear it announced, not without astonishment indeed, that recently some travellers have succeeded, through a favour of the Sultan, in obtaining permission to visit the interior of this far famed temple. ${ }^{[57]}$

Fiske got into the Dome and the al-Aqsa in 1857 , protected by thirty soldiers, but still his boots were stolen. ${ }^{[58]}$ Paul entered the Dome in 1865 , and was told by the imam that King David had his study there, and that this was where he wrote the Psalms. ${ }^{[59]}$ Another traveller entered in 1866 with the help of the French Consul. ${ }^{[60]}$ Harman entered in 1873 , with his consul's dragoman, plus a soldier: "To enter the inclosure without guards would be sure to bring upon one a shower of stones. ${ }^{\text {"[61] }}$ Crossing palms with silver worked for Basterot in 
1869, and he contrasted his entry with the problems at Damascus: "les autorités de la mosquée apprivoisées par le backsheech ne montrent aucune trace de cette malveillance que l'on rencontre à Damas." ${ }^{[62]}$ By 1879 , Huart could provide a decent description of the interior. ${ }^{[63]}$

Well before the tourist boom aided by Mediterranean steamers, pilgrimage was a business for making money. The Turks held the keys to the Holy Sepulchre, which was far from being a heart-warming ecumenical sacrifice because "toutes les fois qu'il est besoin de monter sur le toit pour quelque réparation, il faut leur en demander la permission.. ${ }^{[64]}$ Light in 1818 reckoned the perquisites were immense:

Each pilgrim pays, on his first entrance, a sum nearly equal to fifteen shillings. The convents pay about one shilling and sixpence for each time they have it opened; and every ceremony costs a certain sum, in proportion to its duration. ${ }^{[65]}$

As early as 1822 it was suggested that the Muslims protected the Holy Sepulchre from damage simply for the ticket-office revenue. ${ }^{[66]}$ Sceptics abounded, perhaps as a result of paying through the nose for entry, or through the evident territorial predations of the warring factions of the monks, ${ }^{[67]}$ which survived with added strength into the 2oth century. ${ }^{[68]}$ Clarke suggested in 1815 that "if Helena had reason to believe she could identify the spot where the sepulchre was, she took especial care to remove every trace of it, in order to introduce the fanciful and modern work which now remains." ${ }^{\text {[69] }}$ Evliya Çelebi, a Muslim, visited in 1672 , yet "the wonder of this place is that, with so much beautiful adornment, it lacks spirituality; it is more like a tourist attraction." ${ }^{\text {[70] }}$ Here as elsewhere, though, repairs to Christian buildings were officially controlled to be minimal in part through administrative wiles, ${ }^{5}$ and we might wonder whether this was a defence mechanism to prevent churches ever outshining mosques.

However, pilgrims Christian or Muslim do not seem to have made the city prosperous, in spite of the several days they usually spent there. Muslim pilgrims had an itinerary, just as did the Christians, ${ }^{[71]}$ but for different monuments. Evliya Çelebi, for example, spent ten days and nights there in $1672,{ }^{[72]}$

5 Peri 2001, 89, Jerusalem in early Ottoman period: "Preserving and repairing existing sites involved awkward and tedious procedures for securing official permits to start and complete any renovation job. In brief, any non-Muslim shrine in need of repair had first to be inspected, surveyed and measured by officially appointed experts. As noted, Islamic law forbids enlarging, adding to, or making any major alterations to such buildings." 
and had already visited the Holy Sepulchre in 1648. Here he found a dome "constructed on four red porphyry columns, each one worth the annual revenue of Turkey. These columns are so highly polished that one can see one's features reflected in them." ${ }^{[73]}$ In 1854 Dandolo commented on the dust, the narrow streets and the lack of water, and, how this ancient capital of Judaea "sembra essa stessa nel suo interno un deserto ammasso di case basse e senza finestre." ${ }^{[74]}$ And even in the late 1860 os this city on a hill did not shine brightly: Freese found it "like a confused mass of rough stone walls, with here and there a Muslim minaret pointing derisively toward heaven," and not to be associated with beauty. ${ }^{[75]}$ In 1863 Schickler's first impression was of a city in ruins, with its various layers of history simply crumbling to dust:

Ici rien ne dissimule aux yeux de l'homme le néant de ses œuvres; elles s'en vont toutes lentement en poussière sans qu'il s'efforce d'en retarder la chute, et ces poussières s'entassent et se confondent. ${ }^{[6]}$

Wortabet, a native Syrian, did not like the place, lambasting its streets, houses, dirt and lack of commerce: "it was not the sympathy we generally feel with fallen grandeur that first made me so melancholy; but the idea that Jehovah in his anger had passed by, and cursed the city for its sins." [77]

\section{Herodium}

Due south of Jerusalem and not far from Bethlehem, Herodium was a palace and mausoleum for himself built by Herod, and "elaborately described" by Josephus. ${ }^{[78]}$ It was on an extravagantly engineered and very conspicuous artificial mound. It has been extensively excavated in recent years. However, little was left on the surface in the 19th century. It could not be inhabited after the destruction of Herod's aqueduct, but had nevertheless been assumed in popular memory to have housed a crusader fortress. ${ }^{[79]}$ Little architecture was visible because it had surely been extensively robbed out, one marker being the time taken to find the remains of the mausoleum half-way down the hill. ${ }^{6}$ Bourassé saw a few low walls in 1867:

Le voyageur distrait ne soupçonne guère, pas plus que les Arabes, que ce monticule lui jadis couronné de somptueux monuments, le séjour brillant des fêtes et le rendez-vous d'une cour livrée à la dissipation et aux plaisirs. ${ }^{[80]}$

6 Magness 2012, 187-191. 
In 1889 Conder admired the masonry blocks, and described the remains visible at the bottom of the hill, which "present no very interesting architectural features." ${ }^{[81]}$ The PEF in 1893 described what remained to be seen, ${ }^{[82]}$ and had already targetted the site as well worth excavation (see Chapter Eleven).

\section{Jericho and Hebron}

Jericho was a mystery to our travellers, except to Vergoncey in 1615 , who evidently got the site wrong, and reported an old amphitheatre and a fine hippodrome. ${ }^{[83]}$ For Tristram in 1865 "the ruins and shapeless heaps around us are old Jericho," and he identified what he thought were the arches, vaults and aqueducts of the sugar mills developed by the Crusaders, "now only the refuge of our horses in the heat of the day, and the retreat of the jackals at night." [84] The English had dug there, but Depelchin noted in 1877 that the works "ne paraissent pas avoir eu les résultats qu'on pouvait en attendre." ${ }^{[85]}$ Lombay in 1892 saw some of the column shafts presumably from the English dig, but there were problems about digging here: "Le village indigène fournirait probablement un plus ample butin aux archéologues s'ils avaient le loisir de le fouiller; mais il est bien gardé par ses farouches habitants."[86]

The building housing the tombs of Abraham, Isaac and Jacob at Hebron was a mosque by the 19th century. It was barred to Christians and Jews, and Thomas Legh did not dare to try entry in 1816, "even in our present correct costume of Arabs." ${ }^{[87]}$ Stephens was barred in 1838 , likewise Durbin in $1845 .{ }^{[88]}$ It had been barred to de la Broquière early in ther 15 th century. ${ }^{[89]}$ The Jews believed the walls were built with the ruins of the Temple of Solomon, ${ }^{[90]} \mathrm{dem}-$ onstrating that they knew all about spolia, but mis-dated the great blocks to be seen at both sites, which were Herodian. Moudjir-ed-dyn (d.1521) thought it the work of the djinns, ${ }^{[91]}$ while Morone in 1669 attributed the structure to Constantine. ${ }^{[92]}$

\section{Tiberias}

Tiberias $^{7}$ was known for its (Roman) baths in the Middle Ages, when Edrisi described them c.110o. ${ }^{[93]}$ In the mid 14th century, Niccolò found the town in ruins, and does not mention the baths. ${ }^{[94]}$ In 1812 Burckhardt described columns and other ruins along the water as far as the hot springs, but did not identify any baths: "no vestiges of buildings of any size are visible here; nothing

7 Petersen 2001, 299-306: Tiberias. 
being seen but the ruins of small arched buildings, and heaps of stone."[95] Inscriptions were lacking. ${ }^{[96]}$ Sometime in the next decade, then, the locals developed working baths there, described by Buckingham, who also noted antiquities in the town:

observed many foundations of buildings, some fragments of others still standing, and both grey and red granite columns, some portions of the latter being at least four feet in diameter; but among the whole we saw neither ornamented capitals nor sculptured stones of any kind, though the city is known to have been a considerable one. ${ }^{[97]}$

Tiberias was for a time a go-ahead place, but this did not last. Destroyed by earthquake in 1837, new houses had been built by $1839 .{ }^{[98]}$ Plenty of columns and other antiquities survived around the hot springs in $1839 .{ }^{[99]}$ However, the "handsome" bath erected by Ibrahim Pasha in 1833 (presumably improving the "small and mean" structure described by Buckingham in 1822) was by 1857 "neglected and falling into a state of dilapidation. The doors have fallen from the hinges, and some of the marble baths in the private rooms are broken and useless." ${ }^{[100]}$ That small structure had nevertheless been in working order in 1822. ${ }^{[101]}$ The town itself was by the 1850 s nothing but "l'ombre et la réduction d'elle-même," with a makeshift citadel, and with "monuments çà et là épars, dont les fragments de marbre, les tronçons de colonnes en syénite d'Egypte ont concouru à la formation des derniers remparts." ${ }^{[102]}$ Yet Howe found a structure with twenty-one granite columns, some still standing, and surmised that it was a long-ruined Roman temple. ${ }^{[103]}$ By 1872 Guérin could count only "une trentaine de fûts de colonnes intacts ou mutilés," ${ }^{[104]}$ while five years later the PEF reported that the ruins "have been largely excavated for cut stone for modern buildings. A great number of fine granite columns are lying about, in one place as many as nine close together; there are also remains of the sea-wall, with towers, along the coast." ${ }^{[105]}$ Between Tiberias and Caesarea, at Sepphoris, there were still plenty of ancient remains in $1822 .{ }^{[106]}$

\section{Beisan / Beth Shean / Scythopolis}

Jadis fu la mestre citez de Galilée, si com il pert és granz ruines et à la grant plenté de marbre que len trueve és édifices qui là furent; mès ele est ore si dechoite que nus n'i habite fors seulement en un petit chastelet qui siet és paluz, où pou de gent se pooient receler. ${ }^{[107]}$ [after 1184] 
Marble there might once have been, both from the ancient temples and then the churches. ${ }^{8}$ William of Tyre presumably knew of marble here because columns were re-used in the 12 thC fortress by his Crusader colleagues, along with large blocks from the ancient city. Indeed, Tristram wrote that "the ruins of the more modern citadel were, in large measure, composed of beautiful marble columns, and some capitals built horizontally in tiers or lying across the massive walls." ${ }^{[108]}$ Van De Velde in 1854 was sure excavation here would be important, but "in order to prosecute this undertaking the protection of a considerable force would be necessary, as Beisan is noted for the avarice and lawlessness of the Bedouins, from whom peaceful antiquarians must expect every annoyance." ${ }^{[109]}$ Even Burckhardt's visit had been a quick one, for he saw only one standing column, remarking that the villagers "are in a miserable condition, from being exposed to the depredations of the Bedouins of the Ghor, to whom they also pay a heavy tribute."[110] Buckingham in 1825 noted (presumably from earlier accounts) that there were "several remains of antiquity at this place, particularly the vestiges of a theatre, and many marble columns erect and fallen;" but he did not cross the river to visit the site. ${ }^{[111]}$ Tristram commented on how hurried this must have been for he counted over twenty columns, ${ }^{[112]}$ and noted a Roman bridge in black basalt ("it has been able to withstand, in some degree, the ravages of time, and the carelessness of Muslims") and two more of limestone. ${ }^{[113]}$

8 Tsafrir 2003 for the christianisation of the town. Khamis 2007 for excavation of the shops.
[1] Stanley_1856_115-116
[2] PEF_Committee_1873_ 1-19
[3] Laurent_1873_53-54
[4] Lortet_1881_63
[5] Niccolò_1945_62
[6] Morone_1669_I_336
[7] Arvieux_II_1735_82
[8] Baedeker_1876_341
[9] Richardson_1822_II_298
[10] AMS_I_1851_213
[11] Taylor_1860_97-98
[12] Newman_1864_333
[13] Tristram_1865_134-135
[14] Paul_1865_96
[15] Bourassé_1867_389
[16] Luynes_I_1874_43-44
[17] Berners_1876_191-192
[18] Clarke_1817_IV_262
[19] Guérin_1864_404
[20] Curtis_1903_261
[21] Robinson_\&_Smith_ 1856_II_408
[22] Guérin_1877_60-61
[23] Bovet_1883_364
[24] Millard_1843_267-268
[25] Clarke_1817_IV_290
[26] Fiske_1857_157-158
[27] Moudjir-ed-dyn_1876
[28] Stanley_1856_178
[29] Warren_\&_Conder_1884
[30] Dankoff_\&_Kim_2011_ 306-324
[31] Conder_1889_361
[32] Moudjir-ed-dyn_1876_ 95-96
[33] Arvieux_II_1735_120
[34] Ibn_Battuta_1982_130
[35] Dankoff_\&_Kim_2011_ 313-314
[36] Dankoff_\&_Kim_2011_ 318-319
[37] Clermont-Ganneau_ 1899_257
[38] Warren_\&_Conder_ 1884_44-80




\author{
[39] Vitri_1896_LXII \\ [40] Vitri_1896_LXII \\ [41] Michaud_1829_214 \\ [42] Clermont-Ganneau_ \\ 1899_145 \\ [43] Khosrau_1881_72-99 \\ [44] Dankoff_\&_Kim_2011_ \\ 315-316 \\ [45] Dankoff_\&_Kim_2011 \\ 319 \\ [46] Michaud_1829_IV_217 \\ [47] Niccolò_1945_46-47 \\ [48] Guylforde_1506_43-44 \\ [49] Ali_Bey_1814_III_130-131 \\ [50] Bramsen_I_1820_276-7 \\ [51] Geramb_1840_I_235 \\ [52] Geramb_1840_I_236 \\ [53] Gaskin_1846_15 \\ [54] Dupuis_I_1856_39 \\ [55] Tobler_1859_307 \\ [56] Tobler_1859_309 \\ [57] Dupuis_I_1856_42-43 \\ [58] Fiske_1857_159-161 \\ [59] Paul_1865_67 \\ [60] Marquise_de_L_1866_62 \\ [61] Harman_1873_123 \\ [62] Basterot_1869_209 \\ [63] Huart 1879_69-70 \\ [64] Ali_Bey_1814_III_205
}

[65] Light_1818_182

[66] Buckingham_1822_I_390

[67] Hahn-Hahn_II_1845_179

[68] Curtis_1903_472-473

[69] Clarke_1817_IV_315

[70] Dankoff_\& Kim_2011_323

[71] Affagart_1902_64

[72] Dankoff_\&_Kim_2011_318

[73] Dankoff_\&_ Kim_2011_320

[74] Dandolo_1854_385

[75] Freese_1869_42

[76] Schickler_1863_148

[77] Wortabet_1856_I_169

[78] Thomas_1900_232

[79] Wilson_I_1881_144

[80] Bourassé_1867_313-314

[81] Conder_1889_217-218

[82] PEFQS_1893_25

[83] Vergoncey_1615_390

[84] Tristram_1865_204

[85] Depelchin_1877_178-179

[86] Lombay_1892_125

[87] MacMichael_1819_ 196-197

[88] Durbin_1845_I_207

[89] Broquière_1892_18

[90] Stephens_1838_II_126
[91] Moudjir-ed-dyn_1876_11

[92] Morone_1669_I_301

[93] Edrisi_I_1836_347-8

[94] Niccolò_1945_67

[95] Burckhardt_1822_ 23061812

[96] Scholz_1822_64B

[97] Buckingham_1822_II_ 366-367

[98] Pardieu_1851_302-303

[99] Raguse_III_1839_17

[100] Stewart_1857_440

[101] Richardson_1822_II_306

[102] Pigeory_1854_242-243

[103] Howe_1854_99-200

[104] AMS_VII_1872_415

[105] PEFQS_1877_121

[106] Scholz_1822_64

[107] Guillaume_de_Tyr_II 1880_456

[108] Tristram_1865_503

[109] Van_De_Velde_1854_II 361-362

[110] Burckhardt_1822_ 02071812

[111] Buckingham_1825_9

[112] Tristram_1865_501

[113] Tristram_1865_50o 


\section{East of the River Jordan}

Several architectural characteristics (such as stone doors and re-used Roman monuments) found just to the north, in the Hauran, were also to be found further to the south, in what is now northern Jordan, where the cadence of settlement also seems to match. ${ }^{1}$ The area was still awaiting comprehensive archaeological investigation at the beginning of the 2oth century, ${ }^{[1]}$ but scholars such as David Kennedy have illuminated Jordan's military history, as have others her legacy of churches. ${ }^{2}$

\section{Irbid}

Oliphant (who largely parrotted Seetzen ${ }^{[2]}$ ) visited one house at Irbid / Abila, which was missing the actual door: "the framework of the door was all carved stone; and there were sockets in the lintels and thresholds for pivots to work in, showing that formerly the door was a slab of stone turning on a stone hinge."[3] More might have survived in 1810, when Seetzen visited the town, finding it deserted:

Some beautiful remains of the ancient walls are to be discovered, together with a number of arches, and of columns of marble, basalt, and grey granite. On the outside of these ancient walls I found also a great many columns, two of which were of extraordinary magnitude, from which I concluded that there must have been formerly in this spot a considerable temple. ${ }^{[4]}$

Merrill saw "fine Roman ruins, and some evident marks of very great antiquity" at Irbid in 1881, including "a small, well-preserved Roman building, which may have been a temple or a tomb, was an inscription within a nicely carved wreath, perfectly round." ${ }^{[5]}$ He questioned people about Roman roads and antiquities in the vicinity, and was told what they said was the road:

1 El-Khouri 2009: the archaeological landscape in north-west Jordan, including (27-60) sites, roads and agriculture, and 61-139 for catalogue of Roman sites. 142-143 concludes that Roman sites were intensively occupied in Byzantine and early Umayyad periods, then declined, to grow again only in the 2othC.

2 Hamarneth 2003: Christian settlement in Byzantine \& Islamic Jordan. 
This is on arches, and is for water; that Pharaoh brought water by this road. I suppose that these men were confounding two things. Both a road and an aqueduct existed here in former times; a road led from Gadara to the east, as they testify; also an aqueduct started from near Dilli. ${ }^{[6]}$

Little of antiquity remains at Irbid, which is today the second largest city in Jordan, after Amman. However, not far away was El Husn ("the castle"), where the local villagers led Merrill to extensive ruins: "Those on the surface are largely of Arab origin, but about the brow of the hill is a wall constructed of older materials, and the stones in some portions of it antedate the Roman occupation of the country."[7]

\section{Pella}

We found ourselves among the veritable remains of an ancient and important city. Not only are large stones scattered about, but portions of the walls are still standing, and the line of streets is here and there traceable. ${ }^{[8]}[1854]$

One of the cities of the Decapolis, now in Jordan, in the Jordan Valley, NW of Jerash, this town prospered especially in the Byzantine period, but the great earthquake of 747AD diminished its population, and few lived there until the end of the 19th century. Tristram was rushed away by his colleagues, and "all that I possess as memorials of my visit are a few pieces of Mosaic pavement, some fragments of Roman pottery, and a piece of the calcareous deposit."[9] Le Strange, travelling in 1884, thought the site would "doubtless yield a rich archaeological harvest to anyone who could spend some days among the ruins, and carefully examine the very large number of broken cornices and other carved stones which lie about on every hand." ${ }^{[10]}$ Perhaps not knowing about the 747 earthquake, he thought that Pella, like Jerash and other centres, was abandoned shortly after the Muslim conquest. ${ }^{[1]]}$ Digging was evidently desirable, but a crowbar would do, by

turning over the drums and the cornices which, to all appearances, have lain in their present position since the days of the Arab invasion; and greatly do I regret that, in our hurried visit, I had not the tools with me nor the leisure-time that was required for a detailed examination of this little-visited ruin. ${ }^{[12]}$ 
Yajuz

Corinthian and other capitals, columns, large slabs of stone, lintels, squared blocks of the best Roman work, some bevelled stones, various kinds of ornamentation, rosettes, several different forms of crosses, and some carved figures and statues that have been mutilated. [1881]

Several kilometres to the north west of Amman was Yajuz, on the Roman road from there to Jerash, and with a Roman garrison. Little survives today, but there were "fine ruins" to be seen in 1881, as Merrill relates, together with roofed reservoirs, the remains of a temple and a church, as well as traces of "many public buildings that were large and elegant." Yet there was evidence that this site had been or was being (chronology is unclear) systematically dismantled:

Near these quarries a great many squared stones had been laid out, as if they had been prepared ready for shipping or for use, and the owner having died, perhaps the demand having ceased, or for some other reason, they were left and remained untouched to the present day. ${ }^{[13]}$

Schumacher, passing by eight years later in a survey on behalf of the PEF, found no settled inhabitants in the neighbourhood, but remarked on the "extensive remains of carved Byzantine capitals, squared blocks, and the foundations of numerous edifices." ${ }^{[14]}$ On his way to the site, he came across fragments of six broken columns, and concluded that these were on their way somewhere else, for "one is led to the supposition that these fragments have at some period been transported hither from the great centre of ruins at Yajuz." ${ }^{[15]}$

\section{Umm al-Jimal}

The houses, which were built of stone, are not only the finest but the best preserved of any that I have seen in the Hauran, or in all the country east of the Jordan. This is the best place to study the architecture of private dwellings of an early period, because the houses were originally of a fine order, and because they have been so well preserved. ${ }^{[16]}[1881]$

Close to the Syrian border, this basalt town, now in Jordan, was probably brought down by the earthquake of 747 , then wracked by plague and famine. Merrill gives a good description in the above quote, but its wider contextual 
history has become clearer with recent investigation: as part of Rome's frontier. ${ }^{3}$ It included a fortress and praetorium, the former of which housed squatters in later centuries, while the latter became housing and, together with another large house, was elaborately remodelled. ${ }^{4}$ Such use of fortresses as villages was common, ${ }^{5}$ while large temple complexes (such as that at Palmyra) could also contain houses.

The first Western traveller to visit this site ${ }^{6}$ was William John Bankes who, as we have already seen, made several important mistakes in the contentious travel-book stakes. He shared his information too freely; he did not publish his own book; and he put himself in the position of getting sued for plagiarism by Buckingham, who won. He was in the Orient 1815-1820, in Egypt, Nubia, Syria, Asia Minor and Greece, the first to make drawings of Petra and Jerash, and the first to visit Umm al-Jimal 39 years before Graham, the supposed discoverer of the site. Bankes was the unrecognised co-author of Irby \& Mangles, published 1823, some of it dictated by Bankes to Irby, another part written by Bankes himself.7 Graham found the site "among the most perfect of the old cities which I saw," with its town walls, paved streets, and "some very large public buildings." And some of the houses were very large,

consisting usually of three rooms on the ground floor, and two on the first story, the stairs being formed of large stones built into the house-walls, and leading up outside. The doors were, as usual, of stone: sometimes there were folding-doors, and some of them were highly ornamented.[17]

3 Kennedy 2000, 397: "Unexpectedly full steppe and desert landscape studded with villages and roads." Peak settlement was in the Roman period, followed perhaps by sedentarisation of some nomads.

4 Vries 1998, 91-127 for the location, plan and design of the late-antique town; ibid., 229-241 "Towards a history of Umm-el-Jimal in late antiquity" - 2nd to 4th century town housed a Roman imperial administrative establishment, while a pre-existing civilian village (1st to 4 th century) lay to the east; $236-240$ for late antique prosperity; Brown 1998 for the praetorium.

5 Kennedy 2004, 72 for Deir El-Kahf: "At the beginning of this [2oth] century the ruins were totally uninhabited; today the modern village has encroached on them and much stone has been removed including all of the inscribed blocks once visible."

6 Kennedy 2004, 86 for Umm al-Jimal, its Nabatean, Roman and Early Islamic remains, with inscriptions, fortress and water supply.

7 Lewis 1996, fig. 3 for the large number of villages visited by Bankes, with Umm al-Jimal the only one that far south. 
In 1865 Porter exclaimed that at Umm al-Jimal "though deserted for many centuries, the houses, streets, walls, and gates are in as perfect preservation as if the city had been inhabited until within the last few years."[18] Cyril Graham had been there shortly before Porter, and registered a similar impression:

On reaching this city, I left my Arabs at one particular spot, and wandered about quite alone in the old streets of the town, entered one by one the old houses, went up stairs, visited the rooms, and, in short, made a careful examination of the whole place; but so perfect was every street, every house, every room, that I almost fancied I was in a dream, wandering alone in this city of the dead, seeing all perfect, yet not hearing a sound. ${ }^{[19]}$

The town was so "perfect" because it apparently had not been rebuilt, so that only Roman and Christian structures were to be seen. Merrill in 1885 was also impressed, but reported that

I am sorry to state that the Arabs are every year carrying off the stones of this city to other places. As many as six men were at work while we were there, throwing down the walls and getting the long roof-stones, which were to be carried away on camels. Just before we reached the place we met thirty or forty camels that had started with a load of stone taken from these ruins. It is easy to see how important inscriptions may be carted off, and thus valuable historical material for ever lost. ${ }^{[20]}$

So impressed was he that he took but two photographs of the whole city, and this on a funded expedition. ${ }^{[21]}$ Yet at least his camera plates were of a good size, $9 \times 11^{\prime \prime}$ and $11 \times 15{ }^{.}{ }^{[22]}$ Dussaud in 1903 guessed that the fortifications protected the town from marauding nomads, and ensured continuing prosperity and indeed expansion: "L'agrandissement, à l'époque byzantine, nécessita une réfection des murs et on utilisa pour cela certains monuments modernes, comme la grande église au nord du village."[23]

\section{Gadara}

We found the remains of a row of columns which lined the main street on either side; two theatres, in tolerable preservation, are within the walls, and without them, to the northward, is the Necropolis; the sepulchres, which are all under ground, are hewn out of the live rock, and the doors 
which are very massy, are cut out of immense blocks of stone; some of these are now standing, and actually working on their hinges. ${ }^{[24]}[1823]$

Gadara, or Umm Qais, ${ }^{8}$ is between the Golan heights and Lake Tiberias to the north, and the Jordan Valley to the south. It was one of the cities of the Decapolis, and early 19th-century travellers founds its ruins extensive but degraded, as the quote above makes clear: columns were still standing, and many tombs still had their working stone doors: "We found the only inhabitants there living in the ancient tombs, which are cut in the live rock, and have doors of stone to them, still turning on their pivots, and securing them at night., [25]

It boasted two theatres, two long paved streets at right angles (once colonnaded) with a temple at one end, and large numbers of sarcophagi and tombs. When Burckhardt saw the site in 1812, he counted seventy sarcophagi, and there were "immense heaps of cut stones, columns, \&c. dispersed over the plain." ${ }^{[26]}$ Irby \& Magles, in 1823, found that the locals used tombs as housing, and these guests were lodged in one capable of containing thirty plus cattle. The pavement of the city was very perfect and "the traces of the chariot wheels are still marked in the stones." The next account is by Robinson in 1838, and he remarks that the site was uninhabited, and that this was a dangerous region to visit. ${ }^{[27]}$ Lindsay, however, in the same year, noted that nearly all the tombs were indeed inhabited, conceivably because they could easily be secured: "the massive stone doors, that originally closed them, still move on their hinges, and open or shut at the option of the present owners." The doors and their decoration were, he declared, far more handsome than those they saw later in the Hauran. ${ }^{[28]}$ Some were obviously abandoned by the time Luynes arrived in 1864, because debris had accumulated in front of their doors. ${ }^{[29]}$

Because the locals continued to live in the tombs, this was still the state of affairs when Guérin visited in 1877 , and "La cité des morts égalait par sa magnificence et par son étendue celle des vivants." ${ }^{[30]}$ Perhaps sarcophagi survived at Gadara in the 1830 s because "La ville n'est point habitée. Le pays qui l'environne est fort dangereux."[31] However, many of the ruins have been incorporated into new housing, so little survives today of the ancient town, except for an underground mausoleum. ${ }^{9}$ Little except piles of ruins were in evidence in 1881:

8 Hoffmann 1999; Hoffmann \& Kerner 2002: Gadara and the Decapolis; Hoffmann 2002: the town's topography.

9 Weber 1990: Gadara, with fig. 1 showing modern village separate from the ancient site. 20-25: the "only completely intact monument from ancient Gadara" - an underground mausoleum, Roman, plus Byzantine crypt. 
Columns, Corinthian and Ionic capitals, a vast amount of carved ornamental work, and large, fine eagles still perfect, whose wings spread three feet. There are also some inscriptions among the ruins. ${ }^{[32]}$

Recent investigation suggests that the monumental gate fell down in the 8thcentury earthquake because it was badly built, with pretend-ashlar masonry, and not much mortar! $!^{10}$

\section{Difficult Sites - Jerash, Amman, \& Petra}

Fear of robbers caused inattention to monuments, rushed visits to only parts of sites and, occasionally, no visits at all. The unfortunate effect was to restrict pleasurable, calm and extensive access to sites, causing travellers to skimp on their inspection and to omit whole town sections or areas of territory if their guides were uneasy or unco-operative. Sites such as Amman and Jerash were noted for such problems, and therefore before the late 19th century we do not learn as much as there was to know. In 1851 Monk was surely whistling in the dark when he proclaimed the ease of now getting to Jerash: "So long as a military governor with an armed force remains in the country, the tour beyond the Jordan will be as safe and as easy of accomplishment as that from Jerusalem to Beyrout."[33] The following year at Jerash another traveller learned from farming Arabs that "a strong party of the warlike tribe of the Benneseukers [BeniSakhar] were encamped not far off," and immediately fled. ${ }^{[34]}$ It was evidently difficult to decide whether it was the Bedouin or the armed villagers who presented the greater danger. For Bankes in 1816 it was the latter: "we felt little alarm from wandering Arabs, but much more from peasants and cultivators, who seldom are at peace with them, and always carry fire-arms in that country, so that we shunned all villages."[35]

Many of the sites already discussed in this book were still occupied when travellers described them, having been robbed out, built over and reworked for centuries. Very few had been completely abandoned by permanent residents (living in houses not tents), but this was indeed the case with Jerash, Amman and Petra. (Palmyra is almost in the same category, for it housed only a small village.) There was plenty at these sites for scholars, and for learning about the "complete" past, as at Pompeii (with which Le Strange compared Jerash ${ }^{[36]}$ ) and Herculaneum! Where else, except further east, were untouched sites awaiting the new science of archaeology? In 1838 Lynch and his party "deeply 
regretted" their inability to visit Jerash - but "what a field the Hauran presents for exploration!"[37]

However, trouble-free access was not to be (either east of the Jordan or at Palymra), because Bedouin marauders kept traveller visits short if sweet for decades. The 1876 Baedeker advises travellers to take a bedouin escort, describes the (cosy) setup developed by their sheikhs, and the fees required, and warns that anyone travelling without such insurance "will profit little by appealing to his consul." However, those venturing east of the Jordan will pay more where "the Turkish supremacy is but nominally recognised, and where, especially in the border districts, the petty shekhs affect to disdain francs and shillings, and often demand English sovereigns for their services." [38]

Seetzen went to Jerash in 1809, disguised as an Arab, but still omitted large sections of the site:

Je ne vis que la moitié de l'espace qu'occupait la ville; mais il est trèsprobable que dans l'autre moitié, de l'autre côté du ruisseau, on trouve encore mainte chose remarquable. ${ }^{[39]}$

Burckhardt went there three years later, and

I had, at most, only four hours to make my survey, and it was with great difficulty that I could persuade my three companions to wait so long for me. None of them would accompany me through the ruins, on account of their fear of the Bedouins.

Nor was this all, for he had to skip part of the town near the south gate, and convinced himself that this did not matter, for "I have reason to believe, from the view which I had of it while on the temple hill, that nothing of consequence, either as to buildings or columns, is there to be met with." ${ }^{\text {[40] }}$ In 1825 Buckingham faced similar dangers at Amman: he ran over the theatre, "scrawling the few notes I could make of it, in secret, beneath my outer garment, and looking behind me at every step, in the apprehension of being perceived and interrupted." ${ }^{[41]}$ One tenuous solution to avoiding robbery or worse was to look poor. In 1822 Buckingham, wishing to cross to Jerash, had heeded the advice of his guides "to take with us nothing that could excite the cupidity of strangers," partly because his group was poorly armed. ${ }^{[42]}$ But Jerash was rarely safe, Rey in 1861 being chased off by horsemen of the Beni-Sakhar." [43]

Once arrived at the desired site, therefore, the traveller's worries were far from over. Most were deserted and covered with ruins, providing ideal hiding 
places for robbers. The upshot is many apologies in the literature for a site inspection hurried, or incomplete because some areas were just too dangerous. Burckhardt admits his description of Amman is "very imperfect," because "a traveller who is not accompanied with an armed force can never hope to give very satisfactory accounts of the antiquities of these deserted countries." ${ }^{\text {[44] }}$ His guides had seen some fresh horse-dung, and rode off without waiting for him:

When I reproached them for their cowardice, they replied that I certainly could not suppose that, for the twelve piastres I had agreed to give them, they should expose themselves to the danger of being stripped and of losing their horses, from a mere foolish caprice of mine to write down the stones. I have often been obliged to yield to similar reasoning. ${ }^{[45]}$

Guides at Jerash were also in firm control of their travellers, perhaps fearing for their own life. Buckingham in 1822 visited parts of the site, but only glimpsed others, "none of which we could examine with any degree of attention, from the restraint under which our guides had placed us."[46] In 1838 Robinson faced the same problem at this site where, having glimpsed Arabs, they left as night approached, although they had planned to stay for several days. ${ }^{[47]}$ In the very same year Carne opined that "recently many wanderers have gone there in safety and at leisure," pointing out that it cost a third of the expense for Palmyra, but yet adding that "a visit to this place, the ancient Gerasa, as is supposed, is not without risk from the Bedouins, who sometimes conceal themselves beneath the trees that over-shade the river."[48] The obvious answer was, if possible, to make a second visit. In 1874 the duc de Luynes planned to do likewise for Zat-Rass, but this was aborted because it was suspected robbers had passed that way. ${ }^{[49]}$

Palmyra in the $17^{\text {th }}$ century presented similar dangers, and made a group of visiting merchants very jumpy, fearing that "should the Mountain Arabs... have intelligence of us, they might either fall upon or endeavour to intercept us in our return." [50] In the 1750s Wood was apprehensive about his return from Palmyra, and on their guard against surprise incursions "from the King of the Bedouins, or wandering Arabs, who might have had the intelligence of us, and think us a prize worth looking after." ${ }^{\text {[51] }}$ In 1840, Layard's companion Mitford had obviously heard the plentiful horror-stories about marauding Bedouin, so declined to visit Petra, Jerash or Amman. ${ }^{[52]}$ Fear was still abroad in the 1880 s and 1890 s, when a commentator saw many eager devotees arrive at Damascus, "but owing to the expense, danger, and general hardships of the journey, few of the multitude had been permitted to look upon her beauty."[53] 
In the 1880 os Jerash and Amman were newly populated with Circassians, ${ }^{11}$ conceivably chosen for such wild frontier regions because they were known to be tough, and valued as soldiers. But they looted any valuables they found in tombs, and destroyed many antiquities to build their stone houses, no doubt helped by the effects of earthquakes, which brought down columns and dislocated stone walls, ${ }^{[54]}$ such as that recorded at Jerash in $1833 \cdot{ }^{[55]}$ Just how many Circassians arrived is unclear: Baedeker in 1898 estimated 300 at Jerash ("Destruction by the hand of man is making rapid progress"[56]) but to these should be added the many villages in the region (especially Kuneitra and environs) where several thousand were probably in residence by $1905,{ }^{[57]}$ and no doubt using their carts (an innovation here) to transport wood and stone for building. If we are to believe Cook's 1907 handbook (which probably pirated the information), there were already several thousand at Amman. ${ }^{[58]}$

\section{Jerash}

There are upwards of twenty principal ruins; and it is marvellous that, while every one is familiar with Baalbec and Palmyra, so little is known of Gerash, except by eastern travellers. If a provincial city of Imperial Rome could exhibit such magnificence, what must the great cities themselves have been in their glory? ${ }^{[59]}[1865]$

Jerash, ${ }^{[60]} 48 \mathrm{~km}$ north of Jordan's capital, Amman, was a member of the Syrian Decapolis, and lavished with monuments (and a plethora of columns ${ }^{12}$ ) in the first and second centuries AD, some by governors of Syria. ${ }^{13}$ Because of the colonnades, its effect is frequently compared to that of Palmyra. ${ }^{[61]}$ The whole region appears to have been prosperous in the Byzantine period, anchored by the earlier foundation of churches, and with Islamic monuments as well. ${ }^{14}$ The city was also occupied under the Umayyads, struck by an earthquake in AD 749, and finally fortified during the Crusades. ${ }^{[62]}$ However, the region may have

11 Mackey 1979 passim: the Circassians in Jordan. 43 for arrival dates (in various waves): Amman 1875-9, 1880, 1882; Jerash 1885.

12 Seigne 2002 with excellent plans, elevations and images.

13 Thomas 2007, 101-103: monumental architecture at Jerash. Ibid. 87 for some important dedications. Seigne 1997: Hellenistic and Roman housing at Jerash.

14 Hamarneth 2003, 213; 245-308 for catalogue of 66 sites [Byzantine and Islamic, in Jordan] he has examined. Piccirillo 2002, 114-137: La Gerasa chrétienne.Walmsley 2002, 143-5 for the Islamic Governor's Palace. 
declined in prosperity from the later 8thC, because not only were churches not repaired, but most villages were abandoned in the IX-X century, as the pottery record demonstrates. ${ }^{15}$ In 1225 Yakut relayed that it was "now a total ruin.. ${ }^{[63]} \mathrm{A}$ description of the site was first provided to Westerners by Seetzen in 1810, who was puzzled how the site "can have so long escaped the notice of all lovers of antiquity" $[64]$ - although perhaps he was simply underlining how clever he was to have "found" it. He gave an overview of the monuments, but had to bribe his guide to stay another half-hour because "there were some Arabs about."[65] Irby \& Mangles followed in 1823 and affirmed (another misguided tourist topos we have met before) that "the marks of the chariot wheels are visible in many parts of the streets." ${ }^{[66]}$ We have to wait for Robinson in 1838 for a full description of the site. ${ }^{[67]}$

"If the Decapolis reared such cities under the pagan government of the Antonines," wrote Skene in 1864, "what is to be said of the Mussulman government of the Sultans, under which they have been mere ruins in a desert during so many centuries?"[68] These were the ruins which re-population would part-destroy, as we shall see. Chapter Two has already discussed reasons for the abandonment of settlements, include problems with agriculture and marauding Bedouin, as well as with earthquakes. For travellers up to the 188 os, Jerash was a deserted city ripe for exploration, if marauding Bedouin could be kept off. However, surrounding villages contained surly and "fanatic" residents, as Bankes discovered in 1816. ${ }^{[69]}$

Long before the Circassians arrived, there were a few settlers here, in 1838 some living in the theatre: "The galleries are now the private dwelling-houses

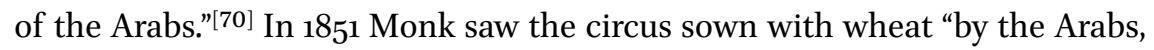
who take up their abode during the summer among the ruins of the place.,[71] Visitors marvelled at the extent of the remains, especially the colonnades, ${ }^{[72]}$ Conder in 1889 counting more than 200 standing columns, "one of the noblest ruins of Syria almost without a history." ${ }^{\text {[73] }}$ Merrill in 1881 had counted over $3^{300,}{ }^{[74]}$ so either mathematics are faulty, or perhaps they were already being pulled down for their materials. The state of preservation of the monuments was impressive, ${ }^{[75]}$ as were "triumphal arch, gateways, theatres, temples, long lines of columns, and architectural masses."[76] However, Butler in 1904 recorded his distress at how the ruins were being demolished: "The chief sport of the boys was a sort of glorified game of bowls, in which great building-stones were detached from the higher parts of buildings and sent crashing down the slope."[77]

15 Hamarneth 2003, 228-229. 
The beginning of modern Jerash, if not quite the end of the ancient city, was initiated by the arrival of Circassian immigrants planted here in the 188 os by the Ottoman government and left to fend for themselves. The same approach, with the same results, was used by the French when settling Algeria with new immigrants. ${ }^{16}$ This they did, and administrators must have known that this would be at the expense of the ruins, certainly much more extensive before they arrived. In 1876, Baedeker notes that "Part of the site of the ruins is cultivated by the peasants of the village of Suf (l hr. to the N.) and other half-Beduins." In 1885 Le Strange was relieved that the Circassians "had fortunately taken up their abode on the left bank of the stream, where the ruins are comparatively insignificant, and they had not as yet begun to meddle with the magnificent theatres, colonnades, and temples crowding the right bank., ${ }^{[78]}$ He repeated his relief four years later that "the stones of the great Temple of the Sun and of the theatres have nowhere been pilfered for building material." Going on to write "against the thievish propensities of the Christian Circassians,"[79] he might have been more circumspect. Heber-Percy visited in 1896, counted fifty sarcophagi in the cemetery, and noted that "all these had been dug up and ransacked by the Circassians in the hope of finding treasure." Yet he evidently did not disapprove, because he could purchase some of the loot: "I bought from them some perfect glass Khol jars that they had taken from here, one with the bronze spatula in it for applying the khol to the eyes." ${ }^{[80]}$ Cook's Handbook of 1907 simply echoed Le Strange's assessment, ${ }^{[81]}$ presumably without visting the site - and thereby illustrating the awkward fact that nobody visiting a quarter of a century after the Circassians arrived could know what they had destroyed in the meantime. Nor should Wikipedia entries necessarily be accepted as accurate. ${ }^{[82]}$

By 1910 1,500 inhabitants were recorded by Baedeker, although Cuinet in 1901 put the number of Circassians at 6oo. ${ }^{[83]}$ The local Muslims certainly did not like the (Christian) Circassians, who by 1889 were

a thorn to the Moslems in their agricultural operations, and further debar them from seeking for treasure among the vaults and cisterns of Jerash, a city built, as one of the sheikhs was good enough to inform me, by his own ancestors, the 'Adites, of the Days of Ignorance.. ${ }^{[84]}$ 
Recent excavation has improved our knowledge of the ancient town and its Christian successor buildings. ${ }^{17}$

\section{Amman}

Amman est une ville antique, ruinée dès avant l'islamisme, et dont mention est faite dans l'histoire des Israélites. Il en reste des ruines imposantes aux pieds desquelles coule la Zarqâ, rivière qui se trouve sur la route des pèlerins de Syrie. ${ }^{[85]}$ [early 14 thC]

As we see in the above quote Abulfida (who presumably did not visit) believed Amman, capital of present-day Jordan, to be in ruins before the arrival of Islam, so he did not know about the (perhaps Umayyad) palace on the citadel. ${ }^{18}$ Nor before him did al-Muqaddasi in 985 recognise an Islamic palace here, so it was perhaps already out of use..$^{19}$ But al-Muqaddasi did note the theatre and a mosque, and "the city is even as a harbour of the Desert, and a place of refuge for the bedawin Arab." ${ }^{[86]}$ The Citadel seems to have been neglected by many travellers. In 1866 Tristram found its plateau

strewn with a hopeless mass of ruins of every age and character except Jewish. There is one principal group of six enormous columns, of which the bases only are standing, while the prostrate shafts are five feet in diameter. ${ }^{[87]}$

Heber-Percy in 1896 mentions its strong wall, and "part of a large temple, and a beautiful Sassanian building., ${ }^{[88]}$ Indeed, few travellers discuss the Islamic remains, ${ }^{20}$ and one wonders how many could recognise them. However, they certainly recognised the prehistoric remains, including some 20 dolmens, written up by St Clair in $1892,{ }^{[89]}$ and by Baedeker in $1910 .{ }^{[90]}$

17 Brenk 2009 for discovery of a cathedral portico destroyed in the 749 earthquake. Some elements of this portico were spolia, such as a small acanthus capital and a large Augustan composite one (Abb. 7, 8).

18 Gorbea 1983: this Umayyad, and concludes 204 that the complex is based on the ruins of monumental Roman constructions. The book includes many early photos.

19 MacAdam 1992, 71-104, Amman: the Umayyad palace.

20 Northedge 1992, 47-55: Amman's history in early Islamic period. Ibid. 57-61: archaeological typography for Roman and Islamic periods. Arce 2008: the Islamic city/citadel. MacAdam 1992 is useful for plentiful early photos, by e.g. American Palestine Exploration Society, Palestine Exploration Society, Creswell Archive etc. 
In 1812 Burckhardt had great difficulty in finding a guide to taken him from Es-Salt to Amman, because "the Beni Szakher were at war with the Arabs of Adouan, with the government of Damascus, and with the Rowalla, a branch of the Aeneze; and we heard daily of skirmishes taking place between the contending parties." ${ }^{[91]}$ His description of the monuments is no more than an outline; ${ }^{[92]}$ but then he often demonstrates his lack of a good knowledge of architecture. Nor could he get further south to visit Umm el Rasas, or "the ruins called El Kohf, with a large temple, and many columns." ${ }^{[93]}$ El-Kahf ${ }^{[94]}$ had many tombs, some sufficiently grand to be described as temples. Seetzen visited in $1806,{ }^{[95]}$ but his description is short, ${ }^{[96]}$ so perhaps he also feared meeting the Bedouin there. Brünnow \& Domaszewski spent little time there a century later, ${ }^{[97]}$ although their book title was to be Arabia Petraea, including this important city.

Given the plentiful water, the site for centuries apparently attracted thirsty animals but, curiously, no settlers, perhaps because of frequent earthquake damage. ${ }^{21}$ In 1838 Robinson found no inhabitants, but camels and sheep sheltering amidst the ruins. ${ }^{[98]}$ La Salle noted the site was bigger, but the monuments in worse condition, than Jerash. ${ }^{[99]}$ In 1868 Porter described Amman as totally desolate, with monuments "defiled by the flocks that seek a temporary shelter beneath their tottering walls, and by the mangled carcases and bleached bones of animals that have fallen to rise no more. Jackals prowl around it; vultures hover over it; but no human being seeks a home within it." ${ }^{[100]}$ Because "most of the buildings have something of the aspect and stench of an ill-kept farm-yard," ${ }^{[101]}$ perhaps Porter gave less than due attention to the ruins. He should have visited during another season, when the flocks were up on the hills. ${ }^{[102]}$

By 1880 , however, the site did indeed have inhabitants. The forum was in use for growing onions, a temple had become a cattle pen, and Corinthian capitals were in use as stepping stones across the river, next to the ruined bridge. The Circassians were in residence:

A man was plowing in and out between beautifully carved pedestals, cursing the ornamented fragments of stone which he turned up, to the detriment of his plow and his furrows... it seemed as if these barbarians, unable to satisfy their vengeance upon the civilization of the present, had determined to wreak it upon that of the past. ${ }^{[103]}$

21 MacAdam 1992, 160: Severe earthquakes recorded for Amman in 1033, 1068 and 1202, and more distant ones (which might also have caused damage there) in 1105 and 1170. 
In 1882, the new settlers ("here planted by the Turkish Government") were still living in wattle huts. "Some of these poor exiles have seized on the theatre, living where wild beasts were once caged, or where gladiators awaited their fate." ${ }^{[104]}$ But as a result of Circassian settlement Amman "re-emerged as a modern city."22

Le Strange also noted Circassians at Amman, where "the wonders of Greek architecture that have hitherto lain peacefully entombed beyond the Jordan... now given over by the Ottoman Government to be a habitation for Circassian colonists." [105] This was far too complacent, surely, for a man who knew local habits so well. Indeed, by 1909 it was even being suggested that Circassians were using gunpowder to bring down columns at Jerash, ${ }^{[106]}$ though what they might have been using them for is not stated.

In 1865 Tristram described a large public building near the basilica, "its river face consists of two enormous round bastions with flat curtain walls between them, built of large stones with the Judaeo-Roman bevel, and a deeply arched massive postern, with four successive arches of different heights." [107] This must have been the reworked mediaeval fortress, clearly visible in a Bonfils photograph of perhaps the $188 \mathrm{os}$. But it had gone by the time clutches of photographs had appeared at the end of the century or later, showing a cottage inside the basilica, houses built within and all around the monuments, and marble gathered within the north-west baths, with a spolia-built house in the middle, and what looks like a lime kiln behind it. By 1905 Amman was a growing town, and with "an aspect so superior to anything we had seen since leaving Jerusalem" that this must have been because of the Circassian sense of order: "The houses, built partly of mud brick and partly of ancient material like those of Madaba, were well placed, most had porticos and balconies, and some were enclosed with well-swept yards." ${ }^{\text {[108] }}$ Perhaps the columns the Circassians collected were re-used to support their porticoes or balconies.

"A handful of buildings, museums and the ruins on the citadel testify to the city's long history," writes the 1993 edition of the Lonely Planet Guide. This was at least in part because of the doubling of population numbers from a 5000-strong Circassian village in 1921 to 10,000 or more within a decade, as Amman became a capital city. Within another decade that there was no more cultivated land available because "the only Government land near Amman is on the border of the desert and with recent years of good rainfall all the felaheen and bedouin are beginning to cultivate these areas." ${ }^{23}$ Goodrich-Freer visited in 1905, and noted the disappearance of one basilica, and part of the Baths:

\footnotetext{
22 MacAdam 1992, 47.

23 Alon 2007, 64, 130.
} 
But the Muchtar, who may, perhaps, be likened to the mayor of the town, has forbidden further depredations, and, happily, the new population has not chosen to establish itself among the ruins. ${ }^{[109]}$

This is a location directly contradicted by the Cook's Guide. ${ }^{[110]}$ The confusion was surely because the settlers were spreading out, transport was improving, and the ruins were deteriorating in parallel. As Butler wrote in 1905, "Amman, in the hands of the Circassians, is becoming a large and thriving town. The Hijaz Railway has a station not far to the east, and the ruins, I fear, are doomed to certain and rapid destruction." [111] He was correct, for little survives today. The railway station was only $3 \mathrm{~km}$ from Amman, and this "brought both prosperity and challenge to the Circassians and brought both traders and settlers to the area." The Bedouin were far from pleased because they "saw the railway as a threat to the revenues they had heretofor collected from pilgrims using the route to Mecca." 24

As Bell wrote in 1908 when visiting Kastal, to the north of Amman and 14km from Madaba, she saw families newly established amongst the ruins:

Circumstances which should no doubt warm the heart of the lover of humanity, but which will send a cold chill through the breast of the archaeologist. There is no obliterator like the plough-share, and no destroyer like the peasant who seeks cut stones to build his hovel. I noted another sign of encroaching civilisation in the shape of two half-starved soldiers, the guard of the nearest halting-place on the Hajj railroad, which is called Ziza after the ruins a few miles to the west of it. ${ }^{[112]}$

The new settlers probably did more damage even than Ibrahim Pasha and his troops, who had apparently trashed one of the two fortresses, itself (thought Tristram) a temple and then a fortress before it became a mosque. ${ }^{[13]}$

\section{Um Rasas}

The number of small semicircular arches which are standing everywhere, and which have formed both the roofs of houses and the arcades of streets, is really countless. They remain intact both above and below the rubbish. It was often easy to see the old street among the debris below, as we stepped from arch to arch of these long parallel arcades. ${ }^{[114]}[1873]$ 
This, a World Heritage site since 2004, the Mother of Lead, was thus named according to Buckingham "from the circumstance of there having been dug up here, at some former period, leaden cases containing treasure," which, however, he could not confirm. ${ }^{[115]}$ These could perhaps have been lead sarcophagi, or perhaps columns drums and other architectural elements were joined by lead inserts. It was an ancient town, with narrow streets and plain houses built from very large stones, its walls "quite perfect all around" in $1825 \cdot{ }^{[116]}$ The problem for visitors with the site was the lack of discernable structures within those walls. Irby \& Mangles went there in 1823 , saw plenty of Christian remains, but it was dangerous:

There is no architectural remnant worthy of notice. Mr. Bankes, with his janissary, took a second tour in search of inscriptions, while we remained under the wall. While walking about the ruins, an armed Bedouin made his appearance and robbed him of his abba. ${ }^{[117]}$

This frequently offhand pair of adventurers were evidently correct about the architecture, for Robinson fumed that the site was "sans un seul édifice remarquable qui nous dédommageât de la peine que nous nous étions donnée pour y arriver." ${ }^{[118]}$ The town walls were still intact, but not at full height, in 1873. ${ }^{[119]}$ Hamilton in 1875 was disappointed with the remains in the whole area:

There is little of note in the ruins of Um Rasas, Madebar, and other places. They are merely the ruins of deserted towns, which evidently were of small extent. This was the first country in which I witnessed the remains of town after town left completely deserted, without a sign of either animal or vegetable life around. ${ }^{[120]}$

This site was fully described by Brünnow \& Domaszewski in 1905. ${ }^{[121]}$

\section{Iraq Al-Amir}

The remains at 'Arak el Emir, whatever may be their date, cannot fail to strike the traveller with somewhat of that same feeling of awe which he experiences when standing for the first time beside the huge stones either at Baalbek, the platform of Persepolis, or the Egyptian Pyramids. Greek and Roman ruins are dwarfed into insignificance beside these, for they tell of an age when labour and time were held as of no account in the calculations of kings who built for themselves such temples, palaces, or 
tombs. It was with difficulty that we tore ourselves away from these wonderful relics of a bygone civilization. ${ }^{[122]}[1889]$

This is the location, $17 \mathrm{~km}$ west of Amman, of a Hellenistic palace (unfinished: see incomplete carvings) in the early second century BC, known as the Qasr Al-Abd, Palace of the Servant, and erected by the Tobiad prince Hyrcanus. Like other sites in the region, it began to be visited in the second half of the 19th century, although Thomas Legh saw the site in 1816, and believed he recognised caves cut "some apparently intended as stalls for horses, and others for the accommodation of a numerous retinue of servants." [123] The remains attracted attention because of their bas-reliefs on huge blocks: the first five courses ranged in weight from seven to thirty-two tons. The Duc de Luynes visited the site in 1864, and identified it immediately as Hyrcanus' palace, being particularly impressed by the animal frieze, with its two-metre-long lions. ${ }^{[124]}$ His geologist located the nearby quarry, where "on voit affleurer des couches d'un beau calcaire blanc cristallin superposées à des assises de calcaire compacte à nérinées et à exogyres." [125] The geology perhaps helped with Josephus' statement that the palace was white because, as Le Strange remarked in 1884, "when we come to examine here the carved blocks, alongside of which the inquisitive traveller feels dwarfed to the dimensions of an insect, we find that they are all, without exception, cut out of stone most remarkably black." The Duke was impressed by the size of the complex, and especially by the quality of the workmanship:

dans ses décombres, en pierre ou en marbre blanc, des chapiteaux quasi corinthiens, quasi doriques, des fûts de colonnes cannelées formant des extrémités d'antes, des fûts, doriques de même, de belles moulures de corniche de style mixte, des rangées d'oves d'une belle exécution. ${ }^{[126]}$

In 1867 De Saulcy, the first to excavate in the Holy Land (some problems and results are given in Chapters Two \& Three above) gives a long description of his work at this site. ${ }^{[127]} \mathrm{He}$ decided he wanted souvenirs, and fixed his attention on a charming capital. He then sent to the town of Salt (30km NE of Amman) for a mason, but then he got more enthusiastic, and wanted more:

Je lui ai d'abord montré le chapiteau, qui, en moins d'un quart-d'heure, a été détaché de son frère; puis j'ai voulu faire subir la même opération à une base à cannelures, partant de l'aisselle de feuilles d'acanthe. Cette fois, malheureusement, la pierre avait des fils, et la pauvre base s'est débitée 
d'elle-même en trois ou quatre morceaux. Mais comme les morceaux en étaient bons, je les ai mis en réserve.

The locals thought he had overpaid for the work of gathering stones "qui, à leurs yeux, ne valaient pas la peine d'être ramassées."[128]

This important site was in Baedeker's guidebook by $1876,{ }^{[129]}$ and was a target for reconstruction on paper or on site for much of the last century, until the results appeared in $1991 .^{25}$

\section{Madaba}

The Sheik told me they had found much mosaic pavement here, and then shewed me some Corinthian capitals, some mouldings, etc.; but they simply use these old buildings as a quarry, and four men were at work breaking up and squaring the fine old-faced stones into convenient little squares to build their new houses. ${ }^{[130]}[1896]$

Some indication of how many Syrian antiquities have disappeared, and why, is provided by the story of the 6th-century Madaba Mosaic Map, depicting and naming plans and pseudo-elevations of some of the main Christian sites of the Holy Land. In an area rich in churches, and of many churches rich in mosaics, ${ }^{26}$ this was discovered in 1884, but through indifference and then clumsy work its remains did not become known to scholars until December $1896 .{ }^{27}$

25 Larché 2005, XI: note how long this work took: 1864 accounts by De Vogüé and De Saulcy, the structure just a few courses high when illustrated by De Saulcy in 1867; Butler in 1904; Lapp in 1963; Will in 1976; results appearing in 1991. And the stratigraphy didn't get analysed until Lapp in 1963. Will 1997, 115: reconstruction of this stunning palace, and Larché 2005, Plates 16-34. Salles 2010 for discovery and reconstruction; much excavation was needed to recover and rebuild the hundreds of blocks for the reconstruction - see figs 14-15. Etienne 2010, 86-92 \& Fig 30 for reconstruction - a splendid gate. Etienne 2010, 94-122 for the Qasr al-Abd: Reconstruction of ruins at figs 14-15 seen in figs $31-32$. Two stories, with a peristyle colonnade on the upper floor. Figs $36-37$ for axonometric reconstructions and figs 40-46 for decoration of panthers, lions/lionesses, and eagles.

26 Michel 2001, 419-425: Corpus des églises disparues [from Jordan].

27 Meimaris 1999. 
The ancient town of Madaba was prosperous, and boasted several churches, some of which were richly decorated, and with some spectacular mosaics. ${ }^{28}$ (Indeed, Jordan was very rich in similarly decorated churches. ${ }^{29}$ ) The 747 earthquake seems to have destroyed the town, and it was abandoned. When Burckhardt visited in 1812, not one ancient building was standing, although columns and capitals were in evidence. ${ }^{[131]} \mathrm{He}$ made out the foundations of a temple, as did Robinson in $1838 ;^{[132]}$ presumably this had been converted into a church. A few columns remained erect on the site, remarked Tristram in $1873,{ }^{[133]}$ and there were some streets with vaulted houses occupied by Bedouin shepherds, ${ }^{[134]}$ and a large colonnaded square with most of the bases in place. ${ }^{[135]}$ Gray Hill, pondering in 1888 the unfinished "palace" of Mschatta, wondered where the materials had come from:

There is no other building nearer than Madeba (about four hours' journey; where the houses are all recently built out of cut stones found at that spot, and, therefore, the material cannot have been used up there. ${ }^{[136]}$

In the years following 1880 Christians and some Muslims were moved from Kerak to Madaba, presumably to develop agriculture in the area, for in 1865 "in the vast country between Kerak and Salt there remains not an inhabited house, still less a village. ${ }^{[137]}$ At Madaba, in a town with a street of columns, ${ }^{[138]}$ the new inhabitants built their houses on the town's ruins. "Grâce à l'intervention du patriarcat latin et du consulat français à Jérusalem, Midhat Pacha, gouverneur de Syrie, autorisa, en 1880, les chrétiens de Kérak à s'établir dans les ruines de Mâdaba et à cultiver les terres environnantes." ${ }^{[139]}$ Heber-Percy was told by Greek orthodox priests in 1896 that these houses were built by Christians recently arrived from Kerak (to the north), "that in digging to find stones for building they had found columns, capitals, and some mosaic pavement, and offered to take us to see them, which we gladly accepted."[140] Indeed, he was then shown

28 Michel 2001, 302-328: the churches of Madaba, with some spectacular mosaics, especially the map in S. George. Piccirillo 2002, 138-189 Madaba et ses mosaïques.

29 Michel 2001, XI: "The churches [in Jordan] are numerous, at least 150 have been sufficiently preserved for study ... It is not rare for a given locality to count ten or fifteen churches." These are mostly basilicas with a few centralised/cruciform as at Jerash, Gadara and Madaba. She catalogues 151 churches. There are 14 at Umm-al-Jeman, 9 at Rihab, 19 at Jerash, 8 at Madaba, 14 at Umm-al-Rasas, 6 at Amman. 
to a house built of stone arches covered with stone rafters, with a beautiful mosaic floor in almost perfect preservation. The women of the house wetted the floor and wiped it to shew it well. It is a really beautiful piece of work, and more perfect than we have seen anywhere. ${ }^{[141]}$

If the new occupancy of a ruined town eventually led to the discovery of some important mosaics, we might wonder just how much building (and how many mosaics) were destroyed in the process, especially in the decade following $1895 .{ }^{[142]}$ Certainly, "Ce n'est qu'à la longue, et souvent par hasard, qu'on a découvert des mosaïques sous la plupart des masures, avec une dizaine d'églises."[143]

The 6th-century Madaba Mosaic Map ${ }^{30}$ was found by a Greek monk in 1884, and reported to the Patriarch, who did nothing. In 1890 a new patriarch arrived, found the monk's letter, and sent instructions for the mosaic to be incorporated in the new church to be built above it:

We have the testimony of four monks that, at this time, the mosaic was almost complete, but the intelligent workman destroyed much of it in order to lay the foundations of the church, sacristy, and out-buildings; broke up part to insert a pilaster, and left much of the bordering, with its decorations of biblical imagery, outside. He then returned, with the assurance that the mosaic was unimportant. ${ }^{[144]}$

The Mosaic Map originally measured about $7 \mathrm{~m}$ in width, and some $21 \mathrm{~m}$ in length. Of these $147 \mathrm{sqm}$ some 8osqm survive. Since this is the only large mosaic map to have survived, the loss of over $40 \%$ is a pity, the more so when it is claimed by "trustworthy witnesses" that the map "recorded the position of Ephesus, Smyrna, and Constantinople."[145]

\section{Petra $^{31}$}

Ici les morts sont mieux logés que les vivants... Toutes ces tombes superbes qui font de la vallée de Pétra une imposante nécropole, n'ont point été outragées par le temps, et nous pouvons croire qu'elles ne se briseront qu'au bruit de la trompette du dernier jugement. ${ }^{[146]}[1867]$

\footnotetext{
$30 \quad$ Meimaris 1999 .

31 Fiema 2002, 220: by mid-6thC the town centre was "a less-than-respectable reflection of a once-glorious metropolis." 238-241: Petra's economic and political transformation in late antiquity. Rababeh 2005: the building of the town.
} 
Famously (except that the Crusaders got there well before him), ${ }^{32}$ Burckhardt discovered the site for the Western world in $1812,{ }^{[147]}$ did so in Arab dress, and without an armed guard:

I was without protection in the midst of a desert where no traveller had ever before been seen; and a close examination of these works of the infidels, as they are called, would have excited suspicions that I was a magician in search of treasures; I should at least have been detained and prevented from prosecuting my journey to Egypt, and in all probability should have been stripped of the little money which I possessed, and what was infinitely more valuable to me, of my journal book. Future travellers may visit the spot under the protection of an armed force; the inhabitants will become more accustomed to the researches of strangers; and the antiquities of Wady Mousa will then be found to rank amongst the most curious remains of ancient art. ${ }^{[148]}$

Because of access difficulties, visits thereafter were initially few. ${ }^{33}$ Irby and Mangles in 1823 relayed Burckhardt's account, but "since the death of the poor sheikh [Burckhardt, d. 1817], no European living has seen this place, or indeed the others to the S.E. of the Dead Sea. ${ }^{[149]}$ When Thomas Legh met the pair in 1816, they had just returned from an unsuccessful attempt to reach Petra, their Bedouin having reneged on an agreement, "and the travellers, after suffering great privations from the want of food, effected a most masterly retreat from Salt, escaped the tents of their treacherous guides, re-crossed the Jordan, and returned to Jerusalem." [150]

Several travellers arrived in the 1830 s and $1840 .^{34}$ Stephens saw several names inscribed within the Treasury, and exalted that he was the first American; so "independently of all personal considerations" he wrote his name and that of his dragoman in the same place. ${ }^{[151]}$ Nationalism took a grip with the arrival of two more Americans in 1843: Olin wrote a decent description of the site, ${ }^{[152]}$ while Millard, having overnighted in a tomb, inspected the site and noted approvingly the names of the "few American travellers who have visited the place." ${ }^{[153]}$ The following year Measor, an English clergyman, was brave enough to bargain down the fee demanded by about fifteen Arabs. ${ }^{[154]}$ In 1864 the Duc de Luynes took a boat and sailors with him to explore around the Dead Sea, and also Petra, where they were very useful down by the wadi: "Sur

\footnotetext{
32 Marino 1990.

33 Laborde/Bellefonds 1994: Burckhardt and Laborde at Petra, with useful notes.

34 Bellefonds 2011 for Laborde's Cairo-Petra travels in 1828.
} 
le quai même gisait à demi enterré sous le sable un fragment de marbre, débris d'une statue drapée. Je chargeai nos matelots de la déterrer."[155]

Wadi Musa was of course known to Muslim travellers, ${ }^{[156]}$ but there is relatively little on Petra (a World Heritage site since 1985) from early Western travellers because the site was difficult to get to: Laborde lists them, in a subtle piece of traveller triumphalism, ${ }^{[157]}$ and Lindsay gives a good description in $1838 .{ }^{[158]}$ Even in the 1840 , for example, the writ of Ibrahim Pasha did not run there, so his troops could not provide safety for travellers. Layard therefore had to ponder advice in Jerusalem from the British Consul that travel to Petra was unsafe, for "wherever I might go I should find myself in the midst of robbers and assassins," and Bedouin marauders. "Handsome backshish" would have to be paid, for no military escort could be provided. ${ }^{[159]} \mathrm{He}$ nevertheless did get to the site. He planned a visit to Moab, but was accused by the Consul of

unjustifiable foolhardiness in undertaking so dangerous a journey under such conditions, and foretold that all manner of mishaps were certain to befall me, the least of which would be that I should be stripped to the skin and have to find the way back to Jerusalem naked and barefooted.

He survived, and wrote that his belief in the hospitality of the Bedouin saw him through. ${ }^{[160]}$

The site was a rich one, with some imported marble (mostly veneer) and granite, while most columns were stuccoed sandstone. ${ }^{35}$ Such variety has contributed to the recent efforts to preserve the site. ${ }^{36}$ The statue uncovered for the Duc de Luynes was, he stated, of Parian marble. ${ }^{[161]}$ An earthquake in 363AD left serious damage, the city declined, the Great Temple was abandoned to housing, and lime kilns were built - hence the small amounts of surviving marble.

Hospitality had an exchange-like complexion ("for the most undisguised rapacity"), just as it sometimes did at Palmyra. It disgusted Legh in 1816, for "this was the only occasion, during our stay among the Arabs, on which a pecuniary remuneration was expected from us, in exchange for the rites of hospitality."[162] Daylight robbery (translation: site fees with menaces) was not the only problem for visitors to Petra. In 1868 Porter condemned the tribe who would escort visitors to the site as "an impudent and lawless set of vagabonds

\footnotetext{
35 Rababeh 2005: 40-3 use of marble at Petra, but its source not yet investigated; 43-44 Granite columns in the Blue Chapel Church, perhaps from Mons Claudianus, and perhaps reused from a Nabatean monument; 49-83 quarries and quarrying at Petra.

36 Tuttle 2013.
} 
as ever pilgrim had to deal with"[163] and, once there, the fees demanded as blackmail and intimidating: "News of his arrival spreads among the neighbouring tribes; strangers flock in to see what they can make by blustering or pilfering; and the escort becomes anxious to flee from complicated difficulties." [164] No guidebook-wielding traveller could say warnings were not given; and in 1876 Baedeker characterised the whole area south of the Dead Sea as insufficiently explored, "travelling being difficult and unsafe owing to the numerous different hordes of Beduins whose boundaries meet here," and concluding that "a visit to the ruins of Petra, therefore, is a troublesome and costly expedition." ${ }^{[165]}$ By the 1898 edition Baedeker noted that "this expedition is somewhat troublesome," now not because of Bedouin, but rather on account of the time required to complete it: sixteen days at least. ${ }^{[166]}$ Indeed, by 1905 the land was being cultivated, the Bedouin were scarce, and communications had improved. ${ }^{[167]}$
[1] Michaelis_1908_280-281
[2] Oliphant_1881_111
[3] Oliphant_1881_112
[4] Seetzen_1810_30-31
[5] Merrill_1881_293
[6] Merrill_1881_296
[7] Merrill_1881_354
[8] Van_De_Velde_II_ 1854_353
[9] Van_De_Velde_II_ 1854_355
[10] Le_Strange_1889_275
[11] Le_Strange_1889_274
[12] Le_Strange_1889_ 276-277
[13] Merrill_1881_273-274
[14] Schumacher_1889_ 305-306
[15] Schumacher_1889_303
[16] Merrill_1881_83
[17] Graham_1858_250-251
[18] Porter_1882_69
[19] Porter_1882_79
[20] Merrill_1881_85
[21] PEF_1876_53-54
[22] Merrill_1881_92
[23] Dussaud_1903_33

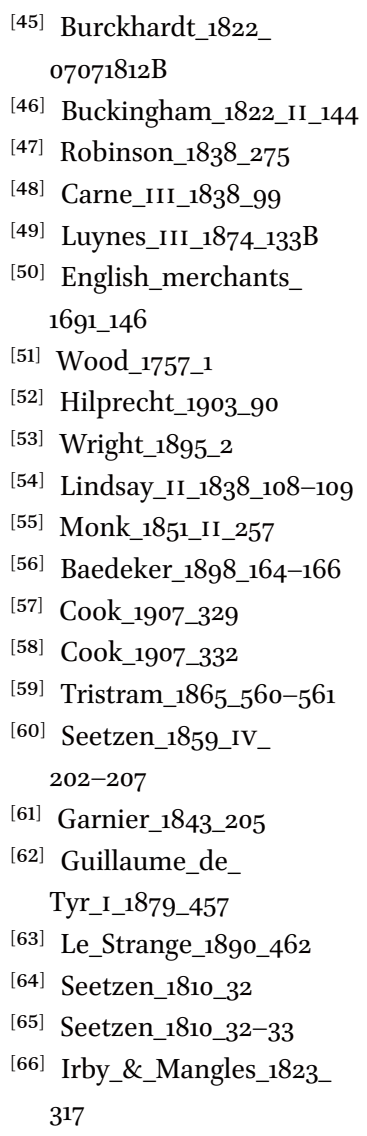




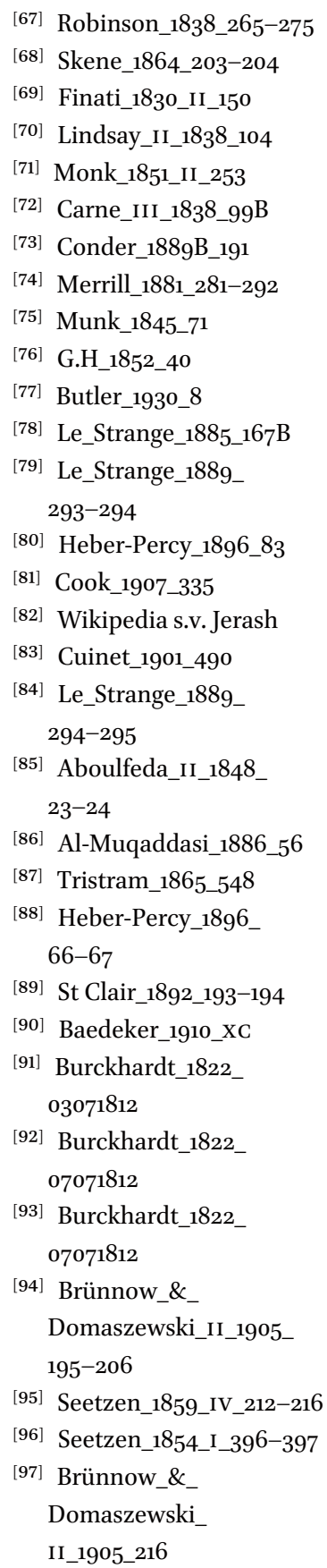

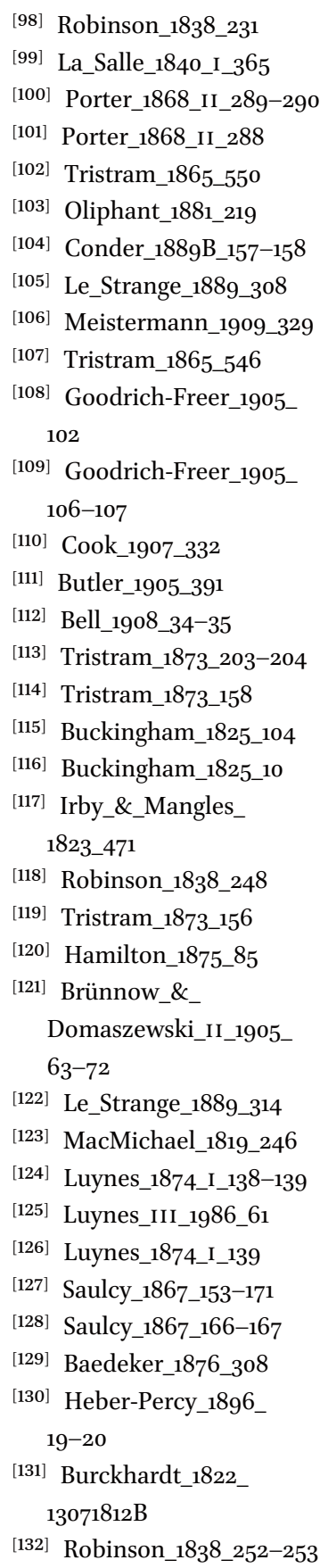

$\begin{array}{ll}{[133]} & \text { Tristram_1873_319 } \\ {[134]} & \text { Tristram_1873_326 } \\ {[135]} & \text { Tristram_1873_324 } \\ {[136]} & \text { PEFQS_1890_173 } \\ {[137]} & \text { Tristram_1865_551 } \\ {[138]} & \text { Goodrich-Freer_ }\end{array}$ 1905_55

[139] Meistermann_1909_272

[140] Heber-Percy_1896_16

[141] Heber-Percy_1896_ 20-21

[142] Goodrich-Freer_1905_ 53-54

[143] Meistermann_19o9_272B

[144] Goodrich-Freer_1905_

$$
\text { 59-6o }
$$

[145] Goodrich-Freer_1905_63

[146] Bourassé_1867_47

[147] Burckhardt_1822_ 23081812

[148] Burckhardt_1822 22081812

[149] Irby_\&_Mangles_ 1823_310

[150] MacMichael_1819_188

[151] Stephens_1838_II_56

[152] Olin_1843_14-49

[153] Millard_1843_194

[154] Measor_1844_156

[155] Luynes_I_1874_283

[156] Le_Strange_1890_548

[157] Laborde_1836_19-39

[158] Lindsay_1838_II_32-40

[159] Layard_I_1903_280

[160] Layard_I_1903_282

[161] Luynes_I_1874_298

[162] MacMichael_1819_232

[163] Porter_1868_II_39-40

[164] Porter_1868_II_44

[165] Baedeker_1876_29o

[166] Baedeker_1898_205

[167] Sykes_1904_55 


\title{
Fortresses Roman, Muslim and Crusader
}

\begin{abstract}
Si la Syrie est facile à attaquer, elle est difficile à conquérir. Son sol est si âpre et si montueux, qu'une petite armée pourrait s'y défendre longtemps contre une plus grande et y réduire la guerre à des affaires de postes. En Mésopotamie et en Egypte, une bataille gagnée donne tout le pays, au lieu qu'en Syrie une victoire ne peut donner d'autre avantage que d'occuper une position plus avancée, et d'aller d'une vallée dans une autre. ${ }^{[1]}[1829]$
\end{abstract}

This chapter divides naturally into three sections according to the periods at which travellers came across and took an interest in fortifications. We have already reviewed a variety of port and harbour fortifications in Chapter Four, which travellers would meet as they arrived by ship in Syria, or travelled up or down the coast. Here we deal first with land castles both Muslim and Western of the Crusader centuries, between 1099 and $1291,{ }^{1}$ plus continuing forts such as Baalbek, but not with the history of the Crusades, for which there are plentiful sources. $^{2}$ It is pointless to try completely to divide Muslim from Christian fortresses, since the same structures (including the famous Krak des Chevaliers) were often occupied in succession by each side, and built improvements as required, ${ }^{3}$ probably with each side learning from the other, ${ }^{4}$ and even perhaps

1 Faucherre 2004 includes treatment of the main forts, plus papers on construction techniques and cultural exchange; Eydoux 1982 passim. Kennedy 1994, 1-10: Prologue to the study of Crusader castles, including a sketch of the history of their study, including De Vogüé and Rey. Nicolle 2004 \& 2005, for authoritative guides, well-illustrated with photos, reconstructions and plans, to several of the best known fortresses, the first volume 1097-1192, the second 1192-1302. They include a short section on the fate of the fortifications, and another on "Visiting the fortifications today," with long lists of the sites.

2 Cahen 1940, 1-32: the Latin sources of northern Syrian history for the Crusades; and ibid. 33-93 for the Arabic sources.

3 Kennedy 1994, 63: Many of the Crusader castles in Tripoli and Antioch were redevelopments of existing structures, whereas, with very few exceptions, the castles of the Kingdom of Jerusalem were new foundations.

4 France 2006, 294: "a simplification to suppose that [the First Crusade] pitted a sophisticated military architecture against a society capable only of producing crude work. The general cultural superiority of Islam did not mean that its political authorities had invested in military architecture for cities, and castles were relatively rare" - this changed by end of 
using each others' masons. We then examine the faux-fortresses, which were often more like palaces, and traditionally called "desert castles," "which is rather a misnomer since many of these structures are neither castles nor located in the desert." Finally, we turn to actual Roman and Byzantine forts (in some cases models for the faux-fortresses) which most intrepid travellers came across later in the 19th century as they braved the Hauran south of Bosra, or crossed the Jordan to face once more the marauding Bedouin. Some fortresses survived with a complement of soldiers; many were treated as secure villages.

Western travellers might be interested in fortresses because they saw so many back home, but also because by the 19th century the positive and romantic vision of the Crusades in Walter Scott and Chateaubriand had overtaken earlier doubt, as had the scholarly editions of Jean-François Michaud's 1822 Histoire des Croisades and his 1829 Bibliothèque des Croisades. Already in 1806 the Académie Française had set a prize competition asking for a reassessment of the Crusades in light of French Revolution, so that "For the academicians, the Crusades were just another - yet very important - phase in the development of European culture." ${ }^{\prime}$ However, attention to these often magnificent relicts of the Crusades was disappointingly slight, the more so since the "Western" castles were ranged down the coastal towns or on the hills above, and were both massive and perfectly visible. Masyaf, girded with romance as the Assassins' headquarters in Syria, was only one of many neglected by Westerners, and Newbold charts similar disregard for Beaufort on the part of Buckingham, Robinson and Smith. ${ }^{[2]}$

As we shall see, Rey was to devote attention to them, and Deschamps was to publish on several of them. ${ }^{7}$ But, famously, it was Lawrence of Greater Syria (in his earlier configuration) who first wrote about them at length in English, in an undergraduate thesis for his Oxford degree, and visiting many of them on foot, with only a Mauser for company.

By definition, most fortresses were built on prominent hills, and generally on the same site century after century because it offered the best strategic location. Most were built on top of rock outcrops on hills, and cut their blocks from the necessary fosse. This was the case at Kerak, where the fosse provided "a most convenient and inexhaustible quarry, thus doubly increasing the strength of the place."[3] And at Saône (Qalaat Saladin) the northern fosse (which might

12thC. Michaudel 2006: development of Islamic military architecture during the Ayyubid and Mamluk reconquests of Syria.

5 Cobb 2010, 246.

6 Ellenblum 2007, 1-39: National discourse and the study of the Crusades. Quote: 12.

7 Deschamps 1934, 1939\& 1973 . 
have been part-Byzantine, part-Crusader) included a 28 -metre-high needle to support a drawbridge, which was conceivably left by the masons to underline just how much material had been cut away for the building or refurbishment of the fortress. This was a common practice in ancient Rome, to be seen (for example) in the great protruding bosses on parts of the Aurelian Walls, which were decidedly not left there as lifting aids.

Because of the vast scale of any construction, materials for fortresses were necessarily local, but occasionally stone was imported for decorative features; and in 1286 c.72 tons came from Venice to Acre, ${ }^{8}$ conceivably for fortresses, and because such quantities were easier to move by sea than overland (and, in any case, ships needed ballast). In some cases, structures with a different use because fortresses, using the older materials on site. At Bethgibelin, for example (not to be confused with Ibelin), the refectory tables were fashioned from marble column shafts cut lengthways, and set on stone supports with the flat side up. ${ }^{9}$ The whole question of spolia, entitled "Chasteaus abatuz est demi refez," was the subject of a conference in $2008 . .^{10}$

\section{Building and Rebuilding "Crusader" Fortresses}

Prominent Crusader fortresses are Saone, which was a small Byzantine fort in 1119, and had the donjon added in 1132; Margat, largely 12thC and 13thC; Krak des Chevaliers, mostly ${ }_{12} \mathrm{C} \&{ }_{13} \mathrm{C}$, much of it Muslim work from $1271 \mathrm{ff}$ when it fell to Baybars; Athlit, built 1217ff; and Caesarea Maritima, built in the mid13thC. These were built or extended to protect territories they had won, and to assure sea access from the West. ${ }^{11}$ Hence the Crusaders converted several seabord towns for these purposes, ${ }^{12}$ since all their fortresses were on the sea or within easy reach of it, except for Aleppo and Kerak; while Muslim forts built to oppose them were inland from Hama and Homs to Baalbek and Damascus. Saladin's campaigns left only Krak des Chevaliers, Margat, Tortosa, Tripoli and

8 Boas 2010, 36 .

9 Boas 2010, 131.

10 Bernard et al 2008, passim.

11 France 1999, 91: "they reflected the proprietary pattern of the kingdom and the way in which it developed piecemeal, rather than anything else. Some castles were established for strategic reasons."

12 Piana 2008: accounts of the Crusader towns of Acre (242-251), Ascalon (263-273, with column-ties in the towers), Sidon (367-383, with column-ties also in the sea fort), Tiberias (384-395) and Tripoli (422-437). Butzer \& Butzer 2008 for Crusader building techniques from east to west - Palermo, Monreale, Castel del Monte, Cyprus. 
Tyre in Crusader hands, which is why "Crusader" appears in quotes in the subtitle above. The fortresses were strongly built because of developing military technologies, ${ }^{13}$ including the trebuchets which flung large projectiles (often of marble or hard limestone) still to be seen in several of them.

The Crusaders may well have studied Roman fortresses in Syria, and they knew plenty about them from back home. ${ }^{14}$ French scholars such as Rey attempted to classify Crusader fortresses by style and sources. ${ }^{[4]}$ These, whether built by Christians or Muslims, frequently made use of earlier structures on the same site for their materials. This was evidently a well known technique, as we learn from William, Archbishop of Tyre (c.1130-c.119o). He wrote his History of the deeds done beyond the sea, dealing with the Latin Kingdom of Jerusalem from 1127 to 1184 . This detailed and well-rounded book was rapidly translated from Latin into French, and offers much information on topography, archaeology and politics as well as building. To the north of Ascalon, the Crusaders built Ibelin in 1143, using large quantities of blocks found at and near the site from previous constructions, and William comments that "pierres troverent assez en cel leu des forteresses qui jadis i avoient esté; car, si com l'en dist: Chasteaus abatuz est demi refez." ${ }^{[5]}$ Jacques de Vitri, Bishop of Acre from 1217, confirms this with his comment that the stones came from Gath, the Philistine city. ${ }^{[6]}$ Such convenient finds might also have occurred at Montfort, in Western Galilee, which was but a heap of stone when Mariti visited the site in 1791; but there he saw large blocks: "ce qui m'étonna beaucoup, ce fut de voir sur cette montagne des matériaux immenses \& prodigieux, que la route, étroite \& impraticable, n'a pas dû permettre d'y transporter, ou bien il faut que l'outrage des tems l'ait rompue \& détruite., $[7]$

While the Crusaders might have picked up a taste for marble-rich luxury on their way out east (for example at Venice), their eyes were probably opened at Constantinople and Cairo. The same William of Tyre described a palace at Constantinople with a flight of steps "fez mout richement à tables de marbre, et si i a lions et colombes hautes de marbre de maintes coleurs," ${ }^{[8]}$ while in the Cairo citadel "En pluseurs leus de celé cort avoit fontaines qui sordoient par tuiaus d'or et d'argent, et fesoient unes noes en fosses trop beles que l'en leur

\footnotetext{
13 DeVries 2002. DeVries \& Smith 2012 chap. 4 for non-gunpowder artillery; chap. 9 includes Crusader Castles.

14 Kennedy 1994, 11: "The legacy of Roman military architecture in the west was much more obvious to eleventh-century men than it is to us today and they did not have to look to North Africa or the Middle East to see examples of the classical tradition; they only had to look at the walls of Senlis, Le Mans or Pevensey to see high stone walls with projecting towers ranged at intervals along them."
} 
avoit fêtes, et pavées de marbre."[9] The rich marble and porphyry were still attracting visitors' comments there in the 16th century. ${ }^{[10]}$

\section{Saphet}

Saphet (Safad, Safed) near Acre was one Crusader fortress built with walls of very large stone blocks, the only section not brought down by earthquake, ${ }^{[11]}$ and we might wonder whether any of the materials for the superstructure came from nearby Kefr Bir'im where, in 1852, was still visible a large building "with a portico of columns in front, of no Greek order. Behind the columns is a large portal in the middle, with a smaller door on each side." ${ }^{[12]}$ Egmont \& Heyman were told by a local in 1759 that Saphet contained "the ruins of a very stately palace, and many of the stones with which it is built, equal to those we viewed with such astonishment in Balbec castle."[13] The Europeans did not visit the site, and the description suggests either that the locals could not recognise a fortress (which seems unlikely) or, rather, that it was lavishly decorated Ibelin-style, as at Beirut (see below). Dimashqi had certainly visited the site when the castle was in operation, and offered a 390-word description of the machinery for raising water from a cistern; ${ }^{[14]}$ so perhaps this fortress was indeed super-sophisticated.

\section{Shaizar}

Shaizar, north of Hama, guarded an important crossing over the Orontes. It was another fortress built in part with antiquities (of which there are plenty still in evidence), and on the site of an ancient town. Destroyed by an earthquake in 1157, it was rebuilt, and was part of the Muslim defences against the Crusaders. It has recently been intensively studied. ${ }^{15}$ Burckhardt in 1810 identified its date as "of the time of the latter Califes," but also noted that

from the many remains of Grecian architecture found in the castle, that a Greek town formerly stood here. Fragments of columns and elegant Corinthian and Doric capitals lie dispersed about it: amongst them is a coffin of fine marble, nine feet long, but I could find no remains of any ancient building. ${ }^{[15]}$ 
But then he went on the plain to the south and south-west, and found remains "which indicate the site of a town; several fragments of columns, wrought stones, and a great deal of rubbish, are lying about. We dug up an altar."[16] Sachau in 1883 correctly identified this ancient site as Larissa (as had Baedeker in 1876 , mentioning the village outside the walls $\left.{ }^{[17]}\right)$, and noted column fragments and other antiquities at the base of the fortress' hill. ${ }^{[18]}$

\section{Baalbek}

Because of its location close to Beirut, and near to an important road, the fortress most travellers would have known was Baalbek, with Pococke observing correctly in 1745 that some sections seemed designed to resist cannon, ${ }^{, 19]}$ and that the town was fortified with mediaeval walls. ${ }^{[20]}$ In the $13^{\text {th }}$ century Dimashqi noted that Baalbek was indeed a fortress, dating the complex back beyond Abraham, and noting the trilithon as part of the defences. ${ }^{[21]}$ Of Baalbek, Abulfeda [d.1331] reported "une muraille et une forte citadelle de grande dimension.. ${ }^{[22]}$ In 1714 Lucas saw what he called meurtrières in the ramparts, ${ }^{[23]}$ but does not mention soldiers, so the fort was presumably unoccupied, as it was in 1735, when Arvieux says the complex consisted of a round temple and a château, but writes of munitions storage in the past tense. ${ }^{[24]}$ Egmont \& Heyman described in 1759 how the Turks had fitted parts of the complex "to defend themselves against an enemy," but that "at present the Turks make no use of this castle, which is utterly going to ruin."[25] Dimashqi had a good eye for such buildings, writing that Marqab "a été bâtie par Râshid sur d'anciens monuments, puis rebâtie par les chrétiens," and in his day was a Muslim stronghold, ${ }^{[26]}$ judged by Abulfeda that "elle surpasse Palmyre pour la hauteur de ses colonnes et ses grands blocs de pierre."[27] It is impossible today to see what might have happened to the re-used monuments, unless they ended up as the band of white marble in the south tower.

\section{Beirut}

Willibrand of Oldenborg, Canon of Hildesheim, nephew of Willibrand, Count of Harlemunt, and a pilgrim to the Holy Land in 1211, visited the castle of John of Ibelin, the powerful lord of Beirut, and saw in one of its towers "recently built, an apartment had been constructed of such beauty that he deplores his inability to do it justice in description." Originally in Latin, ${ }^{[28]}$ his account told of a marble mosaic floor, marble veneer walls, a zodiac on the ceiling, and a 
fountain feeding a marble cistern in the centre of the room. ${ }^{[29]}$ Since this was "a luxury which the worthy Canon concludes by telling us he went there to indulge in every day he sojourned at Beyrout," we might wonder whether this was some kind of bath-house. This passage was well known, being cited by for example Rey, who first visited Syria in 1857 . He is the author of the 1871 Etudes sur les monuments de l'architecture militaire des Croisés en Syrie et dans l'île de Chypre, who in 1883 speculated about palaces on the Syrian coast:

Ces habitations renfermaient des divans et de vastes salles où l'art syroarabe avait épuisé toutes les richesses de l'ornementation. Les murs en étaient revêtus de placages de marbres, ou décorés de fresques et de mosaïques. ${ }^{[30]}$

William says he got these details from contemporary travel accounts but, disappointingly, does not cite them, although he does refer briefly to his own finds. ${ }^{[31]}$ For Kennedy, "the whole passage gives an idea of the luxury which could be found in some Crusader castles, an aspect of their architecture whose physical traces have almost entirely disappeared."16 There are three possibilities for the source of this room decoration: (1) it is a Romano-Byzantine ensemble taken over in place by the Crusaders, perhaps from the surviving Roman baths at Beirut; (2) it is Romano-Byzantine and assembled by the Crusaders from elements found elsewhere; (3) it is a new creation made from re-cut spolia marble. If it was indeed a bath house, then it could well have been inspired by local hammams, and even put together by local craftsmen.

There is evidence that both Muslims and Christians prized marble and mosaic, the former since at least the refurbishment of the Umayyad Mosque in Damascus, when one account suggests troops were enjoined "enjoined to bring back from the land of Rum a measure of mosaic cubes and a sheet of veined marble."17 The Westerners acquired similar tastes, evidently hoarding such materials at Jerusalem, so that in 1187 when Saladin reconquered the city, "What they could not sell, beds and boxes and casks, the Franks left behind; even superb columns of marble and slabs of marble and mosaics in large quantities." ${ }^{[32]}$ For Saladin's restoration of the al-Aqsa, "marble of an unrivalled quality was brought, and golden tesserae from Constantinople and other necessary materials that had been kept in store for years." ${ }^{[33]}$ And supposedly the Muslims "threw down the marble framework that enclosed the Sepulchre of

16 Kennedy 1994, 120.

17 Greenhalgh 2009, 148-149. 
Our Lord [the Holy Sepulchre] and took the carved columns that stood in front of it and sent them to Muhammad at Mecca as a sign of victory."18

\section{Athlit}

One famous Crusader fortress of which little survives today, but which was much visited by our travellers because it was on the coast, was Athlit (Château Pélerin). ${ }^{19}$ Built in 1218 , this was another fortress that re-used local materials, some perhaps from the fine city which Ritter in 1866 was convinced had once stood here. ${ }^{[34]}$ Just south of Acre (and now opposite Haifa, across the bay), the site once had gardens, but by 1819 these "sont devenus des marais infects et impraticables."[35] Four years later Brocchi was impressed by the fortress' size and its "grandi massi squadrati, assai più voluminosi di quelli di Cesarea."[36] The blocks here evidently impressed the masons rebuilding the fortifications at Acre, for in 1838 (perhaps because of damage caused by the 1837 earthquake) it was part-blown up to provide materials for rebuilding there. Since it was next to the sea, transport was easy by ship. Materials were still going to Acre in 1864, when Guérin fretted that the locals "qui ont élu domicile au milieu de ces magnifiques ruines s'acharnent avec une ardeur déplorable à les détruire de plus en plus, et je n'ai plus retrouvé certains édifices dont j'avais admiré les débris il y une dizaine d'années." ${ }^{\text {[37] }}$ Yet enough was left for Berners travelling in 1875 to aver that "of all the ruins that I saw during my journey through Syria it ranks second only to Baalbec in the grandeur of its masonry, and the extent of ground which it occupies." ${ }^{[38]}$ Indeed, the masonry was very impressive. ${ }^{[39]}$

The site of Athlit was huge, ${ }^{20}$ and by 1873 this "prosperous well-built fortress, situate in a pleasant fertile district" was "disfigured by the mud hovels of the fellahin, built over it like the mud nests of the wall bees over Egyptian temples." ${ }^{\text {[40] }}$ The complex perhaps included a palace, as Mislin suggested in 1876 , for he saw that "des fûts de colonnes en granit gris, des rosaces, des chapiteaux, gisaient çà et là." He also saw under the water that "la mer a englouti ses plus beaux ornements: on les voit au fond des eaux parmi les algues et le sable, ${ }^{,[41]}$ so either the sea level had changed, or what he saw were the spolia accidentally dropped in the ship-loading process. De Hass, a Doctor of Divinity, and misled by reading about biblical times, sees "deep ruts worn by the

\footnotetext{
18 Boas 2001, 108.

19 Kennedy 1994 fig. 16: plan and section.

$20 \quad$ Gates 2011 fig. 11.5 for a plan.
} 
war-chariots" in the road up to the fortress, ${ }^{[42]}$ so that we might wonder both about his knowledge of history, and his study of the physical remains of the past. As coastal population picked up from the 1850 s, Athlit's convenient location right on the sea made it ripe for plundering. The town itself had almost disappeared apart from traces of the walls, and the remaining village was within the fortress:

Malheureusement, les habitants qui ont été domicilé au milieu de ces magnifiques ruines s'acharnent avec une ardeur déplorable à les détruire de plus en plus, et je n'ai plus retrouvé certains édifices dont j'avais admiré les débris il y une dizaine d'années. C'est pour Saint-Jean-d'Acre principalement qu'ils débitent les belles pierres de taille diamantées, arrachées à leurs murs écroulés. ${ }^{[43]}$

Guérin agreed that Acre was the destination, pointing to that town's double walls were "construite avec les débris de ses anciens monuments ou avec les énormes blocs à bossage provenant des ruines d'Athlit, le Castellum Peregrinorum de l'époque des croisades." [44] Indeed, the enormous blocks of Athlit (which most travellers would have passed on their way down the coast) were a useful comparison with other sites, such as Qasr er-Rabad in the Ajlun, $22 \mathrm{~km}$ W of Jerash, which Le Strange admired in 1884:

Its vaults and halls are certainly some of the finest existing in Palestine, the masonry equalling that to be seen at 'Athlit, on the sea-coast above Caesarea, which is always quoted as one of the most remarkable of Crusading ruins. Kusr-er-Rabad amply deserves a more extended examination than any that has as yet been accorded to it. ${ }^{[45]}$

Digging foundations could sometimes be profitable as well as necessary. At Athlit, for example, Jacques de Vitri records the finding of springs as foundations were dug, but also "beaucoup de colonnes et des trésors qui avaient appartenu à des temps tout-à-fait ignorés." God had come to their aid, wrote Godfrey the Monk, for as well as "un grand vase de terre rempli d'une monnaie d'argent inconnue aux modernes... Le Seigneur leur fournit là une grande quantité de pierres et de ciment." ${ }^{[46]}$ As late as the 1830 much survived:

plusieurs tours de plus de cent pieds de hauteur y sont encore debout; les murailles qui subsistent ont en plusieurs endroits plus de douze pieds d'épaisseur. Nous avons distingué parmi les ruines, des colonnes de granit, des fenêtres, des créneaux, des dômes, les restes d'une église et d'un 
palais du grand-maître; une espèce de havre qui s'avance jusque sous les murs, peut recevoir de petits bateaux. ${ }^{[47]}$

This was not to last, for less than two decades later "Le château est détruit, le bourg s'en va pierre à pierre."[48]

\section{Kerak}

Kerak (or Karak, or Crac), now in Jordan, and not to be confused with Krac des Chevaliers, was described in 1873 as "by far the grandest monument of crusading energy now existing."[49] It was built by King Baldwin I of Jerusalem in 1132, and fell to Saladin in 1188, after Jerusalem. Bombarded by Ibrahim Pasha without result in 1840 (he was trying to conquer all of Syria), it is one of the best preserved of fortresses, and was suggested for serious examination in 1882. ${ }^{[50]}$ Burckhardt visited in 1812, but found no antiquities except for a few fragments of granite columns in the town. ${ }^{[51]}$ The chapel walls also had column shafts built into them, presumably against earthquakes. ${ }^{[52]}$ Irby \& Mangles found more in 1818, noting some bas-reliefs and column shafts, but seemed dejected by the experience: "Évidemment, il y aurait à découvrir à Karak beaucoup de restes d'antiquités, appartenant même à l'époque moabitique, mais j'avoue, en toute humilité, que je ne me chargerai pas d'en aller faire la recherche."[53] The Duc de Luynes visited in 1864, and found the plan of fortress and town easily readable, ${ }^{[54]}$ although he reckoned extensive digging was necessary to establish the details of internal buildings. Destruction was already under way: "On remarque encore debout, cependant, l'ancienne chapelle chrétienne, dont les ornements peints qui ont été signalés par quelques voyageurs ont été détruits par ordre du scheikh Midjaly."[55] In the town, he was shown one bath, and then a room with a mosaic floor and columns which he was told was also a bath. ${ }^{[56]}$ In the previous year Tristram probably visited the same room, and was then given

other proofs of Roman occupation... several imperial coins of gold and silver, besides a gold medal of Helena. The gold coins were all sold to me for rather less than their value as old gold... We also obtained a few cameos, to which the finders did not attach much value, and which were all chipped. ${ }^{[57]}$

However, here the locals were surly, demanding payment for entering the fortress, ${ }^{[58]}$ and living conditions were restrained: "A Kerak house is entered by 
a low door-way four feet high, generally arched, of dry stones, but often with a massive lintel, taken from some more ancient building." [59] Their surliness could have been fear, since in 1816 it was reported that they even threshed their crops in the safety of the fortress, for "the inhabitants dare not perform this process in the fields, lest they should be attacked by some of the wandering hordes." [60]

\section{Krak des Chevaliers}

Krak, today Qalaat al-Husn, was first fortified by the Kurds in 1030, and destroyed by earthquake in 1170, eventually to fall to the Muslims after the siege of 1271 . Burckhardt could identify it in 1810 (when there were a few defenders) as "one of the finest buildings of the middle age I ever saw. It is evidently of European construction... commands the communication from the eastern plains to the sea shore"[61] Its "Europeanness" helped its popularity and, with their conviction that to French Crusaders went the glories of fortress architecture in Syria, the French took it to their bosom as their own. ${ }^{21}$ Since it escaped both tourists and archaeologists in the 19th century, ${ }^{[62]}$ several of whom passed by but did not visit ${ }^{[63]}$ was it perhaps then off-limits as a military installation? The French under the mandate cleared out the village inside it in 1927, and restored it. As Burns notes, "the castle was ceded to Syria in compensation for the damage inflicted by the French bombardment of Damascus in 1945."22

\section{Desert Castles}

If the collectively named Desert Castles were once in perhaps strenuously cultivated areas, a glance at the map will show that now, centuries after their abandonment, they are firmly in the desert. Some were evidently located in frontier regions probably dangerous since at least Roman times, so it is no surprise that they were to be late discoveries by travellers. If fortresses further north towered over highways and passes (see and be seen), the desert castles were usually on flat land in areas without highways.

21 Biller 2006, 31-40, Krak: Die Forschungsstand und das Werk von Deschamps/Anus.

22 Burns 2009, 184. 
Since debate is ongoing about just what these structures served, not to mention their origins, ${ }^{23}$ as is research about their layout and dependencies, ${ }^{24}$ it is sensible to retain their traditional appelation to underline this fact. There are various suggestions for the purpose of these castles. Regularly spaced, these are in "temporary use as resting places and not for permanent habitation;" they were part of grand estates, broken by the 747 earthquakes and the fall of the Umayyads in $75^{\circ}$ so that in the 9 thC the balance shifts again in favour of pastoralism; ${ }^{26}$ on the margin of the cultivated land (not in the desert), some were to watch over nomads, but most were large agricultural latifundia. ${ }^{27} \mathrm{Cobb}$ suggested a range of possibilities, including "hunting lodges, defensive strongholds, urban cores, spas, palaces and ... country estates: these are sites of the farmer's life as much as they are of la dolce vita," ${ }^{28}$ the last epithet being a reference to Hillenbrand's 1982 paper, which calls them palaces.

The French term "château" is suitable here, since in that language such a structure can be a fortress, or a pretend-fortress such as any of the Châteaux de la Loire, often with splendid gardens, which some of the Syrian châteaux certainly had. For Oppenheim, although he does not provide any extensive evidence, so intense was some of the occupation on Jebel Druze that he called the settlements around such castles "Desert Cities." [64] Everyone was clear that Syria had no fixed boundaries and, indeed, that any frontier shifted with the movements of tribes. ${ }^{[65]}$ Such estates went hand-in-hand with the development of irrigated agriculture ${ }^{29}$ and, although there were some small structures, "others were clearly sites dedicated to elite distraction and self representation." ${ }^{30}$ Thus a variety of uses is suggested by their very location. As well as survivals in

23 Fowden 2004, 315-316, footnote: "A major question that awaits an answer is the extent to which the Umayyads were inspired by the residences of the late Roman military elite in Syria." Milwright 2010, 38: "there can be little doubt that the landscape of early Islamic Greater Syria was populated by many standing Roman fortresses and legionary camps." Genequant 2012: Deals with composition of sites (chap. 10), their economics (chap. 11, including aqueducts, reservoirs, agriculture) and their function (chap. 12). Excellent survey, well illustrated, wide ranging, and well referenced.

25 Bisheh 1992, 41.

26 Kennedy 1992.

27 Piccirillo 2002; Villeneuve 2001 for Diyatheh: The easternmost ruins of importance in S. Syria, with c.10o ancient houses, a Roman fort, cemetery, water-mills, disused irrigation system. Author suggests village was attempt to extend the settled population of the Hauran toward the steppe, in 2 ndC and $3 \mathrm{rdC}$, but stagnation from 4 thC.

28 Cobb 2010, 245-246. See note 40 for the literature.

29 Geyer 2006: irrigation and qanats in the arid margins.

30 Cobb 2010, 245-246, 250. 
present-day Syria, there are ten Desert Castles within boundary of present-day Jordan, and eight more which were once a castle or Umayyad occupation of a Roman fort. ${ }^{31}$

\section{Qasr El-Hallabat}

In the case of Qasr (or Khan) El-Hallabat there was no single use. This was originally an early 3rdC Roman fort (and, like Umm al-Jimal, on the Via Nova Traiana), then a monastery, and finally a desert castle. Situated $31 \mathrm{~km}$ SE of Palmyra, the site is off the road due west, in the desert.

Butler visited the site in the early 2oth century, and to the south "could be made out the low walls which marked out the fields, cultivated when this was a Roman stronghold." [66] The area is still farmed today, and "despite looting of stone in modern times, the surviving fort remains impressive and excavation and clearance of mounds of collapsed masonry has brought it into sharper focus." ${ }^{32}$ The same was the case with Qasr al-Heir West, a monastery (originally a fort?) before it became a "hunting lodge." When Baedeker directed his readers there in 1876, "maltese crosses are said to have been detected on the walls. In the vicinity lie many hewn stones, some of them of marble."[67] East of Amman Qasr el-Ezraq/Azraq, to be used as a meeting point and refuge by Lawrence of Arabia, was once a Roman fort, with a surviving dedicatory inscription, a basalt door which still works, and a Roman road nearby. ${ }^{[68]}$

\section{Mschatta $^{[69]}$ and Nearby Antiquities}

Situated on the open plain, with higher ground about it, surrounded by a flat, arid desert, entirely destitute of water, with no human habitation in sight for many a weary mile, far from any highway; what could have been the motive that led to its construction? and from whence came the building material? ${ }^{[70]}[1886]$

In the above quote Thomson expresses his astonishment at finding such a structure out in the desert: a mighty enterprise, with limestone, bricks and

\footnotetext{
31 Northedge 1992, 50. Hamarneth 2003, 45-94: I villaggi [in Jordan] sorti presso i castra romani.

$32 \quad$ Kennedy 2004, 96.
} 
workmen all imported from a great distance. How could anyone start such a structure, and then abandon it? For "it is very evident that the façade, and indeed the entire structure, at Mushatta was not only never finished, but it

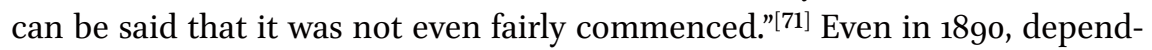
ing on the season of the year, travellers to this site needed to take care: "It is situated in the country of the Beni Sokr, and to be quite safe one should take an escort of that tribe from Madeba." The escorts limited the time at the site, and few Westerners had in fact made the journey: "The Adwan Sheikh told us that, except an American gentleman whom they conducted at the time of the American exploration of the Dead Sea, we were the only people whom his tribe had escorted to the place."[72]

However, Thomson should have paid more attention to the surrounding area: there is surely no mystery about materials or workmen, since the site is only about ten kilometres from Ziza, and under thirty from both Madaba and Amman. Near Ziza is Al-Qastal, another desert castle, and both these are very near the railway, the successor to an English project. In 1905 GoodrichFreer camped within the walls of Mschatta, "where, amid kind and hospitable friends, and in comfortable tents, bearing the familiar initials T.I.W. (Thames Iron Works), relics of the abandoned English railway, we found leisure to rest and to dream. ${ }^{[73]}$ Ziza was a Roman town which could have supplied materials to Mschatta: Tristram saw there re-used materials from Byzantine churches and, before the destruction wreaked by Ibrahim Pasha in his struggle to secure the area, "the large buildings inside the town had their roofs entire, and were often used as places of shelter. The other castle, to the east of this, is apparently of the Roman age."[74]

At Al-Qastal (El-Kastal), very near Ziza and not far from Mschatta, Tristram thought the site showed earlier constructions:

two capitals of pure white marble... the many fragments of fine white marble, certainly not indigenous, and which must have been brought, at great cost, from beyond sea, belonged to these earlier Castles, which are probably either Herodian, or the work of some of the Syrian successors of Alexander. ${ }^{[75]}$

But it is more likely that the materials came directly from Ziza or Madaba. Indeed, Ziza was garrisoned by Ibrahim Pasha's Egyptian troops, "who did much damage to the ruins of Ziza, and wantonly destroyed a very perfect building in the town, and several perfect Christian churches. Zadam assured us that, before the Egyptian invasion, the large buildings inside the town had their roofs entire, and were often used as places of shelter."[76] 
Mschatta is an example of a large château, unexcavated, the façade of which was gifted to Berlin because of the intervention of the Kaiser, who sent the Sultan in return a team of thoroughbred horses. As Goode writes, "Although the sultan thought he had gotten the better of the exchange, Ottoman officials were furious, none more than Hamdi Bey. He began tightening restrictions on the Germans, denying them new excavation permits, sometimes refusing to allow them a share of antiquities from some of their sites in Iraq." As Goode commented, "These worsening relations emphasized the danger of trying to outmaneuver officials, who could frustrate foreign archaeologists in spite of apparent agreement at the top." ${ }^{33}$ The lack of thorough excavation here is a pity, for Chauvet \& Isambert indicated interesting clues in what they call the palace proper: "trois arcades semi-circulaires, reposant sur des pillars surmontes de chapiteaux corinthiens. Les assises inférieures construites en marbre blanc, sont couvertes d'inscriptions." ${ }^{[77]}$ Even today, and more urgently because so many structures have been destroyed, we need to know much more about Islamic structures; whereas any scholar could navigate most Roman forts blindfold just as easily as any chain-hotel bedroom.

\section{Qasr al-Heir West}

West of Khan al-Hallabat, and 8okm sw of Palmyra near the modern Damascus road, is Qasr al-Heir-West (al Gharbi), in what Burns describes as a "bleak spot." The eastern fortress, Qasr al-Heir-East (al Sharqi) is NE of Palmyra, and near the road from Palmyra to Deir al Zor, and 10okm from Resafa. Established on the site of a monastery, Qasr al-Heir West was built by Hisham in 727, as we learn from the inscription over the entrance, not carved into the (reused) marble lintel, but cast in bronze and attached to the stone with pegs, a device "unique in early Islam ... extremely elegant piece of work." ${ }^{34}$ Naturally, the bronze has been robbed out. The whole gateway with its stucco decoration has been translated to Damascus and is preserved as the entrance to the National Museum. The structure (including a bath) and its gardens were fed by the Harbaka Dam, $17 \mathrm{~km}$ distant. The site was abandoned following the 14th-century Mongol invasions. Such structures could not have been viable

33 Goode 2007, 28; Shaw 2003, 121-122 for a blow-by-blow account of what happened.

34 Fowden 2004, 165. Ebla to Damascus 1985: summaries of both sites; 484-7 for Qasr Al-Heir East; 488-493 for Qasr Al-Heir West. 
without the dams routed along the Roman Strata Diocletiana, ${ }^{35}$ which was an important and long-standing artery. Qasr al-Heir East, with immense gardens, was also built by Hisham, and was fed by a $5.7 \mathrm{~km}$ canal. Its entrance gate is now in Deir al-Zor Museum. As with other sites, access to water was the key. The dearth of wells was sometimes pressing even for travellers from Aleppo to Damascus, ${ }^{[78]}$ and the promotion of agriculture perhaps the aim of the whole enterprise. ${ }^{36}$ For Schlumberger, the fall of the Omayyads in 750 led to abandonment, and then to occupation by fellahs. ${ }^{37}$

\section{Qasr al-Heir East ${ }^{38}$}

This site consists of two enclosures, perhaps a palace and a khan, on a standard caravan route from Aleppo to Basra in present-day Iraq. ${ }^{[79]}$ Englishmen passed by but did not stay long. In 1745 Beawes gave a one-sentence description, "but within there appears no remains." ${ }^{[80]}$ Carmichael in $175^{1}$ was more interested in the aqueduct, and does not say he visited the site. ${ }^{[81]}$ James Capper visited here in 1778 , calling it Gussur-Ul-Bain, or the walled castle with aqueduct, and the columns he mentions were probably part of the mosque, now restored:

L'enceinte, divisée en deux quarrés, est coupée par un passage d'environ cinquante pas de large. La façade de l'un des quarrés est de près de deux cent cinquante pieds de long et de trente de hauteur. De quarante pieds en quarante pieds sélèvent des tours, dont les deux plus petites accompagnent la porte qu'on remarque au centre de la partie occidentale. Dans l'intérieur on découvre les ruines d'un bâtiment, et tout auprès un passage sous terre, qui conduit à une espèce de cave ou de cellier. A l'angle sud-est de la place existait un portique d'ordre corinthien; les fûts des colonnes sont encore épars sur la terre, mais nous ne pûmes en trouver ni les bases, ni les chapiteaux. ${ }^{[82]}$

35 Calvet 1992, 79-92 for the structures; ibid., 93-105 Les barrages des forts de la Strata Diocletiana, with photos, and a reconstruction (fig. 55) of Khan Al-Manqoura, with barrage and vegetable gardens.

36 Milwright 2010, 37: "the distribution of the qusur in Jordan and eastern Syria suggests an attempt to create an infrastructure to support the key routes running north from the Hijaz." Ibid. 38: "it is becoming increasingly clear that the hydraulic projects associated with some of the Umayyad qusur of Jordan and Syria were designed with the ambitious goal of promoting agriculture in otherwise marginal lands."

37 Schlumberger 1986, 26; Schlumberger 2010, 23-76.

38 Grabar 1978; Genequant 2012, 95-159: Qasr al-Hayr al-Sharqi: une ville neuve. 
Coote visited the site in 1780 , counted the towers of both structures (the larger has 28 towers, not 24), and described the larger building's interior with "a number of arches supported by pillars of white marble finely polished." These were evidently disappearing in his day:

several broken pillars of marble were scattered about the area, in one part of which, where the Arabs appeared to have been digging, we found large vaults double arched, and it is probable the whole of the area was vaulted in the same manner. ${ }^{[83]}$

He had no time to make a plan, but noted "the ruin of an aqueduct that came from the mountains on the right to this palace, and from thence across the plain into the other building." [84]

The nearest town was Taiba / al-Taybe, in ruins when Capper (in fear of Bedouin) camped nearby, ${ }^{[85]}$ but perhaps inhabited earlier in the century. And it was "a place of refreshment for the caravans; the grounds around still exhibited the signs of cultivation, for they were ditched and crossed in many parts by small aqueducts that conveyed water from the fountains." ${ }^{[86]}$ When the site was dug in 1964-72, fourteen columns were found, most of limestone, some of marble or granite: "all of them must have been imported from some other building."39 Conceivably, some of the spolia in Qasr al-Heir East (such as the granite columns and Corinthian capitals) could have come from here, described as follows by two East India Company captains in 1750:

Il y a vu des chapiteaux de l'ordre corinthien admirablement exécutés, mais sans désigner la place où il les a vus; je ne pus jamais les retrouver... on n'y voit plus que les vestiges d'une place forte, et qui pouvait être autrefois fort peuplée et très-florissante; mais aujourd'hui elle est ruinée ... La porte d'entrée, faite en arc, conserve encore quelques restes d'une ancienne beauté; il y a dessus quelques inscriptions en caractères palmyriens, qui annoncent qu'elle fut autrefois la splendeur de cette ville. ${ }^{[87]}$

Why was this site, evidently once rich in antiquities, not better known to travellers heading for Palmyra? The answer might come from Chauvet \& Isambert's 1882 guidebook, when their only two sentences on the site are that "On rencontre $(8 \mathrm{~h}$.) une tour en ruines, Qasr el-Haïr, avec une porte sculptée. Tout auprès se trouvent les débris d'un aqueduc et un réservoir."[88] This remarkable site was not even accorded a description, but perhaps the difficulty revolved 
around access to water. They had travelled eight hours from their start that day, at Al-Qaryatein, and they camped by water at two hours distance from the château; but they were still five hours away from Palmyra, with no springs intervening. In 1907 Cook's guidebook has travellers camp at Qasr al-Heir East, but "As Kasr el Herr is unprovided with springs we must the next day traverse for five hours a waterless region to reach the spring Ail el-Beida, where we spend our last night en route."[89] Butler during his 1909 expedition encountered the same problem when he wished to examine in detail Qasr al-Hallabat: "the camp could not be moved to that place because it had no water."[90]

We might add the local fauna, which kept nervous travellers away from some monuments, to the list of problems: Carmichael avoided the ruins at Hiqla, near Aleppo, because "the Arabs report that there are many black scorpions among these ruins; for which reason we encamped at a distance." ${ }^{[91]}$ That same Arab was nervous at Ukhaidir, refusing to enter; so Carmichael entered alone, a pistol in each hand, "creeping thro' a hole in the gate-way, which was nearly filled up with rubbish." ${ }^{\text {[92] }}$ The previous year Plaisted had camped near Ukhaidir, but apparently did not visit the site. ${ }^{[93]}$

\section{Roman Fortresses}

Roman fortresses are to be distinguished from the Desert Castles discussed above, and appear last in the chapter because they were the last to be visited and described by travellers. What is more, they either flanked or were well inside sometimes-dangerous deserts. They marked the fortified limit (the limes) or boundary of the Roman Empire, but even this changed as conquest and withdrawal led to several lines of forts. Given the monastic taste for desert living of many early Christians, their desert (and deserted) sites were popular for conversion into monasteries. ${ }^{[94]}$ No visibly Roman fortresses were identified anywhere near the Crusader forts Muslim and Christian placed at the start of this chapter, because only forts in desert areas which were later abandoned could survive intact. However, it is certain that several in crusading areas further north were buried in such foundations, because siting a fortress is not rocket science, and the requirements (height, view, quarry, access to water) never changed. Nor did parts did the limes change radically, and there are instances of Muslim forts built directly on top of Roman ones. ${ }^{[95]}$ Crusader fortresses such as Shobak (now in Jordan) were also close to a Roman network: "passing by two volcanic craters on our left, and one on our right, observed a Roman road formed of lava, upon which we continued for some distance, when we lost sight of it, and arrived at Shubac at six o'clock in the evening."[96] 
Père Poidebard's magnificent La trace de Rome dans le désert de Syrie: le limes de Trajan à la conquête Arabe, Recherches aériennes (1925-1932), Paris 1934, was one product of the French Mandate for Syria, to be discussed in Chapter Eleven. He solved the perennial travel and sight-line problem by flying, and the necessary documentation by photography to augment or even replace his sketches. ${ }^{40}$ It was the French Mandate which facilitated Poidebard's work over Syria. Similarly, the British Mandate ensured that "in 1939 his imitator, the Hungarian-British orientalist, Sir Aurel Stein, spent several weeks being flown over Transjordan by the RAF explicitly to record the extension from Syria of the Roman Limes." ${ }^{41}$ There were also strictly military aerial reconnaissances as well, such as over the Euphrates in $1922 .{ }^{42}$

Poidebard landed when he saw something interesting, and if his explanations for the purpose of the forts complex are not wholly accepted today, ${ }^{43}$ his and Stein's surveys remain, for archaeology, the most substantial and farreaching results of the two Mandates, just as the aerial photos taken by Western airforces in the region were invaluable until satellites came along. He thought the limes was not in fact a limit to Roman rule, but rather

un ensemble de routes fortifiées formant une zone défendue, en lisière du territoire d'empire: routes parallèles à la limite du territoire, souvent même un peu en retrait, puis routes s'enfonçant perpendiculairement aux précédentes dans le territoire barbare, allié ou soumis, qui formait un glacis avancé. ${ }^{44}$

The limes was however an important line of defence, carefully designed, ${ }^{[97]}$ as well as a customs zone, and provided with roads, water, pasturage and agriculture, and Poidebard believed the stone bergeries he found were of nomad origin, and built for defence, because the nomads participated in that defence. ${ }^{45}$

40 MacAdam 1986, 231-369: catalogues of photo collections of Archaeological Expeditions to the Near East on file at Princeton. 233: accidental discovery of 28,00o prints in the attic of the Harvard Semitic Museum in 1970.

41 Kennedy 2004, 21-22.

42 Institut français de Damas 1995.

43 Bauzou 2004: critique of some of Poidebard's interpretations.

44 Poidebard 1937, 8.

45 Poidebard 1934, 191-196, 199. Cf. Cumont's Preface for explanation of the setup, with forts and water provided at camel-caravan halts. These Poidebard followed and photographed from his plane. He then landed and measured them. There were plenty of milestones on the road network, often grouped (49) in three or four at each mile. 


\section{Qasr el-Abyad}

One example of a (late?) Roman fort with intriguing links for desert castles ${ }^{46}$ was the Qasr el-Abyad, south east of Damascus, in the Safa. ${ }^{[98]}$ This was no less than 6om square, and included a lot of spolia:

A large building of white stone. This building, whatever it may have been intended for, was unfinished; but so fresh did it appear, that the workmen might have left it yesterday. That it was more modern than the rest of the town, not only does its architecture testify, but in the tower I saw many stones which had evidently been employed in some former building: amongst others some curious ornamental carvings. ${ }^{[99]}$

Graham refers here to some of the wall decorations, including a profuse collection of animals and birds. He asked the locals

if they had any traditions about when and by whom this place had been inhabited. All they could tell me was that it had been inhabited up to the time of Tamerlenk, but that this warrior had driven all the inhabitants away and destroyed their city. ${ }^{[100]}$

De Vogüé had underlined the exotic nature of such decorations in 1865, noted their connection with Byzantine styles, and suggested that

Rien n'est plus naturel que d'attribuer la construction de ce château à l'une des familles venues de l'Arabie méridionale, peut-être à l'un des rois Ghassanides qui regnèrent dans ces régions entre le cinquième et le septième siècles, et qui laissèrent dans le Haouran des traces écrites de leur passage. ${ }^{[101]}$

Dussaud \& Macler in 1901 believed that this or a similar structure could be inspiration for Mschatta, further to the south: "L'artiste orne une pierre, un linteau par exemple, en couvrant toute sa surface de dessins très géométriques dans leur apparente complication et, bien qu'il s'y mêle quelques emprunts

46 Gaube 1974, 137: this highly decorated monument has a "plan which makes the monument an important link between Roman-Byzantine limes castles and Umayyad desert palaces." 138: "some kind of country residence used only for a few months in the year. Climatic and hydrological conditions make it impossible to live in the area except from March to May." 
gréco-romains, la technique est purement orientale. Certain linteau avec sa décoration en rosaces entourées d'entrelacs rappelle telle dalle assyrienne."[102]

\section{Qasr el-Bai'j}

On his 1904-5 Princeton Expedition, Butler visited another "large and interesting” Roman fortress, called Qasr el-Bai'j. From this site were visible both Umm al-Jimal (wherein there were "about twenty tents in the ruins; for Bedawin were tending the Druse flocks") and, to the west, the railway. ${ }^{[103]}$ This was to change, for by the late 2oth century "Although the aerial view reveals the core of the site quite clearly, the modern village has destroyed much of what was standing when the Princeton Expedition recorded the site in 1904 and obscured much of what survives." 47

\section{Masada and Its Siege Camps}

Masada, 97m above the desert floor, was a palace built by Herod the Great and, because of its location, a fortress, the story of its capture by the Romans in 70AD told by Josephus in his Jewish Wars. Masada is therefore not a Roman fortress, but the siege works and massive ramp put in place by the legate Flavius Silva are extensive, ${ }^{[104]}$ their only competitor for extent and survivability being Alesia in Gaul. Because of its important place in history, the site had been visited since 1842 (Wolcott was the first ${ }^{[105]}$ ), and Lynch saw in what he believed was "perhaps the court-yard or quadrangle of the castle, now filled with rubbish, fragments of marble, mosaic and pottery." ${ }^{\text {[106] }}$ In 1865 Tristram viewed the siege works from the summit:

In the plain to the east beneath us, and on the opposite slopes to the west, were the Roman camps, with their outlines and walls as distinct as on the day when they were left, one large and two smaller square camps on the plain eastwards, and a long series of encampments on the slopes facing us westward. Apparently not a stone had been removed. Built without mortar, they had fallen from walls to sharp ridges, but all in gentle, though desolate decay. ${ }^{[107]}$

$47 \quad$ Kennedy 2004, 91. 
He is one of few visitors to describe the siege camps, and he illustrates one of them. On the summit itself, there was little left to admire, especially after De Saulcy visited in 1854, and concentrated on what his Bedouins said was the palace - namely Herod's northern ship-prow-like palace, not the rectangular western palace. Here he found some cubes of red, white and black stone:

I therefore tempt my Bedouins with the promise of a bakhshish, and whilst I am drawing the plans of the different apartments, and Belly is engaged in taking a sketch of this extraordinary ruin, the rubbish is cleared from the floor, and a handsome mosaic pavement, disposed in circular knots, is brought once more to light. Unfortunately all is broken in pieces; I feel, therefore, no scruple in carrying away some specimens. We also take designs of several fragments of moulding in white marble, and pick up samples of the pieces of red pottery and glass with which the ground is covered. ${ }^{[108]}$
[1] Beaujour_1829_375
[2] Newbold_1850_356
[20] Pococke_II.1_1745_ 106-107
[3] Tristram_1873_89
[21] Dimashki_1874_268
[4] Rey_1867_356
[5] Guillaume_de_ Tyr_1880_83
[6] Vitri_1896_XLI
[7] Mariti_1791_II_148
[8] Guillaume_de_Tyr_ II_1880_346
[9] Guillaume_de_ Tyr_1880_277
[10] Affagart_1902_175
[11] Darboy_1852_371
[12] Robinson_1852_5
[22] Aboulfeda_II_1848_32
[23] Lucas_I_1714_177
[24] Arvieux_II_1735_436- 442
[25] Egmont_\&_ Heyman_1759_II_272
[26] Dimashki_1874_284
[27] Michaud_1829_550
[28] Laurent_1873_166-167
[29] Lindsay_II_1838_372- 373
[13] Egmont_\&_Heyman_ 1759_II_292
[14] Le_Strange_189o_ 524-525
[15] Burckhardt_1822_ 22021810
[16] Burckhardt_1822_ 22021810B
[17] Baedeker_1876_559-56o
[18] Sachau_1883_69
[19] Pococke_II.1_1745_11
[30] Rey_1883_7
[31] Rey_1883_8
[32] Gabrieli_2010_87
[33] Gabrieli_2010_86-87
[34] Ritter_1866_285
[35] Forbin_1819_76-77
[36] Brocchi_1842_45
[37] Guérin_1864_414-415
[38] Berners_1876_64-65
[39] PEFQS_1873_102-103
[40] PEFQS_1873_102
[41] Mislin_1876_II_86
[42] De_Hass_1887_234
[43] AMS_I_1864_414-415
[44] AMS_VII_1872_418
[45] Le_Strange_1889_287
[46] Michaud_1829_III_21-22
[47] Michaud_\&_Poujoulat_ IV_1834_149-150
[48] Yanoski_\&_ David_1848_37
[49] Tristram_1873_92
[50] PEFQS_1881_73-74
[51] Burckhardt_1822_ 15071812
[52] Tristram_1873_91
[53] Saulcy_1853_I_55
[54] Luynes_1874_II_108
[55] Luynes_1874_II_109
[56] Luynes_1874_II_110
[57] Tristram_1873_97
[58] Tristram_1873_95
[59] Tristram_1873_96
[60] MacMichael_1819_236
[61] Burckhardt_1822_ 01031810
[62] Van_Berchem_1895_ 13-14 

[63] Robinson_1856_565
[64] Oppenheim_1899_91
[65] Dussaud_1902_76-77
[66] Butler_1930_37
[67] Baedeker 1876 521
[68] Dussaud_1902_31
[69] Goodrich-
Freer_1905_79-88
[70] Thomson_1886_633-634
[71] Thomson_1886_632
[72] PEFQS_1890_174
[73] Goodrich-Freer_1905_88
[74] Tristram_1873_202-203
[75] Brünnow_\&_
Domaszewski
II_1905_100-102
[76] Tristram_1873_188
[77] Chauvet_\&
Isambert_1882_506-507

[78] Lithgow_1632_204

[79] Carmichael_1929_ 143-144

[80] Beawes_1929_15

[81] Carmichael_1929_140

[82] Capper_1796_273

[83] Coote_1780_207

[84] Coote_1780_207B

[85] Capper_1796_271

[86] Coote_1780_208

[87] Capper_1796_353

[88] Chauvet_\& Isambert_1882_650

[89] Cook_1907_356

[90] Butler_1930_36

[91] Carmichael_1929_136

[92] Carmichael_1929_161

[93] Plaisted_1929_77

[94] Dussaud_1902_77
[95] Dussaud_1902_438-439

[96] MacMichael_1819_216

[97] Bouchier_1916_48

[98] Brünnow_\&_

Domaszewski

II_1905_263-266

[99] Graham_1858_238

[100] Graham_1858_237

[101] Vogüé_1865-1877_70

[102] Dussaud_\&_

Macler_1901_43-44

[103] Butler_1930_34B

[104] Brünnow_\&

Domaszewski

III_1909_221-244

[105] Rey_1861_288-300

[106] Lynch_1849_332

[107] Tristram_1865_313-314

[108] Saulcy_1854_I_221 


\title{
Mayhem: Archaeology, Museums and Mandates
}

\author{
Les Anglais, les Français, les Allemands, se donnent réciproquement et à \\ bon droit les noms de vandales et de dévastateurs; hélas! la question n'est \\ plus aujourd'hui que de savoir si les débris des plus beaux monuments de \\ l'Orient font meilleure figure dans les musées de Berlin que dans ceux de \\ Londres ou de Paris. ${ }^{[1]}[1876]$
}

A concatenation of circumstances already described in earlier chapters spelled grave consequences for the antiquities of Syria, and much the same thing happened all over the Eastern Mediterranean and North Africa. That is, creeping modernisation and westernisation countered the free-for-all experienced by early private collectors (conspicuously Lord Elgin), eventually replacing it with a régime of strict permits which allowed only the favoured (such as the Kaiser) to export antiquities. Mislin in the quote above laments the squabbles between the European nations, condemning their extraction of antiquities from the region as vandals who devastated the land for the profit of their museums back home. Unfortunately, modernisation also occasioned a vigorous repopulation of areas erstwhile fallow but rich in archaeological remains. These new settlers proceeded to recycle in vast quantities, obliterating many sites. As awareness of antiquities grew, and travel to see them increased, so their quantity and integrity inexorably declined, perhaps leading us to question whether Elgin, the Kaiser and their ilk were not saviours rather than vandals?

Thus it is the very acme of irony that, as knowledgeable perception of areas worthy of archaeological investigation went up, so their number was whittled away. On the same see-saw, those tourists who contributed to the growing prosperity of Syria (and perhaps contributed to exploration societies, and encouraged museums to collect) necessarily encountered fewer antiquities than did previous generations. Because in earlier decades the country was traditional rather than modern - supposedly the biblical landscape that so enchanted those modern pilgrims ignorant of the intervening centuries of history and monuments. And there is a further irony: if we can congratulate the Ottoman Government on trying to quell the rapacity of foreign diggers and their museums back home, the population policies they promoted in their efforts to modernise the Empire (as hinted above) served to destroy some of the very sites that their later antiquities legislation was designed to protect. Under their mandate, the French tried to save objects and cluster them into 
local museums, as at Suweida. Captain Carbillet arrived as Governor of this djebel in 1923, and founded the museum in 1924, because on his tours "il fut frappé de l'abondance des documents anciens qui gisaient un peu partout et de l'état lamentable d'un bon nombre de monuments."

In spite of the frequent attachment on the part of our travellers to the lands they visited and described, the enduring result of European engagement with outposts of the Ottoman Empire was far from beneficial. Indeed, it was deadly a foul brew of scholarly, political and military mayhem, laced with lies all round and the betrayal of several promises to aid local independence. The first involved archaeologists in unseemly and often duplicitous attempts to populate the museums back home before local regulations and silly locals could prevent such exports (some of them simple smuggling) by cutting off supplies. The second occupied European governments from at least the mid-19th century in planning what they might gain by the break-up of that Empire which was already feeble, antiquated and fragmenting, and judged in dire need of continuing European expertise, meaning a takeover.

The trigger for the actual breakup of the Ottoman Empire was indeed military mayhem, resulting from Western machinations during and then following the First World War, helped along by Kemal Ataturk and the Young Turks. The new country of Turkey was formed, centred on Anatolia, but the outposts were dealt with by France and Britain, which at San Remo, following the division of the spoils at the Paris Peace Conference, accepted mandates covering Syria (1922-45) and Palestine (1920-48) respectively. As we admire trophies from the Middle East in our museums, and puzzle over the foolhardiness and huggermugger secrecy of the artificial maps drawn by the victorious powers, it is far from hysterical to view current developments in Syria and the whole region as distasteful results part-fathered by crude European interference and imperialism, and possibly aided by pre-war spying by archaeologists such as Wooley, Bell and Lawrence, plus an equivalent cast of Germans. ${ }^{2}$ Later Western interference in the region has been no less disastrous.

\section{Archaeology}

As we have frequently seen in previous chapters, many travellers thought Syria in need of all kinds of development, and especially education, the alibi

1 Dunand 1934, 1.

2 Satia 2008; Sconzo 2008: development of Syrian archaeology. 
for appropriating antiquities (and trying to avoid local regulations) ${ }^{3}$ being the perception that the locals were unable to take care of them, and the undeniable proof being that monuments were fast disappearing. Conversely, it was an object of faith that museums, an European invention, could give objects context, constructing "a coherent historical network made up of works culled from diverse ancient sites and repositioned into a three-dimensional compendium located at home." ${ }^{4}$ Nor were exploration and digging confined to Syria. ${ }^{5}$ Yet just how removing objects from their original context could help coherence and understanding was surely puzzling: the task would presumably be left to the labelling.

All the developments described in detail in previous chapters (trade, tourism, steamships, pilgrimage, desertification, Bedouin, marauding sheikhs) had important knock-on effects on archaeology. Without local knowledge about routes, sites, assistance, translators, possible firmans and protection provided by traders and their supporting consuls, no expedition of any size could proceed. Modern ships hauled baggage for archaeologists as well as tourists whose enthusiasm for the area helped generate financing from back home, and eventually encouraged the founding of various exploration societies, conspicuously the Palestine Exploration Fund (London 1865), the Palestine Exploration Society (New York 1870), and in Berlin the Deutsche Orient-Gesellschaft and then the Deutsche Institut für ägyptische Altertumskunde (1896 and 1897). ${ }^{[2]}$ Interest in Greater Syria was provoked by travellers' accounts, and also by discoveries of sites and antiquities, for example:

3 Díaz-Andreu 2007, 159: antiquities laws of 1874 \& 1884: "From then on, being under Ottoman rule, legislation led to the most valuable pieces being sent to the museum in Constantinople instead of to the European and the new American powers." Chevalier 2002, 13-112: L'archéologie française dans l'Empire Ottoman. 29-46 Ottoman regulations and French reactions. Ibid. 283ff: L’archéologie française en Syrie et au Liban. Vernoit 1997, 3-4: the Deutsche Orient-Gesellschaft, and the spinoff excavations in Palestine and Mesopotamia, including Babylon and Ashur. Brion 1937 for an overview of recent discoveries entitled "La resurrection des villes mortes" I 119-152 for Syria; I 153-182 for Palestine. The book emphasises French archaeology, and newly discovered sites such as Ras Shamra and Mari.

4 Shaw 2003, 37-38: details the European extraction and export of antiquities from Ottoman territory.

5 Chevalier 2009 for the French at Susa; 29-51: Trente années de la vie quotidienne d'une mission au Perse (1884-1914) - Marcel \& Jane Dieulafoy, Jacques de Morgan, then Pillet. Cf. 176-181 for biographies of the diggers. Liverani 1994: overview of archaeological surveying in the East. 
1812: Burckhardt discovers Petra;

1827: Laborde in Syria and Arabia Petraea;

1845-7: Layard excavates Nimrud;

1857-8: Rey travels in the Hauran;

1861-2: De Vogüé travels in the Hauran;

1864: Luynes travels in Syria;

1881: Clermont-Ganneau travels in Phoenicia;

1887: Tombs of princes, Alexander sarcophagus, found at Sidon;

1897-8: Brünnow and von Domaszewski in Arabia;

1899 \& 1904: Butler in Syria;

1899-1904: German investigations at Baalbec.

National pride was involved in the frequent cozening of competitors, ${ }^{6}$ and the French had a better grip because of their long-lived engagement with Syria. ${ }^{7}$ There were parallel developments in Egyptian archaeology, where Muhammad Ali had already given orders in 1835 for a museum to be founded. ${ }^{[3]}$

It was in the 19th century that archaeology developed somewhat fitfully from trophy-collecting, which had been one aim of consuls and travellers for centuries, especially the French. ${ }^{8}$ Pingaud in 1887 defines the interests of Choiseul-Gouffier, French consul at Constantinople in the later 18th century, as having nothing to do with the modern meaning of archaeology:

Il demandait à la pierre les témoignages d'un art exquis et non l'histoire fragmentaire d'une civilisation... Cette poursuite ardente de tant de chefs-d'œuvre mutilés constituait, avec leur reproduction par le crayon, le principal intérêt de son œuvre. ${ }^{[4]}$

And this Ambassadeur Académicien was recompensed by the French government for "une nombreuse collection de médailles \& d'antiques; ses dépenses énormes pour faire fouiller les tombeaux de la Troade, mouler la plupart des chefs-d'œuvre d'Athènes, \& réunir plusieurs milliers de vieux morceaux de marbre."[5]

Just what might be unearthed by large digs was seen in present-day Iraq, where in $1843-4$ Mohl \& Botta employed 300 workmen to excavate Khorsabad, believing it to be Nineveh, and in $1845^{-7}$ Layard excavated Nimrud, privately

6 Chevalier 2002, 46-63: L'archéologie française face à l'Angleterre et à l'Allemagne (1842-1890).

7 Roederer 1917, 33-41: L'influence intellectuelle de la France en Syrie et en Palestine; 45-47: Langue et culture française en Syrie.

8 Chevalier 2004 for an overview. 
funded by Stratford Canning. Greece was also yielding up her treasures: in 1863 a dig was organised at Kavala in Greece by the French Vice-Consul Champoiseau; work was then started at Samothrace, just across the water, in 1873, and four years later (again by the French) on Delos. In recent decades Syria has presented archaeologists with excellent digging opportunities. ${ }^{9}$

Certainly, sailing ships had transported large and heavy artefacts back to eager museums in London, Paris and Berlin; and the only way to satisfy such a growing thirst was to document and illustrate the Oriental past, and to dig up what might still be called trophies for European museums, all of which were in effect looters. As Flinders Petrie wrote in 1918 of vandalised tombs in Egypt:

The most beautifully sculptured tomb at Thebes had the best parts prized away - now in Berlin. Another, a painted tomb, was wrecked, and its fragments are in Florence. The most beautiful of the early sculptured tombs was ruined, and the broken fragment of the best part is in the British Museum. These pieces have all been obtained with open eyes, knowing quite well how they were stolen, and what damage was done for this filthy lucre. ${ }^{[6]}$

Tourism itself provoked thirst for antiquities, and museums felt pressure to satisfy the need back home for erstwhile travellers, now educated by what they had seen abroad. Here Napoleon was from one perspective exemplary but unfortunate. In 1798 on his invasion of Egypt, as well as the first printing presses for Cairo (to print his proclamations), he took no fewer than 167 scholars, members of the Commission des Sciences et des Arts with him who eventually produced the monumental Description de l'Égypte (23 vols, Paris 1809-29). This was no mere flummery on Napoleon's part: he was a member of the Institut de France, was very proud of the fact, and in Paris wore its uniform rather than military dress. Banishing the regret that the French did not research and publish likewise for Syria, this was the greatest of Western contributions to knowledge of Egyptian civilisation ancient and modern, and has never been surpassed for detail, accuracy and illustrations. Unfortunately, Napoleon set the tone for the export of antiquities during his European conquests; the Italian states, for example, would not join in any scholarly applause, for many of their artworks ended up in French museums, and not all were returned.

9 Contribution française 1989, IX, Tate: "La Syrie est le plus riche du monde par le nombre, la variété et intérêt scientifique de ses vestiges archéologiques. Aussi les missions de fouille et de prospection y sont-elles plus nombreuses qu'ailleurs." 
Marooned by Nelson, who destroyed the majority of his fleet, Napoleon took his army into Syria, unsuccessfully attacked Acre, and descended on Jaffa, where his army was devastated by plague. ${ }^{10}$ His expedition was translated into academic tourism for the many later scientific expeditions to the region, funded by the French government, ${ }^{[7]}$ and from the fruits of which several reports appear throughout this book. In 1799 a French artillery officer, Boussard, found the Rosetta Stone, taken along with other antiquities as spoils of war by the British, and for ever afterwards in the British Museum. This and other trophies triggered poetic admiration back home, such as Shelley's Alastor, or the Spirit of Solitude, of $1816 .{ }^{11}$ But the French also derived a good laugh from the exercise, since it was a Frenchman, Champollion, who deciphered it. The French also had the expertise to decipher the Moabite Stone, if not the luck to get it to the Louvre in one piece.

For Syria, Flinders Petrie in 1918 worried about the innumerable mounds, containing buildings "more or less perfect":

All of these buildings need preservation, and cannot be left to be quarried out as mere masonry. In Egypt most of the ancient sites have been claimed by land grabbers within living memory. ${ }^{[8]}$

A long view was required:

When once the security of life and produce, without extortion, is assured, the rapid development of unworked lands is certain in the present age. We must not have repeated in Mesopotamia and Palestine the ghastly results of our inefficiency, which we have exhibited in Cyprus and in Egypt. ${ }^{[9]}$

Digging was needed to retrieve buried structures. The digging impulse was fed by nationalist interpretations of the past erected during the 19th century, which is where the Young Turks caught the disease. The emphasis was "on retrieving ancient works of art to fill national and private collections in Europe."12 The

10 Hachicho 1964, 117-130: military operations against Napoleon.

11 Hachicho 1964, 192: Obedient to high thoughts, has visited / The awful ruins of the days of old: / Athens, and Tyre, and Baalbek, and the waste / where stood Jerusalem, the fallen towers / Of Babylon, the eternal pyramids....

12 Vernoit 1997, 2: "This discovery of ancient civilizations greatly overshadowed curiosity in Islamic history ... the development of Islamic archaeology had more in common with the archaeology of medieval and later Europe than with that of ancient times." 
French persuaded themselves that the Crusades were part of the French past and of French culture, just as the Germans "harnessed the popularity of the Crusades and Crusader archaeology to the wagon of German nationalism." In 1873 the Kaiser provided funds to buy the cathedral site at Tyre, and search (fruitlessly) for the remains of Barbarossa. ${ }^{13}$ A silver belt was found, naturally associated with Barbarossa, and sent to Berlin as a present for the Kaiser. ${ }^{[10]}$ In France scholars such as De Vogüé saw Gothic in the Holy Land as specifically a French invention, to the disdain of the Germans; the battle was a long one, exemplified in Pierre Francastel's Paris 1945 assertion that the Germans did not invent Gothic: L'Histoire de l'Art instrument de la propagande allemande, a classic demonstration that old architecture can serve contemporary political ends.

In Syria, there was an embarras de richesses for archaeologists. Grand dreams were formulated, but the majority remained just that - dreams. They were continually prompted about where to dig (as they continue to do when possible),${ }^{14}$ but funds were nearly always lacking. In 1840 La Salle thought the ruins of Jerash so extensive that a commission of painters, architects and archaeologists was needed to deal with them. ${ }^{[11]}$ It would indeed have been wonderful to have a complete plan and description of antiquities classical and Islamic at this date, before later re-occupation of that site! In 1868 Porter proposed a program for archaeological action in Syria and Palestine, ${ }^{[12]}$ beginning with mapping the exact location of important towns and ancient sites, copying all inscriptions, making a geological survey of the shores of the Dead Sea, and also:

3. Excavate some of the artificial mounds in the plains of Damascus, Buka'a, and Hums, and in the valley of the Orontes.

5. Excavate the sites of Tyre, Sidon, Gebal [Byblos], and Aradus, as far as practicable, for remains of Phoenician art and inscriptions. The recent discovery of sarcophagi at Sidon may serve as a sufficient stimulus to this work...

6. Excavate and examine the subterranean tombs of Palmyra, and copy the Palmyrine inscriptions.

To which he added an examination of mosques: "The best specimens are, like Mohammedanism itself, rapidly decaying." Porter's desiderata echoed the plan of campaign on which the PEF had been launched in 1865, such as plotting maps and towns, and pointing out what treasures had been found elsewhere:

13 Ellenblum 2007, 32, 36-39.

14 Clermont-Ganneau 1923. 
Who can doubt that if the same intelligence, zeal, knowledge, and outlay were applied to the exploration of Palestine that have recently been brought to bear on Halicarnassus, Carthage, Cyrene - places without a single sacred association, and with little bearing on the Bible - the result would be a great accession to our knowledge of the successive inhabitants of Syria - Canaanite, Israelite, Roman?[13]

Archaeologists no doubt agreed with Porter's ambitious program - for who would not? But they were caught between a rock and a hard place, trying to balance scarce funds against perceived importance. It was certainly easier to dig at home where, however, there was often not just one past to be investigated, but a choice of several. In 1849 a complaint was registered in Britain against the emphasis on recording Roman remains there, while "slabs and crosses covered with beautiful and singular sculpture, and often bearing inscriptions which have to the present time baffled the skill of the keenest antiquaries, lie scattered over Great Britain and Ireland, a few only of which have hitherto been engraved." ${ }^{[14]}$ Great Britain did not see its own Ancient Monuments Act until 1882, "and yet, though the monument is thus to be maintained at the public expense, it neither becomes public property, nor is it made accessible to the public." ${ }^{\text {[15] }}$

There were two ways of making archaeology useful, and bringing it to public attention. One was to ensure that expensive digs abroad (along the lines of Porter's 1868 proposal above) uncovered and brought home spectacular antiquities with which to amaze not only the home constituency but also the whole of Europe, and to generate funds which would allow archaeologists to target likely sites not yet explored. In 1883 Conder \& Kitchener listed the best sites for exploration: Caesarea, Samaria, Ascalon, Herodium and Masada, ${ }^{[16]}$ plus the large number of tells in Judaea not yet examined. ${ }^{[17]}$ Herodium was an obvious target, well known from Josephus, and with little left on the surface: "Les aqueducs, les escaliers en marbre, les palais, la ville même, tout a disparu ... on ne rencontre dans la plaine que quelques blocs dépareillés et quelques monceaux de débris informes." ${ }^{[18]}$ Kitchener repeated his list in 1891, adding Jerash, Baalbek and Carchemish:

Unfortunately the state of the East is very unfavourable to the antiquarian; but it must not be supposed that exploration is complete while fields as yet hardly worked exist all along the eastern shores of the Mediterranean. ${ }^{[19]}$

The second solution was to travel into little explored regions, and substitute exploration and discovery for digging. For example, Rey and De Vogüé went 
to the Hauran, and others further south and east of the Jordan. Merrill paid a compliment to De Vogüé by translating extracts from him in his own 1881 volume, which reported on the 1875 American Expedition to east of the Jordan: "the reader may the more readily indulge me in placing before him in this manner the views of this well-known scholar upon this deeply interesting subject."[20] Topographical precision was valued, so Schumacher's 1889 railway planning for a line to run from Haifa to Damascus, through the Hauran, was accompanied by plenty of prospective archaeological meat: "the country is so rich in antiquarian and archaeological remains that a survey to be thoroughly

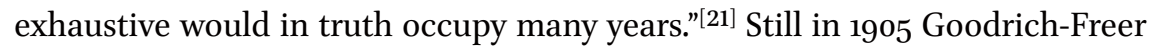
was pointing out sites for excavation, for example at Beisan, near Tiberias, and invoking the nationalist bogey, discussed below:

Where can the archaeologist find richer promise? There is, happily, a rumour that it is one of the many sites likely to be taken in hand by German skill and perseverance. ${ }^{[22]}$

Unsurprisingly, then, here was the third way, compounded of increasing political and military influence, and money. The French had adopted this approach in the mid-19th century, but towards its end it was the Germans who drove developments. Softened up by the Kaiser's 1898 visit to Baalbek, ${ }^{[23]}$ the Porte issued a firman for digging there, and 160 workmen were employed for two years:

They have cleared the walls to their foundations; they have restored columns and pillars that had fallen in many places; they have built new masonry to sustain old arches; have repaired much of the damage done by the earthquakes and have removed all Arab construction so far as possible. ${ }^{[24]}$

Failing transporting prestigious finds, publishing information, plans and photographs was the new and inevitable trend, as governments tightened up and sometimes banned the export of antiquities. Paper reconstructions could also be made. At Beisan, for example, in 1854 Van De Velde suggested that "numerous columns everywhere scattered about demand the scientific skill of the archaeologist to call again into fancied being the buildings of which once they were so prominent a part." ${ }^{[25]}$ By the new century, Butler's Princeton Expedition brought back no antiquities; instead they published topographical data, site and monument plans, some of them measured, and inscriptions, plus many photographs. ${ }^{[26]}$ 
Intemperate excavation could ruin sites. The Duc de Luynes, travelling in 1864, complained about the work of the French Commission at Ras-el-Abiad (and Haran or Omm-al-Awamid = the Mother of Columns), on the Phoenician coast, where it

\begin{abstract}
vint faire des fouilles en ce lieu et bouleversa ces ruines en les explorant avec trop peu de méthode. II en résulte beaucoup d'incertitude sur les édifices dont on comprendrait bien mieux le plan et l'usage, s'ils étaient restés tels que leur destruction naturelle les avait laissés. Quoi qu'il en soit, il faut espérer que le savant chef de l'expédition tirera parti de son exploration, et l'on dit qu'il a exhumé de ces ruines une inscription phénicienne d'une certaine valeur scientifique. ${ }^{[27]}$
\end{abstract}

\title{
Digging in Palestine
}

In Syria it seems to have been partly a lack of safety, and partly a developing governmental reluctance to help populate foreign museums, which held back serious digging. Many locals, as narrated in Chapter Three, were convinced foreigners dug in their country to retrieve the treasure the location of which (they believed) was indicated in inscriptions, or arrived at by magic. When locals took an interest in exploratory digs, it was often so that, having avoided the hard work of soil-shifting, they could move in and filch any useful stones.

The hardest place was Jerusalem itself, where excavations in 1866 had to go some $12 \mathrm{~m}$ deep in laying foundations for a church. ${ }^{[28]}$ But the main problem was not detritus but rather bureacracy. An 1869 letter to The Times pointed out that the bureaucratic maze ensured that "prejudice or allowable sentiment opposes to our search a barrier harder than porphyry." Nevertheless, "even through these difficulties many curiosities have been sent to England by Lieut. Warren, and nine cases of those newly found will be shipped in the steamer with me."[29] However, the prospect for research in Jerusalem was disappointing as an 1873 report made clear:

Considering the great portions of the city which have been already turned up in the many recent public and private buildings with such small results, we may fairly expect that we shall find little to reward us from an archaeological point of view in any future research. ${ }^{[30]}$

This was a plea for money, so that the PEF might "explore by means of scientific agents on a well-defined plan," followed by the irresistable dig (a keep-off-thegrass hallowed by all archaeologists) that any donor "may help the Americans 
by not encouraging small expeditions into that tempting country east of the Jordan, where so many treasures lie hidden."[31]

The Americans were in the forefront of well-funded expeditions, sending out a surveyer and archaeologist to Syria in 1875, and funded for two years with $\$ 6$,ooo: "the larger part of the money raised by the American Society has been subscribed by leading New York merchants." No doubt the funds were provided from sheer philanthropy, for the notice mentions a survey but not digging; or were objects for museums also to be sought? ${ }^{[32]}$ One result of penury in the United Kingdom was for the PEF in 1877 to change focus and, instead of digging, turn to the examination of topography, which would illustrate "the accuracy and consistency of the Bible history; and thus the discovery of even the most obscure of Bible towns." Such work, plus the examination of the ethnography of the peasant population, constitute "studies of infinitely more valuable character than the costly attempt to explore by excavation, with results which, though of antiquarian interest, have no bearing on Bible questions."[33] The subtext here (for what must have been recognised as a second-best) seems to be that such work would not be contentious, and could interest a readership that did not focus exclusively on Greater Syria via the Bible. The PEF was presumably attempting to widen its audience as a conduit to generating more funds. What excavations were conducted could be written up in glowing terms. Thus Conder in 1891 trumpeted excavations round the Haram al-Sharif as prime examples of "measurement and scientific exploration," ${ }^{[34]}$ while De Hass four years previously was still convinced that "fragments of sculpture, rare marbles, and beautiful columns found in the Mosque of Omar, Church of the Holy Sepulcher, and other more modern buildings, without doubt belonged to the Temple and its cloisters."[35]

Revived pilgrimage and biblical study both contributed to archaeological exploration, with "science" as a tool, which was a common 19th-century idea. For archaeology was believed by some to be necessary to prove the truth of the Bible and thereby put Darwin to flight. In $185^{2}$ Wilson had already lamented that there was so much to find in Jerusalem, but serious digging was then impossible. A firman was granted to Warren in 1869 "to make excavations, under certain conditions, at localities where antiquities are likely to be found," but the Temple Mount was excluded. ${ }^{[36]}$ By 1871, however, "at last the excavations of Jerusalem have been begun." ${ }^{[37]}$ But outside the Jerusalem area (and outside the auspices of the Palestine Exploration Fund, which was perenially short of funds) $)^{15}$ very little extensive excavating was done. Butler of Princeton led expeditions in 1904-5 and 1909, and took large numbers of photographs

\footnotetext{
15 Bar-Yosef 2005, 165-181: The PEF, the Public, and the 'Popular.' 166: PEF's poor finances and membership.
} 
and measurements. ${ }^{[38]}$ In 1908 they camped near Jericho, and "late in the afternoon we walked over to the site of the ancient city to see the German excavations then being carried on."[39] At Qanawat they began work early, "some going with a band of muleteers to do a little excavating at Sî." [40] But throughout their published volumes there is nothing on excavation; and none of the words spade, shovel or trench appear; excavation appears only in relation to German work at Jericho.

\section{Filling Western Museums}

France had a long track-record of exporting antiquities from the Orient, and presumably saw no reason why she should stop doing so. Antiquities seized in earlier centuries from the East were many, and the French were well aware of the source of Venice's splendour. ${ }^{[41]}$ One illustrious name is Claude Fabri de Peiresc, whose very networking was impressive as he sought information and objects for his private collection. ${ }^{16}$ Some searchers were government employees, as were those calling the tune; they thoughtfully provided shopping lists of desiderata. In 1671 Carcavy, the Royal librarian, asked Père Wansleben to find "des statues ou bas-reliefs, qui soyent de bons maistres," and to note that at Baalbek "quantité de belles statues ensevelies sous des ruines, qu'on pourroit en tirer, ayant la permission du bâcha de Damas d'y faire fouiller." ${ }^{\text {[42] }}$ In 1683, at the behest of Colbert, D'Arvieux sent from Aleppo to Paris "une grande caisse de très beaux manuscrits orientaux très bien choisis pour sa bibliothèque et celle du roi," ${ }^{[43]}$ and drawings of Palmyra and Baalbek (from Tripoli) reached Paris in 1706 , long before Wood's publication. ${ }^{[4]}$ Direct orders came from the King's representative to Lucas ${ }^{17}$ in Syria telling him not only what to collect (specific medals only, to fill in gaps in the collection!), but also the route to take; other instructions reckoned Greece and the Propontis should also be trawled. ${ }^{[45]}$ A catalogue of Lucas' finds was published as part of his travel narrative. ${ }^{[46]}$ Like coins and medals, manuscripts were a favourite collecting item, being easily portable, and to be welcomed within Vatican collections as well. ${ }^{[47]}$ The Marquis de Villeneuve, travelling ${ }^{1730-1740, ~ s e n t ~ a t ~ l e a s t ~ t w o ~}$ cases of manuscripts back to the King, most of them from Syria. ${ }^{[48]}$ With

16 Brentjes 2010, Variorum pagination VII 1-56: Peiresc's interests in the Middle East and Northern Africa in respect to geography and cartography. 4-14 Peiresc's network in the Ottoman Empire and its dependencies [including Syria] - an impressive list.

17 Göçek 1987, 98: Lucas' haul, and for those of Pitton de Tournefort and the Abbé Sevin, the last returning with $600 \mathrm{MSs}$. 
the help of the French navy, in the early 18th century the King's consul at (Libyan) Tripoli was shipping back statues and columns to France. ${ }^{[49]}$ The various find-lists and instructions written for the King's servants found a wider circulation in Montfaucon's c.1720 Mémoire pour servir d'instruction à ceux qui cherchent d'anciens monumens dans la Grèce et dans le Levant, which was still in use in $1742 \cdot{ }^{[50]}$

Of course, selling antiquities to foreigners was a cottage industry everywhere. De Saulcy, at Sidon in 1853, wrote that "Partout on nous offre des médailles, des pierres gravées et des débris antiques de toute espèce." ${ }^{[51]}$ Unfortunately, however, by then the locals had nothing interesting to sell. ${ }^{[2]}$ He did better at Hebron, however, buying "une sorte de petite capse en marbre blanc, et en forme de sarcophage, portant une croix patée, à branches égales, sur r'une de ses faces," probably extracted from local chamber tombs. ${ }^{[53]}$ Buying coins and medals often seemed to be easy, since few locals realised their inherent value, and often sold them for only a little more than the value of the metal. ${ }^{[54]}$ But the supply was evidently running out, as Hunter found at Beirut in 1842, where he picked up a lot of items for only two shillings, "these included the only articles I thought worthy of attention."[55] Finding-lists such as the French had been issuing for centuries were perhaps the natural vade mecum for explorers in lands new to them. In 1864 Guérin proved to the government his credentials for Samaria by emphasising the lists he had made of his discoveries. ${ }^{[56]}$ The result was lists like Rey's in his report to his French Government sponsors, for example of the 27 objects he sent back to Paris in $1867 .{ }^{[57]}$

In a perfect world, European acquisitions would have ceased when export regulations were enforced, and local museums founded. But this rarely happened. Even today, trophy-collecting by prominent museums is not always frowned upon, as some recent high-profile investigations have demonstrated. Looting continues to be a curse. ${ }^{18}$ Many trophies collected in earlier centuries remain in our museums, and they remain indispensable to demonstrate the skill and results of excavation. Museum labels can also be very instructive, those in the Louvre (for example) indicating provenance, with much Syrian material accessioned from the 186 os onwards. ${ }^{19}$ And as already noted, nationalistic impulses frequently made digs and discoveries a competition between

\footnotetext{
18 Gerster 2005, 373-379: The curse and frustration of archaeologists - looting.

19 Dentzer-Fedy 1993: much of the material entered the Louvre 1880-90, later acquisitions being largely from private collections.
} 
Western countries, to the inevitable impoverishment of the regions from which antiquities were extracted. ${ }^{20}$

For the Europeans, confronting antiquities in the Middle East was a race against time (and vandalising tourists and locals), and an exercise in evading regulations as soon as they were set in place. Egypt evolved a monuments protection policy under Auguste Mariette from 1858, as did the Ottoman Empire under the control of the Ministry of Education in $1884 .{ }^{21}$ From 1884 Hamdy Bey was in charge of archaeology in the Ottoman Empire, and "henceforth no person received permission to explore more than one ancient ruin at the same time, and this only with the express stipulation that all the antiquities recovered became the exclusive property of the Imperial Museum in Constantinople."[58] However, already in 1872 Burton found the policy of preventing export under the pretext that they were wanted for a home collection as "highly invidious," at least in part because he knew how it could be circumvented:

Were this the case, no complaint could be made; the step has been taken by civilised powers. But here it means simply a bakhshish ad valorem to the local governor, and the place for housing such valuables is yet in nubibus... Meanwhile interesting remains are left in the streets to be broken by boys; and foreigners are subject to all manner of annoyance. ${ }^{[59]}$

Yet even if formal restriction did not exist in the 1850s, Van De Velde was eyeing the ground around Sidon: "If it were possible to make excavations in the grounds around Sidon, without getting into difficulties with the Turkish government, many an interesting relic of antiquity would be dug up."[60]

"Do not export" did not mean "Do not collect," and several foreigners living for years in Syria formed large collections. One was that of M. Péretié, dragoman to the Consulat de France in Beirut, which received a glowing review from Luynes, travelling in 1864. Clearly, Péretié had agents who dug, and brought interest items to him for his collection:

Le salon, plus loin, était un vrai musée d'antiquités, terres cuites, bronzes, médailles, pierres gravées, cylindres, choisis avec un goût excellent parmi

20 Weber 2006 for museum survivals: \#1 torso of naked youth, found in reuse in the Umayyad Mosque, in mediaeval masonry; \#2 fragment of colossal arm, marble, same source; ${ }_{56-57}$ for tribal shrine at Ahr al-Ledja; 79-82 sculpture from Umm Al-Jimal; 83-9o Bosra, where some 50 sculptures have been found; 92-97 sculpture from Qanawat; 100-109 sculpture from Souweida.

21 Vernoit 1997, 2. 
ce que les fouilles et les découvertes opérées par les agents de M. Péretié pouvaient offrir de plus remarquable. ${ }^{[61]}$

Conder describes his collection as "probably the finest in Syria." ${ }^{[62]}$ After his death, his collection was dispersed, some early material going to the Rev. Greville J. Chester (who was interested in Phoenician material), and an archaic head to Copenhagen. The Duc de Luynes had already bought from him the Esmunazar Sarcophagus, of black stone, found in Sidon in 1855 on land Péretié subsequently purchased, and now in the Louvre. It was this splendid find which brought Sidon to the attention of scavenging archaeologists. ${ }^{[63]}$ Two Sidon sarcophagi of white marble were also sold direct by Péretié to the Louvre. Renan's 1864 Mission de Phénicie is full of references to Péretié, because he got there first, and Renan was obliged in his turn to purchase land from him in order to execute some of his digs. ${ }^{[64]}$

Renan naturally sent quantities of material back to the Louvre, including a fine mosaic from a church at Tyre, ${ }^{[65]}$ and another for which he engaged a mosaicist from Rome to lift, so that it might be installed in Paris, in the Palais de l'Industrie. ${ }^{[66]}$ No doubt his interest in matters Phoenician drew local attention, for by the 1880 s inscriptions were being forged, ${ }^{[67]}$ and much interest was developing in the remains of Syria much earlier than the Romans. ${ }^{[68]}$ When Clermont-Ganneau sent back to Paris the finds from his 1881 excavations (including 23 bronze statuettes and 13 sculptures ${ }^{[69]}$ ), he did not even mention any difficulties with regulations, so presumably had made arrangements beforehand. Similarly, he wrote of a "magnificent marble head found some years ago [at Samaria], and taken by me to the Louvre in 1882."[70]

Before Hamdy Bey's iron rule, the Sidon sarcophagi were too important to go uncontested by Britain and France. When Wortabet arrived in 1855, a new sarcophagus had just been discovered, but "so warm became the discussion between these allies of the Turkish government, that the pasha deemed it best to bury the sarcophagus under ground, until these "deputy-provisionarysub-vice-pro-acting-consuls" should have settled the matter amicably in a lawsuit, which he would hear and decide upon. They had been a month engaged upon it, and the law-suit was as far from termination as on the first day it began."[71]

In spite of Hamdi Bey's efforts, in Syria (and elsewhere in the Ottoman Empire) there was minimum regulation (sometimes not even enforced) before the First World War, and quantities of antiquities went to Europe and the United States, some of them under an agreed division of spoils with the government, but some of them actually smuggled. The Mandate authorities for Syria, naturally with a European rather than local perspective, encouraged 
European and American digs "in Greater Syria, allowing them to repatriate many of their finds, at a time when such liberality had become a thing of the past in Egypt and Iraq and, of course, in Turkey as well." When archaeologists found they could not fruitfully dig in Turkey, they went to Syria. ${ }^{22}$ Funding was still on the museum mind: "As one plainspoken official at the British Museum stated, regarding a proposed expedition in Syria, 'the question is, will [it] give the trustees an adequate material return for their money." Local museums could also be deployed to serve political purposes, the French in Syria demonstrating Arab roots, but the Phoenicians in Lebanon differently, "to appeal to a Maronite constituency."23 What was Syria, and what was Lebanon? ${ }^{24}$

Money bought objects, Gallois finding it normal that in exchange for their work at Baalbek the Germans should have the right to choose

quelques jolis souvenirs archéologiques, ce qu'elle n'a pas oublié en envoyant à Berlin, statues, frises, morceaux d'entablement, sculptures variées, tous souvenirs, comme bien on pense, triés avec soin et naturellement non des moins intéressants et des moins précieux. ${ }^{[72]}$

In 1910 Jessup assessed the political implications of the Kaiser's visit:

This has already had its effect. It has diminished sensibly the prestige and influence of France in Syria and Palestine... French influence here has been identified with the worst phases of Jesuit intrigue and anything that weakens it is a public benefit. ${ }^{[73]}$

The Kaiser certainly intended to make an impact: with 1,00o in the party (supplied by 250 mules and horses), he had a staff of 120 , bolstered by 140 naval and military officers. ${ }^{[74]}$ The German politicians were after railway concessions, and their archaeologists after digging rights. (Indeed, building railways

22 Goode 2007, 2; 59 for details of digs in the 1920s \& 1930s, including the Committee for the Excavation of Antioch and Vicinity, which provided loot for the Louvre and for several museums in the USA.

23 Goode 2007, 12-13, 14.

24 Salibi 1988, 71: "To the Syrian people, Syria is simply a country which happens to be there, perhaps fortunately, to serve as 'the throbbing heart of Arabism', as the country is often poetically described. With Lebanon, it is a different matter. Even before the present Lebanese state came to exist on the political map of the modern Arab world, a number of theories had been developed, sometimes locally, sometimes by external parties, which depicted Lebanon as a national entity of special historical character. Are any of these theories historically or philosophically plausible?". 
or roads, and digging for antiquities, are often consonant activities.) Thus the American Vice-Consul at Haifa (Schumacher, explorer and archaeologist) gave up his American nationality in favour of Germany because "he could get no rights and secure no concessions for archaeological excavation and exploration, whereas a German subject can get any concession that is desired." ${ }^{\text {[75] }}$ The railway was indeed the hand of fate as far as antiquities were concerned, Adolf Michaelis commenting mournfully in 1908 that "Fate has been more favourable at Baalbec-Heliopolis than in the Hauran, although here also the railway, the friend of man, but the enemy of ancient structures, has approached to within a short distance., ${ }^{[76]}$ The Germans celebrated by carrying off sections of Baalbek's architecture for re-erection in the Pergamon Museum in Berlin, where they can be seen today.

In clear competition with the Germans (some of whose ancestors also crusaded in the Holy Land) scholarly propaganda in Syria was developed to appeal to a French constituency, by the publication of accounts of surviving religious and military monuments, built by the French (or so it was affirmed). As Batissier wrote in 1851, "ils appartiennent à notre ancienne civilisation et à notre histoire."[77] This free-for-all from Europe and the USA was not to last, as Pingaud vainly thought in 1887 , because "l'Orient se rapproche insensiblement de l'heure où il échappera sans effort, pour commencer un nouvel avenir, à ses maîtres d'aujourd'hui.."[78]

In Britain as well as in Germany and France, an interest in the crusading past developed in tandem with a focus on national history and document archives, strengthening throughout the 19th century. France was to the forefront in crusader studies, and also in paying for scholars to visit and report on Syria. Hence it is scarcely surprising that it was France who, through trade as well as church and school foundation and proselytising (long before the American evangelicals) believed she had a strong claim to be a principal guide for the development of sections of Syria after the First World War. In a sense, this chapter has been a preliminary briefing for the two mandates, which were to make easier the acquisition of antiquities from Syria for European museums.

\section{The First World War and the French \& British Mandates}

[L'Europe] devrait s'appliquer uniquement à développer tant d'éléments divers par l'influence matérielle et morale qu'elle exerce sur les populations de la Syrie, et à les protéger contre tous périls par son autorité et son intervention prévoyante dans les affaires d'Orient... Dans cette grande tâche, le rôle principal appartient naturellement à la France. ${ }^{[79]}$ [1861] 
At the behest of the Ottoman Empire, in the 19th century Western experts helped develop necessary infrastructure such as roads and railways, just as they had in matters military (training, fortifications, uniforms, ships, artillery) in the previous century. Western companies continued to be involved in international trade but, by the late 19th century, this was focussed on providing local markets for European goods whereas in the past it had been Europe which bought the products made in or merchandised through Syria. Tourism then provided countries such as Syria, Turkey and Egypt with foreign exchange, and generated dependencies which have grown enormously in the decades following the Second World War.

Western involvment with Syria, and Syrian dependence on Europe, was therefore part-realised well before the disastrous carve-up following the First World War, and was clear to commentators a generation beforehand. ${ }^{[80]}$ Many had measured the country against governance and prosperity in the West and found it wanting; and a few had seen it as ripe for Western colonisation. In the famous Chinese prevarication (prophecy?), it is too soon to tell whether the French Revolution was a success. No such doubt surrounds the consequences of Western involvment in the Middle East from the Crusades and into the 21st century, as we shall see in the Epilogue (below).

Yet there were compartmentalised and partial successes, such as the opportunities the Mandates gave to archaeology. ${ }^{25}$ For example, it was the French who created of the Institut des Lettres Orientales at Beirut, and the Institut Français at Damascus, as well as museums at Beirut, Damascus, Aleppo and Suweida, and "Effective steps were taken to preserve existing monuments; and restorations, usually in excellent taste, were carried out on a wide scale. The restoration of Krak of the Knights was in itself a major achievement."26 Again, it was French rather than British scholarship which was responsible for first attentions to Islamic monuments in Cairo. Nor had the local governor been idle. Cemal Pasha had been sent to Syria in 1914, and was enthusiastic both about the modernisation of her towns, but also about the restoration of her monuments, which he considered as complementary endeavours. In 1916 he proposed a programme as follows, targeting monuments of the Byzantine,

25 Kennedy 1994, 4-5: "The [French] mandate may not have been a happy period politically but it saw an unparalleled explosion of archaeological activities, among them the excavations at Ugarit and Byblos, the aerial survey of the Roman desert frontier by Poidebard and the study of the antique villages of the limestone plateaux of the north by Tchalenko. Crusader studies too benefited from this interest, especially as the presence of Franks in the area in the twelfth and thirteenth century could give a sort of legitimacy to their presence in the twentieth." 
Islamic, and Turkish (pre-Ottoman and Ottoman) periods, which he placed placed under the direction of Theodor Wiegand:

1. The creation of a reliable inspection agency for the preservation of monuments; 2. The removal of new buildings inside and around old buildings, the cleaning of ruins, and the prohibition of using ruins as building materials; 3 . The improvement of access roads to ruin sites and the creation of suitable accommodation to facilitate visits by domestic and foreign [tourists]. ${ }^{27}$

But war made the completion of this ambitious programme impossible, and Cemal's plans met with financial objections from fellow administrators, and jealousy (at the intrusion of Germans) or worse from the French.

The breakup/carveup after the First World War was helped by the fact that the Ottoman Empire and its constituent, Syria, were a congeries of different peoples and groups with entirely different interests. It was dragged down by its fragmented nature which, as Volney noted, even in Syria was not one nation, "mais comme un alliage de nations diverses." ${ }^{[81]}$ Wortabet echoed this in 1856: "I am a native of Syria, but I cannot tell you to what race I belong. Our country has been overrun, over, and over, and over again. It has been re-re-reconquered." ${ }^{[82]}$ This was frequently stated, "Turkey, though an empire, is not a nation; it is rather an aggregate of nationalities or governments accidentally united by having been the subjects of a common conquest," ${ }^{[83]}$ which fact was to contribute to its break-up, and to the emergence of numbers of minorities jostling for survival. ${ }^{28}$ Various military disasters were experienced by the Ottoman Empire early in the 2oth century, and the loss of much of the Balkans was, demographically, "a terrible economic blow for the Ottoman economy and state." 29

The First World War further fractured the Empire, with the forced movement, maltreatment and massacre of hundred of thousands of Armenians, partly the result of "a monumental failure by the state to protect and sustain the deportees." 30 The earlier resettlements of Circassians had been on a smaller scale, and made for reasons of political economy and planting

27 Çiçek 2014, 192-196; quote 194.

28 White 2011, passim.

29 Quataert 2005, 112.

30 Erickson 2013, 4: "Although it is true that individuals, and large groups of Armenians, were relocated from all parts of the empire; provincial-scale relocations en masse were regionalized in just six militarily critical provinces in the empire's core, while elsewhere the relocations were limited to selected groups of Armenians." Quote 221. 
prosperity; whereas the Armenians in Anatolia were claimed to be a danger to the state, and had to be moved, some as far as Deir al-Zor, $440 \mathrm{~km}$ to the east of Damascus. Such population movements dictated by governments had a long history, but now they were joined by nationalist ideas. These were another European import, profoundly antithetical to imperialism, the basis of which "everywhere shifted from liberalism to authoritarianism, statism, and ethnocentrism." ${ }^{31}$ Sympathy for the Christians militated against any welcome for the French Mandate from other inhabitants.

Much reported throughout Europe, the Armenian massacres helped sealed the fate of the Ottoman Empire from the outside, bolstered by the nationalistic attitudes and then actions of the Young Turks themselves. ${ }^{32}$ The 1915 decision to relocate Armenians was also used by Britain to influence American attitudes to the war effort, ${ }^{33}$ while Western pre-war policies toward Syria and Palestine were labyrinthine and confused..$^{34}$ Other faiths and ethnicities had played an important (if inferior, and often heavily taxed) part in the functioning of the Empire. The post-war plan of the Young Turks was to turn the Empire into a nation, ${ }^{35}$ with emphasis on Turkish nationality, made definitive by the exchange of populations between Turkey and Greece in 1921. This was but the final act, for several hundred thousand Greek Orthodox Christians had been forcibly relocated before and during the War. Both the French and the British had clients to satisfy, ${ }^{36}$ with Jordan (given to Abdullah) and Iraq (given to his brother Faisal) new countries created for the chessboard. ${ }^{37}$ Britain and France squabbled over the post-war spoils, ${ }^{38}$ the former aiming at one point to annex Syria to Egypt, while "for religious, economic and historical reasons, France saw herself as having a role to play in Syria's affairs." ${ }^{39}$ This was partly in response to the long-standing Christian connections between the two

31 Bloxham 2005, 92: "nowhere else during the First World War was the separatist nationalism of the few answered with the total destruction of the wider ethnic community from which the nationalists hailed." Ibid. 59 for quote.

32 Butler 2011, chap.10: The Fall of the Sultan's Realm. Bloxham 2005, 101-103 Kemal and Resurgent Turkish Nationalism, 1919-23.

33 Uyanik 2016.

34 Khalidi 1980.

35 Kayali 1997; Barkey 2008, chap. 8: On the Road out of Empire: Ottomans Struggle from Empire to Nation-State.

36 McHugo 2015, chap 2: French rule, 1920-1946., emphasising the arbitrary nature of the mandate boundaries.

37 Ansari 2009, 311.

38 Andrew \& Kanya-Forstner 1981, 222-226.

39 Fromkin 1989, 94. 
countries. As Smith wrote in 1918, it was not true that "Palestine is the national home of the Jewish people and of no other people... Has Christianity "made no history" and "left no image of its spirit" on the Holy Land?"[84]

This is not the place for a detailed examination of the European carve-up of the Ottoman Empire after the First World War, and the intricacies of the British and French Mandates, ${ }^{40}$ let alone for the movement or imposition of new populations, although this was a lingering hot topic. Plenty of justifications of the French Mandate were written, but only by Christians, not by Muslims. ${ }^{41}$ The carve-up in fact began in 1916 with the Sykes-Picot agreement between Britain and France, ${ }^{42}$ and was to be enforced with troops. Nor should we devote space to rail at the disgraceful treatment handed out by Allied governments to its peoples, (with the British promising, in exchange for their support, territory to the Hashemites, Saudis and Jews $)^{43}$ except to remind the reader of how conveniently it met the expectations and suggestions of many travellers from the 18th century onward encountered earlier in this book. A century later, the continuing impact of such mis-steps is clear.

Britain and France must have known via travellers and diplomats just what a task they would be taking on with their wartime meddling and then their mandates. Syria especially had long been viewed in the West as a country rich in resources and labour, and ripe for exploitation and modernisation, "where France might one day have territorial claims and where, therefore, it was essential to maintain the primacy of French influence,"44 the result deriving from "une vision de la puissance française projetée outre-mer." ${ }^{\text {I }}$ In 1911 was founded the Comité de défense des intérêts français en Orient, a pressure group to publicise and develop "toutes les OEuvres qui font honneur à la France dans les pays d'Orient et contribuent à y étendre son action."[85] A member was sent out to visit French-based educational establishments, and also

40 Fedden 1955, 212-223: overview of the the French and British Mandates; Salibi 1988, passim.

41 George-Samné 1921, a Greek Catholic from Damascus.

42 Nevakivi 1969, 13-44: the 1916 partition of Asiatic Turkey (the Sykes-Picot agreement). Ibid. 148-171: Deterioration in Anglo-French relations regarding the Syrian Settlement. Fulton 1984, 157: the diminished power of French governments. Fourtnié \& Riccioli 1996: France's engagement with the Near East, 1916-1946.

Ansari 2009, 298: "Despite the many quibbles, qualifiers, and disclaimers offered over the years about who agreed to what and what was promised to whom, that's the gist of the situation, and it guaranteed an explosion in the future."

44 Fulton 1984, 138. Tannenbaum 1978: France's Middle Eastern policies during World War I and the ensuing peace conference.

45 Cloarec 2010, 391. 
("subsidiairement" he writes so unconvincingly!) "de recueillir quelques informations sur les principales entreprises financières, industrielles, commerciales et agricoles créées ou dirigées par nos nationaux dans le Levant." ${ }^{[86]}$ In 1913 this merged with the Comité de l'Asie Française, and echoed other pressure groups such as the Comité de l'Orient and the Comité Libanais de Paris. ${ }^{46}$

Even before the mandates were conferred, the Allies took over the country. Damascus was abandoned by its Turkish garrison in late September 1918, and at the Versailles Peace Conference in 1919 Syrian attempts to acclaim Faisal as king were defeated. ${ }^{47}$ Then the two mandates gave them control. The French Mandate for Syria (1922-45) was not welcomed there, and when a 1925 revolt in the Hauran spread to Damascus the French bombed the city. Scars remain from citizens' clashes with the French, who gained from the occupation with bursts of scholarship, ${ }^{48}$ indeed over large areas of the Middle East, ${ }^{49}$ spin-offs from recent French influence in the Levant. ${ }^{50}$ Archaeology in Algeria had also been relatively well served by the French occupation (or rather "opened up to science," as Michaelis has it ${ }^{[87]}$ ), although the country and its inhabitants suffered from their century-plus occupation.

From its seat in Beirut, the Service des Antiquités established in 1919 (i.e. before the Mandate) promised formal protection, and promoted the archaeological investigation of antiquities throughout Lebanon and Syria, which it divided into four provinces. For Roederer in 1917,

L'histoire du Levant, c'est presque dans l'histoire de France qu'on devrait l'apprendre, tant les deux sont intimement mêlées. Chaque phase de notre vie nationale eut sa répercussion là-bas et s'y manifesta par un acte. ${ }^{[88]}$

Unsurprisingly, then, "this sense of (French) ownership over the antiquities of Syria and Lebanon was to continue, and increasingly cause friction as Europe descended once again into war."51 Nor were local traders delighted, for their developing prosperity since the later 18 th century was clear to see..$^{52}$ However,

\footnotetext{
46 Andrew \& Kanya-Forstner 1981, 46-47. Chevalier 2004.

47 Fromkin 1990, chaps 36 \& 37: The Road to Damascus; The Battle for Syria.

48 Burns 2005, 272. Ibid. xiii, "tremendously fertile outpourings of French scholarship during and after the Mandate years recorded the city's past."

49 Chevalier 2002, 215-392: L'archéologie française au Moyen-Orient de la première à la seconde guerre mondiale.

50 Cloarec 2010, 11-18.

51 Potts 2012 I, 80; ibid. 82 for quote.

$5^{2}$ Norris 2013, 18-19 for Palestine: "In the late 18th and 19th centuries the heightened interest of imperial states in the Eastern Mediterranean as a new sphere of colonial development
} 
one anglophone judgment on the French "colony" of Syria, dripping with Schadenfreude, was that "they thought to make it a second Morocco, they have succeeded in making it a second Rif."53

Ownership of Syria was physical as well as spiritual. In 1929 Krak des Chevaliers, its villagers displaced, was appropriated as a French monument under the care of the French Administration des Monuments Historiques and, as Kennedy writes, "meticulously restored, joined Palmyra, Baalbek and Qal'at Sim'an among the great tourist attractions of the French Levant." French scholars promoted the connection between the Levant and Paris. Dussaud visited and wrote much, and eventually headed the Department of Oriental Antiquities at the Louvre. In 1925 Enlart strengthened the Crusader/Christian link with his Les Monuments des Croisés dans le royaume de Jérusalem: architecture religieuse et civile. ${ }^{54}$ Exhibits had also familiarised the West with some important monuments in Palestine well before the Mandates..$^{55}$ Rostovtzeff saw the Mandate as a grand opportunity for protection, restoration and digging at Palmyra, noting that "since the introduction of motor-cars the despoiling of Palmyra had made giant strides. In a few decades scarcely a column or an arch would have been left standing on the site."[89] Dura Europos was similarly blessed with digging thanks to the initiative of the Académie des Inscriptions, the Belgian archaeologist Franz Cumont using soldiers of the French Foreign Legion as workmen. ${ }^{[90]}$

For reasons elaborated in previous chapters, Palestine received more digging attention in the 19th century than the rest of Syria, ${ }^{56}$ and also attention from the French. ${ }^{57}$ The British Mandate for Palestine article 21 offered legal

had given rise to a new breed of merchant, highly attuned to the possibilities this process presented for intermediary economic actors. This was particularly the case in the coastal regions of today's Syria, Lebanon, and Palestine."

Roberts 1929, 602; 6o3: "France failed, because she antagonized the town-dwellers and then, almost inconceivably, alienated her former supporters, the rural producers. This she could accomplish only by a studious disregard of their interests."

55 Bar-Yosef 2005, 136-165 'Palestine has come to them': Panoramas, Models, and Exhibitions. Ibid., 154: "Jerusalem, too, was transferred to the West in a similar fashion: the massive, 11-acre 'Jerusalem' constructed at the 1904 St Louis World's Fair included full-scale reconstructions of the Holy Sepulchre, the Wailing Wall, and the Dome of the Rock, as well as twenty-two streets, 300 buildings, and 1,00o indigenous Jerusalemites who were brought over from Palestine." Fortin 1999 for a well-illustrated Paris exhibition, which naturally and concentrated on exhibitable small objects.

56 Murray 2007, 715-717: Palestine from the 19th century, with details of digs.

57 Chevalier 2002, 354ff: Archéologie française dans les pays sous mandat anglais. 
protection of monuments. "This law shall ensure equality of treatment in the matter of excavations and archaeological research to the nations of all States Members of the League of Nations." It offered yet more for diggers, who were assured of their loot: "The proceeds of excavations may be divided between the excavator and the competent Department in a proportion fixed by that Department." ${ }^{n 8}$ The document offers nothing about arrangements for any local museums. But the Mandate did improve safety for visits to Petra: the Bedouin were cowed, or if rowdy, vigorously pursued, by the Transjordanian Legion; and, as a result, "European and American ladies run but a very slender chance of being carried off by some wild Arab sheikh and must fall back upon such romantic incidents as may happen in Petra's tents." ${ }^{[91]}$ As with Syria, so with the British Mandate a Department of Antiquities was established in 1920, which in the 1930s saw excavation at Khirbat al-Mafjar and Qasr al-Heir West and in the 1960 s at Qasr al-Heir East. ${ }^{59}$ What should be dug is still a hot topic, with the influence of the Bible sometimes eclipsing attention to the monuments of Islam:

Palestinian archaeologists accuse biblical scholars of neglecting Islamic sites and overlooking Islamic layers not only because they lack interest, but also because they lack knowledge of Islamic civilization and culture. ${ }^{60}$

$5^{8}$ El-Eini 2006, 465-466, Mandate Article 21, notes $7 \& 8$.

59 Vernoit 1997, 6, including the development of Islamic archaeology.

6o Pollock \& Bernbeck 2005, 71.
[1] Mislin_1876_II_620
[2] Michaelis_1908
[3] EB_1910 SV
[4] Pingaud_1887_41
[5] Ferrières-
Sauveboeuf_1790_I_ 210-211
[6] Flinders_Petrie_1918_ 84-85
[7] AMSL_1890_Table
[8] Flinders_Petrie_1918_88
[9] Flinders_Petrie_1918_1
[10] Berners_1876_38
[11] La_Salle_1840_I_363
[12] Porter_1868_I_xlviii-xlix
[13] PEF_Committee_ 1873_14B
[14] AJ_VI_1849_86
[15] AR_I_1888_189-190
[16] Conder_\&_ Kitchener_1883_443
[17] Conder_\&_ Kitchener_1883_176
[18] Mislin_1876_III_124
[19] Conder_1891_242-243
[20] Merrill_1881_6o
[21] Schumacher_1889_ 241-242



[33] PEFQS_1877_40
[34] Conder_1891_4
[35] De_Hass_1887_147
[36] Wilson 1871_256
[37] Wilson 1871_XIV
[38] Butler_1930_2
[39] Butler_1930_83-84
[40] Butler_1930_93
[41] AMS_IV_1867_327-328
[42] Omont_1902_60
[43] Masson_1896_507
[44] Omont_1902_274
[45] Omont_1902_332
[46] Lucas_II_1720_321-345
[47] Omont_1902_528
[48] Omont_1902_677
[49] Omont_1902_1046
[50] Omont_1902_414
[51] Saulcy_1853_I_34
[52] Saulcy_1853_I_42
[53] Saulcy_1853_I_110
[54] Saulcy_1853_I_587

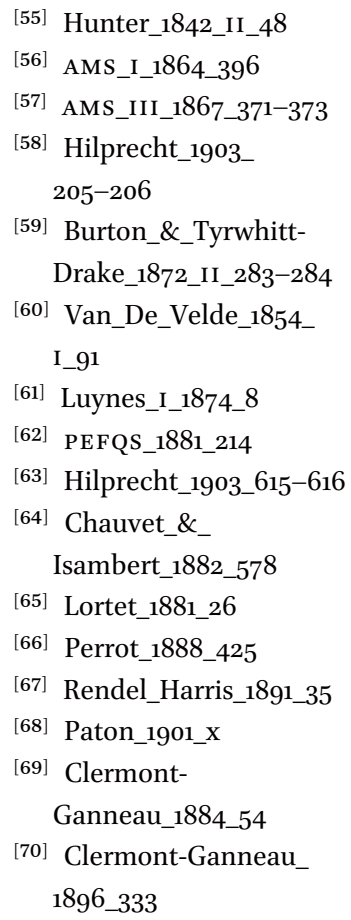

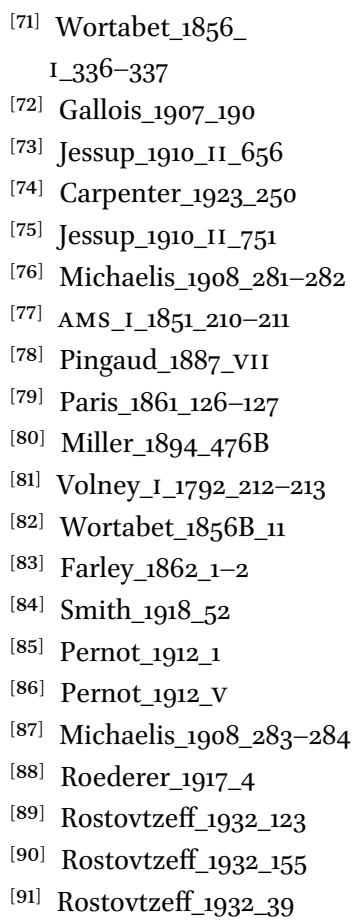




\section{Conclusion}

This book has analysed the descriptions and information provided by travellers who wrote about the monuments of Greater Syria, and their experiences when they visited the region; periodicals and associations dedicated to archaeology joined travel books as another rich resource on the country and its treasures. Its aim has been to enable today's readers to understand how and why some of her monuments disappeared, while so many survived. Because of its sources, it has approached the region from a European perspective. Westerners were convinced by about 1800 that the Ottoman Empire was collapsing, because it could or would not modernise sufficiently quickly, and because its population, infrastructure and monuments were embedded in the "Eternal" (hence unchanging) East. Such an assessment, encouraged by reference to a focussed reading of the Bible, rather than to changes everywhere apparent, was proved false in the course of the 19th century. Indeed, many visitors were alarmed by the very speed at which change was happening, population increasing, and old building stock being torn down for re-use in new structures. In those years before governments wrote their own reports or set up official commissions, travellers' accounts are the key to our understanding of the vicissitudes faced by Syria's monuments.

The majority of travellers came from the United Kingdom and France, plus Germany and, increasingly, the USA. Their backgrounds and interests were varied: diplomacy, trade, and frequently Grand Tour sensitivity to the monuments of the ancient world. Palestine was the first focus of Christianity, and Western involvment in the region dates from the Crusades which, although successful in the Iberian Peninsula, eventually failed to defeat and marginalise the Muslims in the Middle East. That European presence also failed to reverse history and enable Christianity to re-establish itself as the controlling religion and the largest population in the region. Following the collapse of the Crusader Kingdoms which encouraged settlement, pilgrimage was left as the thread joining the Christian past to the present, with evidence of churches left in ruins, or converted into mosques. Pilgrimage enjoyed increasing numbers from the mid-19th century, encouraged by evangelism back home, by an increased emphasis on the veracity of the Bible in the face of Darwinism and science, and by easier travel and greater safety in Palestine. Before Zionism, there were no more than a few speculative reveries about possibilities for colonisation. ${ }^{1}$

1 Grishina 2012: New but different Biblical reasons for travelling to Palestine, including Zionism. 
Authors' briefings on Greater Syria should sometimes be balanced against the past history of the Ottoman Empire and always against Muslim attitudes to and actions against Christians, which Dalrymple sets in today's context. ${ }^{2}$ The Ottomans had once been very dangerous to the West. They had after all threated Europe via Malta (siege 1565) Vienna (second siege, 1683), and relief was general that they failed, hence perhaps the nervous feelings of superiority so frequently evinced by Western travellers (which are far different from what some might try to define as Orientalism). The constant theme of Westerners was the decline of the Empire, illustrated at length, again with relief that the Sick Man of Europe was easier to cope with than the previous incarnation as Terror of the World. Several travellers commented that the Empire was a mix of nations and languages, and listed prejudicial actions and taxes against their Christian and Jewish subjects.

The above chapters have also demonstrated the contribution of map-making and exploration as path-finders opening Syria more extensively for trade and popular travel. The 19th century was addicted to geography (concentrating not only on Africa and distant Asia, and the race to empire), and could read about the expansion of the knowledge of European powers in books and popular magazines, frequently illustrated, sometimes well. While our travellers were extending the Grand Tour to lands written about for centuries, we should also be clear that they were little more than that: although they recount many difficulties (some no doubt detailed simply to add some salt for consumption back home), they were not in most cases explorers. Of this completely different genre the 19th century saw many in North America, Sub-Saharan Africa, Asia and Australasia. In such far-lying continents there were no ambassadors, consuls, friendly residents, traders from home, or postal possibilities, let alone recognisable languages. To such territories there were no maps, and explorers had to plot them as they went, whereas Syrian travellers covering very modest distances usually had some maps to rely on or rail against. Yet as we have seen, in some areas they still faced difficulties and danger, contending against wildly inaccurate maps, or plotting their own. In general the less known the area, the safer its monuments stood, at least until the age of mass tourism.

Naturally, attitudes local and European impacted on the ways in which the monuments of Syria were treated and their features discussed. Europeans were ringing alarm bells throughout the 19th century as monuments degraded and were demolished for re-use as building materials by an expanding population. They usually saw this as a barbarous activity, forgetting or not knowing about similar if distant practices in the West, such as followed the Dissolution of the

2 Dalrymple 1997. 
Monasteries in Britain, when so much spolia stone became available, and so many buildings begging for re-use.

Our travellers also retailed stories about fanatical Muslims who, concentrated in towns such as Damascus and Jerusalem, kept Christians well outside (and sometimes out of close sight of) their great mosques. It is because of such restrictions that this book has concentrated on ancient monuments; had the locals been more accommodating, Westerners would have learned more about Islamic monuments, written down their observations, and thus filled in those many gaps which still remain about their sources and development. Hence it should be acknowledged that it is not from Ottoman authors but rather from Western accounts that we learn about Muslim as well as ancient architecture. And if it is legitimate to claim (as already noted) that the study of Islamic art and architecture lags behind even today, it must equally be asserted that denial of access to important Muslim complexes was scarcely helpful (many mosques across North Africa are still closed to non-Muslims). Travel accounts discussing architecture and ancient sites and written in Arabic and Turkish cannot be found to parallel Western texts. Whether Westerners did or did not view Greater Syria through the distorting lens of Orientalism is beside the point, because without their accounts charting the survival and destruction of monuments our knowledge of their history and development would be just about non-existant.

Tones of disapproval are detectable in many of the cited accounts of Western digs in Syria and of the appropriation of antiquities (whether by stealth, diplomacy, money or mandate) with which to populate museums back home. Presumably the alternative might have been to place finds in some local museum (had these existed), since leaving them on-site was to invite destruction. The dilemma was insoluble until more local museums were founded, since shipping everything to Constantinople's Ottoman Imperial Museum (founded 1868) was not practical, and that institution was not universally admired: by 1911 "the Turkish Museum contains some good classical sculpture and a great deal of rubbish." ${ }^{[1]}$ A comprehensive account of Western museums and Middle-Eastern sites would require another and different book.

Museums in the West have been on the defensive since the development of museology as an academic discipline, because when it deals with the Middle East it is usually bolstered by the twin narrratives of orientalism and colonialism, while in some collections the actual source of the object is left a mystery. Attempts at defence are regarded as arrogant complacency, especially by those (mandate-supporting?) visitors without Arabic to the National Museum in Damascus (founded 1919) grateful for the bilingual Arabic/French labelling. Conversely, visitors to the Louvre's very recently developed galleries 
containing material from Syria will find a few labels in Spanish and even English, but none in Arabic, the majority being exclusively in French. (Hiring audio guides in one's own language is no real substitute to deal with what the American military might call full-spectrum coverage of all exhibits rather than of a bijou selection.) Louvre labels are often very informative about the date and source of an object's acquisition, which is more than can be said for labels in London and Berlin. Is not provenance important, and should not all bestpractice museums display it on their labels? Is the lacuna modesty, lack of space, or embarrassment at how and when the object entered the collection? To amend a well-known quip, European and American museums certainly still have a lot to be modest about, as measured by court cases alleging exhibits improperly acquired.

Yet in spite of frequent and distasteful echoes of predatory greed in accounts of their looting, no alternative was available during the period covered by this book to the collection and export of Syrian artefacts by the Western powers. Have such actions saved objects which otherwise would have disappeared, as an updated version of the Elgin Defence? The Metropolitan Museum has acquired and imported an Egyptian temple; might we have wished them to have bought from Palmyra the Temples of Bel or of Baalshamin, both blown up by IsIs? When Syria is rebuilding, will Western museums empty their collections to populate museums in Syria? No. We can all agree that museum objects distant from the sites they attempt to illuminate are very much a second best, and that on-site museums are far preferable - until something goes wrong. As the Lebanese archaeologist Joanne Farchakh noted in 2012,

One of the problems is that for 10 years before the war, the Syrian regime established 25 cultural museums all over the country to encourage tourism and to keep valuable objects on these sites - many placed stone monuments in outside gardens, partly to prove that the regime was strong enough to protect them. Now the Homs museum has been looted - by rebels and by government militias, who knows? ${ }^{3}$

Today tourism, and the enjoyment of antiquities such as our travellers reported, are important earners of foreign currency, and not just in Syria: Turkey, Egypt and Tunisia, for example, are heavily reliant on the tourist trade, and all three countries have been hit by terrorist coups specifically designed to discourage tourists and hence cut that income. Our travellers in earlier centuries related often in great details the difficulties, dangers and cost of travel, but the chance

3 Independent, Sunday 5 August 2012, Robert Fisk: Syria's ancient treasures pulverised. 
of getting killed was smaller than that of disease, which the quarantine stations tried to control. Today travel is cheaper and speedier than ever, but current dangers are sometimes too great to attract tourists back to the Middle East, as an analysis of international flight passengers and hotel occupancy rates will make clear. Since tourism is one of the rationales for funding archaeology, when might we expect to see a healthy level of digging in Syria?

Yet time supposedly heals all. Reconstruction after civil war in Syria will be a lengthy process, although there are still plenty of standing monuments and important archaeological sites to attract the visitor today. As well as rebuilt towns and villages to attract refugees back to Syria, will there also be new museums to attract tourists and thereby help bolster the economy? Readers may inform themselves about the current fluid and confusing situation, and auguries for the future, by turning now to the Epilogue.

[1] EB_1911_s.v. Museums

of Art 


\section{Epilogue: The Monuments of Syria in 2016}

[The Holy Land] is one tourist destination, or actually part of a larger tourist destination that includes at least Jordan, Syria, Lebanon, and Egypt. There should be no doubt that maintaining archaeological sites and the protection of the Holy Land's cultural heritage can play a vital role in the economic revival of the country and the region as a whole. Economic viability will be one of the most crucial issues facing Palestine, Israel, and indeed the entire region in peacetime, and archaeologists have an important role to play in this regard. ${ }^{1}[2005]$

This book has detailed travellers' experience of and reactions to Greater Syria over the centuries, ending with a short account of how the 1914-18 war and the ensuing mandates affected the country and its monuments. This epilogue offers pointers to information sources on those monuments during the intervening century since the First World War, focussing on the past few years, when fighting and bombing have devastated the modern country of Syria. It attempts no political analysis, no more than any forensic distinction between freedom-fighers and terrorists of various stripes: see the cartoon showing a man holding a kalashnikov labelled as a "terrorist," and the same man holding a kalashnikov and an American flag as a "moderate terrorist."

It bears pointing out that, although much has been accomplished, ${ }^{2}$ there is still much detailed archaeological work to be done in Greater Syria: for example, the northern border is militarised, preventing work; ${ }^{3}$ many sites in Jordan remain to be excavated, and century-old sketch plans corrected and improved. ${ }^{4}$ Lebanon has also been devastated by civil war. As a general rule, it appears that over the past few years monuments outside towns have suffered less than those within them. For example, at Palmyra it was the modern town

1

2 Weiss 1997, 97: Twenty-seven Syrian archaeological reports are presented here, covering approximately two-thirds of the field research undertaken in 1993-1995 (fig. 1). The reports are listed alphabetically, as many of them summarize research across several distinct time periods.

3 Beaudry 2014, 255 .

4 Kennedy 2004, 23; 27: "without excavation, the current interpretations are uncertain at best and the reliance on inscriptions and typology is unwise... here has been a simplistic tendency to identify every square structure as a 'fort', and every 'fort' as Roman." 
(as distinct from the ruins, less harmed) which suffered perhaps 50\% damage. But Aleppo's monuments are clustered within or close to its walls, and suffered accordingly.

What follows does not include an update on the other countries I included within Greater Syria, namely Lebanon, Jordan, Gaza, Occupied Palestine or Israel. Inevitably, much of the information below is to be found on the internet, rather than in printed books, which are of fixed date. Naturally, plentiful images of Syrian towns and monuments are also to be found there. The internet offers not only continual updating, but also accounts of varying depth to suit all tastes, as well as a plethora of images, sometimes in distressing before-andafter pairs. Readers should note, however, that only some web pages are regularly updated, and many offer a snapshot marooned in time, for circumstances can sometimes change rapidly. But the amount of information the internet provides, and the quantity of images, is very large. Wikimedia Commons, for example (https://commons.wikimedia.org/wiki/Main_Page) is a database of over 31 million images, of which there are plenty of Greater Syria; https://www .facebook.com/ offers large quantities of images, videos and comment; while http://archnet.org/ offers an "Extensive multimedia library on the built environment of Muslim societies across the world." A few of the websites listed below are recent creations, and some of their assertions express potential, and not yet achievement.

Note that the offerings below are merely samples, and not comprehensive. They do not repeat bibliographical items referenced in the body of the book, and offer only a brief bibliography on Syrian monuments and their research over the past century. Wikipedia, like any encyclopaedia, should be used with caution, but is invaluable for its images and links as well as text.

\section{Syria: Timelines}

http://www.asor-syrianheritage.org/resources/heritage-timeline/ from 2014. https://en.wikipedia.org/wiki/History_of_Syria https://en.wikipedia.org/wiki/Timeline_of_the_Syrian_Civil_War https://reeseerlich.com/syria-timeline/ Syria 1914 to the present day. http://www.worldatlas.com/webimage/countrys/asia/syria/sytimeln.htm зооовС to present. 


\section{History of Archaeology and Travel in Syria}

Since the accounts written by our travellers, over 1300 sites in Syria and Lebanon have been excavated or surveyed. ${ }^{5}$ Some of these fall within the purlieu of Levantine archaeology where, as Wikipedia relates, they are "marked by a degree of acrimony not shared in other area studies in the field that is often influence by the complex politics of the region. Classical archaeologists who consider Biblical scriptures to be legitimate historical documents have been attacked by alternative archaeologists who consider the data from excavations as being incompatible with the Biblical historical record." 6 Given the attitudes and disagreements around the Bible recounted in Chapter Two, such divisions are not surprising.

http://arachne.uni-koeln.de/drupal/ "Arachne is the central Object database of the German Archaeological Institute (DAI) and the Archaeological Institute of the University of Cologne... Arachne is intended to provide archaeologists and Classicists with a free internet research tool for quickly searching hundreds of thousands of records on objects and their attributes."

http://www.archive.org This invaluable site store large quantities of freely downloadable out-of-copyright materials on a host of subjects. A search for "Syria" (or Lebanon, Palestine, Jordan, etc.) will produce over 8,0oo hits (texts, images, movies, audio) which can then be ordered (for example) by "date published" (when the most recent additions will be at the top) or "date archived." The entries are presented discursively, but unchecking the "show details" box will yield just title, date and creator.

http://gallica.bnf.fr for a large collection of downloadable out-of-copyright texts and images, fronted by a search engine. The focus is largely but not exclusively French. Why does the United Kingdom, let alone the USA, have nothing similar?

http://www.ub.uni-heidelberg.de/Englisch/helios/ for the University's large digital library.

http://digi.ub.uni-heidelberg.de/en/sammlungen/archaeologie.html downloadable archaeological literature for our region.

5 Lehmann 2002, 3: "The bibliography encompasses more than 1300 sites [including towns, in Syria and Lebanon]. Following approaches of landscape archaeology, the site concept includes all remains of human activity in the past. However, in most cases, a site in this bibliography is some kind of settlement. Sites listed here have usually been excavated. Although in some cases sites were included which have been only surveyed."

6 https://en.wikipedia.org/wiki/Levantine_archaeology. 
http://www.crlv.org/ Centre de Recherche sur la Littérature des Voyages.

http://www.csc.org.il/ Bibliography on Christianity in Palestine/Eretz-Israel.

This project was launched in the year 2000 on behalf of the Center for the Study of Christianity of the Hebrew University of Jerusalem.

http://www.ifao.egnet.net/archives-scientifiques/inventaire for Western travellers to the East.

http://www.ifporient.org/node/627 Institut français du Proche-Orient: La mission archéologique française en Syrie du Sud (up to 2011).

http://www.mae.u-parisio.fr/arscan/Atlas-et-guides-archeologiques.html Maison René Ginouvès: archaeological guide-books.

http://www.mae.u-parisio.fr/arscan/La-Syrie-du-Sud.html Maison René Ginouvès: Archéologie du Proche-Orient hellénistique et romain, La Syrie du Sud.

http://www.orient-latin.com/ Forteresses d'Orient (Lebanon, Syria, Jordan, Israel, Turkey).

http://www.persee.fr/web/revues/home/prescript/revue/syria for the journal Syria, published by IFPo. The top-level site http://www.persee.fr offers access to large numbers of scholarly papers on our region.

Chevalier, Nicole, "L'administration de la recherche archéologique française dans le Moyen-Orient du milieu du XIXe siècle à la Seconde Guerre Mondiale," thesis, Université Panthéon-Sorbonne, 1993. Chronicles the struggle between Ottoman authorities to protect and keep antiquities, against countries such as France which needed trophies for their museums. Chevalier, Nicole, La recherche archéologique française au Moyen-Orient 18421947, Paris 2002.

\section{Recent Political/Military Developments in the Region, and Their Sources}

Al-Rodhan, Nayef R.F., Herd, Graeme P., \& Watanabe, Lisa, Critical Turning Points in the Middle East, 1915-2015, London 2011.

al-Sabouni, Marwa, The battle for home. The vision of a young architect in Syria, London 2016. A feisty account of Homs; in Roger Scruton's assessment in his Foreward, "She gives a moving account of traditional Islamic architecture and the way in which its principles have been misunderstood or bowdlerized into architectural clichés. And she boldly criticizes the corruption that has surrendered her city to both materialist vandalism and hate-filled revenge." 
Ammon, Francesca Russello, Bulldozer. Demolition and Clearance of the Postwar Landscape, New Haven \& London 2016. Not about Syria, but about the "culture of clearance" that Syria will have to confront in any rebuilding phase.

Barr, James, $A$ line in the sand. Britain, France, and the struggle for the mastery of the Middle East, London etc. 2011. "What makes this venomous rivalry between Britain and France so important is that it fuelled today's ArabIsraeli conflict."

Çiçek, M. Talha, War and State Formation in Syria Cemal Pasha's governorate during World War I, 1914-17, London \& New York 2014. In the Routledge Studies in Middle Eastern History, which includes several titles pertinent to Syria.

Cockburn, Patrick, The rise of Islamic State: ISIS and the new Sunni revolution, London \& New York 2015.

Fisk, Robert, The great war for civilisation: The conquest of the Middle East, London 2005 .

Fisk, Robert, The age of the warrior: selected essays, New York 2008.

The Independent, Syria: Descent into the abyss, 2011-2014. An unforgettable anthology of contemporary reportage, London 2014.

Kamrava, Mehran, The modern Middle East. A political history since the First World War, 3rd edn Berkeley etc. 2013.

Lister, Charles R., The Syrian jihad:Al-Qaeda, the Islamic State and the Evolution of an Insurgency, Oxford 2015: "Where did the jihadists come from in the first place? How did they establish themselves, and what was their role in the revolution? What role did external actors play in facilitating the rise of jihadists and how might us-led and Russian intervention impact their status in Syria?"

McHugo, John, Syria: a history of the last hundred years, New York \& London 2015 .

McMeekin, Shaun, The Ottoman endgame. War, revolution and the making of the modern Middle East, 1908-1923, New York 2015.

Shehadeh, Raja, \& Johnson, Penny, eds., Shifting sands. The Unravelling of the Old Order in the Middle East, London 2015.

http://www.counterpunch.org for robust commentaries on recent events and Western involvment.

http://www.terrorismanalysts.com/pt/index.php/pot for a variety of conflicts, including Syria.

http://journalisted.com/robert-fisk?allarticles=yes articles by Robert Fisk about the Middle East, not just Syria. 


\section{Websites Detailing Syria's Monuments}

http://digitalarchaeology.org.uk "The Institute for Digital is a joint venture between Harvard University, the University of Oxford and Dubai's Museum of the Future that promotes the development and use of digital imaging and $3^{\mathrm{D}}$ printing techniques in archaeology, epigraphy, art history and museum conservation."

http://digitalarchaeology.org.uk/media/ 3D images of Syria archaeological treasures go online.

http://www.europeana.eu/ Over 5,000 results for "Syria," including over 2,000 images.

http://www.loc.gov/pictures/search/?q=syria offers over 1,200 results of largely out-of-copyright items, some of which are of albums with dozens of images.

http://www.manar-al-athar.ox.ac.uk/ Multi-media resource for the study of the Middle East.

http://www.millionimage.org.uk/ "The documentation of cultural heritage in areas affected by conflict or natural disasters, including through the use of new digital technologies, is a critical step to preserve the memory of our past and mitigate the risk of possible damage or loss of precious cultural assets ... One of the goals of the Million Image Database Project is to produce life-like $3 \mathrm{D}$ virtual models of at risk, damaged, and destroyed architectural archaeological objects."

http://monumentsofsyria.com/ Begun in 2011, the site is a window on Syria's past, with itineraries, by Ross Burns, from whom two books are also under way - a history of Aleppo and a study of the monuments of Lebanon.

"Ross has accumulated an archive of 80,000 photos and slides of archaeological sites, which he is planning to make available online through the Near Eastern Archaeological Foundation at the University of Sydney. Meanwhile, a foretaste of the archive can be seen at www.monumentsofsyria.com and at the Flickr site www.flickr.com/photos/monsyr/collections."

http://whc.unesco.org/en/statesparties/sy/ - Syria's World Heritage sites (Aleppo, Bosra, Damascus, Ancient Villages of Northern Syria, Krac des Chevaliers and Qal'at Salah El-Din, and Palmyra).

http://wnep.com/2015/o8/28/using-3d-cameras-to-save-antiquities-from-isis/ "Can 3-D cameras save antiquities from ISIS? A team of archaeologists has come up with a cheap $3 \mathrm{D}$ digital camera that can capture a record of buildings and artifacts - and they are sending thousands into hot spots in the Middle East and beyond."

http://www.syriaphotoguide.com/home "A comprehensive guide to the cultural and historic sites of Syria," by Daniel Demeter. This offers illustrations 
of sites by region, itineraries, maps and notes. Maps and sites are labelled in Arabic and English. Notification of new posts is available via email.

http://shirin-international.org "is an initiative from the global community of scholars active in the field of archaeology, art and history of the Ancient Near East. It brings together a significant proportion of those international research groups that were working in Syria prior to 2011, with the purpose of making their expertise available to wider heritage protection efforts. Accordingly, its International Committee includes the directors of a number of long-term international research programmes, and others who share their strong commitment to the effective protection of the heritage of Syria."

https://en.wikipedia.org/wiki/List_of_World_Heritage_Sites_in_Jordan (including Petra, Qasr Amra, Madaba and Wadi Rum).

http://www.smb.museum/museen-und-einrichtungen/museum-fuerislamische-kunst/sammeln-forschen/forschung-kooperation/erstellungdigitaler-kulturregister-fuer-syrien.html.

\section{Damaged Sites, Monuments and Museums}

http://www.aaas.org/geotech/culturalheritage "Ancient History, Modern Destruction: Assessing the current status of Syria's World Heritage sites using high-resolution satellite imagery." Executive summary 2014: "five of the six World Heritage sites exhibit significant damage ... except for the Ancient City of Damascus."

http://apsa2011.com/apsanew/ Association for the Protection of Syrian Archaeology, with useful links at http://apsa2011.com/apsanew/links/

http://www.archdaily.com/788316/ The V\&A Presents "A World of Fragile Parts" at the Venice Biennale's Applied Arts Pavilion: "The project will examine threats faced by global heritage sites and how copies can act as an aid in the preservation of cultural artifacts."

https://eca.state.gov/cultural-heritage-center/conflict-antiquities "The pioneering symposium brought together senior State Department officials, national and international law enforcement, museums, auction houses, dealers, and collectors to review international cooperation against the looting and trafficking of antiquities from the conflict in Iraq and Syria."

https://en.wikipedia.org/wiki/List_of_heritage_sites_damaged_during_... List of heritage sites damaged during the Syrian Civil War.

http://icom.museum/resources/red-lists-database/red-list/syria/ Emergency Red List of Syrian Cultural Objects at Risk. 
http://iconem.com/fr/heritage_syrien/ Renouveau. La technologie au secours du patrimoine syrien: "Le projet Syrian Heritage a pour but de créer une base de données digitale des monuments syriens, mais également de mettre en place une équipe nationale capable de l'enrichir continuellement. Nous considérons qu'il est de notre devoir commun de préserver la connaissance de l'histoire syrienne."

http://www.themissingexhibit.com/ Exhibition 2015/16 curated by Erin Thompson \& Thalia Vrachopoulos at CUNY: "The Islamic State in Iraq and Syria (ISIS) has engaged in a systematic campaign to destroy the past, smashing, bombing, and bulldozing irreplaceable cultural heritage across the region ... The Missing: Rebuilding the Past is the first exhibit to showcase the efforts of artists and scholars to resist IsIs and other forms of destruction of the past through creative and innovative reactions, protests, and reconstructions."

http://www.unesco.org/new/en/safeguarding-syrian-cultural-heritage/ Resolutions, initiatives, workshops, damage assessment.

\section{Photographic Evidence of Destruction in Syria}

Readers may wish to consult any of the many collections of photographs from the early zoth century, before reconstruction or restoration projects lay scheming hands on surviving monuments. Djemal Pascha's Alte Denkmäler aus Syrien, Palästina und Westarabien (Berlin 1918) offers high-quality photographs, with descriptive text for each monument. Updates on destruction have been regularly posted by European and American newspapers.

http://www.aaas.org/geotech/culturalheritage-SyrianTWHS-122014.html. https://www.rt.com/news/338187-palmyra-before-after-pictures/ of Palmyra show what Isis has destroyed.

https://www.facebook.com/Archeologie.syrienne?fref=nf_Le patrimoine archéologique syrien en danger.

http://www.theguardian.com/world/2014/jan/26/syria-heritage-in-ruins ... The Guardian, 26 January 2014.

\section{Guides/Surveys to Monuments and Regions}

Ball, Warwick, Syria: A historical and architectural guide, New York 2006. Burns, Ross, Damascus: A History, London 2007. 
Gates, Charles, Ancient cities. The archaeology of urban life in the ancient Near East and Egypt, Greece and Rome, 2nd edn. Abingdon 2011.

Gerster, Georg, \& Wartke, Ralf-B., Flugbilder aus Syrien von der Antike bis zur Moderne, Mainz 2003. 213 photos, plans and maps.

Hanson, William S., \& Oltean, Ioana A., eds, Archaeology from historical aerial and satellite Archives, New York etc 2013.

Kennedy, David, \& Bewley, Robert, Ancient Jordan from the air, Council for British Research in the Levant, London 2004. 216 colour photos.

Murphy-O'Connor, Jerome, The Holy Land. An Oxford Archaeological Guide from earliest times to 1700, 5th edn. Oxford etc 2008.

Stern, Ephraim, \& Lewinson-Gilboa, Ayelet, New encyclopedia of archaeological excavations in the Holy Land, 4 vols, Jerusalem 1993. Well illustrated site by site, with plans and photos, and with extensive bibliographies for each.

http://www.apaame.org/ Aerial Archaeology in Jordan Project, with an archive. https://dataverse.harvard.edu/dataset.xhtml?persistentId=hdl:1902.1/14011 Corona satellite photos declassified, including "Landscapes of Settlement and Movement in Northeastern Syria,"

https://www.flickr.com/photos/apaame/collections/72157644171507048/ Southern Hauran Survey: "The survey was concerned with locating and mapping the traces of all human activity in the region from earliest times up to the end of the Ottoman period (1919). 381 images.

http://lcweb2.loc.gov/frd/cs/sytoc.html us Library of Congress top-level directory, for access to early images.

http://www.lonelyplanet.com/syria for overview of travel information for Syria, with sections on the country's history, major cities, weather, and important sites.

http://monummamluk-syrie.org/ "site dédié aux monuments en Syrie médiévale (ou Bilad al-Sham), propose un inventaire des édifices construits durant la période Mamluk, période qui s'étend de 658/126o à 923/1517, au Proche Orient actuel. Cet inventaire repose sur l'ouvrage de l'archéologue allemand Michael Meinecke, Die Mamlukische Architektur in Agypten und Syrien (648/1250 bis 923/1517), paru en 1992."

http://www.state.gov/r/pa/ei/bgn/358o.htm u.s. Department of State background notes for an extensive overview of Syria.

http://www.syriatourism.org/index.php?newlang=eng Official Syrian Government tourism site. 


\section{Computer Reconstructions}

When structures have been blown up, as at Palmyra, simple rebuilding techniques are impossible. Scholars are examining ways of conjuring up (the term is surely appropriate?) destroyed buildings into three-dimensional images by means of existing photographs, from which full-scale reproductions can then be built. Computers are the key to such work, but readers should be aware that "virtual reality" is just that, and not the real world. Thus a computer model of Baalbek might construct an armature from photographs, and then fix the various elements using yet more photographs for colour and texture. The result could be impressive and all dimensions accurate, especially if laser measurement were involved, but the result would be a simulachrum, only a little more realistic than a model of the Eiffel Tower built from Lego or Fischer-Technik. The initial construction might be achieved with a computer graphics programme such as Autocad; but it is the computer which will build the representation of the monument, so the result remains a simulachrum. Note that it is the very technique of computer construction that cannot and never will exactly match reality, not the speed or subtlety of the hardware and software involved in the process. The initial building blocks for such reconstructions are high-quality and comprehensive suites of photographs. Most of the myriad images on the web are individual, and coherent and overlapping sequences are rare, because they must be carefully planned and executed. Do such sequences exist for any of the monuments of Syria?

Several other avenues toward realism in the representation of architecture and its environment are being explored. ${ }^{7}$ One is generating building models. A two-thirds scale version of Palmyra's Triumphal Arch, built using ${ }_{3} \mathrm{D}$ technology, was recently erected in Trafalgar Square, London, and is intended to travel. But this is not realistic, and such reconstructions can never be more than toytown evocations of the real world, in the manner of Disneyland.

But if building three-dimensionally accurate computer models will perhaps remain illusionary, one alternative is the construction of panoramas from sequences of adjacent views, which today's digital cameras and computers can easily produce. (see http://www.36o-foto.dk/index.html for a series of 360 -degree zoomable panoramas). But again there is the perennial problem

7 Amoruso, Giuseppe, Handbook of Research on Visual Computing and Emerging Geometrical Design Tools, 2 vols Milan 2016. The collection "combines aspects of geometry and representation with emerging tools for $\mathrm{CAD}$, generation, and visualization while addressing the digital heritage of such fields." 
generic to photographs, namely that such setups deal in two-dimensional façades, not really in volumes, because they are necessarily taken from one fixed point, which is the "eye" of the camera/viewer. However, such panoramas are often of very high quality, with the viewer sometimes able to see more (and in greater comfort) than by visiting the site itself. Such panoramas can also be linked together so that, for example, the viewer may take a tour of a site by clicking on a succession of hot points, moving from Room A to Room B to Exterior, and so forth. In this fashion, the computer-viewer can see exactly (no less and no more) what a visitor to the site itself will see.

\section{Conclusion: Warnings about Restoration}

An old archaeological conundrum asks whether the prehistoric axe that has had two handles and three new blades really is a prehistoric axe. "Original" and "restored" both seem simple terms, but the sad truth is that monuments get altered over the centuries, and we are unlikely ever to know the original state of most of them. Travellers visiting French cathedrals (or fortress-cities like Carcassonne) equipped with old drawings or early photographs should be startled by what they see, for 19th century "restoration" was more like whimsical "creation" or, if you prefer, arrogant and ignorant destruction. In present-day Germany, one travels far to discover an authentic old house or street, because many were flattened during the Second World War, and then exactly rebuilt (with original inscribed dates!) as if nothing untoward had ever happened to them. And in Athens, just how many tourists know or care that the gleaming Stoa of Attalos dates from $195^{2-56}$ ? Of mosques and churches in Syria that were once temples we might ask a similar question: what has time done to the country's artefacts? Our travellers have documented changes from temple to church to mosque, dismantled here, rebuilt there. So we must accept that many buildings are patchworks of dates and styles. Greater Syria has suffered earthquakes, fires, bombing, rioting, wars, Lloyd George, the Balfour Declaration, the Sykes-Picot re-mapping (not accepted), and two mandates. Her monuments have been stolen or gifted for European museums, and some have been bombed in Berlin, matching (as it were) the French bombing of Damascus. Recent scholarly attention has underlined the problems in dealing with antiquities in war zones. ${ }^{8}$

8 Kila 2013. 
We might predict that any reconstructions at Palmyra will be taken back to their ancient form, an easy case because of the virtual abandonment of the site in Late Antiquity. Krak des Chevaliers can be treated likewise, because it received no alterations after the Crusades. Baalbek has been dealt with a century ago, and all its Muslim fortress and palace elements stripped out to take it back to the original temples. But how will intricate and multi-monument environments such as Aleppo be dealt with? Its monuments accrued and changed over centuries, and restoration to the status quo would be enormously costly and time-consuming.

Much archaeological work over the past century has improved our knowledge of the country's past. Restored and reconstructed monuments (and some World Heritage classifications) have allowed us to see versions of monuments as they stood before the great 19th and 2oth century population expansion knocked so many of them down, and nibbled away at others for their building materials. The recent Civil War, with profligate use of heavy artillery and bombing, has trashed much of the country of Syria, and there have been wellpublicised attacks on monuments and museums in Iraq as well. Towns have been devastated, and complexes such as the commercial khans of Aleppo substantially destroyed. Will such complexes be rebuilt to their former state? This was not the universal choice after the Second World War, which is why I have included Ammon's Bulldozer. Demolition and Clearance of the Postwar Landscape in the bibliography.

We shall never be able to see Greater Syria as it appeared to the travellers whose accounts make up this book, and who so often provided details about what still stood and what was already disappearing one or two centuries before our own day. Furthermore, readers should be aware as hinted above that the very notion of "restoration" has been contentious since the implementation of the notion in earlier 19th century Europe. Restore the building to its original state? How, and on what authority?

Reconstruction is very different from restoration: if a structure has been brought down completely by earthquake, and lies complete but on the ground, just like a collapsed pile of dominoes, then it can easily be re-erected. Archaeologists with heavy lifting equipment and cranes presented with a large proportion of original elements can effect anastylosis, namely re-erecting a monument from its collapsed parts. Sites such as Aphrodisias, Ephesus and Pergamum demonstrate how effective this technique can be.

The ravages of war, then, are much more destructive than earthquakes, which so often toppled buildings and left their elements intact. Bombs flatten into rubble, rather than toppling, and the images of many of the towns of Syria post-war echo those of Berlin or Dresden in 1945. Oppenheimer, the 
1899 discoverer of the Aramean Royal Palace at Tell Halaf, "saved" the work by having its sculptures taken to grace the new Tell Halaf Museum in Berlin, until shattered into small pieces by Allied bombing in $1943 .{ }^{9}$

No doubt any repairable buildings in Syria will indeed be repaired, but many structures will need to be completely rebuilt from the ground up. Baedeker's guidebooks have appeared frequently in the above pages, guiding visitors to all that was worth seeing in Syria; the same publication (in the "Baedeker raids") famously helped the Second World War bombing raids on Germany, where there are few old town centres left standing - but plenty rebuilt, or rebuilding. The reconstruction of Dresden, for example, is scarcely finished. Perhaps the same will happen in Syria, but such work will take decades to complete. First the infrastructure of the country will need rebuilding, and then refugees welcomed back and temporarily rehoused. Skilled scientists and technicians, Syrian and perhaps also foreign, will need to be identified and trained for the enormous tasks ahead. Next large sections of towns will need to be rebuilt, and that enormous programme funded. Restoring and rebuilding monuments may be considered a priority, because the government may perceive the need to generate tourist revenue, which fluctuates according to perceived threats (cf. Tunisia, Egypt and Turkey). Eventually, alert travellers will no doubt distinguish between the genuinely old and the recently rebuilt, and Syria's splendour will shine once more.

9 Cf. http://ww2.smb.museum/smb/gerettete-goetter/index.php?node_id=4 for the Pergamon Museum exhibition publication Tell Halaf. Im Krieg zerstörte Denkmäler und ihre Restaurierung, Regensburg 2012. 
Michael Greenhalgh - 978-90-04-33460-1 Downloaded from Brill.com12/05/2021 10:56:24PM via Australian National University 


\section{Appendix \\ Brief Biographies of Traveller-Scholars}

The following scholars feature frequently in this book. A few others are commented under their name in the Bibliography of Sources. Further information on these and some of the many other travellers dealt with in this book may be obtained from national biographies, various encyclopaedias, or the internet.

Arvieux Laurent d' (1635-1702), French diplomat and traveller who spent twelve years in the Orient. His father was French Consul at Sidon, and Laurent arrived there in 1653, learning Arabic, Persian, Turkish, Hebrew and Syriac. He was himself Consul variously at Constantinople, Algiers and Aleppo. His Mémoires were published in 1735, in six volumes.

Bankes, William John, M.P., F.R.S. (1786-1855), explorer, Egyptologist, and collector, little recognized until recently, much of whose work on Greater Syria remained unpublished. But see Finati's memoirs, published 1830, which he translated; these I assume to be or to reflect Bankes' own unpublished account of his travels.

Buckingham, James Silk (1786-1855), English journalist and traveller, publishing on Palestine and Syria, and eventually Member of Parliament. Contentious and crusading by nature, his disagreement with William Bankes was only one of his fights.

Brünnow, Rudolf-Ernst (1858-1917) and his friend and colleague Domaszewski, Alfred von, (1856-1927) explored and photographed in 1897-8 the former Roman province of Arabia, which formed parts of Greater Syria. in the area that today comprises parts of Syria, Jordan, and Lebanon. Brünnow later held a chair at Princeton, and Domaszewski at Heidelberg.

Burckhardt John Lewis (1784-1817), Swiss orientalist who studied at Leipzig and Göttingen, London and Cambridge. Arrived in Aleppo in 1810, travelling throughout Syria and parts of Egypt, in Arab dress and disguised as a Muslim (as Sheikh Ibrahim Ibn Abdallah) and soon with fluent Arabic. He wrote journals and notes and, for our purpose, his Travels in Syria and the Holy Land was published in 1822 after his death.

Burton, Sir Richard Francis (1821-1890), explorer, translator, extraordinary linguist, orientalist, and prolific author, travelled to Mecca 1851-3. British Consul in Damascus from 1868 , but reassigned to Trieste in 1872 . 
Guérin, Victor (1821-1891), French university geographer and archaeologist. From the Lycée d'Alger in $185^{\circ}$ he moved to the École Française d'Athènes in 1852, and subsequently undertook missions in Greece and Greater Syria, as well as in Egypt, publishing his extensive results.

Irby Charles Leonard (1789-1845), a naval officer, accompanied by his friend Captain James Mangles, roamed across Syria, the Holy Land and Egypt, and together published Travels in Egypt and Nubia, Syria and Asia Minor, during the years 1817-18 in 1823. This, together with Burckhardt's account published the previous year, was one of the first thorough 19th-century accounts of the region.

Laborde, Marquis Léon de (1807-1869), French archaeologist and politician, first travelled to the East in 1827 , and among his many publications is his Voyage de la Syrie, of 1837, especially valuable (as is his Voyage de l'Asie Mineure, 1838) for the quantity and quality of the drawings of monuments included.

Le Strange, Guy (1854-1933), English scholar and linguist, translator of Arabic texts, wrote extensive accounts of the historical geography of the Middle East, based on largely mediaeval Arabic sources.

Michaud, Joseph-François (1767-1839), and his collaborator Poujoulat, Jean-JosephFrançois, (1808-1880), were both historians and journalists. They wrote on the Crusades, and their Correspondance d'Orient, $1830-1831$ is frequently quoted in this book.

Pococke, Richard (1704-65), English clergyman and eventually a bishop, was educated at Oxford. He travelled to Alexandria in 1837 , and eventually reached Jerusalem and Baalbek, returning to England in 1742. The first volume of his Description of the East (Egypt) appeared in 1743, and vol II (Palestine, Syria, etc.) in 1745 .

Porter, Josias Leslie (1823-89), Irish clergyman, ordained 1846 after theological studies at Edinburgh. Went to Damascus in 1849 as a missionary to the Jews. Travelled widely in Palestine, publishing Five Years in Damascus in 1855, and in $185^{8}$ the Handbook for Travellers in Syria and Palestine for John Murray. He returned to Ireland in 1859, and to a chair, writing his The Giant Cities of Bashan and Syria's Holy Places in 1865, and numerous encyclopaedia entries.

Rey, Emmanuel Guillaume (1837-1916), French archaeologist and orientalist, wrote on French colonies in Crusader Syria, and on their fortresses. His Voyage dans le Haouran et aux bords de la Mer Morte appeared in 1861. 
Robinson, Edward (1794-1863), and Smith, Eli, (1801-1857). Robinson was an American biblical scholar, with Hebrew, Greek and German, and a pioneer of biblical geography, studying from 1837 for three years in Palestine and Germany. He travelled in the Holy Land with Eli Smith, who graduated from Yale in 1821, arrived in Beirut in 1827, and was put in charge of the missionary press, with its Greek, Italian and Armenian fonts, to which he added Arabic. Together they published Biblical Researches in Palestine in 1856. According to PEF_1873_7, Robinson was the first who "conceived the idea of making a work on Biblical Geography, to be based, not on the accounts of others, but on his own observations and discoveries."

Saulcy, Félicien de (1807-1880), French archaeologist, numismatist, museum conservator, and one of the founders of scientific biblical archaeology. Travelled to the Middle East in 1845, 1850 and 1863, and published extensively.

Seetzen, Ulrich Jasper (1767-1811), German explorer who spent six months in Constantinople, then went to Smyrna, thence to Aleppo. Here, from November 1803 to April 1805, he studied Arabic and local customs. He travelled through Palestine and Sinai April 1808 to March 1809, and wrote at length about what he saw.

Taylor, Baron Isidore-Justin-Severin (1789-1879) was a French soldier and polytechnician, with links to archaeology (he had the Luksor Obelisk brought to Paris in 1833) and the fine arts, being Inspecteur des Musées and (in 1869) senator. He travelled and published widely, including La Syrie, l'Égypte, la Palestine et la Judée in 1838, travelling and writing here as Laorty-Hadji.

Tristram, Rev. Henry Baker (1822-1906), biblical scholar and dedicated traveller, visiting Palestine in $1858,1863,1872$, and again in 1881 . The land of Israel (1865) and The land of Moab (1874) are two of his many publications.

Volney, Constantin-François Chassebœuf, comte de (1757-1820), French politician, orientalist and enlightenment philosopher, spent $1782-7$ in the East, and published his Voyage en Syrie et en Égypte pendant les années 1783, 1784, et 1785 in two volumes in 1787. His often lugubrious The ruins: or a survey of the revolutions of empires of 1790 drew inspiration not only from his own experiences in France and America (he was solidly anti-Napoleon), but also from his travels in Syria. 


\section{Bibliography}

\section{Sources}

Addison, Charles Greenstreet, of the Inner Temple, Damascus and Palmyra: a journey to the East with a sketch of the state and prospects of Syria, under Ibrahim Pasha, 2 vols, Philadelphia 1838. Good descriptions of the monuments.

Aboulfeda [b. 1273 Damascus, d.1331], Géographie, ed. Reinaud, 2 vols, Paris 1848, Aboulfeda_1848_I_II-XXXVI for A's biography.

Affagart, Greffin, Relation de Terre Sainte (1533-1534), Chavanon, J., ed., Paris 1902.

Ali Bey, Voyages en Afrique et en Asie pendant les années 1803, 1804, 1805, 1806 et 1807, III, Paris 1814. This traveller procured access to many places, in his assumed character, to which Christians were not permitted to go. [Larousse: Badia y Lebligh (Dominique), aventurier espagnol, né en Biscaye en 1766. mort à Damas en 1818. Il apprit l'arabe, se fit circoncire, et prit le nom musulman de Ali-Bey. De 1803 à 1807, il visita le Maroc, l'Egypte, La Mecque, la Syrie. Constantinople, puis revint en Espagne où il fut prêlet sous Joseph Bonaparte. En 1813, il se réfugia en France, puis fit un nouveau vovage eu Orient, où il mourut empoisonné, dit-on. Il a publié, sous le titre de Voyage d'Ali-Bey-el-Abassi (Paris, 1814), une relation qui offre le plus vif intérêt.]

Allen, Richard, Letters from Egypt, Syria and Greece, reprinted from the General Advertiser, Dublin 1869 .

Allen, Captain William, The Dead Sea: a new route to India; with other fragments and gleanings in the East, $\mathrm{I}$, London 1855 .

Al-Muqaddasi, (c.985) The best divisions for knowledge of the regions, trans. Collins, Basil, Calcutta 1897 .

—, Description of Syria, including Palestine, ed. trans. Le Strange, Guy, London 1886.

Andrews, Rev. Emerson, Travels in bible lands, Boston 1872.

Aramon, M. d', Ambassadeur pour le Roi en Levant, Le voyage de Monsieur d'Aramon, escript par le noble homme Jean Chesneau, Schefer, Charles, ed., Paris 1887. travelling 1549 .

Archives des Missions Scientifiques - abbreviated as AMs_vol_date_page.

Ariosto, Fra Alessandro, Viaggio nella Siria, nella Palestina, nell'Egitto fatto dal 1475 al 1478 , ed. Ferraro, Giuseppe, Ferrara 1878. Very little description of towns.

Aucher-Éloy, Rémi, Relations de voyages en Orient de 1830 à 1838; revues et annotées par M. le, comte Jaubert, 2 vols, Paris 1843 . Short entries only, and very few detailed descriptions.

Baedeker, Karl, Palestine and Syria. Handbook for travellers, 3rd edn, Leipzig 1898. -, Palästina und Syrien. Handbuch fur Reisende, Leipzig 1910. 
Bagatti, Ernesto, Dieci anni in Levante: reminiscenze, 2 vols, Milan 1857.

Barrault, E., Occident et Orient: études politiques, morales, religieuses pendant 1833-1834, Paris 1835 .

Basterot, Vicomte de, Le Liban la Galilée et Rome. Journal d'un voyage en Orient et en Italie septembrer 1867-mai 1868, Paris 1869.

Batissier, L., "Mission scientifique en Orient pendant l'année 1846 [to search for Crusader monuments]," in AMs_I_1851_198-211.

Ibn Battuta, Voyages: De l'Afrique du Nord à la Mecque, Yérasimos, Stéphane, ed., Paris 1982.

Beaufort, Emily A., Egyptian sepulchres and Syrian shrines, including some stay in the Lebanon, at Palmyra, and in Western Turkey, 2 vols, 2nd edn, London 1862. Rev.ed. London 1874. Travelled 1858. Detailed, sensible and interesting about people as well as monuments.

Beaujour, Baron Félix de, sometime consul général to Greece, Voyage dans l'Empire Othoman, ou description de ses frontières et de ses principales défenses, soit naturelles soit artificielles, II, Paris 1829. Also wrote Tableau du commerce de la Grèce, 1800.

Beauvau / Beauveau, Henry de, Relation journalière du voyage du Levant, Toul 1608.

Beawes, William, "Narrative of a journey from Aleppo to Basra in 1745," in Carruthers 1929, 1-40.

Belgiojoso, La Princesse de, Asie Mineure et Syrie. Souvenirs de voyages, Paris 1858. Travelling in $185^{2}$.

Bell, Gertrude Lowthian, The desert and the sown, London 1908.

Bement, R.B., Tyre; the history of Phoenicia, Palestine and Syria, and the final captivity of Israel and Judah, by the Assyrians, Alton IL 1858.

Berchem, Max Van, \& Fatio, Edmond, Voyage en Syrie I, Cairo 1914. For the maps.

Berger, Philippe (1846-1912), Notes de voyage: de Paris à Alexandrie, l'Egypte, la Palestine, la côte de Phénicie, la Syrie, le retour, Paris 1895.

Berners, Charles H., Two months in Syria in 1875; or, reminiscences of tent life, London 1876. With many unfascinating details about camping, baggage, mules, storms, etc.

Bertou, Jules de (Cte). Essai sur la topographie de Tyr, Paris 1843. Seems to include a lot of wishful thinking prompted by the chaotic ruins, especially the column shafts in the sea.

Besson, Le P. Joseph, La Syrie et la terre Sainte au XVII siècle, and edn, Poitiers / Paris 1862.

Binos, Abbé de, Voyage par l'Italie en Egypte, au mont Liban et en Palestine ou TerreSainte, 2 vols, Paris 1787. Done as letters home - a common device.

Bird, Rev. Isaac, Bible work in Bible lands, or, events in the history of the Syria Mission, Philadelphia 1872.

Bleaney, C.H., Modern Syria: an introduction to the literature, Durham 1979. Contains 984 items. 
Bliss, Frederick Jones, The development of Palestine exploration, New York 1906 - for an excellent chronological account, with chapters on the early years, the Age of Pilgrimage, The Crusades and after, From Fabri to Robinson, etc. with excellent index.

Blondel, Édouard, Deux ans en Syrie et en Palestine (1838-1839), Paris 1840.

Boucher de la Richarderie, G., Ex-Juge en la Cour de Cassation, et Membre de la Société française de l'Afrique intérieure, instituée à Marseille, Bibliothèque universelle des voyages, ou Notice complète et raisonnée de tous les Voyages anciens et modernes dans les différentes parties du monde, publiés tant en langue française qu'en langues étrangères, classés par ordre de pays dans leur série chronologique; avec des extraits plus ou moins rapides des Voyages les plus estimés de chaque pays, et des jugemens motivés sur les Relations anciennes qui ont le plus de célébrité, II [for volume dealing with Turkey] Paris 1808 - title says it all: a bibliography of what to read, with comments, and lengthy extracts. Cf IV Paris 1808, 387-431 for the rest of "La Turquie Asiatique" namely Syria and Palestine.

Bouchier, E.S., Syria as a Roman province, Oxford 1916. Good general account, from ancient authors and a few modern accounts. Demonstrates how much was knowable about Roman Syria without visiting that country.

Boullaye-Le-Gouz, Les voyages et observations, Paris 1653 .

Bourquenoud, Père Alexandre, Mémoire sur les ruines de Séleucie de Piérie ou Séleucie de Syrie, Paris 1860. In Syria 1858-1859.

Bourassé, Abbé J-J, La Terre-Sainte. Voyage dans l'Arabie Pétrée, la Judée, la Samarie, la Gililée et la Syrie, 2nd edn, Tours 1867.

Bovet, Felix, Egypt, Palestine and Phoenicia. A visit to sacred lands, Eng. Trans New York 1883. The first edition was written in 1858 ; this is a translation of the 8 th edition.

Bramsen, John, Travels in Egypt, Syria, Cyprus ... in a series of letters, 2nd edn, London 1820.

Breuvery, Jules-Xavier Saguez de, De Damas à Palmyre, fragment inédit d'un voyage en Orient, Saint-Germain-en-Laye 1848.

Breves, M. de., Relation des voyages de M. de Breves, tant en Grèce, Terre-Sainte etc., Paris 1628.

Brocchi, Giambatista, Giornale delle osservazioni fatte ne'viaggi in Egitto, nella Siria e nella Nubia, III, Bassano 1842. In Syria 1823-24. Mineralogist and botanist: cf. Wikipedia.

Bromfield, William Arnold, Letters from Egypt and Syria, London 1856. Not much on Syria.

Browne, W.G., Travels in Africa, Egypt, and Syria, from the year 1792 to 1798, London 1799. Brünnow, Rudolf Ernst, \& Domaszewski, Alfred v., Die Provincia Arabia auf Grund zweier in den Jahren 1897 und 1898 untergenommen Reisen und der Berichte früher Reisender, II \& III, Strasburg 1905 \& 1909. Essential reading with, as subtitle 
indicates, the accounts of earlier travellers. These are given in detail in their original language. These volumes offer the best-commented set of photographs, in profusion and large format, of the areas covered, together with plans and elevations.

Buckingham, James Silk, Travels in Palestine, through the countries of Bashan and Gilead, east of the River Jordan, including a visit to the cities of Geraza and Gamala, in the Decapolis, 2 vols, 2nd edn., London 1822. Travelling in 1816, with long descriptions of important towns, such as Jerash in vol II.

- Travels among the Arab tribes inhabiting the countries east of Syria and Palestine, London 1825. Interesting, discursive and detailed, as well as accurate, and transcribes many inscriptions in Greek and Latin.

-, Autobiography, 2 vols, London 1855. Bankes gets one mention, in vol II. He intended four volumes, but died after completing the first two; hence we have nothing from him herein on Syria, Bankes, or the dispute and court case.

Bunel, Louis, Jérusalem, la côte de Syrie et Constantinople en 1853, Paris 1854.

Burton, Richard F., \& Tyrwhitt Drake, Charles F., Unexplored Syria I, London 1872.

Busch, Moritz, Die Türkei. Reisehandbuch für Rumelien, die Untere Donau, Anatolien, Syrien, Palästina, Rhodus und Cypern, Trieste 1870. Lacking in the detail of Murray or Baedeker, with crude illustrations, and poor on antiquities.

Callier, Colonel C., Carte de la Syrie méridionale et de la Palestine dressée en 1835 . . . d'après ses observations et ses reconnaissances en 1832 et en 1833 , Paris 1840.

Campbell, John, Travels through Egypt, Turkey, Syria, and the Holy-Land, London $175^{8}$.

Camp, Maxime du, Egypte, Nubie, Palestine et Syrie. Dessins photographiques recueillis pendant les années 1849, 1850 et 1851; accompagnés d'un texte explicatif et d'une introduction historique, Paris $185^{2}$. The 125 photographs are largely of Egypt, but Jerusalem and Baalbek are included.

Canning, Stratford, The life of the right-honourable Stratford Canning...from his memoirs and private and official papers, Lane-Poole, Stanley, ed., 2 vols, London 1888.

Capper, James, Colonel, East India Company, Voyage en retour de l'Inde, par terre, et par une route en partie inconnue jusqu'ici, par Thomas Howel; suivi d'observations sur le passage dans l'Inde par l'Egypte et le grand désert, par James Capper, Paris 1796.

Caraman, Adolphe de, "Voyage de Homs à Palmyre et retour [in 1837]," in Bull. Soc. Géographie XIII 1840, 321-345, with plenty on negociating with the Bedouin for passage, and comparisons between Palmyra and Luxor.

—, "Aperçus généraux sur la Syrie," in Bull. Soc. Géographie XV 1841, 5-26.

Carmichael, John, "Narrative of a Journey from Aleppo to Basra in 1751," in Carruthers 1929, 129-179.

Carne, John, Recollections of travels in the East, London 1830.

, Syria, the Holy Land, Asia Minor etc., illustrated in a series of views drawn from nature, III, London \& Paris 1838. 
Carruthers, D., "The Great Desert Caravan Route, Aleppo to Basra," in Geographical Journal 52.3 1918, 157-184. For 16 th to 18 th century travellers.

Carruthers, Douglas, ed., The Desert Route to India, The Hakluyt Society, Second series, lxii, 1929, with useful and well-referenced introduction, xi-xxxv.

Casola, Pietro, Canon Pietro Casola's pilgrimage to Jerusalem in the year 1494, Newett, Margaret, ed., Manchester 1907.

Castlereagh, Viscount, M.P., A journey to Damascus through Egypt, Nubia, Arabia Petraea, Palestine and Syria, 2 vols, London 1847.

_- Catalogue d'une jolie collection d'objets d'antiquités... provenant de fouilles faites en Syrie, Paris 1853.150 objects briefly described - pottery, glass, medals, and some sculpture.

Chantre, Ernest, "De Beirout à Tiflis (à travers la Syrie etc.)," in Tour du Monde LVIII 1889, 209-304. Began 1881. Includes El-Barrah and Serjilla, but not much on either, and quotes de Vogué.

Chateaubriand, F.A. de, Travels in Greece, Palestine, Egypt, and Barbary, during the years 1806 and 1807,2 vols, London 1812.

Chauvet, Ad., \& Isambert, Émile, Itinéraire descriptif, historique et archéologique de l'Orient III: Syrie, Palestine, comprenant le Sinaï, l'Arabie Pétrée et la Cilicie, Paris 1882. Clarke, Edward Daniel, Travels in various countries of Europe, Asia and Africa IV, Greece, Egypt and the Holy Land, 4th edn, London 1817. Travelling 1799-1803. Described by Bar-Yosef 2005, 78, as "the first in a long succession of British Protestants who were obsessed with unearthing the actual locales of the New Testament events."

Clermont-Ganneau, Charles, Mission en Palestine et en Phénicie entreprise en 1881. Cinquième rapport, Paris 1884 .

—, Archaeological researches in Palestine during the years 1873-1874, II, London 1896.

, Archaeological researches in Palestine during the years 1873-1874, I, London 1899. Excellent and well-illustrated descriptions of the Haram al-Sharif, Holy Sepulchre etc.

Conder, Major Claude Regnier, Tent work in Palestine. A record of discovery and adventure, London 1887 .

- Syrian stone lore: or, the monumental history of Palestine, London 1889.

, Heth and Moab. Explorations in Syria in 1881 and 1882, 2nd edn, London 1889. Preface: "In this volume Captain Conder gives the more popular results of his short but most interesting and valuable campaign in 1881-82." Entered as Conder_1889B. , Palestine, 2nd edn, London 1891. (Leader of the Palestine Exploring Expedition). Recounts considerable trouble with robbers, assaults, expired firmans etc. Plentiful descriptions of dolmens and other megalithic monuments. He drew 150 dolmens in Moab alone. 
Conder, Lieut. C.R., \& Kitchener, Lieut. H.H., The survey of Western Palestine: memoirs of the topography, orography, hydrography and archaeology, I, sheets I-VI: Galilee, London 1881; II, sheets VII-XVI: Samaria, London 1882; III, sheets XVII-XXVI: Judaea, London 1883 - both authors Royal Engineers. The most frequent word in all these volumes is "ruins." The Survey does a very large amount of verbatim quoting from Guérin, Victor (1880) Description géographique, historique et archéologique de la Palestine, 7 vols, $1868-80$ - of which his La Terre Sainte (2 vols 1882-4) is a popular abridgement.

Conder, Josiah, The modern traveller I, III.II: Syria and Asia Minor, London 1824 \& 1830. Several sections quoted (or slightly re-worded) from accounts by Burckhardt, and no doubt from others as well.

Cook, Thomas, Cook's tourists' handbook for Palestine and Syria, London 1876.

—. Cook's Handbook for Palestine and Syria, London 1907, has 249 references to ruins, 25 to the Bible, 72 to destroy/destruction, and and 39 to the Old/New Testaments.

Coote, Sir Eyre, "Diary of a Journey with Sir Eyre Coote from Bussora to Aleppo in 1780 Communicated by Sir Woodbine Parish, from the original MS," in JRGS XXX 1859, 198-211.

Corancez, Louis-Alexandre-Olivier de (1770-1832), Itinéraire d'une partie peu connue de l'Asie mineure, contenant la description des régions septentrionales de la Syrie, Paris 1816.

Cuinet, Vital, Syrie, Liban et Palestine. Géographie administrative: Vilayet de Beyrouth, Paris 1896. Excellent summaries of the state of knowledge, including antiquities as well as population, manufactures and agriculture. Many of his descriptions are referenced by their distance from the railway, which he obviously used for his survey, and expected his readers to do likewise.

—, Syrie, Liban et Palestine. Géographie administrative: Mutésarriflik du Liban, Paris 1896.

— Syrie, Liban et Palestine. Géographie administrative: Vilayet de Syrie, Paris 1898. , Syrie, Liban et Palestine. Géographie administrative: IV, Paris 1901.

Curtis, William, Eleroy, To-day in Syria and Palestine, Chicago etc. 1903.

Curtis, George William, The Howadji in Syria, New York 1856.

Dacier, Bon Joseph, Notice sur les ouvrages de M. D'Anville, Paris 1802.

Damer, Mrs G.L. Dawson, Diary of a tour in Greece, Turkey, Egypt and the Holy Land, 2 vols, London 1841.

Damoiseau, Louis, attaché à la mission de M. De Portes, Voyage en Syrie et dans le Désert, Paris 1833. Left Marseille 1818.

Dandolo, Emilio, Viaggio in Egitto, nel Sudan, in Siria ed in Palestina (1850-51), Milan 1854 . 
Darboy, Georges, l'abbé, Jérusalem et la Terre Sainte, Paris 1852.

De Forest, J.W., Oriental Acquaintance; or, letters from Syria, New York 1856.

De Hass, Frank S., American Consul at Jerusalem, Buried cities recovered, or, explorations in Bible lands, rev.ed. Philadelphia 1887. His descriptions of monuments are straightforward and apparently well observed, although he writes of Djezzar Pasha's Mosque at Acre as still in existence, and some of his beliefs make him seem gullible.

Dehérain, Henri, "Lettres de William Henry Waddington sur son voyage archéologique en Syrie en 1861 et 1862," in Journal des savants 12 June 1914, 269-277.

Delaplanche, Jean-Constant-François, Le pèlerin: voyage en Égypte, en Palestine, en Syrie, à Smyrne et à Constantinople, 2nd edn, Livarot 1876.

Delaroière, M., Voyage en Orient, Paris 1836.

Deville, Capitaine Louis-Georges, Palmyre: souvenirs de voyage et d'histoire, Paris 1894. Depelchin, Paul, Souvenirs de Terre-Sainte, Paris 1877.

Deshayes de Courmenin, French ambassador at Constantinople, Voyage du Levant fait par le commandement du roi en l'année 1621, par le sieur D.C., Paris 1624. Good on contemporary politics, but only moderate on monuments.

D'Estourmel, [or Destourmel] le comte Joseph, administrator, and prefect under the Restoration, Journal d'un voyage en Orient $\mathrm{I}$, Paris 1844.

Deschamps, Barthélemi, Recollet de la Province de Flandre, Voyage de la Terre Sainte et du Levant, Liége 1678. With descriptions and histories of Tyre, Sidon, Caesarea, etc.

Dieterici, Dr. Fr., Reisebilder in dem Morgenlande. II: Sinai, Petra, Palästina, Berlin 1853. Dimashqi, Muhammad ibn Abi Talid al-, (born 1256), Manuel de la cosmographie du Moyen Age, ed. trans Mehren, A.F., Copenhagen 1874. Pays great attention to the fortresses of his day, and older ones as well. $15^{2}$ occurrences of the word forteresse in the text, not surprising given when and where he lived.

Djemal Pascha, A., Alte Denkmäler aus Syrien, Palästina und Westarabien, Berlin 1918. High-quality photographs, with text for each.

Doubdan, J., Le voyage de la Terre Sainte, Paris 1661.

Drummond, Alexander, нм Consul at Aleppo, Travels through different cities of Germany, Italy, Greece, and several parts of Asia as far as the banks of the Euphrates, London 1754.

Dupuis, Hanmer L., The holy places. A narrative of two years' residence in Jerusalem and Palestine, 2 vols, London 1856.

Duray, l'Abbé, La Terre Sainte illustrée, 2nd edn, Paris \& Tournai 1861.

Durbin, John Price, Observations in the East, chiefly in Egypt, Palestine, Syria and Asia Minor, 2 vols, New York 1845. Careful straightforward descriptions, bolstered from Robinson and Smith.

Dussaud, René, "Rapport sur une mission scientifique dans les régions désertiques de la Syrie moyenne," in France, Ministère de l'instruction publique, Nouvelles archives des missions scientifiques et littéraires, Paris 1902, 411-481 (then inscriptions). 
, Mission dans les régions désertiques de la Syrie moyenne, Paris 1903 [also in Nouvelles Archives des Missions Scientifiques et Litteraires 10 1902, 411-746].

Dussaud, René, \& Macler, Frédéric, Voyage archéologique au Safâ et dans le Djebel ed-Drûz, Paris 1901. Mainly concerned with inscriptions, with many details of the work and finds of their predecessors.

Edwards, Richard, La Syrie 1840-1862, histoire, politique etc., Paris 1862.

Edrisi, Géographie, trans. Ed. Jaubert, P. Amédée, I, Paris 1836.

Egerton, Lady Francis, Journal of a tour in the Holy Land, in May and June, 1840, London 1841.

Egmont, Aegidius van, \& Heyman, John, Travels through part of Asia Minor... Syria, 2 vols, London 1759.

Eiselen, Frederick Carl, Sidon. A study in oriental history, New York 1907.

Elliott, C.B., Travels in the three great empires of Austria, Russia and Turkey, 2 vols, London 1838 .

Ellis, Tristram J., On a raft, and through the desert. The narrative of an artist's journey through Northern Syria etc., 2 vols, London 1881. A careful observer and clear describer of architecture.

English Merchants, "An Extract of the Journals of Two Several Voyages of the English Merchants of the Factory of Aleppo, to Tadmor, Anciently Call'd Palmyra," in Phil Trans 19 1695-1697, 129-160. Travelling 1678. Entered as English_merchants_1678 and English_merchants_1691 (the dates of the two journeys).

Euting, Julius, Tagebuch einer Reise in Inner-Arabien I, Leiden 1896. Eutung produced 26 diaries and 10 sketchbooks from his travels in the ME and North Africa: available for download from Universitätsbibliothek Tübingen.

Eyriès, Jean-Baptiste-Benoît (1767-1846), Voyage pittoresque en Asie et en Afrique, résumé général des voyages anciens et modernes, d'après (then long list of his sources), Paris 1839 .

- Voyage en Asie et en Afrique, Paris 1859.

Fabri, Felix, The Book of the wanderings of Brother Felix Fabri (travelling 1480-1483), Stewart, Aubrey, trans., Palestine Pilgrims' Text Society 7, I Part I, London 1896; 8, I Part II, London 1896; 9; II part I, London 1893; 10, London 1893.

Failoni, Giovanni, Viaggio in Siria e nella Terra Santa, Verona 1833.

Farley, J. Lewis, late Chief Accountant of the Ottoman Bank, Beirut, Two years in Syria, London 1858. Deals with statistics, climate and excursions, for the merchant, the invalid, and the tourist respectively. Really a "How to Do Syria" book, with only barebones monument accounts.

-, The resources of Turkey, considered with especial reference to the profitable investment of capital in the Ottoman Empire, London 1862. Excellent succinct account of present state and potential, with figures.

, Modern Turkey, London 1872. 
- Egypt, Cyprus and Asiatic Turkey, London 1878.

Farren, John W., "Letter on the present state and prospects of Syria," in Lindsay_II_ 1838_239-341.

Febvre, Michel, Théâtre de la Turquie... Traduit d'italien en françois, par son auteur le Sr Michel Febvre, Paris 1682. [Sous le pseudonyme de Michel Febvre s'est caché le P. Justinien de Tours, capucin et missionnaire pendant vingt ans au Levant. Il a laissé plusieurs ouvrages écrits en arabe, entre autres une défense du Christianisme contre les Musulmans].

Ferrières-Sauveboeuf, comte de, Mémoires historiques, politiques et géographiques des voyages faits en Turquie, en Perse et en Arabie, depuis 1782, jusqu'en 1789, 2 vols Paris 1790.

Fermanel, Gilles, et al., Le voyage d'Italie et du Levant. De Fermanel, Fauvel, Baudouin De Launay, De Stochove. Contenant le de Gouvernements, Villes, Bourgs, Villages, Eglises, Palais, Mosquées, Edifices, anciens \& modernes; vies, mours des Turcs, Juifs, Grecs, Arabes, \&, Rouen 1670. Very similar phraseology to Stochove_1650.

*B* Feyler, Gabrielle, "Contribution à l'histoire des origines de la photographie archéologique: 1839-1880," in Mélanges de l'Ecole française de Rome. Antiquité 99.2 1987, 1019-1047. Includes its use on several missions to Syria.

Finati, Giovanni, Life and adventures, Bankes, William John ed., II, London 1830. Since Finati dictated his account to Bankes in Italian, and Bankes translated it and added notes, I have assumed that the extracts cited here are in effect the work of Bankes himself.

Fiske, Samuel Whelock, Mr. Dunn Browne's experiences in foreign parts, Boston 1857.

Fitzner, Rudolf, Aus Kleinasien und Syrien I, Rostock 1904. For imports and exports by tonnage and value.

Fleming, Wallace B., The history of Tyre, New York 1915.

Fletcher, Rev. J.P., Notes from Nineveh, and travels in Mesopotamia, Assyria, and Syria, Philadelphia $185^{\circ}$.

Flinders Petrie, William Matthew, Eastern exploration past and future, London 1918.

Forbin, Cte Auguste de, Voyage dans le Levant en 1817 et 1818, 2nd edn, Paris 1819.

Fowler, George, Turkey; or, a history of the origin, progress and decline of the Ottoman Empire, 2nd edn, London 1854. One of many books charting the Empire's decline, with particular emphasis on the 19th century.

Freese, Jacob R., Palestine, Syria and Asia Minor. Travel, incident, description and history, Philadelphia 1869.

Fuller, John, Narrative of a Tour through Some Parts of the Turkish Empire, London 1829.

Gabrieli, Francesco, Arab Historians of the Crusades, London 2010.

Gallois, Eugène (1856-1916), chargé de Mission par l'Instruction Publique, Asie-Mineure et Syrie (sites et monuments), Paris 1907. This author has also produced books on 
Burma, Indo-China, Oceanea and Japan. Generalised writing, although he claims (see 6) to have spent long months in the country.

Garnier, E.-Henri, Jérusalem et la Judée, description de la Palestine ou Terre-Sainte, Tours 1843 .

Gaskin, James J., Geography and sacred history of Syria, including Phoenicia, Palestine, or the Holy Land, with Idumea, made interesting, Dublin 1846. For students, as his Preface makes clear.

Gasparin, Catherine Valérie Boissier, comtesse de, Journal d'un voyage au Levant, par l'auteur des horizons prochains, 2nd ed., III: Le désert et la Syrie, Paris 1866 travelling 1848.

Gédoyn "le Turc," Consul de France à Alep 1623-1625, Journal et correspondance, Boppe, A., ed., Paris 1909.

Geramb, Marie-Joseph de, Monk of La Trappe, A pilgtimage to Palestine, Egypt and Syria, 2 vols, London 1840.

G.H., An excursion from Jericho to the ruins of the ancient cities in the country east of the River Jordan, London $185^{2}$.

Goodrich-Freer, A., In a Syria saddle, London 1905.

Goujon, Jacques, Histoire et voyage de la Terre-Sainte, Lyon 1670.

Graham, Cyril C., "Explorations in the Desert East of the Hauran and in the Ancient Land of Bashan," in Journal of the Royal Geographical Society 28 1858, 226-264.

Green, J., ed., A Journey from Aleppo to Damascus: with a description of those two capital cities, and the neighbouring parts of Syria, London, 1736. [2: "communicated to me by a friend."]

Griffiths, J., Travels in Europe, Asia Minor, and Arabia, London, 1805.

Guérin, Victor (1821-1891), "Rapports sur une mission scientifique en Palestine," in AMs I 1864, 373-422.

"Mission Scientifique dans la Terre Sainte," Troisième Rapport, in AMSL VII 1872, 408-430.

- "Rapports sur une mission scientifique en Palestine," in AMSL, 2nd series I, 1864, 373-390, 391-402, 402-420. Very concerned to let the Minister know that he got to site X first; it is not on any map; others scholars do not know about it, etc. And he makes long lists of sites visited - but doesn't give any indication of what he actually did when he got there.

—- Description géographique, historique et archéologique de la Palestine, Judée I Paris 1868; Judée II \& III, Paris 1869; Samaria I, Paris 1874; Samaria II, Paris 1875; Galilée I \& II, Paris 1880 - These volumes are conscientious descriptions of what he sees, down to the smallest village well with column-shafts.

, "Rapports sur une mission en Palestine," in AMSL 2nd series VII, 1872, 381-393, $393-406,408-430$. 
$5^{0}-63,64-8,78-98$.

—, Rapport envoyé par M.V. Guérin à M. le ministre de l'Instruction publique sur une nouvelle mission scientifique qu'il vient d'accomplir en Palestine, Paris 1884.

— L L Terre Sainte, son histoire ses souvenirs ses sites ses monuments, 2 vols 2nd edn, Paris 1884. Profusely illustrated, and pedestrian.

—, Guillaume de Tyr et ses continuateurs, Paris, Paulin, ed., 2 vols, Paris 1879 \& 1880. Written after 1184.

Guylforde, Richard, The pilgrimage of Sir Richard Guylforde to the Holy Land, A.D. 1506, Ellis, Henry, ed., London 1851.

Guys, Henri, Beyrout et le Liban: relation d'un séjour de plusieurs années dans ce pays, 2 vols, Paris 1850.

Guys, Henri, Beyrout et le Liban. Relation d'un séjour de plusieurs années dans ce pays, II, Paris 1850 .

—, Voyage en Syrie, peinture des moeurs musulmanes, chrétiennes et israélites, Paris 1855 .

Hahn-Hahn, Ida, Letters of a German countess; written during her travels in Turkey, Egypt, the Holy Land, Syria, Nubia etc. in 1843-4, II, London 1845.

Halifax, Dr William, "Relation of a voyage to Tadmor in 1691," in PEFQS for 1889, 273303. Transcribes many inscriptions.

Hamilton, Charles, Oriental zigzag or wanderings in Syria, Moab, Abyssinia, and Egypt, London 1875. "Record of two years travel in the East." A tourist rather than a traveller.

Hani, Nassralla, Guide de l'entrepreneur Nassralla Hani, de Beyrouth (Syrie). Entreprise de voyage pour les pays du Levant, Paris 1885 . Timings and costs for travel itineraries, with nothing to alarm the travellers, e.g. for Hauran, 12: Le voyage dans cette contrée est un peu plus difficile que celui de la Terre-Sainte.

Harff, Ritter Arnold von, Die Pilgerfahrt des Ritters Arnold von Harff von Cöln durch Italien, Syrien, Aegypten, Nubien, Palästina, die Türkei, Frankreich und Spanien, wie er sie in den Jahren 1496 bis 1499 vollendet, Cologne 1860.

Harman, Henry M., D.D., A journey to the Holy Land in 1869-1870, Philadelphia 1873. For Baalbek, simply quotes large chunks of Robinson.

Hasselquist, Frederick, Travels in the Levant, in the years 1749, 50, 51, 52, London 1766.

Haut-Commissariat de la République Française en Syrie et au Liban, La Syrie et le Liban en 1921. La Foire-Exposition de Beyrouth. Conférences. Liste des récompenses, Paris 1922. 191-207 Prost, "Le Tourisme en Syrie et au Liban."

Ibn Hawqal, [later 1othC] Oriental geography, trans Ouseley, William, London 1800.

Heber-Percy, Major Algernon, A visit to Bashan and Argob, London 1895.

, Moab, Ammon, and Gilead, London 1896.

Hill, S.S., Travels in Egypt and Syria, London 1866. 
Haussmann de Wandelburg, Mgr. A-H de, Études et souvenirs sur l'Orient et ses missions: Palestine, Syrie et Arabie, 2 vols, Paris 1883 . Tied to the religious route; e.g. his chapter VIII has as title Jaffa. Prophétie de Jonas. Vision de saint Pierre.

Henniker, Frederick, Notes during a visit to Egypt, Nubia, the Oasis, Mount Sinai and Jerusalem, London 1823 .

Herschell, Ridley H., A visit to my father-land, being notes of a journey to Syria and Palestine in 1843, London 1845. Not exactly true, since Herschell (father of Farrer Herschell, Lord Chancellor of England) was born in Strzelno, Poland, converted to Christianity, and helped found British Society for the Propagation of the Gospel among the Jews.

Hilprecht, Hermann V., Explorations in biblical lands during the 19thcentury, Philadelphia 1903. Excellent overview; mostly concerned with Assyria and Babylonia; useful thumb-sketches of travellers such as Rich, Buckingham, Layard and Ker Porter.

Hoole, W. Stanley, "Visit to the Holy Land in 1837," in Journal of the American Oriental Society 95.4 1975, 633-644 (by Midshipman Edward Clifford Anderson).

Houry, Charles-Borromée, De la Syrie considérée sous le rapport commercial, Paris 1842. Howe, Fisher, Oriental and sacred scenes from notes of travel in Greece, Turkey and Palestine, New York 1854.

Huart, Clément, Notes prises pendant un voyage en Syrie, extrait du Journal Asiatique, Paris 1879 .

Humann, Karl, \& Puckstein, Otton, Reisen in Kleinasien und Nordsyrien, Berlin 1896.

Hunter, W. Patison, Narrative of the Late Expedition to Syria under the Command of Admiral Sir Robert Stopford, 2 vols, London 1842.

Irby, Charles Leonard, \& Mangles, James, Travels in Egypt and Nubia, Syria, and Asia Minor, during the years $1817 \& 1818$, London 1823 .

Isidore of Seville, Etymologiarum, ed. Lindsay, W.M., I, Oxford 1911.

Jahn, Johann, Biblical archaeology, translated from the Latin, with additions and corrections, Upham, Thomas C., ed., Andover 1823. Deals with domestic antiquities, housing, nomads, agriculture, arts, sciences, commerce, clothing, etc. etc. There is no internal evidence that Jahn ever visited the sites, and everything is focussed on the biblical past, NOT on the present-day country. A good example of (a) putting the cart before the horse; and (b) painting out over 1500 years of subsequent history.

Jenour, Matthew, The route to India through France, Germany, Hungary, Turkey, Natolia, Syria, and the Desert of Arabia, London, 1791.

Jessup, Henry Harris, D.D., Fifty-three years in Syria, 2 vols, New York etc. 1910.

Joanne, Adolphe, \& Isambert, Émile, Itinéraire de l'Orient, ouvrage entièrement nouveau, Paris 1861. Excellent and detailed up-to-date guidebook, punctiliously offering a section called État actuel for most sites.

John of Würzburg, (1160-1170) Description of the Holy Land, London 1890. 
Jolliffe, Thomas Robert, Letters from Palestine, descriptive of a tour through Gallilee and Judaea ... and of the present state of Jerusalem, London 1819.

—_, Lettres sur la Palestine, la Syrie et l'Égypte ... fait dans l'année 1817, Paris 1820.

Jollivet-Castelot, François, Trois semaines en Palestine, Douai 1878.

Jones, George, Excursions to Cairo, Jerusalem, Damascus and Balbec, from the USS Delaware, New York 1836. Cruising 1834.

Jouannin, Joseph-Marie, Turquie, Paris 1840. Does not include any descriptions of Syria: this is a history of the Ottoman Empire.

Jowett, Rev. William, Christian researches in Syria and the Holy Land in 1823 and 1824 , 2nd edn, London 1826.

Kamal-ad-Din (1191-1262), Histoire d'Alep, Blochet, E., ed., Paris 1900, for earthquakes and the damage and great loss of life they caused.

Kelly, Walter Keating, Syria and the Holy Land, their scenery and people, London 1844.

Kennard, Adam Steinmetz, Eastern experiences collected during a winter's tour in Egypt and the Holy Land, London 1855.

Kenrick, J.: Phoenicia: Its Coasts, Climate, Products, Origins: with a Large Plan of Tyre, London 1855. Largely devoted to ancient Phoenicia, with the last chapter (433-455) being Phoenicia under the Greeks and Romans, and in the Middle Ages. Evidently all written from earlier works, rather than as a result of his own feet and eyes visiting the region. E.g. 457: "The Topography of Tyre is represented chiefly on the authority of Bertou, combined with the Admiralty charts."

Ibn Khaldoun, Les prolégomènes, trans ed. De Slane, Mac Guckin, 3 vols, Paris 1863, $1865,1868$.

Kinnear, John G., Cairo, Petra and Damascus in 1839, with remarks on the government of Mehemet Ali, and on the present prospects of Syria, London 1841. With a long account of dealing with dodgy sheikhs at Petra.

Kinneir, John Macdonald, Journey through Asia Minor, Armenia, and Koordistan, in the years 1813 and 1814 , London 1818 .

Khosrau, Nassiri, Sefer Nameh. Relation du voyage de Nassiri Khosrau en Syrie, en Palestine, en Égypte, années de l'Hégire 437-444 (1035-1042), trans ed. Schefer, Charles, Paris 1881. With appropriate parallel quotations from other Arabic authors cited at length in the footnotes.

Kitto, John, D.D., F.S.A., Scripture lands: described in a series of historical, geographical and topographical sketches, London $185^{\circ}$. His general index charts each name with scripture name, classical name, tribe, country, scripture refs, distance and bearing from Jerusalem, and modern country. No indication that Kitto ever visited the areahis book is to provide a commentary for the maps, which are not good enough to reproduce, because very small and detailed. A confected work, smelling of library oil and little more. 
Knox, Thomas W., The Oriental world, or new travels in Turkey, Russia, Egypt, Asia Minor, and the Holy Land, San Francisco 1879. Includes a large number of tediously jokey cartoons à la Punch, to match the often jokey text.

Laborde, Léon de, Voyage de la Syrie par Mrs Alexandre de Laborde, Becker, Hall, et Léon de Laborde, Paris 1837.

— Journey through Arabia Petraea, to Mount Sinai, and the excavated city of Petra, London 1836. By "excavated" he means cut from the rock.

Lamartine, Alphonse de, A pilgrimage to the Holy Land, 2 vols, New York etc. 1848. Travelling $183^{2}$.

Lammens, Henri, S.J., La Syrie. Précis historique, II, Beirut 1921. Excellent overview.

Laorty-Hadji, Le R.P., (Baron Taylor), first published 1838, La Syrie, la Palestine et la Judée. Pèlerinage à Jérusalem et aux lieux saints, 16th edn, Paris 1854. (Isidore Severin Justin, Baron Taylor - anagram is Laorty. Inspecteur des Beaux-Arts from 1838.)

Larènaudière, G. de, "J.L. Burckhardt, Voyage en Arabie, Analyse critique," in Nouvelles Annales des Voyages 1835 I, 105-119, 205-224. NB Arabia NOT Syria. 106: Il ne se borne pas même à étudier dans les universités de Leipsig et de Gœttingen l'arabe, cet idiome du monde musulman qui va remplacer, pour lui, les langues du monde chrétien. C'est dans l'Orient qu'il va se familiariser avec sa phraséologie et sa prononciation; c'est en Syrie qu'il va se métamorphoser complètement en sectateur du prophète y qu'il va s'exercer à toutes les privations du désert; là qu'il se fait à la sobriété des Bédouins, aux longues courses à pied, aux longues courses à cheval, plus fatigantes encore; là qu'il se promène tête nue au soleil de midi; là qu'il se couche à terre à l'ombre seule de son cheval; là qu'il dort dans le sable brûlant ou sous la bise froide des nuits; là qu'il vit de plantes sauvages et d'eau saumâtre; là qu'il s'habitue à tous les ennuis des solitudes, à ce rôle de Musulman si délicat au milieu de populations si défiantes; à ce rôle qu'un mot peut trahir et dans lequel sa tête était l'enjeu de tous les jours.

La Roque, Jean-François de, Voyage de Syrie et du Mont Liban, contenant la description de tout le pays, la description des ruines d'Héliopolis aujourd'hui Balbek, etc., 2 vols, Amsterdam 1723. Left Marseille May 1688. Long descriptions of Baalbek, where his party spent 14 days.

La Salle, Eusèbe, Pérégrinations en Orient, ou voyage pittoresque, historique et politique en Égypte, Nubie, Turquie, Grèce pendant les années 1837-38-39, 2 vols, Paris 1840.

Laurent, J.C.M., ed., Peregrinatores medii aevi quatuor, 2nd edn, Leipzig 1873.

Laurie, Rev. Thomas, Historical sketch of the Syria mission, Boston 1866.

Layard, A. Henry, Autobiography and letters from his childhood until his appointment as H.M. Ambassador at Madrid, I, London 1903.

Leandro di Santa Cecilia, F., Carmelite, Palestina ovvero primo viaggio in Oriente, Rome 1753 . 
Leary, Lewis Gaston, Syria, the land of Lebanon, New York 1913.

Le Brun, Corneille, Voyage au Levant. C'est-à-dire, dans les principaux endroits de l'Asie Mineure, de même que dans les plus Considérables Villes d'Égypte, de Syrie, et de la Terre Sainte, Paris 1714, Paris 1725.

Leclercq, Dom H., Manuel d'archéologie chrétienne II, Paris 1907.

Le Ray, Madame, Voyage aux ruines de Palmyre, Lyon 1885.

Leroux, Alcide. Esquisses sur l'Orient: Tyr, Sidon, Nantes 1882.

Le Strange, Guy, Palestine under the Moslems. A description of Syria and the Holy Land from A.D. 650 to 1500, translated from the works of the mediaeval Arab geographers, London 1890. Splendid book, with a superb index.

"A ride through Ajlun and the Belka during the autumn of 1884," in Schumacher $1889,268-323$.

— , "Account of a short journey east of the Jordan," in PEFQS 17-18 1885, 157-180. Revised from Schumacher's account.

Leval, André, Voyages en Levant pendant les XVI ${ }^{e}, X V I I^{e}$ et XVIII ${ }^{e}$ siècles: Essai de bibliographie, Paris 1897 .

Libanius, Antioch as a Centre of Hellenic Culture as Observed by Libanius, Norman, A.F., trans, Liverpool 2000.

Light, Henry, Captain of the Royal Artillery, Travels in Egypt, Nubia, Holy Land, Mount Libanon, and Cyprus in the year 1814, London 1818.

Lord Lindsay (Earl of Crawford \& Balcarres), Letters on Egypt, Edom and the Holy Land, 2nd edn, I, London 1839, first edn I, London 1838. With useful and extensive source notes, largely from earlier travellers.

Lithgow, William, The Totall Discourse of the Rare Aduentures, and painefull Peregrinations of long nineteene Yeares Trauayles, Lyon 1632.

Lombay, G. de, Au Sinaï, Palestine et Syrie, Paris 1892.

Lortet, Louis, Doyen de la Faculté de Médecine de Lyon, chargé d'une mission scientifique par M. le Ministre de l'Instruction Publique, "La Syrie d'aujourd'hui," in Tour du Monde XLI 1881, 1-16, 17-32, 33-48, 49-64, 65-80.

Louet, Ernest, Expédition de Syrie. Beyrouth, Le Liban, Jérusalem, 1860-1861. Notes et souvenirs, Paris 1862. With references to the excavations of Renan and Durighello, etc.

Lucas, Paul, Voyage du Sieur Paul Lucas, fait en MDCCXIV etc. par ordre de Louis XIV dans la Turquie, l'Asie, Sourie, Palestine, etc., I, Paris 1714; II, Amsterdam 1720.

Lusignan, Sauveur, History of the revolt of Ali Bey against the Ottoman Porte, including an account of the form of government of Egypt; together with a description of Grand Cairo, and of several celebrated places in Egypt, Palestine, and Syria; also the journal of a gentleman who travelled from Aleppo to Bassora, by S.L., London, 1783 .

Luynes, Honoré Théodoric, Duc de, Voyage d'exploration de la Mer Morte, à Petra, et sur la rive gauche du Jourdain. II, De Petra à Palmyre, de Jérusalem à Karak, 2 vols, Paris 1874. Travelling 1864. Punctilious, evidently recording everything he saw every 
day (and timed in hours and minutes), and good on ancient ruins, Roman roads, milestones, etc.

Lycklama a Nijeholt, T.M., Voyage en Russie, au Caucase et en Perse, dans la Mésopotamie, le Kurdistan, la Syrie, la Palestine et la Turquie: exécuté pendant les années 1866, 1867 et 1868 , IV, Paris 1875 . Includes plentiful quotes from earlier travellers.

Lynch, W., USN, Narrative of the United States' expedition to the River Jordan and the Dead Sea, London 1849.

Macbrair, R. Maxwell, Sketches of a missionary's travels in Egypt, Syria, Western Africa, etc. etc., London 1839.

Macedo, A. de. Pèlerinage aux Lieux Saints, suivi d'une excursion dans la Basse Égypte, en Syrie et à Constantinople, Paris 1867 .

Macleod, Norman, D.D., Eastward, London \& New York 1866.

MacMichael, William, Journey from Moscow to Constantinople, London 1819. Thomas Legh was one of Bankes' travelling companions, and his account was entrusted to MacMichael to write [here 184: "it is from the remarks he made on that journey, that I have been permitted to compose the narrative contained in the following Chapter"], to the surprise and annoyence of Bankes, for the publication would damage any book published in his own name. None ever appeared.

Madden, R.R., Travels in Turkey, Egypt, Nubia and Palestine in 1824, 1825, 1826 and 1827, 2 vols, London 1829.

Madox, John, Excursions in the Holy Land, Egypt, Nubia, Syria, etc., including an excursion to the unfrequented district of the Haouran, II, London 1834. Travelling 1824-5 (start of Vol. II). Repeated reference to fear of being attacked, plundered or killed. Does not spend long in the Hauran. His architectural descriptions are skimpy and uninteresting.

Maqdisi, Le livre de la création et de l'histoire, Huart, Claude, ed., II Paris 1901, III Paris 1903.

Marmier, X., Du Rhin au Nil. Souvenirs de voyage, III, Brussels $185^{2}$.

Mariano Morone da Maleo, Padre, Terra Santa nuovamente illustrata, 2 vols, Piacenza 1669.

Mme la Marquise de L, Esquisses de voyages 1862-1863, Metz 1866. Entered as Marquise_de_L_1866.

Mariti, Abbé G.F., travelling 1760-68, Voyages dans l'isle de Chypre, la Syrie et la Palestine, avec l'histoire générale du Levant, I, Neuwien 1791.

Martin, Eustace Meredith, A visit to the Holy Land, Syria and Constantinople, London 1883. Sketchy, and much bound to scripture. Spent nine months travelling.

Marten Michael, Attempting to bring the Gospel home. Scottish Missions to Palestine, 1839-1917, London \& New York 2006.

Martin, William Young, The East: being a narrative of personal impressions of a tour in Egypt, Palestine and Syria, London 1876. 
Marcellus, vicomte de, Souvenirs de l'Orient, 2 vols Paris 1839. Travelling 1820.

Marquette, Louise, A travers la Syrie: souvenirs de voyage, Lille 1892.

Mas Latrie, L., "Notes d'un voyage archéologique en Orient," in AMSL I 1850, 94-112.

Massenot, E., Excursion à Saïda (ancienne Sidon): fragment d'un voyage en Orient, Société des sciences naturelles et historiques, des lettres et beaux-arts de Cannes et de l'arrondissement de Grasse, séance du 26 mars 1873, Antibes 1873.

Masson, Paul, Éléments d'une bibliographie française de la Syrie, Marseille 1919. With chronological arrangement of 4,534 items and comprehensive indexes.

Masson, Paul, Histoire du commerce français dans le Levant au XVII siècle, Paris 1896.

Masudi, Les prairies d'or, ed. trans Barbier de Meynard, C, \& Pavet de Courteille, II, Paris 1863: III Paris 1864; IV Paris 1865; V Paris 1869.

Maundrell, Henry, A journey from Aleppo to Jerusalem at Easter, A.D. 1697, Boston 1836.

McCabe, James D., Pathways of the Holy Land, or, Palestine and Syria being a full description of those countries, their history, antiquities, inhabitants and customs, Philadelphia etc. 1875 .

Measor, Rev. Henry Paul, A tour in Egypt, Arabia Petraea, and the Holy Land, in the years 1841-2, London 1844.

Meistermann, Barnabé (1850-1923), Guide du Nil au Jourdain par le Sinaï et Pétra, sur les traces d'Israël, Paris 1909. Straighforward guide book, illustrated with photos.

Merrill, Selah, East of the Jordan: a record of travel and observation in the countries of Moab, Gilead, and Bashan, London 1881. Travelling 1875-7.

Meyer, Martin A., History of the city of Gaza from the earliest times to the present day, New York 1907.

Michaelis, Adolf, Ancient marbles in Great Britain, Cambridge 1882.

- A century of archaeological discoveries, London 1908.

Michaud, Joseph François, Bibliothèque des Croisades III: Chroniques d'Allemagne etc., Paris 1829 .

-, Bibliothèque des Croisades, Quatrième partie: Chroniques arabes, Paris 1829.

Michaud, Joseph-François, \& Poujoulat, Jean-Joseph-François, Correspondance d'Orient 1830-1831, I, Paris 1833 .

Millard, David, A journal of travels in Egypt, Arabia Petraea, and the Holy Land, $5^{\text {th }}$ edn, New York 1843.

Miller, D.L., Wanderings in Bible Lands, Mount Morris ILL 1894.

Mislin, Monsignor Jacques, Les saints lieux: pèlerinage à Jérusalem par l'Autriche, la Hongrie, la Slavonie, les Provinces Danubiennes Constantinople, l'Archipel, le Liban, la Syrie, Alexandrie, Malte, la Sicile et Marseille, 3rd edn., 3 vols, Paris \& Lyon 1876. Visited the Holy Land in 1848 and again in 1855; book first published 1858 . Allusive (with plentiful citations from authors ancient and modern), long and detailed, with much information on trade, agriculture and of course religion. This is a long 
book: vols. I (p. 672) II (p. 831) and III (p. 761). Interesting details, with much accurate historical information included - yet he cannot stop himself citing the Bible re. destruction of this or that town, which becomes tedious.

Mocquet, John, Travels and voyages into ... Syria, Jerusalem and the Holy Land, London 1696.

Monconys, Balthazar de, Journal des voyages, I, Lyon 1665. In Syria 1647-1648.

Monk, Charles James, The Golden Horn; and sketches in Asia Minor, Egypt, Syria, and the Hauran, II, London 1851.

Montague, Edward P., ed., Narrative of the late expedition to the Dead Sea, from a diary by one of the party, Philadelphia 1849. Zestful but mindless. Compare Lynch_1849 for an intelligent and detailed account of the same excursion.

Moore, Rev. Alan, Through Syria and Palestine. A trip by Canadian missionaries, Wakefield 1895. "simply the notes of a few days travel by tired missionaries, on the hills and in the dales of the land of Beulah."

Moore, Megan Bishop, \& Kelle, Brad E., Biblical history and Israel's past. The changing study of the Bible and history, New York 2011.

Mariano Morone da Maleo, Padre, Terra Santa nuovamente illustrata, 2 vols, Piacenza 1669.

Moudjir-ed-dyn (writing end 15thC), Histoire de Jérusalem et d'Hebron depuis Abraham jusqu'à la fin du XV $V^{e}$ siècle: fragments de la Chronique de Moudjir-ed-dyn traduits sur le texte arabe, Sauvaire, Henri, ed., Paris 1876. Detailed account, noting standing buildings and ruins, with many references to the use of marble.

Munk, S., Palestine. Description géographique, historique et archéologique, Paris 1845. With plentiful and extended quotes from earlier travellers, well footnoted, and often contrasting survivals they saw with the fewer remains in the mid-19th century.

Murray, John IV, John Murray III 1808-1892. A brief memoir, London 1919, wherein he claims Baedeker simply imitated his Murray guides.

Napier, Lieut-Col. E., Reminiscences of Syria, and fragments of a journal and letters from the Holy Land, 2 vols, London 1843 \& 1847. Travelled as part of a military mission to the Turks.

Naud, Père Michel (1631-1683), Voyage nouveau de la Terre Sainte, Paris 1702. Travelling 1667.

Neale, F.A., late attached to the consular service in Syria, Eight years in Syria, Palestine and Asian Minor, from 1842 to 1850 , I, London 1851.

Newbold, Captain, Frs, "On the Mountainous Country Portion of Asher between the Coasts of Tyre and Sidon and the Jordan," in Journal of the Asiatic Society III 1850, 348-372.

Newman, Rev. J.P., "From Dan to Beersheba," or, the land of promise as it now appears... with illustrations of the remakable accuracy of the sacred writers in their 
allusions to their native country, New York 1864. A very sensible book, so perhaps the subtitle is just a come-hither.

Niccolò, Fra, of Poggibonsi, A voyage beyond the seas (1346-1350), Jerusalem 1945.

Niebuhr, Carsten, Travels through Arabia and other countries in the East, 2 vols., trans. Heron, Robert, Edinburgh, 1792.

Noroff, Abraham von, Meine Reise nach Palästina, 2 vols Leipzig 1862.

Nugent, Lord, Lands classical and sacred, 2 vols, London 1846.

Oberhummer, Roman, \& Zimmerer, Heinrich, Durch Syrien und Kleinasien. Reiseschilderungen und Studien, Berlin 1899.

Olin, Rev. Stephen, Travels in Egypt, Arabia Petraea, and the Holy Land, II, New York 1843 .

Oliphant, Laurence, The land of Gilead, with excursions in the Lebanon, New York 1881.

- "A ride through 'Ajlun and the Belka during the autumn of 1884," in Schumacher 1889, 243-267.

Olivier, G.A., Voyage dans l'Empire Othoman, l'Égypte et la Perse, fait par ordre du Gouvernement, pendant les six premières années de la République, IV, Paris 1803.

Omont, Henri, Missions archéologiques en Orient aux XVII et XVIII siècles, 2 vols (continuously paginated) Paris 1902.

Oppenheim, Dr. Max Freiherr von, travelling 1893, Vom Mittelmeer zum Persischen Golf durch den Hauran, die Syrische Wüste und Mesopotamien, I, Berlin 1899. Very well illustrated with photographs, but on too small a scale to reproduce well.

Osborn, Henry Stafford, Palestine, past and present, with biblical, literary and scientific notices, Philadelphia $185^{8}$.

- The new descriptive geography of Palestine, Oxford Ohio 1877.

Palestine Exploration Fund Committee, Our work in Palestine being an account of the different expeditions sent out to the Holy Land... since the establishment of the Fund in 1865 , Toronto 1873. Excellent overview.

- Palestine Exploration Fund Quarterly Statement for authoritative descriptions of sites and excavations. Fund begun 1865. Abbreviated in endnotes as PEFQS.

Pardieu, le comte Charles de, Excursion en orient. L'Égypte, le Mont Sinaï, l'Arabie, la Palestine, La Syrie, le Liban, Paris 1851.

Paris, Comte de, Damas et le Liban. Extraits du journal d'un voyage en Syrie au printemps de 1860 , London 1861.

Parsons, Abraham, Travels in Asia and Africa. Including a Journey from Scanderoon to Aleppo, and over the Desert to Baghdad and Bassora, etc., ed. Berjew, John Paine, London, 1808. These travels were performed in $177^{-}-78$, and the account the result of sensible, attentive and careful observation and enquiry. From Scanderoon to Aleppo; over the desert to Baghdad etc. 
Paton, Lewis Bayles, The early history of Syria and Palestine, New York 1901. Includes a long index of от references.

Paul, Léon, Journal de voyage: Italie, Egypte, Judée, Samarie, Galilée, Syrie, Taurus cilicien, Archipel grec, Paris 1865.

Paxton, Rev. J.D., Letters on Palestine and Egypt written during two years' residence, Lexington KY 1839. Knowledgeable about geology, and interested in stones.

PEF, Twenty-one years' work in the Holy Land: (a record and a summary) June 22, 1865-June 22, 1886, London 1889. Published on the 21st anniversary of the PEF.

Peri, Oded, Christianity under Islam in Jerusalem. The Question of the Holy Sites in Early Ottoman Times, Leiden etc. 2001.

Pernot, Maurice, Rapport sur un voyage d'étude à Constantinople en Egypte et en Turquie d'Asie ( janvier-août 1912), Paris 1912.

Perrier, Edmond, La Syrie sous le gouvernement de Méhemet-Ali jusqu'en 1840, Paris 1842.

Perry, Charles, A view of the Levant: particularly of Constantinople, Syria, Egypt, and Greece... etc., London, 1743 .

Perthuis, comte de, Le désert de Syrie, l'Euphrate et la Mésopotamie, Paris 1896.

Petermann, H., Reisen im Orient I, Leipzig 1865. Travelling 1852.

Pfeiffer, Ida, A visit to the Holy Land, Egypt and Italy, London 1852.

Pickthall, Marmaduke, Oriental encounters. Palestine and Syria (1894-5-6), London 1918.

Pierotti, Dr. Ermete, Architetto Ingegnere di Terra Santa, La Palestine actuelle dans ses rapports avec la Palestine ancienne, Paris 1865.

— Rivista generale della Palestina antica e moderna, Florence \& Genoa 1866. All done from the biblical point of view, with a chronology (labelled FATTI) beginning with Abraham in 2197? BC; then does tribes of Israel, and the land divided Judea, Samaria etc. Provides itineraries of 15,30 and 60 days.

Pigeory, Félix, Les Pèlerins d'Orient. Lettres artistiques et historiques sur un voyage dans les provinces danubiennes, la Turquie, la Syrie et la Palestine, avec mission du gouvernement, Paris 1854.

Pingaud, Léonce, Choiseul-Gouffier, La France en Orient sous Louis XVI, Paris 1887.

Pinto, Fernaõ Mendes, Peregrinaçaõ de Fernaõ Mendes Pinto e por elle escritta que consta de muytas, e muyto estranhas cousas, Lisbon 1725. 1509-1583, travelling to India and the Far East in the mid-century. 411-412 for description of Damascus, 413 for Ramala, and for Gaza.

Plaisted, Bartholomew, Extract from "A journal from Calcutta in Bengal by sea, to Busserah, from thence through the Great Desert to Aleppo, etc., in the year 1750," in Carruthers 1929, 49-128.

Pococke, Richard, A description of the East, and some other countries, II.1, London 1745. Particularly interested in aqueducts, of which he traces and describes several. He also provides keys to his plans, and takes the reader through them. 
- Travels in Egypt, in Pinkerton, John, ed., A general collection of the best and most interesting voyages and travels in all parts of the world, $\mathrm{xV}$, London 1814.

Pognon, H., "Rapport sur une mission au Liban (Syrie) (1884)," in AMSL XIV 1888, 345-349.

Porter, Josias Leslie, Five years in Damascus, 2 vols, London 1855. Excellent on the Dead Cities and everywhere, with careful descriptions and interesting details.

- - A handbook for travellers in Syria and Palestine, including an account of the geography, history, antiquities and inhabitants of these countries, the Peninsula of Sinai, Edom, and the Syrian Desert; with detailed descriptions of Jerusalem, Petra, Damascus and Palmyra, maps and plans, rev. edn., John Murray, 2 vols London 1868. - The giant cities of Bashan and Syria's holy places, London 1882. First published 1865 .

Potter, Henry C., D.D., Gates of the East. A winter in Egypt and Syria, New York 1877.

Poujade, Eugène, Le Liban et la Syrie 1845-1860, Paris 1860.

Poujoulat, Baptistin, Voyage à Constantinople, dans l'Asie Mineure, en Mésopotamie, à Palmyre, en Syrie, en Palestine et en Égypte, faisant suite à la correspondance d'Orient, I, Brussels 1841, II, Paris 1841.

Prime, Samuel Irenaeus, Travels in Europe and the East, II, New York 1855.

Puchstein, Dr Otto, Führer durch die Ruinen von Baalbek, Berlin 1905.

Raboisson, A., En Orient II, 1887, folio, illustrated with 148 large photographs.

Rafeq, Abdul-Karim, "Making a Living or Making a Fortune in Ottoman Syria," in Hanna,

Nelly, ed., Money, land and trade. An economic history of the Muslim Mediterranean, London \& New York 2002, 101-123.

R.B. ed., Two journeys to Jerusalem, London 1759.

Raguse, duc de, Voyage du Maréchal Duc de Raguse en Hongroie ... en Syrie, III, Paris 1839 .

Redding, M. Wolcott, Antiquities of the Orient unveiled, containing a concise description of the ruins of King Solomon's cities..., New York 1873.

Reid, John, Turkey and the Turks: being the present state of the Ottoman Empire, London 1840.

Reinach, Salomon (1858-1932), Conseils aux voyageurs archéologues en Grèce et dans l'Orient hellénique, Paris 1886.

Renan, Ernest, Mission de Phénicie, Paris 1864.

Renan, Henriette, Souvenirs et impressions.... Syrie, Paris 1930. In Syria Oct. 1860Sept 1861.

Rendel Harris, James, Some interesting Syrian and Palestinian inscriptions, London 1891.

Rennell, Major James, A treatise on the comparative geography of Western Asia, I, London 1831. Excellent account of how distances were calculated.

Rey, Emmanuel Guillaume, Voyage dans le Haouran et aux bords de la Mer Morte exécuté pendant les années 1857 et 1858, Paris 1861. 
_ "Rapport sur une mission scientifique accomplie en 1864-1865 dans le nord de la Syrie," in $A M S L$ III 1866, 329-373.

_ _ Etudes sur les monuments de l'architecture militaire des Croisés en Syrie et dans l'île de Chypre, Paris, 1871.

__ "Rapport sur une mission scientifique accomplie en 1864-1865 dans le nord de la Syrie," in $A M S L$ 2nd series III, 1867, 329-374. Deals with Krak des Chevaliers and other Crusader fortresses. He does take account of previous travellers to this region, but his accounts of castles are pedestrian, if laced with mediaeval quotations.

- Les colonies franques de Syrie aux XII e et XIII ${ }^{e}$ siècles, Paris 1883 . Travelling in 1859 .

Richardson, Robert. Travels Along the Mediterranean, and parts adjacent; in company with the Earl of Belmore, during the years 1816-17-18, 2 vols, London, 1822.

Richter, Otton-Frédéric de, "Pèlerinages en Orient faits en 1815-1816, par OttonFrédéric de Richter," in Nouvelles Annales des Voyages XXI 1824, 342-384, then XXII 1824, 5-55, 289-333.

Ritter, Carl (1779-1859), The comparative geography of Palestine and the Sinaitic Peninsula, translated and adapted for the use of Biblical students, IV, New York 1866. Conscientious account dredged up from ancient and modern authors, but no hint that the author ever visited the sites. "Ranks along with Alexander von Humboldt as the founder of scientific geography." The в в [1911, s.v. Ritter] calls him "a scientific compiler of the first rank." This is true: he has read widely on the sites of Syria, and provides full-referenced summaries of them.

Roberts, Gaylard, “A journey from Basra to Aleppo in 1748," in Carruthers 1929, 41-47.

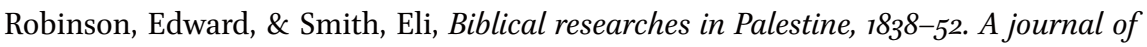
travels in the year 1838,2 vols, London 1856.

Robinson, Edward, et al., Later biblical researches in Palestine, and in the adjacent regions. A journal of travels in the year 1852 , Boston 1856 . Very well footnoted, with detailed and informative text.

Robinson, George, Three years in the East: being the substance of a journal written during a tour and residence in Egypt, Palestine, Syria and Turkey, in 1829, 1830, 1831, and 1832: Syria, London \& Paris 1837.

— from Burckhardt.

Rockroy, E., "Voyage en Syrie. Mission de M. Renan en Phénicie, " in Tour du Monde VII $1863,33-65$.

Roederer, Carle \& Paul, La Syrie et la France, Paris / Nancy 1917. In the series Les Grands Problèmes Coloniaux.

Rogers, Mary Eliza, La vie domestique en Palestine, Paris 1865.

*B* Röhricht, Reinhold, Bibliotheca Geographica Palaestinae. Chronologisches Verzeichniss der auf die Geographie des Heiligen Landes bezüglichen Literatur von 333 bis 
1878, Berlin 1890. Highly detailed work, with authors' itineraries (and enumeration of various sites and sights) included, as well as editions and translations, for some measure of works' popularity and sometimes longevity. Also includes Mss, and copious references to papers in periodicals.

Rosenmüller, E.F.C., D.D., The Biblical geography of Asia Minor, Phoenicia, and Arabia, Edinburgh 1841. With extensive quotations from earlier writers: one wonders just how much he saw with his own eyes.

Rousier, M. l'Abbé L., travelling 1844, Voyage à la Terre Sainte. Monuments, mours, usages de l'Egypte, de la Syrie, de la Palestine, Limoges \& Paris 1856.

Rouwolf, Leendert, Seer aanmerkelyke Reysen, na en door Syrien, 't Joodische Land . . in't Jaar 1573, en vervolgens gedaan, Leiden 1706. 56-98 for a long account of Aleppo in the days of her trading glory.

Russell, Alexander, The natural history of Aleppo, 2nd edn, 2 vols, London 1794.

Russell, Rev. Michael, Palestine, or the Holy Land; from the earliest period to the present time, 3 rd edn, Edinbugh 1832.

Sachau, Eduard, Reise in Syrien und Mesopotamien, Leipzig 1883. Assiduous in the location and description of ruins. Excellent on Dead Cities.

Saint-Aignan, Abbé Laurent de, La Terre-Sainte, description topographique, historique et archéologique de tous les lieux célèbres de la Palestine, Paris 1864. With plentiful quotes from previous travellers.

Saint-Martin, Louis Vivien de, Histoire des découvertes géographiques des nations européennes dans le monde II \& III, Asie Mineure, Paris 1845 \& 1846 . Because so many travellers coupled Syria with Asia Minor, these volumes are invaluable for descriptions of intentions and results as well as itineraries, plus the political conditions which often influenced whether travels were completed, truncated or cancelled. [Vol II: LXVII+548pp; vol III: XVI+813pp, including commented bibliography by date, starting at 1211, and with 381 entries, and index.]

—, Description historique et géographique de l'Asie Mineure, comprenant les temps anciens, le moyen age et les temps modernes, 2 vols, Paris $185^{2}$. Largely a reprint of the above, without the bibliography.

Salmon, Thomas, Lo stato presente di tutti i paesi e popolo del mondo, VI,... della Siria, Palestina, 2nd edn., Venice 1738. A confected work: he has gathered his information from various sources.

Salvator, Ludwig, archduke of Austria, The caravan route between Egypt and Syria, London 1881.

Salverte, Georges de (1833-1899), auditeur au Conseil d'État, La Syrie avant 1860, Paris 1861.

Sandys, George, A relation of a journey begun in An. Dom. 1610. Foure books containing a description of the Turkish Empire, of Aegypt of the Holy Land etc., 7 th edn, London 1673 . 
Sanson, Nicolas, Géographe ordinaire du Roy, L'Europe en plusieurs cartes et en divers traittés, Paris 1683 .

Saulcy, Louis Félicien de (1807-1880), Voyage autour de la Mer Morte et dans les terres bibliques exécuté de Décembre 1850 à Avril 1851, Relation de voyage, 2 vols Paris 1853. Frequent analyses of the travels and discoveries of other explorers, such as Irby \& Mangles. Distances not given but, as usual, time elapsed from one site to the next this, of course, because of the dearth of accurate maps, let alone of site names.

—_ "Seconde lettre de M. de Saulcy, membre du Comité des arts et monuments, en mission en Orient," in AMSL I 1851, 211-216.

— La Syrie et la Palestine, examen critique de l'ouvrage de M. Van de Velde, Paris 1855. A notable demolition job, extracted from the Revue de l'Orient, de l'Algérie et des Colonies, 1855 .

- Souvenirs d'un voyage en Terre Sainte, Paris 1867.

Savigny de Moncorps, Vte de, Journal d'un voyage en Orient 1869-187o. Égypte-SyrieConstantinople, Paris 1873 .

Sayce, A.H., Deputy Professor of Comparative Philology, Oxford, Fresh light from the ancient monuments. A sketch of the most striking confirmations of the Bible, from recent discoveries in Egypt, Palestine, Assyria, Babylonia, Asia Minor, London, 1865. [Published by The Religious Tract Society. 7 th edn, 1892.]

Schickler, Fernand, En Orient. Souvenirs de voyage 1858-1861, Paris 1863.

Scholz, Dr. John Martin Augustus, Travels in the countries between Alexandria and Paraetonium, the Lybian desert, Siwa, Egypt, Palestine and Syria, in 1821, London 1822. Schumacher, Gottlieb, The Jaulân, surveyed for the German Society for the Exploration of the Holy Land, London 1888. 313 mentions of ruins, 42 of Circassians.

- Across the Jordan: being an exploration and survey of part of Hauran and Jaulan, London 1889. Speaks Arabic, and includes numerous sketches of some surviving monuments, and details of the many ruins spread through the villages, including bas-reliefs and inscriptions.

Seetzen, Ulrich Jasper, "Voyage sur les confins de l'Arabie et de la Palestine," in Annales des Voyages VII 1809, 137-190. Travelling 1806.

- A brief account of the countries adjoining the lake of Tiberias and the Jordan, and the Dead Sea, Published for the Palestine Association of London, Bath 1810. Preface, v: "The following Journal, which is now presented to the Reader in an English dress, was written by M. Seetzen, Conseiller d'Embassade de S.M.l'Empereur de Russie. His letters were addressed to M. de Zach, Grand Marechal de la Cour de Saxe Gotha, \&c.; and parts of them appeared at different times in the Moniteur. Some Members of the National Institute at Paris sent over these Papers to Sir Joseph Banks, by whom they were obligingly forwarded to the Palestine Association."

—, Reisen durch Syrien, Palästina, Phönicien, die Transjordan-Länder, Arabia Petraea und Unter-Aegypten, I \& II, Berlin 1854; III, Berlin 1855; IV, Berlin 1859, all 
ed. Kruse, Friedrich (whose notes and commentaries are valuable). Meticulous accounting by day, hour and minute for reaching and passing towns, villages and sites, with much attention given to churches, monasteries and inscriptions, which he copies. By far the best guide to the country at his date, given his interest in people, the Arabic language, natural history and geology. It is a pity he is not more knowledgeable about architecture. But his work as a doctor got him the entrée everywhere, it seems; and he could evidently speak Arabic as well as read it (and Greek). Vol IV contains a wealth of historical and topographical information, with plentiful references to later travellers (viz between 1806 and its publication date of 1859), plus some of Seetzen's sketches, e.g. for the temple at Aere, in Seetzen IV_1859_15 \& 18.

— , "Mémoire pour servir à la connoissance des tribus arabes en Syrie et dans l'Arabie déserte et Pétrée," in Annales des Voyages VII 1809, 281-324. Travelling 1806. Ethnography, mostly derived from conversations with his guide.

Seiff, Julius, civil engineer, Reisen in der asiatischen Turkei, Leipzig 1875.

Senden, G.H. van, Het Heilige Land of Mededeelingen uit eene Reis naar het Oosten, gedaan in de Jaren 1849 in 1850 , Gorinchem $185^{2}$.

Sepp, Johann, Jerusalem und das heilige Land. Pilgerbuch nach Palästina, Syrien und Aegypten I, Schaffhausen 1863. IX-XXXI for earlier 19th-century pilgrimage, with numbers.

Shaw, Thomas, Travels or observations relating to several parts of Barbary and the Levant, 3rd edn., 2 vols, Edinburgh 1808. Originally Oxford 1738.

Skene, James Henry, Rambles in the deserts of Syria and among the Turkomans and Bedaweens, London 1864. Interesting and knowledgeable on the state of the country and its future. Plenty on Circassian immigrants.

Skinner, Major Thomas, Adventures during a journey overland to India, by way of Egypt, Syria and the Holy Land, 2nd edn, 2 vols, London 1837. He includes Baghdad in his Syria.

Smith, Captain Edward, Sailing directions for the coast of Syria from ancient Joppa to the Gulf of Iskenderoon, London 1840.

Smith, George Adam, Syria and the Holy Land, London etc. 1918. Excellent short round-up, including ports, roads, rising population, and potential.

SPCK, published on behalf of, Three weeks in Palestine and Lebanon, 4th edn, London 1835. Author anonymous.

Spencer, J.A., D.D., Egypt and the Holy Land, 4th edn, New York 1857. [first pubd 1849] Supreme lack of interest in anything except biblical; and for detail he simply cites Robinson - 69 times!

Spilsbury, F.B., surgeon of His Majesty's ship Le Tigre, Picturesque scenery in the Holy Land and Syria, delineated during the campaigns of 1799 and 1800 , London 1823. 
Spon, Jacob, \& Wheler, George, Voyage d'Italie, de Dalmatie, de Grèce et du Levant, fait en $1675 \& 1676$, I, II, III, Lyon 1678 .

Spilsbury, F.B., Surgeon in that expedition during both campaigns, Picturesque scenery in the Holy Land and Syria delineated during the campaigns of 1799 and 1800 , London 1823.

Spoll, E.A., "Souvenirs d'un voyage au Liban," in Tour du Monde II 1861, 2-16.

Squire, Lieut-Col., "Travels thrugh part of the antient Coele Syria, and Syria Salutaris," in Walpole, Rev. Robert, ed., Travels in various countries of the East, being a continuation of memoirs relating to European and Asiatic Turkey etc., London 1820, 93-357.

St Clair, George, Buried cities and bible countries, New York 1892.

Stanhope, Hester, Travels of Lady Hester Stanhope, forming the completion of her memoirs. Narrated by her physician, 3 vols, London 1846 . The author does not generally date the excursions he narrates.

Stanley, Arthur Penrhyn, Sinai and Palestine, in connection with their history, 2nd edn, London 1856. Sensible and thoughtful.

Stephens, George, Incidents of travel in Egypt, Arabia Petraea, and the Holy Land, 6th edn, 2 vols, New York 1838.

Stevenson, W.B., The Crusaders in the East, Cambridge 1907.

Stewart, Walter Robert, D.D., The tent and the khan. A journey to Sinai and Palestine, Edinburgh \& London 1857.

Stochove, Vincent, Seigneur de, Voyage du Levant, and edn, Brussels 1650. Ottoman passport issued Constantinople 1631. Travelled with Fermanel, q.v.

Sykes, Mark, Dar-ul-Islam. A record of a journey through ten of the Asiatic provinces of Turkey, London 1904.

Taylor, Bayard, The lands of the Saracen: or, pictures of Palestine, Asia Minor, Sicily and Spain, 2oth edn, New York 186o.

Taylor, Baron J, \& Reybaud, Louis (1789-1879), La Syrie, l'Égypte, la Palestine et la Judée considérées sous leur aspect historique, archéologique, descriptif et pittoresque, I, Paris 1839. Also published as Laorty-Hadji, q.v.

Teixera, Pedro, Travels, Sinclair, William F. ed., London 1902.

Terhune, Albert Payson, Syria from the saddle, New York etc. 1896.

Thenaud, Jean, Le voyage d'Outremer (Egypte, Mont Sinay, Palestine), Schefer, Charles, ed., Paris 1864. Travelling in 1512 . With details of the 12 peregrinations made at and around Jerusalem (14 including Sinai and Bethlehem).

Thevenot, Jean de, Livre second de la première partie du voyage de Mr de Thevenot au Levant, Paris 1689 .

Thomas, Margaret, Two years in Palestine and Syria, London 1900.

Thompson, Charles, Travels through Turkey in Asia, the Holy Land, Araia, Egypt, and other parts of the world, 3rd edn., I, London 1767. 
Thomsen, Peter, Die römischen Meilensteine der Provinzen Syria, Arabia und Palaestina, Leipzig 1917, reprinted from the Zeitschrift des Deutschen Palästina-Vereins XL 1ff.

Thomson, William M., The Land and the Book: or, Biblical Illustrations drawn from the Manners and Customs, the Scenes and Scenery of the Holy Land. Vol. 1. Southern Palestine and Jerusalem. Vol. 2. Central Palestine and Phoenicia. Vol. 3. Lebanon, Damascus and Beyond Jordan, London Vol. 1.1881, 2.1883, 3.1885. First published in 1859.

_ Lebanon, Damascus and beyond Jordan, New York 1886. Vol III of The Land and the Book, or biblical illustrations drawn from the manners and customs, the scenes and scenery, of the Holy Land. Precise and careful descriptions, from somebody who has spent a lot of time in the East: as the title page has it, "forty-five years a missionary in Syria and Palestine."

Tiffany, Francis, This goodly frame the earth. Stray impressions of scenes, incidents and persons in a journey touching China, Japan, Egypt, Palestine and Greece, Boston \& New York 1896.

Till, Charles, The boat and the caravan. A family tour through Egypt and Syria, $5^{\text {th }}$ edn, London 1851. First pubd 1846.

Tischendorff, Constantine, Travels in the East, London 1847.

Tilley, Henry Arthur, Eastern Europe and Western Asia. Political and social sketches in Russia, Greece, and Syria in 1861-2-3, London 1864.

Tobler, Titus, Lustreise ins Morgenland, 2 vols Zurich 1839. Travelling 1835. I deals with Egypt, II with the Holy Land.

— , * $\mathrm{B}^{*}$ Dritte Wanderung nach Palästina im Jahre 1857 , Gotha 1859 . He provides useful footnotes, which I have omitted from my transcriptions: there he gives supporting eidence from earlier authors. His bibliography has its first section as Werke gewiss oder höchst wahrscheinlich von Augenzeugen, then (naturally) Werke von solchen, welche entweder gewiss, oder wahrscheinlich Jerusalem oder Palästina nicht aus eigener Anschauung kennen.

-, Bibliographia geographica Palestinae. Kritische Uebersicht gedruckter und ungedruckter Beschreibungen der Reisen ins Heilige Land, Leipzig 1867.

—, Descriptiones Terrae Sanctae ex saeculo VIII. IX. XII et XV, Leipzig 1874.

Tobler, Titus, \& Kohler, Charles, Itinera Hierosolymitana et descriptiones Terrae Sanctae, I, Geneva 1879 .

Tristram, H.B., The land of Israel; a journal of travels in Palestine undertaken with special reference to its physical character, published under the direction of the...SPCK, London 1865 .

- The land of Moab, travels and discoveries on the east side of the Dead Sea and the Jordan, New York 1873.

Turner, William, Journal of a tour in the Levant, II, London 1820 . Travelling 1815.

Usama Ibn Munqidh (b.1095, book c.1183), The Book of Contemplation, Cobb, Paul M., Intro \& Trans, London 2008. 
Valiani, Abbate Luigi, Viaggio a Gerusalemme per l'Asia e Soria ... l'anno 1826 e 1827 , Florence 1828 .

Van Berchem, Recherches archéologiques en Syrie, ex. Revue Asiatique Nov.-Dec. 1895, separately printed 1896 . This is a grand tour d'horizon, in a letter to Barbier de Meynard.

Van De Velde, Charles William Meredith, Narrative of a journey through Syria and Palestine in 1851 and 1852, 2 vols, Edinburgh \& London 1854. Detailed accounts, some of them canted by a desire to identify places named in Scripture, but balanced by an interest in ruins and antiquities, and frequent reference to earlier travellers.

Varthema, Ludovico di, Travels in Egypt, Syria, Arabia Deserta and Arabia Felix, in Persia, India and Ethiopia, A.D. 1503 to 1508, ed. Badger, George Percy, London 1863.

Vergoncey, Sebastien de, Le pèlerin véritable de la Terre Saincte, auquel, sous le discours figuré de la Iérusalem antique et moderne de la Palestine est enseigné le chemin de la Céleste, Paris 1615 .

Veryard, Ellis, An account of divers choice remarks ... taken in a journey through the Low Countries, France, Italy, and part of Spain; with the isles of Sicily and Malta. As also a voyage to the Levant: a description of Candia, Egypt, ... the coast of Palestine, etc., London, 1701.

Vetromile, Rev. Eugene, Apostolic Missionary, Travels in Europe, Egypt, Arabia Petraea, Palestine and Syria, 2 vols, New York 1871.

Vitri, Jacques de, Bishop of Acre, History of Jerusalem, Stewart, Aubrey, trans., London 1896.

Vogüé, Melchior (1829-1916, marquis de), Les Églises de la Terre Sainte, Paris 1859.

— Syrie, Palestine, Mont Athos; voyage auz pays du passé Paris 1876.

- $\longrightarrow$ Syrie centrale: architecture civile et religieuse du I Ir au VII siècle, I: texte, Paris $1865^{-1877 .}$

\section{- En Palestine, Paris 1898.}

Volney, Constantin François, The ruins: or a survey of the revolutions of empires, London 1796. "The plan of this publication was formed nearly ten years ago; and allusions to it may be seen in the Preface to Travels in Syria and Egypt, as well as at the end of that work, published in $1787 . "$

— Voyage en Syrie et en Égypte pendant les années 1783, 1784, et 1785, rev. edn II, Paris 1792.

Von Kremer, Alfred, The Orient under the Caliphs, Calcutta 1920. Translated from his Culturgeschichte des Orients.

Walckenaer, le Baron, "Sur les voyages recens des Français en Asie-Mineure, en Mésopotamie, en Syrie et en Arabie-Pétrée," in Nouvelles Annales des Voyages 1835 I, 287-322.

Walker, Dean A.M., "The Circassian colonies at Aman and Jerash," in The Biblical World 4.3 1892, 202-204. They moved 1864 Russia-Bulgaria (then Turkey), then in 
the 1876-8 Russo-Turkish war became refugees, because Bulgaria was under Russia control; 1878-81 into Amman \& Jerash.

Walpole, the Hon. Frederick, R.N., The Ansayrii (or Assassins) with travels in the further east in 1850-51, including a visit to Nineveh, 3 vols, London 1851. Intelligent, concise and judicious, from a man speaking both Arabic and Turkish.

Warburton, Eliot, The Crescent and the Cross or, romance and realities of eastern travel, new edn, New York 1848.

Ward, Aaron, Around the pyramids: being a tour in the Holy Land... during the years 1859-6o, New York 1864.

Warren, Charles, \& Conder, Claude Regnier, The survey of Western Palestine:Jerusalem, London 1884.

Warren, William Wilkins, Life on the Nile ... also a tour in Syria and Palestine in 1866-67, 3rd edn, Boston 1883.

Wetzstein, Johann Gottfried, Prussian consul in Damascus, travelling in 1858, Reisebericht über hauran und die Trachonen nebst einem Anhange über die Sabä̈schen Denkmäler in Ostsyrien, Berlin 1860. Excellent, succinct and precise (and with 98 mentions of the Bedouin!).

— 1858," in Zeitschrift für allgemeine Erdkunde 1859, 109-204, 265-319, published as a book in 1860 .

Williams, George, The holy city: historical and topographical notices of Jerusalem, with some account of its antiquities and of its present condition, II, London 1849.

Wilson, Colonel Sir Charles W., Picturesque Palestine, Sinai and Egypt, 4 vols, London 1881.

Wilson, Thomas, Nozrani in Egypt and Syria, 2nd edn, London 1848. [Nozrani = modern Syriac for "Nazarene," "Christian."]

Wilson, William Rae, Travels in Egypt and the Holy Land, London 1823.

Wilson, Capt. R.E., [\& Warren, Capt. R.E.] The recovery of Jerusalem. A narrative of the exploration and discovery in the city and the Holy Land, New York 1871.

Wittman, William, Travels in Turkey, Asia Minor, Syria and across the Desert into Egypt during the years I799, 1800, and 1801, London 1803. Author formed part of a military mission to Turkey.

Wood, James, The ruins of Palmyra, otherwise Tedmor, in the desart, London 1753.

- The ruins of Balbec, otherwise Heliopolis in Coelosyria, London 1757.

Wortabet, Gregory M., Syria, and the Syrians: or, Turkey in the dependencies, I, London 1856.

Wright, Thomas, Early travels in Palestine (Arculf etc.), London 1848.

Wright, William, An account of Palmyra and Zenobia with travels and adventures in Bashan and the desert, London etc. 1895. 
Yanoski, Jean, \& David, Jules, Syrie ancienne et moderne, Paris 1848, in the series Univers: Histoire et Description de Tous les Peuples.

\section{Modern Scholars}

Abu-Husayn, Abdul-Rahim, The View from Istanbul: Lebanon and the Druze Emirate in the Ottoman Chancery Documents, 1546-1711, London \& New York 2004.

${ }^{*} \mathrm{~B}^{*}$ Aiken, Edwin James, Scriptural geography. Portraying the Holy Land, London 2010.

Al-Azm, Amr, "Management and Preservation of Mosaics in Syria: Between Theory and Practice," in Bradshaw \& Fossey 2014, 335-345.

Al-Dbiyat, Mohamed, \& Jaubert, Ronald, "Le repeuplement sédentaire des marges arides à l'époque contemporaine (1848-1960)," in Jaubert \& Geyer 2006, 70-79.

Al-Houdalieh, Salah H., et al., "Building destruction: the consequences of rising urbanization on cultural heritage in the Ramallah Province," in Int. Jnl. Cultural Property $16.12009,1-23$.

Allouche, Adel, "A Study of Ibn Battutah's Account of his 726/1326 Journey through Syria and Arabia," in Journal of Semitic Studies 35/2 Autumn 1990, 283-99.

Al-Tabba, Yasser Ahmed, "The architectural patronage of Nur Al-Din (1146-1174)," PhD NYU, 1982.

Aldrich, Robert, Greater France. A History of French Overseas Expansion, Basingstoke 1996.

Alon, Yoav, The making of Jordan. Tribes, colonialism and the modern state, London 2007 .

Ambraseys, Nicholas, Earthquakes in the Mediterranean and Middle East. A Multidisciplinary Study of Seismicity up to 1900, Cambridge 2009.

Amis de la Bibliothèque du Blanc, Sur les routes d'Europe et d'Asie: écrivains, marchands, missionnaires. Récits de voyageurs $X V I^{e}-X I X^{e}$ siècles, exhibition Château de Valençay etc. 2006.

Andrew, Christopher M., \& Kanya-Forstner, A.S., France overseas. The Great War and the climax of French overseas expansion, London 1981.

Ansari, Tamin, Disputed destiny. A history of the world through Islamic eyes, New York 2009.

* $\mathrm{B}^{*}$ Apostolou, Irini, L'orientalisme des voyageurs français au XVIII siècle: une iconographie de l'Orient méditerranéen, Paris 2009. A doorstep of a thesis! Bibliography Mss and source books 363-389; modern scholars 389-421.

Arce, Ignacio, "The palatine city at Amman citadel," in Bartl \& Moaz 2008, 183-216.

Atassi, Nimet, "La Syrie vue par les voyageurs du dix-huitième siècle, " thesis, Grenoble 1986. 
Badawi, Hassan, "L'opus sectile nelle case aristocratiche di Tiro nell'epoca tardo antica," in Castel et al., eds., 1997, 82-94.

Ball, Warwick, Rome in the East: the transformation of an empire, London \& New York 2000.

*B* Balty, Janine, "La mosaïque romaine et byzantine en Syrie du Nord," in Revue du monde musulman et de la Méditerranée 62 1991, 27-39. For some of the spectacular mosaics found at Apamea.

Baram, Uzi, \& Carroll, Lynda, eds., A historical archaeology of the Ottoman Empire: Breaking new ground, New York etc. 2002.

Bartl, Karin, \& Moaz, Abd Al-Razzaq, eds., Residences, castles, settlements. Transformation processes from late antiquity to early Islam in Bilad al-Sham, Rahden/ Wesf. 2008. Excellent publication for up-to-date research and theories.

Bar-Yosef, Eitan, The Holy Land in English culture, 1799-1917, Oxford 2005.

Bauzou, Thomas, "Poidebard, archéologue de l'extrême," in Poidebard 2004, 130-145.

${ }^{*} \mathrm{~B}$ * Ben-Arieh, Yehoshua, The rediscovery of the Holy Land in the 19th century, Jerusalem

\& Detroit 1979. Well illustrated. Sensible and straighforward account, with useful bibliography of primary sources $235^{-249}$.

Bendakir, M., Architectures de terre en Syrie, 2008. Very well illustrated account, from Neolithic onwards; plenty still in use today.

* $B^{*}$ Beaudry, Nicolas, "Ras el Bassit and the Late Antique Archaeological Landscape of Coastal North Syria," in Aitken, Ellen Bradshaw, \& Fossey, John M., eds., The Levant: Crossroads of Late Antiquity, Leiden 2014, 255-267.

Bellefonds, Pascale Linant de, "From Cairo to Petra: Léon de Laborde and LMA de Bellefonds, 1828," in Starkey 2011, 193-208.

Berchet, Jean-Claude, Le voyage en Orient... dans le Levant au XIXe siècle, Paris 1985. Has 1108pp., dealing with Greece, Asia Minor, Constantinople, Syria-Palestine, Egypt and the Desert. Useful for putting travel to Syria in a broader context. 1077-1097 for useful biographical notes.

Bernard,Jean-François et al., eds., Il Reimpiego in Architettura:Recupero, Trasformazione, Uso, Ecole Française de Rome; Rome 2008. Papers from the conference "Chasteaus abatuz est demi refez." Récupération, recyclage et usages du remploi entre Antiquité et époque moderne, organised by Università di Roma la Sapienza and the Ecole française de Rome, November 2007.

Bessac, Jean Claude, "Le basalte de Syrie du Sud: quelques repères techniques, économiques et chronologiques," in Hauran V.I 2008, 413-423. Includes quarries.

* B* Bianca, Stefano, ed., Syria: medieval citadels between East and West, Turin 2007. Very well illustrated, with several papers on planning and conservation.

*B* Biller, Thomas, et al., Der Crac des Chevaliers, Regensburg 2006. A great work, well written and profusely illustrated. 
${ }^{*} B^{*}$ Bloch, Franziska, et al., Studien zur spätantiken und islamischen Keramik. Hirbat al-Minya - Baalbek - Resafa, Rahden/Westf. 2006.

Bloxham, Donald, The great game of genocide. Imperialism, nationalism, and the destruction of the Ottoman Armenians, Oxford 2005.

Boas, Adrian J., Jerusalem in the time of the Crusades. Society, landscape and art in the Holy City under Frankish rule, London \& New York 2001.

— Domestic Settings Sources on Domestic Architecture and Day-to-Day Activities in the Crusader States, Leiden 2010.

Bowersock, G.W., "The three Arabias in Ptolemy's Geography," in Gatier 1988, 47-52. i.e. on changing perceptions of geographical divisions and regions.

${ }^{*} B^{*}$ Bowmann, Glen, "A textual landscape: the mapping of a Holy Land in the fourthcentury Itinerarium of the Bordeaux Pilgrim," in Starkey 2011, 7-39.

Bowsher, Julian M.C., "An Early Nineteenth Century Account of Jerash and the Decapolis: The Records of William John Bankes," in Levant 29 1997, 227-46.

Braemer Frank, "Prospections archéologiques dans le Hawran (Syrie)," III in Syria 70.1-2 1993 117-170. 1984-89 for surveys - underlining how much work remained to be done in the region. Many of the sites were Bronze Age to start with.

Braemer, Frank, \& Sorin, Sabine, “Toitures de basalte: encorbellement et portique dans l'architecture du Hawran (Syrie) du IVe au II e millénaire," in Paléorient 36.12010 , 89-102.

Brands, Gunnar, \& Severin, Hans-Georg, eds., Die spätantike Stadt und ihre Christianisierung, Wiesbaden 2003.

Brandt, C. Jane, \& Thornes, John B., eds., Mediterranean Desertification and Land Use, Chichester 1996.

* $\mathrm{B}^{*}$ Brenk, Beat, "Die letzte Phase der Antike in der Kathedrale von Gerasa: Die neue aufgefundene Portikus und ihre Ausstattung," in Eichner \& Tsamakda eds. 2009, $21-36$.

Brentjes, Sonja, Travellers ... in the Ottoman ... Empire, Farnham 2010.

Brion, Marcel, La resurrection des villes mortes, 2 vols, Paris 1937 \& 1938, with one map but no illustrations.

Broquière, Bertrandon de la, Le voyage d'outremer, Schefer, Charles, ed., Paris 1892. Useful introduction and with exceptionally informative footnotes quoting other travellers.

Brown, Robin M., "The Roman Praetorium [Umm-el-Jimal] and its later domestic re-use," in Vries 1998, 161-193.

${ }^{*} B^{*}$ Burns, Ross, Monuments of Syria, 1992. Good clear maps, star ratings and itineraries. 1-16 historical sketch.

*B* Damascus, a history, Abingdon 2005.

Butcher, Kevin, Roman Syria and the Near East, London 2003. 
Butler, Daniel Allen, Shadow of the Sultan's realm. The destruction of the Ottoman Empire and the creation of the modern Middle East, Washington 2011.

Butler, Howard Crosby, Preliminary report of the Princeton University Expedition to Syria, in AJA IX 1905, 389-400.

—, "Desert Syria, the land of a lost civilization," in The Geographical Review IX 1920, 77-108.

Butler, Howard Crosby, et al., Syria. Publications of the Princeton University archaeological expeditions to Syria in 1904-5 and 1909, Division I, geography and itinerary, Leiden 1930.

*B* Cahen, Claude, La Syrie du nord à l'époque des croisades et la principauté franque d'Antioche, Paris 1940. Useful for fortresses.

Callier, Camille, Capitaine an corps royal d'état-major, "Voyage en Asie Mineure, en Syrie, en Palestine et en Arabie Petrée," in Bulletin de la Société de Géographie de Paris 1835: 5-22, 239-262.

Callot, Olivier, Huileries antiques de Syrie du Nord, Paris 1984. No time or money for excavation, so "me contenter de les relever ou d'en étudier les vestiges tels qu'ils se présentaient." (1). So not a catalogue, rather a "how were they arranged and worked" book.

Callot, Olivier, "La christianisation des sanctuaires romains de la Syrie du Nord," in Topoi 7/2 1997, 735-750.

Calvet, Yves, Barrages antiques de Syrie, Paris 1992.

Canivet, Pierre, La Syrie de Byzance à l'Islam, colloque 1990, Damascus 1992.

Carmel, Alex, Ottoman Haifa: A History of Four Centuries under Turkish Rule, London 2011.

Carpenter, Frank G., The Holy Land and Syria, Garden City NY 1923.

Castel, Corinne, et al., eds., La maison dans la Syrie antique, du III ${ }^{e}$ millénaire aux débuts de l'Islam, Beirut 1997.

Castellana, Pasquale, Trentacinque anni di ricerche nella Syria christiana: scritti 1970200, Teramo 2011.

Caubet, Annie, "Voyageurs et savants: la redécouverte de la Transjordanie par les Européens," in Delpont 1997, 23-33. Starts with the 1761-6 Danish Expedition, published Niebuhr Copenhagen 1774-8, and in French in Amsterdam 1780. Then gives brief biographies of Burckhardt, Laborde, de Saulcy, August Salzmann (182472), de Vogüé, Rey, Luynes, Clermont-Ganneau.

Chabot, J.-B., "Le voyage en Syrie de W.R. Waddington" [in 1861-2]," in Mélanges syriennes offerts à René Dussand I, Paris 1939, 351-366. 353: Route ancienne entre Slem et Atil, non pavée en dalles, mais empierrée et indiquée par des lignes de pierres ou petits murs. 354: El Muchennef: gros village, bonne eau; petit temple en ruines; 2 antes et 2 colonnes, corinthien; cour pavée devant. Belles portes en pierre aux maisons, comme à Kanawat. 355: Busan, gros village, mais peu d'habitants 
maintenant; il y a de très bonnes maisons anciennes avec de beaux cintres et de belles portes en pierre; il y a eu des édifices publics, mais ils sont tellement ruinés, qu'on ne distingue rien. 357: La grande église de Suweida est faite avec des matériaux anciens. 362 Homs, west of the town, ruines d'un grand tombeau romain, en briques à 3 étages avec quelques pilastres simples et un revêtement réticulé en carreaux blancs et noirs.

Chehab, M.H., Tyr à l'époque des Croisades, II: Histoire sociale, économique et religieux, 2 vols, Paris 1979 .

${ }^{*} \mathrm{~B}^{*}$ Chevalier, Nicole, La recherche archéologique française au Moyen-Orient 1842-1947, Paris 2002. Excellent and detailed book, well illustrated, and with documents and index.

—_, Chronique des premières missions archéologiques françaises à Suse d'après les photographies et mémoires de l'architecte Maurice Pillet (1912-1913), Teheran 2009.

—, "Larchéologie française au Levant," in Poidebard 2004, 118-129.

Chretien-Happe, Isabelle, "Les représentations de temples et sanctuaires sur les monnaies romaines de Décapole et d'Arabie," in Syria 81 2004, 131-146. Well-illustrated survey, with the proviso that the representations are symbolic, and not necessarily accurate reproductions of the temples they show.

Christie, Neil, \& Augenti, Andrea, Vrbes extinctae. Archaeologies of abandoned classical towns, Farnham 2012.

Clauss-Balty, Pascale, "Maisons romano-byzantines dans les villages de Batanée: missions 2002-2004, in Hauran III 2008, 41-103.

Clermont-Ganneau, Charles, et al., Les travaux archéologiques en Syrie de 1920 à 1922, Paris 1923.

${ }^{*} \mathrm{~B}^{*}$ Cloarec, Vincent, La France et la question de Syrie (1914-1918), Paris 2010.

Cobb, Paul M., "The empire in Syria, 705 763," in Robinson, Chase F., editor, The new Cambridge history of Islam, I: The Formation of the Islamic World Sixth to Eleventh Centuries, Cambridge 2010, 226-268.

Cohen, Getzel M., The Hellenistic Settlements in Syria, the Red Sea Basin, and North Africa, Berkeley etc. 2006. For the ancient sources.

Contenau, Georges, "Mission archéologique à Sidon (1914)," in Syria I 1920, 16-55, 108154, 198-229, 287-317. For sarcophagi, cippi and mosaics, plus a large number of figurines.

Cotinat, Guillaume, "L'épisode syrien du voyage en Orient de Léon de Laborde (6 janvier12 mai 1827)," in Laborde 2010, 16-31, with numerous extracts from his account.

—_, Contribution française à l'archéologie syrienne 1969-1989, Damascus 1989, for an exhibition. Very well illustrated.

Daher, Rami Farouk, ed., Tourism in the Middle East. Continuity, change and transformation, Clevedon etc. 2007, 4-5 for development of mass tourism by Thomas Cook, with offices in Cairo (1872), Jaffa (1874) and Jerusalem (1881). 
Dalrymple, William, From the holy mountain, London 1997.

Dankoff, Robert, \& Kim, Sooyong, An Ottoman traveller. Selections from the Book of Travels of Evliya Çelebi, London 2011.

Darrous, Nouha, \& Rohmer, Jérôme, "Chahba-Philippopolis (Hauran): essai de synthèse archéologique et historique," in Syria 81 2004, 5-41.

*B* De Francovich, Persia, Siria... e il Mediterraneo artistico europeo, 1984. Very well illustrated.

Degeorge, Gérard, Grande Mosquée des Omeyyades, 2010. Folio picture book, with sensible text, notes and bibliography. Plenty of comparisons with the mosque's state before the fire.

${ }^{*} \mathrm{~B}^{*}$ De Grummond, Nancy Thomson, ed., Encyclopedia of the history of classical archaeology, London \& New York 1996. Short bibliographies for archaeologists as well as sites.

De Jong, Lidewitjde, "Performing Death in Tyre: The Life and Afterlife of a Roman Cemetery in the Province of Syria," in AJA 114.4 2010, 597-630. This cemetery re-used over several centuries.

Delpont, Eric, ed., Jordanie sur le pas des archéologues, exhibition, Institut du Monde Arabe, Paris 1997. Very broad, from Neolithic to Islam.

*B* Delplace, Christiane, "Palmyre, de la ville centre commercial international à la ville centre militaire et chrétien," in Bradshaw_\&_Fossey_2014_225-253.

Dentzer-Fedy, Jacqueline, Les antiquités de Palmyre au Musée du Louvre, 1993. Much of the material entered the Louvre 1880-90, later acquisitions being largely from private collections.

—_, "Remarques sur les temples de Hebrân et de Sleim (Syrie du Sud) dessinés par W.J. Bankes (1786-1855)," in Syria 74 1997, 161-164.

—_, "Remarques sur le temple de Rîmet Hâzem (Syrie du Sud)," in Syria 75 1998, 201-211. With several sightings of re-used elements.

-, "Le décor architectural des maisons de Batanée," in Hauran III 2008, 183-231. Map and photos plus 169 plates - excellent!

Dentzer-Feydy, Jacqueline, et al., Bosra aux portes de l'Arabie, Beirut 2007.

Dentzer, Jean-Marie et al., "Formation et développement des villes en Syrie du Sud à l'époque bizantine: les exemples de Bosra, Suweida, Shahba," in Hauran V.I 2008, 139-169.

Deschamps, Paul, Les Châteaux des Croisés en Terre Sainte I: le Crac des Chevaliers, Paris, 1934; II: La défense du royaume de Jerusalem, Paris, 1939; III: La défense du comté de Tripoli et de la Principauté d'Antioche, Paris, 1973.

DeVries, Kelly, A cumulative bibliography of medieval military history and technology, Leiden etc. 2002. 
DeVries, Kelly, \& Smith, Robert Douglas, Medieval Military Technology, 2nd edn, Toronto 2012. Chap. 4 for Non-gunpowder artillery; Chap. 9 includes Crusader Castles.

Díaz-Andreu, Margarita, A world history of nineteenth-century archaeology. Nationalism, colonialism, and the past, Oxford 2007.

Dodinet, M. et al., eds., "Le paysage antique en Syrie: l'exemple de Damas," in Syria 67.2 1990, 339-367. Cadastration/centuriation with irrigation canals, perhaps originiating in hellenistic times. Very well illustrated.

Donceel-Voûte, Pauline, Les pavements des églises byzantines de Syrie et du Liban: Décor, archéologie et liturgie, Louvain-la-Neuve 1988, pp. 585 - catalogue followed by discussion of décor, style, iconography and liturgy.

Drachmann, Aage Gerhardt, The Mechanical Technology of Greek and Roman Antiquity: A Study of the Literary Sources, Madison 1963.

Dunand, Maurice, Musée de Soueïda, Paris 1934. Records and illustrates large numbers of statues and bas-reliefs from the Archaeological Museum for Djebel Druze. Captain Carbillet arrived as Governor of this djebel in 1923, and founded the museum in 1924, because on his tours (1) il fut frappé de l'abondance des documents anciens qui gisaient un peu partout et de l'état lamentable d'un bon nombre de monuments.

Dussaud, René, Topographie historique de la Syrie antique et médiévale, Paris 1927.

Dussaud, René, et al., La Syrie antique et médievale illustrée, Paris 1931. With 160 plates. $5^{-22}$ for Introduction, then each plate commented as if this were an exhibition catalogue - small objects as well as architecture. Excellent plates providing good overview.

Ebersolt, Jean, Constantinople byzantine et les voyageurs du Levant, Paris 1919. With plentiful details on early travellers to Syria.

*B* Ebla to Damascus, exhibition, Smithsonian, Washington 1985. Really does start 8ооовс. Very well illustrated. An excellent starting point for overview of Syria, people, agriculture, art and architecture. Exhibition with lots of material borrowed from Syria, and with short papers by the best scholars.

Eichner, Ina \& Tsamakda, Vasiliki, eds., Syrien und seine Nachbarn von der Spätantike bis in die islamische Zeit, Wiebaden 2009.

* $\mathrm{B}^{*}$ Eichner, Ina, "Ländliche Häuser der spätantik-frühbyzantinischen Zeit in Syrien und Kilikien," in Eichner \& Tsamakda 2009, 81-101.

Eldem, Edhem, et al.: The Ottoman City between East and West. Aleppo, Izmir, and Istanbul, Cambridge 1999.

El-Eini, Roza I.M., Mandated landscape. British imperial rule in Palestine, 1929-1948, London \& New York 2006.

El-Hage, Badr, Des photographes à Damas 1840-1918, Paris 2000. 
Eliav, Yaron Z., et al., eds., The sculptural environment of the Roman Near East: reflections on culture, ideology and power, Louvain \& Dudley Ma 2008.

El-Khouri, Lamia, Roman settlements in the region of northwest Jordan. Archaeological studies: land use and landscape development, Münster 2009.

El-Mudarris, Hussein, "Les explorations scientifiques en Asie Mineure à la fin du XVIII et dans la première moitié du XIX ${ }^{\mathrm{e}}$ siècle. La construction et les usages de savoirs géographiques européens sur le monde ottoman," in Laborde 2013, 26-37.

Ellenblum, Ronnie, Crusader castles and modern histories, Cambridge 2007.

Enlart, Camille, Les Monuments des Croisés dans le Royaume de Jérusalem, 2 vols., Paris, 1926-7.

${ }^{*} \mathrm{~B}$ Erickson, Edward J., Ottomans and Armenians. A study in counterinsurgency, New York 2013.

*B* Etienne, Roland, \& Salles, Jean-François, et al., Iraq al-Amir. Guide historique et archéologique du domaine des Tobiades, Beirut 2010.

Eydoux, Henri-Paul, Les Châteaux du soleil: fortresses et guerres des Croisés, Paris, 1982.

Fahd, Toufiq, "Le Hawran à la veille de la conquête islamique," in Farioli Campanati, Raffaella, ed., La Siria araba da Roma a Bisanzio, Ravenna 1989, 35-43.

Fansa, Mamoun, and Bollmann, Beate, eds., Die Kunst des frühen Christen in Syrien: Zeichen, Bilder und Symbole vom 4. bis 7. Jahrhundert, Mainz 2008, with wellillustrated introductory surveys to an exhibition in Oldenburg.

Farioli Campanati, Raffaella, Siria: guida archeologica: architettura tardoantica e protobizantina, Ravenna 2008. Largely N. Syria, and a spinoff from Italian mission to Bosra. 112 colour plates and 78 b\&w. Images of Ezra, Qanawat, Resafa, El Bara, Ruweiha etc. but many of these come from Butler. Done by site, with a bibliography for each important one.

${ }^{*} B^{*}$ Faroqhi, Suraiya, The Ottoman Empire and the world around it, London 2004. An excellent briefing from (as it were) both sides, with a commented bibliography in several languages.

${ }^{*} \mathrm{~B}^{*}$ Faucherre, Nicolas et al., eds., La fortification au temps des Croisades, Rennes 2004. Excellent overview, including treatment of the main forts, plus papers on construction techniques and cultural exchange.

Fedden, Robin, Syria, rev.edn London 1955.

Fiema, Zbigniew T., "Late-antique Petra and its hinterland: recent research and new interpretations," in Humphrey 2002, 191-252.

Fisher, Moshe, "Marble imports and local stone in the architectural decoration of Roman Palestine: marble trade, techniques and artistical taste," in Herz, Norman, \& Waelkens, Marc, eds., Classical marble: geochemistry, technology, trade, Dordrecht $1988,161-170$. 
_ , "Marble, urbanism and ideology in Roman Palestine: the Caesarea example," in Raban \& Holum 1996, 251-261.

—, "Sculpture in Roman Palestine and its architectural and social milieu: adaptability, imitation, originality? The Ascalon Basilica as an example," in Eliav et al. 2008, 483-508.

Flood, F. Barry, The Great Mosque of Damascus: Studies in the Makings of an Umayyad Visual Culture, Leiden, 2001. Includes several views of the mosque before 1892, and also of the extensive fire damage in that year.

${ }^{*} \mathrm{~B}^{*}$ Fowden, Gareth, Qusayr Amra. Art and the Umayyad élite in late antique Syria, Berkeley etc. 2004.

Förster, Gideon, \& Tsafrir, Yoram, "Skythopolis - Vorposten der Dekapolis," in Hoffmann \& Kerner 2002, $72-87$.

* $\mathrm{B}^{*}$ Fortin, Elisabeth, ed., De Khorsabad à Paris, La découverte des Assyriens, exhibition Paris 1994. Excellent catalogue, with plenty of old photos and scholarly papers.

Fortin, Michel, Syrie, terre de civilisations, Paris 1999.

Fourtnié, Pierre, \& Riccioli, Jean-Louis, La France et le Proche-Orient 1916-1946. Une chronique photographique de la présence française en Syrie et au Liban, en Palestine, au Hedjaz, et en Cilicie, Paris 1996. Feet right under the table! Excellent and wellillustrated account.

France, John, Western warfare in the age of the Crusades, 1000-1300, London 1999.

, "Fortifications east and west," in Kennedy 2006, 281-294.

Frézouls, E., ed., Sociétés urbaines, sociétés rurales dans l'Asie Mineure et la Syrie hellénistiques et romaines, Strasburg 1987.

—_, "Les théâtres romains de Syrie," in Annales archéologiques de Syrie, II, 1953, pp. 46-108.

—_, "Les édifices des spectacles en Syrie," in Archéologie et histoire de la Syrie. II, Saarbrücken, 1989, pp. 385-406.

Fromkin, David, A peace to end all peace. The fall of the Ottoman Empire and the creation of the modern Middle East, New York 1989.

Fulton, L. Bruce, "France and the End of the Ottoman Empire," in Kent 1984, 137-164.

Fusaro, Mario, Political Economies of Empire in the Early Modern Mediterranean The Decline of Venice and the Rise of England, 1450-1700, Cambridge 2015.

Gates, Charles, Ancient cities. The archaeology of urban life in the ancient Near East and Egypt, Greece and Rome, 2nd edn, Abingdon 2011.

Gatier, Pierre-Louis, Géographie historique au Proche-Orient (Syrie Phénicie, Arabie, grecques, romaines, byzantines), Paris 1988.

${ }^{*} \mathrm{~B}^{*}$ Gatier, Pierre-Louis, et al. eds., Entre nomades et sédentaires... prospections en Syrie... Jordanie, Lyon 2010.

Gatier, Pierre-Louis, \& Rousset, Marie-Odile, "Temples romains et mausolées de la Syrie centrale," in Gatier et al., 2010, 147-167. 
Gaube, Heinz, Ein Arabische Palast in Südsyrien: Hirbet El-Baida, Beirut 1974.

—, *B* "Islamic Baalbek: the Qal'ah, the mosques and other buildings," in Sader, Hélène, et al., eds., Baalbek: image and monument 1898-1998, Beirut 1998, 305-332useful overview, well illustrated and noted.

—, "A history of the city of Aleppo," in Bianca 2007, 73-102.

Gaudefroy-Demombynes, Jean, La Syrie à l'époque des Mamelouks d'après les auteurs arabes, Paris 1923 - his technique is to do the straight reportage in the text, and to back it up (rather generally) in the footnotes. Useful for its descriptions of Damascus, Aleppo, Hama, Tripoli, Cafad and El Karak.

Gautier van Berchem, Marguerite, "Anciens décors de mosaïques de la salle de prière dans la mosquée des Omayyades à Damas" in Mél. Univ. S. Joseph 46, 20, 1970-1, 285-304.

Gavish, Dov, A Survey of Palestine under the British Mandate, 1920-1948, London \& New York 2005.

Gawlikowski, Michel, "L'habitat à Palmyra de l'antiquité au Moyen Âge," in Les maisons de la Syrie antique du III millénaire au début de l'Islam, conference Damascus 1992, Beirut 1997, 161-166.

— , * $\mathrm{B} *$ "Les sanctuaires du Proche-Orient romain dans la recherche récente," in Topoi 8.1 1998, 31-52. Excellent overview, with bibliography by place.

_ , "Palmyra in early Islamic times," in Bartl \& Moaz 2008, 89-96.

*B* Genequant, Denis, Les établissements des élites omeyyades en Palmyrène et au Proche-Orient, Beirut 2012. Excellent survey, well illustrated, wide ranging, and well referenced.

George-Samné, Dr., La Syrie, Paris 1921.

Gerster, Georg, The Past from Above: Aerial Photographs of Archaeological Sites, Los Angeles: Getty Publications, 2005. 516 illustrations, including some 75 sites of Greece and Rome. Most of the book is a survey of Gerster's aerial shots by type villages and towns, palaces, fortifications, cemeteries etc., from all over the world.

, * B* Flugbilder aus Syrien, Mainz 2003, Superb!! All great photos, accompanied by maps and plans, and all explained in detail by Wartke. This, together with the Smithsonian catalogue, forms an excellent introduction to the remaining landscapes of Syria. (Cf Blum et al., Luftbilder antiker Landschaften und Statten de Turkei, Mainz 2006 - good, but not in the same class for either photos or information.)

Gertwagen, Ruthy, "The Crusader Port of Acre: Layout and Problems of Maintenance," in Autour de la première croisade: Actes du Colloque de la Society for the Study of the Crusades and the Latin East (Clermont-Ferrand 1995), Balard, M. ed., Paris 1996, $553-82$.

Geyer, B., Conquête de la steppe, Paris 2001. Sections on bronze Age, and on II-VIIC.

Geyer, Bernard et al., "Les peuplements anciens," in Jaubert \& Geyer 2006, 55-69. Irrigation and qanats in the arid margins.

Gharaybeh, Abdul Karim M., "English Traders in Syria, 1744-1799," doctoral thesis, University of London, $195^{\circ}$. 
Gingeras, Ryan, Sorrowful Shores: Violence, Ethnicity, and the End of the Ottoman Empire, 1912-1923, Oxford 2009. Concentrates on a study of Muslim immigrants and native Christians in the South Marmara,

Glucker, C.A.M., The city of Gaza in the Roman and Byzantine periods, BAR International series 325, Oxford, 1987.

Göçek, Fatma Müge, East encounters West. France and the Ottoman Empire in the Eighteenth Century, New York \& Oxford 1987.

Gonnella, Julia, "The citadel of Aleppo: recent studies," in Kennedy 2006, 165-175.

— , "Introduction to the Citadel of Aleppo," in Bianca, Stefano, ed., Syria:medieval citadels between East and West, Turin 2007, 103-128.

, "Die aiyubidische und mamlukische Zitadelle von Aleppo: Residenzstadt und Befestigung," in Piana 2008, 139-147.

Gonnella, Julia, et al., Die Zitadelle von Aleppo und der Tempel des Wettergottes: neue Forschungen und Entdeckungen, Münster 2005.

Goodchild, R.G., "The coast road of Phoenicia and its Roman milestones," in Berytus 9 (1949) 91-127.

Goode, James F., Negotiating for the past. Archaeology, Nationalism, and Diplomacy in the Middle East, 1919-1941, Austin TX 2007. Excellent and subtle account, highly alert to the politics of the past.

Goosens, G., Hiérapolis de Syrie. Essai de monographie historique, Louvain 1943.

Gorbea, Antonio A., El Palacio Omeya de Aman I, La arquitectura, Madrid 1983. Concludes 204 that the complex is based on the ruins of monumental Roman constructions. Includes many early photos.

Gossman, Lionel, The Passion of Max Von Oppenheim: Archaeology and Intrigue in the Middle East from Wilhelm II to Hitler, Cambridge 2013.

Grabar, Oleg, et al., City in the desert, 2 vols 1978. Qasr al-Hayr East.

${ }^{*} B^{*}$ Grant, Christina Phelps, The Syrian desert. Caravans, travel and exploration, London 1937. Excellent!!

Greenhalgh, Michael, Marble Past, Monumental Present. Building with Antiquities in the Mediaeval Mediterranean, Leiden \& Boston 2009.

— Constantinople to Córdoba: Dismantling Ancient Architecture in the East, North Africa and Islamic Spain, Leiden \& Boston 2012.

*B* Grishina, Evgenia, Ein Land im Licht, Studien zur Palästina - Reiseliteratur (19181934), Heidelberg 2012.

Grotzfeld, Heinz, Das Bad im arabisch-islamischen Mittelalter: Eine kulturgeschichtliche Studie, Wiesbaden 1970.

Guérin, Alexandrine, "Organisation de l'espace habité en milieu rural à la période islamique: Msayké, un village dans le Leja (Syrie du sud)," in Les maisons de la Syrie antique, Castel, C., et al., eds., Beirut 1997, 195-202.

, "Le village de Mseikeh et le Leja à la période islamique (VII ${ }^{\mathrm{e}}-\mathrm{XV}^{\mathrm{e}}$ siècle). Archéologie du peuplement et histoire des territoires," in Hauran III 2008, 233-298. 
Guillot, Xavier, "From One Globalization to Another: In search of the seeds of modern tourism in the Levant, a Western Perspective," in Daher 2007, 95-110.

Hachicho, Mohamad Ali, "English Travel Books about the Arab near East in the Eighteenth Century," in Die Welt des Islams 9.1 1964, 1-206.

Hadjar, Abdallah, Historical monuments of Aleppo, Aleppo 2000. Ten illustrated walking tours of Aleppo's monuments, with ground-plans and fold-out maps. Highly recommended.

Hall, Linda Jones, Roman Berytus. Beirut in Late Antiquity, London \& New York 2004.

${ }^{*} \mathrm{~B}$ * Hamarneth, Basema, Topografia cristiana ed insediamenti rurali nel territorio dell'odierna Giordania nelle epoche bizantina ed islamica V-IX secolo, Vatican City 2003.

Hammad, Manar, Palmyre: transformations urbaines, Paris 2010. Excellent book: could do with more on later periods.

Hanisch, Hans-Peter, “Die Zitadelle von Damaskus 14/635-1410/1995," in Vermeulen $2007,235-305$. Built on late antique foundations.

Hanssen, Jens, Fin de Siècle Beirut. The Making of an Ottoman Provincial Capital, Oxford 2005.

*B* Hauran III: L'habitat dans les campagnes de Syrie du Sud aux époques classique et médiévale, Clauss-Balty, Pascale, ed., Damascus 2008. Very well illustrated.

*B* Hauran IV: Sahr Al-Ledja II, Dentzer, Jean-Marie, \& Weber, Thomas Maria, eds., Beirut 2009.

*B* Hauran V.I, al-Maqdissi, Michel, et al., eds., Damascus 2008. Very well illustrated.

${ }^{*} \mathrm{~B}^{*}$ Heneine, Alice, Lady Esther Stanhope et le Liban, 2 vols Beirut 1983.

Hillenbrand, Robert, "La dolce vita in early Islamic Syria: The evidence of later Umayyad Palaces," in Art History 5 1982, 1-35.

— , "Anjar and Early Islamic urbanism," in G. Brogiolo and Bryan Ward-Perkins, eds., The Idea and Ideal of the Town between Late Antiquity and the Early Middle Ages, in the series The Transformation of the Roman World 4, Leiden and Boston 1999, 60-98.

Hinrichsen, Alex: Baedeker's Reisehandbücher: 1832-1990; Bibliographie 1832-1944, Verzeichnis 1948-1990: Verlagsgeschichte mit Abbildungen und zusätzlichen Übersichten, 2nd edn, Bevern 1991.

Hirschfeld, Yizhar, "The Monasteries of Gaza: An archaeological review," in BittonAshkelony, Brouria, \& Aryeh Kofsky, Aryhe, eds., Christian Gaza in Late Antiquity, Leiden \& Boston 2004, 61-88.

Hitti, Philip, Syria: a short history, New York 1959.

${ }^{*} \mathrm{~B}^{*}$ Hodgson, Barbara, Rêve d'Orient, Paris 2006. Well illustrated. On the practicalities of travel for women - dress, harems, baths, etc. 
Hoffmann, Adolf, "Gadara - Stadt und Umland," in Schwander, Ernst-Ludwig, \& Rheidt, Klaus, eds., Stadt und Umland: neue Ergebnisse der archaeologischen Bauund Siedlungsforschung, Mainz 1999, 223-236.

— , "Topographie und Stadtgeschichte von Gadara/Umm Qais," in Hoffmann \& Kerner 2002, 98-124.

* ${ }^{*}$ Hoffmann, Adolf, \& Kerner, Suzanne, eds., Gadara-Gerasa und die Dekapolis, Mainz 2002.

*B* Holum, Kenneth G., "Caesarea's temple hill. The archaeology of sacred space in an ancient Mediterranean city," in Near Eastern Archaeology 67.4 2004, 184-199.

— , "Caesarea's fortune: ancient statuary and the beholder in a late antique city," in Eliav 2008, 539-558.

Horton, Fred L., Jr, "A sixth-century bath in Caesarea's suburbs and the transformation of bathing culture in Late Antiquity," in Raban, Avner, \& Holum, Kenneth G., Caesarea Maritima: a retrospective after two millennia, Leiden 1996.

Hudson, Leila, Transforming Damascus. Space and modernity in an Islamic city, London \& New York 2008.

Hughes, J. Donald, The Mediterranean: an environmental history, Santa Barbara CA 2005 .

Humbert, Jean-Baptiste, ed., Gaza méditerranéene. Histoire et archéologie en Palestine, Paris 2000. Exhibition, hence concentrates on portable items.

Humphrey, J.-J., ed., The Roman and Byzantine Near East 3, Portsmouth Rhode Island 2002.

Inälcik, Halil, \& Quataert, Donald, An Economic and Social History of the Ottoman Empire, I: 1300-160o. Cambridge 1994.

Institut français de Damas, Une mission de reconnaissance de l'Euphrate en 1922, Damascus 1995 .

Issawi, Charles, The Fertile Crescent 1800-1914, a documentary economic history, New York \& Oxford 1988.

Jaubert, Ronald, \& Geyer, Bernard, eds., Les marges arides du croissant fertile. Peuplements, exploitation et contrôle des ressources en Syrie du Nord, Lyon 2006.

Jaussen, Antonin, \& Savignac, Raphaël, RR. PP., Mission archéologique en Arabie, III: Les châteaux arabes de Qeseir 'Amra, Haraneh et Tuba, Paris 1922, text plus separate atlas of 63 plates.

Kader, I., Propylon und Bogentor, Mainz 1996.

Kappler, Claude, "Les voyageurs et les langues orientales: interprètes, traducteurs et connaisseurs," in Debout, Marion, et al., eds., Routes d'Asie: marchands et voyageurs $X V^{e}-X V I I I^{e}$ siècle, Colloque Paris 1986, Istanbul/Paris 1988, 25-36. Good overview. Colloque mostly concerned with Central Asia and China. 
Karpat, Kemal H., Ottoman Population, 1830-1914. Demographic and socialcharacteristics, Madison Wisconsin 1985. Includes extensive population tables, and breakdowns by religion, region, etc.

Karsh, Efraim, \& Karsh, Inari, Empires of the sand: The struggle for mastery in the Middle East 1789-1923, Cambridge Mass 1999.

Kasaba, Reşat ed., A Moveable Empire. Ottoman Nomads, Migrants, and Refugees, Seattle 2009.

Kayali, Hasan, Arabs and Young Turks: Ottomanism, Arabism, and Islamism in the Ottoman Empire, 1908-1918, London 1997.

Kennedy, David, The Roman army in Jordan, 2nd edn. London 2004.

—, Gerasa and the Decapolis. A "virtual island" in northwest Jordan, London 2007.

—_, "Water supply and use in the southern Hauran, Jordan," in Jnl Field Archaeology $22.31995,275^{-290 .}$

— , "The frontier of settlement in Roman Arabia: Gerasa to Umm al-Jimal ... and beyond," in Mediterraneo Antico 3.2 2000, 397-453.

- Crusader Castles, Cambridge 1994.

Kennedy, Hugh, Muslim military architecture in Greater Syria, Leiden \& Boston 2006.

- "The impact of Muslim rule on the pattern of rural settlement in Syria," in Canivet 1992, 291-297.

Kenney, Ellen, "Power and Patronage in Mamluk Syria: The Architecture and Urban Works of Tankiz al-Nasiri, 1312-1340," PhD NYU 2004.

Kent, Marian, ed., The Great Powers and the End of the Ottoman Empire, London 1984. A clear exposition, with chapters devoted to one entity (Hapsburg Monarchy, Italy, Russia, Germany, France and Great Britain). See the chapters on Italy and on Germany for the archaeological opportunities they took.

Kerner, Suzanne, ed., The Near East in antiquity. German contributions to the archaeology of Jordan, Palestine, Syria, Lebanon and Egypt, I Amman 1990, II Amman 1991, III Amman 1992.

Khalek, Nancy, Damascus after the Muslim Conquest: Text and image in early Islam, Oxford etc. 2011.

Khalidi, Rashid, British Policy towards Syria and Palestine, 19o6-1914, London 1980.

Khamis, Elias, "The shops of Scythopolis in context," in Lavan et al., eds. Objects 2007, 439-472.

Klinkott, Manfred, "Der antike Stadtraum in Syrien und Kleinasien," in Winter, Engelbert, ed., Vom Euphrat bis zum Bosporus: Kleinasien in der Antike, II, Bonn 2008, 373-383.

Kila, Joris D., "Cultural property crimes in the context of contemporary armed conflicts," in Journal of Eastern Mediterranean Archaeology and Heritage Studies, (hereafter JEMAHS ) 1.4 for 2013 in 319-342. "With the rapid spread of armed conflict 
and civil uprising throughout the Middle East and North Africa, the protection of cultural property takes a backseat to more pressing concerns about the destruction of lives and economic resources. In this article and the responses that follow, the complexities of preserving the past in the context of a volatile present are explored." Knost, Stefan, "The impact of the 1822 earthquake on the administration of waqf in Aleppo," in Sluglett 2010, 293-305.

Konrad, Michaela, "Roman military fortifications along the eastern desert frontier: settlement continuities and change in North Syria, 4th-8th centuries," in Bartl \& Moaz 2008, 433-453.

Korn, L., "Die Bauten Saladins. Kairo, Damaskus und Jerusalem in der Baupolitik des An-Nasir Salah Ad-Din," in Vermeulen \& De Smet II 1998, 209-235. cf. author's Magisterarbeit, Tübingen 1994. 32: constructions in Damascus; and 9 in Jerusalem cf. Tables $2 \& 3$.

* $\mathrm{B}^{*}$ Korn, Lorenz, Ayyubidische Architektur in Ägypten und Syrien: Bautätigkeit im Kontext von Politik und Gesellschaft, Heidelberg 2004.

Krencker, Daniel, \& Zschietzschmann, Willy, eds., Römische Tempel in Syrien, nach Aufnahmen und Untersuchungen von Mitgliedern der deutschen Baalbekexpedition, 1901-1904, 2 vols Berlin \& Leipzig 1938.

*B*Kuhnen, Hans-Peter, Palästina in griechischer-römischer Zeit, Munich 1990.

—, "Églises d'Apamée" in Bull. Études Orientales 251972 5-35.

${ }^{*} \mathrm{~B}^{*}$ Laborde, Léon de, Le voyage en Orient de Léon de Laborde, exhibition 2010 . The catalogue of the exhibition $83 \mathrm{ff}$ is of 179 plates from his book.

Laborde, Léon de, \& Bellefonds, Linant de, Petra retrouvée. Voyage de l'Arabie Pétrée, 1828, Paris 1994.

Laidlaw, Christine, The British in the Levant. Trade and Perceptions of the Ottoman Empire in the Eighteenth Century, London \& New York 2010.

Larché, François, Iraq Al-Amir. Le château du Tobiade Hyrca, II: Restitution et reconstruction, 2 vols, Beirut 2005.

* $\mathrm{B}^{*}$ Lassus, Jean, Sanctuaires chrétiens de Syrie: essai sur la genèse, la forme et l'usage liturgique des édifices du culte chrétien, en Syrie, du III e siècle à la conquête musulmane, Paris 1947. XIII: book is the result of 8 years in Syria. XXIV-XXVII for bibliography of travellers' accounts.

— , * B* Voyage en Asie Mineure, exhibition, Le Blanc 2013. Very well illustrated.

Lazzarini, Lorenzo, ed., Pietre e marmi antichi. Natura, caratterizzazione, origine, storia d'uso, diffusione, collezionismo, Milan 2004.

Lee, Michael J., The erosion of biblical certainty. Battles over authority and interpretation in America, New York 2013.

${ }^{*} \mathrm{~B}^{*}$ Lehmann, Gunnar, Bibliographie der archäologischen Fundstellen und Surveys in Syrien und Libanon, Rahden/Westf. 2002. 
Le Lasseur, Denyse, "Mission archéologique à Tyr (avril mai 1921)," in Syria III 1922, 1-26, 116-133.

Lemke, Wolf-Dieter, “The Kaiser in Lebanon," in Sader 1998, 51-88.

Leriche, Pierre, "Urbanisme défensif et occupation du territoire en Syrie hellénistique," in Frézouls 1987, 57-79.

Lewis, Norman, Nomads and settlers in Syria and Jordan, Cambridge 1987.

—_, "Peuplement et développement de la steppe en Syrie (1800-1920)," in Bocco, Riccardo, et al., Steppes d'Arabies. États, pasteurs, agriculteurs et commerçants: le devenir de zones sèches, Paris 1993, 45-6o.

Lewis, Norman N. et al., "William John Bankes.Travaux en Syrie d'un voyageur oublié," in Syria 73 fascicule 1-4 1996, 57-95.

Liverani, Mario, “Voyage en Orient.' The Origins of Archaeological Surveying in the Near East," in Amoretti, Biancamaria Scarcia, ed., The East and the Meaning of History, Studi Orientali 13 1994, 1-16.

Long, Burke O., Imagining the Holy Land. Maps, models and fantasy travels, Bloomington IN 2003. Deals with 20thC as well as 19thC; subtle and wide-ranging, but broad in focus, so little depth.

${ }^{*} \mathrm{~B}$ * Long, Pamela O., Technology and Society in the Medieval Centuries: Byzantium, Islam, and the West, 500-1300, Washington, DC 2003. A historiographical guide to technological development in the medieval period throughout the Mediterranean area.

MacAdam, Henry Innes, Studies in the History of the Roman Province of Arabia, Oxford 1986. Includes map of routes of the extensive Princeton expeditions of 1904-5 and 1909 .

— , "The history of Philadelphia in the classical period," in Northedge 1992, 27-45.

Mackey, Bruce Douglas, "The Circassians in Jordan," thesis, Naval Postgraduate School, Monterey CA, 1979. Includes the circumstances of their flight, and of their arrival in Jordan.

*B* Maclean, Gerald, \& Matar, Nabil, Britain and the Islamic world, 1558-1713, Oxford 2011.

Magness, Jodi, The archaeology of the early Islamic settlements in Palestine, Winona Lake, IN, 2003, esp. $195 \mathrm{ff}$.

- Archaeology of the Holy Land from the destruction of Solomon's temple to the Muslim conquest, Cambridge etc. 2012.

Mango, Marlia, "Baths, reservoirs and water use at Androna in late antiquity and the early Islamic period," in Bartl \& Moaz 2008, 73-88.

Marcus, Abraham, The Middle East on the eve of modernity. Aleppo in the eighteenth century, New York 1989. Cultural, religious, economic and political history, but little on architecture.

Marino, Luigi, et al., "The Crusader Settlement in Petra," in Fortress 7 1990, 3-13. 
Mart, Yossi, \& Perecman, Ilana, “Caesarea: unique evidence for faulting patterns and sea level fluctuations in the Late Holocene," in Raban \& Holum 1996, 3-24-including list of earthquakes and tsunamis 23-24.

Masse, Danièle, Burckhardt, le bédouin de Petra, Toulon 1996. Biography of his travels, but without footnotes or any kind of references in the text.

Maupoix, Michel, "Léon de Laborde voyageur, entre oubli et présence," in Laborde 2013, 95-106.

*B* Mayer, Wendy, \& Allen, Pauline, Churches of Syrian Antioch, Louvain etc. 2012. XV: "This is the book we hoped someone else would provide."

McCormick, Michael. Origins of the European Economy: Communications and Commerce, $A D$ 300-90o, Cambridge 2001. An excellent recent study of a critical period in the history of the European economy, including detailed consideration of Mediterranean southern Europe.

- Charlemagne's survey of the Holy Land. Wealth, personnel and buildings of a Mediterranean church between Antiquity and the Middle Ages, Washington 2011. A fact-finding tour of shrines in the Holy Land, which Charlemagne would gift if he got good reports. Author reckons (XIV) he is using documents "whose neglect by historians ... is as remarkable as the documents' content, and implications."

McHugo, John, Syria: a history of the last hundred years, New York 2015.

*B* Mansel, Philip, "The Grand Tour in the Ottoman Empire 1699-1826," in Starkey 2011, 41-64. Excellent overview, including Syria.

Meimaris, Yiannis, "The Discovery of the Madaba Mosaic Map. Mythology and Reality," in The Madaba Map Centenary, Jerusalem 1999, 25-36.

Meinecke, Michael, \& Aalund, Flemming, Bosra:Architektur und Archäologie, Rahden/ Westf. 2005 .

Michaudel, Benjamin, "The development of Islamic military architecture during the Ayyubid and Mamluk reconquests of Frankish Syria," in Kennedy 2006, 106-121.

Michel, Anne, Les églises d'époque byzantine et umayyade de Jordanie (provinces d'Arabie et de Palestine) $V^{e}-V I I I^{e}$ siècle, Turnhout 2001. Very well illustrated: plenty of churches have mosaics.

Milani, Celestina, "La continuità del mondo classico negli Itineraria ad loca sancta (IV-VI secolo d.C): istituzioni e tradizioni," in Finazzi, Rosa Bianca, \& Valvo, Alfredo, eds., Pensiero e istituzioni del mondo classico nella cultura del Vicino Oriente, Alessandria 2001, 145-96.

Miller, J Maxwell, "Burckhardt-Robinson features in 19thC maps of the Kerak plateau," in Stager et al. 2000, 351-366. For their influence on later travellers via sites and routes they mis-located.

Milwright, Marcus, An introduction to Islamic archaeology, Edinburgh 2010.

Murphy-O'Connor, Jerome, The Holy Land. An Oxford Archaeological Guide from earliest times to $1700,5^{\text {th }}$ edn, Oxford etc. 2008. 
Murray, Tim, Milestones of archaeology. A chronological encyclopedia, Santa Barbara CA etc., 2007.

Musil, Alois, Arabia petraea, Vienna 1907-8.

—, Arabia deserta: A topographical itinerary, New York 1927.

—, Palmyrena: A topographical itinerary, New York 1928.

Naccache, Albert Farid Henry, "Beirut's memorycide: hear no evil, see no evil," in Meskell, Lynn, Archaeology under fire: nationalism, politics and heritage in the Eastern Mediterranean and Middle East, London 1998, 140-58.

Nash, Geoffrey, From empire to orient. Travellers to the Middle East 1830-1926, London \& New York 2005.

Naval Staff Intelligence Department, A handbook of Asia Minor IV.2: Cilicia, Antitaurus, and North Syria, London 1919. Entered as Naval_Staff_1919.

Neglia, Giulia Annalinda, Aleppo. Processi di formazione della città medievale, Bari 2009 .

Nevakivi, Jukka, Britain, France and the Arab Middle East 1914-1920, London 1969.

Nicolle, David, Crusader castles in the Holy Land 1097-1192, Oxford 2004. Nicolle's two volumes are richly illustrated with plans, views and reconstructions, with up-todate photos of many sites, and some older photos of features now gone.

- Crusader castles in the Holy Land 1192-1302, Oxford 2005.

- Saracen strongholds AD 630-1050, The Middle East and Central Asia, Oxford 2008. Includes desert castles/palaces, Anjar, Ukhaidir, Umm al-Jimal. About half the sites covered are in Greater Syria.

-, Ottoman fortifications 1300-1710, Oxford 2010. 30 for illustration charting the long line of Ottoman forts from Payas down through Egypt.

Norris, Jacob, Land of progress. Palestine in the age of colonial development, 1905-1948, Oxford 2013 .

${ }^{*} \mathrm{~B}^{*}$ Northedge, Alastair, et al., Studies on Roman and Islamic Amman I, Oxford \& New York 1992.

${ }^{*} \mathrm{~B}^{*}$ Nour, Antoine Abel, Introduction à l'histoire urbaine de la Syrie ottomane, (XVI ${ }^{\mathrm{e}}-$ XVIII ${ }^{\mathrm{e}}$ s.), Beirut 1982.

Oates, Joan, "Archaeological research in Northeastern Syria. The first 100 years $\left(185^{-}\right.$ 1950)," in 100 Jahre archäologischen Feldforschungen, Bonatz, Dominik, \& Martin, Lutz, eds., Berlin 2013, 1-16.

Obenzinger, Hilton, American Palestine. Melville, Twain and the Holy Land mania, Princeton 1999. Very allusive, and based on literature (as title suggests) not archaeology.

Pamuk, Şevket, The Ottoman Empire and European Capitalism, 1820-1913. Trade, Investment and Production, Cambridge 1987. For the consequences of European economic penetration on agriculture and manufacturing. 
Pentz, Peter, Hama fouilles 1931-8, 1997.

*B* Pentz, Peter, From Roma Proconsularis to Islamic Ifriquiyah, Gothenburg 2002.

Petersen, Andrew, Gazeteer of buildings in Muslim Palestine (Part 1), Oxford 2001. Divided by type, then gazeteer.

—, "Mamluk new towns in Palestine," in Vermeulen 2007, 496-509.

Philipp, Thomas, \& Schaebler, Birgit, eds., The Syrian Land: processes of integration and fragmentation: Bilad ash-Sham from the 18th to the 2oth Century, Stuttgart 1998, 1-154.

*B* Piana, Mathias, ed., Burgen und Städte der Kreuzzugszeit, Petersberg 2008. Superb. Very well illustrated.

Picard, Charles, "Les frises historiées autour de la cella et devant l'adyton, dans le temple de Baccus à Baalbek," in Mélanges syriens offerts à René Dussand I, Paris 1939, 319-343. All comprehensively hammered on the blocks, which remain in place: see his figs $5^{-8,11-12 .}$

* $\mathrm{B}^{*}$ Piccirillo, Michele, L'Arabie chrétienne, Paris 2002. Excellent folio picture book with index of sites, and large emphasis on mosaics. He deals with the Roman Province of Arabia - Syria, Lebanon, Jordan, Palestine. Best introduction to the topic.

, * $\mathrm{B}^{*}$ Palestina cristiana, I-VI secolo, Bologna 2008. No footnotes. An unillustrated account of Christianity here, with 203-210 for chronology from the birth of Christ to the arrival of Islam in Jerusalem in 638.

Pignot, Hélène, La Turquie chrétienne. Récits de voyageurs français et anglais dans l'Empire Ottoman au XVII siècle, Vevey 2007 - extracts from source texts, the whole Empire, so little on Syria, and no index.

Ploug, G., Hama Graeco-Roman town, Copenhagen 1985.

Poidebard, R.P. Antoine, La trace de Rome dans le désert de Syrie: le limes de Trajan à la conquête Arabe, Recherches aériennes (1925-1932), 1934.

—, Un grand port disparu: Tyr, recherches aëriennes et sous-marines 1934-1936, Paris 1939.

—_ "La trace de Rome dans le désert de Syrie. Organisation du limes," in Mélanges d'archéologie et d'histoire 54 1937, 5-24.

${ }^{*} \mathrm{~B}^{*}$ (Poidebard, R.P. Antoine), Une aventure archéologique. Antoine Poidebard, Marseille etc., 2004. Very well illustrated. Entered as Poidebard 2004. 29-30 for chronology.

Polkehn, K., Palästina: Reisen im 18. und 19. Jahrhundert, Berlin 1986.

Pollock, Susan, \& Bernbeck, Reinhard, Archaeologies of the Middle East, Malden MA etc., 2005.

Potts, D.T. ed., A companion to the archaeology of the ancient Near East, 2 vols, Chichester 2012.

Pringle, Denys, Secular buildings in the Crusader Kingdom of Jerusalem: an archaeological gazetteer, Cambridge 1997. 
_ , "Richard I and the walls of Ascalon," in Palestine Exploration Quarterly 116 1984, 133-47.

—, "Town defences in the crusader Kingdom of Jerusalem," in The medieval city under Siege, Corfis, I.A., \& Wolfe, M., eds., Woodbridge 1995, 69-112. General survey. *B* Quataert, Donald, The Ottoman Empire 1700-1922, 2nd edn, Cambridge 2005.

Rababeh, Shaher M., How Petra was built, Oxford 2005.

Raban, Avner, The Harbours of Caesarea Maritima. Results of the Caesarea Ancient Harbour Excavation Project 1980-85, 2 vols, Oxford, 1989.

- "The inner harbor basin of Caesarea: archaeological evidence for its gradual decline," in Raban \& Holum 1996, 628-666.

Raban, Avner, \& Holum, Kenneth G., eds., Caesarea Maritima: a retrospective after two millennia, Leiden 1996.

Raymond, André, Grandes villes arabes à l'époque ottomane, Paris 1985. See http:// books.openedition.org/ifpo/1664.

— Damascus 1998. See http://books.openedition.org/ifpo/505.

Rée, Peta, "James Silk Buckingham (1786-1855): an anecdotal traveller," in Starkey 2011, 169-178, for his travelling biography.

Richard, J., "Les bases maritimes des Fatimides, leurs corsairs et l'occupation franque en Syrie," in Vermeulen \& De Smet II 1998 115-129: on the key importance of the ports for both sides.

Roberts, Stephen H., The history of French colonial policy 1870-1925, London 1929.

${ }^{*} \mathrm{~B}^{*}$ Rodenbeck, John, "Dressing native," in Starkey 2011, 65-100. Excellent and wideranging paper.

Rodinson, Maxime, "De l'archéologie à la sociologie historique. Notes méthodologiques sur le dernier ouvrage de G. Tchalenko," in Syria 38.1-2 1961, 170-200.

Rogers, Stephanie Stidham, Inventing the Holy Land:American Protestant Pilgrimage to Palestine, 1865-1941, London etc. 2011.

Rostovtzeff, Michael, Caravan Cities, Oxford $193^{2}$.

Sader, Hélène et al., eds., Baalbek image et monument, Stuttgart 1998.

Salibi, Kamal, A house of many mansions. The history of Lebanon reconsidered, London 1988.

Saliby, Nassib, “Un palais byzantino-omeyyade à Damas," in Castel et al., eds., 1997, 191-194.

Salles, Jean-François, "Histoire d'une découverte et d'une reconstruction," [of Iraq Al-Emir] in Etienne 2010, 42-48: much excavation needed to recover and rebuild the hundreds of blocks for the reconstruction - see figs 14-15.

Salmon, Olivier, "Le voyage en Asie Mineure dans la première moitié du XIX siècle," in Laborde 2013, 38-51. 
— 9-15.

Sartre, Maurice, Inscriptions grecques et latines de la Syrie: Bostra (supplément) et la plaine de la Nuqrah, Beirut 2011. Gives historical introductions and visitors to some of his villages, e.g. 139-140 Jmarrin, 153 Kharaba, 221 Kerak (where he saw lots of spolia in the modern houses), 233 Deit Al-Khuleif Umm Walad, 287 Hrayyek.

—_, "Villes et villages du Hauran (Syrie) du Ir au IVe siècle," in E. Frézouls, ed., Sociétés urbaines, sociétés rurales dans l'Asie Mineure et la Syrie hellénistiques et romaines, Contributions et travaux de l'Institut d'Histoire Romaine 4, Strasburg, 1987, 239-57.

Sartre-Fauriat, Annie, Des tombeaux et des morts: monuments funéraires, société et culture en Syrie du Sud du Irr S. av J-C au VII S. apr.J-C, II: synthèse, Beirut 2001.

—, "William John Bankes (1786-1855): voyageur en Orient au début du XIX siècle," in Voyageurs et antiquité classique, Duchêne, Hervé, ed., Dijon 2003, 135-144.

Satia, Priya, Spies in Arabia: The Great War and the Cultural Foundations of Britain's Covert Empire in the Middle East, Oxford 2008.

Sattin, Anthony, The young T.E. Lawrence, New York \& London 2014.

Scham, Sandra A., "The political theater of the past: visits by state leaders to archaeological and historical sites," in JEMAHS 1.1 for 2013, 66-87.

Scheffler, Thomas, "The Kaiser in Baalbek: tourism, archaeology and the politics of imagination," in Sader 1998, 13-49.

Schlumberger, Daniel, Qasr El-Heir el Gharbi, Paris 1986. 84 plates. The decorations now in the Damascus Museum, including the entrance. 26: reckons fall of the Omayyads in $75^{\circ}$ led to abandonment, and occupation by fellahs.

* $\mathrm{B}^{*}$ Schlumberger, Daniel, L'Occident à la rencontre de l'Orient, Damascus \& Beirut 2010. Well illustrated.

Schmidt, Andrea, \& Westphalen, Stephan, Christliche Wandmalereien in Syrien, Wiebaden 2005. Fragments survive from what must have been very extensive decorations - the authors deal only with Qara and Kloster Mar Yakub, plus Ma'arrat Saydnaya.

Sconzo, Paola, "Leonard Woolley, Lawrence d'Arabie et les fouilles de Karkémish," in Al-Maqdissi, Michel, ed., Pionniers et protagonistes de l'archéologie syrienne 1860196o, d'Ernest Renan à Sélim Abdulhak, Damascus, 2008.

${ }^{*} \mathrm{~B}^{*}$ Segal, Arthur, Town planning and architecture in Provincia Arabia, Oxford 1988.

—, Theatres in Roman Palestine and Provincia Arabia, Leiden etc. 1995. 30 in all.

Seigne, Jacques: “Gerasa-Jerasch - Stadt der 1000 Säulen," in Hoffmann \& Kerner 2002, $6-22$.

Seyler, Dorothy U., The Obelisk and the Englishman: The Pioneering Discoveries of Egyptologist William Bankes, Amherst NY 2015. 
${ }^{*} \mathrm{~B}$ * Shiyyab, Adnan, Der Islam und der Bilderstreit in Jordanien und Palästina, Munich 2002. Excellent thesis.

Seigne, Jacques, "Habitat hellénistique et romain de Gerasa," in Castel et al., eds., 1997. Shaw, Wendy M.K., Possessors and Possessed. Museums, Archaeology, and the Visualization of History in the Late Ottoman Empire, Berkeley \& LA 2003.

Sivan, Hagith, Palestine in late antiquity, Oxford 2008. A clearly written, well-referenced and broad survey.

*B* Smith, Andrew, Roman Palmyra, Oxford 2013.

Sperber, Daniel, The city in Roman Palestine, New York \& Oxford 1998. There are 26 references in the text to the "Land of Israel," which some may find puzzling in a book dedicated to the Romans.

Schwartz, Joshua J., "Archeology and the City," in Sperber 1998 149-187.

*B* Sluglett, Peter, ed., Syria... under Ottoman rule, Leiden 2010 [101-175 for 4 papers on economic history.]

Stager, Lawrence E. et al., eds., The archaeology of Jordan and beyond. Essays in honor of James A. Sauer, Winona Lake Indiana 2000.

Stanzl, Günther, "Die Palastvilla von Inkhil: Bauforschung und restaurierung," in Hauran III 2008, 135-168.

*B* Starkey, Paul \& Janet, eds., Unfolding the Orient, Reading 2011. Excellent overview, with a large bibliography.

Strube, Christine, Baudekoration in Nordsyrischen Kalksteinmassif I, Mainz 1993. Dedicated to 4 thC \& 5 thC churches, catalogue and 124 plates, most multi-photo magnificent publication!!

— , *B* Die "Toten Städte." Stadt und Land in Nordsyrien während der Spâtantike, Mainz 1996. Excellent, well-illustrated summary.

Talbert, Richard, Barrington Atlas of the Greek and Roman World, Princeton 2000, with CD-ROM. 102 maps, covering 1000BC to 640AD.

Talmon-Heller, Daniella, Islamic Piety in Medieval Syria: Mosques, Cemeteries and Sermons under the Zangids and Ayyubids (1146-1260), Leiden \& Boston 2007.

Tannenbaum, Jan Karl, "France and the Arab Middle East 1914-1920," in Trans AM.Phil. Soc. LXVIII.7 1978, 1-50. See 3: "The purpose of this study is to delineate France's Middle Eastern policies during World War I and the ensuing peace conference. In so doing, the study will show how France was able to gain control of Syria and Lebanon in 1920."

Tate, Georges, Les campagnes de la Syrie du Nord du II e au VII siècle: un exemple d'expansion démographique et économique à la fin de l'antiquité, I, Paris 1992. Very well illustrated. Subtitled Un exemple d'expansion démographique et économique à la fin de l'antiquité.

— siècles," in Gatier 1988, 249-256. 
—_, "La maison rurale en Syrie du nord," in Castel et al., eds., 1997, 95-101.

Tate, Georges, et al., Serjilla, village d'A pamène, 2 vols Beirut \& Damascus 2013. A splendid publication, cataloguing each building, and replete with plans and photos for vol. I text, and vol. II 241 plates.

Taylor, G., The Roman Temples of Lebanon: a Pictorial Guide; Les temples romains au Liban; guide illustré, Beirut, 1971.

Tchalenko, Villages antiques de la Syrie du Nord. Le massif de Bélus à l'époque romaine, 2 vols, Paris 1953. Includes plans of a large number of villages. A splendid publication!!

—_ Villages antiques de la Syrie du Nord. Le massif de Bélus à l'époque romaine III, Paris 1958, for inscriptions, and catalogue of convents.

Ten Hacken, Clara, “The description of Antioch in Abu al-Makarim's History of the churches and monasteries of Egypt and some neighbouring countries," in Ciggaar, K., \& Metcalf, M., eds., East and West in the Medieval Eastern Mediterranean, I: Antioch from the Byzantine Reconquest until the end of the Crusader Principality, Louvain 2006, 186-216.

Thirgood, J.V., Man and the Mediterranean forest. A history of resource depletion, London 1981.

Tigay, Jeffrey H., “'Archaeology' of the Bible and Judaism in Late Antiquity and the Middle Ages," in Stager et al. 2000, 490-497.

Todt, Klaus-Peter, "Antioch in the middle Byzantine period (969-1084): the reconstruction of the city as an administrative, military, economic and ecclesiastical center," in Cabouret, B., et al., eds., Topoi Supplement 5: Antioche de Syrie: histoire, images et traces de la ville antique, Lyon 2004.

Tonghini, Cristina, Shayzar I: The Fortification of the Citadel, Leiden \& Boston 2012.

Trümpler, Charlotte, "Aerial photography in archaeology and its pioneers," in Gerster 2005, 9-23.

Tsafrir, Yoram, "The christianisation of Bet Shean (Scythopolis) and its social-cultural influence on the city," in Brands \& Severin 2003, 275-284.

Turhan, Filiz, The other empire. British romantic writings about the Ottoman Empire, London \& New York 2003.

Turnheim, Yehudit, \& Ovadiah, Asher, Art in the public and private spheres in Roman Caesarea Maritima, Rome 2002.

Tuttle, Christopher A., "Preserving Petra sustainably (One step at a time): The Temple of the Winged Lions Cultural Resource Management Initiative as a step forward," in JEMAHS 1.1 for 2013, 1-23.

* $\mathrm{B}^{*}$ Uggeri, Giovanni, La via dei pellegrini. In Terrasanta nell'età di Costantino, Bologna 2013.

*B* Ulrich, Roger B., \& Quenemoen, Caroline K., eds., Companion to Roman architecture, Chichester 2014. 
Uyanik, Nevzat, Dismantling the Ottoman Empire. Britain, America and the Armenian question, London \& New York 2016.

Vermeulen, Urbain, Egypt and Syria IV, (Louvain colloque 2000-2001), Louvain 2005. , Egypt and Syria V, (Louvain colloque 2005), Louvain 2007.

Vermeulen, Urbain, \& De Smet, Daniel, eds., Egypt and Syria in the Fatimid, Ayyubid and Mamluk eras, 2 vols, Louvain 1995 and 1998.

Vernoit, Stephen, "The Rise of Islamic Archaeology," in Muqarnas 14 1997, 1-10. Excellent overview, with detailed notes and references.

Villeneuve, François, "Prospection archéologique et géographique historique: la région d'Iraq al-Amir (Jordanie)," in Gatier 1988, 257-288. - illustrates the dangers of interpreting epigraphy without excavation, and on the mute nature of archaeology!

_ - "Occupation du sol et vestiges architecturaux sur les marges arides de Syrie du sud. L'exemple de Diyatheh," in Geyer 2001, 159-187.

* $\mathrm{B}^{*}$ Vingopoulou, Ioli, Le mode grec vu par les voyageurs du XVIe siècle, Athens 2004. Useful for the biographies of the many travellers (such as Belon, Ghistele, Postel, and Villamont) who also visited Syria, maps of their trajectories, and their remarks on agriculture, trade, etc.

Viret, Jérémie, “Aux origines de l'archéologie sous-marine," in Poidebard 2004, 146-169. * $\mathrm{B}^{*}$ Vries, Bert de, et al., Umm El-Jimal. A frontier town and its landscape in northern Jordan. I: Fieldwork 1972-1981, Portsmouth RI 1998.

*B* Walmsley, Alan G., Early Islamic Syria. An archaeological assessment, London 2007. , "Die Dekapolis-Städte nach dem Ende des Römischen Reiches: Kontinuität und Wandel," in Hoffmann \& Kerner 2002, 137-147.

Watenpaugh, Heghnar Zeitlian, The image of an Ottoman city. Imperial Architecture and Urban Experience in Aleppo in the 16th and 17th Centuries, Leiden \& Boston 2004.

- ${ }^{*} \mathrm{~B} *$ "Museums and the construction of national history in Syria and Lebanon," in Méouchy, Nadine, \& Sluglett, Peter, eds., The British and French mandates in comparative perspective, Leiden \& Boston 2004, 185-202. Entered as Watenpaugh_2004B.

${ }^{*} B^{*}$ Weber, Thomas Maria, Sculptures from Roman Syria in the Syrian National Museum at Damascus, Worms 2006. 83 plates.

— Damascus. Ottoman modernity, I, 2009. Very well illustrated.

-, "One hundred years of Jordanian-German fieldwork at Umm Qais (1890-199o," in Kerner 1990, I, 15-27.

- "The making of an Ottoman harbour town: Sidon/Saida from the sixteenth to the eighteenth centuries," in Sluglett 2010, 179-239.

— , "Die Skulpturen aus Sahr und die Statuendenkmäler der römischen Kaiserzeit in südsyrischen Heiligtümern," in Hauran IV 2009.

Weiss, Harvey, "Archaeology in Syria," in AJA 101.1 1997, 97-148. 
White, Benjamin Thomas, The emergence of minorities in the Middle East. The politics of community in French Mandate Syria, Edinburgh 2011.

Wickham, Chris, Framing the Middle Ages: Europe and the Mediterranean 400-80o, Oxford 2005.

Wiegand, Theodor, et al., Baalbek: Ergebnisse der Ausgrabungen und Untersuchen in den Jahren 1898 bis 1905, 3 vols, Berlin and Leipzig, 1921 \& 1923.

—, Palmyra. Ergebnisse der Expeditionen von 1902 und 1917, Berlin 1932, II: plates.

Will, Ernest, "La Tour funéraire de la Syrie et les monuments apparentés" in Syria 26.3-4 1949, 258-312.

— - "Le château hellénistique d'Iraq al-Amir," in Delpont 1997, 113-115. Apparently found in 1818 by Irby and Mangles.

Wilson, John Francis, Caesarea Philippi, London \& New York 2004.

Winter, Stefan, The Shiites of Lebanon under Ottoman Rule, 1516-1788, Cambridge 2010.

Wright, G.H.R., Ancient building in south Syria and Palestine, I, Leiden/Cologne 1985.

Wright, John Kirtland, The geographical lore at the time of the Crusades, New York 1925.

Yerasimos, Stephane, Les voyageurs dans l'Empire Ottoman (XIV $-X V I^{e}$ siècles). Bibliographie, itinéraires et inventaire des lieux habités, Ankara 1991.

Yovitchitch, Cyril, "La citadelle de Bosra," in Fauchère, Nicolas, Mesqui, Jean, \& Proutreau, Nicolas, eds., La fortification au temps des Croisades, Rennes 2004, 205-217. 


\section{Index}

Abulfeda $\quad 136,148,219,287,361$

Acre $17,22-23,25,83,97,101,133,136$, 143-44, 202, 204, 209, 212, 214-15, 217 agriculture $1-2,5,13-15,17-18,35,37-40,42$, $83,85^{-86}, 220,295,304,306-7,315^{-16}$, $341-42$

and commerce $\quad 62,108$

cultivation $\quad 6,18,20-21,31,38-39,110$,

$187,220,294,320,337,345,366-67,372$

difficulties $\quad 26,40,86-87$

irrigation $135,249,298,367$

See also landscape

Ajlun 134, 158, 315, 364

Alandarin $\quad 258$

Aleppo $\quad 21-25,27-28,54-55,86-88,100-102$, $122,127-28,146-48,150,184-88$,

238-39, 241-43, 245-49, 251-53, 257-59

quarries 163

Alexandria $\quad 11,46,48,161,224$

Algeria 17, 30, 59, 108, 342, 400

Ali, Mehmet 108

Ali, Muhammad 19, 21, 88, 144, 382

Amman 6, 8, 10, 30-32, 39, 41-42, 99, 104, 134, 295-96, 332-33, 337-40, 343-46, 348,350

amphitheatres 105, 136, 145, 198, 200, 219, $221,287,293,327$

Anjar $\quad 3,266,282-83$

Antioch $\quad 6-8,22,27-28,127-28,130,133,135$, $154,158-59,162-63,186,188-89,240-41$, 245,248

antiquities $154,172,213,232,248,254,309$, $311,328,349$

buying \& selling $134,152,272,381$, 391-92

Christian $\quad 54-55$

earthquakes 22

export 14, 42, 156, 201, 203, 212, 239,

$379-81,383,387,390-91,407$

fakes 152

prehistoric 314

regulations $31,33,42,171,379,381,386$,

392-93

evading $\quad 380-81,392$

See also archaeology
Apamea $6,39,83,100,105,134,146,192,241$, $245,250-51$

aqueducts (see also cisterns), 135-36, 174-75, 178, 214, 217, 220, 222, 242-43, 283, 293, $297,327,332,367,371-72$

Arabia, Roman province of $7,14,127$

Arabia Petraea $\quad 24,344,382$

Arabs 20, 51, 83, 88, 195, 267, 280, 326

archaeologists $1,6,62,73,106,282,287,366$, $370,380-81,385-87,393-95,409,411,414$

American $\quad 388-89$

Belgian 401

French 71,383

German 211, 271, 382, 387, 390, 411

archaeology $\quad 45,56,63-65,68-69,73,277$, 379-87, 389, 391-93, 395-97, 399-401, $403-4,408,411,414-15$

Crusades 167,385

Egypt 382

excavations 119, 121, 123-24, 168, 170-71, 204, 206-7, 211, 220-22, 227-29, 231, $347-48,385,389-96,400-402$

Islam $98,384,402$

scholarly missions $\quad 32,73,384,389$

workmen $116,121,157,166,212-13,227$, $369,375,382,387,401$

See also antiquities

architectural elements $\quad 41,45,98-100,160$, 166, 238, 240, 244-45, 299-300, 323, $326,333,344,347,406$

arches 130, 135, 137, 148, 152, 191-92, 198, $244-45,252,256-57,259,327,331-32$, $345^{-46}, 35^{1}$

sculptured 145

triumphal $30,191,341$

capitals 192, 194, 204, 207-8, 224, 226, 228, 248, 251, 287-88, 296, 298, 328-29, $348,35^{\circ}$

bronze 217,281

byzantine 149,333

Corinthian 49, 196, 229-31, 264, 301, $321,343-44,349,372$

Doric 260,360

Ionic 298,337

mutilated 323 
colonnades $100,102,189,191,208,214,241$, 250, 266, 268, 275, 277, 280, 340-42, 349 streets $4,79-80,162,266-67,310,320$, 350

columns $138,141,158-59,163,166,192$, 195, 197, 199-200, 208-11, 224-26, $252-53,280-81,361,363-64$ monolithic $97,139,141,199,224,227$ porphyry 222 stylites $\quad 252-53$

cornices $165-66,170,175,212,223,283$, 296-97, 299, 301, 306, 332

entablatures $137,140,143,197,223,228$, 264, 321

porticoes 138-39, 141-42, 208-9, 214, 247, 252, 254, 264, 268, 271, 283, 297, 299, 343,345

architecture

columns, monolithic $\quad 270$

Egyptian 48

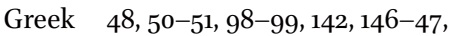
$15^{0}-52,155,262-63,269,272,293,297$, $345,347,350$

Hellenistic 255, 348

refurbished $136,157,170,186,204,224$, $254,358,362$

Roman 48, 99-100 military sites $\quad 282,333,359,367,370$, 376

Ar Rastan 124, 148

Arsous 186

Ascalon 9, 119, 121, 152, 154, 166, 170, 185, 214, 224-29, 282, 358-59, 386

Asia Minor $\quad 8,35,41,47-50,53,55^{-56}, 59,63$, $83,104,154,184-85,243,268,293$

Athens $99,107,272,319,382,384$

Parthenon 272

Athlit / Château Pélerin 121, 127, 144-45, 185, $358,363-64$

Atil 294, 298-99

Baalbek 22, 99-101, 103-4, 118-19, 122, 126, 139-41, 144-47, 162, 267-69, 271-72, 274, $276-77,281-83,361$

trilithon $\quad 270-71,361$

village 27,273

Babylonia $\quad 76-77,159,258,381,384$

Baghdad 52, 128
Banias 22, 136, 139, 141, 194

Bara 148, 159, 247-48

Bashan 10, 72, 105, 309-11, 315

baths \& bathing $\quad 70,93,136,158-59,174-75$, 200, 217, 219, 253, 256, 266, 303, 305-6, 328,362

Baybars $155,219,225,242,264,35^{8}$

bedouin $15-16,20,30,33-34,36,39,82-83$, $86-88,172-73,175,304,307,334,337,339$ raids $16,20,26,30-31,34,38-39,42$, 86-87, 294, 298, 335, 338-39, 341, 353, 357

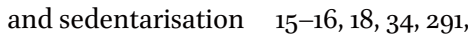
307,334

Beirut 26-27, 46-48, 108-10, 130-31, 153, 158, 16o, 170, 199-201, 203-4, 206-7, 211-13, $360-62,391-92,396$

Beisan 10, 328-29, 387

Bethgibelin $35^{8}$

Bethlehem 59, 62, 117, 163, 169, 322, 326

Beth Shean 136,328

Bible $47,49,51,55^{-75}, 78,110-11,116-17$, 289-90, 310-11, 319, 322, 386, 389, 402, 404

and archaeology $\quad 60,68,105$ and evangelicals 21, 73, 395

influence 56,61 and Protestants $\quad 21,65,69,95$ scholars $56,62-63,310,402$ societies 63,69 and Syrian locations $\quad 22,57,65,389$ and tourism 49

Bosra 10-11, 87-88, 90, 92, 108-9, 128, 174, 176, 287-91, 293-97, 299-301, 303-5, 307, 309, 315-17 cathedral $\quad 289$

bridges $\quad 127-28,130-31,136,186,194-95,200$, $219,244-45,284,329$

modern 130

Roman 304

Burak 294, 299, 303, 309-10

Byblos $53,128,135,147,169,185,190,197,385$, 396

Byzantium $3,28,45,124,140,155,240,243$, $245,255,258,263,291,332,340$

churches $41,160,232,336,369$

craftsmen 157

palaces 258 


\section{Byzantium (cont.) \\ ruins $157,255,362$ \\ walls $219,35^{8}$}

Caesarea 24, 28, 33, 135-36, 153-54, 156, 168-70, 184-85, 208, 210, 215, 217, 219-22, 224, 228

Cairo 29, 48, 93, 104, 117, 155-56, 169, 266, $323,359,383,396$

Capernaum 319, 321

cemeteries $166,205,214,220,231,242,342$ mausolea $77,150-51,257,264,314,326$ sarcophagi 151, 231

Sidon 205, 382, 393

tombs $67,148,166,229,383$

tomb towers $244,302,316$

churches (see also monasteries), 63, 66, 142, 144-45, 147, 155-56, 174-75, 177, 211-13, 216, 221-22, 241, 244, 296, 299-300

Circassians $27-32,37,41,123,249,312-13$, $340-42,344-46,397$

immigrants $28,30-32,244,249,312,342$, 345

settlements $30,36,100,255,313,345$ cisterns (see also aqueducts), 136, 205, 207, 246, 249, 292, 305, 309, 342, 36o

coast $4,9,22-24,47-48,128-29,133,138-39$, $169,184-87,201-2,210-12,217,220-24$, 251, 362-64

anchorages 219, 221 dangerous $133,185,201,203$

bradysism 209-10

local boats 203, 227

Phoenician 388

population 364

ports, winter 188

towns $23,42,135,185,203,357-58$

See also harbours

coins $61,121,137,152,203,226,390-91$

Asmonaean $\quad 152$

gold 31, 121, 123, 204, 314, 365

imperial Roman 365

Constantinople $13,15,19,139,143,150,153$, 159, 206, 208, 265, 269, 359, 362, $381-82$

Crusades 62-64, 145-46, 154, 167-68, 195-97, 208-11, 215-16, 221-22, 232, $240-42,250-51,323,356-65,385,396$
Cyrrhus 243-45

Cyzicus 268, 271

Damascus $\quad 9-10,16-18,21,27-29,68-71$, 93-97, 108-10, 141-42, 155-57, 200-203, $262-67,269,307-8,323-25,398-400$

French bombardment 366

Umayyad Mosque $\quad 52,57,76,93-94,96$, 99, 101, 109, 146-47, 150, 155, 157-58, $262-63,265,324$

Umayyad Palace 265, 343

Dead Cities (see also houses), 1, 10, 30, 40, 42, 101-2, 148, 156, 245-47, 249, 295

Decapolis $332,336,341$

Deir al-Zor 127

Deir-Semman 102

Deraa 6, 291, 294-95, 304-5, 310

desert castles $\quad 282,357,366,368-69,373,375$.

See also fortresses

Dimashqi 117, 146-47, 150, 161, 172, 190-91, 194, 262, 268, 276, 36o-61

diplomacy $\quad 3-4,18,404,406$

ambassadors

British 91

Byzantine 263

French 70

consuls $15^{-16}, 5^{2}, 74-75,83,89,109,240$, $338,353,381-82,405$

American 395

British 16, 25, 122, 131, 142, 187, 19o, 353

European $\quad 51,53,95-96,107-8$

French 54, 95, 167, 203-4, 206, 324, $350,382-83$

disease $15,17,21-25,41,186,220,333,384,408$ marshes $1,15,187-88$

quarantine 24,408

Djezzar Pasha $136,152,203,215,217-18,227$

mosque 144, 217, 224

spolia $152,204,217$

drains \& sewers $188,192,266$

Druzes $1,5,18,21,31,84,88,173,175^{-76}, 178$, 293, 297-98, 301-4, 307-9, 315

earthquakes $21-23,136-38,146,187,209-10$, 239, 241-43, 267-69, 273-74, 287-88, $332-33,340-41,343-44,360,365-67$

Ephesus $\quad 48-49,267,351$ 
Euphrates, River $3,6,9,11,39,133,162,243$, 316,374

exploration $46,50,62-63,77,159,247,304$, $312,338,341,369,381,386,395,405$

archaeological $\quad 28,49,389$

expeditions $13,46,51,84,91,104,267$.

280, 307, 354, 373, 381, 384, 389, 394

archaeological 374

funding $46,55,335,389$

military 46

explorers $37,63,70,125,207,391,395,405$

societies $107,343,379,381$

Deutsche Orient-Gesellschaft $\quad 381$

Palestine Exploration Fund $32,47,51$, 61-62, 73, 294, 343, 381, 386, 389

See also travelling \& travellers

Ezraa $10,151,174,176,294,307-9$

Faccadine, Emir $\quad$ 200, 202-3, 216 underwater defences 205

First World War 4, 7, 11, 25, 380, 393, 395-99

fortresses $128,150,153,192,312,356,361,368$, $371,373-74,395,409$

Byzantine $\quad 357-58$

Crusades $58,64,151,154,158,196,205$, $215,242,273,356,359,362,366,373$

Muslim 269, 271, 357

pretend 357,367

Roman $312,356-57,359,361,363,365$, 367-69, 371, 373, 375-77

walls, strengthened with columns 53 ,

153-54, 194, 199, 205, 208-9, 215, 226-27 See also Crusades

France $24,26,35,76,86,134,173,216,356$, $358,380,382-83,390-95,398-401,404$

Franco-German rivalry 107

Gadara $94,104,151,176,192,332,335^{-36}, 35^{0}$

Galilee $6,130-31,147,158,170$

Gaza $6,70,139-40,15^{2-53}, 166,170,185^{-86}$, 208, 214, 228-32

Germany 40, 73, 395, 404

Franco-German rivalry 107

Germans $36,40,76,100,370,380,385$, 387, 394-95, 397

Kaiser $\quad 274-75,370,379,385,387,394$

Gilead 16, 52

Golan Heights 311-12, 336. See also Jaulan government $\quad 18-20,23,36,40,42,85-86,167$, 170-71, 212-13, 227, 229, 387, 391, 393, 397-98

French $\quad 55,106,124,382,384,391,399$

Ottoman $15,17-18,23,28,31,33,42,82$, $86,119,123,341-42,345,392-93,396$ central $5,13,15,20,25,33-35,41,82$, $90,307,315$

governors $4,83,85,91,15^{2-53}, 192$, 202, 224, 263, 274, 340, 380

militias 34,407

officials 314,390

taxation $1,18,20,28,30,48,82,84-86$, $88,173,294,307,312,315,405$

See also Ottoman Empire

Greater Syria (see also Syria), 2, 6-7, 11, 27, 46, 56, 178, 192, 357, 381, 389, 394, 404-6, 409-10

Greece $\quad 4,47,53,60,93,99-100,103-4,319$, $334,383,398$

guidebooks $55-57,61,63-64,72,74,76-78$, $171,258,372$

Baedeker $\quad 67,74-77,140,142,201,207,212$, $293,301,303,338,340,342-43,349,354$

Cook 75, 77, 82, 174, 258, 279, 306, 309, 340, 346,373

Guides Joanne 77

Michelin 102, 107

Murray $63,76-77,277,401$

Haifa $\quad 24,110,166,169,185,218,387,395$

Halaf $104,127,25^{8}$

Hama 149, 248, 254

harbours $13,15^{-17}, 22-25,47-48,153-54$, 184-205, 207-11, 213, 215-19, 221-29, 231, $233,235,237,241$

artificial 195

breakwaters $153,185,195-96,209,221,223$

dangerous 185,224

installations $\quad 25^{-26}, 196,215,225,269$

moles $186,188,198,202,205,208-10,223$, 226

natural 184,207

silting 188,210

unhealthy 47

See also coast

Hauran 10-11, 15-16, 30-31, 35-36, 38, 85, $87-88,128-30,134,171-76,290-96,301$, $306-7,314-16,382$ 
Hebron 101, 129, 327, 391

Hellenism 4, 135, 197, 208, 250, 282

Herodium 326,386

Herod the Great as builder $58,129,135,156$, 169, 210, 219, 221, 225, 229, 319, 323, $326-27,369,376$

Heusn Nieha 139

Hijaz 108, 239, 307

Hit 299

Holy Land $\quad 7-8,11,16,19,32,45-47,54-56$, $59,62-65,67,76,78-80,82,348-49$, 409

Homs $6,39,83,87-88,136,141,148,156,253$, $255^{-} 57,277,358,412$

Hosn Suleiman 141, 259

houses $101-2,158-59,167-68,170-78$, 196-98, 203-5, 230-31, 246-47, 254-56, 295-300, 303-5, 307-16, 333-37, $345^{-46,349-51}$

deserted 119, 304, $35^{\circ}$

doorways 175, 229, 259

decorated $92,99,102,189,298,302$

Hauran 30, 54, 290, 303, 306

high-quality $148,156,271,302$

huts $33,68,140,194,212,273,278,280$, $306,313,321,346$

modern 23, 31, 97, 106, 122, 231, 253, 287, 296

mud \& straw 242

prepared for guests $\quad 279,292,336$

Roman 288, 297

ruined 192, 240, 289, 307

sheikh's 175,299

stone doors $142,165,171-72,176,293$,

295-99, 302, 304, 308, 310, 331, 336

stone roofs $101,172,176,292-93,299,335$, $350-51$

wooden 23

Ibelin 220, 358-61

Ibn Battuta $\quad 80,144,191,208,225,242,253,267$

Ibn Hawqal $\quad 77,271$

Ibn Jubair 148

Ibn Khaldun $\quad 20,23,34-36,99,118,147,165$, 255

Ibn Tulun 215, 219

Ibrahim Pasha $19,130,144,152,187,194,226$, $242,256,269,306,346,353,365,369$ inscriptions $\quad 9-10,106-7,119-21,149-51,153$, 192, 231, 245-48, 254, 257-59, 292-93, 309-10, 334-35, 370, 385-88

Christian, dated $174,245,248$

copying 121, 247, 273

Greek 57, 122, 151, 199, 245, 247, 249, 255, 305

Latin 199, 202, 267

Moabite Stone $107,146,384$

Phoenician 305

Rosetta Stone 384

Semitic 107, 146

unreadable 120,303

Iraq $6,11,36,370-71,382,398$

Iraq al-Amir $\quad 99,164,347$

Irbid $33^{-}-32$

Iskenderun / Alexandretta 8, 23, 25, 40, 128, 133, 185-86, 188, 224, 238, 252

Israel $\quad 6,8,11,46,150,314,316,409-10,412$

Italy $47,79,134,163,272,319$

Jaffa $6,21,24,51,92,110,125,129,169-70,185$, $221-28,384$

Janin $\quad 319-20$

Jaulan 30-31, 119, 168, 291, 294, 310-14. See also Golan Heights

Jebel Druze 294, 367

Jerash $8,10,30,32-33,90,92,99-100,104$, $123,295-97,332-34,337-42,344-45$, $350,385-86$

Jericho 22, 327, 390

Jerusalem $\quad 46-47,49,61-62,67-68,82,87$, $89,92-94,155-57,163,225,322-23$, $35^{2-53}, 388-89,401$

Dome of the Rock $52,93-95,99,101,116$, $152,155,157-58,258,263,289,322-24$, 326,401

Haram al-Sharif $\quad 52,58,93-95,153,157$, $162,322-24,389$

Herod's Temple $\quad 163,194,222,322-23$

Holy Sepulchre $\quad 69,93,126,158,161,168$, $263,322-23,325-26,363$

Latin Kingdom of $\quad 21,185,356,359$

mosques, al-Aqsa $\quad 52,93,95,322-24,362$

Ottoman 325

Solomon's Temple $\quad 99,153,322-23$

Jews $1-2,16,62,67,95,105,156,217,322,327$, 399 
Jordan $\quad 6-9,11,31,34,38-39,50-51,128-30$, $332-33,337-38,340,349-50,368,371$, $387,409-12$

river $319,321,323,325,327,329,331,333$,

$335,337,339,341,343,345,347$

Kerak 9, 106, 132, 134, 350, 357-58, 365

khans 94, 144, 194, 310

Krak des Chevaliers, Qalaat al-Husn $\quad$ 9, 356, $35^{8}, 366,396,401$

Kuneitra $\quad 30-32,312-13,340$

landscape $\quad 49-50,55,58-60,72,173,178$

biblical $\quad 68,379$

depopulation $17,27-28,41-42,85,174$, 184,246

desertification $13^{-14}, 17,30,32,35^{-36}$, $38,42,184,220,319,381$

deserts $6,9-11,13,16,19,21,33-34,36-38$, $66,341,343,345,352,366-68,373$

fertility $3,17,20,30,35-36,38-40,42$, $68,82-83,88,177,291,294-95,307$, 316

See also agriculture

Lattakia / Laodicea $\quad 23-24,41,122,147,151$, $158,161,169,185-86,188,190-93$ tetrapylon 192

Lebanon $6,11,14,21,27,36,38-39,121,126$, 137-38, 141, 394, 400-401, 409-12, 414

Ledja $\quad 37,39,90,120,171,173,178,291$, 294-95, 299, 303, 306-7, 309-10, 315

looting $169,205,368,391,407,415$

Lydda 124, 146, 151

Maarat al-Numan 120

Madaba $31,138,345^{-47}, 349-50,369$

Map 158

Mandates, British \& French $\quad$ 29, 86, 294, 374, 379, 395-96, 398-402

maps $8-11,47-49,63,65,106,108,238,246$, 248, 258, 306, 312, 350-51, 405, 415

d'Anville $\quad 8-9$

inaccurate 304,405

large-scale 106

Madaba Mosaic Map 351

Palestine 9, 33, 245

reliable 132

Maqdisi 118 marble $136,147,155-57,160-63,166,169-70$, 200-202, 213, 224-27, 262-63, 265-66, $275,329,359-60,362$

blocks 268

cipollino 270

coloured 161, 266

Africano 230

Aleppo "marble" 163

giallo antico $161,163,217,223$

red 163

yellow 217

columns 94, 147, 194, 196, 199, 209, 211, 220, $225,228-31,281,288,320,328-29,331$

imported 16o, 214, 219, 253, 353

lime kilns 345,353

mortar $164,305,337,376$

limestone look-alike $\quad 162$

Paros 16o, 218, 230, 353

pavements $141,158,243,265$

polished 154, 157

Proconnesus 214

rare $152,155,322,362,389$

veneer $\quad 155-57,163,361$

white $94,162,228,230-31,282,288,361$, $369,372,377,393$

See also stones

Margat 151,358

Marqab 361

Masada 376, 386

masons $152,164,167-68,262,305,348$,

$357-58,363$

Masudi $150,156-57,161,241,271$

Masyaf 357

Mejdel 147,283

Menbij 243

Mismiye 309

Moab 22, 28, 56, 86, 123, 129, 138, 311, 353

monasteries (see also churches) 14, 88, 127, 169, 248, 251-52, 299, 368, 370, 373, 406

monuments $1-4,29-34,41-42,47-49,70-72$, 95-102, 107-11, 116-19, 125-27, 149-51, $165-69,171-73,241-43,270-76,404-6$ ancient $\quad 28-30,58,60,99-100,165^{-66}$, 171, 174, 194-95, 316, 319, 322, 361, $364-65,406,408$ spolia $\quad 166-68,170-71,197,200$, 229-31, 242, 265-66, 268, 296, 299, $308,310,323,358,361-64$ 
monuments (cont.)

megalithic 5, 71, 314, 343

Roman, palaces 231

ruined $61,141,146,192,213,217,249,251$, $268,328,363-64$

mosaics 94, 96, 152, 154-6o, 200, 204-5, 207, $232,252,255,257,262-64,266,349-51$, 362

floors 3, 153-59, 200, 214, 232, 239, 241, $252,255^{-56}, 266,301,320,349-51,361$, 365

Jerusalem, Solomonic 157

Madaba mosaic map $\quad 351$

pavements, byzantine 154

re-used 152

tesserae $\quad 154-57,170,201,258,362$

mosques $2-3,31,49,93-94,96-97,119,156$, 169-71, 215-17, 230, 239-40, 262-68, 299-300, 308-10, 312-13

ruined $94,231,273,289$

Mosul 24, 77

Moudjir-ed-dyn $\quad 155,327$

Mschatta $350,368-70,375$

Al-Muqaddasi $\quad 94,99,130,157-58,161,209$, 215, 219, 225, 262, 343

museums 107, 127, 370, 406

Antakya 159

Berlin 50, 107, 125, 370, 379, 381, 383, 385, 394-95, 407

British Museum 77, 383-84, 394

Constantinople $\quad 159,205,392,406$

Deir al-Zor 371

Europe $3,42,125,154,159,205,379,383$, $388,390,395,406-7$

Homs 407

and looting $\quad 127,205,342,383,394,402$

Louvre $151,154,205,385,394,401,406$

Suweida 380

Musmieh $\quad 171,175,294$

Nablus $\quad 160$

Napoleon $\quad 2-3,24-25,29,107,215,225$,

$$
383-84
$$

Nineveh $\quad 76-77,382$

nomads. See bedouin

obelisks 100, 269

Paris, Place de la Concorde $\quad 100,270$

pink syenite 222
Omm-al-Awamid $\quad 388$

Orontes, River $39,50,58,130,171,188,190$, $253,257,360,385$

Ottoman Empire $\quad 2,5,19,37,41-42,46-47$, $131,178,380,390,392-93,396-99,404-5$

buildings 221,314

barracks 41, 143, 171, 211, 213, 230, 242, 256, 258-59, 268, 280, 300, 309

modernisation $13,29,42,95,108-9,266$, 379, 396

nationalism $34,352,384-85,387,391$, 398

sultans $18,28,84,133,169,208,275,324$, 341,370

See also government

Palestine $\quad 1,3-7,11-13,22,46,56,59-62$, $71-72,74-77,122-23,319,384-86$, 398-99, 401, 404

Palmyra 6, 9, 11, 90-92, 100-102, 149-50, 161-62, 267, 272, 276-77, 279-81, 337-40, 370, 372-73, 401

Peiresc, Claude Fabri de 390

Pella 332

Péretié, Aimé $\quad$ 205, 392-93

Petra $8,10-11,82,88,91,100,102,104,123$, $192,334,337,339,351-54,402$

Phoenicia 1, 7, 49, 160, 184, 197, 382, 385, 393 photography 13-14, 65-66, 248, 252, 275, 278, 292-93, 298-99, 335, 343, 345, 371, $374,387,389$

pilgrims $8,13,45-46,54,61,64,66-67,70$, $78,81,213,220,251-53,322-23,325$

Pompeii $79,101-2,108,172,242,297,337$ population, decline \& growth $5,13,15^{-17}$, 20-23, 38-39, 41-42, 201, 241, 249-50, 278, 289-91, 303-4, 319-20, 398-99, 404

Pyramids $\quad 117,126,274,308,384$

Qalaat Mudiq 250

Qanawat 92, 104, 108, 118, 137, 150, 294, $301-3,315,390,392$

Qasr al-Ablaq 264

Qasr al-Heir East $\quad 370-73,402$

Qasr al-Heir West $368,370,402$

Qasr el-Abyad 375

Qasr Ibn Wardan $\quad 258-59$

Qasr Namrud 141 
quarries $32,118,124-25,160-61,164,168,170$, 199, 212, 228, 268-71, 274, 348-49, 353, 357

Aleppo, "marble" 162-63

granite 161,275

limestone $176,239,275$

marble 48-49, 160, 190

sandstone 213

railways $10,13,33,40,108-10,129,132-34$,

177, 201, 219, 274, 313, 369, 376, 394-96

abandoned English $\quad 369$

Acre-Damascus 133

Euphrates Valley Scheme 23

Haifa 307

Haifa-Damascus $\quad 133-34$

Hijaz 132, 134, 346

Jaffa-Jerusalem 133

planning 313,387

stations 284,346

tunnels 133

Ramleh 124, 146, 159, 165, 186, 263, 266

roads $13,15-16,74,110,127-32,136,158-59$, 174-75, 201, 203, 213-14, 243-44, 258-59, 331-32, 395-98

modern 110, 127-31, 154, 170, 301

Roman 58, 61, 108, 128-32, 158-59, 214, 250, $297,314,331,333,368$

milestones $127-28,131-32,214$

network 373

paving stones $214,265,320$

preserved 129-30, 158, 300

Strata Diocletiana $\quad 371$

Via Nova Traiana 368

Roman shrine $\quad 259$

Roman sites 41, 49, 130, 145, 197, 231, 266, $292,305,322,331,334,368-69$

Rome 4, 99-100, 106-7, 139, 172-73, 178, 253, 270, 272, 298, 319

Ruad 147, 195

ruins $21-23,30-33,70-73,121-25,141-44$, 147-50, 196-200, 213-16, 250-53,

272-76, 279-84, 299-301, 326-29, $331-38,340-47$

Phoenician 195, 198, 211-12, 393-94

as quarries $145,164,304$

Sahr 292

Saladin $169,185,215,219,225,322-23,358$, 362,365
Salkhad $135,176,296,303-5$

Samaria $72,88,136,152,170,191,319,386,391$, 393

Sanamein 296

San Simeon 102, 156, 252

Saône / Qalaat Saladin $\quad 357-5^{8}$

Saphet 360

Sardis 48,269

Sarepta 207

sculpture $\quad 98-100,102,135,137,140-41,151$, $273,276,278,290-92,294,297,328$, 331-33, 392-93

bas-reliefs $144,168,172,189,254,268$, $292,302,304,342,348,365,390,405$ eagle 274

mutilated 271, 277

Crusader 196

defaced 277

fragments $\quad 222,278,389$

friezes 226, 228, 268, 271, 274, 289, 299, 348

pedestals $192,308,344$

re-used 199,313

statues $136-37,139,150-51,153,189,200$, 203, 206, 211, 226, 228, 232, 302, 390-91,

394

broken 292, 300

buried 390

colossal 121, 190, 221, 228-29, 273-74, 392

cult 273

equestrian 292

female 126,313

headless 227-28

Scythopolis 328

Seleucia Pieria 22, 126, 133, 143, 156, 169, $185^{-86,188}$

Serjilla 148, 159, 247

Shahba $92,174-75,292,294,296-99$

Shaizar 360

sheikhs $\quad 42,85,89-92,108-9,119,134$, 147-50, 278-79, 297, 299-301, 307, 310, $313^{-15}, 338,342$

profiteering 90, 279, 381

Shobak 98, 373

Sidon 119, 124, 129-30, 136, 144, 158, 166, $168,202-9,213,215,218,382,385$, 391-93

Slim 142-43, 298-99, 301

Sodom 22, 68, 71 
Solomon as builder $15,19,58,69,96,118,121$, $150,163,229,268,271-72,276,327$

Stanhope, Lady Hester $\quad 91,119,121,124,226$ stones $117-21,124-29,138-40,145-47,159-65$, 167-69, 173-76, 194-99, 211-14, 216-18, 222-24, 253-57, 269-71, 331-36, 358-61

basalt $79,177,192,256,287-88,293,295$, $313,329,377,393$

blocks 258

chancel screens $\quad 137$

Ionic columns 141

pillars $\quad 257$

towns 333

blocks 124, 127, 140-41, 168, 212, 220, 242, $272,283-84,297,321,368$

large $147,194,196,243,245,259$, 270-71, 299, 309, 311, 332, 334, 345, $347-48,35^{8}$

granite $136,138,160-61,166,192,196-97$, 199-200, 210, 213-14, 217, 220, 222-26, 256-57, 280, 284

columns $149,152-53,156,191-92$, 195-96, 199-201, 205, 209-11, 222, $226-28,265,270,275,328,365$ as manufactured stone $\quad 161$ limestone $49,55,138,147,160,163,165$, $253,256,270,275,283,320,368,372$ pavements 323

porphyry $96,149,160,163,230,326$ pudding-stone 163,223

ready-cut $\quad 124-25,167,242,349$

See also marble

Suleim 148

Sulkhad 294

Sunamein 294

superstitions $\quad 5,16,67,70,116,119-20,166,282$

djinns $118,120,123,267,276,327$

inscriptions \& treasure-hunting 107 121-23, 149, 151

magic $\quad 119-21,123,306,352,388$

treasure-hunting $84,107,111,116-24$, 149-51, 204, 227, 273, 277, 313-14, 321, $342,383,385,388-89$

Suweida 10, 128, 143, 175, 188-89, 294, 296, 299-301, 380, 396

Syria

borders $7,11,333$

See also Greater Syria

colonies 239 deserts 21, 35, 37, 255, 258, 279

French influence $394,399-400$

frontiers

the "limes" 148, 279, 284, 334, 373-74

various $7,258,367$

peoples $5,26,29,118,133,166,186,326$, 394,400

population $29,215,312-13,342$

sites, ancient $\quad 3,15,32,49,61,123,134,168$, $246,251,274,302,336,381,384-85$

technology 130, 134, 172, 209

temples $\quad 94-96,136-47,150,156-57,173-74$, 211-12, 226-29, 231-32, 265-78, 280-81, 283-84, 296-303, 307-10, 322-24, $341-44$

decorated 298, 310

Egyptian 150, 363, 407

Nabatean 292

theatres $79,81,136,169,173-75,177,197-98$, 200-201, 219, 221-22, 287-92, 297, 302, $335-36,341-43$

Tiberias $10,22,39,136,192,327-28,358,387$

Lake $\quad 55,336$

Tortosa $185,195,358$

tourism $81,145,325,384,401,405$

guidebooks 77

hotels $74,76,215,230,281$

independent 75

package $15,74-75,81$

vandalising tourists 107,392

towns $13-16,22-24,85-88,139-52,158-59$, 166-70, 187-89, 191-92, 196-208, 213-28, 238-41, 254-58, 293-305, $308-13,315^{-16}$

ancient $42,102,170-71,174,177,196,255$, 259, 266, 295, 336, 343, 347, 350, 360

deserted $\quad 36-38,40,86,101-2,108-9,137$, 159, 173-74, 222, 295, 303-4, 309, 315, 341,347

Roman 4, 100, 174, 293, 296-97, 305, 369

ruined $33,36,38,118,124,129,137,216$, 248, 250, 255, 304, 307, 309, 315

See also villages

trade $1,25^{-26}, 33,46,83,131,184,190,194$, $203,238,279,346,381,405$

British 4, 24, 26, 239

Circassian 30 
European $\quad 2,18,23,26,42,47,133,184$, 208, 215, 240, 396, 398

French $\quad 25,131,186,203-4,216$

Levant Company $\quad 16,25,239$

tourist 46,407

transport $108,161,340$

antiquities $147,167,208,216,270,278$, $333,359,387$

baggage $81,84,381$

camels $30,39,48,81,83-84,110,127,129$, $131,148,155,163-64,166,335,344$

caravans $10,26,77,87-88,108,110,131$, 226, 280, 372

carts $30,58,340$

donkeys $68,84,110,129,145,163$

horses $81,84-87,92,129,176,250,305$, $308,327,339,348,394$

mules $82,84-85,88,110,145,390,394$

shipping 144, 151, 193-94, 198, 203, 208, 217,220

international $23-24,26,29,47-48$,

184-85, 187, 190, 201, 209-10, 219, 221, $356,358,381,383$

navigation $48,133,184,207$

steamers $28,46,48,74,81,103-4,184$, 194, 204, 325, 381, 388

wheeled vehicles $30,32,40,58,79$, $128,131,164,241,336,341$

travelling \& travellers $4-6,8,14,45-46,48$, $83-84,87-92,128-29,132-33,15^{0-51}$, $162,247-49,268,352,404-5$

American $\quad 58-59,81,84,95,270,352,369$, 402

dragoman $75,77-78,81-82,92,95,110$, $148,324,352,392$

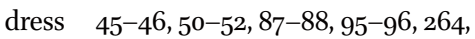
327

European 2, 19, 50, 86, 100, 127, 150, 158, $161,173,178,185,268,271$

expenses 81, 91, 99

firmans $83,89,92,123,139,167,324,381$, 387,389

Grand Tour 47, 404-5

guides $50,52,55,60,71,74-75,82,89-90$, $116,312,314,337-39,341,344,35^{2}$

itineraries $7,46,54,67-68,81,240,243$, 325

languages $\quad 2,50-51,55,59,77,87,119,151$, 248,405
Muslim 150, 271, 323, 353

robbery $15^{-17}, 19-20,29,33-34,42,48$, $76,78,82-84,87-88,217,219-20,310$, 337-39, 353

safety $9,19,50,52,76,89,111,123,295$, $339,353,366,388,402,404$

scholars 11, 14, 46, 53-56, 61-63, 100-101, 105, 291, 293, 366, 370, 383, 387, 395-96, 400

plagiarism 12, 76, 334

telescopes $\quad 95,106,108-9,111,273,304,315$

See also exploration

Tripoli $16,23-24,46,88,120,129,135,137,150$, $153,185^{-86}, 195^{-96}, 356,35^{8}, 390-91$

Tyre $6,9,22,24-25,70-72,128-30,152-53$, $156-57,168,170,202-3,206-10,212-16$, $359,384-85$

Umm al-Jimal 10, 104, 106, 147, 333-35, 368, 376,392

Umm el Rasas 344

vandalism $29,91,107,116,124-26,165,206$, $275^{-76}, 379,383$

Venice $46,70,152,232,270,390$

pilastri acritani $\quad 232$

villages $27,30-31,83,85-88,140-42,168$, 171-74, 207-8, 245-46, 248-49, 290-92, 295-96, 298, 312-16, 340-42

ancient $106,172,178,248,290,306,312$, 396,414

deserted 21, 27, 85, 88, 173, 245, 248-49, $283,298,312,315$

inhabited 246, 313

modern $88,140,214,260,278,334$

villagers $48,84,122,142,162,167,246,313$, 329, 337, 401

See also towns

wars \& monument damage $\quad 88,130,144,169$, 212, 346, 362, 397-98, 407, 409

weapons

artillery, non-gunpowder 359

gunpowder $34,169,197,221,271,307,345$ guns $34,52,84,90,147,268,278,310,312$ projectiles $153,216,271,359$

Yajuz 333

Yakut 118, 148, 150, 219, 244, 262-63, 276, 341 
Michael Greenhalgh - 978-90-04-33460-1 Downloaded from Brill.com12/05/2021 10:56:24PM via Australian National University 
Illustrations

$\because$ 
Michael Greenhalgh - 978-90-04-33460-1 Downloaded from Brill.com12/05/2021 10:56:24PM via Australian National University 


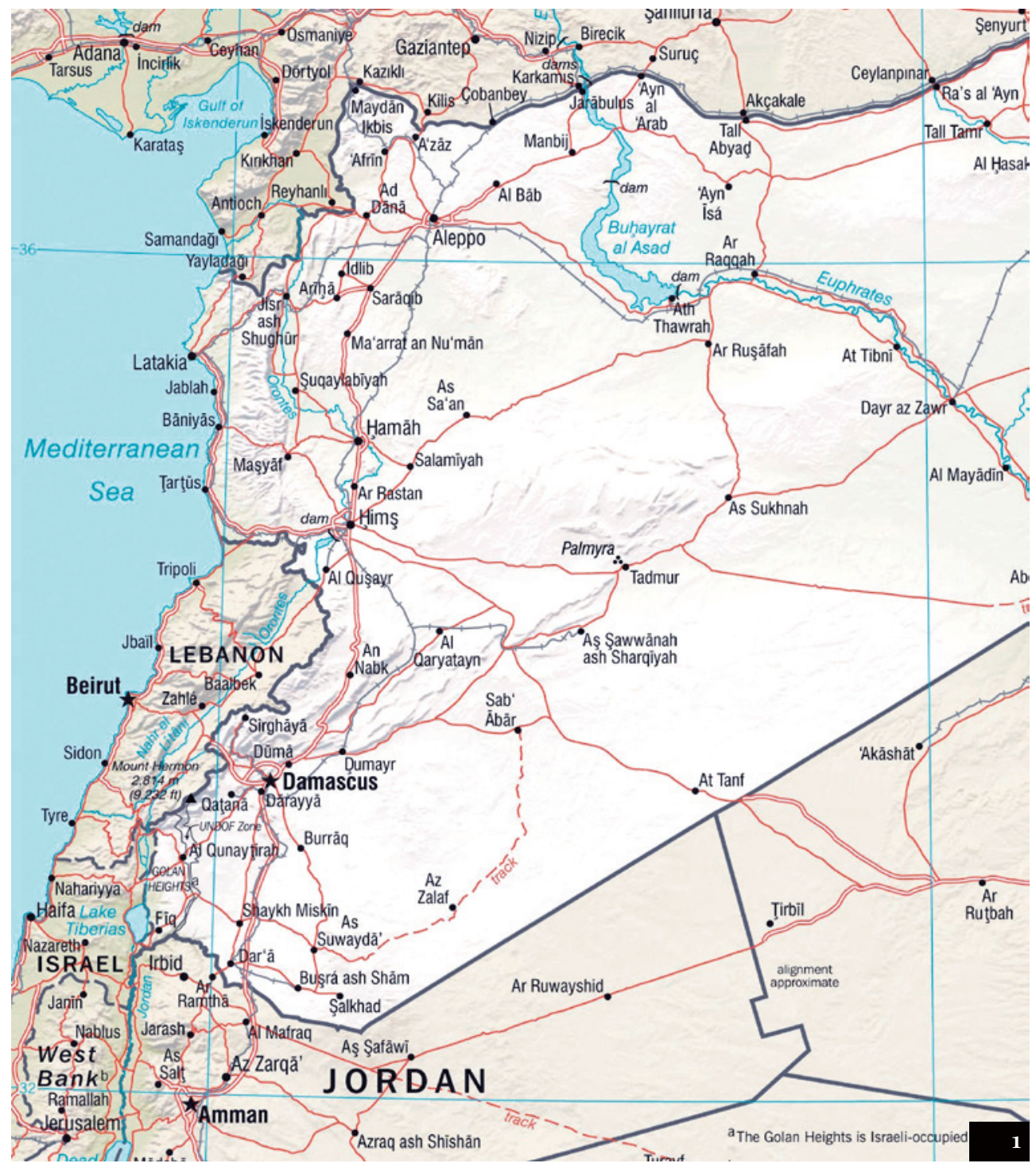

1. Map of the area covered in the book, with modern country divisions. The single and double lines between towns indicate roads and motorways, but most of these are less than a century old.

Max von Oppenheim had Tel Halaf (Ras al-Ain, north-east of Aleppo, top right corner of this map) excavated from 1911. All materials had to come from Aleppo on nearly 10oo camels, and this was a 20-day journey.

Again, the direct paved road from Palmyra to Deir ez-Zor is is post-war, as is that from Damascus to Palmyra. Lindsay's expedition to Palmyra in 1838 was well-armed, and kept the Bedouin away: "seven gentlemen, four servants, two muleteers, five soldiers, and four camel-drivers bestriding twenty-one horses and mules, two donkeys, and five camels." 

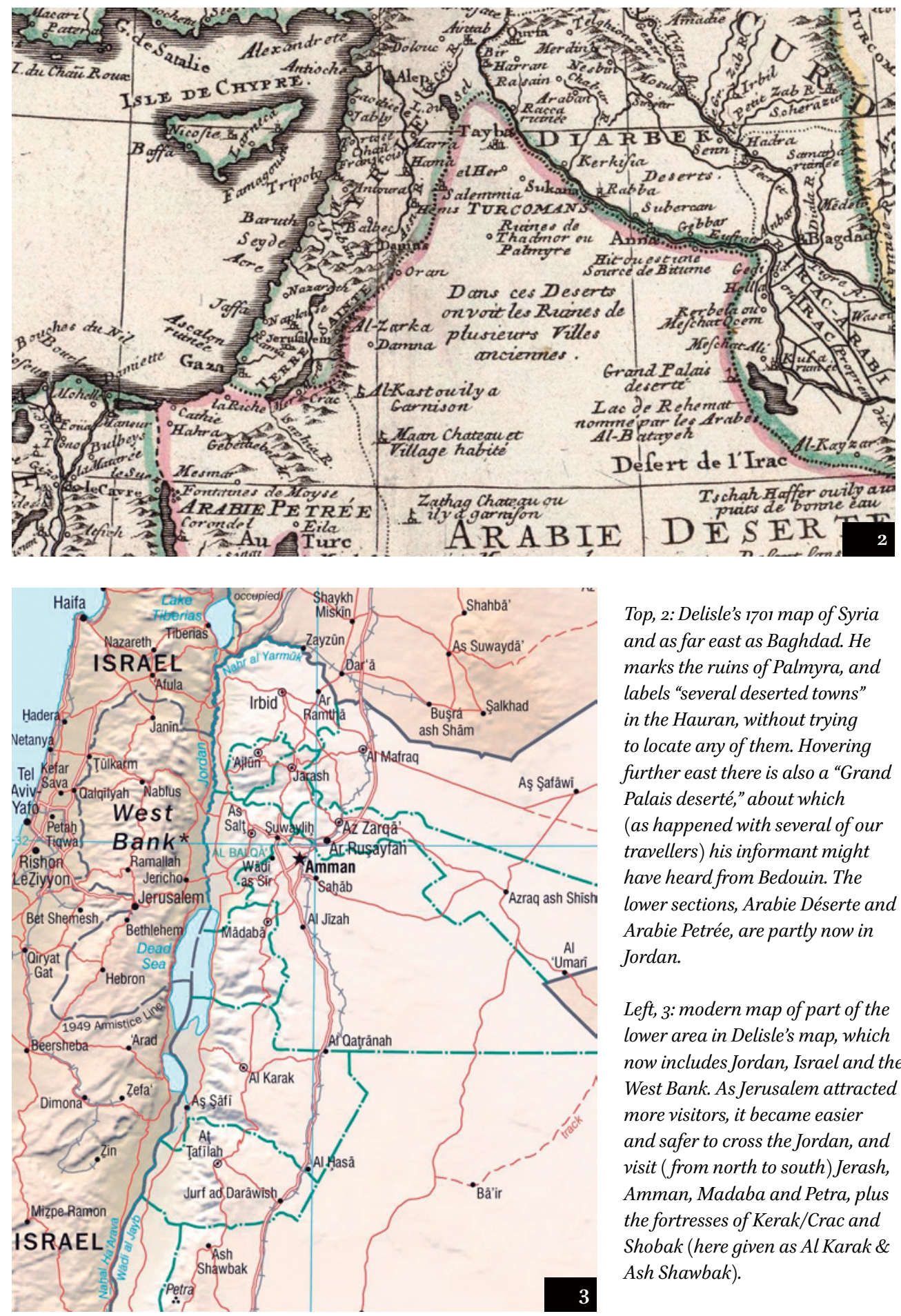

Top, 2: Delisle's 1701 map of Syria and as far east as Baghdad. He marks the ruins of Palmyra, and labels "several deserted towns" in the Hauran, without trying to locate any of them. Hovering further east there is also a "Grand Palais deserté," about which (as happened with several of our travellers) his informant might have heard from Bedouin. The lower sections, Arabie Déserte and Arabie Petrée, are partly now in Jordan.

Left, 3: modern map of part of the lower area in Delisle's map, which now includes Jordan, Israel and the West Bank. As Jerusalem attracted more visitors, it became easier and safer to cross the Jordan, and visit (from north to south) Jerash, Amman, Madaba and Petra, plus the fortresses of Kerak/Crac and Shobak (here given as Al Karak \& Ash Shawbak). 
All images Aleppo. Right, 4: The citadel in 2003. Centre right, 5: the glacis strengthened with through-columns. Many of the stone slabs covering the glacis have been removed for building in the town. Lower left, 6: Projectiles are still to be seen inside the citadel, from the defensive ballistae. Since 1822 and indeed before, the citadel was not completely defensible,

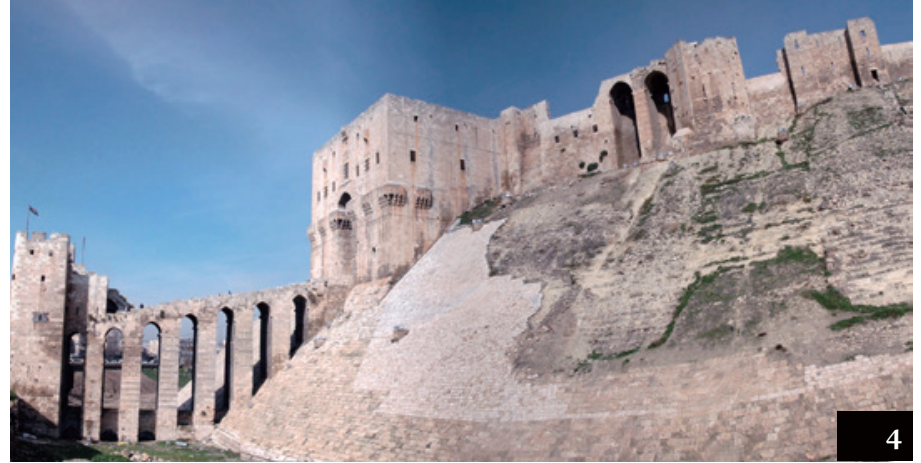
and contained a village.

Bottom left, 7: Madrasa Halawiye, showing the remains of the 6th-century Cathedral of S. Helen. Bottom right, 8: 13th-century Madrasa Firdows, mihrab, with interlocking design of marble and stone.
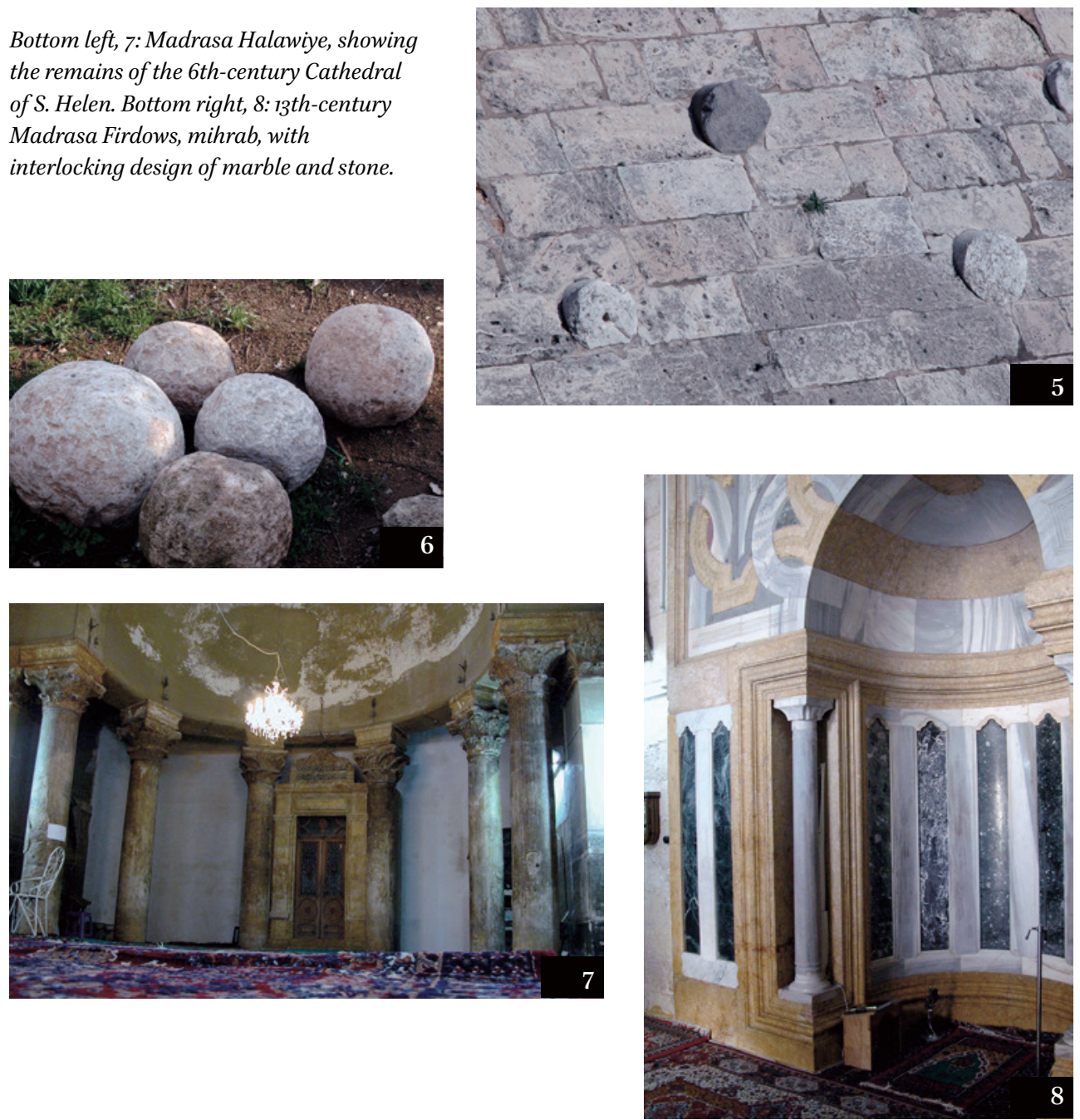

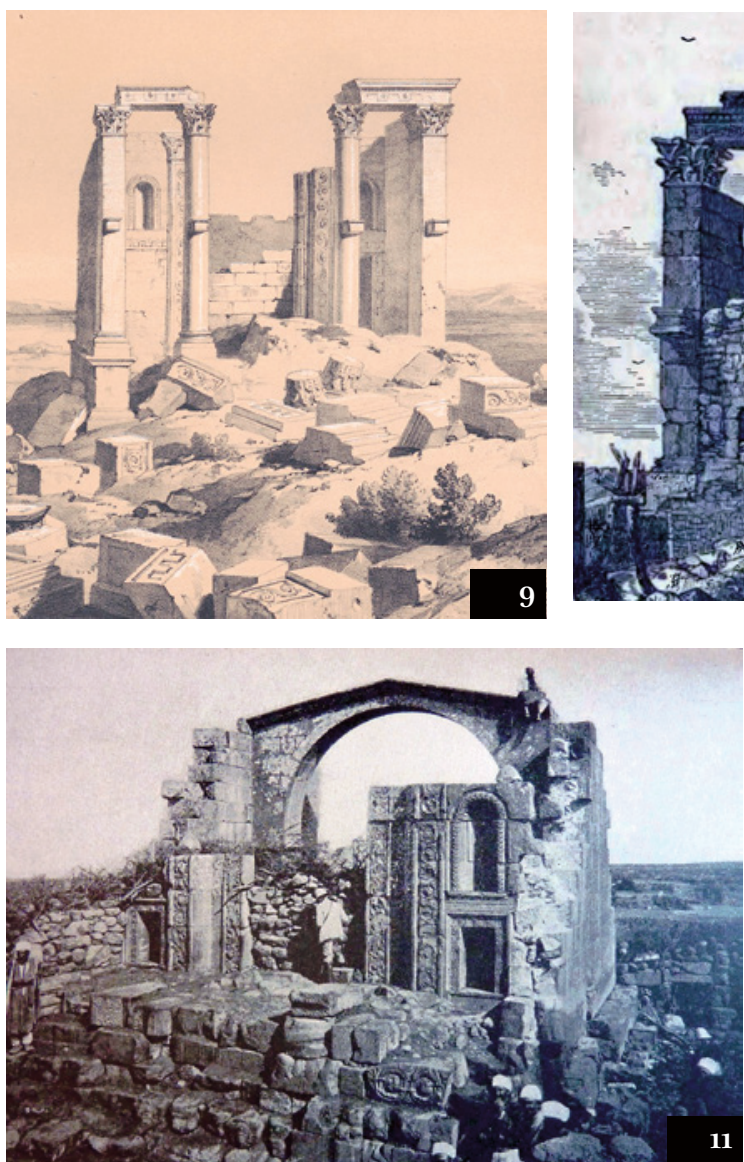

Aatil, one of several sites in the Hauran being partly re-occupied in the later 19th century. Top left \& right, $9 \& 10$ : the southern temple in a print by Laborde, of 1837 , and converted into a house, in a print of 1881 . Centre left, 11: the northern temple in a photograph of 1904. Centre right, 12: the Duc de Luynes' 1864 exploration of Ammon and Moab: one of several illustrations of prehistoric antiquities. Bottom right, 13: a tomb at Amman (long since destroyed) in a print by Laborde in 1837.

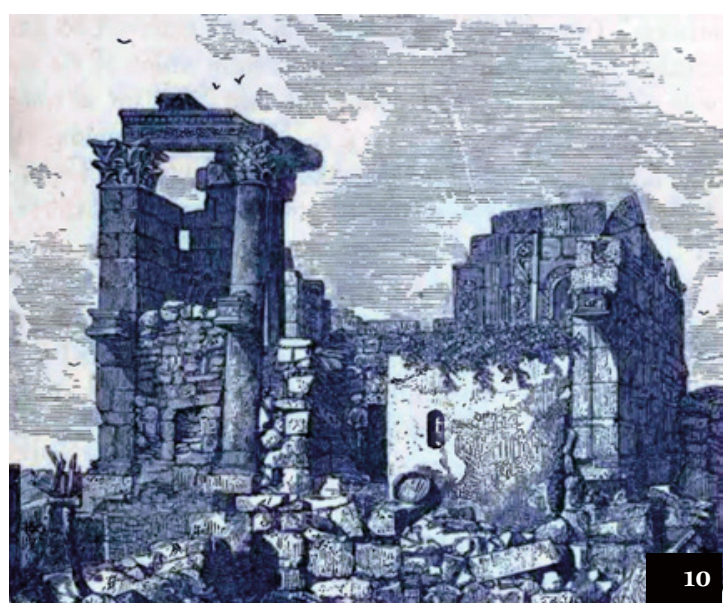

AUES at Wak.

ass
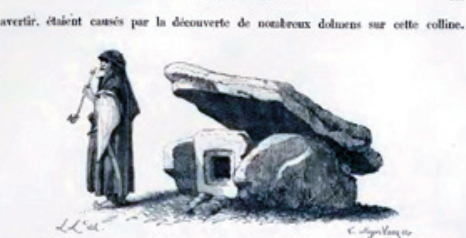

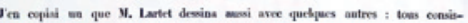
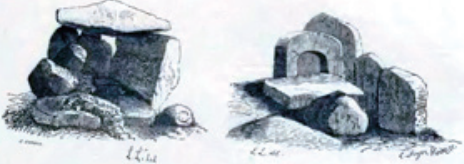

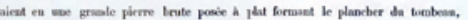

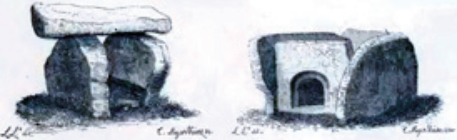

un pierms seablables dresiles pour les citis, une peer le cheret.

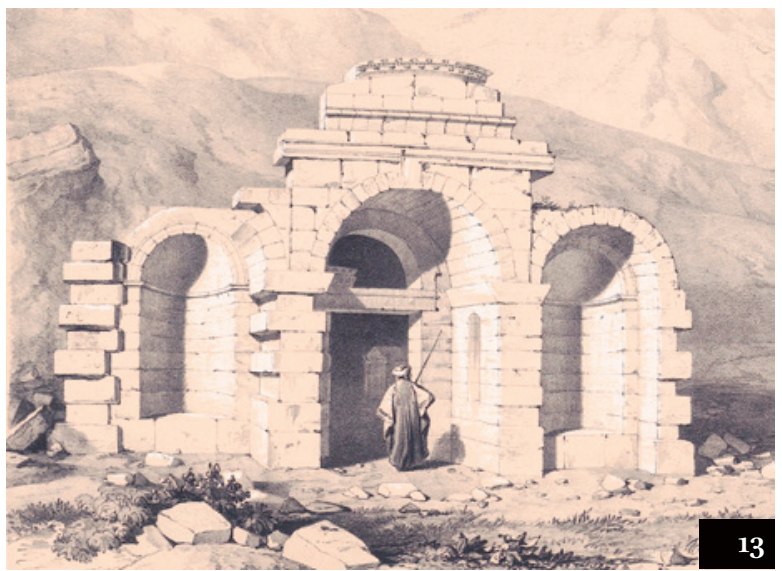



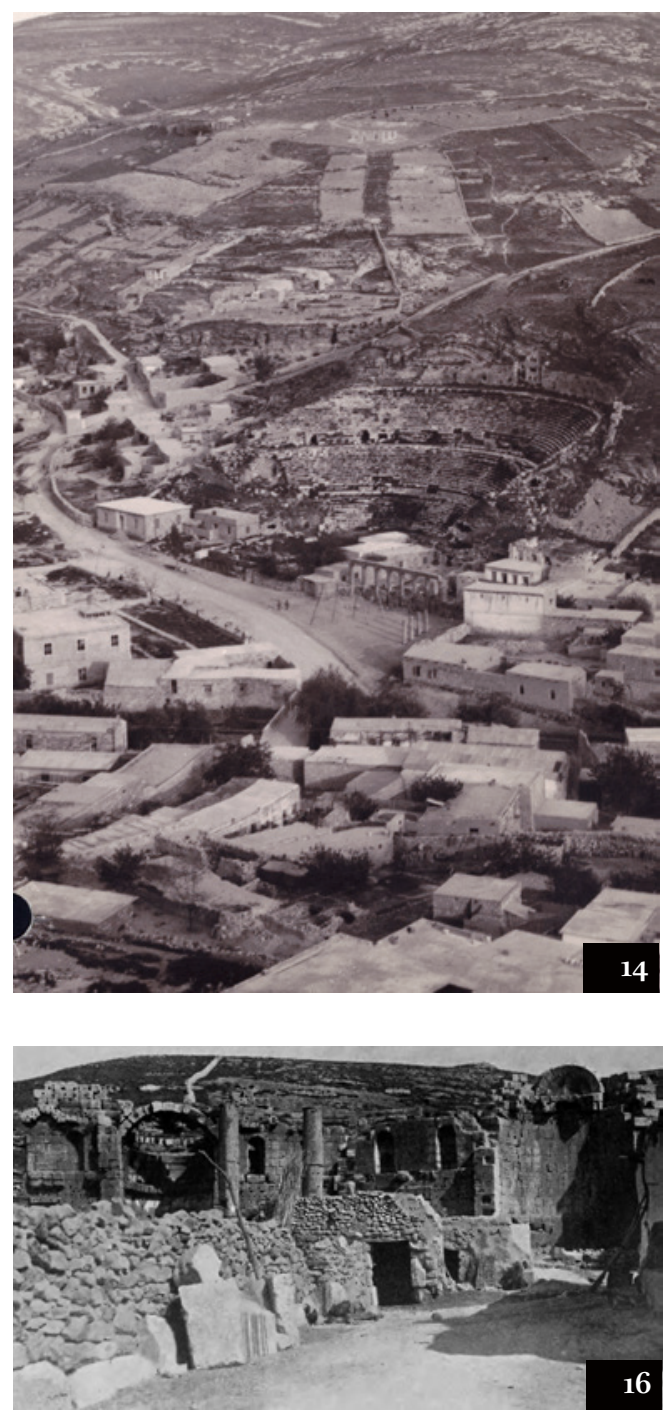

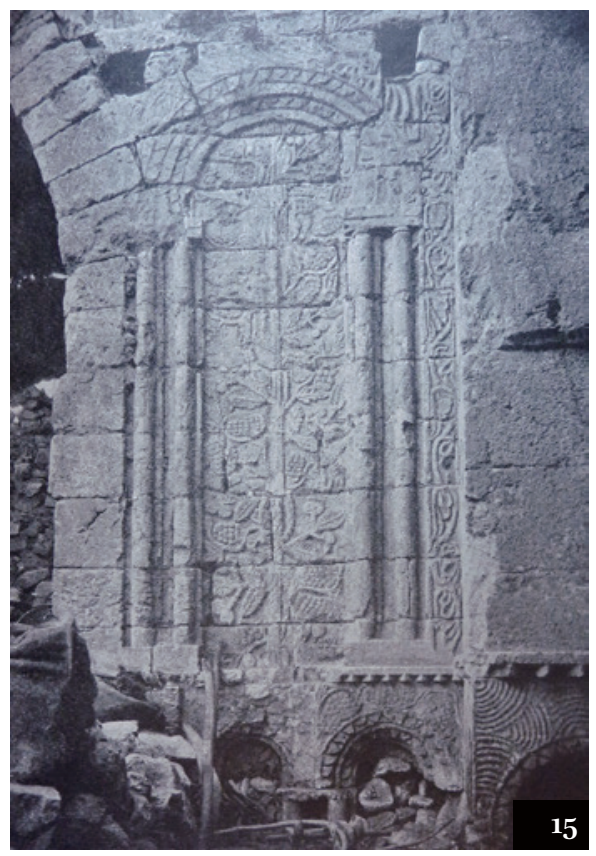

Amman, capital of the new state of Jordan from 1923, after which modern development increased, Circassians arriving and colonising the area. Top left, 14: view of the town, photo after 190o. Top right, 15: the 8th-century Islamic "Palace," photo of 1904. Centre left, 16: the baths, with perhaps a mason's hut in the centre, and blocks of marble against the wall, for re-use or lime-making. Bottom, 17: theatre, in a print of 1839. The site was deserted as late as 1868, when Porter described it: "defiled by the flocks that seek a temporary shelter beneath their tottering walls, and by the mangled carcases and bleached bones of animals that have fallen to rise no more. Jackals prowl around it; vultures hover over it; but no human being seeks a home within it."

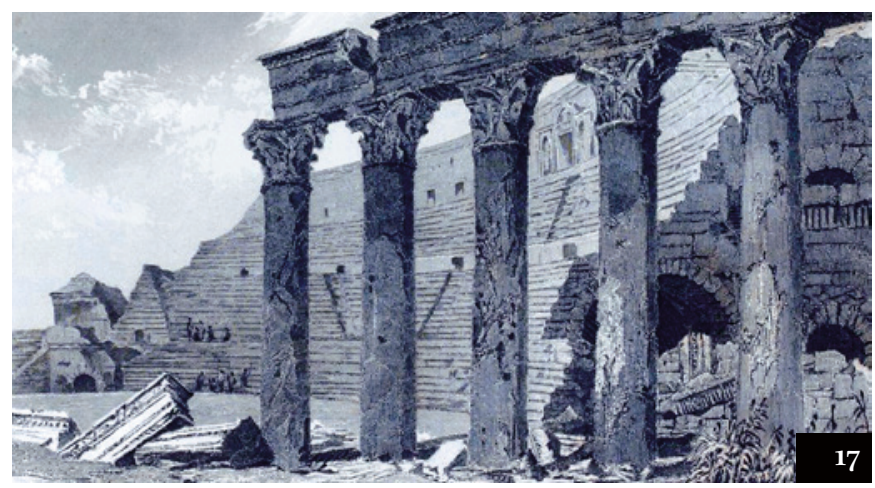



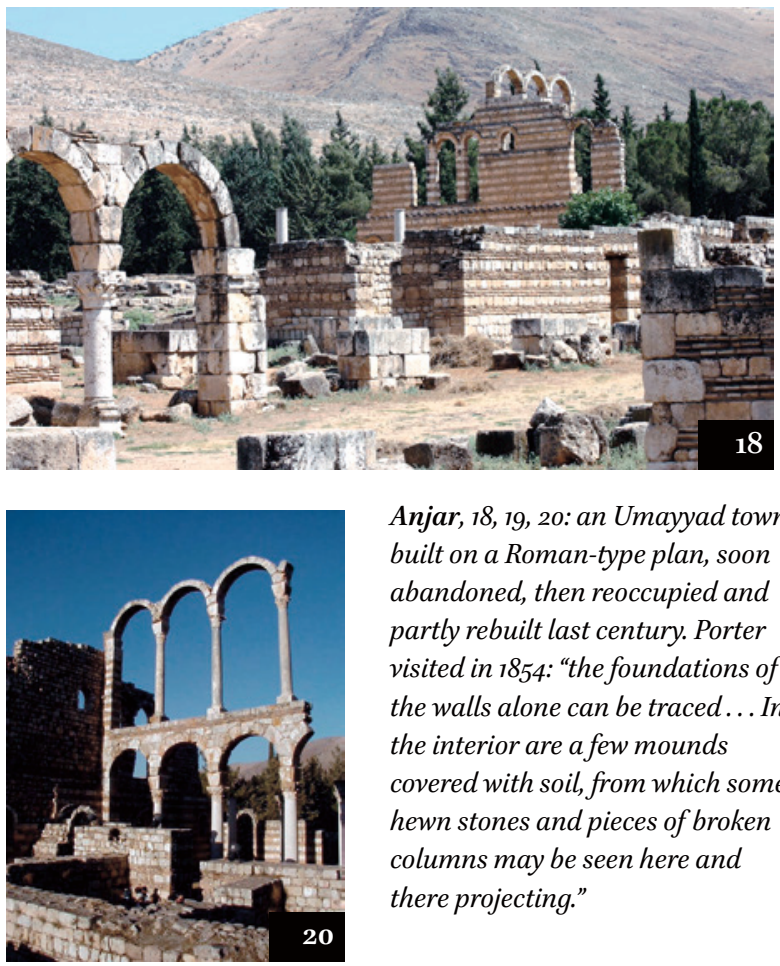

Anjar, 18, 19, 20: an Umayyad town built on a Roman-type plan, soon abandoned, then reoccupied and partly rebuilt last century. Porter visited in 1854: "the foundations of the walls alone can be traced... In the interior are a few mounds covered with soil, from which some hewn stones and pieces of broken columns may be seen here and there projecting."

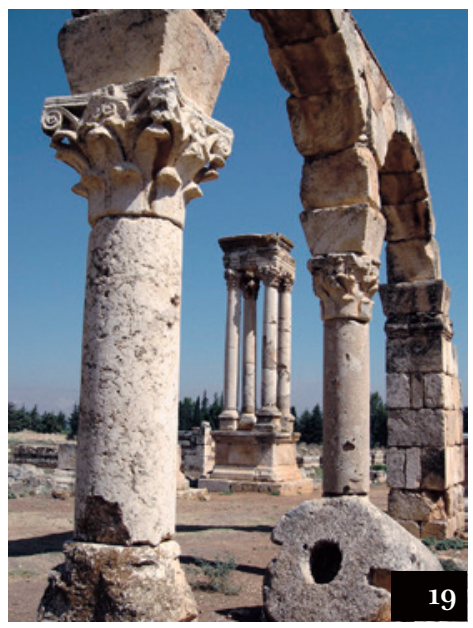

Antioch, a strong fortified city during the Crusades. Lower right, 21: Baedeker's map of 1876 shows how little of the town was occupied. Cassas'view of 1803 (bottom, 23) shows the walls as dilapidated; sections would soon be demolished for building materials. Lower left, 22: Some antiquities have survived, such as these Roman sarcophagi and statue, photographed near the Orontes in the 193os.
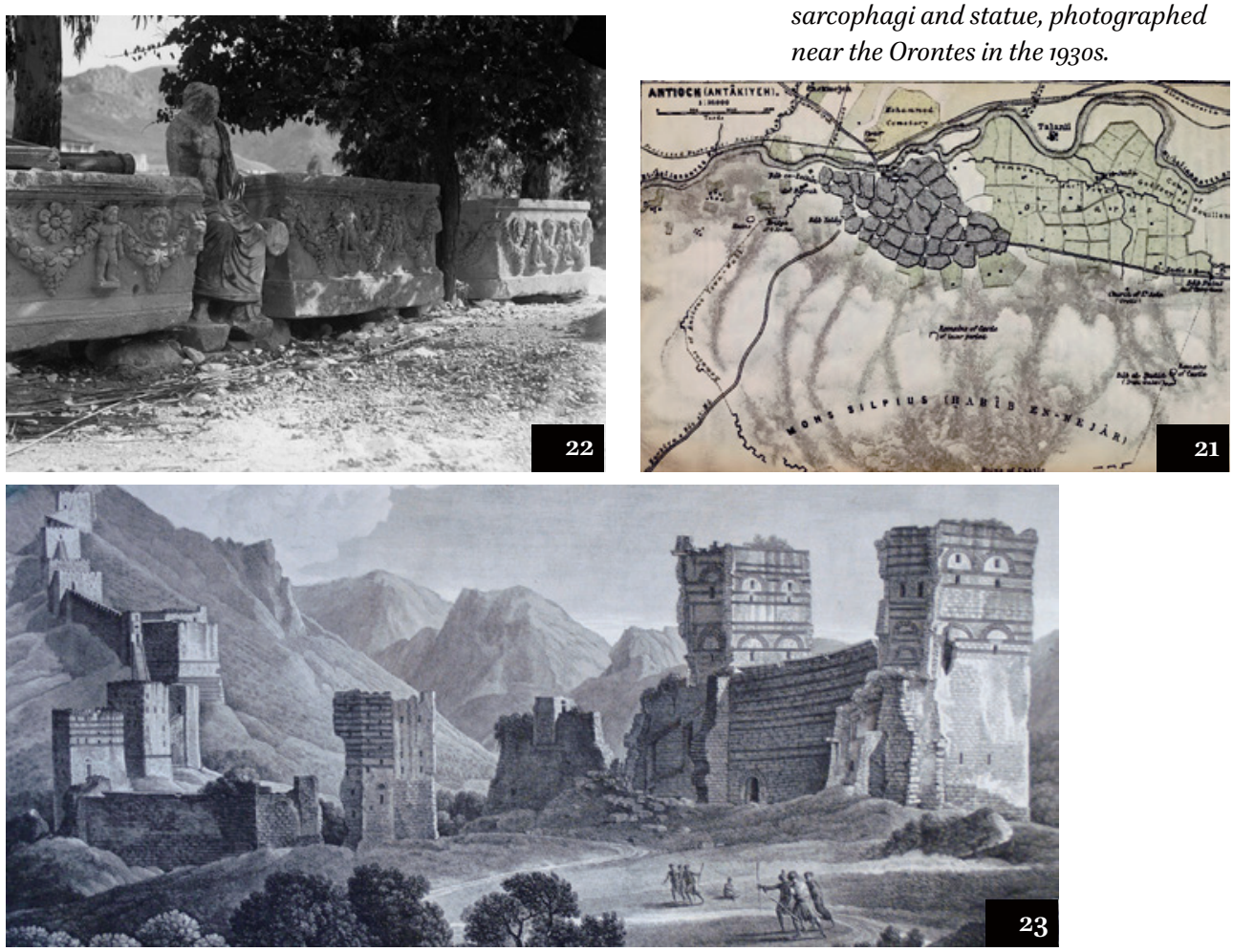

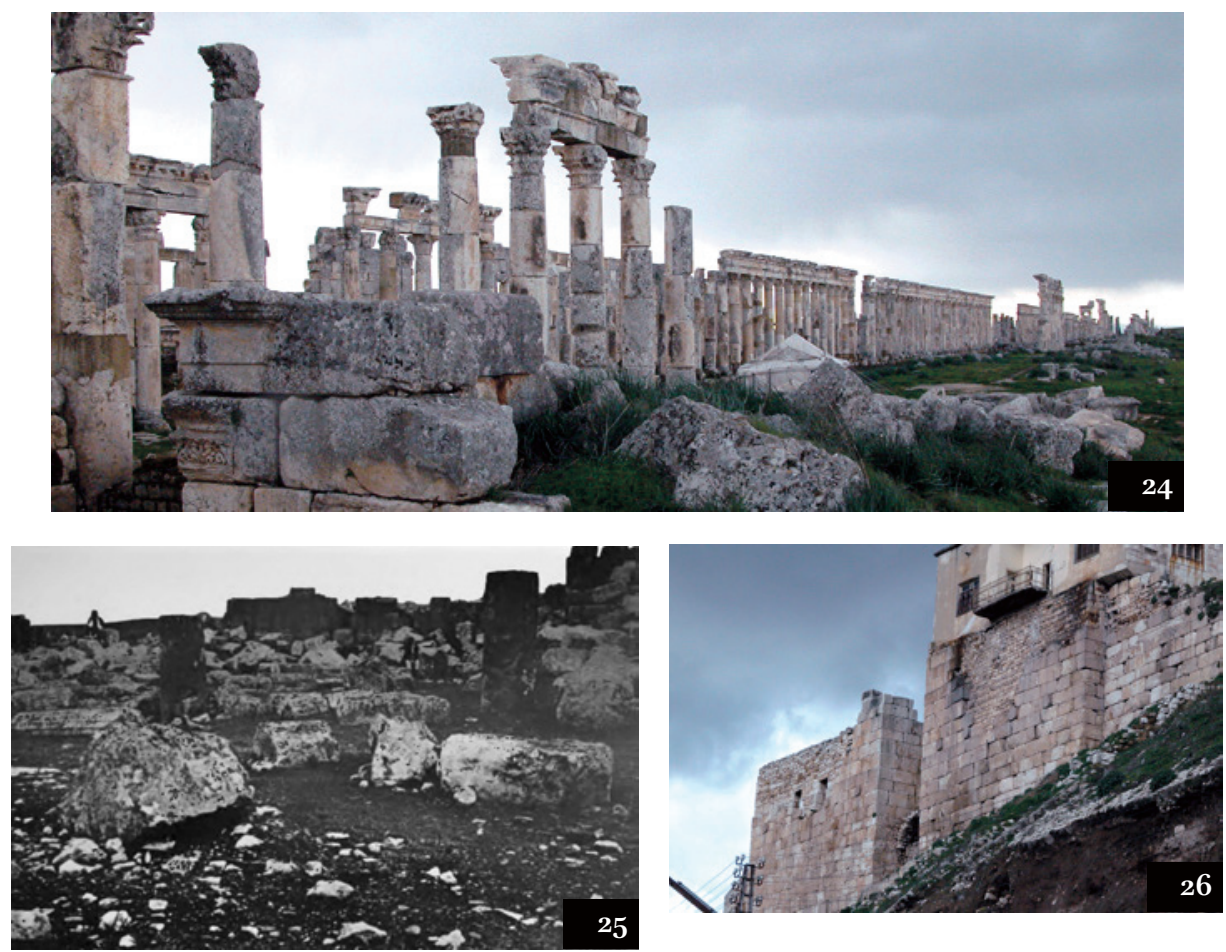

Apamea: Top, 24: colonnades, re-erected in the 1990s, and below (25) a view of the same street in 1883. Centre right, 26: view of the fortress overlooking the site, tie-bars in its walls, and modern houses on top. This was a powerful retreat during the Crusades, and De Forest camped here in 1856 , writing of the sight below: "of the eighteen hundred or two thousand shafts necessary to fill out this immense design, every one had fallen, and lay as if with its face to the earth, in an eternal woe of desolation. Every edifice, also, was prostrate, exhibiting no other sign of its former beauty than a confused wreck of hoary stones."
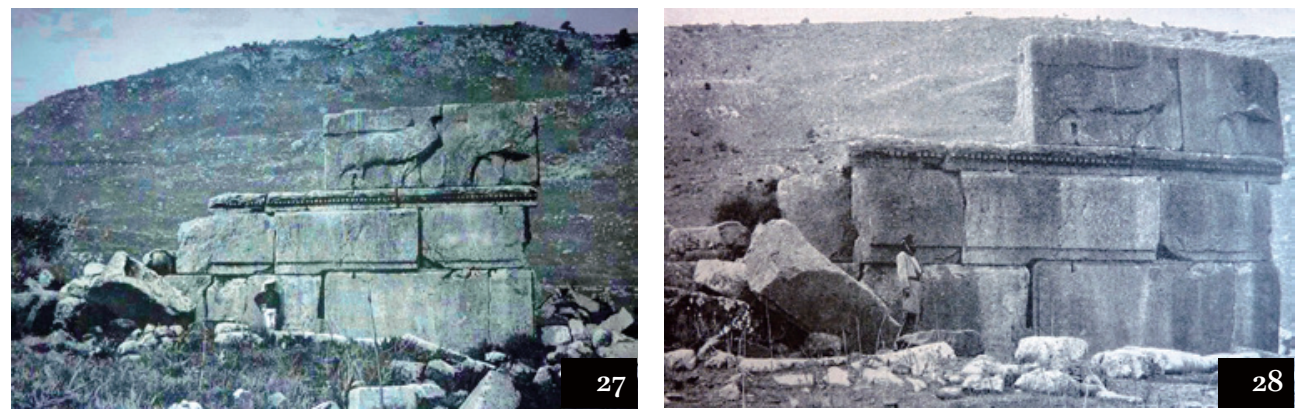

Above: Arak el-Emir / Iraq al-Amir, Hyrcanus' palace in photos of 1874 (left, 27) and 1904 (right, 28), built well before the Romans arrived, shows an equal addiction to very large blocks (the largest is $7 m \times 3 m)$. Large parts have now been reconstructed. 


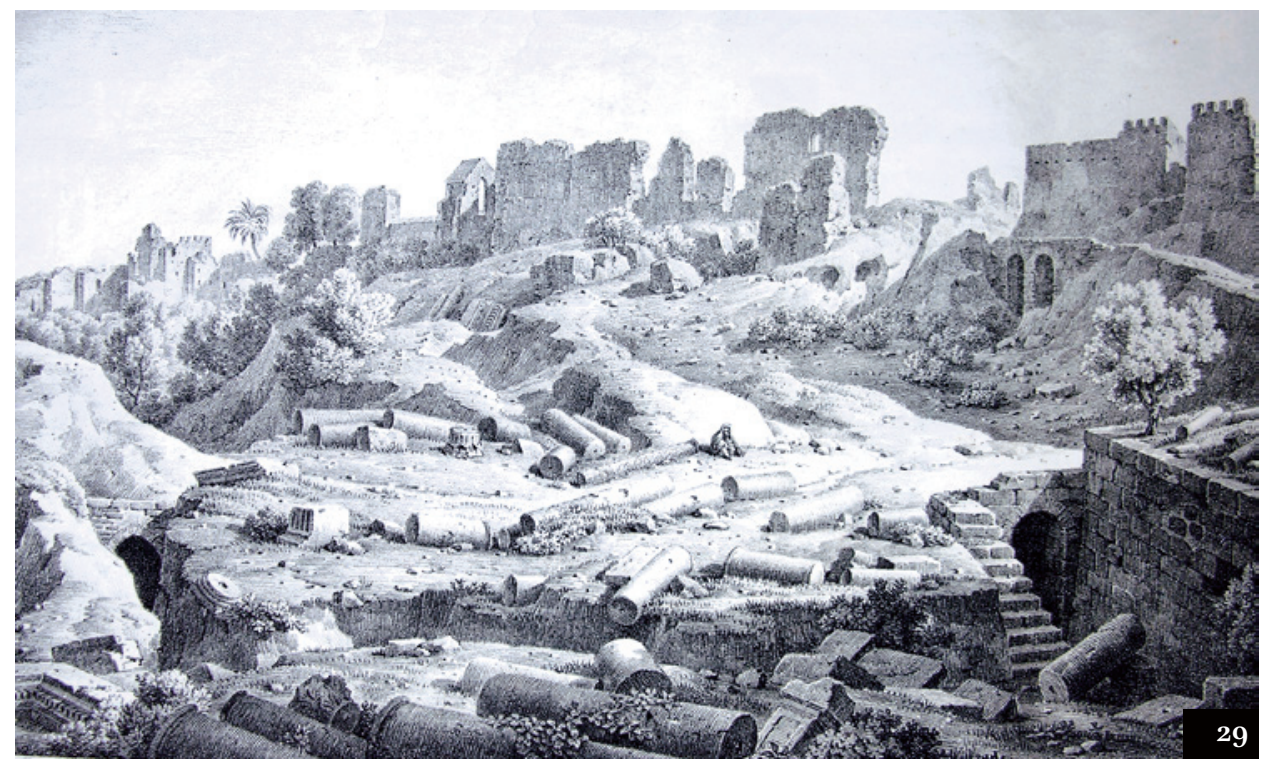

Ascalon. Top, 29: the town's ruins, with column shafts and cellars, from Forbin, 1819. Bottom left, 30: Plan of Ascalon, of 1883. Antioch had some gardens within its walls by this date, but Ascalon is almost all fields. Ibn Battuta had noted the antiquities in the early ${ }_{14}$ th C when some monuments were evidently part-standing: "des colonnes de marbre sans pareilles pour la beauté. Les unes sont debout, d'autres couchées à terre." Bottom right, 31: Athlit, from Guérin's Terre Sainte of 1884. His illustrator has tried to make the view accurate, but romantic.
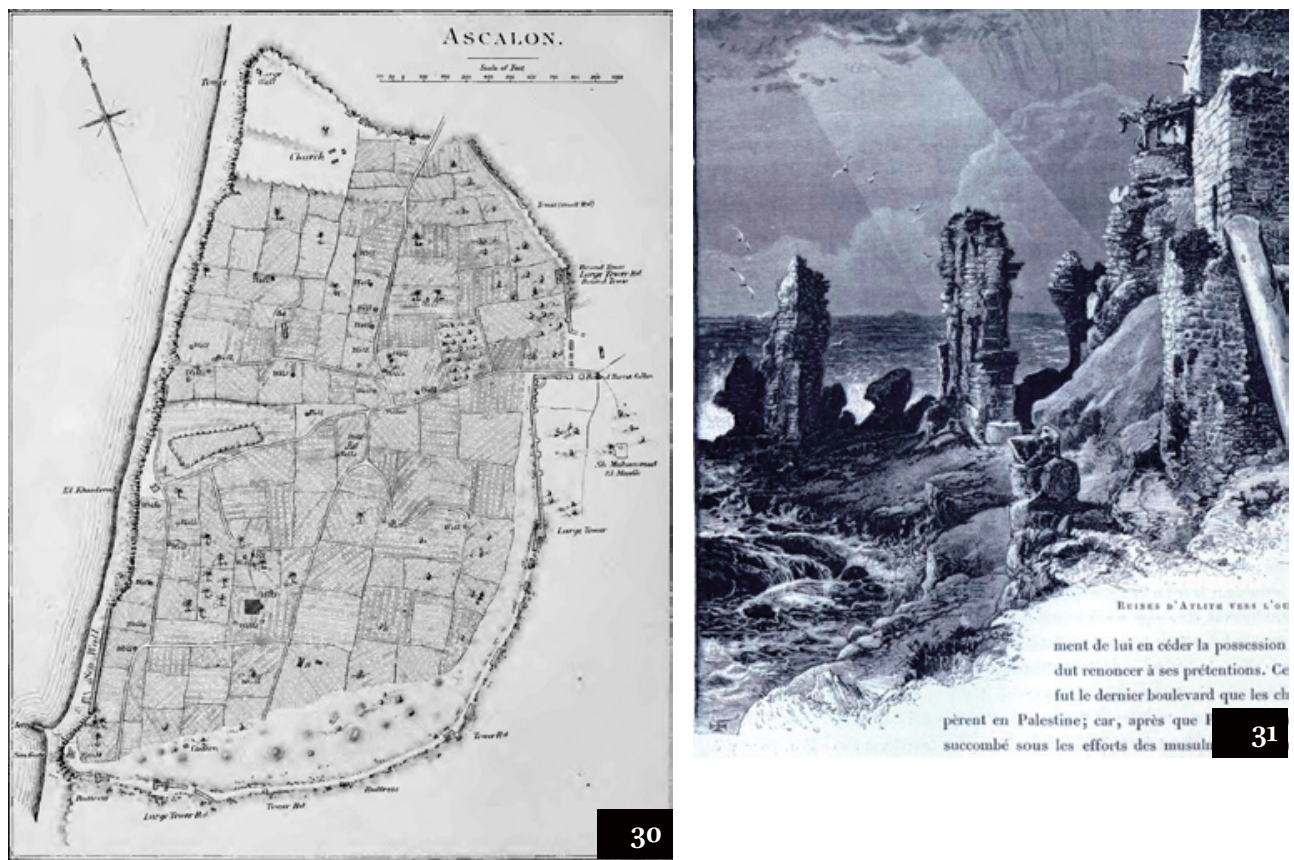


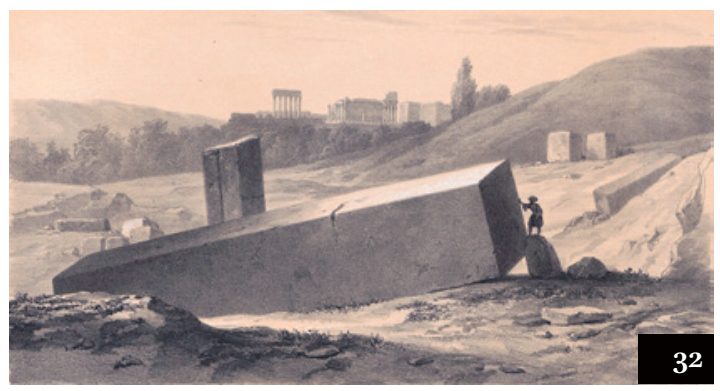

Baalbek. Top left and right, 32 \& 33: block in the quarry, and portico with dropped keystone, both prints by Laborde, 1837. An even larger stone, at some 1,650 tonnes, was discovered in the quarry in 2014. Centre left, 34: the small temple in 1892, with Islamic additions. Centre right, 35: the mosque, built from temple spolia with 13 thC arcading, photo of 1905 . Bottom left, 36 : the trilithon, each block over 19m by 4.3m: note the human figure at the corner. As Bird wrote in 1872, one of these stones was "of the size of a small farm-house." Bottom right, 37: several columns were brought down because of scavenging for the metals which attached column elements together.
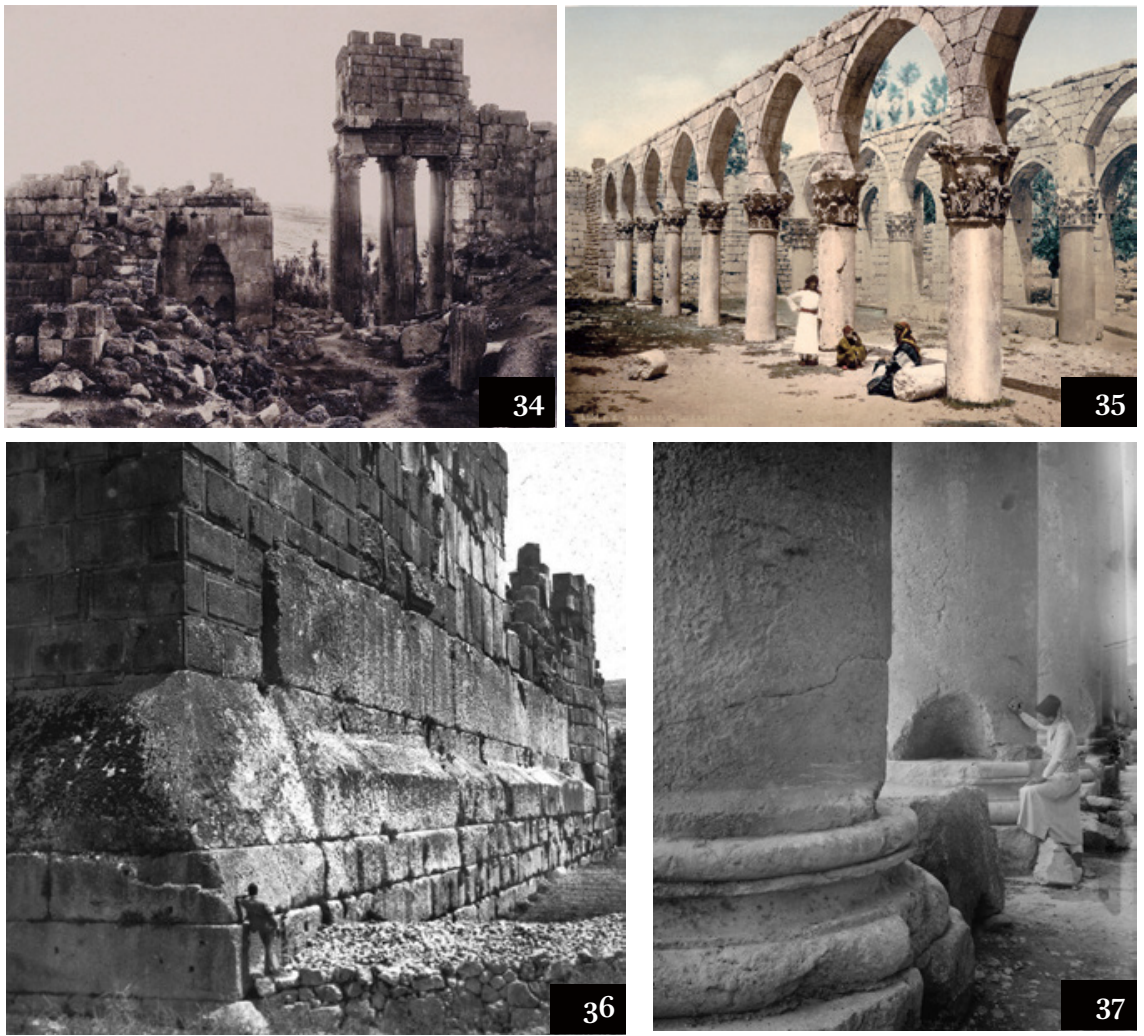

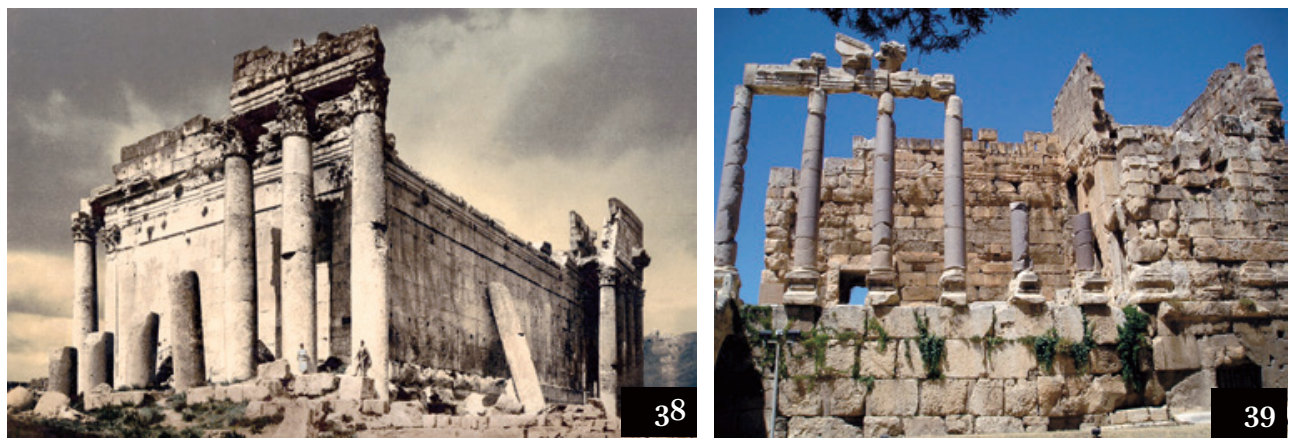

Baalbek, Temple of Jupiter. Top left, 38: colonnade (note the two figures standing against the columns). Top right, 39: reconstructed propylaea.
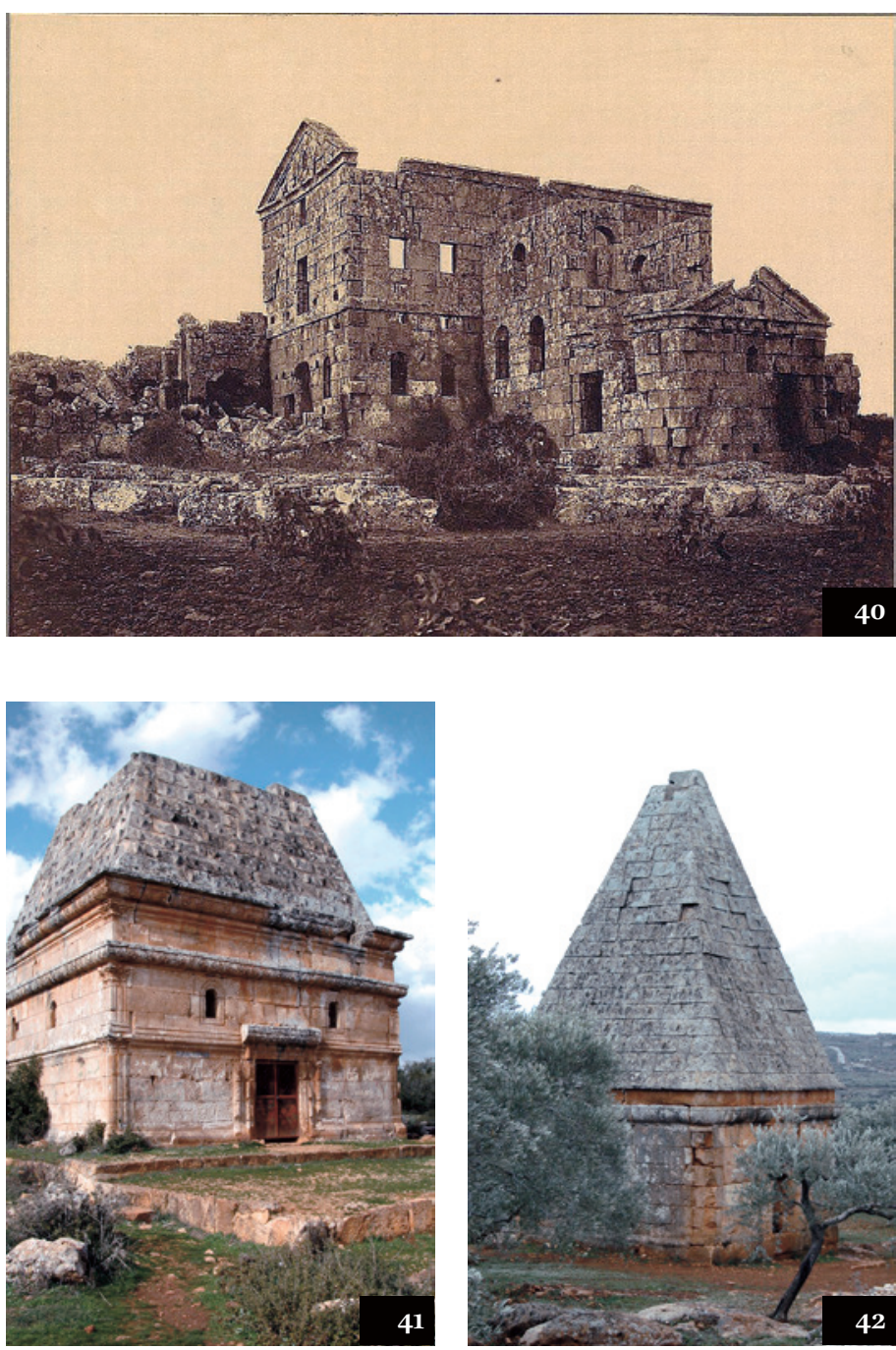

Bara (one of the Dead Cities). Left, 40:

two "palaces," and two pyramidal tombs, $41 \& 42$ (partly rebuilt). Guérin was here in 1864: "village musulman abandonné depuis trente ans; il avait été construit en partie avec des pierres antiques. Sur le seuil d'une petite mosquée, encore debout, gît renversée à terre une colonne cannelée et torse en marbre blanc. Une dizaine de citernes antiques se distinguent au milieu des ruines." Drummond visited in 1754: "Here have been several churches richly ornamented, particularly one, which was very large: great numbers of columns are still to be seen, together with many pyramidical monuments, some of which are now almost intire." 
Beirut, vicinity. Top right, 43: Roman road with inscriptions cut into the rock, near Beirut, 1839. Fuller wrote in 1829: "We ascended a rocky hill, from the top of which a steep descent cut out in the rock leads to the banks of the "River of the Dog." This road is of Roman origin, as several inscriptions of the Antonine age testify. On the flat side of the rock are some curious Persian and Egyptian figures: the latter are distinguished by hieroglyphics, and have been supposed to be the traces of one of the

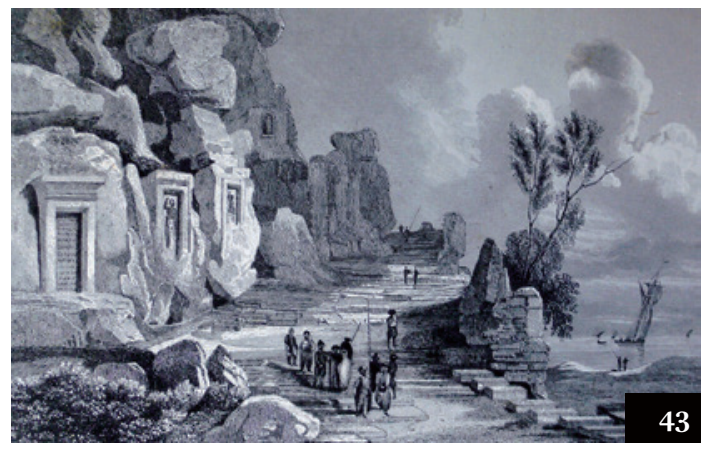
numerous irruptions which the Egyptian kings are recorded to have made into Palestine." Below, 44: Antiquities on the Beirut-Sidon road, from Cassas, touring in 1785 .
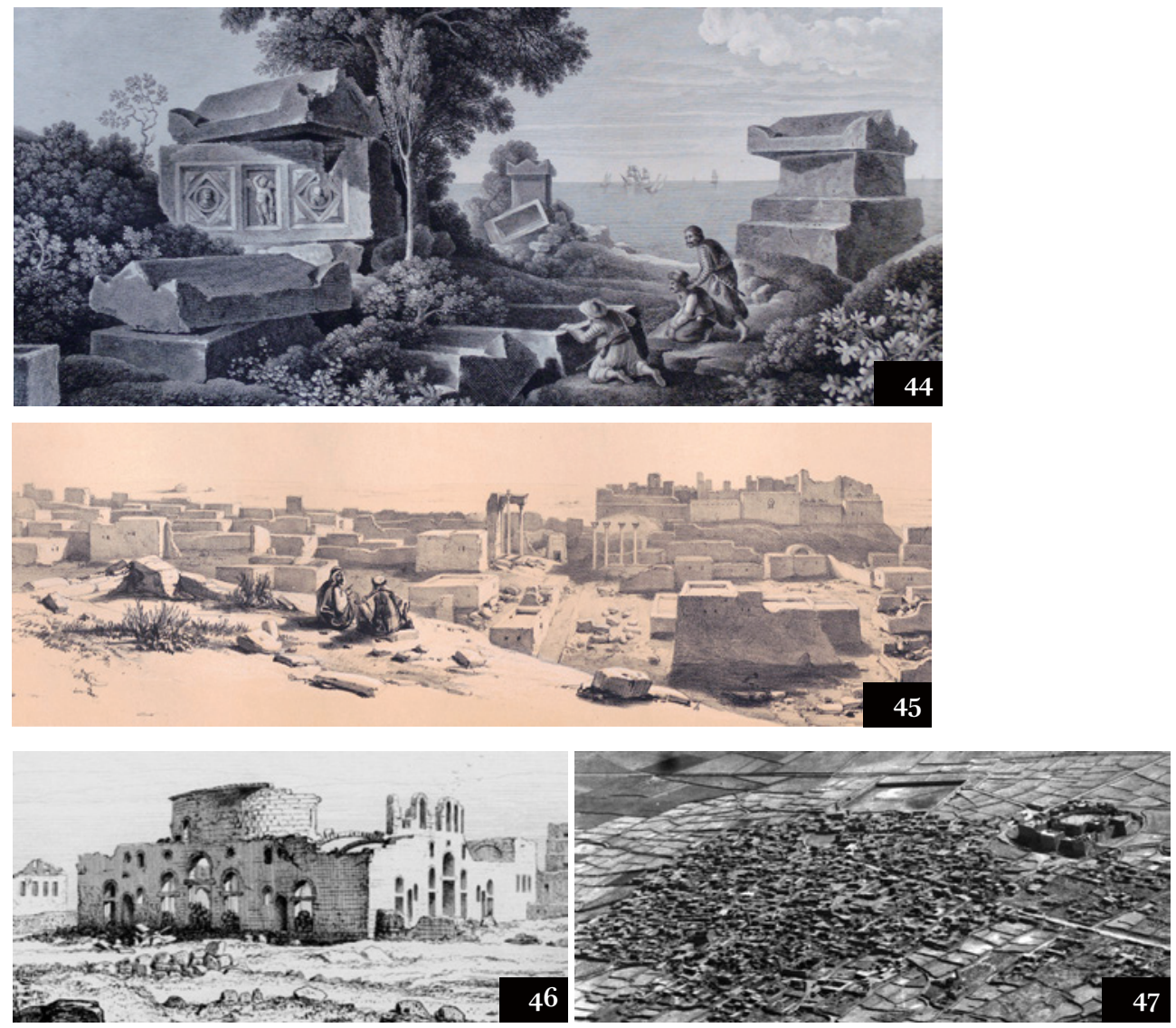

Bosra. In 1812 this was "at present the last inhabited place in the south-east extremity of the Hauran." (Burckhardt). Centre, 45: Laborde's view of 1837, with the fortress to the right. Bottom left, 46: the cathedral, published by De Vogüe in the 1860s, its drum and dome still standing. Bottom right, 47: aerial view (c.1930) with the fortress top right and a large square reservoir nearby. 


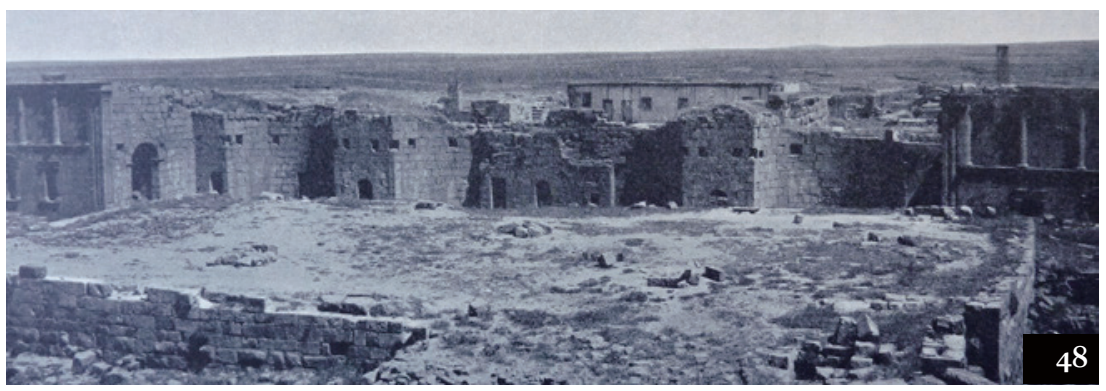

Bosra. Top, 48: the Roman theatre within the fortress in 1909. Right, 49: the theatre in 2003, giving an idea of just how much had to be dug out. Below right, 5o: the decumanus of the ancient city in 2003, with students on their way to classes.

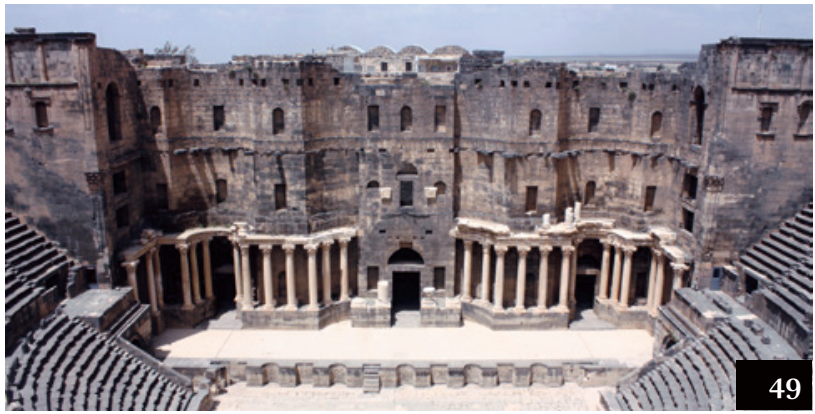

Below: Burj Haidar (Dead Cities), with left, 51, young inhabitant (in 2003) in front of his spolia-built house, and right, 52, a church colonnade. As Butler wrote in 1905 of Jebel Riha: "The buildings of this region, too, especially the churches, are in a better state of preservation than in other parts of Syria. Eight of the eighteen churches still preserve the half domes of their apses; four have both rows of columns and arches standing, and two have one row of arches

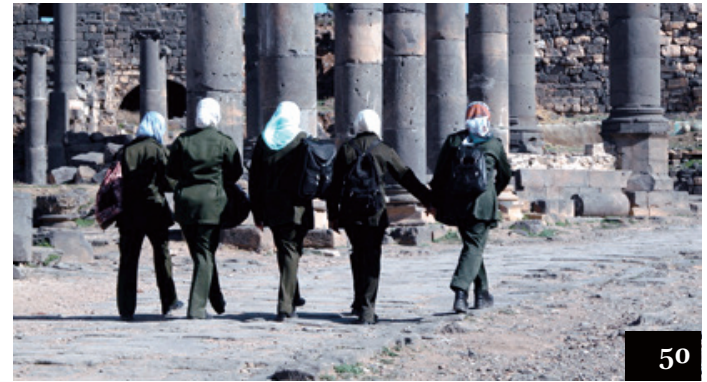
still intact. Four of these buildings are almost perfect so far as stonework is concerned."
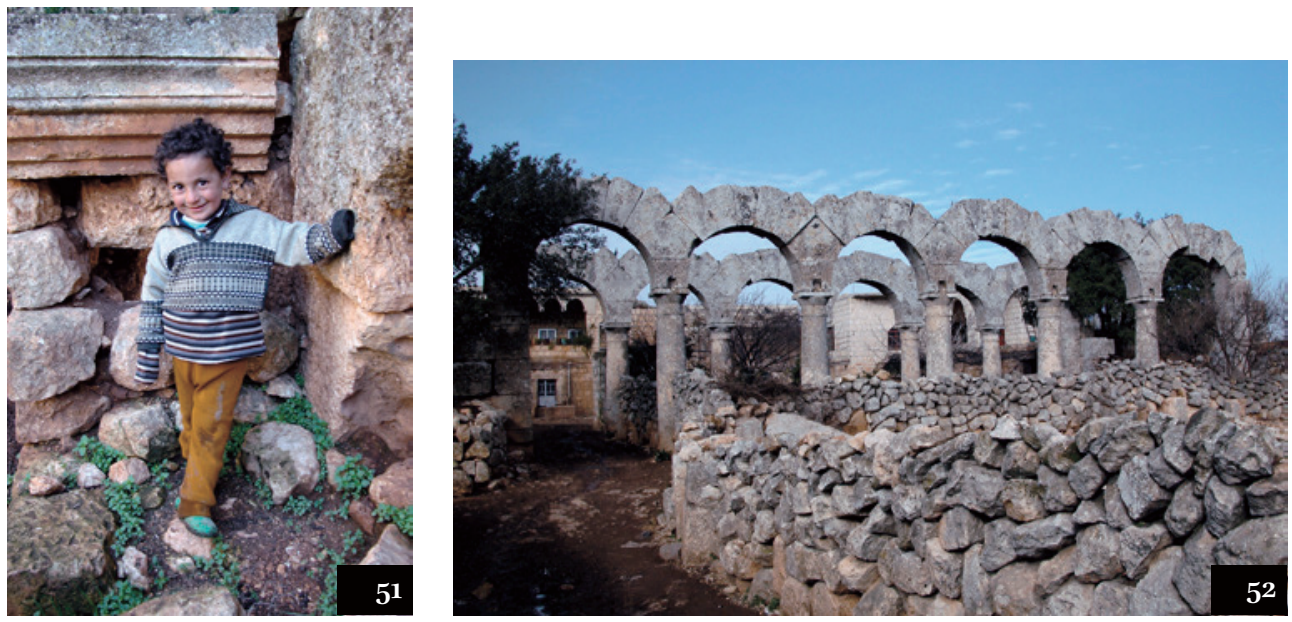
Byblos. Right,

53: Pococke's 1745 illustration of the theatre. Far right, 54: limestone sarcophagus with a marble cornice block to the rear. Egmont $\&$ Heyman wrote of the theatre in 1759: "the whole exhibits but a wretched appearance, and has been greatly abused; all that remains now consists of a semicircle, in the inside of which are some small houses built of the ruins, a great part of it having been blown up designedly by gunpowder; and the great quantity of marble, of which it consisted, converted to build a mosque and a bath."

Caesarea. Right, 55: Conder \& Kitchener's 1882 plan of the Roman and mediaeval ruins, showing the crusader town much smaller than the ancient one. Carne writes in 1830 : "Of the temple, forum, amphitheatre which it formerly possessed; it is difficult now to discover the sites... The walls, as well as the fortress, of which some massive remains exist, were erected by the Crusaders... Within the ruined fortress are several fragments of columns, of considerable beauty, of granite and alabaster: this was probably the residence of many a Norman or Burgundian lord, for the French chivalry had possession of the place, and fortified it."
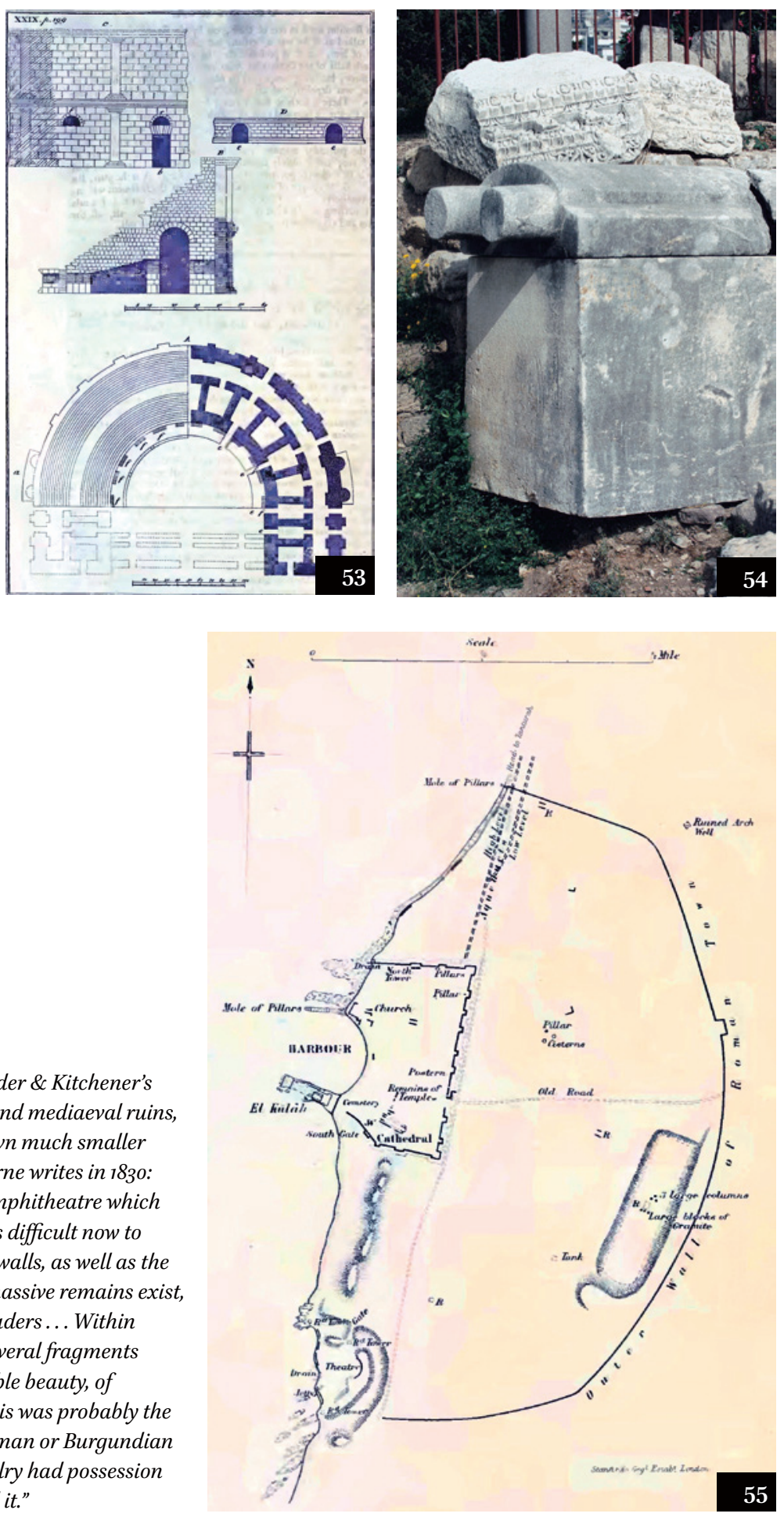
Caesarea. Columns in their hundreds were used to strengthen Crusade-period walls, some of which have collapsed with the shafts still firmly embedded. Right, 56: Thevoz' photo of 1888. Centre left, 58: mole, in a print of 1884. Centre right, 57: Another view of the mole. Some column-shafts were too large to move, such as this one (centre right lower, 59) in the Hippodrome. Bottom, 6o: Taylor-Reybaud's view of the site in 1839. Lynch in 1849 saw that "the whole area within the walls is full of pits, where hewn stones have been dug from the earth accumulated over them in the lapse of ages."
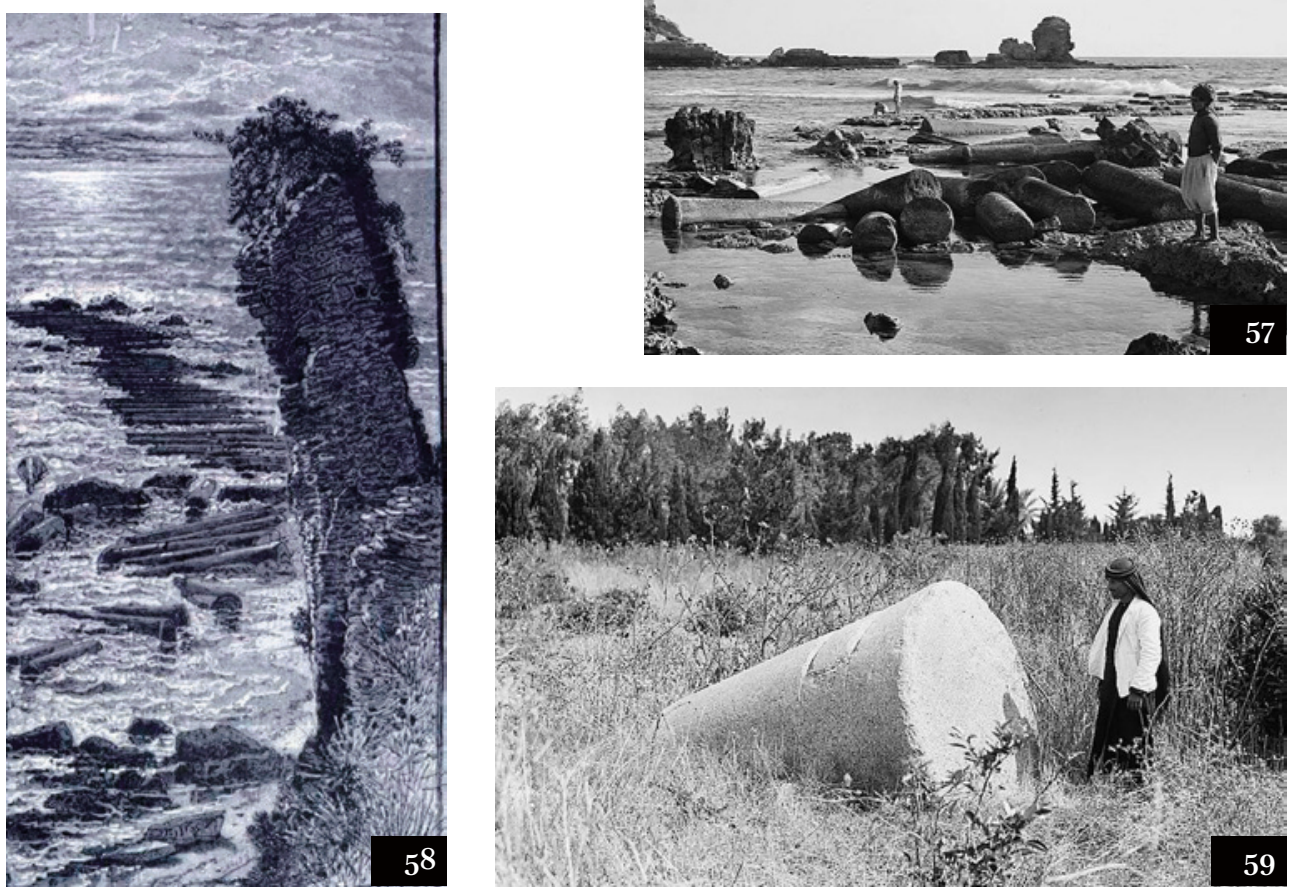

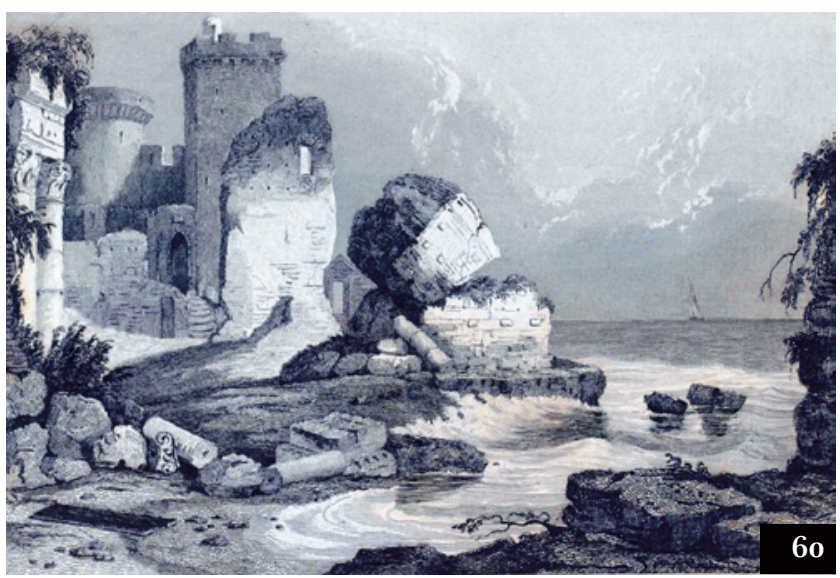




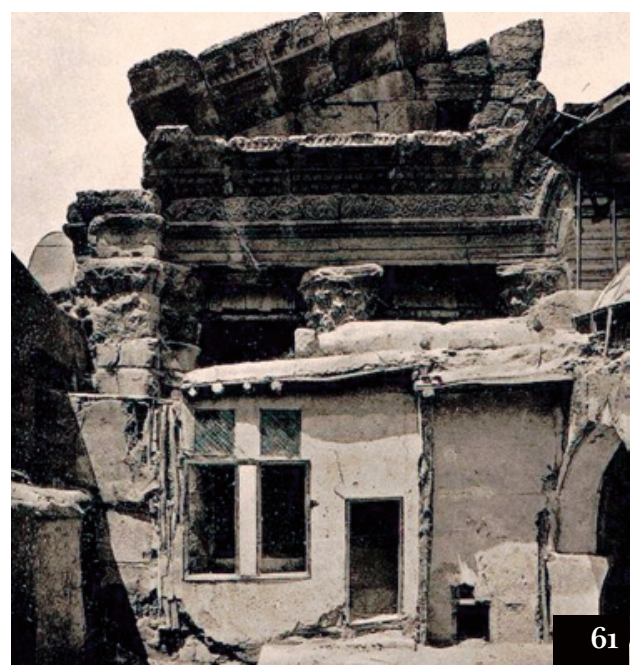

Damascus, Umayyad Mosque. Above left, 6r: the preceding west portico in 1918, embedded in later buildings, and as close as Christians were once allowed to approach. Right, 62: the same in 2003. Centre right, 63: the courtyard "treasury" today: its mosaics have been uncovered, and the colonnade behind has been cased in for strength. Below left, 64: west arcade: mosaics. Bottom, 65: antique pediment to the Maristan Nur-al-Din ( founded 1154), possibly from the nearby temple (which is now the Umayyad Mosque).
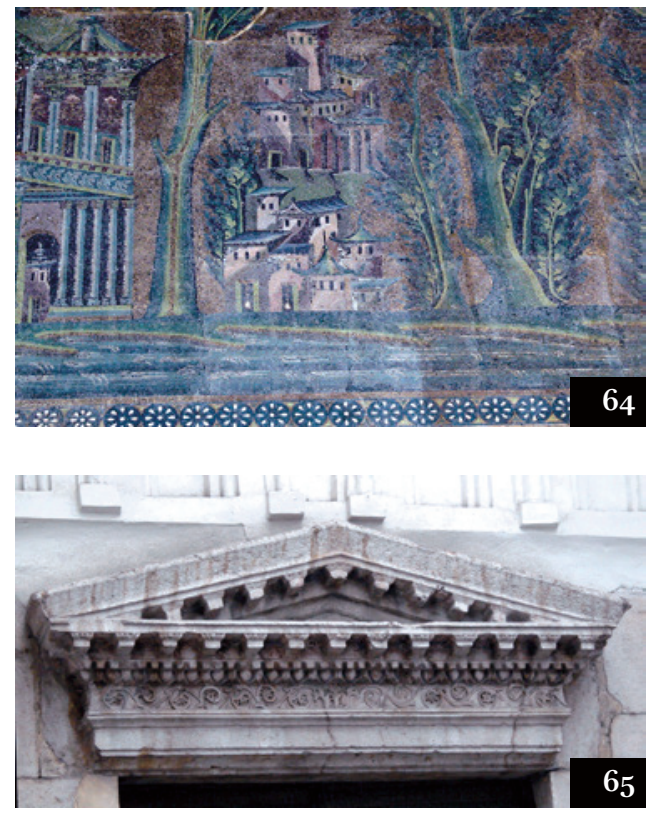
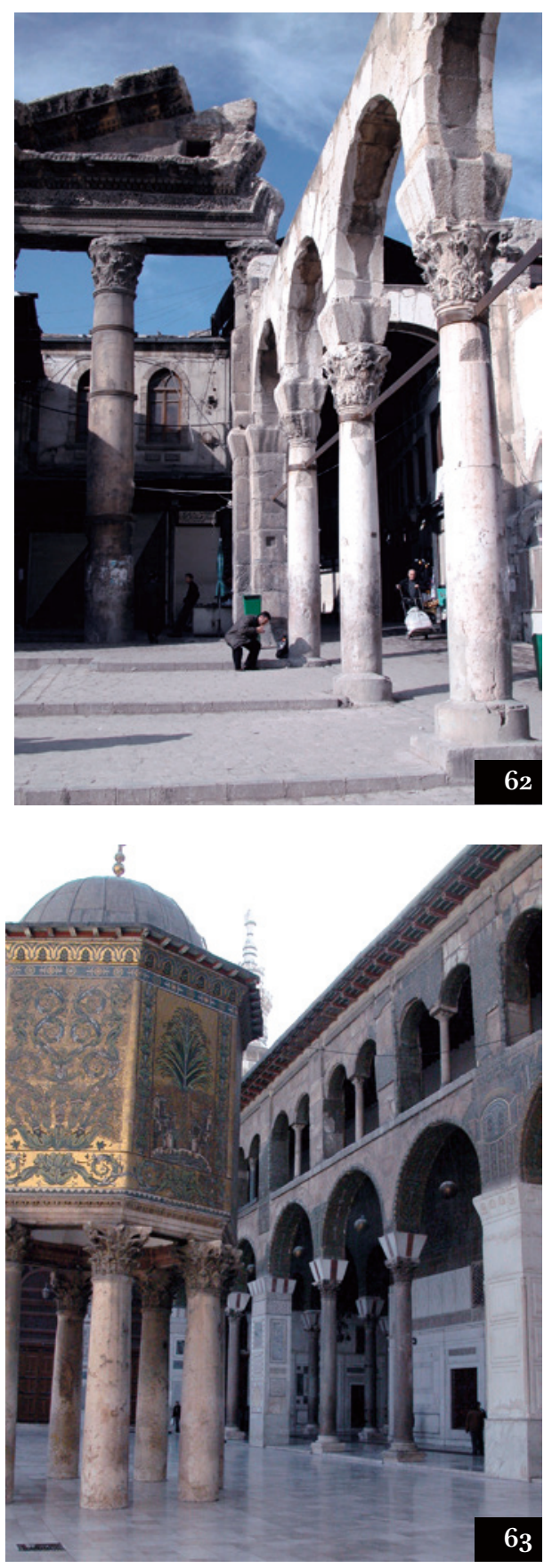
Top left, 66: Damascus, Umayyad Mosque: exterior, north of Bab al-Amara. Top right, 67: Prevented from entering the Mosque, travellers could admire the luxury of the city's private houses, such as the Azem Palace, with marble floor and fountain.

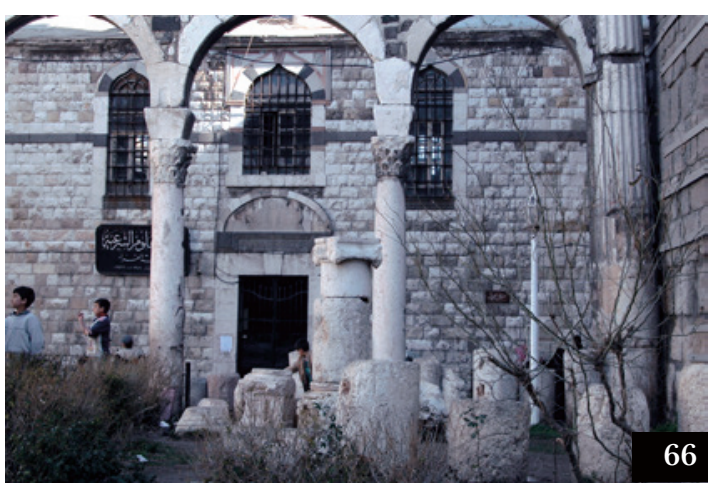

66

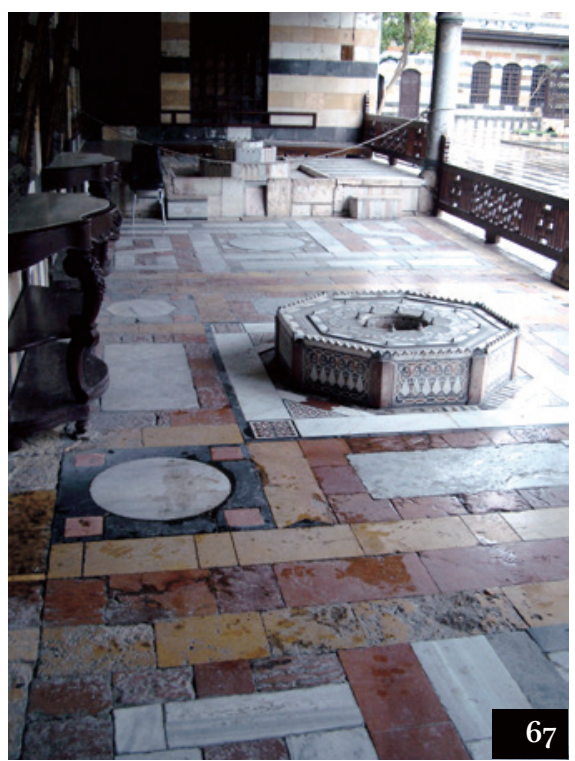

67

Gaza. Bottom left, 68: Sultan's palace in 1819. Bottom right: 69: Marble statue of Zeus, discovered 1879, now Istanbul, Archaeological Museum. The town "rivals Ascalon in this abundance of columns. They are dug up in every yard and garden, and they form every threshold and most of the lintels"(Wilson 1881).
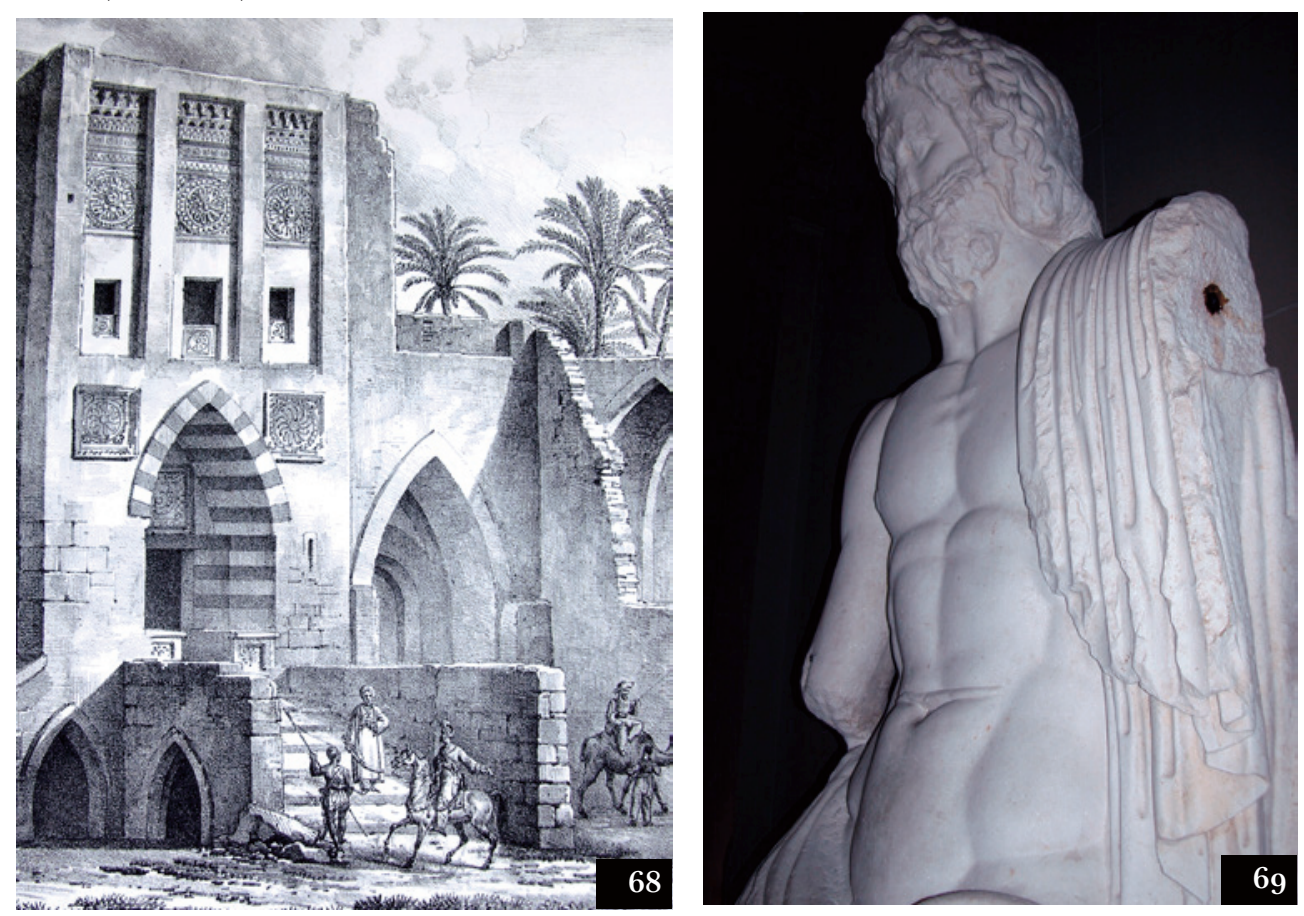
Gaza. Top, 70: view in 1875 from the older site, with the newer town in the distance. This is copied from Darboy's 1852 print (71, directly underneath), giving some hint of the imitation and piracy practised in illustrations as well as in text.
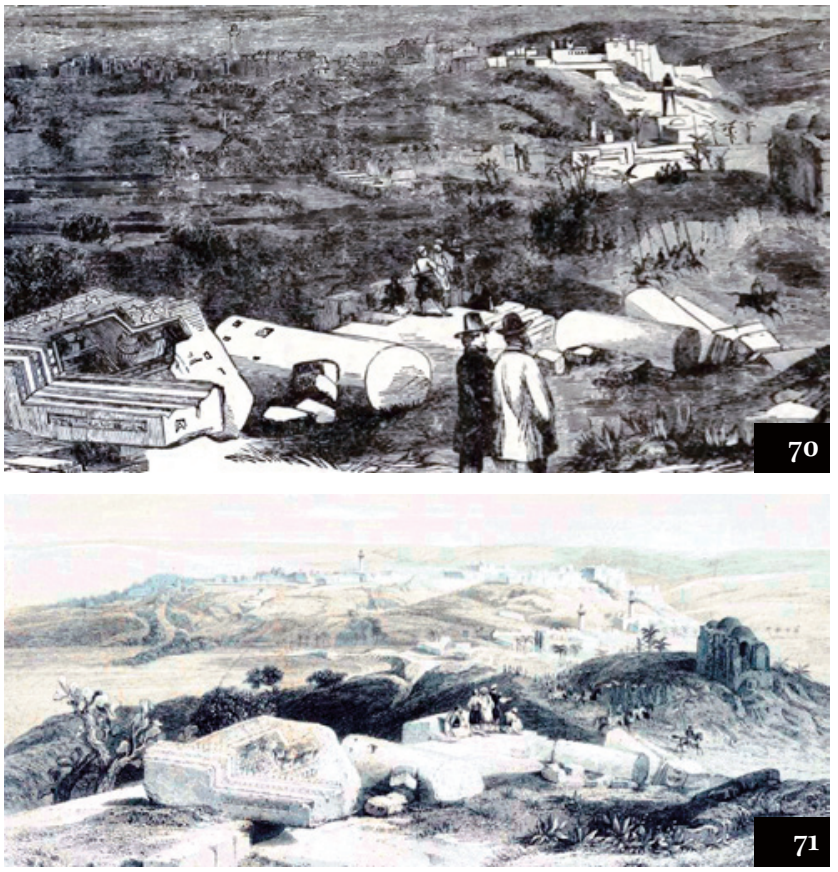

Bottom left, 72: Byblos, in Newman's 1864 print. As Irby \& Mangles wrote in 1823, "We found the remains of a row of columns which lined the main street on either side; two theatres, in tolerable preservation, are within the walls." Bottom right, 73: the keep of the fortress of Byblos, in Rey's 1871 print. T.E. Lawrence ("of Arabia") walked to many of the Syrian Crusader fortresses in 1909, and here noted its "exceptionally heavy masonry."
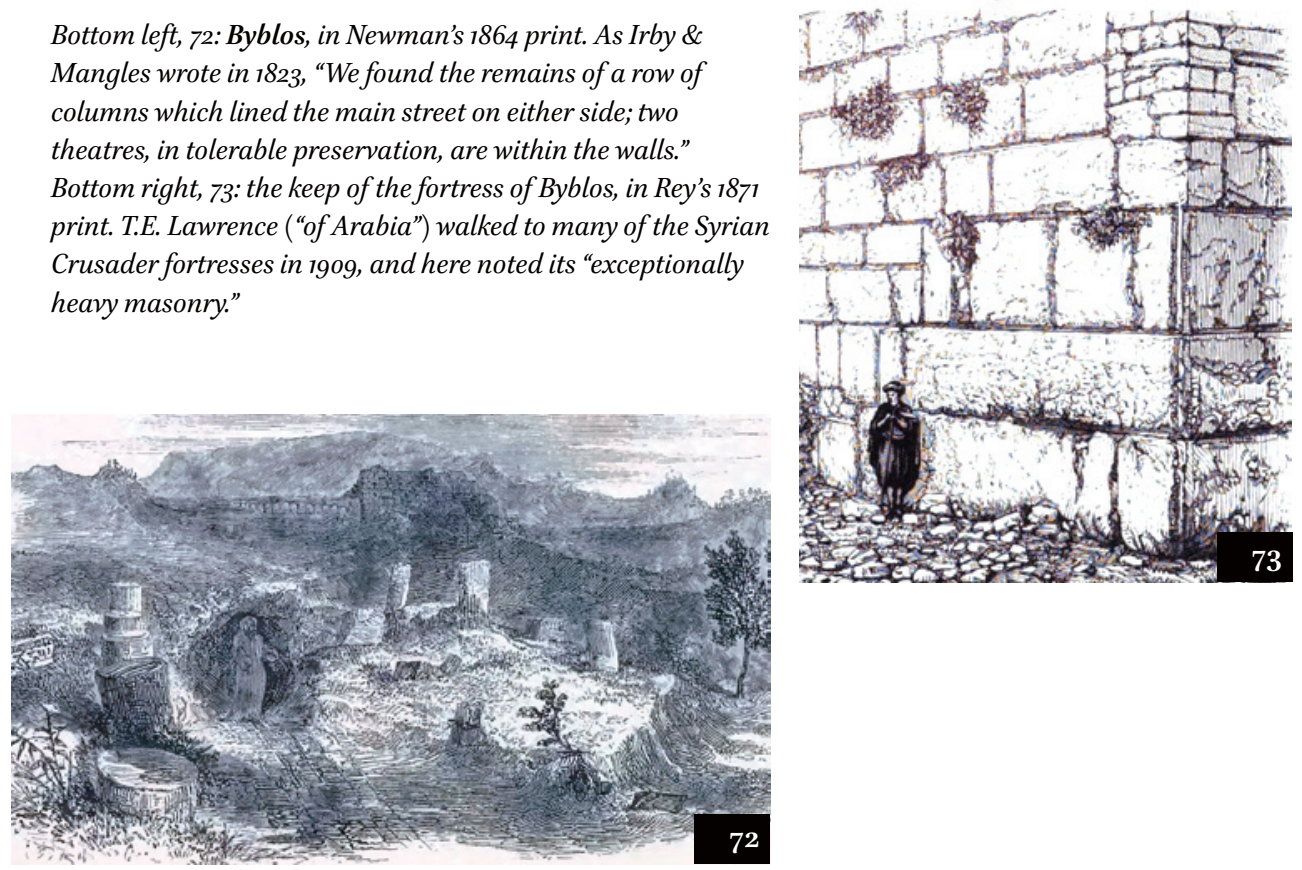

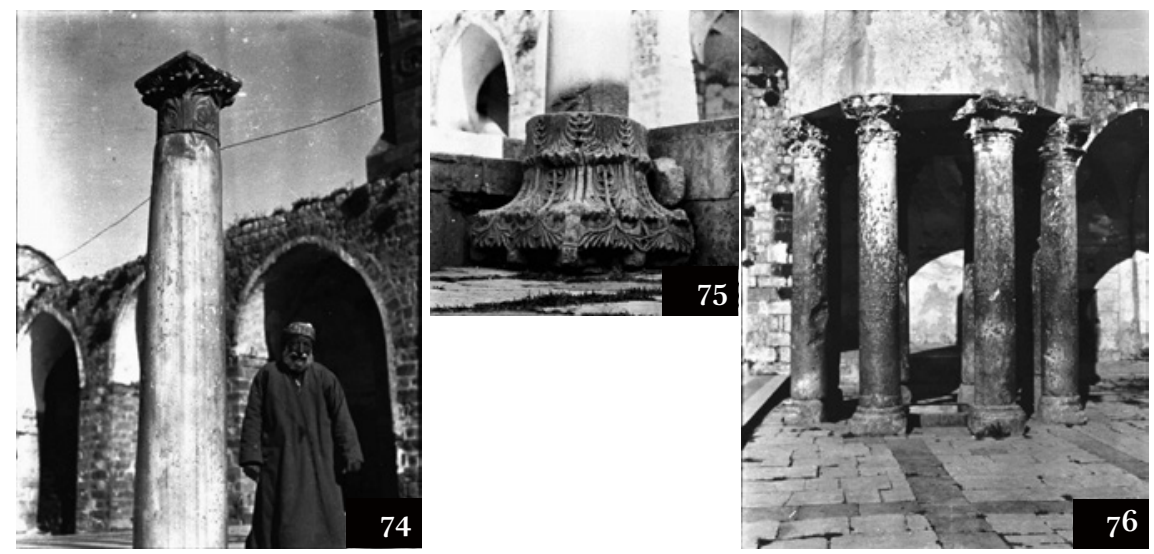

Hama. Above, 74, 75, 76: antiquities re-used in the Great Mosque, photos of 1905. Homs. Centre, 77: Walpole wrote in 1851: "The whole hill is cased over with solid masonry, immense blocks of black, ferruginous stone, of great depth and solidity: here and there columns of the same have been worked in." The fortress is seen here in 1881, with the town behind, and has had many such blocks robbed out.

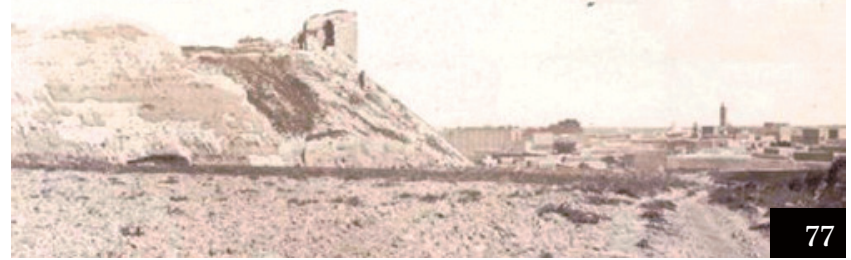

Two similar tombs near Homs town, in prints of 1837 (below, 78) and 1865 (right, 79). Of the left tomb, Buckingham wrote in 1825: "On each part of the square stages at the base were three marble pilasters, the pedestals of which remain on the western, and the plain capitals on the northern side; and between these stages, in a sort, of deep frieze, were sculptured four pediments, with a festoon between the two central ones... The interior walls seem also to have been stuccoed and painted."
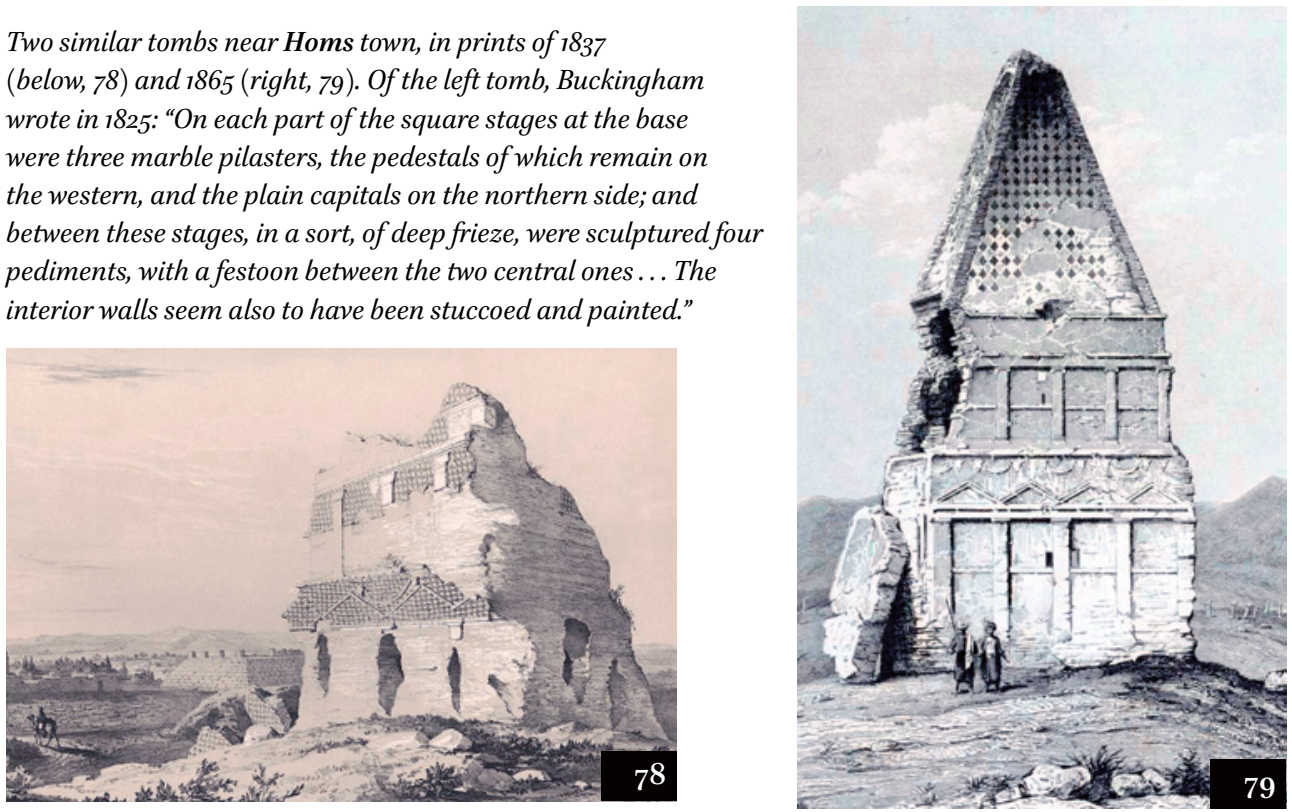


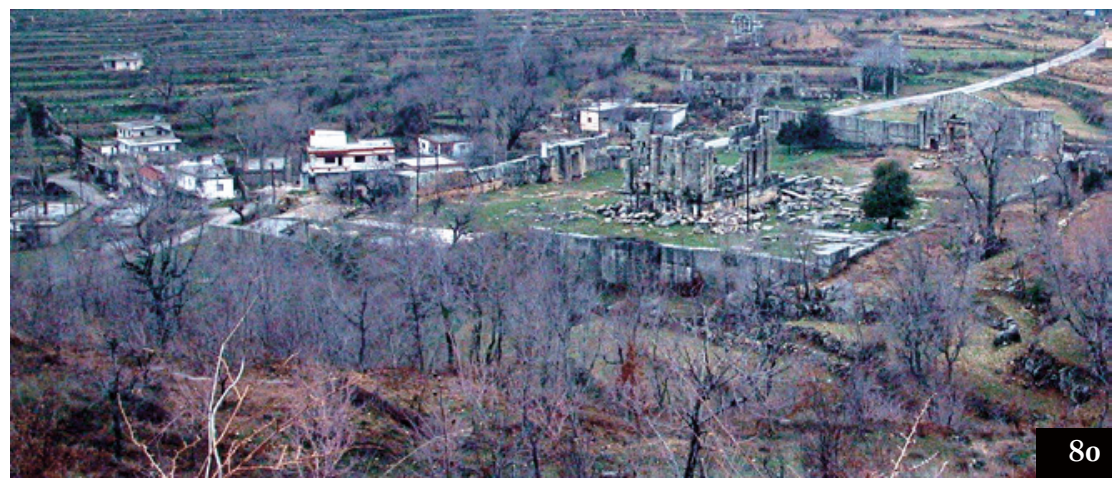

Hosn Suleiman. Top, 8o: the site in 2003. Right, 81: print by Rey, 1867. Lower right, 82: a few of the many massive blocks. Bottom, 83: the temple itself.

Walpole described the site in 1851 : "Hassan Suleiman is situated at the head of a wild gorge, and consists of a large mass of ruins, among which are several Ansayri cottages. The first building I visited is about three hundred feet in length, by one hundred and fifty in width... It consists of a high wall built of stones, some of which are eighteen feet in length, some smaller, and about six or seven in width, of a proportionate height."
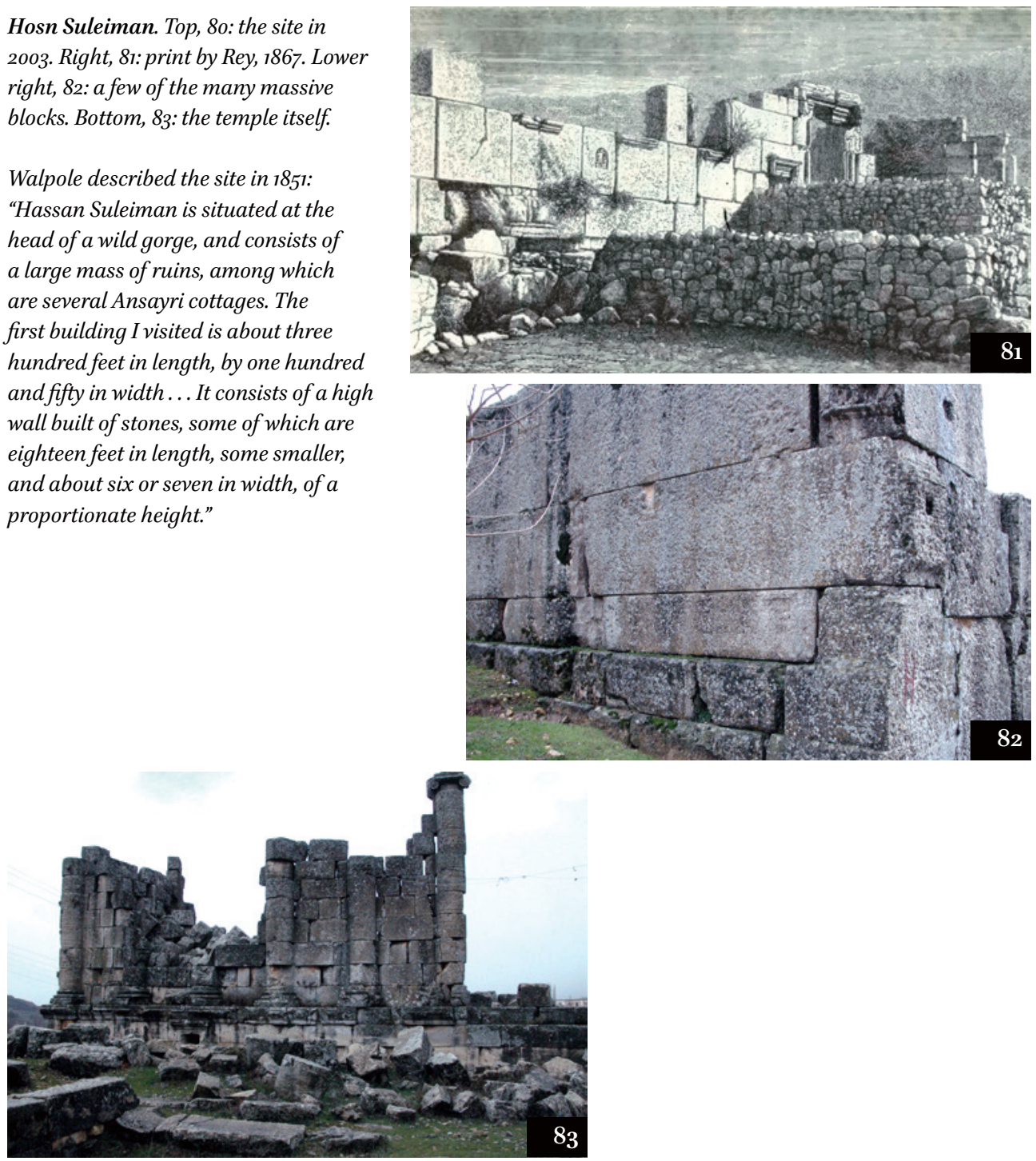
Jaffa. Right, 84:Jan van Cotuuyck's 1619 view, with its ancient ruins. It remained the most perilous port on the coast, well-known for its shipwrecks; and in 1840 "its roadstead in winter is altogether unsafe."

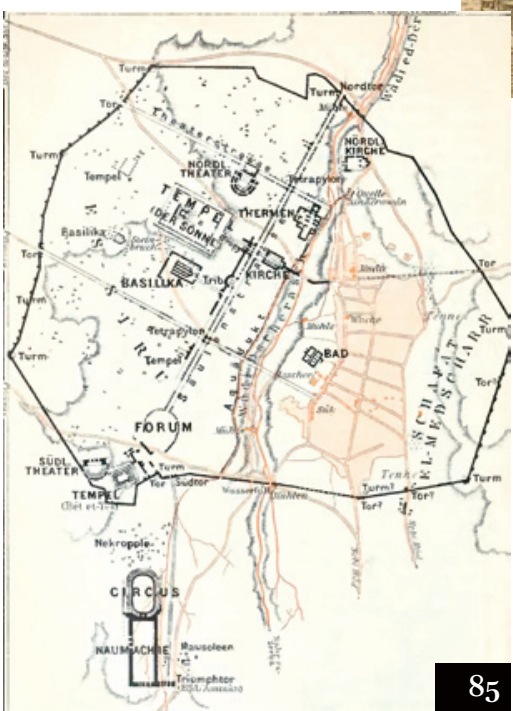

Jerash. Above, 85: Baedeker's 1910 plan. Right, 86, 87, 89: three views of 1837 . The theatre was occupied ("The galleries are now the private dwelling-houses of the Arabs," wrote Lindsay in 1838); the triumphal arch and below, general view of the site. Bottom left, 88: Photo by Bonfils, later 19thC.
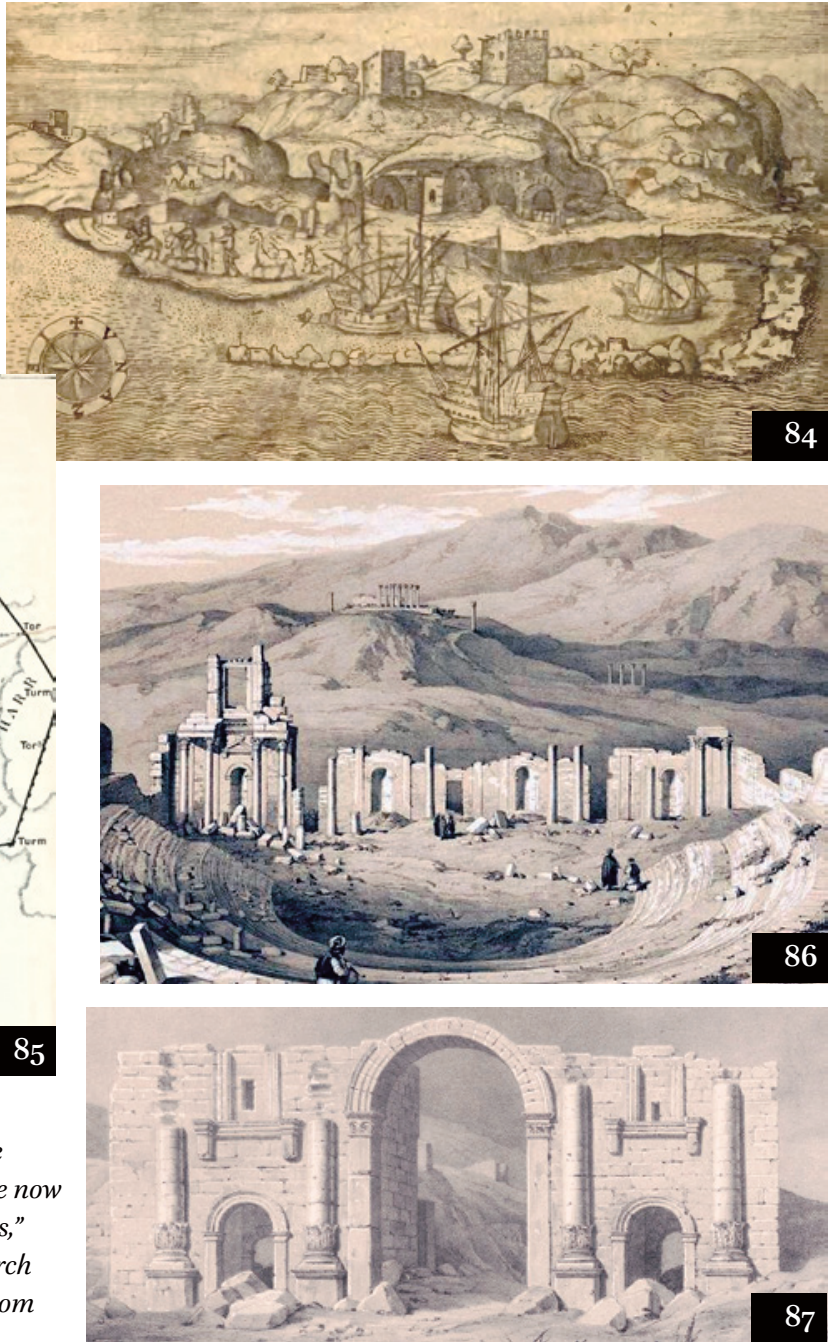
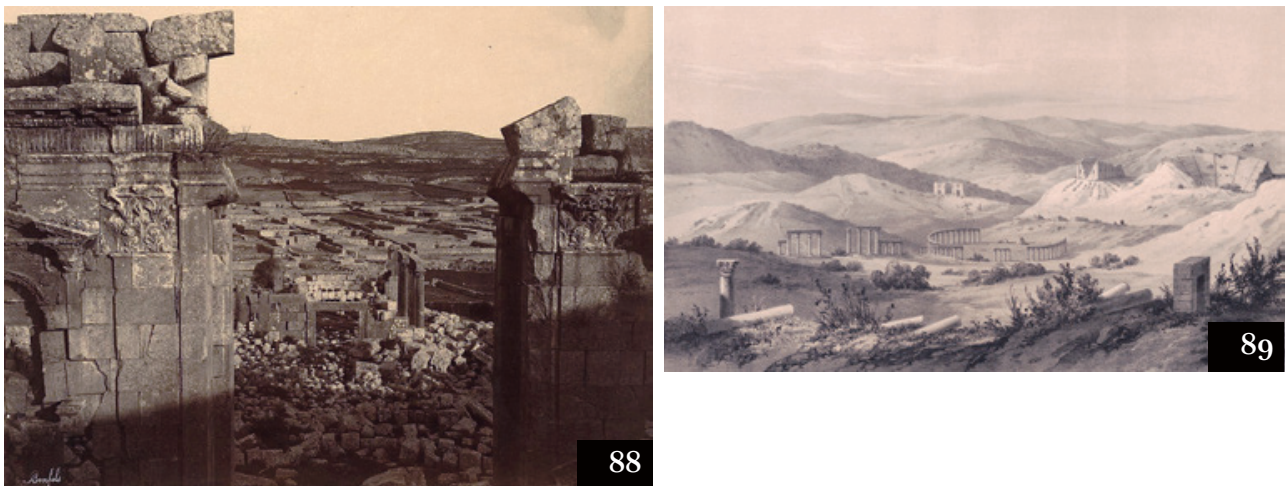
Jerash. Right, go: the oval forum in 1918, with to the rear the town, then housing many Circassian immigrants. In 1885 Le Strange was relieved that the Circassians "had fortunately taken up their abode on the left bank of the stream, where the ruins are comparatively insignificant, and they had not as yet begun to meddle with the magnificent theatres, colonnades, and temples crowding the right bank." Below, 91: ruins in a view of c.1920.
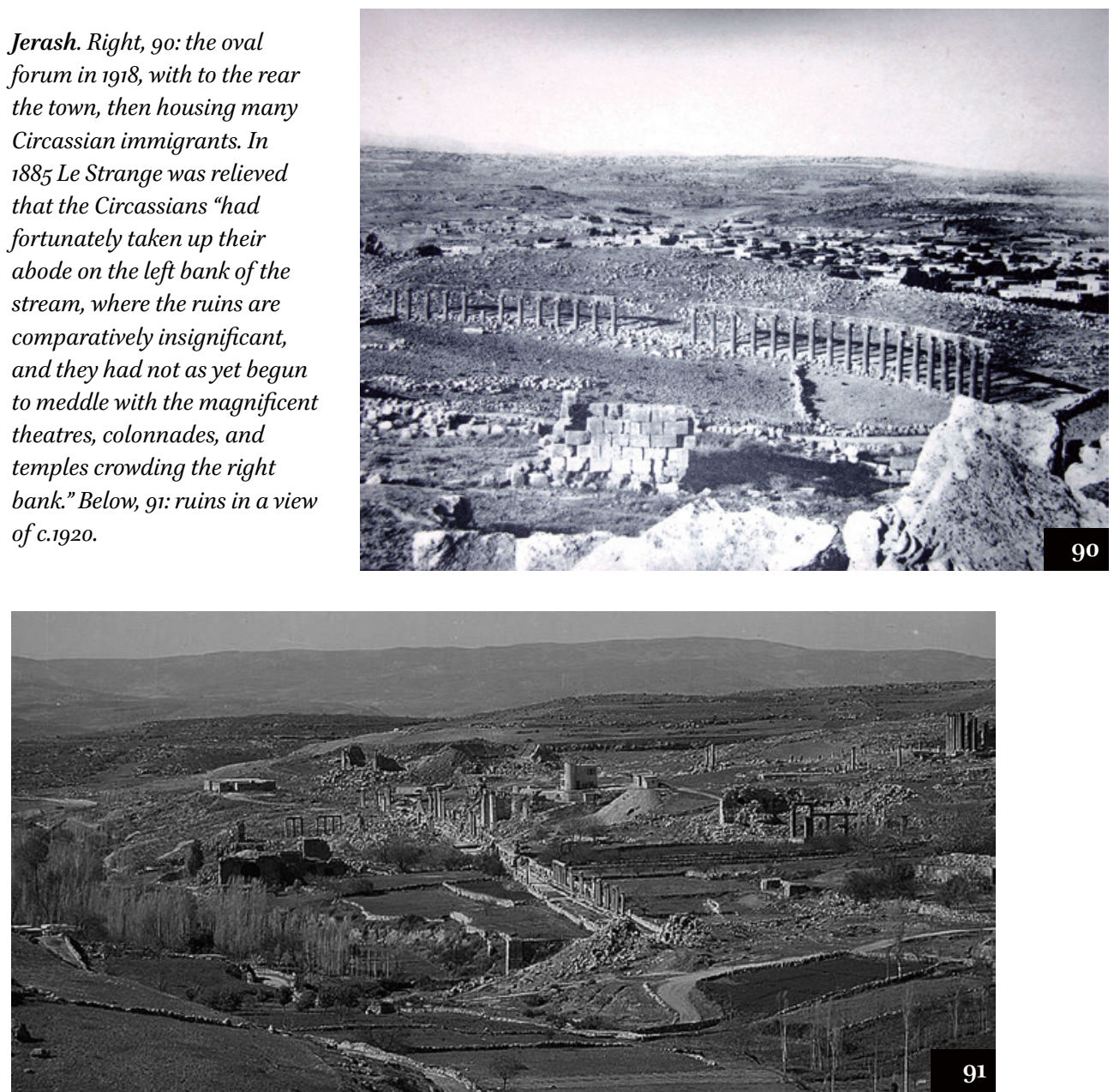

Left, 92: a sophisticated house with portico at Jeredeh, in the Jebel Riha. Waddington wrote in 1861 that the Djebels Riha, Ala \& Seman were "remplies de villes et de villages ruinés ... d'une construction admirable, et à peu près inconnus, bien que d'un très grand intérêt. Il y a peu d'inscriptions, assez cependant pour bien fixer la date des monuments. Il y a là à faire tout un cours d'architecture syro-byzantine, ecclésiastique et civile; des églises, des maisons, des tombeaux." 

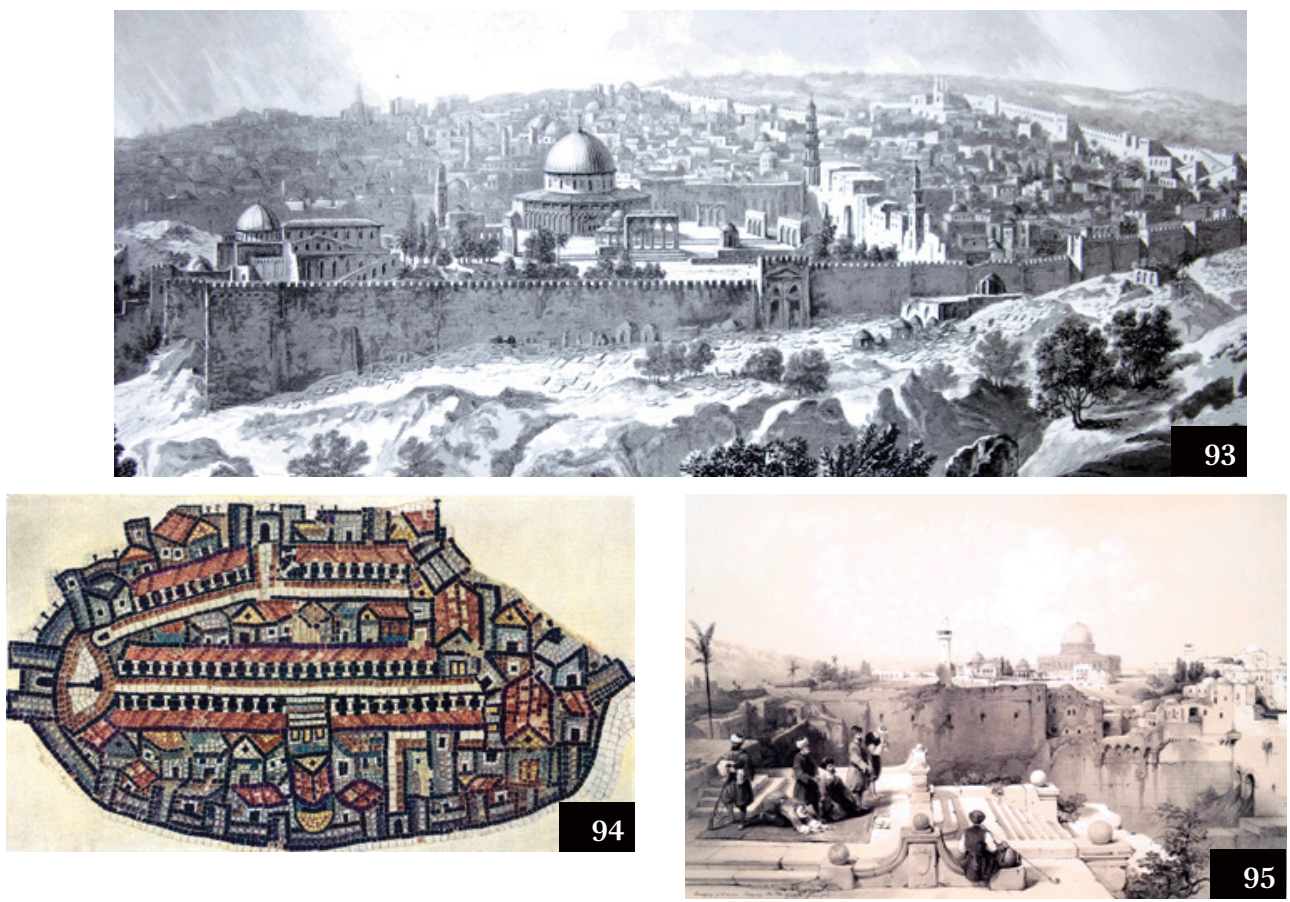

Jerusalem. Top, 93: Forbin's 1819 view with the Haram to the fore. Centre left, 94: the town-plan of Roman Jerusalem from a small section of the Madaba mosaic. Centre right, 95: David Roberts' 1830 s distant view of the Haram, because non-Moslems were not allowed to approach close to the complex. Guylforde in 1506, admiring the exterior only, wrote that "a man may juge by out warde syght ye sayd temple is in largenes, hyght, and sumptuousnes buyldynge fer aboue and beyonde any werke that euer we sawe in all our lyues." Bottom left, 96 : 1925 photo of the mosaic and marble on the exterior of the Dome of the Rock. Bottom right, 97: late 19thC view of its interior.
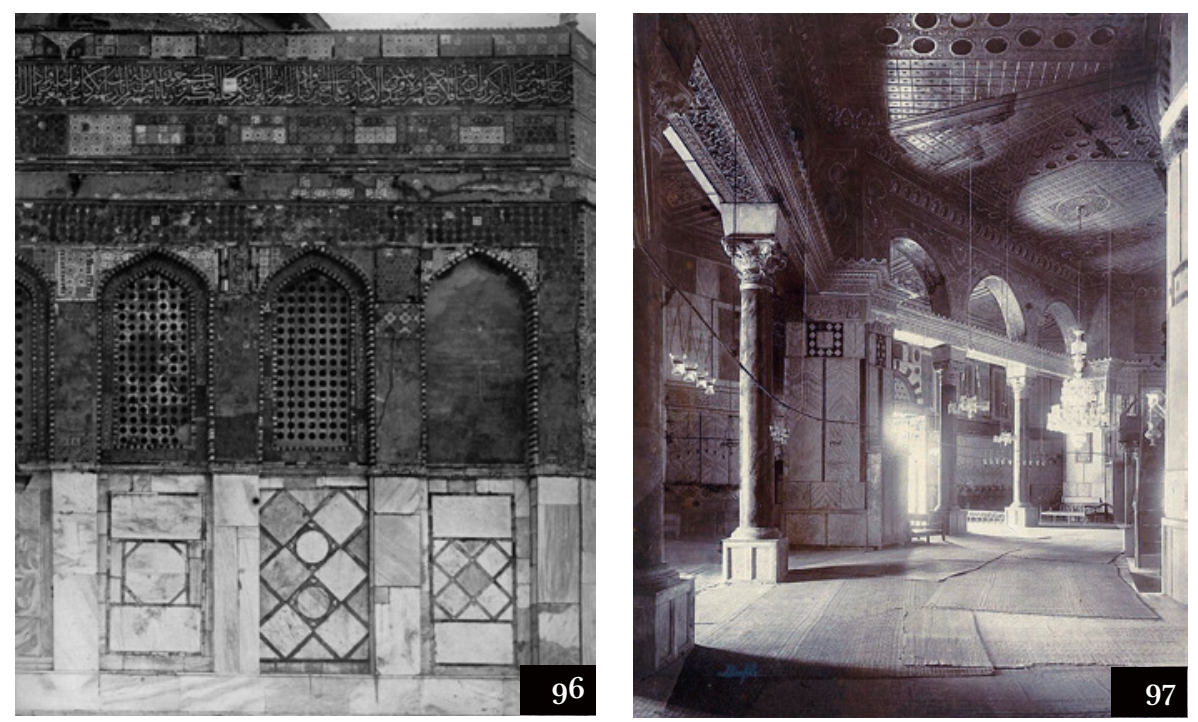

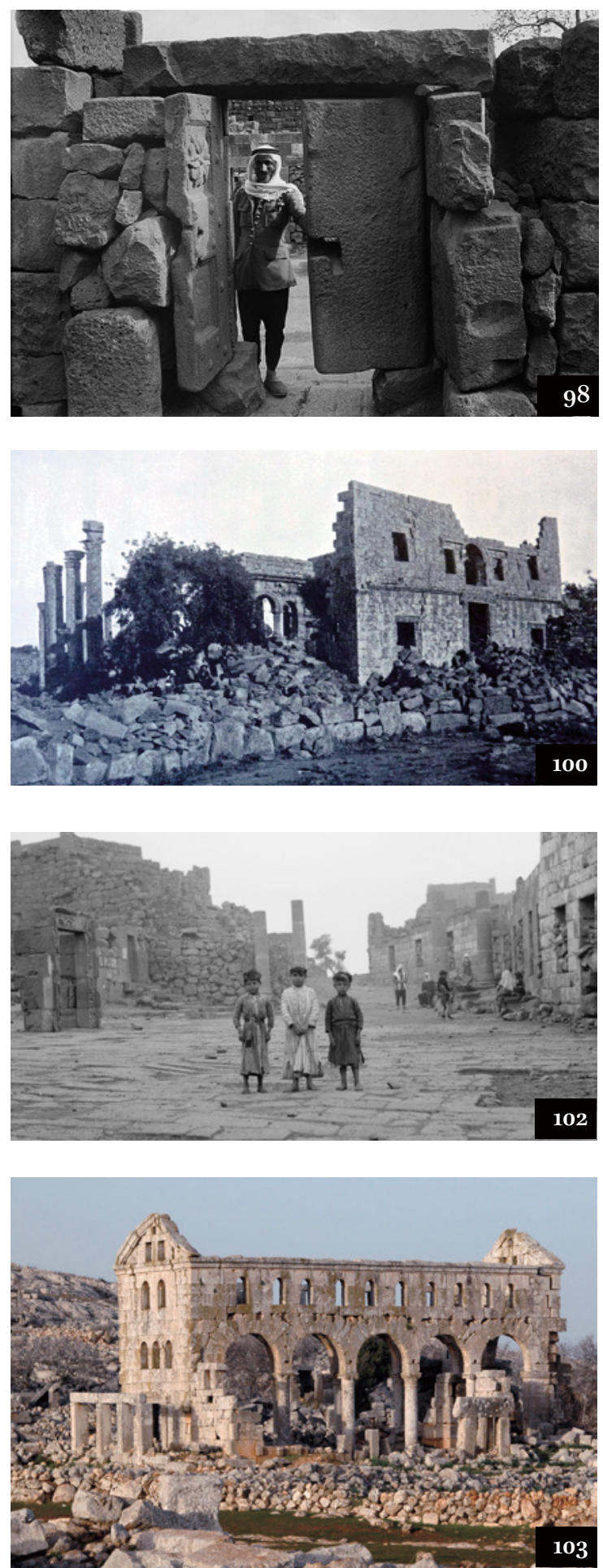
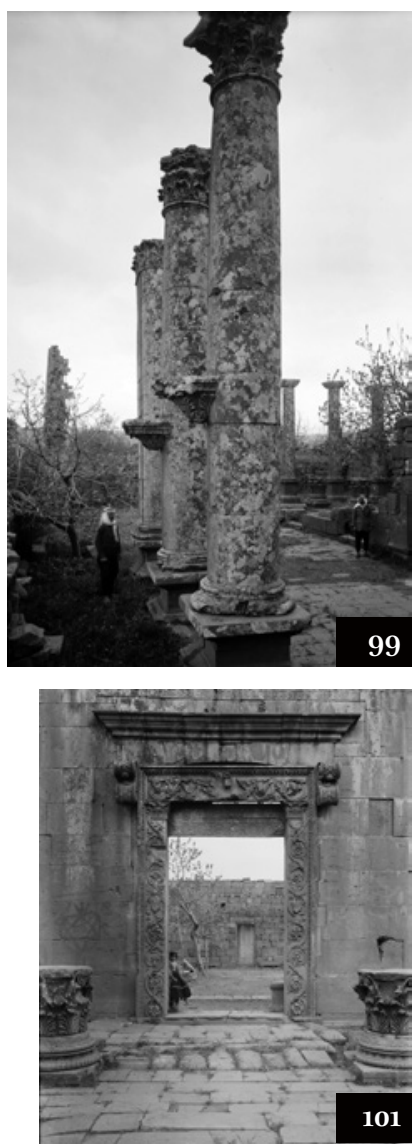

Qanawat. Top left, 98: working stone doors (with stone hinges); note the imitation bossed nailheads, as if this were a wooden door. In 1855 Porter wrote of one house: "Within it are several stone doors of great beauty, with panels and fretted mouldings, and bas-reliefs of flowers and fruit. In one of them I observed a place for a lock and also a keyhole!" Top right and below right, 99 \& 101: the temple and its highly decorated doorway. Upper centre left, 10o: the Serail ("palace"). Lower left, 102: street with Roman pavement, Roman buildings, and Roman doorway to the left. All images early 2othC. Near Qanawat in 1879 Merrill had pointed out to him by a Druse "upwards of forty ruined cities and towns, most of which he called by name," which suggests they were at least part-inhabited. Bottom left, 103: the church at Kharrab Shams, one of the Dead Cities. 

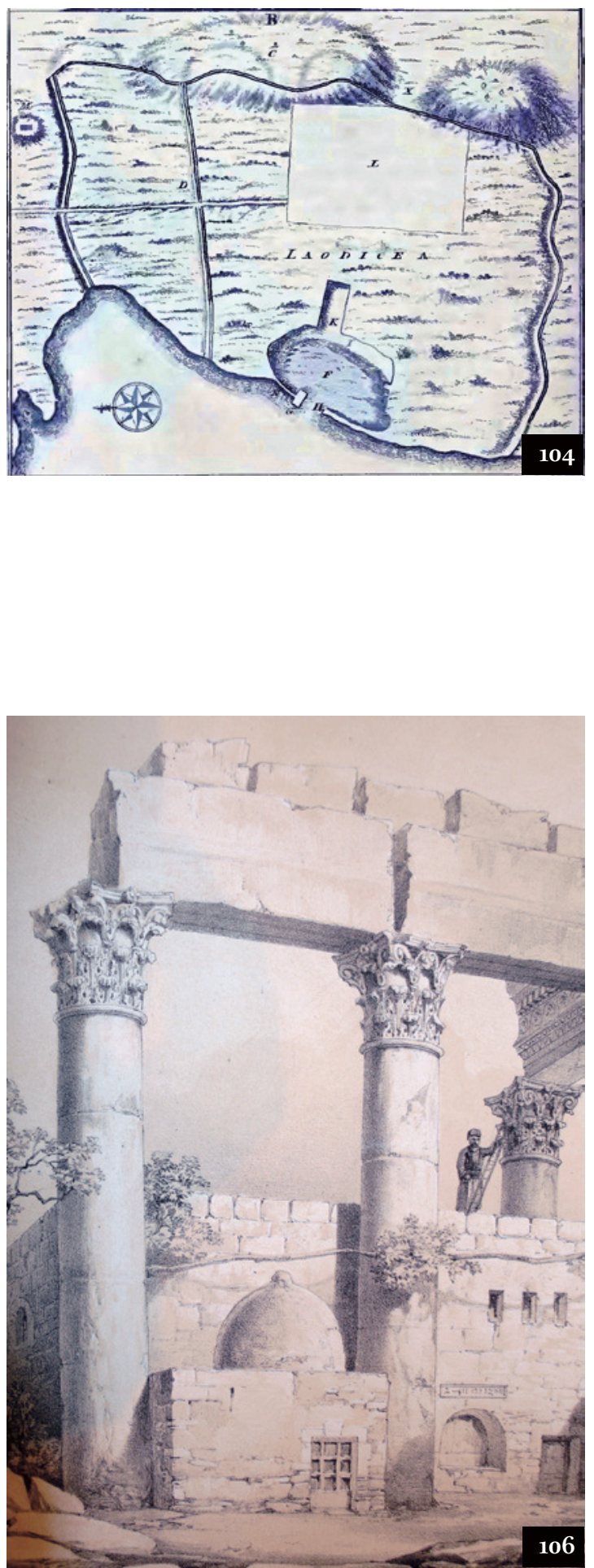

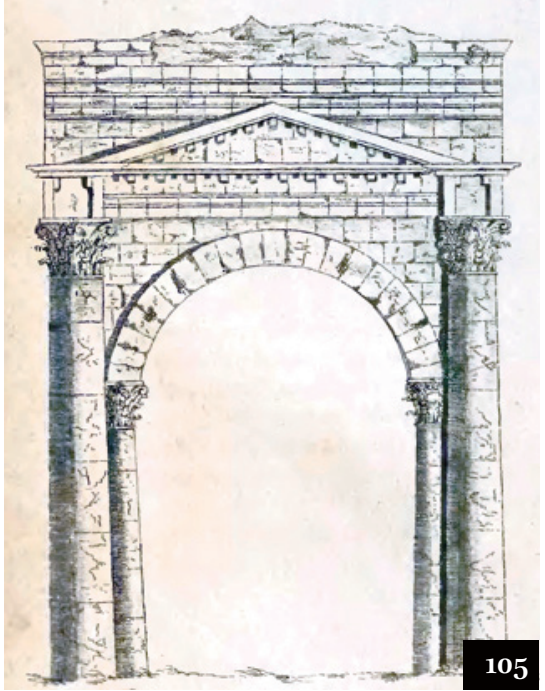

Lattakia. Top left, 104: Pococke's plan of 1745. By 1738, as Shaw wrote, the harbour complex ("capacious enough to receive the whole British navy") was in ruins, recognisable as "a work and structure of great labour and design, though at present it is so much filled up with sand and pebbles, that half a dozen small vessels can only be admitted." Top right, 105: triumphal arch, by Drummond, 1754. Bottom left, 106: "Temple of Bacchus," from Texier, 1864. Bottom right, 107: colonnade shafts (cf. the cross streets on Pococke's plan) built into modern housing, in a photo of 1918.

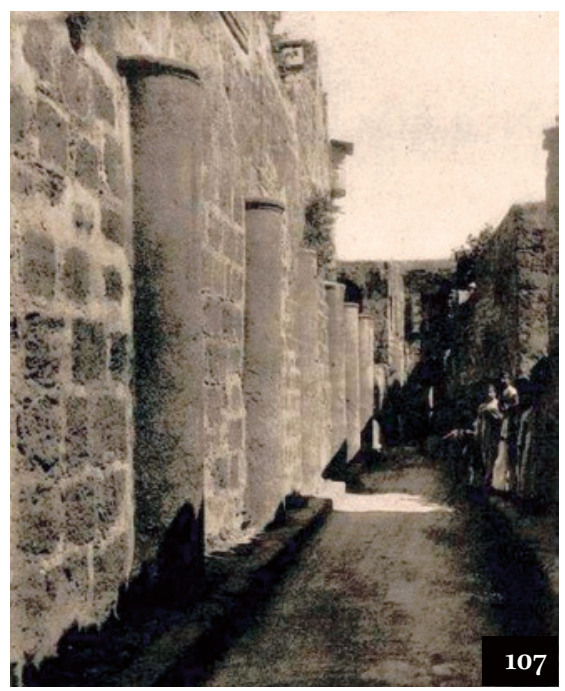




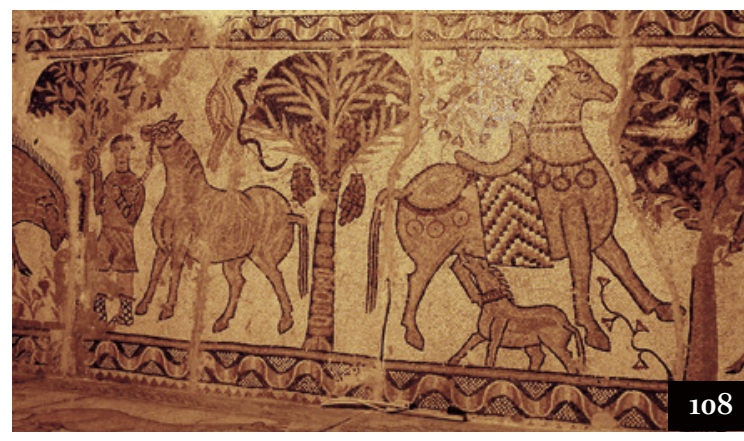

Maarat al-Numan, between Aleppo and Homs, 108: mosaic from a church at Selemiye. Top right and below, 109, 110: Mschatta, plan and detail of entrance façade. As Thomson wrote in 1886: "Situated on the open plain, with higher ground about it, surrounded by a flat, arid desert, entirely destitute of water, with no human habitation in sight for many a weary mile, far from any highway; what could have been the motive that led to its construction? and from whence came the building material?" Lower right, 111: Masyaf, citadel, described by Lawrence as "absurdly weak" and "contemptible." Bottom left, 112: Marqab, of dour volcanic blocks, but with a decorative band in a marble-like stone. Bottom right, 113: De Vogüés 1865 view of Moudjelein (one of the Dead Cities), built of large blocks, and clearly inhabited.
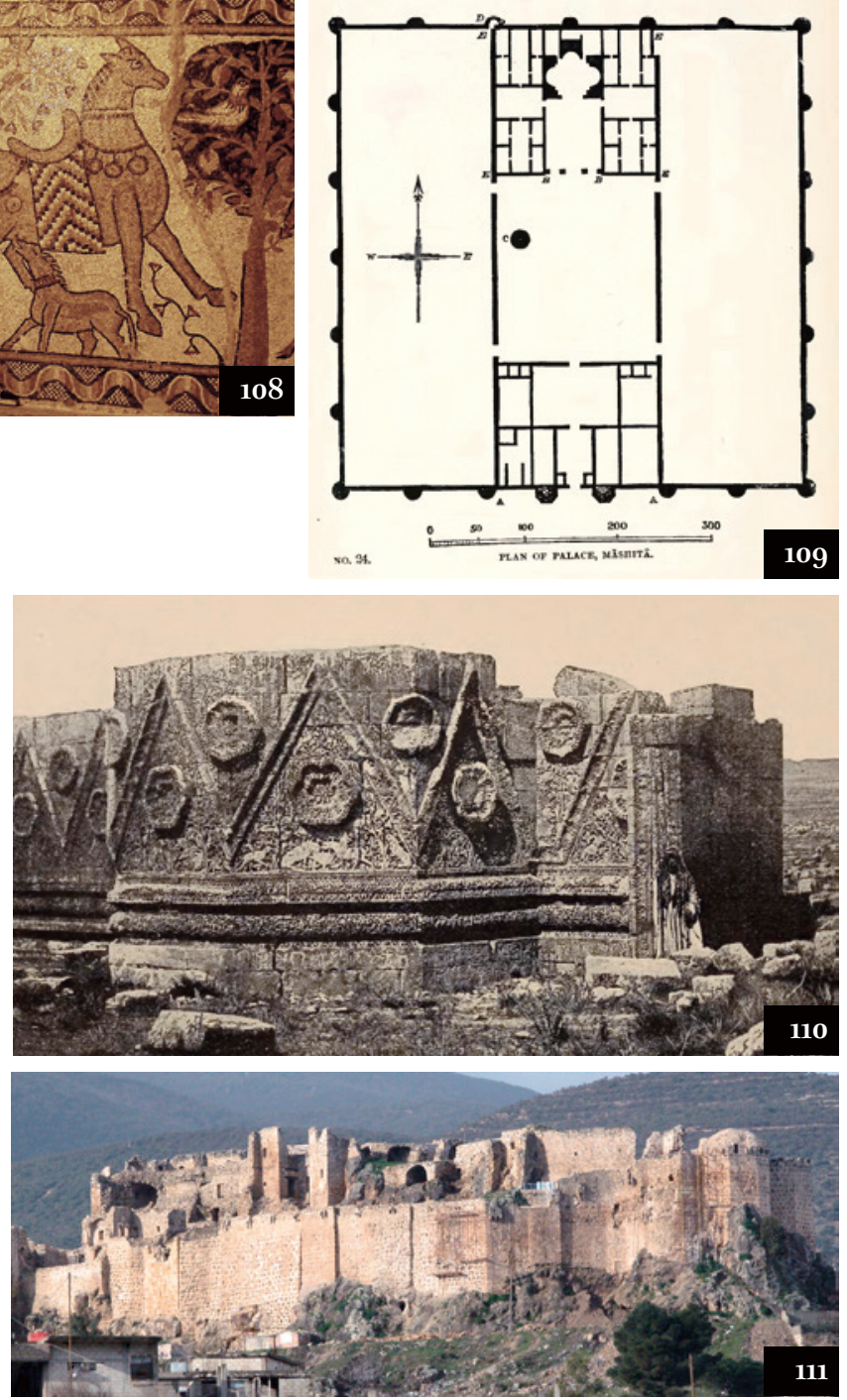

111

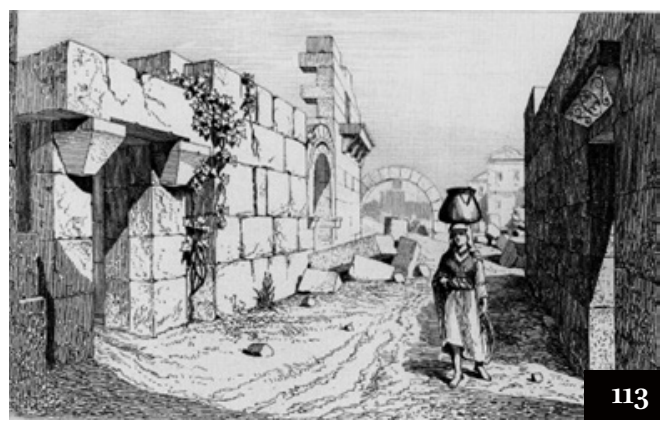



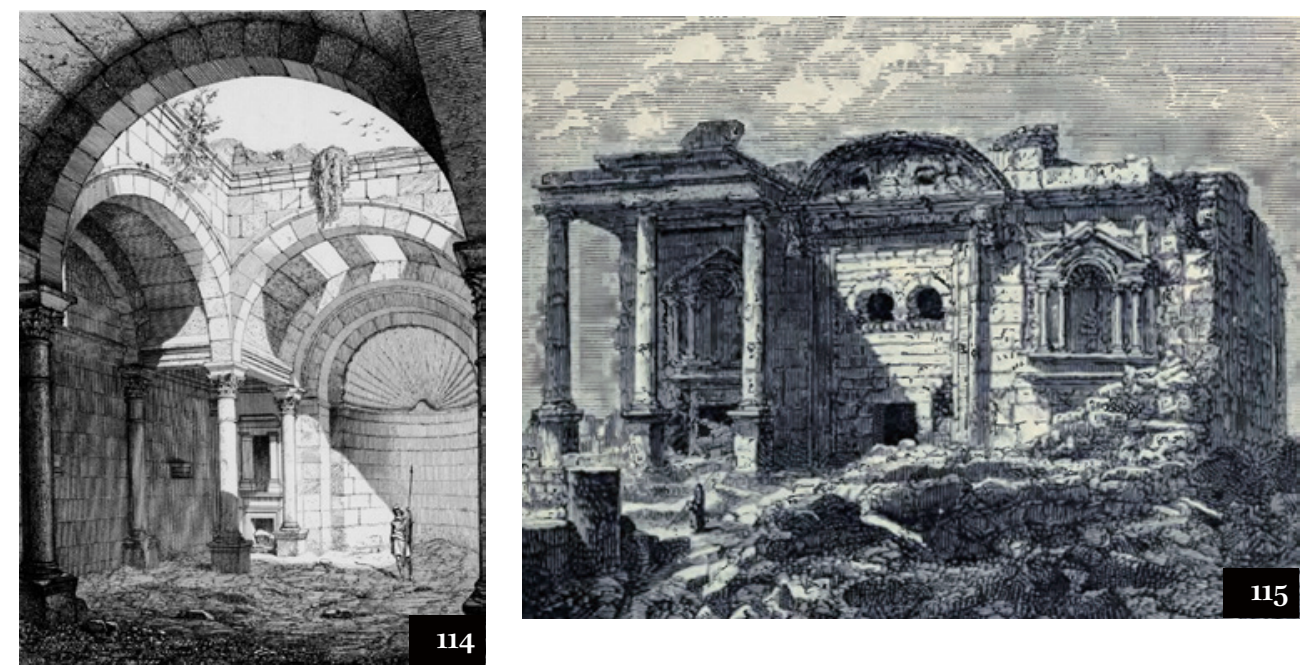

Top left \& right, 114 \& 115: Mismiye, interior and exterior of the temple, now disappeared, in prints of 1865 and 1881 respectively. Here in 1864 Skene found "highly ornamented temples almost entire, well-paved streets, houses still roofed with great slabs of stone, and their massive doors of single blocks of basalt swinging on their pivots, ready to be inhabited." Centre, 116 : church at Mushabbak, one of the Dead Cities. Bottom, 117: Nablus.
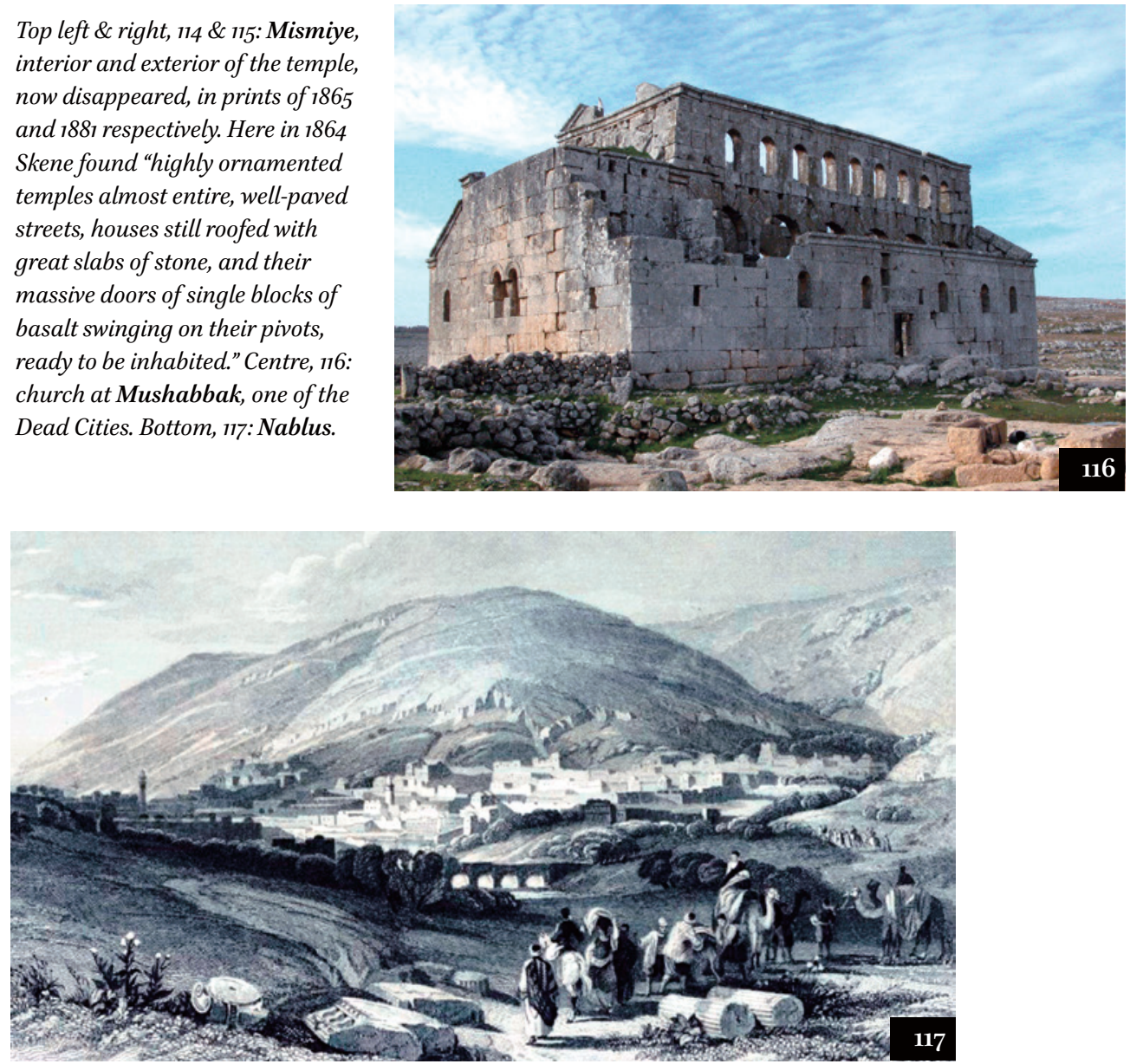

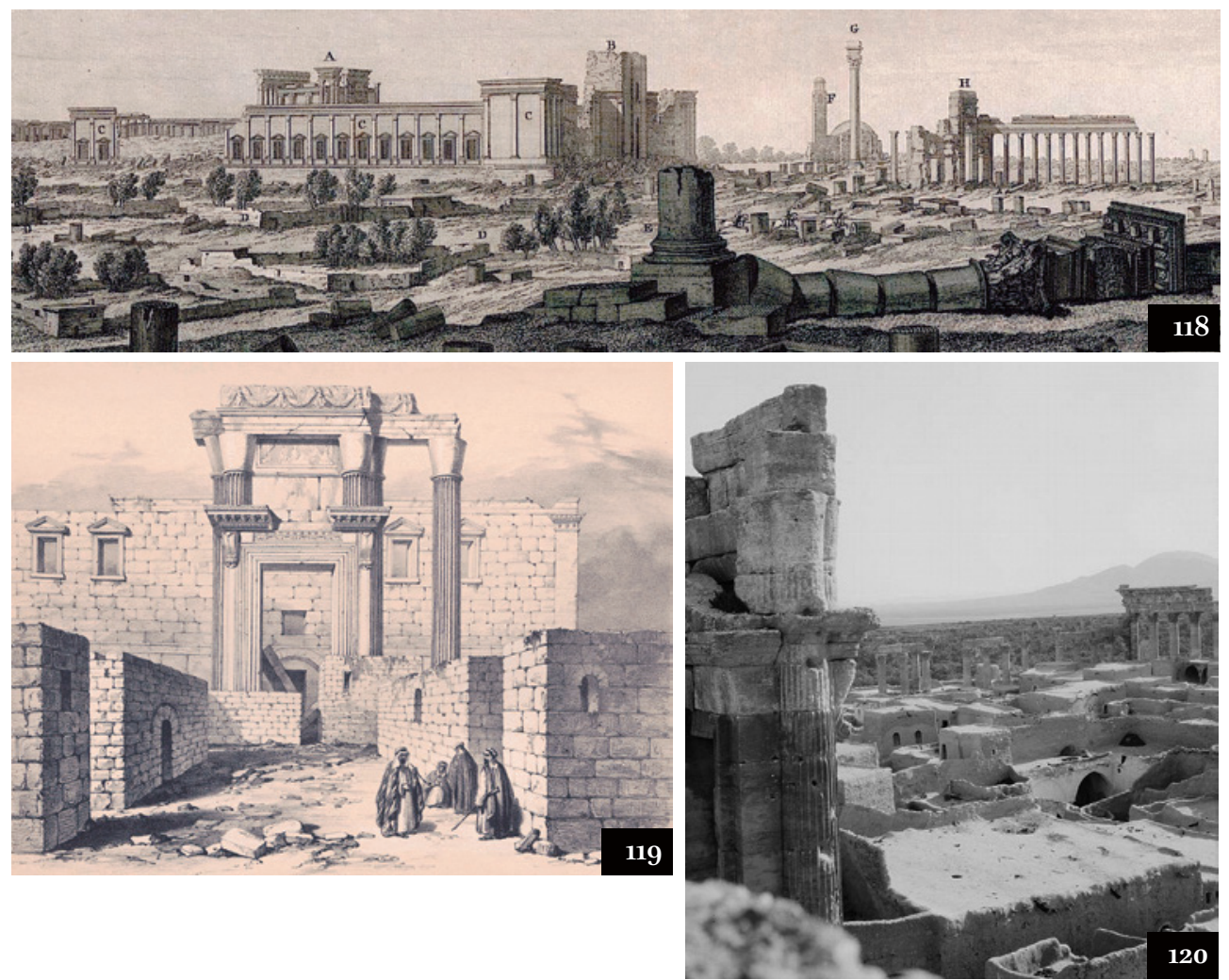

Palmyra. Top \& bottom, 118, 121, 122: Wood's 1753 views the temple complex (with houses), and a colonnade \& triumphal arch. Centre left \& right, 119, 120: Temple of the Sun, lateral entrance, print by Laborde, 1837 , and a 1929 photo of the village inside the complex. These huts were of antique materials cemented with mud, and the nearby mosque was built with fragments of sculpture in its walls. Yakut in 1225 wrote of Palmyra: "There are wonderful buildings here erected on pillars. The people say they were built by the Jinns at the order of Solomon the son of David. At the present day the people there live in a castle surrounded by a stone wall. It has a double gate of stone, and there are temples, of which three remain standing to the present day."
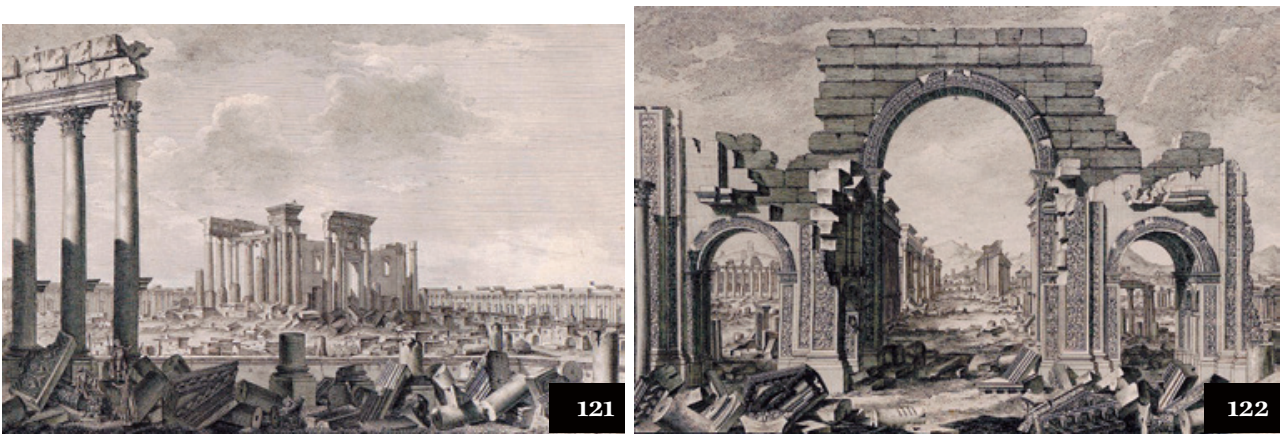

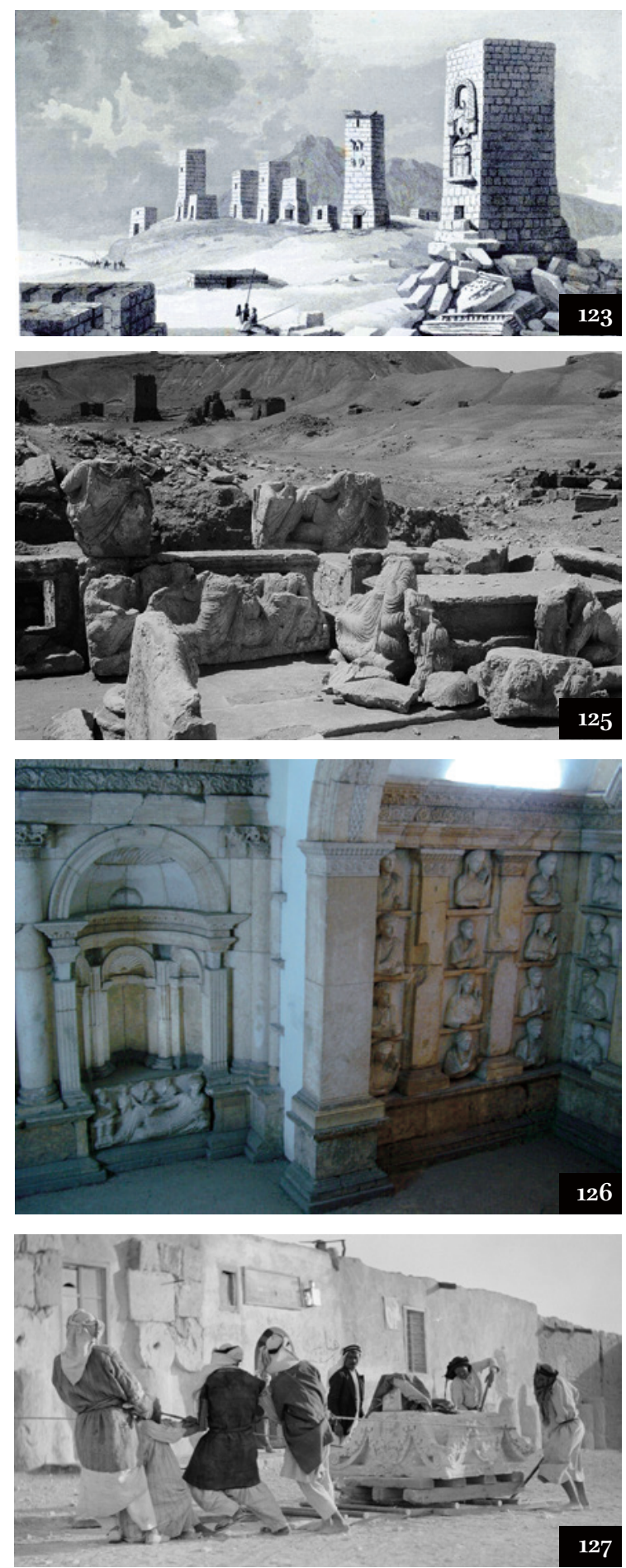

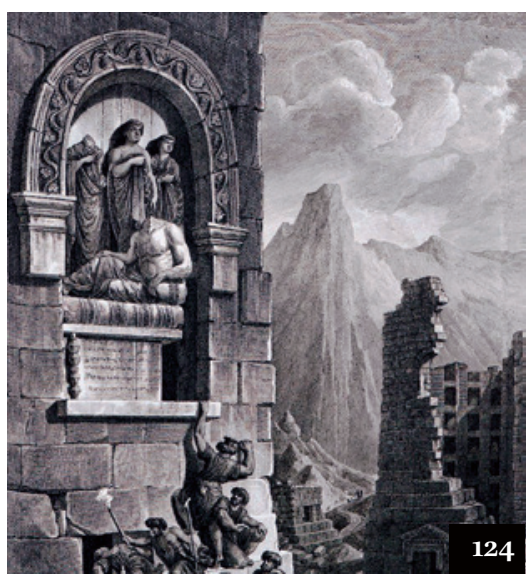

Palmyra, mausolea. Top left, 123: TaylorReybaud's view in 1839. Top right, 124: A mausoleum being investigated in 1800 in a print by Cassas; in the background another, with busts in some of the loculi. Top centre, 125: sculptures from a demolished mausoleum. Lower centre, 126: Yarhai Mausoleum, reconstructed in the National Museum, Damascus. From the 19th century onwards many such mausolea and subterranean tombs were robbed of their sculptures, and taken to European museums. Bottom, 127: moving a heavy capital - and note the antiquities, including column drums, built into the whitewashed wall behind. 

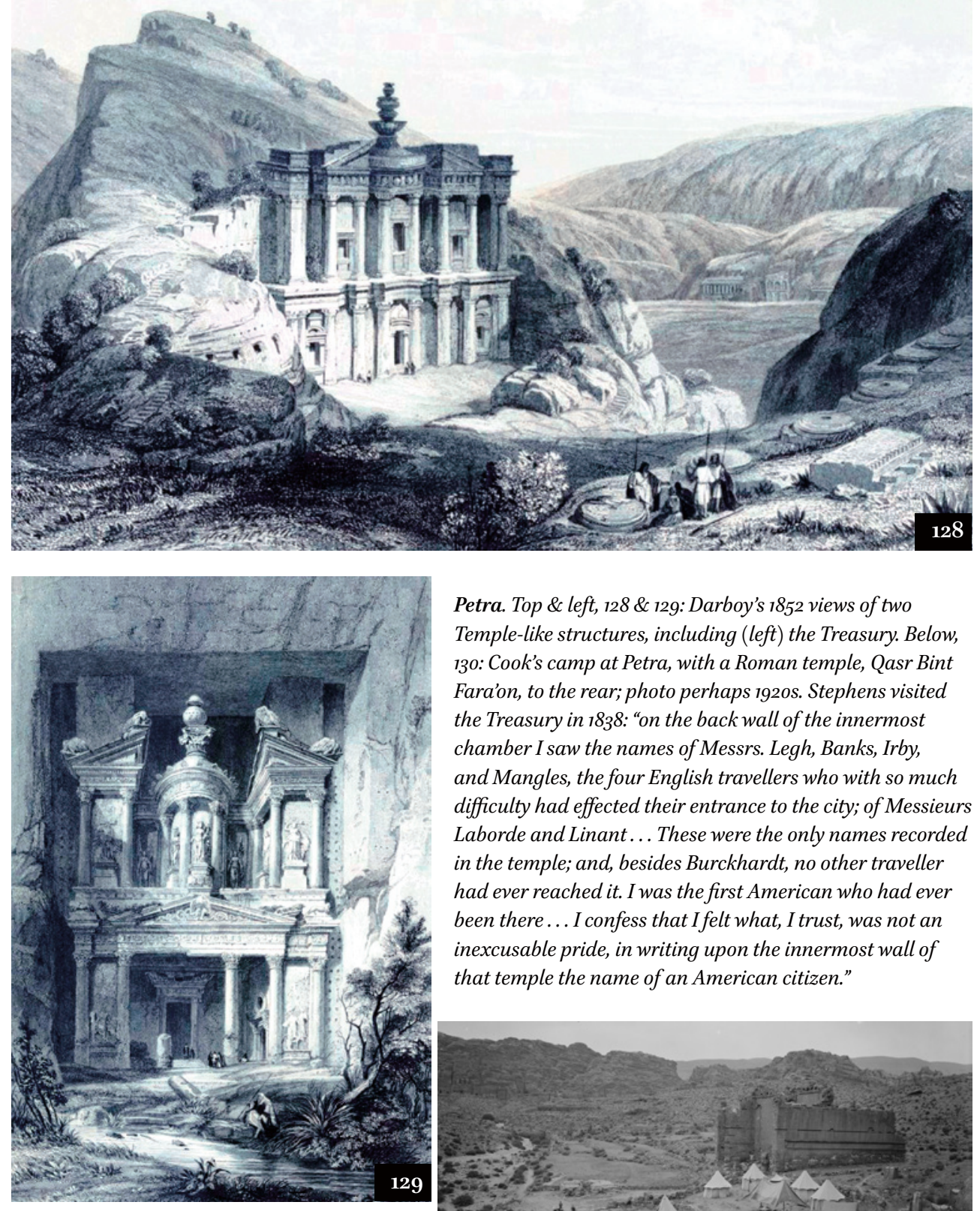

Petra. Top \& left, 128 \& 129: Darboy's 1852 views of two Temple-like structures, including (left) the Treasury. Below, 130: Cook's camp at Petra, with a Roman temple, Qasr Bint Fara'on, to the rear; photo perhaps 1920s. Stephens visited the Treasury in 1838: "on the back wall of the innermost chamber I saw the names of Messrs. Legh, Banks, Irby, and Mangles, the four English travellers who with so much difficulty had effected their entrance to the city; of Messieurs Laborde and Linant... These were the only names recorded in the temple; and, besides Burckhardt, no other traveller had ever reached it. I was the first American who had ever been there... I confess that I felt what, I trust, was not an inexcusable pride, in writing upon the innermost wall of that temple the name of an American citizen."

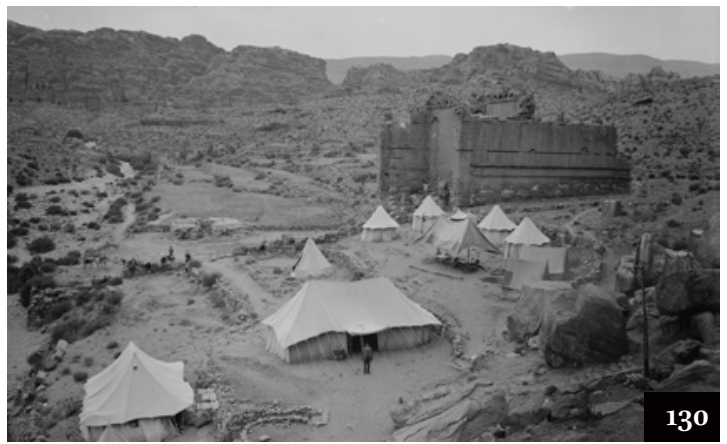


Qalaat Saladin (Saone). Right, 131: the fort is built on rock. A ditch, just visible in the foreground, protected the approaches. Centre \& bottom left, 132 \& 133: view from the bottom of the ditch looking up at the masonry walls. The builders left a $28 \mathrm{~m}$ tall needle of stone. This was to support a wooden drawbridge, but also no doubt to underline just how much rock had been excavated by their efforts. Bottom right, 134: a heavy projectile, one of several at the site.
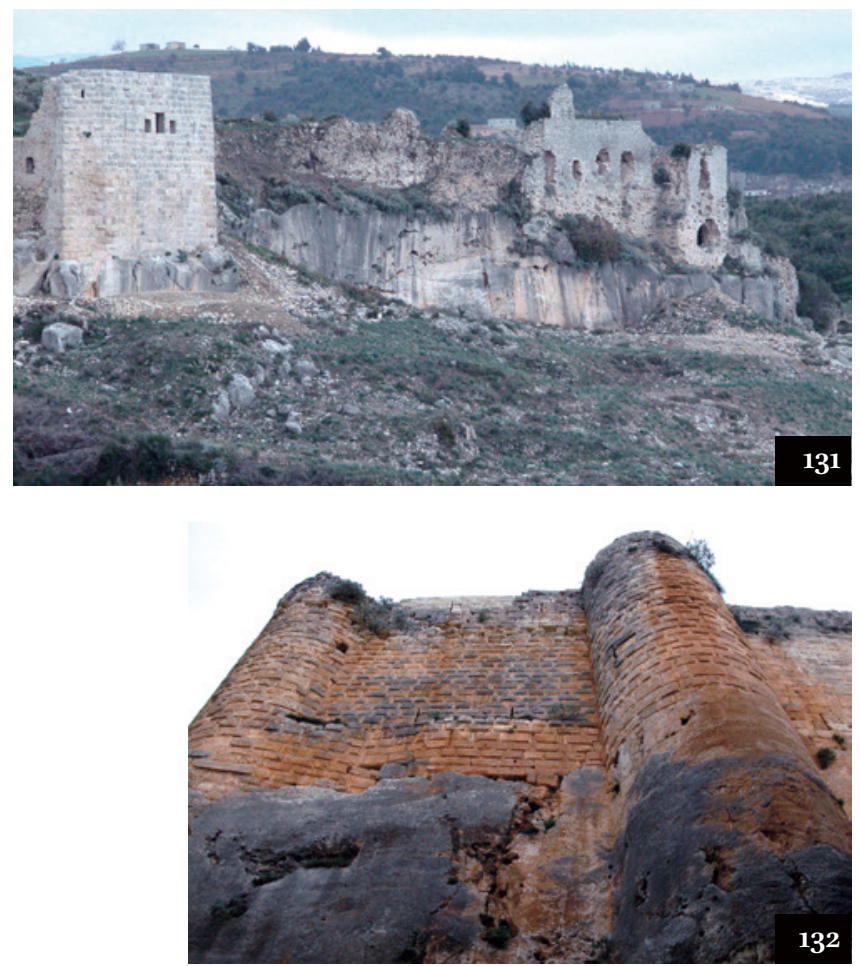

T.E. Lawrence wrote of Saône: "probably the finest example of military architecture in Syria... Saône is of such a colossal size, and so deeply set in inhospitable hills that a complete examination of it is a matter of some exertion and discomfort... The whole moat is very beautifully carved out of the rock, and its sides have generally been finished to a comparatively smooth surface."

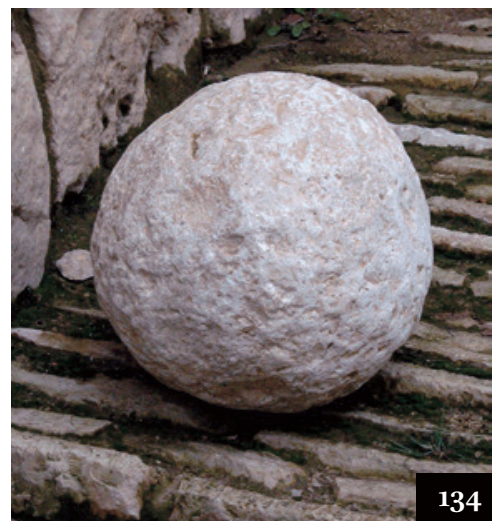



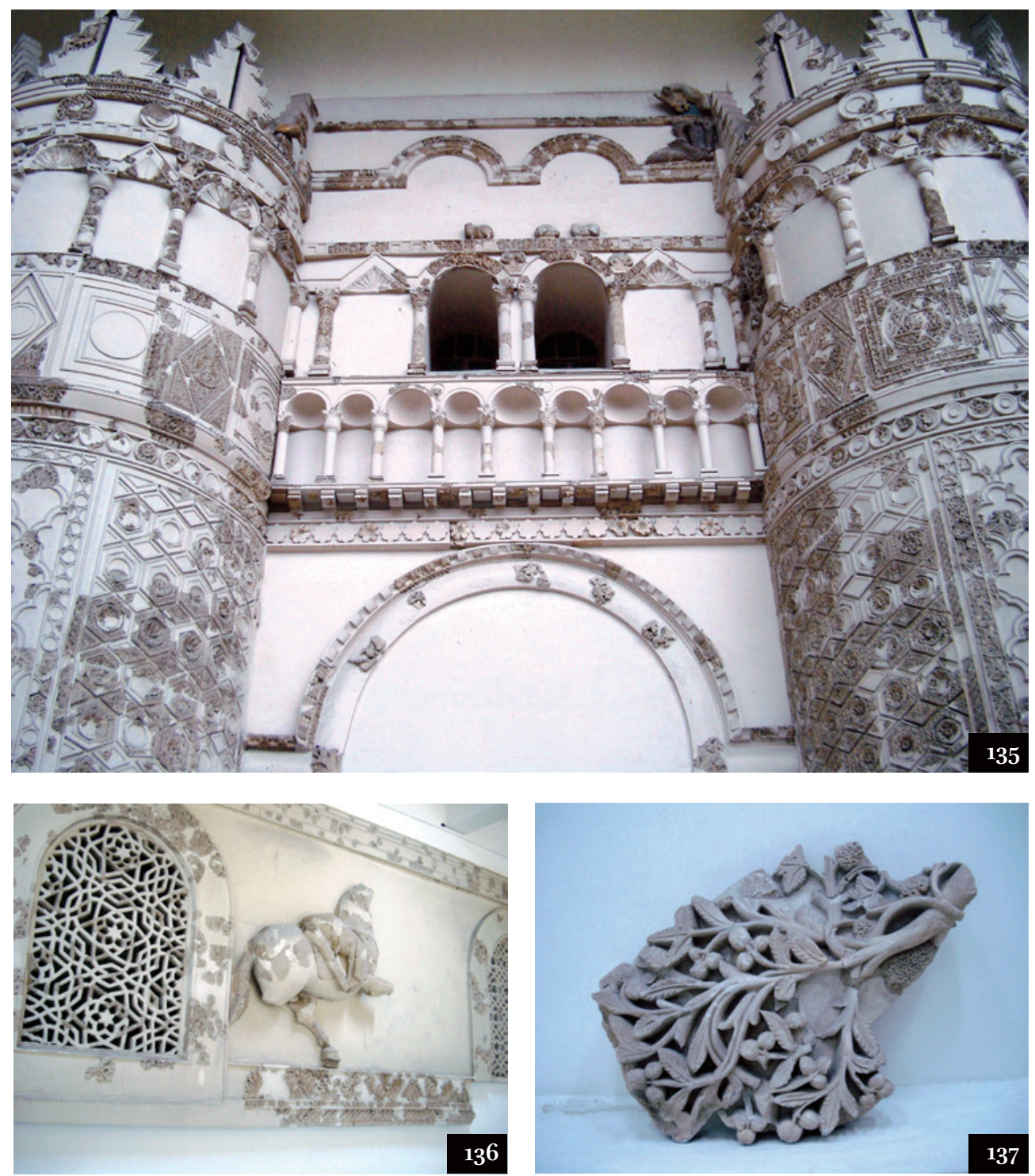

Qasr al-Heir West, 135, 136, 137: Façade and stucco decoration, all now Damascus, National Museum. This entrance has been called a "brilliant piece of stagecraft. It presents to the daunted visitor a huge screen of restless decoration, a more fantastic version of the scaenae frons that formed the backdrop to Roman theatre stages" (Burns 2005, 121). Hence yet another connection between "desert castles" and Roman architecture. 


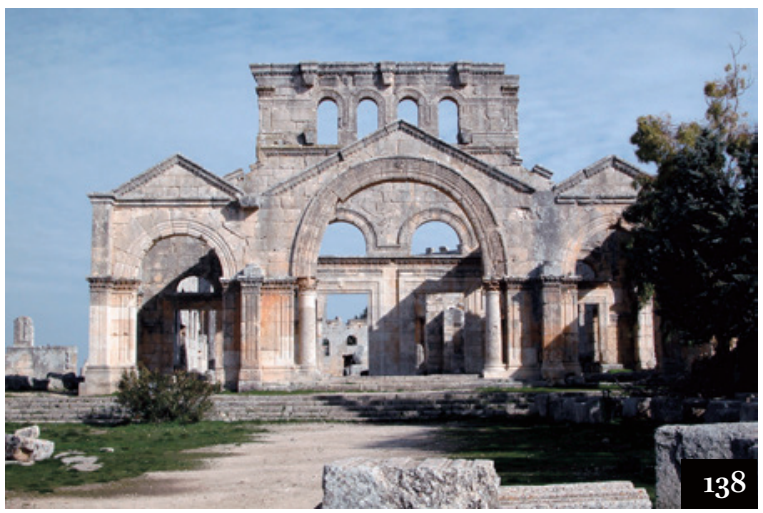

S. Simeon. Top left, 138: church façade. Centre left, 139: interior with supposed stump of saint's column. Centre right, 140: fragments of marble and porphyry which once decorated the basilica. Bottom, 141: Small section of Deir Semaan, the monastery at the bottom of the hill, which catered for pilgrims, seen through the arch leading up to the church.
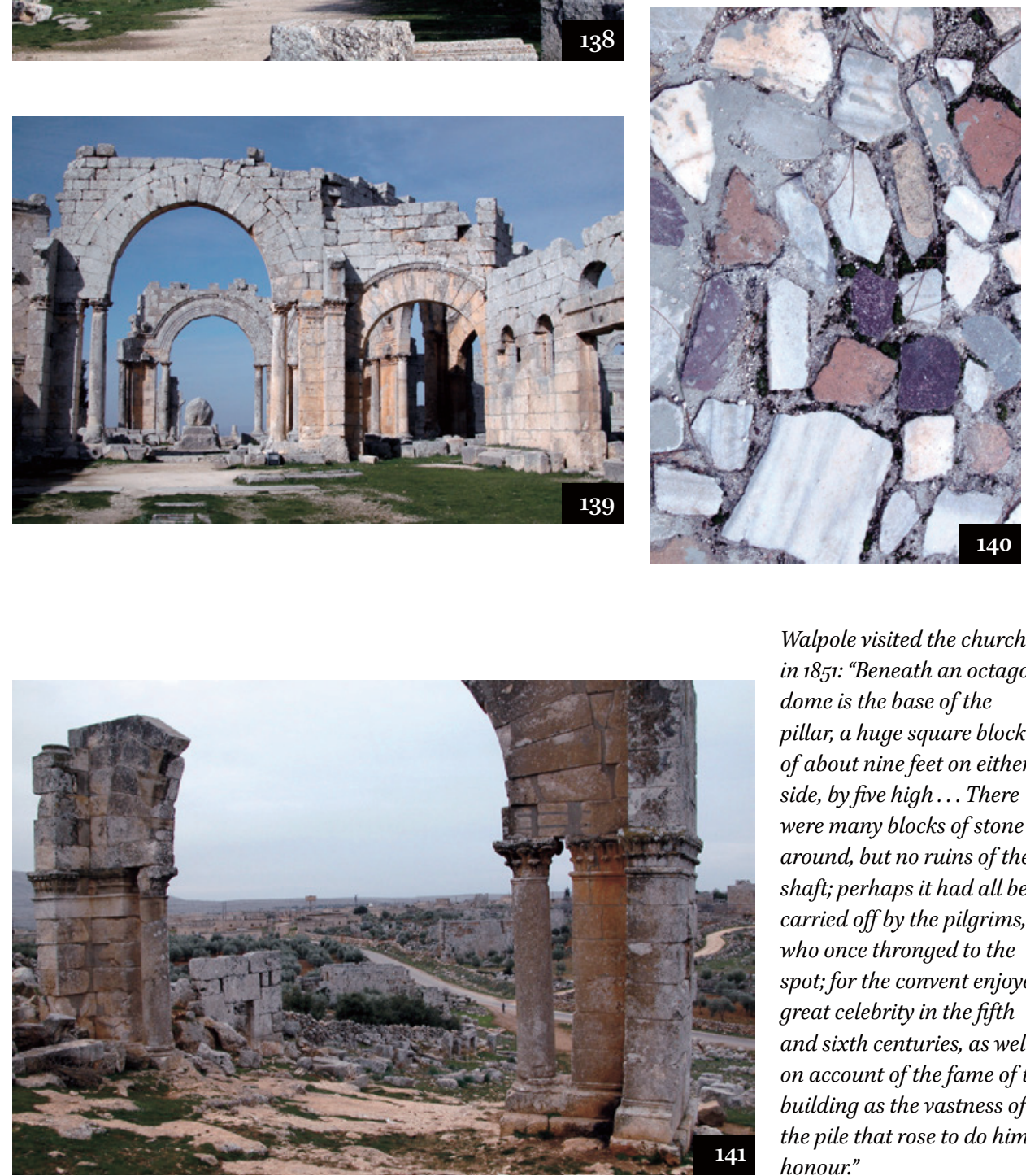

Walpole visited the church in 1851: "Beneath an octagon dome is the base of the pillar, a huge square block of about nine feet on either side, by five high... There were many blocks of stone around, but no ruins of the shaft; perhaps it had all been carried off by the pilgrims, who once thronged to the spot; for the convent enjoyed great celebrity in the fifth and sixth centuries, as well on account of the fame of the building as the vastness of the pile that rose to do him honour." 

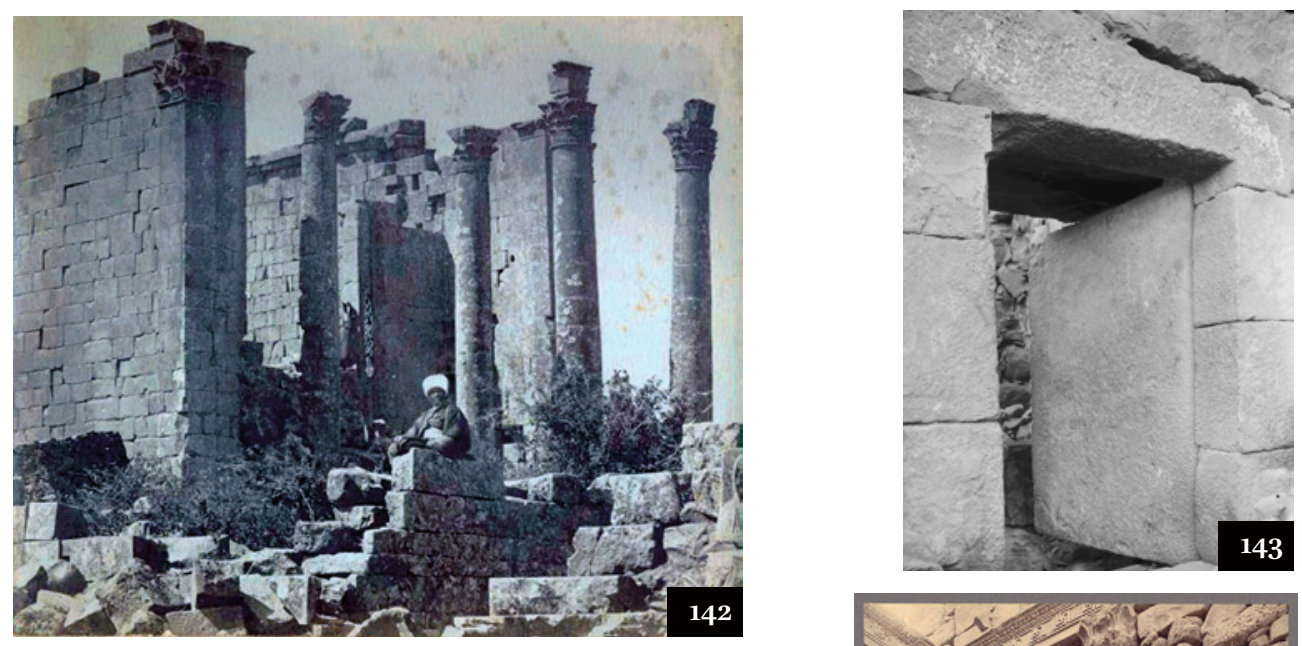

Sanamein, in the Hauran. Top left \& right, 142 \& 143: temple and house door. Right, 144: a "palace." Beke wrote in 1862: "The whole town is full of the ruins of buildings, showing it to have been once a place of importance; but the houses, as at present existing, appear to have been more than once destroyed, and rebuilt with the ruins of former buildings."
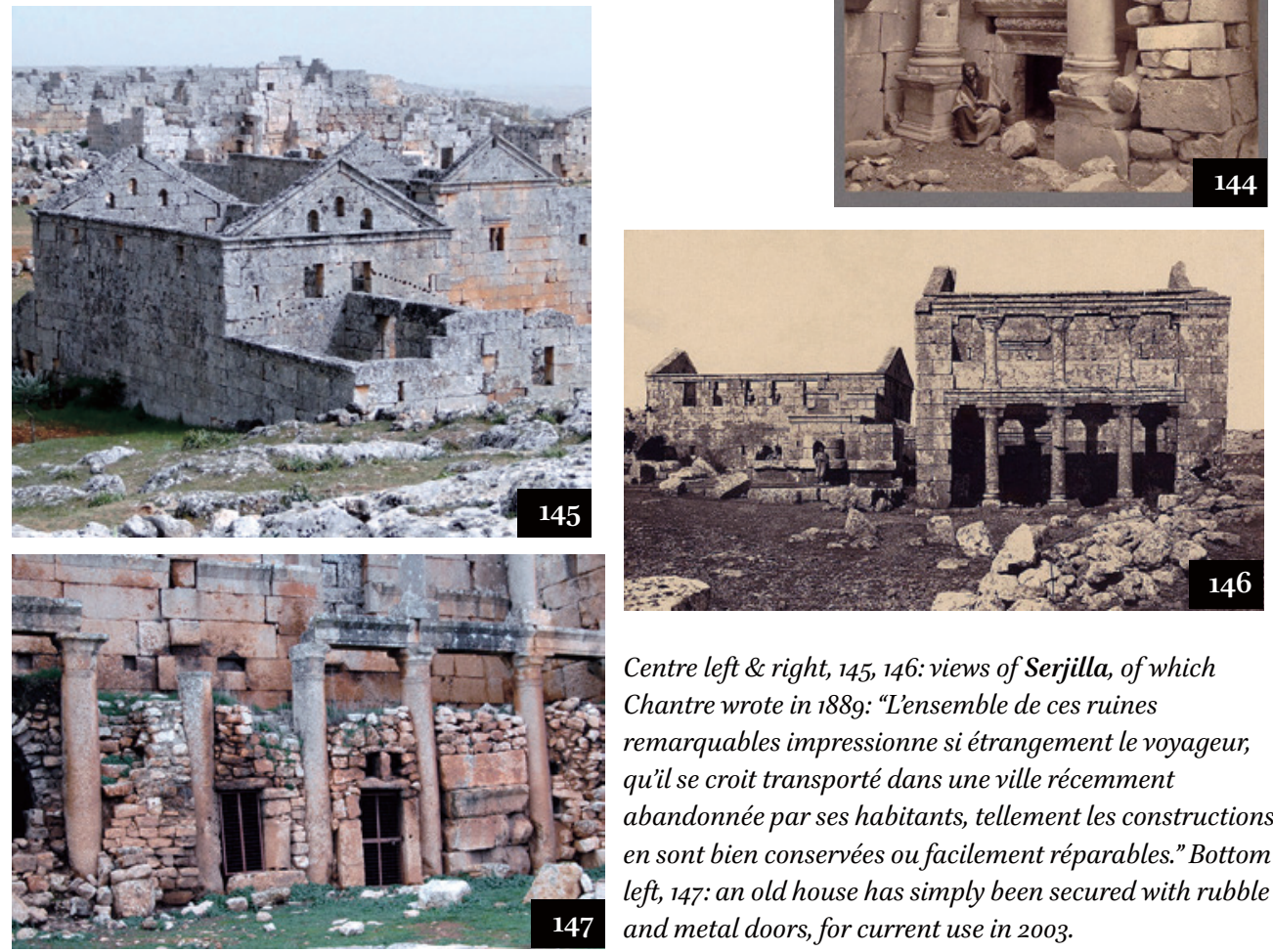

Centre left \& right, 145, 146: views of Serjilla, of which Chantre wrote in 1889: "L'ensemble de ces ruines remarquables impressionne si étrangement le voyageur, qu'il se croit transporté dans une ville récemment abandonnée par ses habitants, tellement les constructions en sont bien conservées ou facilement réparables." Bottom left, 147: an old house has simply been secured with rubble and metal doors, for current use in 2003. 

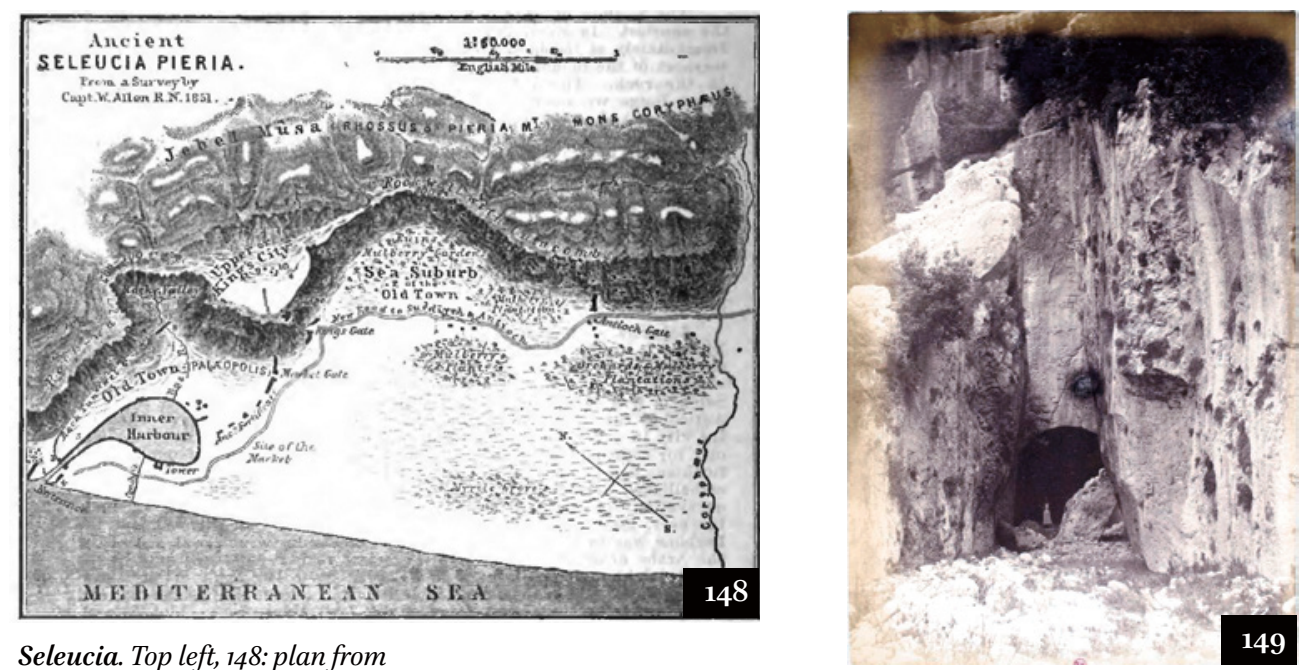

Seleucia. Top left, 148: plan from

Baedeker's 1898 guidebook. Top right \& centre, 149, 150: two photos from Ernest Chantre's 1881 expedition, showing the north part of the Roman tunnel at Seleucia; and a marble sarcophagus discovered there. In 1839 Layard marveled at the "great tunnel and water-course, cut with extraordinary labour and skill through the solid rock, to carry off the waters of a torrent which threatened to fill up the port with the mud and stones that it brought down from the mountains, and which were thus diverted to the sea."

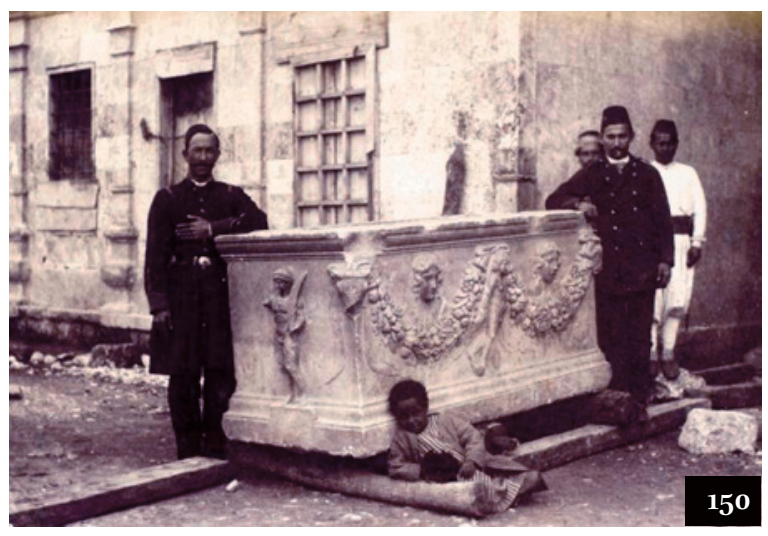

Right, 151: Shahba, in the Hauran: Roman street and colonnade, 1938, taken over by new residents. Monk wrote in 1851: "many houses and public buildings are standing, while the stone doors and windows to this day move in their sockets. These old Roman houses form the habitations of the Druses of the Hauraan, who dwell peaceably in cities once renowned for beauty and splendour,

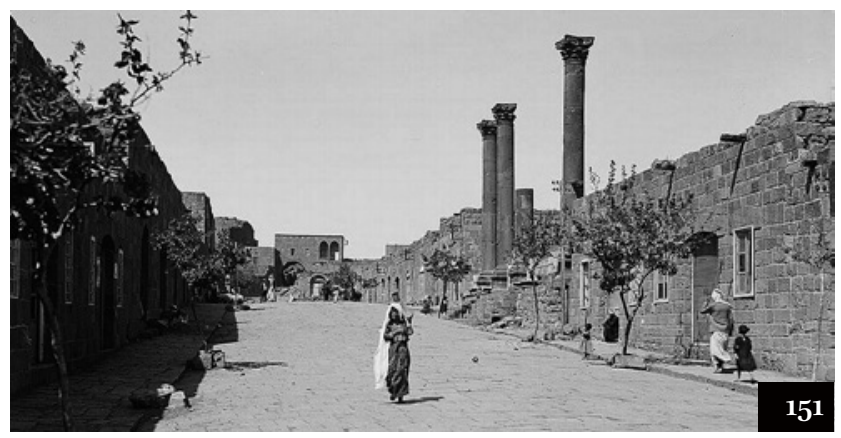
now mere monuments of the instability of mighty empires." 
Shahba. Right, 152: Roman Baths, photo published 1938. Porter wrote in 1855 : "We scrambled over the ruined wall beside a fine Roman gate, and, after watering our horses at a large tank, partly filled with muddy water, we proceeded along a well-paved ancient street to the residence of the sheikh." Below, 153: plan; 154: theatre, and south gate (155), all photographed in 1909. Buckingham wrote in 1825 : "The principal entrance to the city appeared to be from the southward; as in the centre of the southern wall was seen a large gate, with three arches, the central one broken. The principal edifices were at the west end of the town and the private dwellings at the east, with a large bath nearly in the centre, resembling in all these particulars the divisions marked in the ruins of Geraza."
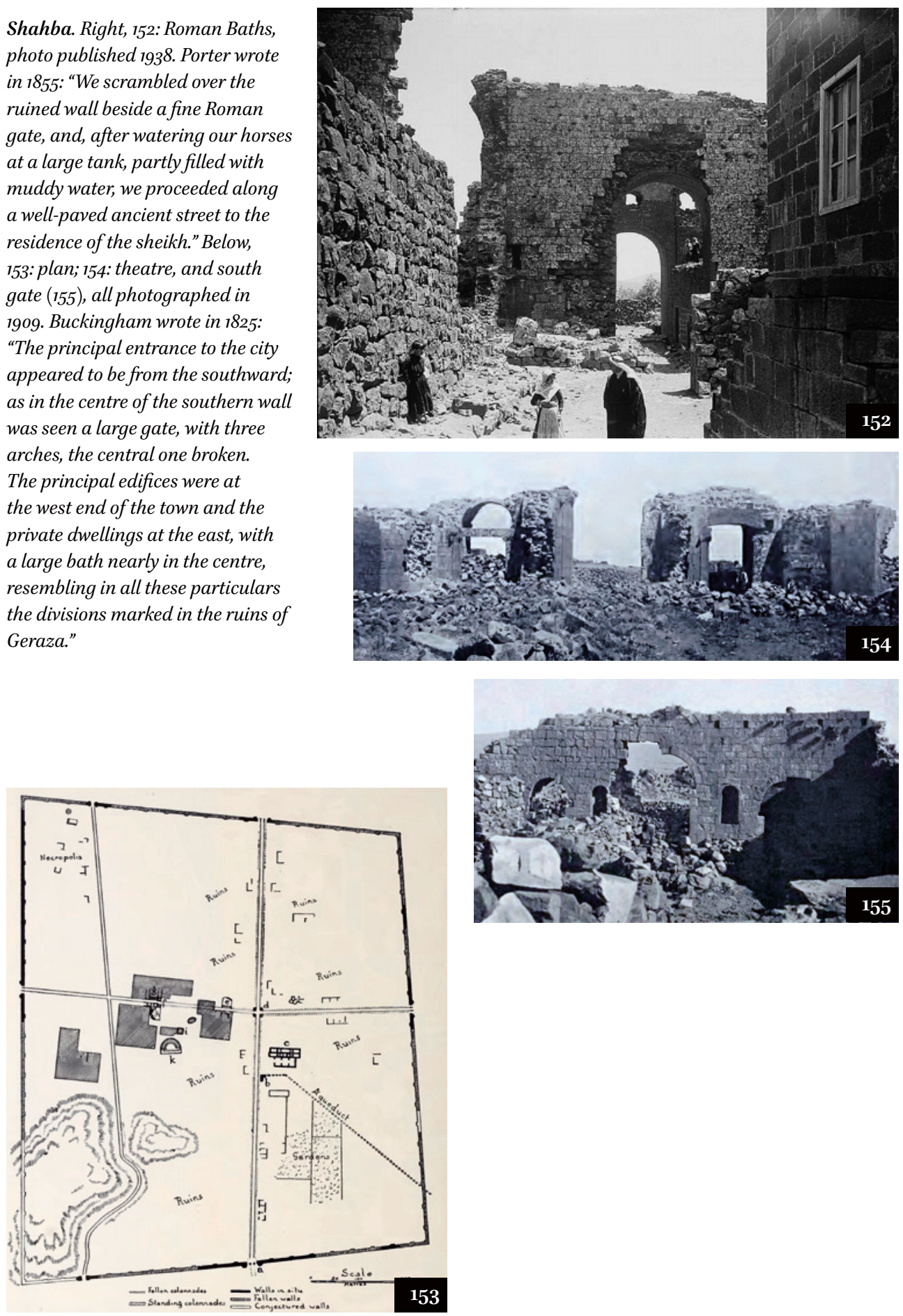

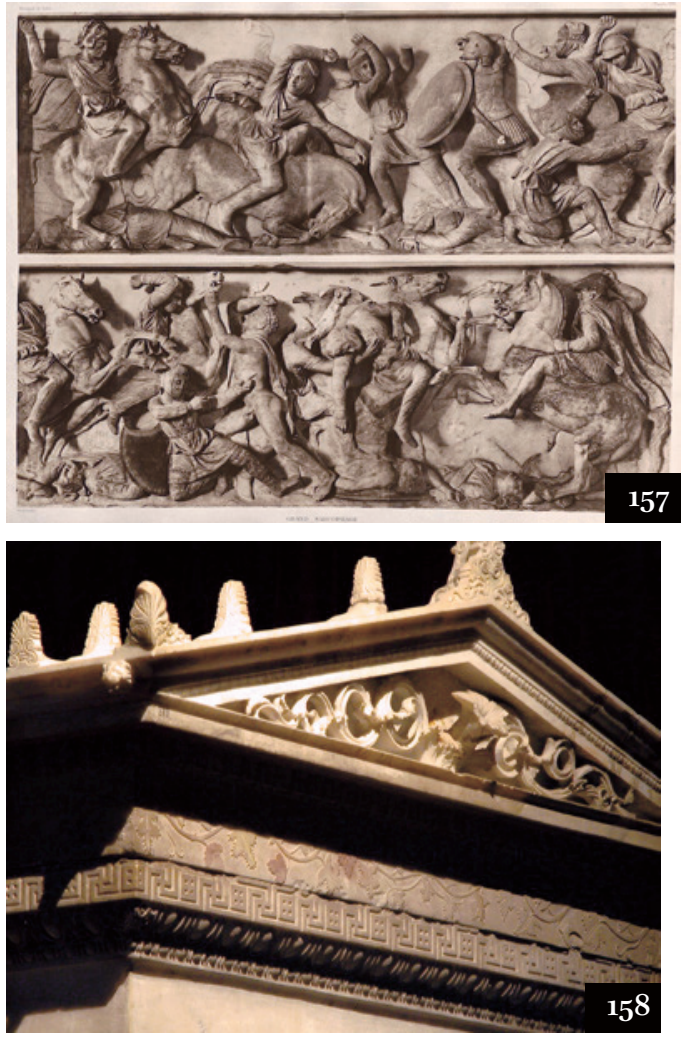

Sidon. Right, 156: plan by Renan, 1864. In 1745 Pococke noted the "great ruins of a fine port ... now choaked up," and it was still current knowledge that Emir Faccadine $(1585-1635)$ had done this, so that "they might not be harbours for the Grand Signor's galleys to land forces against him." Top left, 157: details of the Alexander Sarcophagus, published by Hamdi Bey, Director of the Constantinople Museum, in 1892. Centre left, 158: detail of another of the spectacular sarcophagifound at in the Royal Necropolis at Sidon in the late 19thC (all now Istanbul, Archaeological Museum). Bottom, 159: Fortress "of Saint Louis," photo by the Duc de Luynes, 1864. This, like the Sea Castle (right, 16o) has antique columns as through-ties.

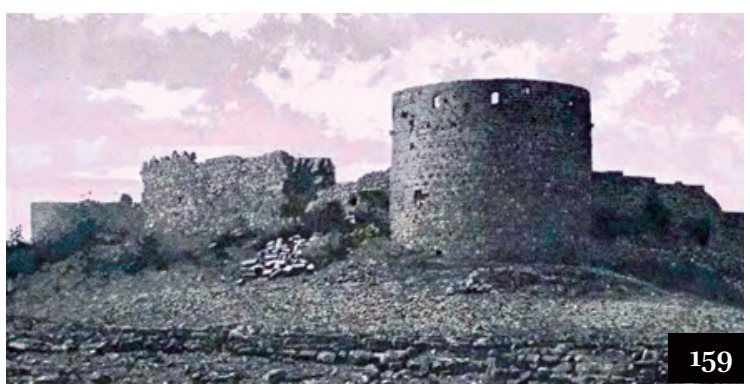

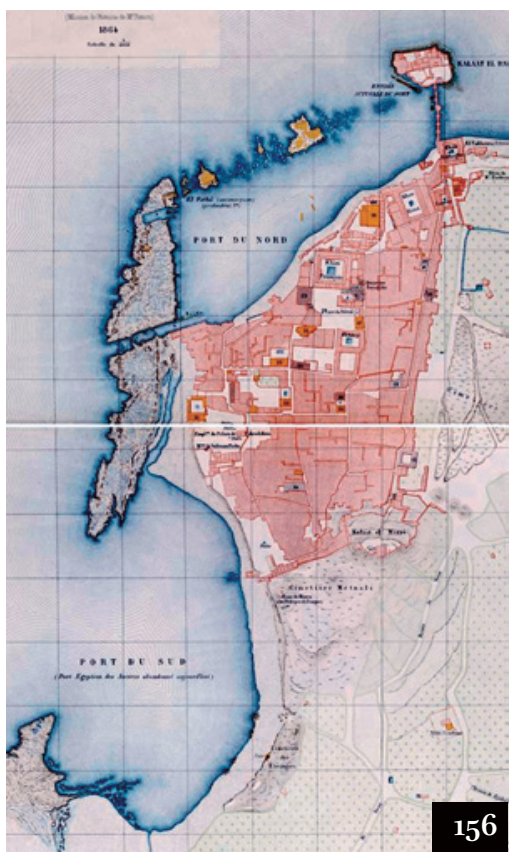

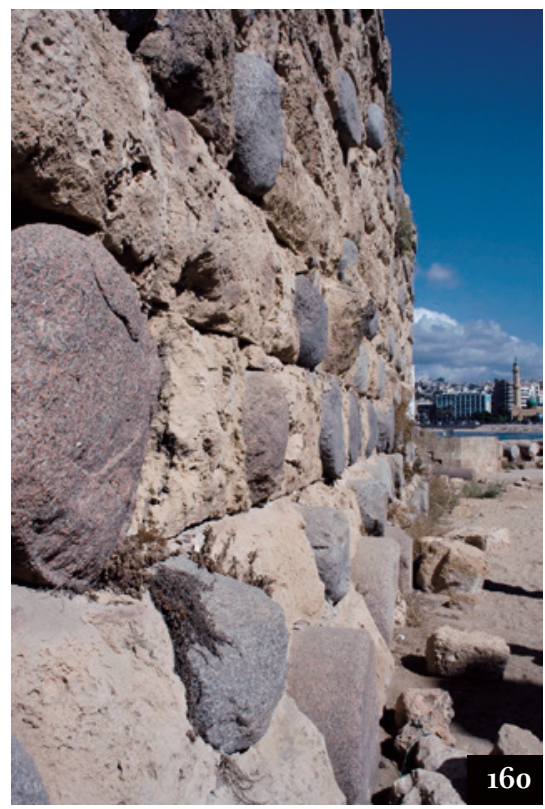



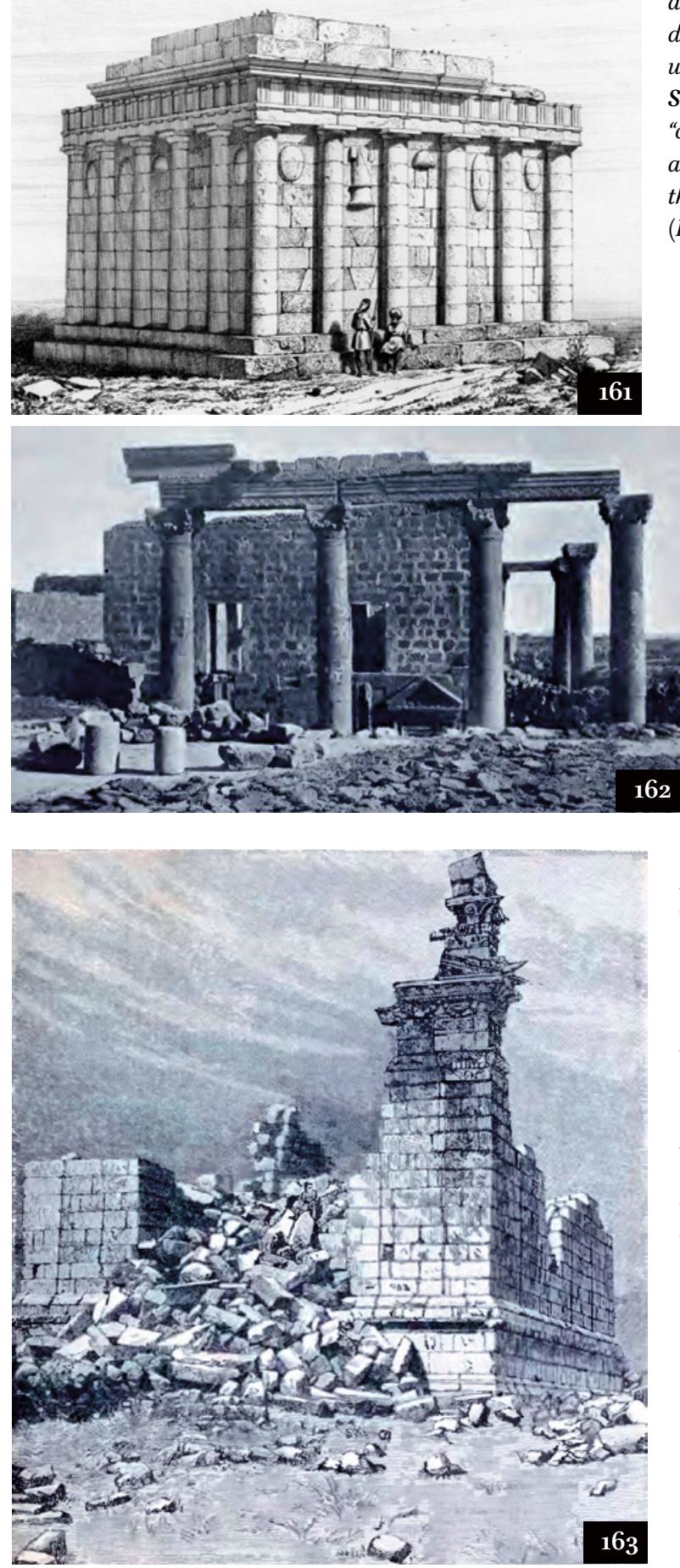

Left 161: Suweida, Tomb of Hamrath, in a print by De Vogüe, 1865 ; this was much deteriorated by 1909, some blocks being used to build a barracks. Centre, 162:

Suweida, temple, photo of 19og. The town "contains about 200 families, of whom 30 are Christians, and all the rest Druses, there being no Mohammedans settled here" (Buckingham, 1825).
Left, 163: the temple at Suleim. Wright wrote in 1895: "the Skeikh Abu Shaln met us with the ever-ready Druze welcome. The sheikh was very proud of his new house, which he had built in the flimsy Damascus style. Into the walls he had built stones with inscriptions and bits of Greek ornaments, as he naively said, to save Englishmen from ranging through the town to look for them. On one stone there were the figures of two animals like lions, with wings and very long necks. They were much defaced, but they seemed to have had the countenances of men." 
Tiberias. Top, 164: view by David Roberts, 1839. Below, 165: the town in 1837 , showing the ruins left by the 1822 earthquake.
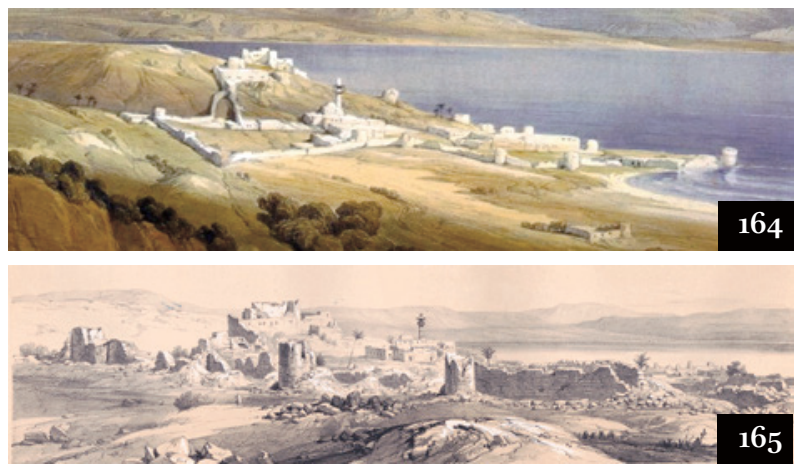

Tyre. Right, 166: View of the isthmus, by Laborde, 1837. Below, 167: Tourists around one of the near-immovable columns of the ruined cathedral. Bottom left, 168 , David Roberts, 1839: ruins of an Ionic temple between Tyre and Acre, at ElHamed. Bottom right, 169 : colonnade at the port (Al-Mina).

At Acre Djezzar Pasha is said to have re-used mosaics, perhaps wall veneer from earlier churches or temples, as well as columns. Two large red granite shafts remained at Tyre, however, because his engineers could not shift them. Were these the multiple shafts in 167 ?
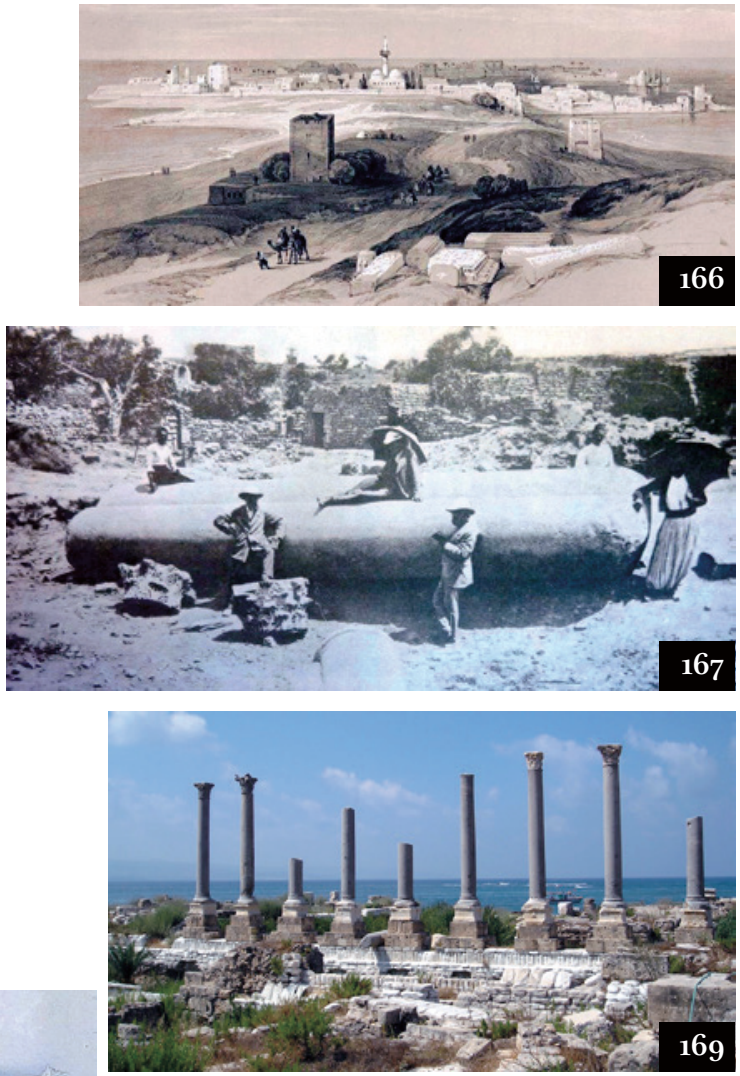

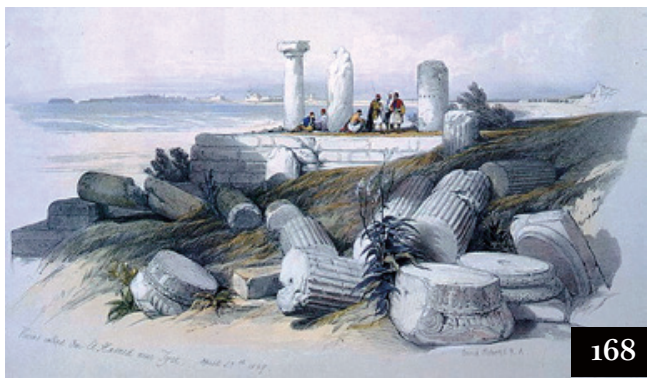



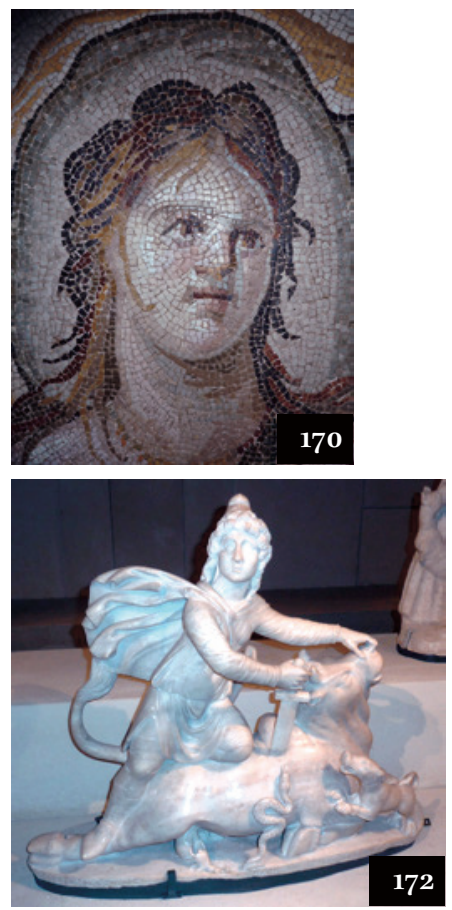
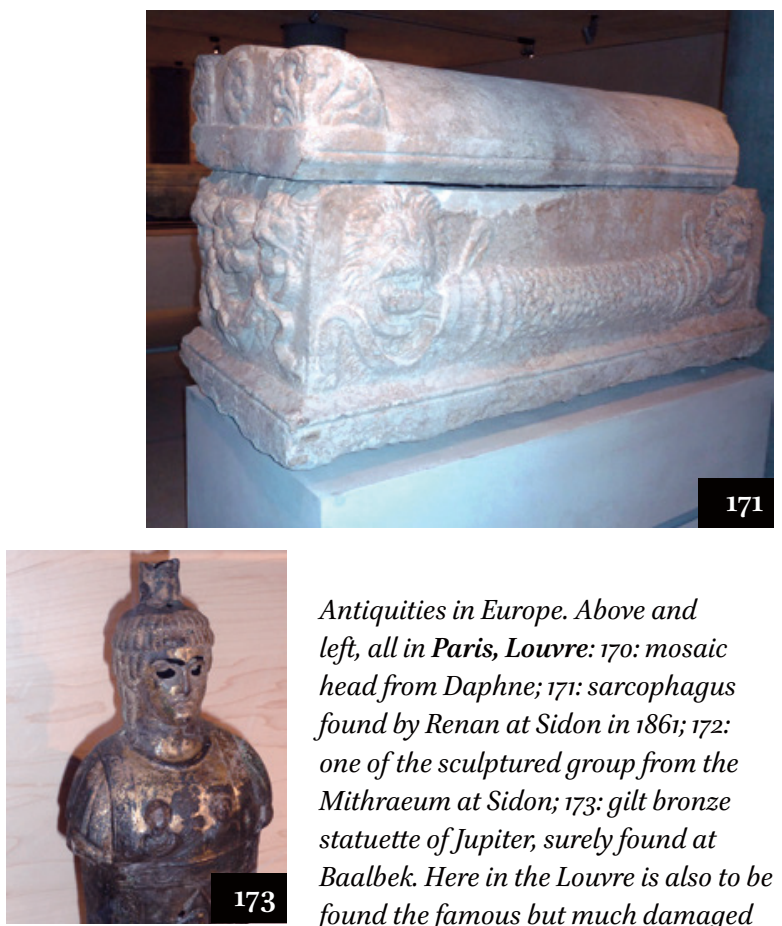

Antiquities in Europe. Above and left, all in Paris, Louvre: 170: mosaic head from Daphne; 171: sarcophagus found by Renan at Sidon in 1861; 172: one of the sculptured group from the Mithraeum at Sidon; 173: gilt bronze statuette of Jupiter, surely found at Baalbek. Here in the Louvre is also to be found the famous but much damaged Moabite Stone.
Antiquities in Europe, all London, British Museum. Right, 174: a bronze dish made for the 14-century Sultan Qalaun. Below: a N. Syrian 12 thC Plate (175), a tile from the Dome of the Rock (176), and a capital from the Haram al-Sharif (177; saved from the lime kiln, writes the PEF in 1887).

In 1873 the PEF anticipated plenty of finds: "Who can doubt that if the same intelligence, zeal, knowledge, and outlay were applied to the exploration of Palestine that have recently been brought to bear on Halicarnassus, Carthage, Cyrene ... the result would be a great accession to our knowledge of the successive inhabitants of Syria-Canaanite, Israelite, Roman?"

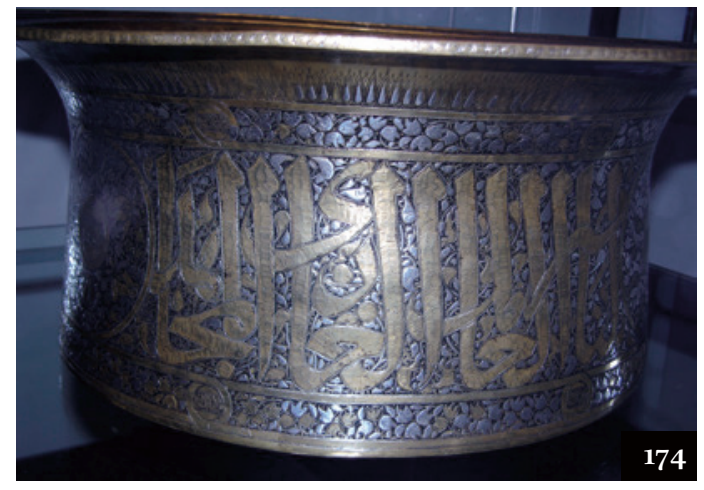

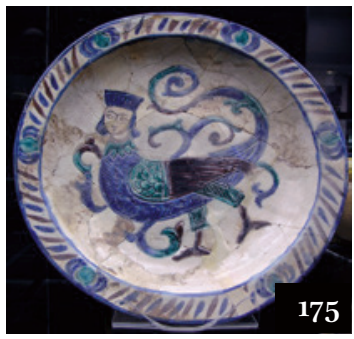
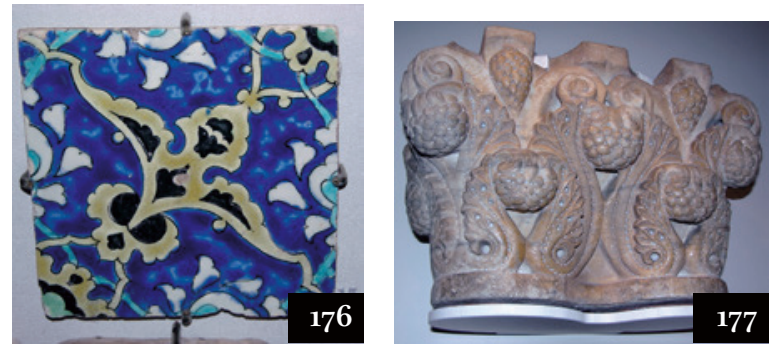

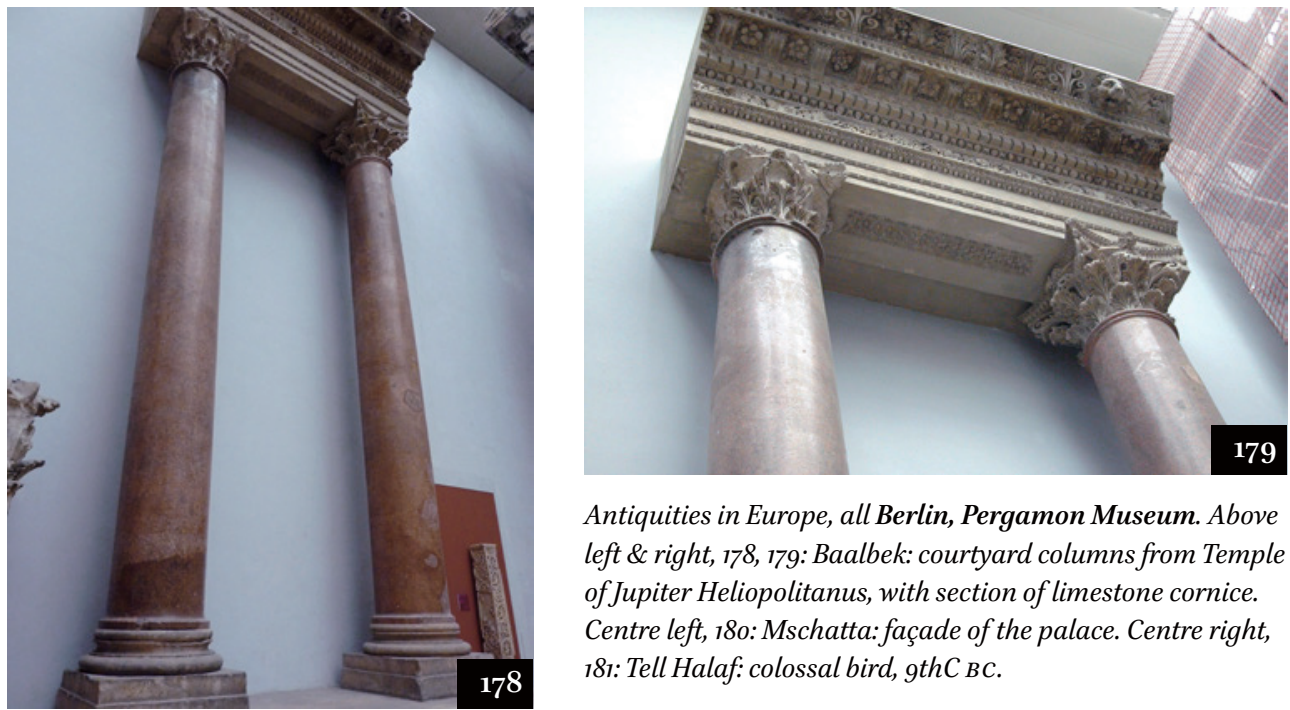

Antiquities in Europe, all Berlin, Pergamon Museum. Above left \& right, 178, 179: Baalbek: courtyard columns from Temple of Jupiter Heliopolitanus, with section of limestone cornice. Centre left, 180: Mschatta: façade of the palace. Centre right, 181: Tell Halaf: colossal bird, gthC BC.
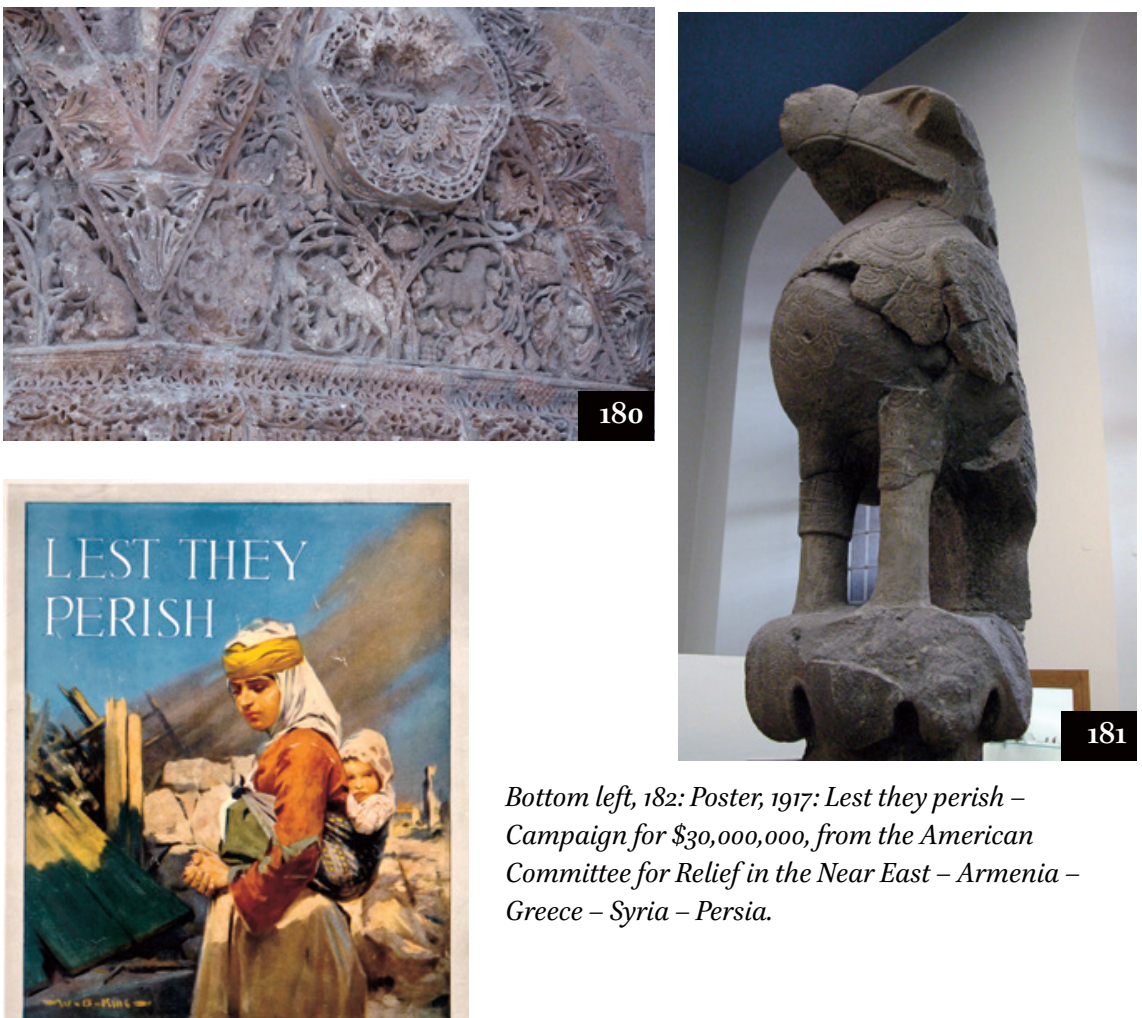

Bottom left, 182: Poster, 1917: Lest they perishCampaign for $\$ 30,000,000$, from the American Committee for Relief in the Near East - Armenia Greece-Syria-Persia.

\section{CAMPAIGN for $\$ 30,000,000$}

AMERICAN COMMITTEE FOR RELIEF IN THE NEAR EAST ARMENIA - GREECE - SYRIA - PERS $\mathbf{1 8 2}$ 